



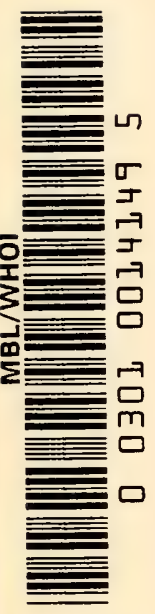





\section{TIIE NORTH AMERICAN CUP-FUNGI}






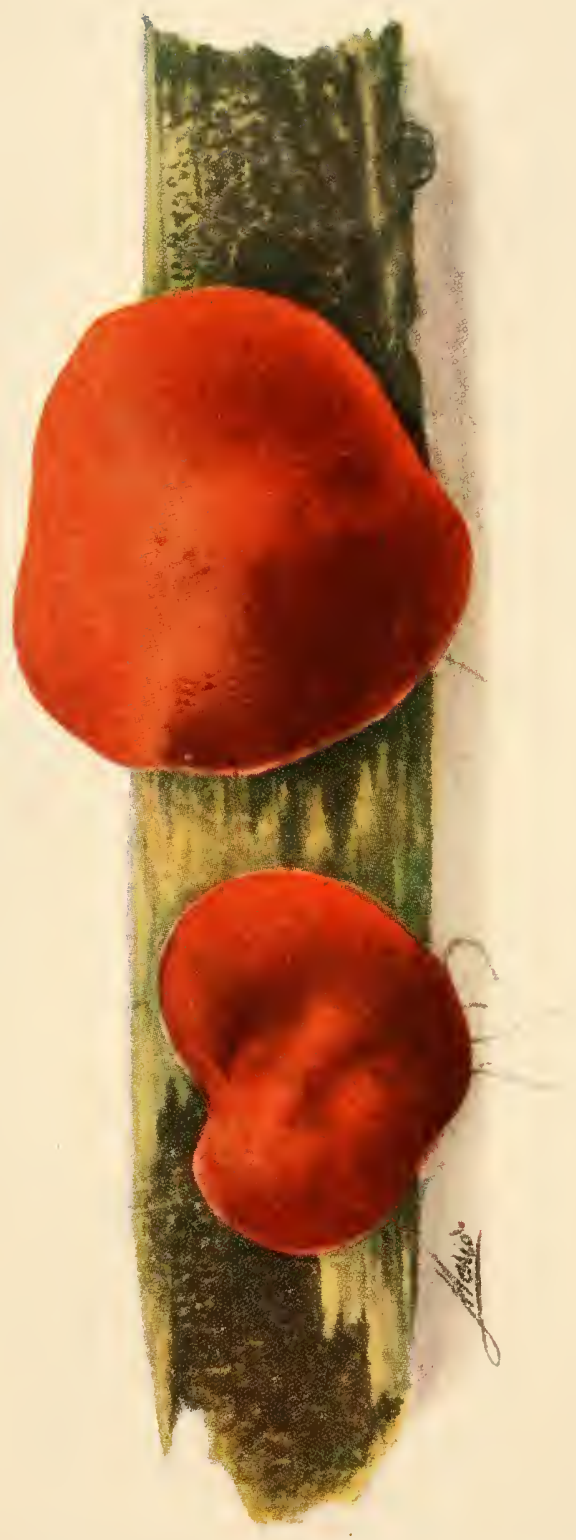

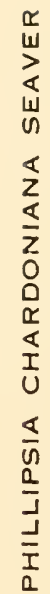




\title{
The North American Cup-fungi
}

\author{
(Operculates)
}

SUPPLEMENTED EDITION

BY

FRED JAY SEAVER, M.S., Ph.D., Sc.D.

Curator in The New York Botanical Garden

AND

Managing-Editor of Mrcologia

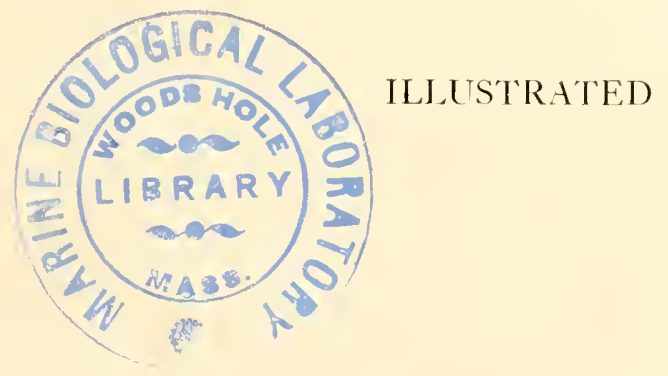

NEW YORK

PUBLISHED BY THE AUTHOR 
COPIRIGH 1928 AND 1942

Bi FREd JAI SEIYER

PRINTED IN THE UNITED STATES OF AMERIC. BY THE LANCASTER PRESS, INC., LANCASTER PA. 
DEDICATE

TO THE MEMORY OF MY WIFE

\section{IHurtense Audatite Srlutulu}

WHOSE LOVE, LOYALTY AND DEVOTION MADE POSSIBI.E THE PRODUCTION OF THIS WORK 

Preface.

General features of the group

The following subjects are briefly discussed: 1 . Phylogeny; 2. Cross morphology; 3. Origin of the apothecium; 4. Ascospore formation; 5. Alternation of generations; 6. Heterothallism and homothallism; 7. Spore discharge; 8. Heliotropism or phototropism ; 9. Dehiscence of the ascus: 10. Significance of the mode of dehiscence; 11. Eccentricity of the aseostome; 12. Asexual reproduction; 13. Ecology; 14. Pyrophilous forms: 15. Coprophilous forms: 16. Spore germination; 17 . Viability of the spores; 18 . Mycophagy; 19. Classification ; 20. Geographical distribution; 21. Nomenclature.

Signs.

Taxonomic treatment

Bibliographical note. . . . . . . . . . . . . . 256

Explanation of plates

Index to recognized genera. 267

Index to genera and species.

\section{SLPPLEMIENT}

Prefatory

viii

General features of the group

The following subjects are briefly discussed: Heterothallism: Spore discharge; Dehiscence of the ascus; Eccentricity of the ascostome; Mycophagy; Asexual reproduction; Classification; Nomenclature; Parasitism.

Additions and Corrections.

Explanation of plates

Bibliography

Index to illustrations

Index to genera and species. 


\section{PREFATORY \\ TO \\ SUPPLEMENTED EDITION}

Since the North American Cup-fungi (operculates) was published in December, 1928, much added information has come to light, consisting of new and unreported species, change of verdict regarding some of those iisted, and extensions of range of many of the species. The amount of material is scarcely sufficient to warrant a complete revision of the book, and it was thought best to submit it rather in the form of a supplement, recording the new information and many illustrations which were not available at the time of the original publication.

The same general system of illustrating is used, i.e. a combination of photographs and drawings. While an attempt has been made to keep these to a common scale, since the drawings have been made at different times, and with slightly different combinations of lenses, this has not been done absolutely, and the reader must depend upon measurements given in the descriptions rather than the comparative sizes, as indicated in the illustrations. A complete bibliography is appended.

To avoid confusion the pagination as well as plate and figure numbers is consecutive with that of the first part of the work.

New York, 1941. 


\section{PREFACE}

The present work is the outgrowth of studies begun under Professors T. H. Macbride and B. Shimek, while a graduate student in the State University of Iowa, where three years were spent as a research Scholar and later Fellow in botany, and has been continued as a special problem, intermittently, up to the present time.

Official connection with The New York Botanical Garden, since the autumn of 1908 , has afforded unusual opportunity to collect in the eastern states and the islands of the American tropics. Two expeditions have been made to the Bermuda Islands; the first in company with Dr. N. L. Britton and the late Stewardson Brown of Philadelphia, and the second with Professor H. H. Whetzel of Cornell University; one to the Island of Trinidad, just off the South American Coast, again in company with Dr. Britton; and one to Porto Rico and the American Virgin Islands, St. Thomas and St. Croix, as guest of the Porto Rican government. All of these trips have furnished valuable data for the work which is now being presented.

No private herbarium has been maintained but all of the collections made by the author have been merged with those of The New lork Botanical Garden, which collection is very rich in American and European material. In the course of the work, collecting has been carried on from North Dakota to Colorado and New Mexico and east to New York and New England. No time has been spent in the far west. These collections have been supplemented by material sent, not only from every part of North America, but from nearly every part of the world.

Early in his work on Discomycetes the author came into contact, by correspondence, with Dr. E. J. Durand, then of Cornell University, and at that time an enthusiastic and, by all means, the foremost student of Disconycetes in America. Unfortunately his work was cut short by death before he had published any considerable part of his results on the operculate cup-fungi. It was the author's privilege to correspond and to exchange specimens with him up to the time of his death. His 
extensive collection, containing much valuable information, is now at Cornell University.

Since there is no monograph of the operculate cup-fungi in America it seems not out of place to publish at this time a summary of our knowledge of the group which has accumulated after many years of more or less intermittent observation and study. In fact the author has been urged by mycologists to do so. If this work is successful it may be followed by a larger and more extensive one with a larger number of illustrations. Looking to this, criticisms and difference of opinion will be welcomed, especially where accompanied by observations, photographs and actual specimens.

One of the chief difficulties to be encountered in the study of this group of fungi is that, while some of the species are very common, others are found only once or twice in a lifetime, so that it is difficult to make a detailed study of such forms over an extended period. Others are so small that they are never seen unless one is looking for them. In such cases the amount of material which is available for study is very limited. Some apparently valid species have been collected, described, and often never seen again. Perhaps this adds interest and is all the more reason for the publication of such a monograph as this at the present time. It should be borne in mind, however, that there is still an inexhaustible field of study for any student who is sufficiently interested to follow it up.

The writer wishes to express his thanks to all those who have in any way contributed to the completion of the work to this point. To attempt to acknowledge them all by name would only result in embarrassing omissions and perhaps require more space than warranted.

Your coöperation is solicited in making this work a success and thereby paving the way for something better. If it does nothing more than to stimulate a renewed interest in this group of fungi the author will feel that his efforts have not been in vain.

New York,

МАRCH, 1928 


\section{GENERAL FEATURES OF THE GROLP}

\section{Phylogeny}

As the higher land plants are thought to have originated from lower aquatic forms, so the Disconycetes or cup-fungi, as well as the other higher fungi, which might be referred to as the "terrestrial thallophytes," are also believed to have been derived from aquatics. We would naturally look for the ancestors of these chlorophylless plants among the chlorophyll-bearing forms, the algae.

While most mycologists will concede that the fungi have evolved from the algae, directly or indirectly, there seems to be a difference of opinion as to whether their course has been a direct or an indirect one. On this point there are two theories, one that the ascomycetes have come directly from the red algae and the other that they have come indirectly through the Phycomycetes or lower fungi.

Those who hold the former view base their argument on the similarity which they seem to see between the sex organs and other structures of the two groups, especially the resemblance of the trichogyne of the ascomycetes and of the red algae. Those who oppose this view contend that they can see no analogy or homology between the unicellular trichogyne of the red algae and the multicellular trichogyne of the ascomycetes. Even in Pyronema where the trichogyne is itself unicellular the wall at the base of the trichogyne is a little barrier which has caused a great deal of discussion.

These and other views advanced are, however, only hypothetical and since the purpose of the present work is to treat the Discomycetes as they are rather than to philosophize on how they might have come to be, we will proceed with the task in hand and leave the question of their origin for those who have given more thought to this phase of the work. For a full discussion of the subject see Atkinson on the "Phylogeny of the Ascomycetes" (Ann. Missouri Bot. Gard. 2: 315-376).

\section{Gross Morphology}

Like all of the higher fungi, the Discomycetes or cup-fungi present two distinct phases in their life histories, the growing 
or vegetative and the fruiting or reproductive. The vegetative stage consists usually of a mass of loose hyphae which penetrate often for a great distance into the substratum in search of food which must be obtained in the organic form since these lowly. plants have no chlorophyll. Occasionally as in the genus $W y$ mnea a sclerotium is formed. From the mycelium or sclerotium the fruiting body is produced usually after a longer or shorter period of vegetative growth, the length of the period varying with the

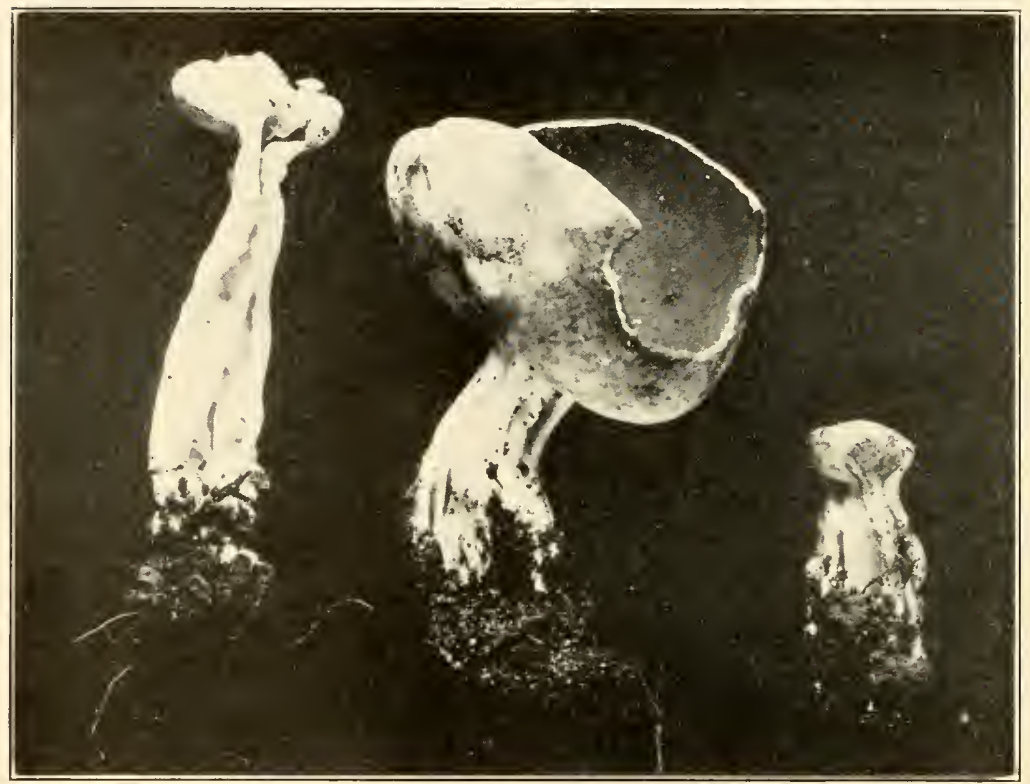

Fig. 1. Stalked apothecia of Paxina sulcata in various stages of growth. Photograph by IV. R. Fisher.

species. We often speak of the fungi as sporadic because they seem to appear at irregular intervals without rule or reason. The vegetative stage, however, is often persistent year after year in the same place where the substratum is constant, only the fruiting bodies being sporadic and even these occur with much more regularity than is usually supposed.

The fruiting stage of the cup-fungus is known as the ascophore, ascocarp, or ascoma and usually consists of a sessile or stalked disc or cup (FIG. 1) or in the Elvelaceae* of a distinct

* Various spellings have been employed for the generic name on which this family is based as follows: Eliela, Elvella, Heliela, and Heliella. The 
stem and pileus. The disc or cup is referred to as the apothecium, while the pileus is simply a modified form of the apothecium. The apothecium consists of two primary parts, the fertile layer on the upper side of the disc or lining the cup and known as the hymenium and the sterile portion below or partially enclosing the hymenium, the hypothecium, the upper portion of which is sometimes referred to as the subhymenial layer. The outer part of the hypothecium is often modified into a more or less well-defined layer, the excipulum. The extreme outer part of the excipulum may be modified still further into a thin membrane, the ectal layer.

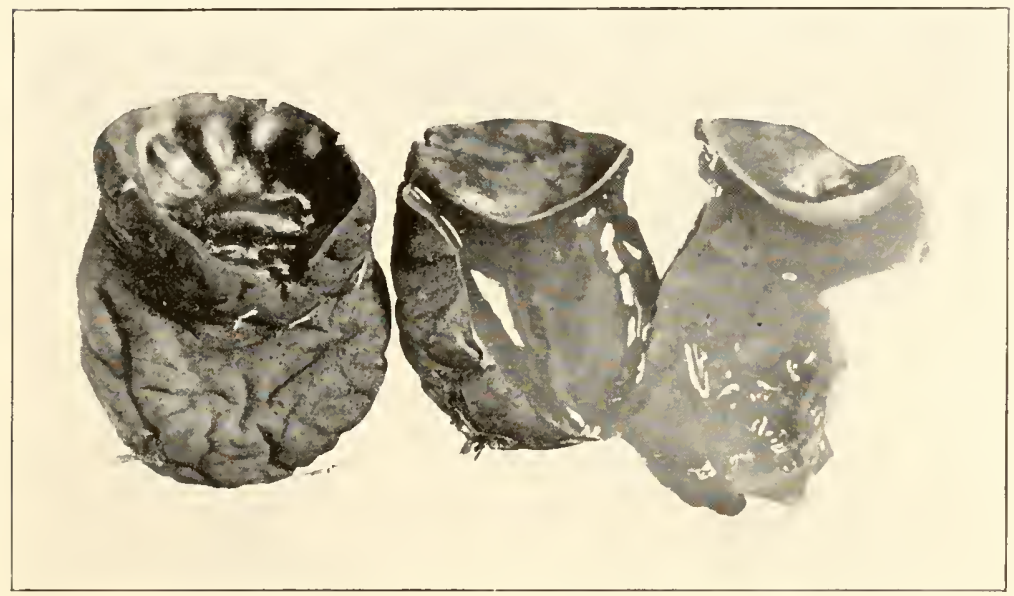

Fig. 2. Ipothecia of Bulgaria globosa.

The apothecium is usually rather thin, only a few millimeters in thickness and often quite brittle. The thickness and consistency vary much in the different species, some being very soft while others are tough and leathery or gelatinous. The extreme is probably encountered in Bulgaria globosa (FIG. 2). In this species the apothecium is at first subglobose, tough and gelatinous, resembling in appearance a rubber ball. When mature the hymenium appears as a circular depression on the upper side. This species seems to be very rare in this country. It has been collected in Canada by Mr. J. W. Gussow, to whom I am indebted for the accompanying photograph.

original spelling has been adopted in this work and citations are macke in this form regardless of the spelling used ly the various authors. 
The tissue of the hypothecium consists of an interwoven mass of mycelium known as prosenchyma, or the mycelium may' be transformed into a parenchyma-like tissue, the pseudoparenchyma. The one grades imperceptibly into the other. The cells of the excipulum may give rise to rigid or flexuous hairs which clothe the exterior of the cup.

The hymenium is composed of a palisade of sterile, clubshaped or filiform bodies, the paraphyses which are often pigmented giving color to the hymenium (see frontispiece), and larger cylindrical, club-shaped or ovoid bodies known as the asci in which the spores are produced in definite numbers in the following ratio: $2-4-8-16-32-64-128$, etc. The variation in the form and markings of the spores will be discussed in a later chapter. Occasionally the tips of the paraphyses form a rather distinct layer, the epithecium.

\section{Origin of the Apothecium}

The formation of the ascophore is known to be preceded in a number of species by a definite sexual process so that it has come to be regarded as the sexual method of reproduction although the process has been demonstrated in a comparatively small number of species and in some of these it is not certain that the organs, though present, are actually functional. Whether sex organs exist in all species of the group but have not yet been found or whether they have been lost in many is a question which can be answered only after long and careful research.

One of the first species in which a sexual process was olserved by the early workers, DeBary and Tulasne, is Pyronema omphalodes, probably because the sex organs are so very large and distinct in this particular form and so easily obtained, since the fungus probably occurs in every part of the world. At any rate, it has been found by the writer in every place that he has collected, both in continental North America as well as in the most obscure islands of the sea. All that is necessary for its growth is a burned area with sufficient moisture to insure growth. Detailed suggestions regarding the artificial grow th of this fungus will be discussed in a later chapter.

The sex organs in Pyronema as described by DeBary consist of clusters or archicarps and antheridia produced side by side and later arranged in pairs. The archicarp consists of a large 
globular cell or oögonium surmounted by a tubular outgrowth, the trichogyne, and attached to the mycelium by means of basal stalk cells. The antheridia are produced in a similar manner and are of about the same length as the oögonia but much more slender. The trichogyne at first grows upright but later curves about and partially surrounds the top of the antheridium, finally fusing with it. A wall is formed at the base of the trichogyne and about the same time the wall breaks down at the point of fusion of the trichogyne with the antheridium.
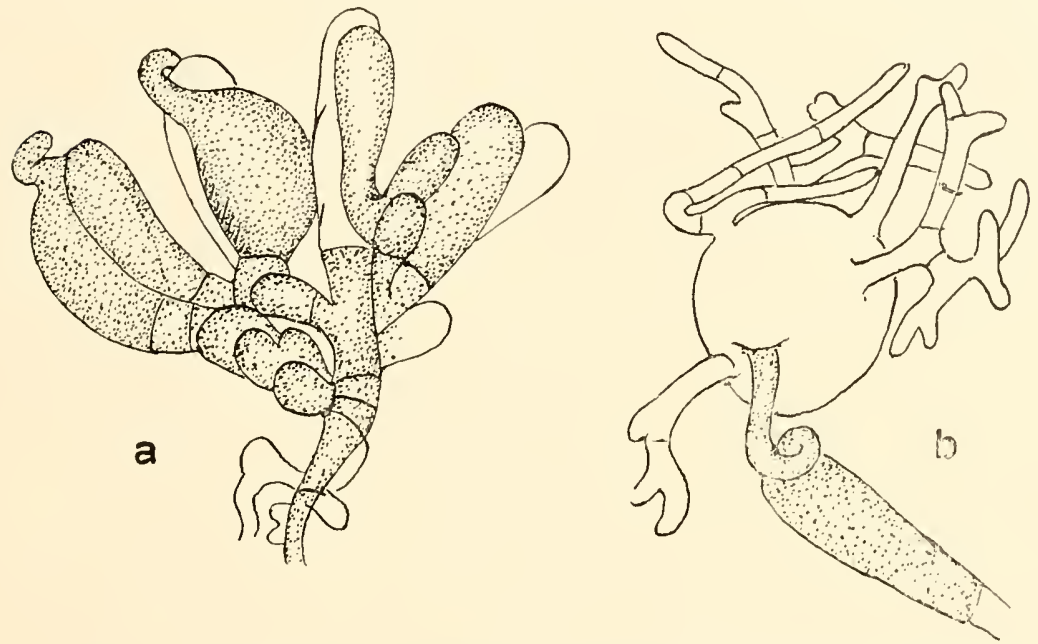

Fig. 3. Sex organs in Pyronema from 1)ebary. a, cluster of antheridia and oögonia. b, ascogonium producing ascogenous hyphae, with antheridium still attached.

After the fusion of the trichogyne with the antheridium the oögonium, which now becomes the ascogonium, swells up and produces outgrow ths in a dozen places or more, which outgrowths become the ascogenous hyphae and eventually give rise to the asci. This is the process as described by DeBary (FIG. 3), but it remained for later workers to add the cytological details.

Both the oögonium and the antheridium are multinucleate as well as the trichogyne. The nuclei of the latter later degenerate. The nuclei from the antheridium gradually pass in to the trichogyne. Although there is some difference of opinion on this point, it is generally conceded that the wall at the base of the trichogyne now breaks down, permitting the male nuclei to pass 
into the oögonium, after which the wall is rebuilt, cutting off the oögonium once more as a single large cell. The male and female nuclei now pair up within the oögonium and eventually fuse, although again opinions differ as to whether they fuse in the oögonium or merely pass in pairs through the ascogenous hyphae, increasing by conjugate division, finally completing their fusion in the ascus. The latter view seems to be the most generally accepted one.

The regetative cells at the base of the archicarps and the antheridia now put out a growth of sterile mycelium which surrounds the ascogenous hyphae, the two forming a compact mass which constitutes the apothecium.

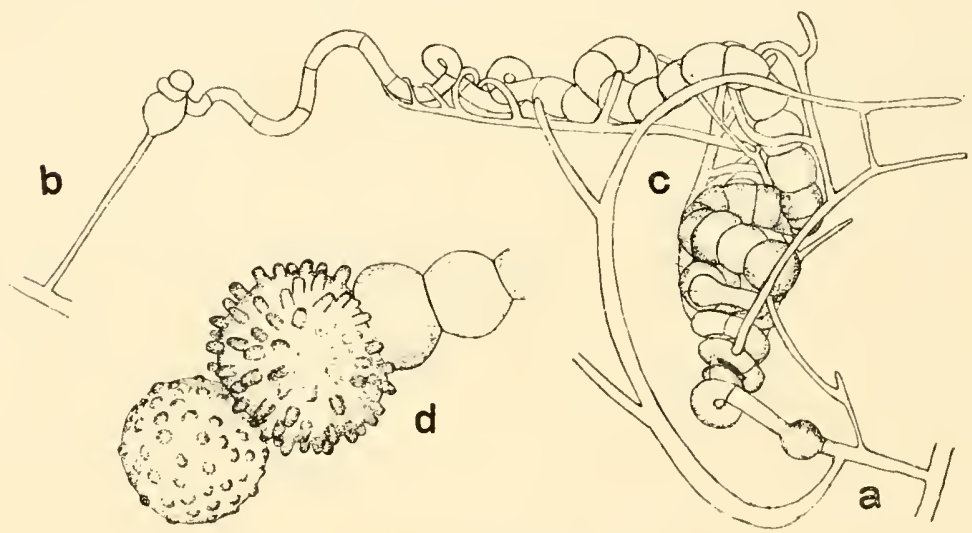

FIG. 4. Sex organs of Ascobolus carbonarius. a, conidiophore with germinating conidium. b, antheridial conidiophore. c, coiled archicarp with trichogyne entwined about the antheridial conidium. d, ascogenous hyphae developing from enlarged cells of the archicarp.

As shown by DeBary and other early workers the archicarp in Ascobolus furfuraceus differs from that of Pyronema in that it consists of a chain of cells of variable size, one of which near the center functions as an oögonium and eventually produces the ascogenous hyphae.

While working as a student in The New York Botanical Garden, B. O. Dodge, at the suggestion of the writer, took up a study of the Ascobolaceae, which study has added much to our knowledge of the morphology of this group of cup-fungi. Perhaps the most interesting of his discoveries is the method of reproduction of Ascobolus curbonarius which, unlike most of the 
members of this genus, grows on burnt ground and up to that time had not been studied morphologically by any American student. In fact the species is so obscure that it had been rarely collected. The reproductive process as described by Dodge is as follows: The mycelium of this species produces a large number of conidia. Some of these conidia while still attached to the mycelium germinate and give rise immediately to an archicarp which consists of a coil of swollen cells (FIG. 4) twenty to forty in number, growing larger then smaller in size as they extend outward, finally tapering off into a multicellular trichogyne which entwines itself about an antheridial conidium similar in appearance to the one from which the archicarp

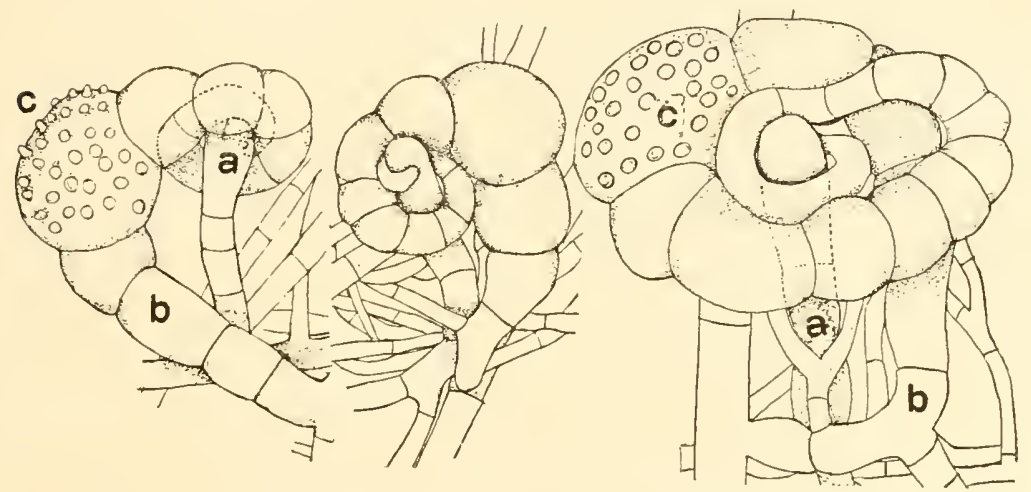

FIG. 5. Sex organs in Ascobolus magnificus. a, antheridial branch. b, archicarp branch. c, ascogonium showing the beginning of the ascogenous hyphae. Figs. 4 and 5, after Dodge.

originated. While these are regarded as sex organs, and probably justifiably so, there is no definite proof that the multicellular trichogyne actually fuses with the antheridial conidium and no cytological details to show that these structures function as sex organs. About three cells of the archicarp nearest the stalk cell enlarge, the second cell of which produces the ascogenous hyphae and is regarded as the ascogonium.

Dodge has also made some interesting observations on Ascobolus magnificus, a species which he himself has described. This species was kept under observation for a long period in the laboratory. According to his report, the apothecia originate from club-shaped bodies which are produced in numbers throughout the colony, often in pairs. The bodies are at first one- 
celled, later two- or three-celled. At this point one ceases to grow and apparently becomes the antheridium. The other continues to grow until it becomes a multicellular archicarp, the end of which tapers into a long slender, multicellular trichogyne which coils itself about and finally fuses with the antheridium (FIG. 5). One of the cells enlarges and becomes the ascogonium. This is similar in all essential details to that recorded for other species of Ascobolus. In this particular case the sex organs are so large that they can be dissected out with fine needles.

While definite sex organs have been observed in a number of species of operculate cup-fungi and the cytological details worked out in several, a great many are still to be investigated before we can draw any general conclusions as to the extent to which these organs are present and actually function.

\section{Ascospore Formation}

After the pairing or fusing of the male and female nuclei in the ooggonium the ascogenous hyphae develop from the
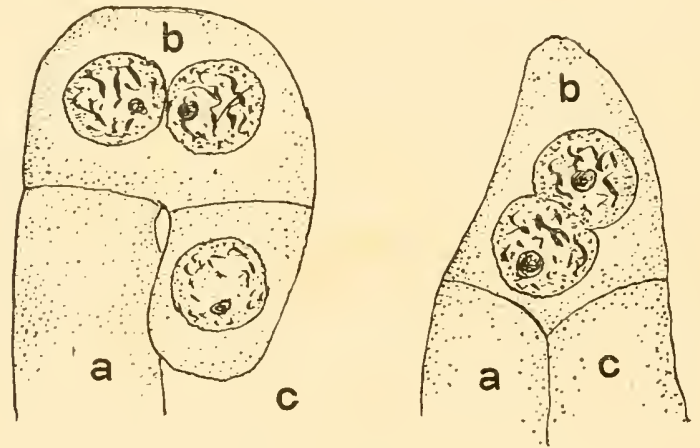

F1G. 6. Beginning of ascus formation. a, basal cell. b, loop cell. c, tip cell.

ascogonium, the paired or fused nuclei passing into the ascogenous hyphae. Just what transpires between the time the nuclei pass into the ascogenous hyphae and the beginning of the formation of the asci from their ultimate branches it is difficult to say since the ascogenous hyphae intertwine in such a manner that it is almost impossible to follow any one through the entire process. The ultimate branch of the ascogenous hypha forms a loop consisting of three cells which might be designated as basal or stalk cell, loop or dome cell, and tip or ultimate cell (FIG. 6). 
The basal and tip cells each contain one nucleus while the loop cell contains two. The two nuclei fuse and the loop cell elongates into the ascus. The original nucleus of the ascus which has resulted from the fusion just mentioned divides three or more times, usually giving rise to as many nuclei as there are to be spores in the ascus although some may degenerate or several be included in a single spore. After arranging themselves in the proper position in the ascus, each nucleus surrounds itself with a part of the cytoplasm of the ascus and becomes a spore, surrounded with a rather firm wall, the firmness of the wall varying much in different species.

The development of the spores by the process of free cell formation has been described in detail by R. A. Harper in his studies on Pyronema (Ann. Bot. 14:363-368). At the pole of each nucleus, after the final division of the fusion nucleus in the ascus, is an aster of fibers which persist and arrange themselves in the form of a wheel about the beak of the nucleus and finally cut out a nearly spherical mass of cytoplasm which encloses the nucleus and, with the development of the wall, becomes the young ascospore. A part of the cytoplasm of the young ascus is used in the formation of the spore and the remainder, which is known as the epiplasm, serves to nourish the young ascospore and to furnish material for the sculpturing of the wall, in those species which have sculptured spores.

All ascospores are at first smooth and many remain permanently so. In a number of species of the present group, however, the walls of the mature spores have elaborate markings of a very definite character. These seem to be formed by an accretion of epiplasm about the spore-wall. The process is well illustrated in Sphaerosoma echimulatum of the writer (which in this work is referred to Boudiera). After the spores are formed in this species, a definite sheath of epiplasm four to five microns thick appears about the spore and is known as the exospore. The sculpturing first appears on the surface of the spore-wall and gradually grows outward until it reaches the outer boundary of the exospore. Even afier the sculpturing is completed a definite line persists which marks the outer limits of the original sheath. In other species such as Lamprospora Crec'hqueraullit the sculpturing seems to come about as a gradual growth after the spore is formed. So far as our observations have gone the spores of the operculate cup-fungi are permanently one-celled, 
although the spores of the inoperculate forms are often multicellular.

\section{Alternation of Generations}

Assuming that the sex organs do function in the cup-fungi and taking as an illustration the best known form, Pyronema omphalodes, it is interesting to trace the alternation of generations as we know it in the fungi. The sporophytic generation would begin with the pairing of the nuclei in the ascogonium and continue through the ascogenous hyphae up to the reduction division in the ascus. The gametophytic generation, initiated at the conclusion of reduction division, is continued through the ascospores, mycelium, and up to the formation and fusion of the trichogyne with the antheridium, and the pairing of the nuclei in the oögonium.

\section{Heterothallism and Homothallism}

While heterothallism has been observed and established in the Phycomycetes and some of the higher Basidiomycetes, it is only recently that it has been demonstrated in the ascomycetes, including some of the species of operculate Discomycetes. Dodge states that in Ascobolus magnificus he was unable to obtain sex organs from one spore culture while they were abundantly formed on the mixing of two strains. In this case the sex organs were not produced in a definite line where the strains come together but the mycelia mixed so that they were produced throughout the culture but more abundantly where the two strains came first into contact.

Under the direction of Dodge, Edwin Betts has recently demonstrated heterothallism in Ascobolus carbonarius (Am. Jour. Bot. 13: 427-432. 1926). While it was found impossible to produce ascocarps from single spore cultures, they could be produced by the intermingling of the mycelia from different spores, eren those from the same ascus. From this it was concluded that sex factors are segregated at the time of the ascospore formation in the ascus and that probably four of the spores are of one sex and four of the other.

It has also been shown that in some species of ascomycetes which have only four spores in the ascus, two nuclei, one of each sex, may be included in the same spore. When such spores are germinated they produce a homothallic or monoecious mycelium, while a spore originally containing only a single nucleus will 
produce a heterothallic, dioecious, or unsexual mycelium. While these facts have been demonstrated in one species of the ascomycetes, further investigation is necessary in order to determine whether this is true of the operculate Discomycetes. A number of species of this group are known to have usually, if not always. four spores instead of eight. Unfortunately these forms are not often collected in sufficient numbers for cytological and cultural study. This phase of the subject also offers excellent opportunity for research.

\section{Spore Discharge}

Once the spores are formed, the next step, so far as the fungus is concerned, is to "broadcast" them so that they

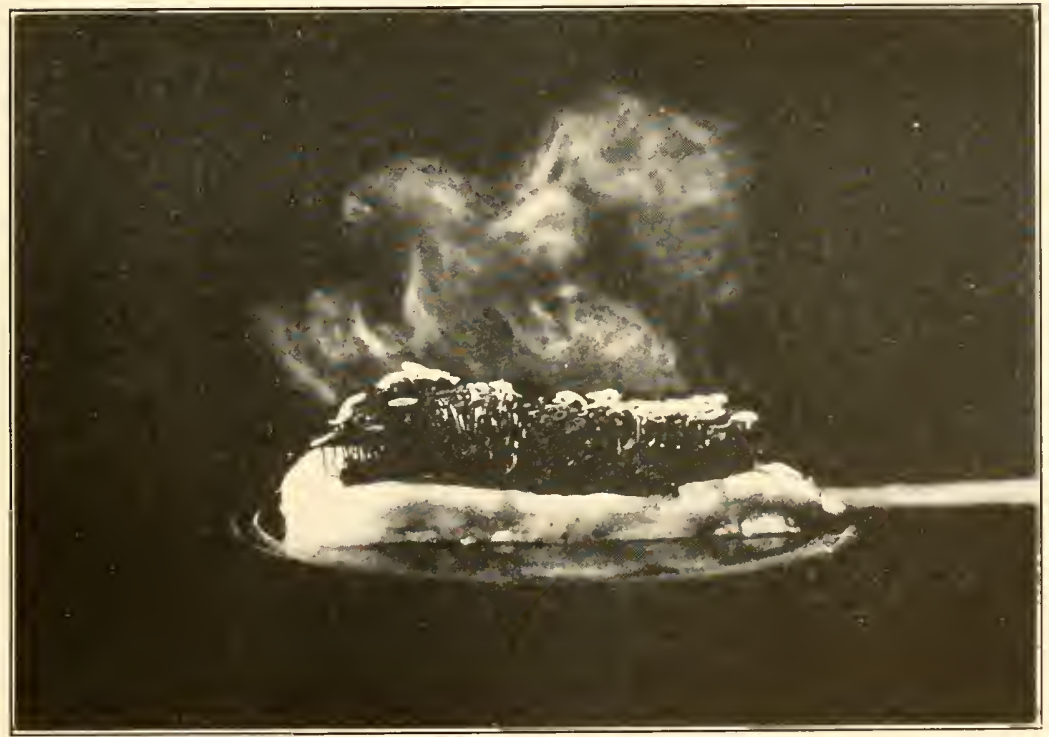

FIG. 7. Puffing of the spores in one of the inoperculate cup-fungi, Sclerotinia Photograph by IV. R. Fisher.

may best serve the purpose for which they were designed, that of the reproduction and dissemination of the species. Probably there is no group of fungi in which the apparatus for spore dissemination is more highly developed than in the present one. Formed in a closed sac or ascus, usually of cylindrical form, they are held there for a time, apparently under high tension. Finally when conditions are just right, the ascus opens in an 
orderly fashion and the spores are literally shot out. Just why so many asci discharge their spores in unison, it is difficult to state except that all naturally respond in a similar manner to the same stimulus. Just what this stimulus is no one has been able to decide with certainty. The contraction of the ascus after rupture would have a tendency to force the spores out. It was at one time thought that the Ascobolaceae ejected their asci but this was a mistake.

In the larger cup-fungi so many asci discharge their spores at once that it gives rise to a faintly audible puff and is apparent to the unaided eye as a cloud of smoke (FIG. 7). This phenomenon is well known to all students of fungi but it remained for Mr. IV. R. Fisher of Cornell University to photograph the process and to him I am indebted for the accompanying illustration which has been previously published in Phytopathology. A. H. R. Buller believes that puffing does not take place under natural conditions. It is certainly frequently observed in the field although it may be due to unusual disturbance of some kind.

The force with which the spores are discharged has been indicated by Buller in his "Researches on Fungi " for A scobolus immersus. His experiments showed that the maximum height of projection was $35 \mathrm{~cm}$., the violence of the discharge probably not being exceeded by any other ascomycete.

\section{Heliotropism or Phototropism}

While the vegetative stage of the cup-fungi is able to grow in the absence of light, being chlorophylless, the fruiting stage invariably seeks the light and is positively heliotropic or phototropic. This is especially apparent in the asci themselves. At maturity, the asci often protrude half their length or more above the surface of the hymenium. This character was at first thought to be restricted to the Ascobolaceae and in fact was the distinguishing character of the family, as at that time known. It is, however, now known to be common to many if not all of the operculate cup-fungi although much more apparent in some than others. It is especially apparent in Ascobolus immersus because of the large size of the spores and asci and the fact that the dark color of the latter renders them more conspicuous by reason of contrast. When grown in the laboratory near the window the asci will be found to bend at a strong angle toward the light. 
This heliotropic response of the ascus is most apparent in those species which have comparatively large spores. It is a prominent character in many species of the genus Lamprospora for, in spite of the small size of the plants of this genus, the asci and spores are relatively large, while in some of the large cups of the genus Peziza it is much less apparent because of the small size of the asci and spores.

If the asci protrude far above the surface of the hymenium the bending in response to light occurs far down on the ascus, while in those that protrude less strongly the lending is nearer the apex, interfering with the bilateral symmetry of the ascus.

\section{Dehiscence of the Ascus}

There are in the Discomycetes several ways in which the ascus may rupture in order to permit the spores to escape. On

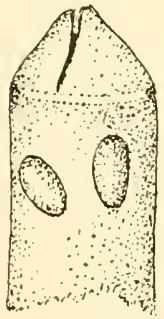

b

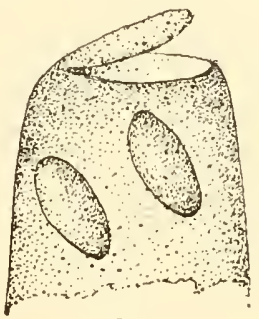

a

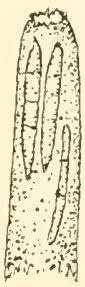

C

FIG. 8. Methods of dehiscence of the ascus. a, operculate.

b, bilabiate. c, inoperculate.

the bases of the dehiscence of the ascus, they may be classified as operculate and inoperculate forms. By the term operculate we mean the presence of a lid which is quite circular in form and of variable size by means of which the ascus opens (FIG. 8, a). The operculum almost invariably remains attached at one side after the discharge of the spores and often one or two spores may be left behind after the process is completed. The opening formed by the rupture of the ascus will be here designater as the ascostome.

The inoperculate method of dehiscence consists of a simple rupture which leaves the margin of the ascostome toothed and ragged after the spores have been ejected (FIr. 8, c) but with no sign of an operculum or lid. 
A third type of dehiscence is known among a few of the cupfungi and is referred to as the bilabiate method (FIG. 8, b). This consists of the rupture of the ascus by means of a transverse slit across the top so that the ascostome gaps open like a fish's mouth after the expulsion of the spores. This is characteristic of the genus Streptotheca and a few allied forms. Roughly this is considered as a modification of the operculate method and those forms which show this type of dehiscence are classed with the Operculates since otherwise they show more affinities with this group than with the Inoperculates.

\section{Significance of the Mode of Dehiscence}

The operculum was first observed by H. M. Crouan in some species of A scobolus but he had not seen it in the larger Pezizaceae. It was at first regarded as one of the characters of Ascobolus and some species in which the operculum had been noted were transferred to Ascobolus for this reason. This is no longer looked upon as a generic character and species originally placed in Ascobolus are now treated as Ascophanus, IIumarina and Lamprospora, the genus A scobolus being used in a more restricted sense.

The inoperculate method of dehiscence was also observed by Crouan but no great importance was attached to it at that time. Later M. E. Boudier found the asci of many of the larger Pezizaceae to be operculate and he first suggested dividing the Discomycetes into two groups, the operculate and the inoperculate forms, and proceeded to show that the presence or absence of the operculum in the ascus was a character of fundamental importance. It is so regarded in this work and, so far as the writer knows, by all modern students of cup-fungi.

As pointed out by Boudier this seems to be a very natural division and there is little difficulty in determining the method of dehiscence although few workers at that time took the trouble to mention it. Boudier also made, in the opinion of the writer, a very important observation when he mentioned that in most cases the operculum was horizontal or at right angles to the long axis of the ascus while in a few species it was oblique.

That the separation of the cup-fungi into the Operculates (Operculatae) and Inoperculates (Inoperculatae) is a natural division and morphologically sound is indicated by the fact that associated with this character are certain other morpho- 
logical "ear-marks" which run true to form so that it is not actually necessary to see the operculum in order to know, with reasonable certainty, that a cup-fungus belongs to the operculate group. These characters are as follows:

The spores of the Operculates are comparatively large, never septate, often warted or sculptured, and ranging from globose to broad-ellipsoid, more rarely fusiform but never very slender or filiform. The plants of this section usually occur on soil, dung, well-rotted wood and only rarely on hard woody stems.

The spores of the Inoperculates on the other hand are comparatively small, usually smooth, narrow and often very long and slender or filiform and often septate or showing a strong tendency to become so. The plants of this group are seldom terrestrial (except the Geoglossaceae) but usually occur on hard stems, wood or leaves. While the spores of this group are in a very few cases globose, they are, in such forms, very much smaller than the globose spores of the Operculates. There is also a decided difference in the type of hairs clothing the outsicle of the apothecia, when such are present.

Some collectors object to using this character as a basis of division because of the erroneous idea that it is a difficult one to observe. This is not the case, but even if it were, it is scarcely a valid excuse for failing to recognize so fundamental a difference.

\section{Eccentricity of the Ascostome}

As mentioned above, the operculum is usually situated at right angles to the long axis of the ascus while in some species it is oblique. In the course of this work the writer has noted this latter character in a number of species of tropical Discomycetes, especially those belonging to the genera Phillipsia, Cookeina and Wynnea. It has also been observed in Plectania hiemalis, a temperate form but one which shows a general relationship with the tropical forms just mentioned. It may occur in many others but these are the forms in which it has been especially noted. Perhaps too little importance has been attached to this character but, up to the present time, it has merely been accepted by the writer as one of the many morphological characters of certain species without attempting to explain the reasons for its existence.

In connection with his excellent researches on fungi Dr. Buller has offered a very interesting theory in an attempt to 
account for the eccentricity of the ascostome. He believes that the phenomenon is heliotropic and that it will vary in the same species with the direction of the light. Following this theory, those species with deep cups in which the asci stand at an angle of 45 degrees, the operculum would be developed on the upper side of the ascus in order that the spores might be directed upwards instead of being shot across to the other side of the cup.

So far as the observations of the writer are concerned, there appears to be no relation between the depth of the cup and the eccentricity of the operculum and ascostome, since the latter character has been found to be very constant in species belonging to certain genera without regard to the form of the cup. A fine example of this is afforded in Phillipsia Chardoniana illustrated

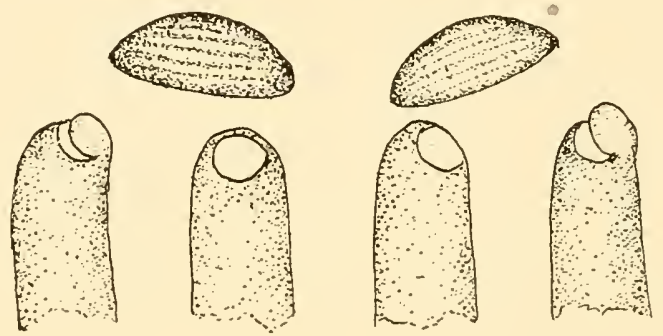

Fig. 9. Eccentricity of the ascostomes in Phillipsia Chardoniana, shown on the frontispiece.

in the frontispiece of this work. In this species the apothecia are as flat as a pancake yet, so far as observed, the ascostomes are always eccentric or, at least, they are conspicuously and predominantly so (FIG. 9).

Another species in which the eccentric ascostome has been especially observed is Cookeina Colensoi, a shallow cup which occurs on wood in the tropics. So far as observed, the ascostome in this species is always located decidedly on one side and is unusually small compared with the size of the spores so that there must be a good deal of stretching when the spores are discharged through it (FIG. 10).

Having noted this character in various species of Phillipsia and Cookeina and recalling that both of these genera have much in common with the genus Wynnea, species of this latter genus were examined and the same conditions found to exist (FIG. 11). In all of these cases, however, it was necessary to work with 
dried material, which is certainly much more unsatisfactory than fresh material would have been.

While no exhaustive observations have been carried on, it can be stated that the eccentricity of the ascostome is a character common, if not universal, in species of Phillipsia, Cookeina and
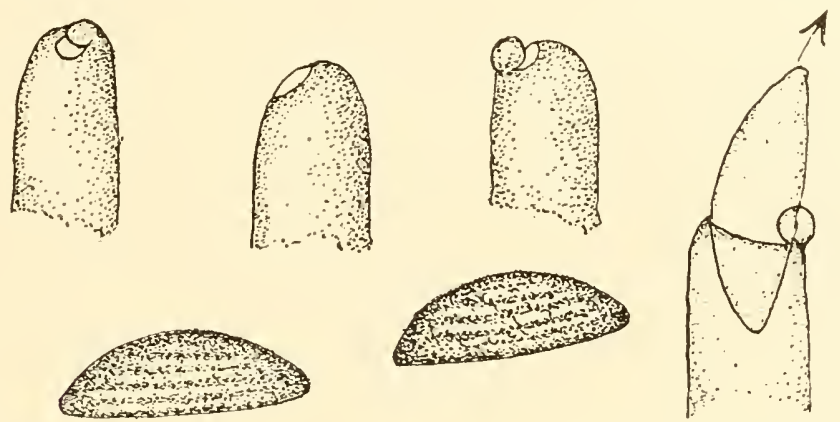

F1G. 10. Asci and spores of Cookeina Colensoi showing eccentric ascostomes and the comparatively large size of the spores.

IVynnea, which genera are essentially tropical although one species of IIynnea has been reported from the north. It has also been observed in Plectania hiemalis, a northern species but one which resembles Cookeina in many respects. It seems to

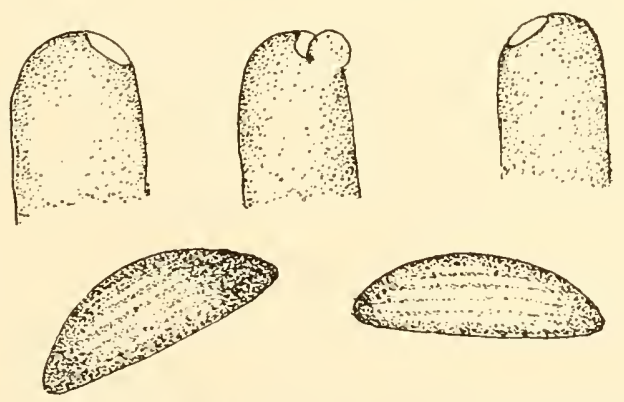

FIG. 11. Asci and spores of Hynnea americana showing eccentric ascostomes and comparatively large size of the spores.

make no difference whether the apothecium is plane, concave, regular or otherwise. This character appears also to be accompanied by certain other morphological characters. The spores are unusually large, fusoid, unequal-sided and in nearly every case marked with the peculiar striations consisting of light and 
dark bands which have been mentioned so frequently by the writer in connection with his studies of tropical ascomycetes. Whether we consider the eccentricity of the ascostome as a morphological character or otherwise there is certainly a striking similarity in all of the species in which it has been observed by the writer, and we are inclined to regard this as one of the "earmarks " of certain genera and groups of operculate Discomycetes. Just how frequently it occurs in other genera than those indicated cannot be stated.

It still remains that if the asci in those species with flat apothecia have eccentrically placed ascostomes, it may be due to the fact that the light rays reached the plant in an oblique manner and that the ascostomes were adjusted accordingly. It is impossible to follow out this line of argument since the forms in which this observation has been made are tropical and we have had no opportunity to experiment with them in a growing condition. Even this theory would not explain the fact that the ascostomes are always eccentric in some species while never so in others, both of which have grown out-of-doors and been subjected to the same light influences. Also it has been noted that where the ascostome is eccentric the operculum usually remains attached at the lower margin of the ascostome where it would impede the passage of the spore in that direction.

Our observations, up to the present time, do not seem to fit in with Buller's theory, and we feel that further evidence is necessary before this can be accepted as an explanation of this interesting phenomenon in the species mentioned above. A careful study of those forms should be made in the field.

In all of the species in which the eccentricity of the ascostome has been noted there is a great discrepancy between the size of the ascostome and the spore which has passed through it (FIGs. 9-11). Since the ascostome is intact after the spores have been ejected from the ascus, there is only one conclusion-that the ascostome has stretched and contracted during the process of spore ejection. Another observation worthy of mention is that the spores in all of these forms are strongly fusoid. From these facts we might easily conclude that the small size of the ascostome, as compared with the spore, is no accident but is in some way concerned with the process of spore ejection. When the spore has passed half-way through the ascostome which is at that time stretched to the limit, the contraction of the ascostome 
would have a tendency to accelerate the force with which the spore is ejected or "snapped out" of the ascus just as a seerl of a citrous fruit may be snapped from between the fingers by bringing them quickly and tightly together. There must be a contraction between each spore ejection, the ascus operating like a machine-gun .

Another point that might be mentioned here is the fact that in all of these forms the spores are not only fusoid, but unequalsided. Since they do not always lie in the same position in the ascus, this would have a tendency to throw the spores in different directions, which would be a decided advantage, as these particular forms have large, heavy spores as compared with other species of the group and would not be so easily blown about by the wind. While these latter facts seem to have no particular bearing on the eccentricity of the ascostome they are mentioned here because they have been noted in connection with that character.

\section{Asexual Reproduction}

While asexual spores have been reported for a few species of operculate cup-fungi, such as Peziza vesiculosa and Peziza repanda, on the whole this type of reproduction is conspicuous by its absence in many of the species of this group, or, at least, has not been observed. Plants of this section are in marked contrast to some of those of the Inoperculates such as Sclerotinia in which the reproduction by means of asexual spores has been developed to a very high degree. So far as Sclerotinia is concerned, this may be an adaptation to the parasitic habits of the plants of the genus, the conidia functioning as repeating spores for the rapid dissemination of the fungus while its host is in a susceptible stage.

The botryoide type of asexual spores has been reported by Dodge for one species of the present group, Patella abundans (FIG. 12). This is a sumprise since this type of conidia is characteristic of one section of the species of Sclerotinia, a genus which in every other character is absolutely unrelated to Patella. Perhaps careful search will reveal asexual spores in cases where they have not been suspected up to the present time.

Since several of the operculate cup-fungi in which conidia have been found are heterothallic, it has been suggested that in this group the conidia are especially adapted to facilitate the bringing together of the plus and minus strains, thereby in- 
suring sexual reproduction. It is easy to conceive that they might serve this purpose.

While asexual reproduction by means of conidia is comparatively rare in the present group, so far as our present knowledge goes, some are readily reproduced from spawn. This is especially true of the coprophilous forms. The dried substratum with the spawn can be kept dormant for long periods, while growth is resumed almost immediately on being restored to moist conditions.

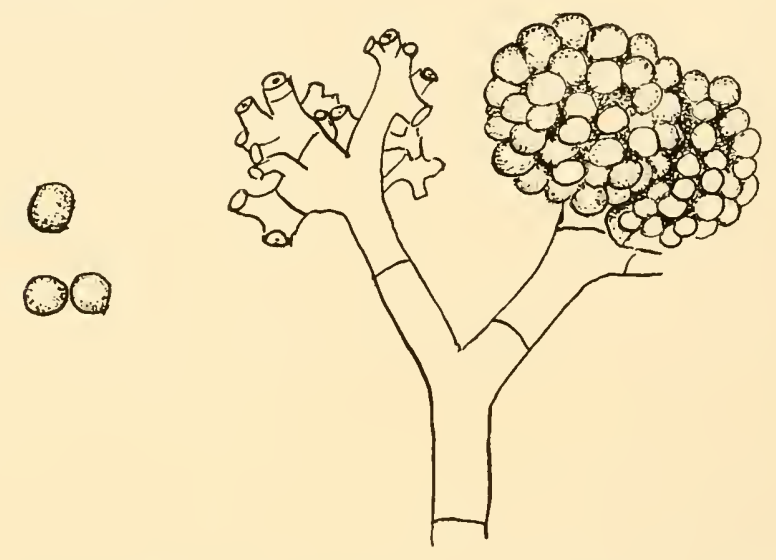

FIG. 12. Botrytis type of asexual spores reported by Dodge for Patella abundans.

\section{Ecology}

With a few possible exceptions, the plants of this group are all saprophytic, although it is not easy to determine absolutely whether a fungus is parasitic or saprophytic without extended investigation. A few species of operculate cup-fungi which appear on dead foliage may have been parasitic on the living host, coming to fruit only after its death. Pithya Cupressi on the foliage of certain evergreens might be cited as one of this type. Also Humarina axillaris grows in the axils of the leaves of a moss and Inmarina ithacaensis on the thallus of a liverwort. The great majority, however, are strictly saprophytic, growing on all kinds of decaying material, especially vegetable humus.

Even saprophytes are often very selective in their habits or tastes and grow only on certain types of decaying material. Several species of IItmarina grow only on the humus of decaying 
mosses and some species of Lamprospora show the same tendency. Others grow on decaying wood, often showing a preference for certain kinds of wood, while still others occur on burnt soil or on dung, being designated as pyrophilous and coprophilous forms respectively. Since the latter forms are of more than usual interest they will be treated more in detail.

\section{Pyrophilous Cup-fungi}

There are quite a number of operculate cup-fungi which occur in nature only on burnt places, especially where piles of

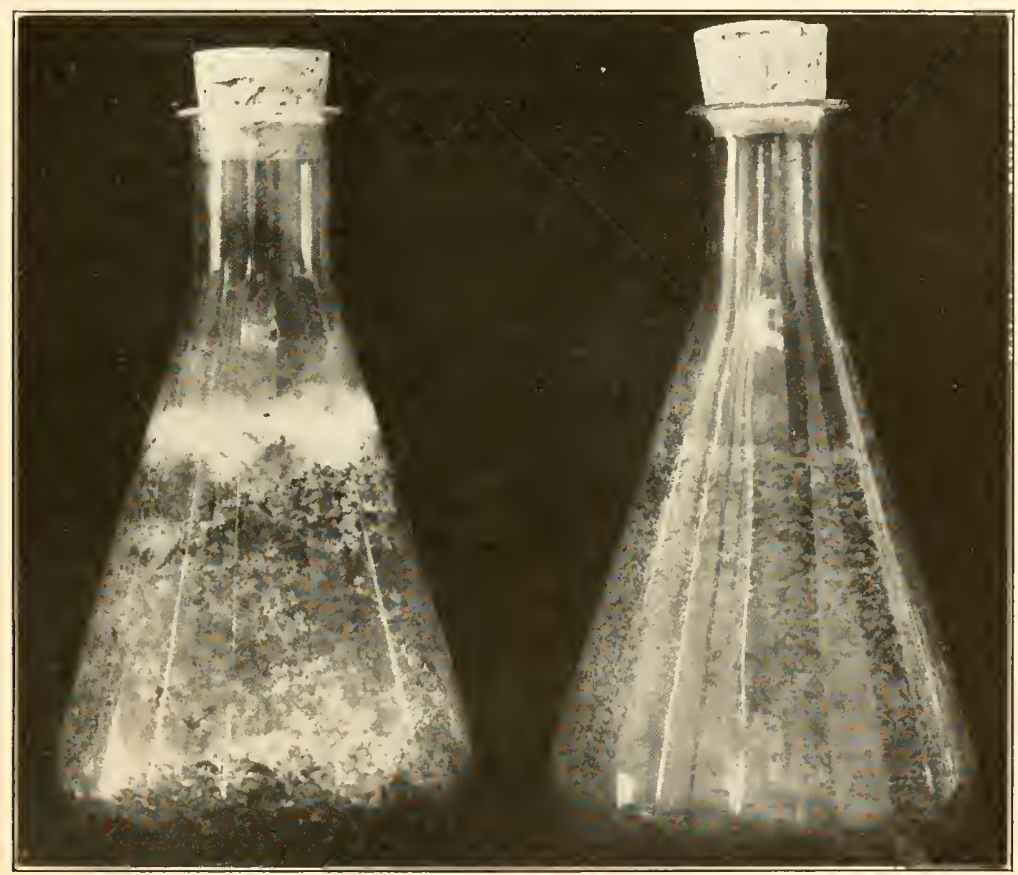

Fig. 13. Left, flask of heated soil with abundant growth of Pyronema. Right, same soil unheated but otherwise treated in the same manner produces no growth.

wood or brush have been burned. The most common of these is the well-known Pyronema, first encountered by the writer during his early work in Iowa. Without stopping to investigate the matter it was simply assumed that this fungus occurred on burnt places because it preferred ashes to grow on as other 
species preferred wood which had been rotted rather than burned.

While working at The New York Botanical Garden as a student in 1906, the attention of the writer was called to a pink fungus overiunning the soil in the greenhouse which had been sterilized with steam. On examination, the fungus proved to be Pyronema. This exploded the previous assumption that the

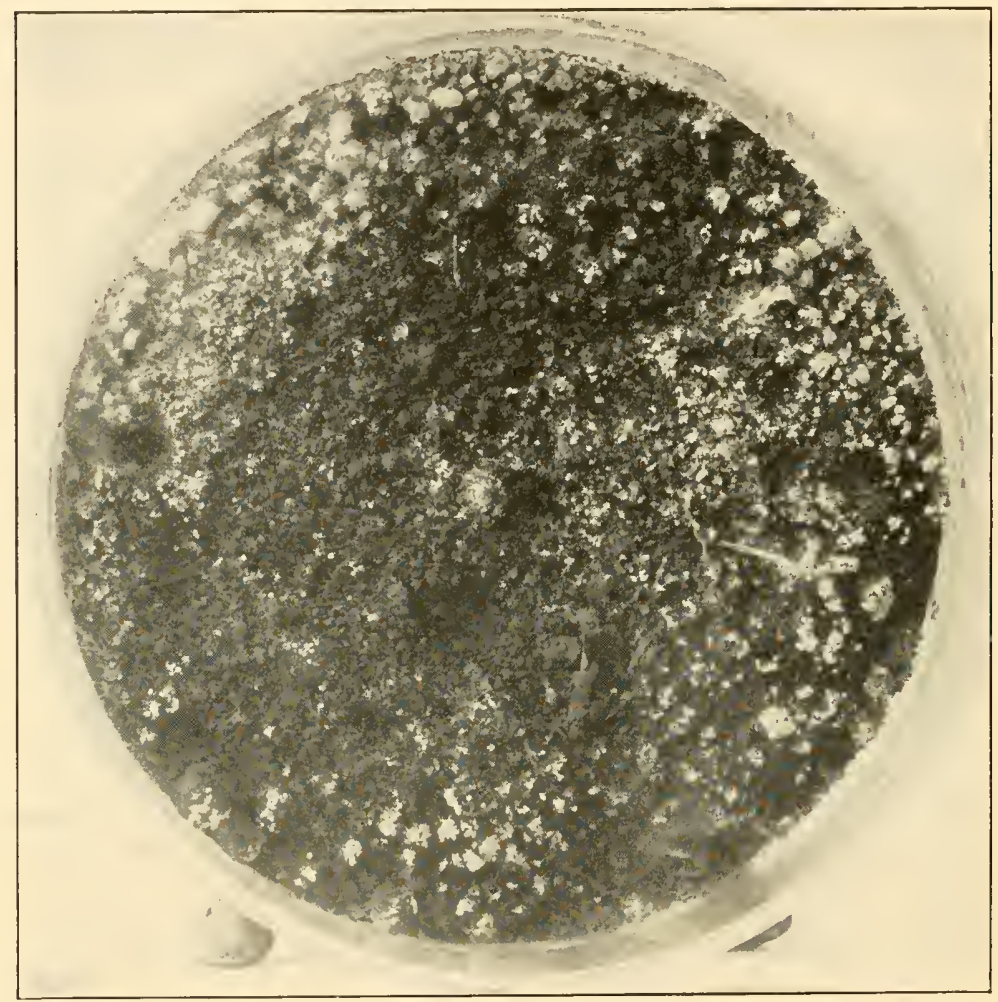

F1G. 14. Culture of Pyronema on heated soil, suitable for class study, showing all stages from the clustered sex organs to mature apothecia.

fungus occurred on burnt places because of the ashes, for there were no ashes in the steam-sterilized soil. As a result of these observations experiments were undertaken which finally proved that Pyronema could be grown on any rich soil which had been heated to a high temperature either by dry heat or steam and later cooled, wet, and inoculated with the spores of the fungus. 
In fact, nature usually supplies the spores provided we comply with the other requirements, but to make certain we usually supply them. Control experiments show that Pyronema cannot be grown on unheated soil, even though the same soil is used and all the other requirements are met (FIG. 13). It must be borne in mind, however, that the spores in this case do not require heating. In fact it is doubtful if they could withstand the process. It is only the soil that should be heated.

Later experiments conducted by the writer in coöperation with Dr. E. D. Clark (Mycologia 2: 109-124. 1910), formerly of the Department of Biological Chemistry of Columbia University, proved that the question of growth of Pyronema on heated soil was purely a food problem. The heating renders insoluble organic matter soluble, which material serves as an excellent medium for the growth of many fungi as well as Pyronema. The growth of Pyronema on steamed soil had been noted in Europe but, so far as we are aware, no one who knew the fungus had ever observed it in America. As full data on this subject have been published in preliminary papers it seems unnecessary to repeat them here.

Whether other species of pyrophilous cup-fungi grow on burnt soil for the same reason has not been demonstrated but it is suspected that this factor may influence them to a greater or lesser degree. Betts (1.c.) mentioned the fact that he could not produce sex organs in Ascobolus carbonarius on agar but that they developed readily when germinated spores were transferred to sterilized soil, indicating that the sterilized soil offered the better medium. Pyronema, however, fruits readily on agar.

\section{Coprophilous Cup-fungi}

This term is applied to those species which grow exclusively on the dung of animals, and some show a decided preference for the dung of certain kinds of animals. Ascodesmis porcina has been grown only on pig dung, first on material from Porto Rico and later on the same kind of dung from New Jersey. It is probable that such a species would grow on the dung of closely related animals but up to date it has been found only on the dung of the one kind. Others are not so discriminating in their tastes but thrive on almost any kind of excrement. That coprophilous forms can grow on other substrata is evident from the fact that they are produced in cultures on agar. 
From the fact that the spores of the species of many coprophilous fungi do not germinate readily, it has been assumed that it is not only possible but necessary that they pass through the alimentary canal of the animal before they could be induced to germinate. Many experiments have been conducted to show that this is the case and there is little question that this process does stimulate germination.

The distribution of the spores in such forms is easily accounted for. Growing as they do on dung in pastures, the spores which are more or less sticky on being discharged from the ascus easily adhere to blades of grass and other forms of vegetation. The grass is eaten by cows or other animals and the spores gain entrance to the alimentary canal and, on being released, are ready for action. It is not unusual to find spores of coprophilous fungi on leaves of living plants in the field. The writer once spent considerable time trying to identify a supposedly parasitic fungus from Bermuda on blades of grass only to find later that they were the spore caps from Pilobolus which adhered so closely that they appeared to have grown there.

\section{Spore Germination}

The spores of many of the species of cup-fungi germinate readily and without any special treatment. In some of the species, however, as indicated above, the spores do not germinate by the ordinary method. This has already been referred to in the coprophilous forms, especially species of Ascobolus. The members of this genus are not all coprophilous, some occurring on wood and one species, Ascobolus carbonarius, on burnt ground and still others on naked soil.

On the assumption that the spores of the coprophilous species must pass through the body of the animal in order to stimulate them to grow, attempts have been made to simulate these conditions by artificial means and favorable results have been obtained by this method.

Dodge in his researches on Ascobolaceae, referred to above, tried many experiments and found that spores of several species of Ascobolus, including Ascobolus carbonarius, could be made to germinate in culture by heating them to a temperature of 50 to 70 degrees centigrade. 'The heat stimulus seemed to be a favorable substitute for the chemical stimulus of the alimentary canal. From this we might assume that Ascobolus carbonarius 
has been evolved from a coprophilous species, the spores of which having been planted on the ground, stimulated by the heat of the fire, and supplied with a suitable nutrient medium released by the heating of the soil, grow and become adapted to this habitat. It differs from Pyronema which it resembles in habitat by the fact that the spores of the latter lo not require the heat stimulus to induce germination.

\section{Viability of the Spores}

The length of time the spores of the cup-fungi will keep their viability probably varies greatly with different species. The writer has not carried on any extensive observations along this line but the one species Pyronema omphalodes has been experimented with and the spores found to keep their viability for nearly three years in an ordinary herbarium packet in the herbarium. How much longer they might have retained their power to germinate has not been determined.

This fact ought to be of especial interest to those who are interested in keeping this fungus on hand for cultivation in class use.

\section{Mycophagy}

The majority of the operculate cup-fungi are too small to be worthy of consideration as articles of cliet. Many of the larger species are recommended by mycophagists and are used whenever they can be found in sufficient quantity. None, so far as the writer knows, are decidedly poisonous although one species has been under suspicion. This is the so-called Gyromitra esculenta (FIG. 15) which the writer here regards as merely a gyrose form of Elvela infula, at least so far as our American forms are concerned. It is interesting to note that this form which was originally designated as "esculent" should be the first one to be brought into disrepute. Of course our American form may be different from the European which goes under the same name. Some mycophagists claim to have eaten it without the slightest discomfort but, if used at all, one should proceed very cautiously.

Probably the most valuable species from the culinary point of view is Morchella esculenta, more commonly known as the "common morel," the "spring mushroom" or the "honeycomb fungus." In the northern states this species occurs almost exclusively in the month of May, hence the name spring mush- 
room. Of the twenty-three specimens in our collections, nineteen were collected in May while the remainder which were obtained in April are usually from the southern states although they may occur in the north during the latter part of April if the season is an early one.

The morel is often found in abundance. Underwood (Trans. Ind. Hort. Soc. 1893: 63. 1894) reports having gathered eightytwo fruiting bodies around an old stump in his back yard in Indiana, and in an apple orchard, twice as many. He refers to the morel as "a storehouse of nitrogenous food as luscious

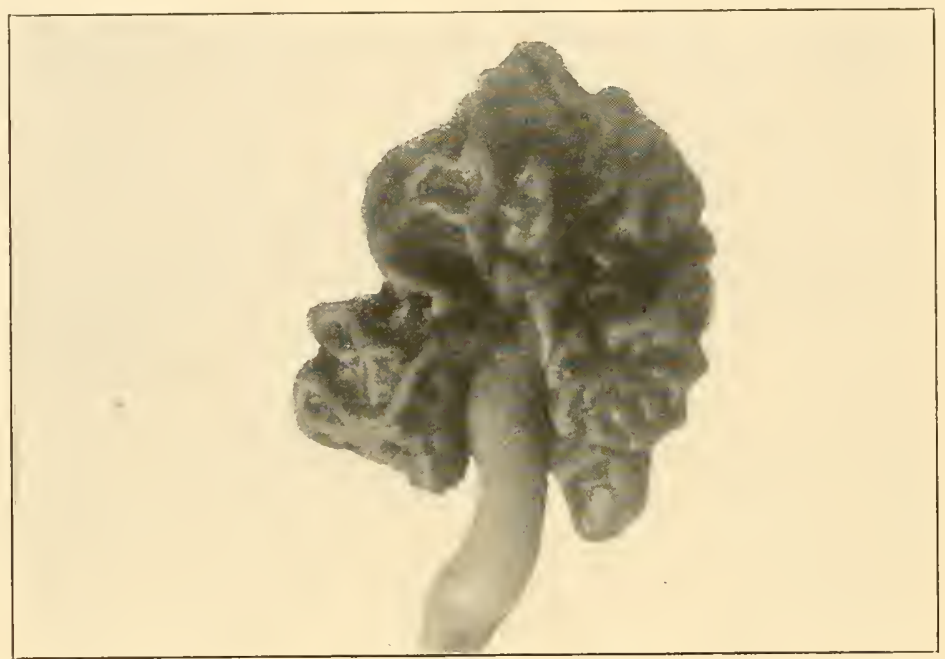

FIG. 15. Gyromitra esculenta gyrose form of Elvela infula.

Photograph by P. J. Anderson.

as an oyster and for an equal weight containing even more nutritious matter." In the same article he states: "It is safe to say that the total natural production of morels in the state of Indiana during each spring is not less than 50,000 bushels, and may be easily double that. These, in a fair market, are worth $\$ 200,000$ and in the best markets would command a much higher price. With the exception of a few plants eaten here and there by a family, this wealth of food, so much esteemed in foreign countries by peasant and wealthy epicure alike, is shamefully allowed to go to waste. The peasants of Germany call the fungi "manna of the poor" while the ancient Greeks justly regarded them as "food of the gods." Any bright boy 
could make large wages collecting and selling these plants, and with little effort the people would learn to esteem them as they do oysters now. There is no reason why they should not be as commonly exposed for sale by grocers as they are in foreign countries."

Since the fruiting season of the morel is short, they could be collected and dried for future use, thus making use of the excess crop. In Europe they are often strung and hung in festoons in the houses, much the same method as used in drying apples in early days.

All of the species of Morchella are edible, not one of them having even been under suspicion. The following directions have been given for preparing and cooking: "Having washed and cleansed them from earth, which is apt to collect between the plaits or hollows of the plant, dry thoroughly in a napkin and put them in a saucepan with pepper, salt and parsley, adding or not a piece of ham. Stew for an hour, pouring in occasionally a little broth to prevent burning. When sufficiently done, bind with the yolks of two or three eggs and serve on buttered toast." These directions may be varied to suit the taste. They may be cleaned, stewed and fried in butter, the stewing being essential, since they are rather inclined to toughness.

\section{Classification}

A classification of any group of plants should serve two purposes: first, to offer a convenient arrangement of the species treated and, second, to show, so far as possible, the natural relationship existing between the various members of the groups and subgroups. The principles of classification have always been a bone of contention with the morphologist, as the idealist, on the one hand, who is clamoring for a classification based on fundamentals only, and the taxonomist on the other, who is compelled to use so-called superficial characters which may or may not show natural relationship.

Some morphologists even contend that there is no use trying to work out a real classification of any group of fungi until we know the life histories of all of the species composing the group, especially the details of sexual reproduction, assuming that it exists. Of course at the present time this is only a "pipe dream" and while waiting for the morphologist to work out his ideals the taxonomist will be compelled to use the characters which 
present themselves in order to secure a convenient arrangement and trust that, to some extent at least, they may also be an index to natural relationship.

But what do we mean by superficial and fundamental characters? Superficial characters are those which may be easily detected by the casual student who does not have access to a fully equipped laboratory or even compound microscope and must rely largely upon a hand-lens or the naked eye in making his determinations of the species. The presence or absence of the operculum in the ascus may be regarded as a fundamental character but, as has already been shown, this rather obscure character is accompanied by several other more superficial ones which will enable the student to place the species in the proper group without actually seeing the operculum. It is not possible in every case to identify a species in the present group absolutely without the use of a compound microscope, but in many cases they may be placed in the proper section or in the gemus and occasionally even referred to the species.

Superficial characters are often a sure index to more fundamental ones and there is no reason why they should not be used by the taxonomist, although there may be a great difference of opinion as to which should or should not be employed. The protrusion of the ascus was at one time used but at the present time is considered of no value as a taxonomic character. Whether the hymenium is exposed from the first (gymnocarpous) or is at first enclosed by the apothecium (angiocarpous) has been made a good deal of in the past but it does not now seem to have any particular value.

No attempt has been made here to revolutionize the classification of the cup-fungi, although it has been somewhat modified to suit the author's own ideas. No doubt a much better one may be devised in the future, but in the meantime the one employed here will serve as a medium through which our ideas regarding species of cup-fungi occurring in North America can be transmitted to the student. If this can be done it will have served its purpose.

The term cup-fungi or Discomycetes is used to include those ascomycetes in which the hymenium is freely exposed at maturity. On this character, the cup-fungi merge into the Hysteriales and Phacidiales although generally the term is restricted to the Pezizales. Following Boudier's suggestion, the entire group is 
then divided into the Operculates and Inoperculates. Only the former are considered in this work and probably the operculate cup-fungi are about as well defined as any section of the fungi. The Elvelaceae and Geoglossaceae cannot be considered in the same section, as has been done by Lindau, since the one family is made up of operculate species and the other of inoperculate. Only two families of operculate cup-fungi are here recognized, the Pezizaceae and Elvelaceae.

The family Pezizaceae has then been divided in to eight tribes, in the segregation of which spore characters have been permitted to play a part. As the details on which these tribes are based are treated fully in the body of the work which follows, it seems unnecessary to discuss them here.

\section{Geographical Distribution}

Like other higher fungi, many of the cup-fungi are cosmopolitan or widely distributed over the surface of the earth, apparently having little regard for climate, altitude or other factors which have such a powerful influence on the distribution of the higher plants. Some, however, seem to be restricted to tropical regions but here the climatic influence may be only indirect. As already indicated, most of the operculate cupfungi are saprophytic, growing on decaying wood and humus resulting from decaying plant remains. As the climate determines the nature of the phanerogamic flora, so it determines the type of humus found in any given region. If a saprophyte chances to be a selective feeder, its occurrence will be governed accordingly, and might be thus indirectly influenced by climate.

Where a saprophyte is not too selective in its habits and the substratum is essentially the same it seems to thrive equally well in tropical and temperate regions. While collecting in the Rocky Mountains the writer was impressed with the number of species found at high altitude there which were identical with those collected at low altitude around New York City. On the other hand, forms which were naturally confined to certain kinds of coniferous wood or branches were restricted to those regions where this particular conifer grew. The altitude seemed to be only an indirect factor in determining the distribution of the fungus. Species of Lamprospora were found among mosses at snow-line in the mountains and a few hundred feet above sea level in New York, where the substrata were apparently similar. 
Again in Trinidad, which is almost under the tropical sun, while some species were found which were restricted to the tropics, the writer was frequently surprised to find what appeared to be Peziza badia of the north. While some mycologists might regard this as a geographical species, no morphological difference could be detected. This was especially common in Trinidad on clay pits where clay had been burned for the surfacing of the roads.

Perhaps the most interesting genus from the standpoint of distribution is Lamprospora, which might be regarded as the writer's "pet" genus since he has made a special effort to collect and study the species of this particular form. Because of their small size, the plants of this genus are usually overlooked by mycologists. Having had great difficulty in determining the species because of inadequate descriptions, the writer in 1914 put out a preliminary monograph calling attention to some of the peculiar markings of the spores.

Following this, 1)r. Ethel McLennan and Miss Isabel Cookson (Proc. Roy. Soc. Victoria 38: 70-76. 1926) have reported from Australia several species described as new in our preliminary monograph. These are as follows: Lamprospora tuberculata; Lamprospora tuberculatella; Lamprospora Maireana; and Lamprospora areolata Seaver, var. australis. Of these Lamprospora Maireana is also known from North Africa as well as North America. A number of other species of the genus are found in Europe, America and Australia and will probably be found to be world wide. It is difficult to draw general conclusions because so little attention is given to these obscure forms.

During the two collecting excursions to the Bermuda Islands, the cup-fungus most commonly collected was a European species, Lamprospora Planchonis, which has never been found on the mainland of North America, or at least has never been reported. This is one of the larger species of the genus and would not have been overlooked if it occurred here as abundantly as it does in Bermuda. From the standpoint of geographical distribution, there seems to be no more reason for its occurrence in Bermuda than in continental North America. When we recall that the soil of Bermuda is made up of disintegrated coral limestone, the nature of the substratum might have something to do with its occurrence there. Under just what conditions it occurs in Europe has not been learned. 
Probably the ease with which the spores of the cup-fungus, as well as fungi in general, can be blown about by the wind has much to do with their dissemination over the surface of the earth. From the observations made, it would seem that where the substrata are essentially identical the most of the species of this group will grow in any part of the world, without regard to climate. It is possible, however, that some of the strictly tropical species may be directly influenced by climate.

\section{Nomenclature}

In general the writer has attempted in the following treatment to follow the rules of the American Code of Nomenclature, which is based on the principle of priority. While the application of the rules of any code will result in some temporary eruptions in a group of this size, we feel that the application of the rule of priority at least tends toward stability. The few radical changes which have been made in the present work in order to conform to rules have been discussed in a preliminary paper, but some of them perhaps should be dealt with a little more in cletail here.

There are those in the mycological world who are avowedly opposed to the strict application of any code of nomenclature on the ground that such application would result in change, as of course it does in some cases. This small group of mycologists proposes to follow "usage," without regard to priority, on the plea that we would thereby avoid change of names. Now if the application of the principle ot so-called usage would accomplish what is claimed for it, there might be some excuse for following these suggestions. But the term "usage" is merely "a snare and a delusion" as can be shown by an attempt to apply this principle in the cup-fungi.

Since there is no extensive monograph of the operculate cupfungi in America, there is naturally no well-established usage in this country. Whether we follow usage or priority, we must look largely to Europe for precedent. There have been several outstanding figures in the study of Discomycetes of Europe, to whom we may look for inspiration and information, of a taxonomic nature, in the study of this group of fungi. Among these are William Phillips, M. C. Cooke, and George Massee of England; H. Rehm and G. Lindau of Germany; C. C. Gillet and M. E. Boudier of France; and P. A. Saccardo of Italy. While all of these have contributed much to our knowledge of the taxon- 
omy of this group of fungi, in the light of our present knowledge, none of them can be accepted as an infallible guide.

Although Boudier suggested in 1879 the presence or absence of the operculum in the ascus as a fundamental basis on which to separate the Discomycetes into two large sections, his contemporaries in other European countries seem to have overlooked or disregarded the suggestion. Both Lindau of Germany and Saccardo of Italy adopted classifications of their own, each different, and each grouping operculate and inoperculate species promiscuously in the same family and often in the same genus, entirely disregarding this most fundamental of morphological characters.

The effect of this diversity of treatment on nomenclature might best be illustrated by taking as an example the genus Lamprospora, as treated in this work. The name Lamprospora was proposed for this genus by De-Notaris in 1864. In 1869, Fuckel introduced the name Cromania, which, however, was untenable, since it had previously been used for another plant genus. In 1889, Saccardo suggested the name Barlaea, but later finding that it was untenable changed it to Barlaeina. Rehm followed Saccardo's suggestion in the use of Barlaea but he, also, later found that it was untenable and proposed the use of the generic name Detonia. Lindau, recognizing the untenability of the name Barlaea, proposed the substitution of Plicariella. Boudier continued to use the name Lamprospora.

This was the situation which confronted the writer in 1914, when he undertook a preliminary monograph of this genus for North America. At least three names were in common use in Europe: Lamprospora by Boudier and his followers; Barlaea or Barlaeina by Saccardo and his adherents; and Plicariella by Lindau. Rehm's suggestion to substitute Detonia for the genus had not gained any wide following. On the basis of usage, what would one do under these circumstances? The writer followed what appealed to him as being the most logical course and adopted the name Lamprospora on the ground of priority as well as usage. Since that time, this name has come into quite general use throughout the world. Yet, notwithstanding this fact, advocates of usage in this country have actually recommended the overturn of the genus Lamprospora, substituting for it Detonia because Rehm proposed it, although he himself never followed the suggestion. If this were done we would have had 
twenty-three new combinations in this genus in the present work, instead of two, by the use of the name Lamprospora. Thus we see that the advocates of usage, which really means nothing, often defeat the very end for which we are all working.

Some have attempted to adopt Saccardo's Sylloge Fungorum as a basis for usage. Although this is a most valuable index, it can scarcely be so used in the present group, for, as already pointed out, Saccardo has adopted a system of classification which leaves entirely out of consideration the most important morphological character, that of the presence or absence of the operculum in the ascus. The genus Bulgaria as treated by Saccardo contains both operculate and inoperculate species, which according to present-day students of Discomycetes belong in different sections of the cup-fungi. Not only are operculate and inoperculate species placed in the same genus but the inoperculate are in this case treated first and have come to be regarded as typical, although the genus was originally established on an operculate species.

After considering the above and other suggestions of the advocates of usage, their propositions have been discarded as absolutely impracticable and not at all conducive to the ends which we all have in view, stability of nomenclature. Even the most radical change made in the present work, the substitution of Patella for Lachnea, could not have been aroided by the most ardent advocates of usage, for eren they would not tolerate the use of the same name for two different plant genera.

The writer, however, is merely stating his position in the matter and has no desire to force his views upon anyone else. Those who have been in the habit of calling Patella scutellata a Lachnea will doubtless continue to do so whether the name is tenable or not. The writer, himself, will probably continue to do the same by force of habit. The tenable name has been adopted in this work, believing that it is just as easy for the new student of the younger generation to learn the right name as the wrong one, assuming that the one adopted here is right. By right we mean in accordance with the principles laid down by some well-formulated code. So far as the writer is aware, the name Lachnea would not be recognized as tenable under any existing code.

In following the rules of the American Code of Nomenclature, the writer, therefore, feels that he has adopted the course which will bring about the least possible confusion. 


\section{SIGNS}

$\mu=$ the Greek mu, which indicates micromillimeters, one of which equals .001 of a millimeter or $1 / 25,400$ of an inch.

$\mathrm{mm} .=$ a millimeter or $1000 \mu$.

$\mathrm{cnr} .=$ a centimeter or $10 \mathrm{~mm}$.

$\S=$ subgenus.

$-=$ dash between extreme measurements.

$X=$ used between numbers representing length and breadth. 


\section{Order PEZIZALES}

Ascophores consisting of discoid or cup-shaped apothecia, or more rarely clavate, columnar, or pileate; apothecia devoid of associated algal cells (except in the Patellariaceae, which family may contain either algicolous or non-algicolous species), free or more rarely seated on a subiculum or springing from a sclerotium, ranging in size from a fraction of a millimeter to several centimeters, variously colored, the hymenium concave, plane, or convex, and circular or subcircular in form, more rarely elongate or star-shaped, either enclosed by the apothecium or the excipulum when young or free from the first, very poorly developed or partially to entirely enclosing the hymenium when young, usually expanding at maturity leaving the hymenium freely exposed or, in a few cases, remaining closed until pierced or ruptured by the maturing asci, the tissue of the hypothecium either composed of loosely interwoven hyphae, prosenchymatous, or giving rise to a parenchyma-like tissue, pseudoparenchyma, or pseudoparenchymatous below and filamentous above; pileus bell-shaped, saddle-shaped, but never cup-shaped, even or irregularly convoluted or corrugated, surmounted by the hymenium; substance fleshy, leathery, cartilaginous, or corneous; asci ovoid to cylindric, two- to many-spored, operculate or inoperculate, rarely bilabiate; spores globose, ellipsoid, fusiform or filiform, one- to many-celled, hyaline or variously colored, yellowish, violet, brown or more rarely olivaceous, smooth or variously sculptured, echinulate, verrucose, tuberculate, reticulate, ringed or marked with irregular ridges; paraphyses filiform to clavate, simple or branched, variously colored.

Asci operculate (opening by a circular lid at the apex), or more rarely by a transverse slit which gives to the open ascus a bilabiate appearance; in the latter the ascus is surrounded just below its apex by a thickened ring or collar.

Section 1. Operculates.

Ascophores consisting of cup-shaped or discoid apothecia; apothecia sessile or more rarely stipitate.

Family 1. Pezizacese. 
Ascophores pileate, subglobose or columnar (never cup-shaped or discoid); pileus saddle-shaped or bell-shaped, always supported by a distinct stem.

Family 2. El Velacede.

Asci inoperculate (opening by a simple pore at the apex).

Section 2. INOPERCULATES.*

* Not treated in this work.

\section{Family 1. PEZIZACEAE}

Apothecia cup-shaped to discoid or more rarely convex, sessile or stipitate, variously colored, externally naked or clothed with hairs; substance fleshy, waxy, leathery, cartilaginous or corneous; hairs varying from a soft tomentum to stiff bristles, hyaline or colored; asci cylindric to ovoid, operculate or more rarely opening by a transverse slit at the apex giving the open ascus a bilabiate appearance, occasionally marked by a thickened ring or collar near the apex, two- to many-spored; spores globose, ellipsoid or fusiform, hyaline or colored, the color ranging from yellowish to brown, violet, or more rarely greenish, smooth or variously sculptured; paraphyses present, filiform to clavate, hyaline or variously colored.

Spores globose, hyaline to pale-brown.

Tribe 1. Sphaerosporeate.

Spores ellipsoid to fusoid or fusiform, more rarely subglobose.

Spores becoming violet, later brown to blackish.

Tribe 2. AsCoBOLEAE.

Spores permanently hyaline or at most palebrown.

Spores becoming reticulate at maturity, and often apiculate.

Spores smooth or sculptured but never reticulate.

Apothecia small, rarely exceeding 1 $\mathrm{cm}$. in diameter and often less than $1 \mathrm{~mm}$., sessile or subsessile. Apothecia naked, or at least not conspicuously setose or hairy.

Apothecia conspicuously setose or hairy.

Tribe 4. Huniriene.

Tribe 5. LACHNEEAE.

Apothecia medium to large, usually exceeding $1 \mathrm{~cm}$. in diameter when mature.

Apothecia strongly unequal sided or split on one side.

Tribe 3. AleurleaE.

Apothecia normally symmetrical in form.

Tribe 6. OtIdeEse. 
Apothecia usually stipitate and densely hairy or tomentose; substance usually tough and leathery.

Tribe 7. SircoscrPHE.IE.

Apothecia sessile or shortstipitate, not densely hairy or tomentose; substance usually fleshy and brittle.

Tribe 8. Pezizeae.

Tribe 1. Sphaerosporeae. Apothecia fleshy to cartilaginous, sessile or stipitate, naked or hairy; hairs either bristly or flexuous, hyaline or colored; asci usually 8 -spored but of ten with a part of the spores undeveloped, of ten strongly protruding, operculate; spores globose or rarely very slightly elongated, smooth or sculptured, hyaline or faintly colored, yellowish to pale-brown or blackish; paraphyses filiform to clavate.

Plants growing on humus or living plants, not restricted to the dung of animals.

Apothecia clothed with well-developed bristles or flexuous hairs.

Apothecia red, brown or greenish; substance soft and fleshy or waxy.

Apothecia black or brownish-black; substance tough or cartilaginous.

1. SPHAEROSPORA.

2. Pseudoplectinia.

Apothecia naked, not clothed with well-developed hairs.

Apothecia subglobose, externally entirely covered by the hymenium; substance approaching cartilaginous:

3. Sphierosomi.

Apothecia discoid to convex-hemispheric with the hymenium restricted to the upper surface and sides; substance soft and fleshy or waxy.

Plants growing on the ground or on humus. Hymenium strongly convex, approaching Sphaerosoma in form.

4. BOUDIER.I.

Hymenium concave, plane or slightly convex.

5. LAMPROSPORA.

Plants growing on living or recently killed foliage and branches of coniferous trees; substance tough and Ciboria-like.

6. Рiтhy.

Plants normally growing only on the dung of animals.

Spores becoming pale-brown as they mature.

7. Asconesuis.

Spores remaining permanently hyaline.

8. CuBONIA.

Tribe 2. Ascobolene. Apothecia usually small, of ten less than $1 \mathrm{~mm}$. or rarely exceeding $1 \mathrm{~cm}$. in diameter, usually 
yellowish or greenish at least when young, very soft and fleshy, the paraphyses and asci often surrounded by a mucilaginous, yellowish or greenish slime, never conspicuously hairy, occurring on dung or more rarely on soil, etc.; asci broad-clavate, operculate, strongly protruding at maturity and very conspicuous on account of their large size and the dark-colored spores which they contain; spores becoming some shade of violet or purple as they mature, later brown or occasionally blackish and opaque, ellipsoid or rarely almost globose, smooth or sculptured, spore-sculpturing taking the form of warts or reticulations, the reticulations consisting of ridges or crevices; paraphyses variable.

Spores free in the ascus.

9. Ascobolus.

Spores united in a ball in the ascus.

10. Saccobolus.

Tribe 3. Aleurieae. Apothecia small to medium or large, usually bright-orange or red, more rarely dark-brown, sessile or stipitate, growing on soil or humus, naked or hairy; hairs soft and flexuous or bristly, hyaline or brown; asci cylindric or subcylindric, operculate, 8-spored; spores hyaline to pale smokybrown, at maturity sculptured; spore-sculpturing consisting of ridges which usually give rise to very regular net-like reticulations; paraphyses usually strongly thickened above and colored.

Apothecia not clothed with colored hairs.

Hymenium bright-orange; spores hyaline.

11. Aleuria.

Hymenium dark-brown; spores smoky-brown. Apothecia clothed with colored hairs.

12. Aleurini.

13. MelistizA.

Tribe 4. Humarieat. Apothecia small, not usually exceeding $1 \mathrm{~cm}$. in diameter and often less than $1 \mathrm{~mm}$., soft and fleshy or rarely slightly tough, scutellate to discoid or occasionally with the hymenium strongly convex, usually sessile, occurring on the dung of animals, soil, or debris; asci cylindric to clavate or ovoid, in a few cases marked with a ring or collar near the apex, operculate or bilabiate, 4- to many-spored; spores ellipsoid, hyaline or subhyaline, smooth, or minutely sculptured; paraphyses variable in size and color.

Apothecia closely attached to the substratum to the

extreme margin, usually occurring on wood.

Apothecia attached to the substratum by the center only, occurring on soil, humus or the dung of animals.

Vegetative mycelium superficial, forming a conspicuous web on burnt places.

14. Psilopezia.

15. Pyronema. 
Vegetative mycelium immersed in the substratum, not usually restricted to burnt places.

Asci 8-spored.

Apothecia fleshy, very soft.

Plants coprophilous.

16. Ascophanus.

Plants humicolous.

Apothecia tough, Ombrophila-like.

17. HuMiRINA.

18. Pseudombrophila.

Asci more than 8-spored.

Asci bilabiate or opening by a transverse

slit at the apex.

19. StreptothecA.

Asci operculate or opening by a circular lid at the apex.

Asci and spores small; spores not exceeding $15 \mu$ long.

Asci and spores large; spores $35-38 \mu$ long.

20. Ryparobius.

21. Theсотнeus.

Tribe 5. Lachneene. Apothecia rarely exceeding $1 \mathrm{~cm}$. in diameter, scutellate to discoid, sessile, or rarely stipitate, externally clothed with hyaline or colored hairs; asci operculate, 8 -spored but often with a part of the spores undeveloped; spores smooth or sculptured, hyaline to pale-yellowish; paraphyses variable.

Apothecia partially to entirely buried in the ground.

22. Sepultaria. Apothecia superficial on the substratum.

Asci with an external thickened ring near the apex; plants occurring on the dead foliage of cedar.

23. Pseudopithyelli.

Asci without external thickener ring; plants occurring on soil, wood, humus, or the dung of animals.

Apothecia densely clothed with brick-red hairs which give to the whole plant a red appearance.

24. Perrotil.

Apothecia clothed with hyaline or brown hairs which appear white or black to the naked eye.

llair simple (without cross-walls).

Hairs septate, usually erect and bristlelike.

25. Lasiobolus.

26. Patella.

Tribe 6. Otidenas. Apothecia unsymmetrical, either elongated or split on one side to the base, occurring singly or springing in clusters from a sclerotium, rather tough and subcoriaceous, externally smooth, pruinose, or occasionally tomentose; asci cylindric, operculate, 8 -spored; spores smooth but often marked 
longitudinally by light and dark bands; paraphyses straight or hooked at their apices and usually enlarged above.

Apothecia springing in clusters from a sclerotium which is

buried in the ground.

27. WYNNEA.

Apothecia usually isolated and not springing from a scle-

rotium.

Spores striate with light and dark bands.

Spores not striate.

28. Phillipsia.

29. Scodellina.

Tribe 7. SArcoscrpiene. Apothecia stipitate, or rarely sessile, tough and inclined to coriaceous (not shrinking much in drying), bright-colored or brown to blackish, growing attached to buried or partially buried sticks (except the genus Paxina, the plants of which genus grow on the ground), externally densely tomentose or bristly; stem very variable in length, its length often depending on the depth at which the substratum is buried, occasionally wanting, slender or more often thick, even or corrugated; asci operculate, 4-8-spored; spores smooth, but often marked with longitudinal light and dark bands as in Wynnea and Phillipsia, or minutely sculptured; paraphyses usually slender but variable.

Apothecia bright-colored, yellow to scarlet within; mycelium white.

Spores striate and hairs fasciculate; plants tropical.

30. Cookeinis.

Spores not striate and hairs not fasciculate; plants temperate.

31. Plectanil.

Apothecia dark-colored, brown to blackish; mycelium usually dark-colored.

Apothecia with a thick gelatinous hypothecium.

32. BULGaria.

Apothecia without thick gelatinous hypothecium.

Apothecium opening with a star-shaped aperture or splitting Geaster-like; growing attached to sticks.

Apothecium not opening with a star-shaped aperture; growing on the ground.

33. URNULA.

34. Paxina.

Tribe 8. Pezizeae. Apothecia sessile or with an inconspicuous stem, externally smooth or nearly so, occasionally slightly tomentose, varying in size from one to several centimeters in diameter; hymenium concave, plane or convex, brightcolored or more commonly brownish or blackish; asci cylindric or subcylindric, operculate, 8-spored; spores ellipsoid to fusoid, hyaline or rarely faintly colored, smooth or sculptured; paraphyses very variable, usually filiform. 
Apothecia superficial..

Apothecia medium-sized, shaped like an acorn-cup with a short slender stem.

35. GEOPYXIs.

Apothecia medium to large, sessile or with a stout stem-like base, often irregularly contorted.

Spores apiculate.

Apothecia attached to the substratum by numerous root-like processes.

36. RHIZINA.

Apothecia not attached by numerous root-like processes.

Spores not apiculate.

37. Discina.

38. PEZIZ1.

Apothecia entirely buried in the ground, at least when young.

39. SARCOSPHAERA.

1. SPHAEROSPORA Sace. Syll. Fung. 8: 188. 1889.

Peziza \$ Sphaerospora Sacc. Michelia 1: 594. 1879.

Sphaerosporula Kuntze, Rev. Gen. Pl. 333: 530. 1898.

Apothecia becoming scutellate or occasionally discoid, externally clothed with hairs; hymenium plane, slightly concave or rarely convex, usually red or brown, more rarely greenish or pale-yellow; hairs bristly or flexuous, hyaline or colored; asci cylindric to clavate, 8-spored; spores globose, hyaline or colored, smooth or becoming sculptured; spore-sculpturing consisting of warts or spines; paraphyses slender below, clavate above.

Type species, Pesisa trechispora Berk. \& Br.

Spores becoming sculptured at maturity.

Spore-sculpt uring consisting of warts.

Apothecia bright-red; hairs rigid.

Apothecia greenish; hairs flexuous.

1. S. trechispora.

2. S. flavovirens.

Spore-sculpt uring consisting of spines.

3. S. perplexa.

Spores remaining permanently smooth.

Apothecia reddish-brown.

Apothecia small, 1-6 $\mathrm{mm}$. in diameter, forming congested masses on burned places.

4. S. brunnea.

Apothecia large, reaching $1 \mathrm{~cm}$. in diameter, scattered, on sandy soil in woods.

5. S. hinnulea.

Apothecia pale-yellow.

6. S. monilifera.

1. Sphaerospora trechispora (Berk. \& Br.) Sacc. Syll. Fung. 8: 188. 1889.

Peziza trechispora Berk. \& Br. Ann. Mag. Nat. Hist. 18: 77. 1846.

Lachnea trechispora Gill. Champ. Fr. Discom. 77. 1879.

Peziza asperior Nyl. Not. Fauna Fl. Fenn. 10:21. 1869.

Lencolona asperior Rehm, Ber. Naturh. Ver. Augsburg 26: 6. 1881. 
Sphaerospora asperior Sacc. Syll. Fung. 8: 188. 1889.

Splacrosporula asperior Kuntze, Rev. Gen. Pl. 33: 530. 1898.

Sphaerosporula trechispora Kuntze, Rev. Gen. PI. 33: 530. 1898.

Ciliaria asperior Boud. Hist. Class. Discom. Eu. 62. 1907.

Ciliaria trechispora Boud. Hist. Class. Discom. Eu. 62. 1907.

Apothecia gregarious or scattered, at first subglobose, expanding and becoming scutellate to discoid, reaching a diameter of $1 \mathrm{~cm}$; the margin slightly elevated, externally clothed with rigid hairs which project and form a conspicuous fringe about the margins of the apothecia, giving them a dark-brown color; hymenium bright-red, plane or very slightly concave, smooth; the excipular cells irregularly polygonal, the walls pale-brown; hairs sharp-pointed, reddish-brown with transmitted light, 2-5septate, variable in length but reaching an extreme of $300-400 \mu$ and a diameter of $20-26 \mu$ at the broadest point a little above the base, contracted toward the point of attachment and often forked at the base; asci cylindric or subcylindric above, gradually tapering below into a stem-like base, reaching a length of 200 $250 \mu$ and a diameter of $25-30 \mu$; spores 1 -seriate, at first smooth and containing one large oil-drop, finally becoming sculptured, reaching a diameter of $20-26 \mu$; spore-sculpturing consisting of rounded wart-like tubercles about $2 \mu$ in diameter; paraphyses clavate, septate, reaching a diameter of $10 \mu$ at their apices, reddish.

On rich soil, especially among mosses.

Type locality: Europe.

Distribution: New York to Colorado; also in Europe.

Illustrations: Boud. Ic. Myc. pl. 375, 378; Cooke, Mycographia pl. 33, f. 129; Gill. Champ. Fr. Discom. pl. 64; Phill. Brit. Discom. pl. 7, f. 41; Grevillea 3: pl. 33, f. 103; Jour. Linn. Soc. 31 : pl. 16, f. 20, 21; Rab. Krypt.-Fl. $1^{2}: 1029$, f. 1-4; Ann . Myc. 4: 208, f. 28; 209, f. 29.

2. Sphaerospora flavovirens (Fuckel) Sacc. Syll. Fung. 8: 189. 1889.

Plicaria flavovirens Fuckel, Symb. Myc. Nacht. 2: 64. 1873.

Peziza flavovirens Cooke, Mycographia 68. 1876.

Phaeopezia elaeodes Clements, Bot. Surv. Nebr. 4: 16. 1896.

Sphaerosporula flavovirens Kuntze, Rev. Gen. Pl. 33: 530. 1898.

Sphaerospora Durandi Rehm, Ann. Myc. 2: 36. 1904.

Apothecia scattered, at first shallow cup-shaped, becoming scutellate to discoid, reaching a diameter of $5 \mathrm{~mm}$. to $2 \mathrm{~cm}$., 
externally pale-brown, slightly verrucose and tomentose; hymenium concave, plane or slightly convex, olivaceous; hairs flexuous, septate, pale-brown; asci cylindric or subcylindric, reaching a length of $200-300 \mu$ and a diameter of $15-18 \mu$; spores 1 -seriate, containing one large oil-drop, at first smooth, becoming rough, reaching a diameter of 12-16 $\mu$; spore-sculpturing consisting of minute warts or indistinct reticulations; paraphyses filiform below, enlarged above, septate, reaching a diameter of 5-6 $\mu$ at their apices.

On damp sand-banks.

Trpe locality: Europe.

Distributiox: New York to Nebraska; also in Europe.

Illustration: Cooke, Mycographia pl. 31,f. 122.

\section{Sphaerospora perplexa Seaver, sp. nov.}

Apothecia gregarious, sessile, when young closely nestling in the substratum, at first closed and globose, expanding and becoming discoid, reaching a diameter of 1-3 mm.; externally clothed about the margin with fascicles of adpressed, palebrown hairs which often form fifteen or twenty tufts about the border of the disc; hymenium plane, bright-orange and slightly darker than the outside of the apothecium; hairs flexuous, clubshaped, sparingly septate and often constricted at the septa, smooth or very slightly roughened, reaching a diameter of $21-33 \mu$ at their apices; asci cylindric or subcylindric above, rather abruptly tapering below into a short stem-like base, reaching a length of $350 \mu$ and a diameter of $23 \mu$; spores 1 -seriate, densely granular within, becoming sculptured, reaching a diameter of 21-23 $\mu$; spore-sculpturing assuming the form of sharp spines (resembling those of Lamprospora Crec'hqueraultii); paraphyses stout, reaching a diameter of $7-8 \mu$.

On bare soil in woods.

Type Locality: IVoods near Yonkers, New York.

Distributiox: Known only from the type locality.

Specimens recently sent from Sweden by Dr. John Axel Nannfeldt appear to conform with the above, which would extend the range of distribution if such should prove to be the case.

This may be only an abnormal form of Lamprospora Crec'hqueraultii, the development of hairs being due to unusual conditions. Except for the hairs it is identical with that species. 
4. Sphaerospora brunnea (Alb. \& Schw.) Massee, Brit. FungusF1. 4:295. 1895.

Pesiza brunnea Alb. \& Schw. Consp. Fung. 317. 1805.

?Peziza schizospora Phill. Grevillea 3:31. Hyponym. 1874.

?Peziza sphaeroplea Berk. \& Curt.; Cooke, Bull. Buffalo Soc. Nat. Sci. 2: 289. 1874 .

Pesiza confusa Cooke, Bull. Buffalo Soc. Nat. Sci. 2: 291. 1875.

Lachnea confusa Phill. Grevillea 18: 83. 1889.

Sphaerospora confusa Sacc. Syll. Fung. 8: 190. 1889.

?Barlaea schizospora Sacc. Syll. Fung. 8: 116. 1889.

Scutellinia brunnea Kuntze, Rev. Gen. Pl. 2: 869. 1891.

Ciliaria confusa Boud. I Iist. Class. Discom. Eu. 62. 1907.

Sphaerosporula confusa Kuntze, Rev. Gen. Pl. 333: 530. 1898.

Apothecia gregarious or more often densely crowded, forming congested masses several $\mathrm{cm}$. in diameter, at first subglobose, expanding and becoming scutellate or discoid, reaching a diameter of 5-6 mm., externally brownish, clothed with short hairs; hymenium plane or slightly concave, pale- to dark-brown; the excipular cells irregularly polygonal, more or less elongated near the margin, pale-brown, of ten reaching a diameter of 25-30 $\mu$; hairs scarcely projecting above the margin of the apothecium, rigid, rather sharp-pointed, subhyaline or palebrown, 1-4-septate, reaching an extreme length of $200 \mu$ and a diameter of $6-\delta \mu$, the young hairs often very irregularly crooked or bent; asci cylindric or subcylindric above with a long slender stem-like base, reaching a length of $160-200 \mu$ and a diameter of $20 \mu$; spores 1 -seriate, containing one large oil-drop, hyaline, smooth or very minutely roughened, reaching a diameter of 15-18 $\mu$; paraphyses clavate, reaching a diameter of $6-7 \mu$ at their apices, filled with brown granules.

On burnt ground and charcoal beds.

TyPe Locality: Europe.

Distribution: Massachusetts to Iowa and Alabama; also in Europe.

Illustrations: Boud. Ic. Myc. pl. 379; Cooke, Mycographia pl. (20,f. 80?); 32, f. 124; Alb. \& Schw. Consp. Fung. pl. 9, f. 8.

5. Sphaerospora hinnulea (Berk. \& Br.) Massee, Brit. FungusF1. 4: 294. 1895.

Peziza hinnulea Berk. \& Br. Ann. Mag. Nat. Hist. IY. 7: 433. 1873.

Peziza scutelloides Ellis, Bull. Torrey Club 9: 18. 1882.

Lachnea hinnulea Phill. Brit. Discom. 219. 1887.

Barlaea hinnulea Sacc. Syll. Fung. 8: 117. 1889.

Sphaerospora scutelloides Sacc. Syll. Fung. 8: 188. 1889.

Sphaerosporula scutelloides Kuntze, Rev. Gen. Pl. 333: 530. 1898. 
Apothecia gregarious or scattered, never densely crowded, at first subglobose, expanding and becoming scutellate to discoid, reaching a diameter of $5 \mathrm{~mm}$. to $1 \mathrm{~cm}$., externally clothed with rigid hairs which project above the margin, giving it a darkbrown color; hymenium slightly concave or plane, reddish-brown; the excipular cells irregularly polygonal, reaching a diameter of $30-35 \mu$, the cell walls pale-brown; hairs straight or irregularly bent, rather sharp-pointed or obtuse, pale-brown, 3-5-septate, reaching an extreme length of $200 \mu$ and a diameter of $10 \mu$ at the base; asci cylindric or subcylindric above with a slender stemlike base reaching a length of $200 \mu$ and a diameter of $20 \mu$; spores at first irregularly 2 -seriate, separating and becoming 1 -seriate, containing one large oil-drop and often several smaller ones, smooth, reaching a diameter of $15 \mu$; paraphyses strongly enlarged above, septate, brown.

On sandy soil in woods, often among mosses.

Type Locality: Europe and Connecticut.

Distribution: New York to Iowa; also in Europe.

Illustrations: Bull. Lab. Nat. Hist. State Univ. Iowa 6: pl. 5, f. 1; Cooke, Mycographia pl. 13, f. 52.

Exsiccati: N. Am. Fungi $838,21+2$.

6. Sphaerospora monilifera (Berk. \& Curt.) Seaver, comb. nov. Peziza monilifera Berk. \& Curt.; Berk. Jour. Linn. Soc. 10:367. 1868. Pyronemella monilifera Sacc. Syll. Fung. 8: 194. 1889.

Apothecia becoming subdiscoid, reaching a diameter of $1 \mathrm{~mm}$., externally pale-yellow, clothed with delicate hairs; hymenium pale-yellow, plane or nearly so; hairs septate, hyaline or faintly colored; asci cylindric; spores smooth, hyaline, reaching a diameter of 15-16 $\mu$; paraphyses slightly enlarged above.

On the ground.

Trpe locality: Cuba.

Distribution: Known only from the type locality.

Illustratiox: Cooke, Mycographia pl. 40, f. 158.

2. PSEUdOPLECTANIA Fuckel, Symb. Myc. 324. 1869.

Caloscypha Boud. Bull. Soc. Myc. Fr. 1: 103. 1885.

Otidella Sacc. Syll. Fung. 8: 99. 1889.

Melascypha Boud. Hist. Class. Discom. Eu. 56. 1907.

Apothec'a gregarious or scattered, sessile or stipitate, mediumsized, usually exceeding $1 \mathrm{~cm}$. in diameter, fleshy to cartilaginous, 
externally clothed with short, slender, flexuous, of ten coiled or twisted hairs, giving to the outside of the apothecium a tomentose appearance, blackish to orange or greenish; hymenium concave, orange or blackish; asci cylindric or subcylindric, 8-spored; spores perfectly globose, smooth, hyaline or faintly colored; paraphyses very slender, straight or curved at their apices.

Type species, Peziza nigrella Pers.

Apothecia entirely black or brownish-black.

Long-stipitate, sparingly clothed with straight or slightly flexuous hairs.

1. P. vogesiaca.

Short-stipitate or sessile, densely clothed with coilerl hairs.

2. P. nigrella.

Apothecia orange or occasionally with a greenish tint about the outer margin.

3. P. fulgens.

1. Pseudoplectania vogesiaca (Pers.) Seaver, Mycologia 5: 300. 1913. (Plate 1, Fig. 1.)

?Peziza fuscocana Alb. \& Schw. Consp. Fung. 312. 1805.

Peziza vogesiaca Pers.; Moug. \& Nest. Stirpes Crypt. 58t. 1818.

Peziza melania Pers. Myc. Eu. 1: 239. 1822.

Peziza melaena Fries, Syst. Myc. 2: 60. 1822.

Peziza spongiosa Peck, Bot. Gaz. 5: 35. 1880.

Bulgaria spongiosa Peck, Bot. Gaz. 6: 241. 1881.

Pseudoplectania melaena Sacc. Syll. Fung. 8: 165. 1889.

Pulparia spongiosa Sacc. Syll. Fung. 8: 612. 1889.

?Otidella fuscocana Schröt. Krypt.-FI. Schles. 3²: 49. 1893.

Melascypha melaena Boud. Hist. Class. Discom. Eu. 56. 1907.

Apothecia gregarious or scattered, stipitate, cup-shaped or occasionally nearly plane, the margin often wavy, reaching a diameter of $2-3 \mathrm{~cm}$. and a depth of 1-2 cm., externally very sparingly tomentose, becoming strongly wrinkled when dry, black or blackish; substance subcartilaginous; hymenium dark olivaceous-brown, concave or nearly plane; stem very variable in length but occasionally reaching $2-3 \mathrm{~cm}$. and about $3 \mathrm{~mm}$. thick, black, attached at the base by a dense mass of coarse, darkbrown hairs; tomentum consisting of short, brown, flexuous, sparingly septate hairs; asci cylindric above, with a very long stem-like base, reaching a length of 200-275 $\mu$ and a diameter of 16-18 $\mu$; spores 1 -seriate, containing one large oil-drop, becoming very pale-brown, reaching a diameter of $12-14 \mu$; paraphyses slender, slightly enlarged above and coiled or hooked at their apices, reaching a diameter of 3-4 $\mu$. 


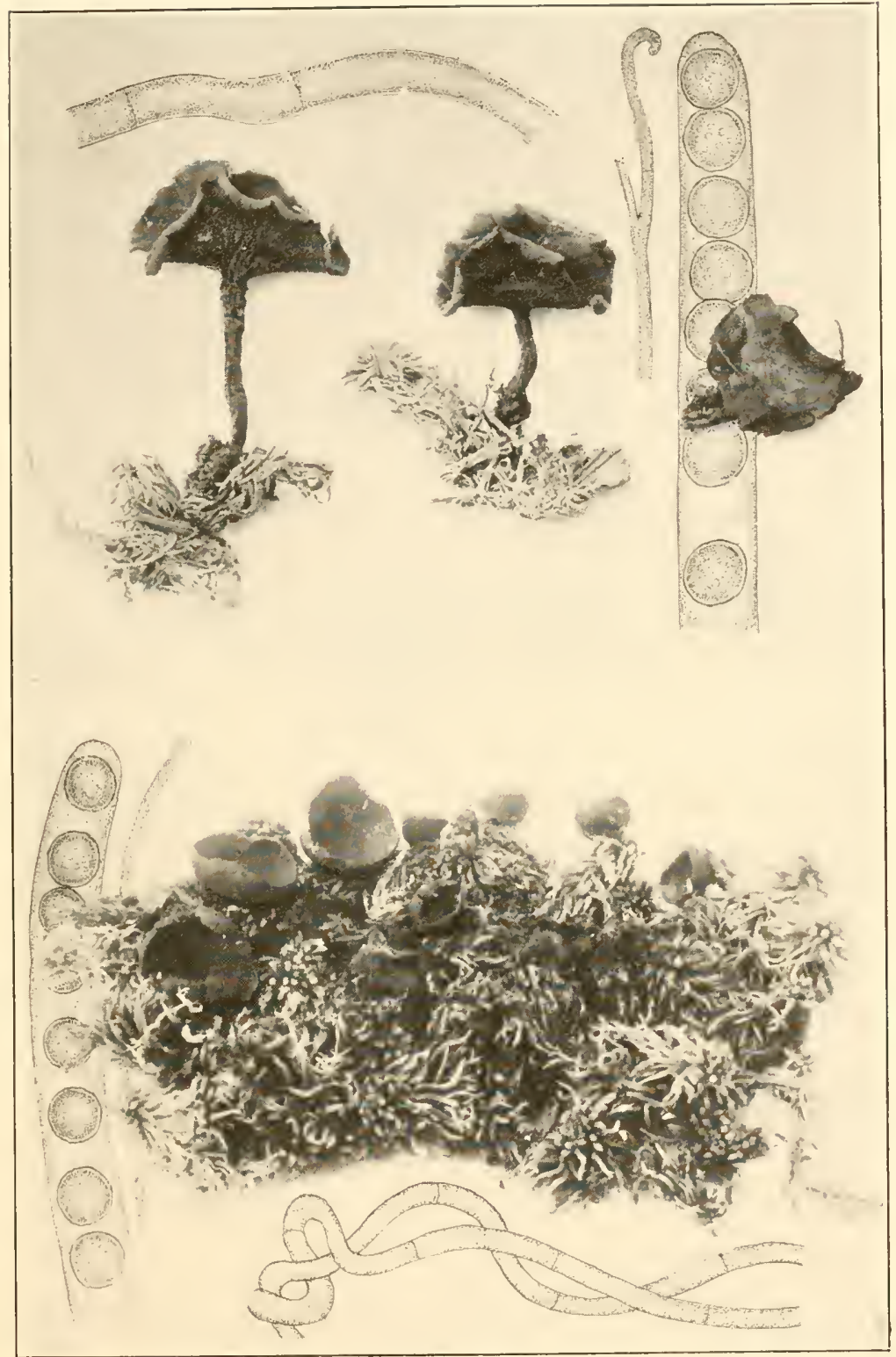

1. PSEUDOPLECTANIA VOGESIACA

2. PSEUDOPLECTANIA NIGRELLA 

On decaying wood in coniferous woods, especially among Sphagnum.

TrPe locality: Europe.

Distribution: Vermont to Wrashington; also in Europe.

Illustrations: Boud. Ic. Myc. pl. 3ł3; Cooke, Mycographia pl. 49, f. 193; Rab. Krypt.-Fl. 13 : 1030, f. 1; Mycologia 5: pl. 109 (upper figure) and pl. 10; Gill. Champ. Fr. Discom. (suites).

2. Pseudoplectania nigrella (Pers.) Fuckel, Symb. Myc. 324. 1869. (Plate 1, Fig. 2.)

Elvela hemisplaterica Wulf. Beob. Nat. Ges. Nat. Fr. Berl. 2': 141. 1787. Not Peziza hemisphaerica Weber. 1780.

Peziza nigrella Pers. Syn. Fung. 648. 1801.

Lachnea nigrella Gill. Champ. Fr. Discom. 78. 1874.

?Peziza stygia Berk. \& Curt. Grevillea 3:153. 1875.

Plectania nigrella Karst. Act. Fauna Fl. Fenn. 2: 119. 1885.

?Pseudoplectania stygia Sacc. Syll. Fung. 8: 166. 1889.

Otidella nigrella Schröt. Krypt.-Fl. Schles. 3²: 48. 1893.

Sphaerospora nigrella Massee, Brit. Fungus-F1. 4: 296. 1895.

Apothecia gregarious or occasionally closely crowded, sessile or substipitate, at first closed and subglobose, expanding and becoming shallow cup-shaped to discoid, margin of ten wavy and slightly incurved, externally clothed with very fine hairs, black or blackish, reaching a diameter of $5 \mathrm{~mm}$. to $1.5 \mathrm{~cm}$.; hymenium concave or nearly plane, smooth, brownish-black; hairs very long but usually coiled and twisted, giving to the exterior of the apothecium a slightly woolly appearance, reaching a diameter of 4-6 $\mu$ and of nearly uniform thickness throughout their entire length, sparingly septate, pale-brown; asci cylindric or subcylindric with a long stem-like base, reaching a length of $300-$ $325 \mu$ and a diameter of $15 \mu$; spores reaching a diameter of $12-14 \mu$, usually containing one large oil-drop and several smaller ones; paraphyses enlarged at their apices and filled with brown coloring matter, reaching a diameter of $4 \mu$.

On decaying wood in coniferous woods, especially among Sphagnum.

TYPE LOCALITY: Europe.

Distribution: New Jersey to Manitoba, Wisconsin, Alabama, and Jamaica; also in Europe and Australia.

Illustrations: Boud. Ic. Myc. pl. 37t; Cooke, Mycographia pl. 31,f. 120; Gill. Champ. Fr. Discom. pl. 65; E. \& P. Nat. Pfl. $1^{1}$ : 179, f. 146, A-B; Rab. Krypt.-Fl. 13 : 1030, f. 2; Mycologia 5: 
pl. 109 (lower figure); Krombh. Abbild. pl. 16, f. a, b; Proc. Roy. Soc. Victoria II. 38: pl. t, f. +6; pl. 6, f. 2.

3. Pseudoplectania fulgens (Pers.) Fuckel, Symb. Myc. 324. 1869.

Peziza fulgens Pers. Myc. Eu. 1: 241. 1822.

Peziza cyanoderma DeBary in Rab. Fungi Eu. 516. 1863.

Aleuria fulgens Gill. Champ. Fr. Discom. 41. 1879.

Otidella fulgens Sacc. Syll. Fung. 8: 99. 1889.

Barlaea fulgens Rehm in Rab. Krypt.-Fl. 133: 930. 1896.

Plicariella fulgens Lindau in E. \& P. Nat. Pfl. $1^{1}: 180.1897$.

Detonia fulgens Durand, Bull. Torrey Club 29: 459. 1902.

Caloscypha fulgens Boud. Hist. Class. Discom. Eu. 54. 1907.

Apothecia scattered or more rarely crowded, regular or irregular in form, occasionally unequal-sided or split Otidealike, substipitate and attached to the substratum by a dense mass of coarse mycelium which penetrates into the humus binding it together, reaching a diameter of $5 \mathrm{~mm}$. to $2.5 \mathrm{~cm}$., externally pale-orange, becoming greenish or olivaceous, especially about the margin, sparingly clothed with poorly developed hairs; hymenium orange, brighter than the outside of the apothecium; hairs short, clavate, consisting of a few loosely united cells; asci cylindric above, gradually tapering below into a long stem-like base, reaching a length of $100 \mu$ and a diameter of $10-12 \mu$; spores at first 2 -seriate, separating and finally becoming 1 -seriate, reaching a diameter of $6-8 \mu$, hyaline; paraphyses slender, scarcely enlarged above, filled with orange granules.

On soil in coniferous woods.

TyPe LOCALITY : Europe.

Distribution: New York to Montana and California; also in Europe.

Illustrations: Boud. Ic. Myc. pl. 319; Cooke, Mycographia pl. 53,f. 209; E. \& P. Nat. Pfl. 1'1 : 179, f. 1.46, C, D; Gill. Champ. Fr. Discom. pl. 38; Pat. Tab. Fung. $f .377$.

The bright-orange color of this species is in marked contrast to that of the other two species recorded here both of which are black. The outside of the apothecium is often overcast with an olive tint. It is a beautiful species but only rarely collected. 
3. SPHAEROSOMA Klotzsch; Dietrich, Fl. Boruss. Pl. 467.1839.

Sphaerozosma Corda, Ic. Fung. 6: 52.1854.

Rullandiella P. Henn. Hedwigia 42: (23). 1903.

Apothecia subglobose, sessile or substipitate; hymenium covering all of the exposed surface of the apothecium, brownish; substance fleshy or slightly cartilaginous; asci broad-cylindric to subclavate, 8-spored; spores globose, at first smooth, becoming sculptured, slightly colored; paraphyses rather slender.

Type species, Sphaerosoma fuscescens Klotzsch.

1. Sphaerosoma hesperium (Setchell) Seaver, comb. nov.

(Plate 2, Fig. 3.)

?Sphaerosoma fuscescens Klotzsch; Dietrich, Fl. Boruss. Pl. 467. 1839.

?Ruhlandiella berolinensis P. Henn. Hedwigia 42: (22). 1903.

Ruhlandiella hesperia Setchell, Univ. Calif. Pub. 4:116. 1910.

Apothecia subglobose or reniform, short-stipitate or attached by a small tuft of mycelium near the center of the under side, reaching a diameter of $2-6 \mathrm{~mm}$.; hymenium covering all of the exposed surface of the apothecium, pale-brown; asci broadcylindric or clavate above, narrowed below, reaching a length of $250-300 \mu$ and a diameter of $28-30 \mu$; spores at first 2-seriate or irregularly crowdect near the end of the ascus, gradually separating and becoming 1 -seriate, at first smooth, becoming sculptured, reaching a diameter of $20-27 \mu$; spore-sculpturing taking the form of reticulations, the reticulations $2-3 \mu$ deep as indicated by the projections about the periphery of the spore, the ridges often appearing as spines; paraphyses filiform, curved at the ends, enlarged and cemented together, forming a rather firm epithecium.

On the ground under leaf-mould.

Type locality: Berkeley, California.

Distribution: California; also in (Europe?).

Illustration: Univ. Calif. Publ. Bot. 4: pl. 15, f. 1-t.

\section{BOUDIERA Cooke, Grevillea 6: 76. 1877.}

Apothecia sessile, at first subglobose, becoming expanded and subdiscoid, or convex-hemispheric and Sphaerosoma-like, rather small, reaching a diameter of $2-5 \mathrm{~mm}$; hymenium occupying the upper surface only or covering the entire exposed surface and 
in vertical section forming a complete semi-circle; asci very broad, 8-spored; spores globose, becoming sculptured; sporesculpturing consisting of reticulations or spines, pale-yellowish; paraphyses very stout and much thickened at their apices.

Type species, Boudiera areolata Cooke \& Phill. Apothecia subdiscoid.

1. B. areolata.

Apothecia convex-hemispheric.

2. B. echinulata.

1. Boudiera areolata Cooke \& Phill.; Cooke, Grevillea 6: 76. 1877. (Plate 2, Fig. 1.)

Plicaria tracheia Rehm, Ascom. 451. Hyponym. 1878. Barlaea areolata Massee, Brit. Fungus-Fl. 4: 398. 1895.

Apothecia scattered, sessile, globose when young, becoming expanded and subdiscoid, reaching a diameter of 2-3 mm., externally smooth, whitish; hymenium occupying the upper surface, convex, dark-brown; asci subcylindric to clavate, tapering below into a long stem-like base, strongly protruding at maturity and appearing in dried specimens as minute, whitish granules over the surface of the hymenium; spores at first 2seriate or irregularly bunched near the apex of the ascus, gradually separating, finally becoming 1 -seriate, at first smooth and surrounded by a hyaline band, gradually becoming sculptured, reaching a diameter of $30-35 \mu$ including the spines; sporesculpturing assuming the form of reticulations which are of ten more or less indistinct or broken, at maturity echino-reticulate, the spines reaching a length of $4-5 \mu$; paraphyses stout, septate, brown.

On damp soil in swampy places.

Type Locality: North Wales.

Distribution: Maine; also in Europe.

Illustrations: Grevillea 6: pl. 97, f. 14, 15; E. \& P. Nat. Pfl. $1^{1}: 192, f .154, A$; Boud. Ic. Myc. pl. 417; Phill. Brit. Discom. pl. 9, f. 53; Rab. Krypt.-Fl. $1^{3}: 1110, f .1$-5; Mycologia 6: pl. 123, f. 5-6.

2. Boudiera echinulata Seaver, comb. nov. (PlAte 2, FIG. 2.)

Sphuerosoma echinulatum Seaver, Jour. Myc. 11: 2. 1905.

Apothecia scattered, gregarious or occasionally crowded, at first almost globose and regular in outline, becoming expanded and finally convex-hemispheric, the lower surface nearly plane, whitish and attached to the soil by very delicate hyphae, very easily detached, reaching a diameter of 5-8 mm.; hymenium 


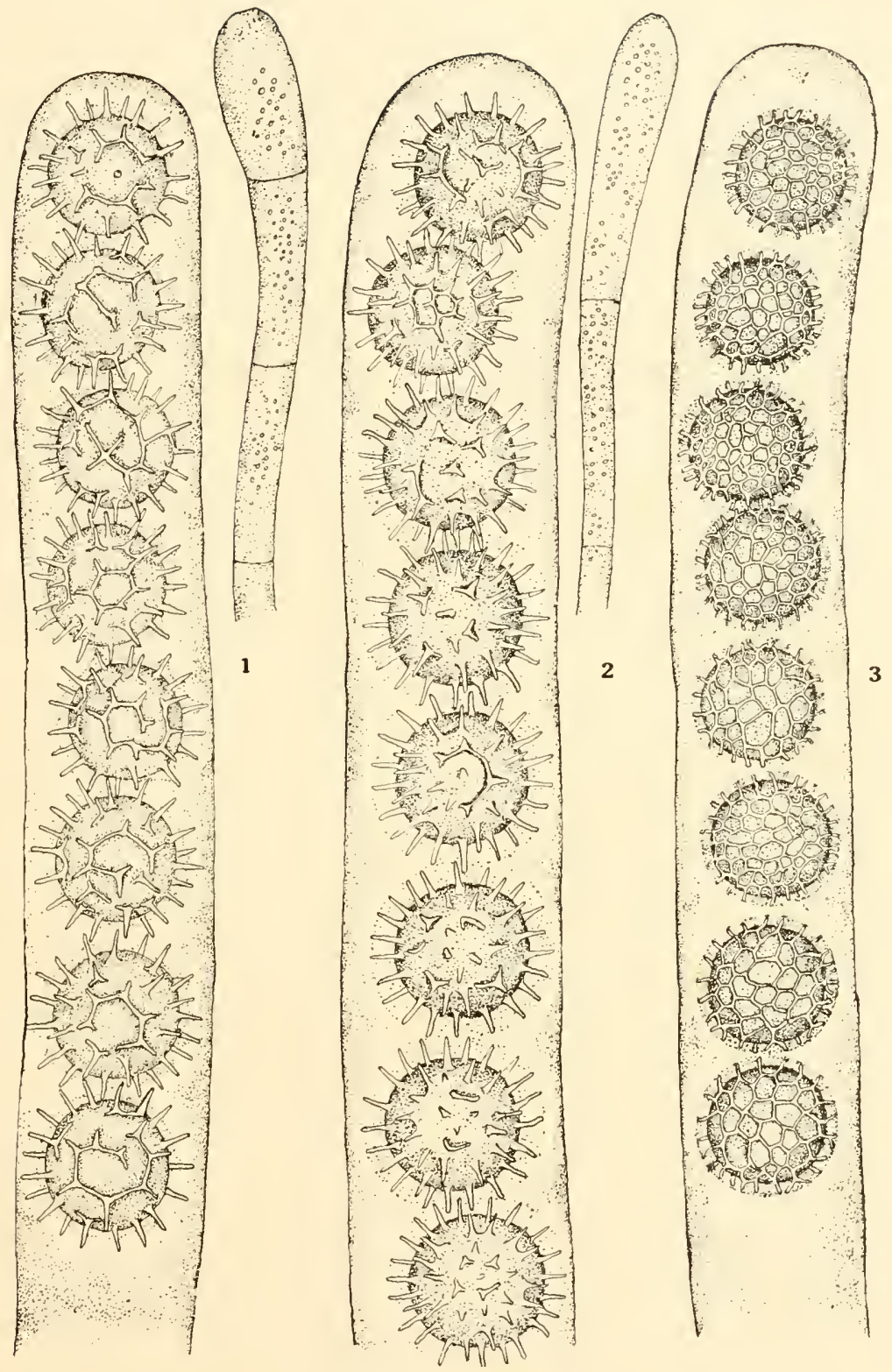

1. BOUDIERA AREOLATA

2. BOUDIERA ECHINULATA

3. SPHAEROSOMA FUSCESCENS 

beginning by a dark-brown spot in the center of the upper surface and expanding until it covers all of the exposed surface of the apothecium, convex-hemispheric, even or becoming convolute and umbilicate, reddish-brown to brown, and velvety in appearance due to the stout paraphyses which extend far beyond the asci; asci clavate above, tapering below, never protruding so far as noted, reaching a length of $300-350 \mu$ and a diameter of $40-50 \mu$; spores at first irregularly bunched near the end of the ascus, gradually spreading, finally becoming 1 -seriate, at first smooth, filled with oil-drops and surrounded by a broad, hyaline band, gradually becoming sculptured, reaching a diameter of $25 \mu$ excluding the sculpturing, or $35 \mu$ including the sculpturing; spore-sculpturing becoming more pronounced with age, of ten assuming the form of reticulations, later strongly echinulate, the spines reaching a length of $4-5 \mu$ and a diameter of $2-2.5 \mu$ at their base, straight or bent at their apices and often with a trace of ridges connecting their bases; paraphyses very stout, septate, brownish, reaching a diameter of $12-15 \mu$ at their apices.

On damp clayey soil in swampy place in the margin of woods.

Type locality: Iowa City, Iowa.

Distribution: Iowa; also in Europe.

Illustrations: Jour. Myc. 11: pl. 75; Bull. Lab. Nat. Hist. State Univ. Iowa 6: pl. 6; Mycologia 6: pl. 123, f. 7-10; Bull. Acad. Sci. Cracovie 1909: 88, f. 3, and 89, f. 4 .

Exsiccati: Rehm, Ascom. 1601.

This species was collected in abundance in a ravine near Iowa City when the writer first undertook the study of the Discomycetes in 1904, and although it was later reported from central Europe, it has never again been encountered in America. The species differs only slightly from the preceding, which was collected once in Maine by Dr. Roland Thaxter. This is the extent of our knowledge of this genus in America.

The writer suspects that Sphaerosoma alveolatum McLennan \& Cookson (Proc. Roy. Soc. Victoria II. 35: 153. 1923) is closely related to, if not identical with, the above.

\section{Doubtful Species}

Boudiera marginata Phill. \& Hark. Bull. Calif. Acad. Sci. 1: 25. 1884. This species is reported on rabbit's dung from California and is said to be 
just as striking as $B$. areolata. The spores are described as globose, $20 \mu$ in cliameter, rufous and areolate. No specimen has been seen, but the description is suggestive of Ascodesmis.

5. LAMPROSPORA De-Not. Comm. Critt. Ital. $1: 388.1864$.

Crouania Fuckel, Symb. Myc. 320. 1869. Not Crouania Agardh. 1842.

Plicaria Fuckel, Symb. Myc. 325. 1869.

Barlaea Sacc. Syll. Fung. 8: 111. 1889. Not Barlaea Reichenb. f 1877.

Detonia Sacc, Syll. Fung. 8: 105. 1889.

Phaeopezia Sacc. Bot. Cent. 18:218. 1884 (in part).

Curreyella Massee, Brit. Fungus-F1. 4: 401. 1895.

Plicariella Lindau in E. \& P. Nat. Pfl. 1': 179. 1897.

Barlaeina Sacc. \& Sydow in Sacc. Syll. Fung. 14: 30. 1899.

Pulvinula Boud. Hist. Class. Discom. Eu. 69. 1907.

Apothecia small to medium-sized, shallow cup-shaped or more of ten scutellate or discoid, externally smooth or verrucose but never clothed with well-developed hairs; hymenium concave, plane or convex, usually bright-colored, some shade of red orange or yellow, more rarely pallid or dark-colored, purple or brownish-black, often roughened by the protruding asci; asci usually clavate or subcylindric, 8-spored; spores globose or subglobose, at first smooth, becoming sculptured or remaining permanently smooth, hyaline or faintly colored; spore-sculpturing very variable, consisting of spines, minute warts, coarse tubercles or ridges, the ridges often assuming the form of reticulations, or in one case forming rings about the spore; paraphyses filiform or clavate, straight or curved.

Type species, Ascobolus miniatus Crouan.

Apothecia small, not exceeding $5 \mathrm{~mm}$. in diameter (usually 1 or $2 \mathrm{~mm}$.); spores hyaline or subhyaline.

Spores sculptured (reticulate, spinulose, verrucose, tuberculate, or annulate).

Spore-sculpt uring consisting of ridges.

Ridges giving rise to reticulations (net-like markings over the surface).

Reticulations shallow, barely roughening the surface of the spore.

Spores at maturity $15-22 \mu$ in diameter, ridges of reticulations about $1 \mu$ thick.

Apothecia reaching a diameter of 3-5 $\mathrm{mm}$.; reticulations regular.

Apothecia not exceeding 1-2 mm. in diameter; reticulations very irregular.

1. L. Cronani.

2. L. laetirubra. 
Spores at maturity $12-15 \mu$ in diameter, reticulations very delicate, scarcely more than lines over the surface of the spore.

Reticulations deep, extending $2 \mu$ or more beyond the periphery of the spore and appearing as a broad band about its surface.

Ridges not giving rise to reticulations.

Ridges usually curved and extending in various directions as in some species of Ascobolus.

Ridges giving rise to two distinct rings about the spore.

Spore-sculpturing consisting of spines, warts, or tubercles.

Spores covered with spines.

Apothecia not exceeding $1 \mathrm{~mm}$. in diameter; spines short, blunt.

Apothecia at maturity $1-5 \mathrm{~mm}$. in diameter; spines long and very sharp.

Spores (including spines) $20-25 \mu$ in diameter; spines slender.

Spores (including spines) $30 \mu$ or more in diameter; spines stout. Spines reaching an extreme length of $10 \mu$, with a diameter of 3 to $4 \mu$ at the base.

Spines conic, about $2-3 \mu$ in diameter and rarely exceeding the same in length.

Spore-sculpturing consisting of warts or tubercles.

Tubercles large, twelve or rarely fourteen or fifteen about the circumference of the spore.

Individual tubercles smooth, not sculptured.

Individual tubercles covered with minute sculpturing, giving them a translucent appearance.

Tubercles small, about twenty or more in the circumference of the spore.

Spores subglobose, on bark among moss.

Spores perfectly globose, on soil.

Apothecia pale-orange.

Apothecia violaceous.
3. L. dictydiola.

4. L. areoluta.

5. L. ascoboloides.

6. L. annulata.

7. L. spinulosa.

8. L. Crec'hqueraultii

9. L. macrantha.

10. L. brevispinosa.
13. L. Wrightii.

14. L. tuberculatella.

15. L. amethystina. 
Spores smooth.

Apothecia pale-orange.

About 3 or $\$ \mathrm{~mm}$. in diameter at maturity, crowded, on burnt ground.

16. L. carbonaria.

About $1 \mathrm{~mm}$. or less in diameter, scattered, on damp soil.

17. L. haemastigma.

Apothecia bright-red.

Several $\mathrm{mm}$. in diameter, on damp soil. Spores $15-20 \mu$ in diameter. Spores $10 \mu$ in diameter.

Less than $1 \mathrm{~mm}$. in diameter; spores $8-9 \mu$ in diameter, on foliage of Sequoia.

Apothecia pallid or creany.

Apothecia salmon-colored.

18. L. Constellatio.

19. L. wisconsinensis.

20. L. gemmea.

21. L. discoidea.

22. L. salmonicolor.

Apothecia large, usually $5 \mathrm{~mm}$. or more in diameter;

spores often faintly colored.

Apothecia dark-colored, purple or brown to blackish.

Brown or blackish, occurring on burnt ground. Spores rough.

Apothecia externally rough; spores about $16 \mu$ in diameter.

Spore-sculpt uring consisting of rather coarse warts.

23. L. trachycarpa.

Spore-sculpturing consisting of minute papillae or pits.

24. L. Detonia.

Apothecia externally smooth; spores about $9 \mu$ in diameter.

25. L. nigrans.

Spores smooth.

26. L. leiocarpa.

Apothecia dark-purple, occurring on damp soil.

27. L. Planchonis.

Apothecia bright-colored, orange.

Spores sculptured.

Spore-sculpturing consisting of irregular lumps.

28. L. lobata.

Spore-sculpturing consisting of minute warts.

29. L. exasperata.

Spores smooth.

30. L. polytrichina.

1. Lamprospora Crouani (Cooke) Seaver, Mycologia 6: 8. 1914. (Plate 3, Fig. 2; 45, Fig. 2, 3.)

Ascobolus miniatus Crouan, Ann. Sci. Nat. IV. 10: 197. 1858. Not $A$. miniatus Preuss, Linnaea 24: 147. 1851.

Ascobolus Crouani Cooke, Jour. Bot. 2: 151. 1864.

Peziza Crouani Cooke, Grevillea 3: 31. 1874.

Crouania miniata Fuckel, Symb. Myc. 320. 1869.

Lamprospora miniata De-Not. Comm. Critt. Ital. 1: 388. 1864.

Aleuria Crouani Gill. Champ. Fr. Discom. 50. 1879. 
Barlaea miniata Sacc. Syll. Fung. 8: 111. 1889.

Plicariella miniata Lindau in E. \& P. Nat. Pfl. 1'1 180. 1897.

Detonia miniata Rehm; Dodge, Trans. Wisc, Acad. 17: 1037. 1914.

Apothecia gregarious or crowded, at first globose, expanding and becoming subdiscoid, externally pale-orange with a whitish fringe-like border, reaching a diameter of 3-5 mm., but often not exceeding $1 \mathrm{~mm}$; hymenium becoming plane or a little concave, bright reddish-orange; excipulum composed of a palisade of parallel or rather loosely interwoven, closely septate, and strongly swollen mycelium, the loose ends of which project above, giving rise to the whitish border, the palisade mycelial threads clavate, reaching a diameter of $10-12 \mu$, of ten delicately roughened; asci cylindric or subcylindric above, reaching a length of $350 \mu$ and a diameter of $20-26 \mu$, tapering below into a pedicel $7-8 \mu$ in diameter; spores 1 -seriate, at first smooth, hyaline, containing one oil-drop which nearly fills the spores, finally becoming sculptured and reaching a diameter of $18-22 \mu$ including sculpturing; spore-sculpturing taking the form of reticulations, the meshes of the reticulations ranging from 2-4 or rarely $5-6 \mu$ in diameter, $3-6$-sided, of ten giving rise to almost perfect hexagonal figures, the ridges of the reticulations less than $1 \mu$ thick and shallow as indicated by the projections about the periphery of the spore; paraphyses stout, about 5 or $6 \mu$ in diameter below, enlarged above and reaching a diameter of $9 \mu$ at their apices, filled with minute orange granules.

On damp soil, usually among mosses.

Type locality: Brest, France.

Distribution: New York to Colorado and Bermuda; also in Europe and Australia.

Illustrations: Ann. Sci. Nat. IV. 10: pl. 13, f. 4t-47; Cooke, Mycographia pl. 5,f. 17; Gill. Champ. Fr. Discom. pl. 52, f. 2; Mycologia 6: pl. 11t, f. 2; Massee, Brit. Fungus-F1. 4: 290, f. 1-4; Ann. Mag. Nat. Hist. III. 15: pl. 16, f. 26; Phill. Brit. Discom. pl. 4, f. 19; Trans. Linn. Soc. 24: pl. 51, f. 19; Bull. Lab. Nat. Hist. State Univ. Iowa 6: pl. 12, f. 1; Pat. Tab. Fung. f. 96; Proc. Roy. Soc. Victoria II. 38: pl. 4, f. 1; Jour. Bot. $2: 151, f .3$.

A well-known, widely distributed and rather commonly collected species, small but rather conspicuous by reason of its bright color. It was commonly collected in Bermuda during our recent expedition there. 
2. Lamprospora laetirubra (Cooke) Lagarde, Ann. Myc. 4: 213 1906.

Peziza laetirubra Cooke, Grevillea 3: 31. 1874; Mycographia 14. 1875.

Apothecia scattered or thickly gregarious, at first globose or subglobose, expanding and becoming patellate, entirely brightorange, reaching a diameter of 1-2 mm.; hymenium strongly convex, becoming pitted and rough with age after the spores have been discharged; asci cylindric or subcylindric; spores perfectly globose, containing one large oil-drop which nearly fills the spore, reaching a diameter of $15-18 \mu$, finally becoming delicately sculptured; spore-sculpturing taking the form of very coarse and irregular reticulations; paraphyses slender, enlarged above, filled with orange granules.

On damp soil in gardens which have been overrun with mosses; also in pastures and meadows.

Type locality: Europe.

Distribution: Iowa and Indiana; also in Europe.

Illustrations: Bull. Lab. Nat. Hist. State Univ. Iowa 6: pl. 12, f. 2 (as Barlaea cinnabarina (Fuckel) Sacc.); Ann. Myc. 4: 213,f. 33; Grevillea 3: pl. 30, f. 56.

According to Fuckel Crouania cinnabarina with which the present species is thought by some to be synonymous has reticulate spores. Examination of a specimen from Fungi Rhenani No. 2481 shows the spores to be smooth. While this may have been an immature specimen it leaves the identity of Fuckel's plant in doubt. It may be the same as the one here discussed. Our specimens are characterized by the very coarse, loose reticulations. These plants have been frequently collected in Iowa.

3. Lamprospora dictydiola Boud. Hist. Class. Discom. Eu. 68. 1907.

Barlaeina dictydiola Sacc. \& Trott. in Sacc. Syll. Fung. 22: 621. 1913.

Apothecia scattered or gregarious but never crowded, at first subglobose, expanding and becoming subdiscoid, reaching a diameter of $1 \mathrm{~mm}$. (in the living plants examined); hymenium becoming plane or nearly so, bordered by a delicate, ragged, fringe-like margin, roughened by the protruding asci, finally becoming more or less pitted apparently from the collapsing of the old asci, orange, a little darker than the outside of the apothecium; asci cylindric or subcylindric, reaching a length of 
$230-300 \mu$ and a diameter of $18-20 \mu$; spores 1 -seriate, at first smooth and containing one large oil-drop, finally becoming delicately sculptured, reaching a diameter of 12-15 $\mu$, hyaline; spore-sculpturing taking the form of reticulations, the meshes of the reticulations not exceeding $1 \mu$ in diameter, the ridges appearing as delicate lines (when examined with a one-sixth objective); paraphyses nearly straight or a little curved, enlarged above, reaching a diameter of $5 \mu$ at their apices.

On charcoal beds which have been overrun with mosses.

TyPe lochlity: France.

Distribution: New York; also in Europe.

Illustrations: Boud. Ic. Myc. pl. 403; Mycologia 6: pl. $114, f .4$.

4. Lamprospora areolata Seaver, Mycologia 4: 48. 1912. (Plate 3, Fig. 3.)

Apothecia gregarious but not crowded, at first globose, expanding and becoming subdiscoid, reaching a diameter of 0.5 to $1 \mathrm{~mm}$., orange to bright-red; hymenium becoming plane or slightly convex, roughened by the protruding asci, of about the same color as the outside of the apothecium; asci cylindric or subcylindric, gradually tapering below, reaching a length of $350 \mu$ and a diameter of 15-22 $\mu$; spores 1 -seriate, at first smooth and containing one large oil-drop, finally becoming sculptured, reaching a diameter of $18-20 \mu$, including sculpturing, hyaline; spore-sculpturing taking the form of deep reticulations, the meshes of the reticulations reaching a diameter of $3-5 \mu, 3-6-$ sided, often forming almost perfect hexagonal figures or with the sides of unequal length, $2-3 \mu$ deep as indicated by the projecting ridges about the periphery of the spore, the ridges scarcely $1 \mu$ thick; paraphyses strongly thickened above.

On damp soil among mosses and algae.

Type Locality: Yonkers, New York.

Distribution: New York and Connecticut.

Illustrations: Mycologia 4: pl. 57, f. 5-8; also 6: pl. 114, f. 3. (Cf. Proc. Roy. Soc. Victoria II. 38: pl. t, f. 2a,b.)

Lamprospora areolata Seaver, var. australis McLennan \& Cookson has identical spore characters but differs mainly in the larger size of the apothecia and in the character of the margin. 
5. Lamprospora ascoboloides Seaver, Mycologia 6: 10. 1914. (Plate 3, Fig. 7.)

Apothecia gregarious, at first globose and closed, nestling in little depressions in the substratum, gradually expanding and, becoming discoid or subdiscoid, externally slightly floccose, usually not exceeding $1 \mathrm{~mm}$. in diameter, pale-orange; hymenium at first concave, becoming plane and finally convex, roughened by the protruding asci, the entire hymenium collapsing in dried specimens and becoming concave; asci cylindric-clavate, tapering rather abruptly below into a stem-like base, reaching a length of $175-225 \mu$ and a diameter of $18-23 \mu$; spores at first smooth and containing one or two oil-drops, finally becoming sculptured, reaching a diameter of 15-18 $\mu$, hyaline; sporesculpturing taking the form of ridge-like markings, the ridges straight or curved and extending in almost any direction, occasionally being parallel or anastomosing and giving rise to a few imperfect reticulations but never perfectly reticulate. about $2 \mu$ thick, resembling those of some species of Ascobolus; paraphyses clavate, reaching a diameter of 5-6 $\mu$, at their apices, densely filled with minute granules.

On the ground among mosses in meadows.

Trpe locality: Portland, Connecticut.

Distribution: Connecticut, New York and Virginia.

Illustration: Mycologia 6: pl. 114, f. 8 .

6. Lamprospora annulata Seaver, Mycologia 6: 11.1914. (Plate 3, Fig. 8.)

Apothecia gregarious but not crowded, at first subglobose and nestling in little cavities in the substratum, expanding and becoming discoid or subdiscoid, pale-orange, reaching a diameter of $0.5-1 \mathrm{~mm}$.; hymenium becoming plane or nearly plane and more or less pitted or roughened, a little darker than the outside of the apothecium; asci cylindric or subcylindric above, rather abruptly attenuated below into a short, much contorted pedicel, reaching a length of $200 \mu$ and a diameter of about $20 \mu$, at first almost filled with the spores, later stretching and the lower part becoming almost equal in length to the spore-bearing part; spores 1-seriate from the first, smooth, when young containing a number of small oil-drops, finally with one large oil-drop, reaching a diameter of $16-18 \mu$, hyaline, becoming minutely verrucose and marked about the proximal and distal sides by 
two rings; spore-rings at first small, increasing in size until they reach a thickness of 3 or $4 \mu$, giving the appearance of four circles where the rings pass about the periphery of the spore, the two rings usually parallel with each other but occasionally shifted out of their normal position and assuming a subspiral position, the whole spore at maturity having a short-cylindric appearance, reaching a diameter of 16-18 $\mu$; paraphyses thickened above and filled with granules, reaching a diameter of $5 \mu$ at their apices.

On soil among mosses and algae.

Type locality: Portland, Connecticut.

Distribution: New York and Connecticut.

Illustration: Mycologia 6: pl. 114, f. 9.

This species, which is very distinct in its spore-markings, has been collected several times by the writer in New York and Connecticut but so far as known has never been found by anyone else.

7. Lamprospora spinulosa Seaver, Mycologia 6: 11. 1914. (Plate 3, Fig. 4; 45, Fig. 5, 6.)

Apothecia closely gregarious but not usually crowded, at first subglobose, expanding and becoming short-cylindric or discoid, their bases closely nestling in little cavities in the substratum, reaching a diameter of $1 \mathrm{~mm}$., pale-orange; hymenium plane or nearly so, roughened by the asci which protrude often half their length above its surface, collapsing after discharging their spores and leaving the hymenium pitted, surrounded by a fringe-like border; excipulum composed of a palisade of strongly swollen, rather closely septate mycelial threads which extend above the hymenium in irregular clusters giving rise to the fringe-like border, the ends of the peridial mycelium reaching a diameter of $17-18 \mu$, minutely granular within and delicately roughened without; asci cylindric above, tapering below into a short, slender, stem-like base, reaching a length of $200 \mu$ and a diameter of $18-20 \mu$, stretching before discharging their spores and then reaching a length of $300 \mu$ and a diameter of $26 \mu$; spores at first smooth, finally becoming sculptured, reaching a diameter of $18-20 \mu$, containing one oil-drop which nearly fills the spore, hyaline; spore-sculpturing taking the form of minute blunt spines $1 \mu$ thick and $2 \mu$ long; paraphyses septate, gradually enlarged above, reaching a diameter of $7-8 \mu$, minutely granular within and dilutely colored, orange. 
On the ground among mosses.

Type Locality: The New York Botanical Garden.

Distribution: New York City and New Jersey.

Illustration: Mycologia 6: pl. 114, f. 5.

8. Lamprospora Crec'hqueraultii (Crouan) Boud. Hist. Class.

Discom. Eu. 69. 1907. (Plate 3, Fig. 1; 45, Fig. 8.)

Ascobolus Crec'hqueraultii Crouan, Ann. Sci. Nat. IV'. 10: 194. 1858.

Peziza modesta Karst. Not. Fauna Fl. Fenn. 10: 122. 1869.

Peziza echinosperma Peck, Ann. Rep. N. Y. State Mus. 24: 95. 1872.

Peziza auriflava Cooke, Mycographia 16. 1875.

Aleuria auriflava Gill. Champ. Fr. Discom. 50. 1879.

Mollisia Crec'hqueraultii Gill. Champ. Fr. Discom. 118.1882.

Crouania asperella Rehm, Hedwigia 24: 226. 1885.

IIumaria Crec'hqueraultii Quél. Ench. Fung. 288. 1886.

Barlaea Crec'hqueraultii Sacc. Syll. Fung. 8: 113. 1889.

Barlaea asperella Sacc. Syll. Fung. 8: 113. 1889.

Barlaea modesta Sacc. Syll. Fung. 8: 113. 1889.

Humaria echinosperma Sacc. Syll. Fung. 8: 130. 1889.

Plicariella modesta Lindau in E. \& P. Nat. Pfl. $\mathbf{1}^{1}: 180.1897$.

Barlaeina Crec'hqueraultii Sacc. \& Trott. in Sacc. Syll. Fung. 22: 621. 1913.

Apothecia gregarious, becoming discoid to scutellate, very pale-orange, externally smooth, reaching a diameter of $2-5 \mathrm{~mm}$.; hymenium becoming plane or more often convex, the margin indistinct, pale-orange fading to a dirty-yellow in dried plants; excipulum composed of large roundish cells below and giving rise to a palisade of mycelium above, the loose ends of which are clubshaped, reaching a diameter of $17-18 \mu$; asci cylindric or subcylindric above, reaching a length of $300-325 \mu$ and a diameter of $27 \mu$, often protruding above the surface of the hymenium; spores 1-seriate, at first smooth, becoming sculptured, reaching a diameter of $20-25 \mu$ including sculpturing, hyaline; spore-sculpturing taking the form of very sharp spines, the spines broad at the base, reaching a length of $2-3 \mu$, in dried specimens often bent or adpressed but regaining their normal form when wet; paraphyses rather stout, reaching a diameter of 3-4 $\mu$ below, enlarged above and often reaching a diameter of $10 \mu$ at their apices.

On clayey soil.

Type locality: Europe.

Distribution: New York to Delaware, Mest Virginia and Colorado; also in Europe and Australia.

Illustrations: Ann. Rep. N. Y. State Mus. 24: pl. 3, f. 
10-13; Ann. Sci. Nat. IV. 10: pl. 13, f. 12-15; Boud. Ic. Myc. pl. 404; Bull. Lab. Nat. Hist. State Univ. Iowa 6: pl. 12, f. 4; Cooke, Mycographia pl. 6, f. 22, 23; Mycologia 6: pl. 114, f. 1; Proc. Roy. Soc. Victoria II. 38: pl. 5, f. t.

Exsiccatr: N. Am. Fungi 840 (as Peziza echinosperma Peck); $8+1$ (as Peziza modesta Karst.); Clements, Crypt. Form. Colo. 115 (as Detonia modesta).

One of the most common and widely distributed species of the genus.

9. Lamprospora macrantha (Boud.) Seaver, sp. nov.

Lamprospora Crec'hqueraultii var. macrantha Boud. Hist. Class. Discom. Eu. 69. 1907.

Apothecia gregarious but not usually crowded, subglobose, becoming short-cylindric, finally discoid, externally pale-yellow, reaching a diameter of 1-2 $\mathrm{mm}$; hymenium becoming plane or very slightly concave, with a delicate fringe-like border, paleorange; excipulum giving rise to a palisade of mycelium above, which forms the fringe about the hymenium, the ends of the palisade mycelium clavate, reaching a diameter of $25-30 \mu$; asci cylindric above, gradually tapering below into a stem-like base, reaching a length of $300-325 \mu$ and a diameter of $30-35 \mu$; spores 1-seriate from the first, smooth and densely filled with oil-drops, becoming sculptured apparently by the accumulation of protoplasmic material about the outside of the spore, reaching a diameter of $20 \mu$ excluding spines and $30-35 \mu$ including spines, hyaline; spore-sculpturing at first indistinct, gradually assuming the form of sharp spines which give the spore a beautiful crystalline appearance, the spines reaching a length of $10 \mu$ and a diameter of 3-4 $\mu$ at the base; paraphyses strongly enlarged above, reaching a diameter of $7-10 \mu$ at their apices.

On clayey soil in wet places.

Type locality: France.

Distribution: New York; also in Europe.

Illustration: Boud. Ic. Myc. pl. 405.

\section{Lamprospora brevispinosa Seaver, sp. nov.}

Apothecia gregarious, at first globose and closely nestling in little depressions in the substratum, expanding and becoming discoid or subdiscoid, externally orange, reaching a diameter of $1 \mathrm{~mm}$.; hymenium delicately roughened by the protruding asci, 
a little brighter than the outside of the apothecium; excipulum composed of a palisade of mycelium, the loose ends of which give rise to a fringe-like border, the ends cnlarged, attaining a diameter of $20-25 \mu$ at their extremities; asci broad-cylindric to clavate, tapering rather abruptly below into a stem-like base, reaching a length of $300-325 \mu$ and a diameter of $30-35 \mu$; spores 1 -seriate, at first smooth, densely filled with orange granules, becoming sculptured, reaching a diameter of $25 \mu$ excluding sculpturing or 30-32 $\mu$ including sculpturing, hyaline; sporesculpturing gradually assuming the form of sharp spines, 2-3 $\mu$ in diameter at the base and of about the same length, the spines decidedly conic in form; paraphyses stout, containing several large oil-drops, reaching a diameter of $12 \mu$ at their apices.

On moist soil among mosses and algae by roadside.

Type Locality : Springside, New Jersey, June 9, 1914.

Distribution: Known only from the type locality.

While this and the preceding might be regarded as mere forms of Lamprospora Crec'hqueraultii, one of the most commonly collected species of the genus, there is such a wide and constant variation in the size and form of the spines with which the spores are decorated that it seems best to segregate the two latter under the names suggested.

11. Lamprospora tuberculata Seaver, Mycologia 4: 47. 1912. (Plate 3, fig. 6.)

Apothecia gregarious in small clusters, not crowded but rarely with two or three in close contact, at first globose or subglobose and almost buried in the sandy soil in which they grow, gradually expanding and reaching a diameter of $0.5-1 \mathrm{~mm}$.; superficial but with the base still nestling in the substratum; hymenium plane or nearly so, orange, a little darker than the outside of the apothecium, roughened by the protruding asci which appear as minute white spines; excipulum composed of a palisade of swollen, closely septate mycelium, the loose ends of which give rise to a delicate fringe-like border, the ends of the peridial mycelium about $10 \mu$ in diameter; asci cylindric or subcylindric, tapering below into a stem-like base, reaching a length of $275-300 \mu$ and a diameter of $20-30 \mu$; spores 1 -seriate, at first smooth and usually containing one large oil-drop, gradually becoming sculptured, reaching a diameter of $18-20 \mu$, hyaline; spore-sculpturing assuming the form of tubercles covering the 

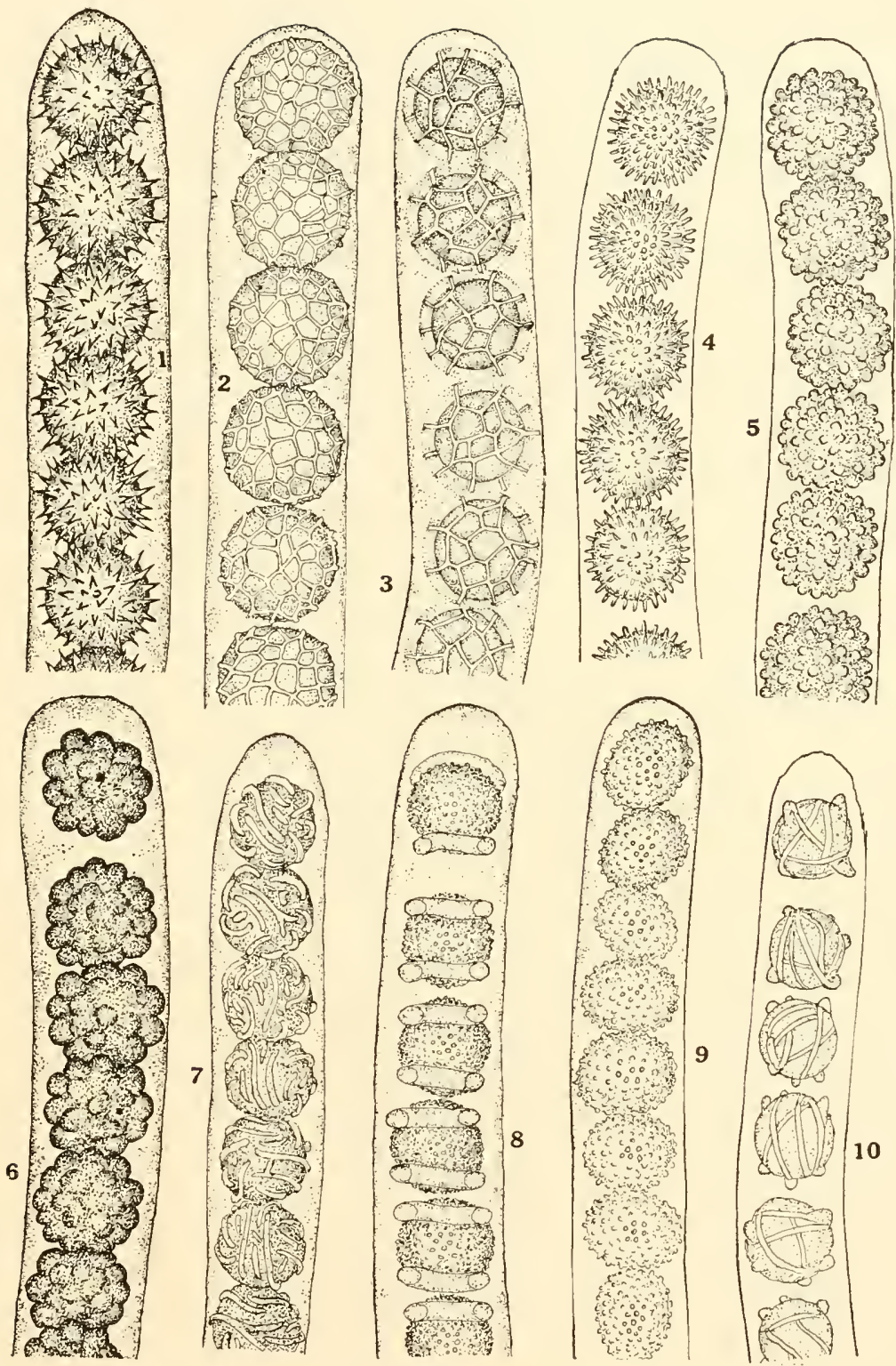

LAMPROSPORA 

surface of the spore and appearing about its periphery like great lumps, often projecting further in one place than another, giving the spore an irregular outline, the tubercles about $3-4 \mu$ in diameter, 12 or 14 , rarely 15 , appearing about the periphery of the spore; paraphyses enlarged above, attaining a diameter of $3-4 \mu$ below and a diameter of $6-8 \mu$ at their apices, filled with minute pale-orange granules.

On the soil in open places among mosses and atgae.

Type Locality: Moods near Yonkers, New York.

Distributiox: New York to Virginia; also in Australia.

Illustrations: Mycologia 4: pl. 57, f. 1-t; also 6: pl. 11t, f. 7; Proc. Roy. Soc. Victoria II. 38: pl. 5, f. 1.

McLennan and Cookson believe that the Tasmanian species described by L. Rodway (Proc. Roy. Soc. Tasmania 1924: 112. 1925) under the name of Barlaea zerrucosa is identical with our species.

\section{Lamprospora Maireana Seaver, Mycologia 6:14. 1914.}

Apothecia gregarious, at first globose, expanding and reaching a diameter of about $2 \mathrm{~mm}$., pale-orange; hymenium plane or slightly concave, of about the same color as the outside of the apothecium; asci cylindric or subcylindric, gradually tapering below in to a stem-like base, reaching a length of $300-325 \mu$ and a diameter of $30 \mu$; spores 1 -seriate, becoming sculptured, reaching a diameter of $23 \mu$, hyaline or subhyaline; spore-sculpturing taking the form of tubercles which are as large as $3-5 \mu$ in diameter, appearing about the periphery of the spore as scallops, the tubercles bearing secondary sculpturing which gives to each tubercle a minutely verrucose appearance and to the whole spore a translucent effect; paraphyses strongly thickened at their apices, reaching a diameter of $8 \mu$.

On the ground among mosses and algae.

Type locality: Algiers, North Africa.

Distribution: New York; also in North Africa and Australia.

Illustrations: Mycologia 6: pl. 114, f. 13; Proc. Roy. Soc. Victoria II. 38: pl. 5, f. 3 .

Exsiccati: Maire, Myc. Bor. Africana 22 (as Lamprospora tuberculata Seaver). 
13. Lamprospora Wrightii (Berk. \& Curt.) Seaver, Mycologia 6: 15. 1914. (Plate 3, Fig. 9.)

Peziza IVrightii Berk. \& Curt.; Berk. \& Br. Ann. Mag. Nat. Hist. III. 15: 444. 1865.

Barlaea Wrightii Sacc. Syll. Fung. 8: 112. 1889.

Humaria Wrightii Boud. Hist. Class. Discom. Eu. 68. 1907.

Apothecia gregarious or scattered, at first globose, expanding and becoming subdiscoid, reaching a diameter of 1-2 mm., externally pale-yellow and minutely roughened; hymenium plane or slightly concave, surrounded by a delicate fringe-like border, a little darker than the outside of the apothecium; asci cylindric or slightly clavate above, rather abruptly tapering below into a stem-like base, reaching a length of $175-200 \mu$ and a diameter of $17-18 \mu$; spores usually 1 -seriate, or occasionally irregularly crowded, globose or very slightly ellipsoid, at first smooth and containing one to several oil-drops, finally becoming sculptured, reaching a diameter of $15-17 \mu$, hyaline; spore-sculpturing taking the form of small warts which are usually rather widely scattered over the surface of the spore; paraphyses strongly enlarged above, filled with granules.

On the bark of trees among mosses.

Type Locality: Bodelwyddan, Flintshire, Wales.

Distributiox: Alabama, Texas, Cuba, and reported from Nebraska; also in Europe.

lllustrations: Ann. Mag. Nat. Hist. III. 15: pl. 15, f. 16; Boud. Ic. Myc. pl. 399; Cooke, Mycographia pl. 3, f. 18; Mycologia 6: pl. 114, f. 11.

14. Lamprospora tuberculatella Seaver, Mycologia 6: 15. 1914. (Plate 3, Fig. 5; 45, Fig. 9, 10.)

Apothecia gregarious but never crowded, often five or six plants in the space of $1 \mathrm{~cm}$., at first subglobose, expanding and becoming short-cylindric, finally discoid, pale-orange, reaching a diameter of $0.3-0.5 \mathrm{~mm}$. or rarely as large as $1 \mathrm{~mm}$.; hymenium becoming plane or nearly so, a little darker than the outside of the apothecium, roughened by the protruding asci which appear as minute white spines, surrounded by a delicate fringe-like border; asci cylindric or subcylindric above, tapering rather abruptly into a stem-like base, reaching a length of $225-250 \mu$ and a diameter of $25 \mu$; spores 1 -seriate, at first smooth and containing one large oil-drop, reaching a diameter of $18-20 \mu$, hyaline, finally becoming sculptured; spore-sculpturing taking the 
form of tubercles, the number appearing about the periphery of the spore ranging from 20-25 in the circumference of the spore; paraphyses gradually enlarged upwards and filled with orange granules, reaching a diameter of $8-9 \mu$ at their apices.

On soil among mosses.

Type Locality: Yonkers, New York.

Distributiox: New York and Maine; also in Australia.

Illustrations: Mycologia 6: pl. 114, f. 6; Proc. Roy. Soc. Victoria II. 38: pl. 5, f. 2.

15. Lamprospora amethystina (Quél.) Seaver, Mycologia 6: 16. 1914.

Humaria Persoonii amethystina Quél. Assoc. Fr. Av. Sci. Comp. Rendu 14²: 451. 1886.

Barlaea amethystina Sacc. Syll. Fung. 8: 116. 1889.

Apothecia gregarious, at first subglobose, expanding and becoming discoid, externally pale, whitish or purplish, reaching a diameter of $2 \mathrm{~mm}$; hymenium becoming plane or a little concave, purplish, a little darker than the outside of the apothecium, bordered by a whitish fringe-like margin; asci cylindric or subcylindric above, gradually tapering below; spores 1 -seriate, at first smooth, hyaline, reaching a diameter of $12 \mu$, becoming sculptured; spore-sculpturing consisting of small warts similar in size and general appearance to those of L. iuberculatella; paraphyses slender, slightly enlarged at their apices.

On the ground among mosses.

Type locality: Jura, France.

Distribution: Iowa; also in Europe.

Illustration: Bull. Lab. Nat. Hist. State Univ. Iowa 6: pl. $12, f .3$.

16. Lamprospora carbonaria (Fuckel) Seaver, Mycologia 6: 16. 1914.

Crouania carbonaria Fuckel, Symb. Myc. Nachtr. 2: 64. 1873.

Peziza sanguinaria Cooke, Crevillea 3:31. 1874.

Barlaea carbonaria Sacc. Syll. Fung. 8: 112. 1889.

?Lamprospora carbonicola Boud. Hist. Class. Discom. Eu. 68. 1907.

Pulvinula carbonaria Boud. Ilist. Class. Discom. Eu. 70. 1907.

Barlaeina carbonicola Sacc. \& Trav.; Sacc. \& Trott. in Sacc. Syll. Fung, 22: 622. 1913.

Apothecia gregarious or crowded, at first globose, becoming expanded and scutellate to discoid, the margin even or wavy, 
pale-orange, reaching a diameter of $1-4 \mathrm{~mm}$; hymenium becoming plane or slightly concave, roughened by the protruding asci, a little darker than the outside of the apothecium; asci cylindric or subcylindric, reaching a length of $225 \mu$ and a diameter of 18-20 $\mu$; spores smooth, hyaline, reaching a diameter of 15-18 $\mu$, containing one oil-drop which nearly fills the spore; paraphyses filiform or slightly enlarged at their apices, extending far beyond the young asci and strongly curved or hooked, reaching a diameter of $3-4 \mu$ at their apices.

On soil among mosses in places which have been burned but subsequently overgrown with mosses.

Type Locality: Oestrich and Budenheim woods, Germany.

Distribution: New York and Connecticut to Montana; also in Europe.

Illustration: Boud. Ic. Myc. pl. 401 (as L. carbonicola).

17. Lamprospora haemastigma (Hedw.) Seaver, Mycologia 6: 17. 1914. (PLATE 45, FIG. 1.)

?Peziza convexella Karst. Not. Fauna Fl. Fenn. 10: 123. 1869.

Humaria haemastigma Quél. Ench. Fung. 289. 1886.

Pyronema haemastigma Sacc. Syll. Fung. 8: 108. 1889. (excl. descr.)

?Octospora haemastigma Hedw. Descr. 2: 17. 1788.

?Barlaea convexella Sacc. Syll. Fung. 8: 114. 1889.

Pulvinula haemastigma Boud. Hist. Class. Discom. Eu. 70. 1907.

Detonia convexella Dodge, Trans. Wisc. Acad. 17: 1037. 1914.

Apothecia rather thickly gregarious but not usually crowded, at first subglobose, expanding and becoming discoid, paleyellow to red, becoming brighter in dried specimens, reaching a diameter of $1 \mathrm{~mm}$; hymenium plane or slightly concave, similar in color to the outside of the apothecium; asci cylindric or subcylindric above, tapering below in to a stem-like base, reaching a length of $300 \mu$ and a diameter of 20-23 $\mu$; spores 1 -seriate, smooth, usually containing one to several oil-drops, reaching a diameter of $20 \mu$, hyaline; paraphyses very slender, straight or often strongly curved at their apices, scarcely thickened above, reaching a diameter of $2 \mu$, densely filled with yellow granules.

On damp soil among mosses.

Type locality: Europe.

Distribution: New York to Wisconsin; also in Europe.

Illustrations: Hedw. Descr. 2: pl. 5, f. 1-5; Boud. Ic. Myc. pl. 406. 
18. Lamprospora Constellatio (Berk. \& Br.) Seaver, Mycologia 6 : 18. 1914. (Plate 45, Fig. 7.)

?Croutania humosa Fuckel, Symb. Myc. 320. 1869. (excl. synn.)

Peziza Constellatio Berk. \& Br. Ann. Mag. Nat. Ilist. IV. 17: 142. 1876.

Leucoloma Constellatio Rehm, Ber. Naturh. Ver. Augsburg 26: 5. 1881.

Pulvinula Constellatio Boud. Bull. Soc. Myc. Fr. 1: 107. 1885.

Aleuria Constellatio Gill. Champ. Fr. Discom, 207. 1888.

Barlaea Constellatio minuta Clements, Bot. Surv. Nebr. 4: 10. 1896.

Plicariella Constellatio Lindau in E. \& P. Nat. Pfl. $1^{1}$ : 180.1897.

Barlaeina Constellatio minuta Sacc. \& D. Sacc. in Sacc. Syll. Fung. 14: $7+9$. 1899.

Barlaeina Constellatio Sacc. \& Sydow in Sacc. Syll. Fung. 14: 749.1899.

Detonia Constellatio Rehm; Dodge, Trans. Wisc. Acad. 17: 1037. 1914.

Apothecia gregarious or scattered, at first globose, expanding and becoming scutellate to discoid, pale-orange, reaching a diameter of 1-5 mm.; hymenium bright-red, the color becoming brighter in dried specimens, often almost scarlet; asci cylindric or subcylindric above, tapering into a long stem-like base, reaching a length of $250-300 \mu$ and a diameter of $20 \mu$; spores 1 -seriate, smooth, hyaline, reaching a diameter of 15-20 $\mu$, containing one large oil-drop which is of ten surrounded by numerous smaller ones; paraphyses filiform, only slightly thickened at their apices and very much curved and hooked, septate, filled with red granules.

On bare ground, especially on rich soil in woods or meadows.

Type Locality: Addlington, Kent, Great Britain.

Distribution: New Jersey to Ontario, Colorado, California and Jamaica; also in Europe.

Illustrations: Boud. Ic. Myc. pl. 407; Cooke, Mycographia pl. 21, f. 81; Pat. Tab. Fung. f. 372.

Exsiccati: N. Am. Fungi 2036.

19. Lamprospora wisconsinensis Seaver, nom. nov.

Barlaea laeterubra Rehm, Ann. Myc. 3: 516. 1905. Not Pesiza laetirubra Cooke.

Barlaeina laeterubra Sacc. \& Trott. in Sacc. Syll. Fung. 22: 622. 1913.

Detonia laeterubra Dodge, Trans. Wisc. Acad. 17: 1037. 1914.

Apothecia scattered, at first globose or subglobose, expanding and becoming discoid or subdiscoid, pale-yellow, scarcely exceeding $1 \mathrm{~mm}$. in diameter; hymenium plane or nearly so, similar in color to the outside of the apothecium; asci cylindric or subcylindric above, tapering below into a stem-like base, reaching a length of $150-175 \mu$ and a diameter of $12-14 \mu$; spores at 
first partially 2-seriate or irregularly crowded, finally becoming 1 -seriate, smooth, granular within but containing no conspicuous oil-drops, hyaline, never exceeding $10 \mu$ in diameter and often smaller; paraphyses filiform, $1.5-2 \mu$ in diameter, slightly thickened above and strongly curved at their apices, sparingly branched, filled with hyaline granules.

On the ground and on burnt ground which has been overrun with mosses.

Type locality: Cemetery woods, Wisconsin.

Distribution: New York and Wisconsin.

20. Lamprospora gemmea (Phill.) Seaver, Mycologia 6: 18. 1914.

Peziza gemmea Phill. Grevillea 7:21. 1878.

Barlaea gemmea Sacc. Syll. Fung. 8: 112. 1889.

Apothecia gregarious, sessile, subturbinate, finally expanding and becoming more or less discoid, externally pale-reddish, reaching a diameter of $0.5 \mathrm{~mm}$; hymenium plane or slightly concave, bright-red; asci cylindric or subcylindric, gradually tapering below; spores 1 -seriate, smooth, hyaline, reaching a diameter of $8 \mu$, granular within; paraphyses filiform, very slender, scarcely enlarged above, branched, straight or more or less curved at their apices, not exceeding $2 \mu$ in diameter.

On decaying foliage of Sequoia sempervirens.

Type locality: California.

Distributios: Known only from the type locality.

Illustration: Cooke, Mycographia pl. 111,f. 398.

21. Lamprospora discoidea (P. Henn. \& E. Nym.) Seaver, Mycologia 6: 19. 1914. (Plate 45, Fig. 4.)

Barlaea discoidea P. Henn. \& E. Nym. Monsunia 1: 33. 1900.

Barlaeina discoidea Sacc. \& Sydow in Sacc. Syll. Fung. 16: 710. 1902.

Apothecia scattered, gregarious or occasionally closely congested, sessile, at first subglobose, finally expanding and becoming discoid, pale-whitish, reaching a diameter of 1-2 mm.; hymenium plane or convex, with the margin slightly elevated, roughened by the protruding asci, whitish or grayish with a tinge of yellow or cream; excipulum composed of a palisade of mycelium, the loose ends of which are clavate; asci subcylindric above, tapering below into a slender stem-like base which is usually forked, reaching a length of $200-250 \mu$ and a diameter of $20 \mu$; spores 
1-seriate, smooth, rather thick-walled, reaching a diameter of 15-20 $\mu$, hyaline; paraphyses slender below, reaching a diameter of $3 \mu$, enlarged upwards to $5 \mu$, occasionally branched, straight or strongly curved or hooked at their apices.

On bare sandy soil or among mosses.

TYPE LOCAlity: Java.

Distribution: New York; also in Europe.

22. Lamprospora salmonicolor Seaver, Mycologia 17: 47. 1925.

Apothecia discoid, with the hymenium plane or slightly convex, reaching a diameter of $2 \mathrm{~mm}$., pale salmon-colored; asci cylindric or subcylindric, reaching a length of $275 \mu$ and a diameter of 20-24 $\mu$; spores globose, filled with minute granules, smooth, $20 \mu$ in diameter when mature; paraphyses clavate.

On bare ground.

Type locality : El Iunque, Porto Rico.

Distribution: Known only from the type locality.

23. Lamprospora trachycarpa (Curr.) Seaver, Mycologia 6: 19. 1914.

Peziza trachycarpa Curr. Trans. Linn. Soc. 24: 493. 1864.

?Bulgaria carbonaria Fuckel, Fungi Rhen. 1137. 1865.

?Peziza atrospora Fuckel, Fungi Rhen. 1224. 1865.

?Plicaria carbonaria Fuckel, Symb. Myc. 326. 1869.

?Plicaria ferruginea Fuckel, Symb. Myc. 326. 1869.

Peziza scabrosa Cooke, Mycographia 170.1877.

Discina trachycarpa Karst. Act. Fauna FI. Fenn. 2: 113. 1885.

Aleuria trachycarpa Gill. Champ. Fr. Discom. 207. 1886.

Detonia trachycarpa Sacc. Syll. Fung. 8: 105.1889.

Phaeopezia scabrosa Sacc. Syll. Fung. 8: 472. 1889.

?Phaeopezia atrospora Sacc. Syll. Fung. 8: 472.1889.

Curreyella trachycarpa Massee, Brit. Fungus-Fl. 4: 401. 1895.

Plicariella trachycarpa Rehm in Rab. Krypt.-F1. 133: 996. 1896.

Apothecia gregarious or densely crowded, often forming continuous masses extending over a space of several cm., at first subglobose, expanding and becoming shallow cup-shaped with the margin elevated and incurved, or more rarely scutellate and closely adhering to the substratum, regular in form or cochleate and becoming very irregular from mutual pressure, externally paler than the hymenium and usually rough and scabrous, reaching a diameter of from a few $\mathrm{mm}$. to $2 \mathrm{~cm}$; hymenium smooth or convolute, dark reddish-brown or slightly olivaceous, becoming black when old or in dried specimens; asci cylindric or 
subcylindric above, reaching a length of 250-300 $\mu$ and a diameter of 14-16 $\mu$ or rarely $18 \mu$; spores 1 -seriate, at first smooth, becoming sculptured, reaching a diameter of $15-18 \mu$, becoming pale-yellow or smoky; spore-sculpturing taking the form of minute warts or short, interrupted ridges; paraphyses about 3-4 $\mu$ in diameter below, sparingly branched, enlarged at their apices where they reach a diameter of $8 \mu$, adhering together, yellowish-brown.

On burnt ground and charcoal beds.

Type Lochlity: Ascot Heath, Great Britain.

Distribution: New Hampshire to Colorado; also in Europe.

Illustrations: Boud. Ic. Myc. pl. 306; Bull. Lab. Nat. Hist. State Univ. Iowa 6: pl. 14, f. 1; Cooke, Mycographia pl. 67, f. 257; Trans. Linn. Soc. 24: pl. 51, f. 3, 5; Mycologia 6: pl. 114, f. 10 .

One of the larger species of the genus and rather commonly collected on burnt places.

\section{Lamprospora Detonia Brenckle, Mycologia 8: 318. 1916.}

Apothecia scattered, scutellate, with the margins elevated, slightly incurved and free from the substratum, externally brown and verrucose, quite regular in form, becoming convolute in drying, reaching a diameter of 5-12 mm.; hymenium smooth, concave to plane, dark-brown to black with a green tint; asci cylindric or subcylindric, reaching a length of $300 \mu$ and a diameter of $15 \mu$; spores 1 -seriate, crowded in the upper third of the ascus, at first smooth, becoming sculptured, containing one large oil-drop, becoming brown and opaque so as to appear black under the microscope, reaching a diameter of $12-15 \mu$; sporesculpturing consisting of minute warts or pits which are much finer than those of L. trachycarpa; paraphyses slender, yellowish, the apex thickened and colored.

Among mosses on shaded ground in woods.

Trpe Locality: Cheyenne River near Anselm, North Dakota. Distribution: Known only from the type locality.

25. Lamprospora nigrans (Morgan) Seaver, Mycologia 6: 20. 1914. Peziza nigrans Morgan, Jour. Cinn. Soc. Nat. Hist. 18: 43. 1895. Detonia nigrans Sacc. \& Sydow in Sacc. Syll. Fung. 14: 747. 1899.

Apothecia at first roundish, expanding and becoming cupshaped, finally scutellate and often more or less irregular, ex- 
ternally smoky-pallid and smooth, attached to the soil by slender fibers, reaching a diameter of 1-2 cm.; hymenium plane or concave, becoming black or blackish; asci cylindric or subcylindric, reaching a length of $150 \mu$ and a diameter of $10 \mu$; spores 1 -seriate, at first smooth, becoming sculptured and smokybrown, reaching a diameter of $9 \mu$; spore-sculpturing consisting of rather coarse warts, the warts rounded, rather conspicuous and about $2 \mu$ in diameter; paraphyses slender, thickened above, yellowish-brown.

On burnt ground.

Type locality: Preston, Ohio.

Distribution: Known only from the type locality.

Illustration: Jour. Cinn. Soc. Nat. Hist. 18: pl. 3, f. 17.

26. Lamprospora leiocarpa (Curr.) Seaver, Mycologia 6: 21. 1914.

Peziza leiocarpa Curr. Trans. Linn. Soc. 24: 493. 1864.

Plicaria foreuta Fuckel, Symb. Мyc. 326. 1869.

Detonia leiocarpa Sacc. Syll. Fung. 8: 105. 1889.

Detonia foveata Sacc. Syll. Fung. 8: 105. 1889.

Aleuria leiocarpa Gill. Champ. Fr. Discom. (suites). 1890.

Curreyella foveata Massee, Brit. Fung.-F1. 4: 402. 1895.

Plicariella leiocarpa Rehm in Rab. Krypt.-Fl. 132: 994. 1896.

Apothecia gregarious, scattered or crowded, at first globose and closed, expanding and becoming shallow cup-shaped, regular in form or cochleate and occasionally incised and Otidea-like, at length scutellate or subdiscoid, externally reddish-brown to brownish-black with a slight tinge of olive, often strongly roughened, reaching a diameter of 2-3 cm.; hymenium smooth and even or undulated and lobed, similar in color to the outside of the apothecium but a little darker; asci cylindric or subcylindric above, tapering below into a stem-like base, reaching a length of $350 \mu$ and a diameter of $15-18 \mu$; spores at first irregularly 2 -seriate, finally separating and becoming 1 -seriate, hyaline or slightly yellowish, rather thick-walled, smooth, reaching a diameter of 10-12 $\mu$, usually containing one large central oil-drop; paraphyses stender, rather abruptly enlarged above, densely granular within, reaching a diameter of $7 \mu$, showing a tendency to adhere together in fascicles.

On burnt ground.

Trpe locality: Ascot Heath, Great Britain. 
Distribution: California, Washington, Idaho, Montana; also in Europe.

Illustrations: Trans. Linn. Soc. 24: pl. 51, f. 4, 6; Boud. Ic. Myc. pl. 304; Gill. Champ. Fr. Discom. (suites).

27. Lamprospora Planchonis (Dun.) Seaver, Mycologia 6: 21. 1914.

Plicaria Planchonis Dun.; Boud. Bull. Soc. Myc. Fr. 3: 92. 1887.

Apothecia gregarious or scattered, sessile, concave-hemispheric or nearly discoid, regular or irregularly contorted, the margin crenate or even, externally minutely warted, dark-purple or almost black, reaching a diameter of 5-8 mm.; hymenium concave or nearly plane, a little paler than the outside of the apothecium; substance bright-purple with transmitted light, the color being easily extracted from the dried plants with water; asci cylindric or subcylindric, tapering below in to a slender stem, reaching a length of $200 \mu$ and a diameter of 13-15 $\mu$; spores 1 -seriate, at first hyaline, becoming pale-purplish, smooth or very minutely sculptured at maturity, containing one to several oil-drops, reaching a diameter of $10-12 \mu$; spore-sculpturing consisting of very minute warts which barely roughen the surface of the spore; paraphyses clavate, reaching a diameter of $6 \mu$ at their apices, filled with purple granules.

On sandy soil by roadsides, hillsides and on sand-dunes.

Type locality: France.

Distribution: Very common in the Bermudas but not known from the mainland of North America; also in Europe.

Illustrations: Bull. Soc. Myc. Fr. 3: pl. $\delta$; Boud. Ic. Myc. pl. 309.

28. Lamprospora Iobata (Berk. \& Curt.) Seaver, Mycologia 6: 22. 1914. (Plate 3, Fig. 10.)

Peziza lobata Berk. \& Curt.; Berk. Jour. Linn. Soc. 10: 365. 1868.

Barlaea lobata Sacc. Syll. Fung. 8: 117. 1889.

Apothecia scattered, at first subglobose, becoming shallow cup-shaped, finally almost scutellate, with the margin undulated or lobed, pale-yellow, reaching a diameter of 5-12 mm.; hymenium concave or nearly plane, a little darker than the outside of the apothecium; asci cylind ric or subcylindric, reaching a length of $250 \mu$ and a diameter of $15-18 \mu$; spores 1 -seriate, at first smooth, becoming sculptured, reaching a diameter of $12-15 \mu$, 
hyaline; spore-sculpturing consisting of four to six tubercles of variable size which extend beyond the periphery of the spore and several indistinct lines or bands extending across the spore and appearing like pieces of coarse twine wound about its surface, the inequality of the tubercles giving to the spore a rather irregular form; paraphyses very slender, reaching a diameter of $1-2 \mu$ and scarcely enlarged at their apices.

On the ground.

Type locality: Cuba.

Distributiox: Known only from the type locality.

Illustrations: Cooke, Mycographia pl. 69, f. 265; Mycologia 6: pl. 114, f. 12 .

29. Lamprospora exasperata (Berk. \& Curt.) Seaver, comb. nov. Peziza exasperata Berk. \& Curt. Grevillea 3: 152. 1874.

Barlaea exasperata Sacc. Syll. Fung. 8: 112. 1889.

Apothecia at first globose or subglobose, expanding and becoming shallow cup-shaped, with the margin inflexed, externally minutely verrucose, reaching a diameter of a little more than $1 \mathrm{~cm}$; hymenium concave, red; asci cylindric or subcylindric; spores 1 -seriate, globose, becoming sculptured, reaching a diameter of $12-14 \mu$; spore-sculpturing consisting of minute warts; paraphyses rather stout.

On burnt ground.

Type Locality: Alabama.

Distributiox: Known only from the type locality.

Illustration: Cooke, Mycographia pl. 6, f. 21.

30. Lamprospora polytrichina (Rehm) Seaver, Mycologia 6: 23. 1914.

?Peziza Polytrichi Schum. Enum. Pl. Saell. 2: 423. 1803.

Peziza leucoloma Karst. Not. Fauna F1. Fenn. 10: 122. 1869. (excl. syn.)

Barlaea Polytrichi Sacc. Syll. Fung. 8: 113 (in part). 1889.

Detonia polytriclina Rehm in Rab. Krypt.-F1. 13 1269.1896.

Plicariella Polytrichi Lindau in E. \& P. Nat. Pfl. 1²: 180. 1897.

Apothecia gregarious, sessile, at first subglobose, becoming scutellate or shallow cup-shaped, margin often wavy, externally paler than the hymenium, whitish and more or less pruinose, reaching a diameter of 5-10 mm.; hymenium concave or nearly plane, bright-orange; asci cylindric or subcylindric, gradually tapering toward the base, reaching a length of $200-225 \mu$ and a diameter of $17 \mu$; spores 1 -seriate, smooth, reaching a diameter 
of 10-13 $\mu$, hyaline, often containing one or several oil-drops; paraphyses slender, slightly enlarged above, straight, slightly curved or more rarely hooked.

On bare soil among mosses, especially Polytrichum.

TyPe LOCAlity: Europe.

Distribution: Minnesota and (Washington?); also in Europe. Illustration: Pat. Tab. Fung. f. 277.

\section{Doubtful and Excluded Species}

Peziza globifera Berk. \& Curt.; Berk. Jour. Linn. Soc. 10: 366. 1868. A Cuban species with pale-yellow apothecia and smooth spores, the spores reaching a diameter of $12-14 \mu$. A microscopic examination of the spores of this species has been made, but our knowledge is too meager to permit of a more complete description.

Barlaea fuliginea (Schum.) Sacc. Syll. Fung. 8: 117. 1889. Peziza fuliginea Schum. Enum. Pl. Saell. 2: 427. 1803. This species is reported from North America by Saccardo. No specimen of the species has been seen and the identity of the species is uncertain.

\section{PITHYA Fuckel, Symb. Myc. 317. 1869.}

Plants saprophytic or semiparasitic on the foliage and bark of coniferous trees; apothecia bright-colored, whitish externally, stipitate or sessile, the substance rather tough, not shrinking much in drying; hymenium bright-orange or yellow, even or lacunose, plane, concave or convex; asci 8-spored; spores perfectly globose, smooth, hyaline; paraphyses filiform or slightly enlarged above.

Type species, Pesiza pithya Pers.

Plants occurring on the bark or foliage of Abies.

Hymenium smooth.

Hymenium lacunose.

On foliage of Juniperus, Cupressus, etc.

1. P. pithya.

2. P. lacunosa.

3. P. Cupressi.

1. Pithya pithya (Pers.) Gill. Champ. Fr. Discom. 225 (as synonym). 1887. (Plate 4, Fig. 3.)

Peziza pithya Pers. Ic. Descr. 43. 1800.

Pitlya vulgaris Fuckel, Symb. Myc. 317. 1869.

Peziza Leineri Gonnerm. \& Rab. Myc. Eu. 1: 9. 1869.

Helotium pithyum Gill. Champ. Fr. Discom. 155. 1883.

Humaria pityina Quél. Ench. Fung. 289. 1886.

Peziza pithyna Pat. Tab. Fung. 7: 73. 1889.

Apothecia gregarious, sessile or short-stipitate, at first subglobose, expanding and becoming subdiscoid, regular in form 
when young, becoming irregular with age, externally pale, whitish or yellowish-white, surrounded at the base by a growtl of white mycelium, margin of the apothecium free or adnate to the substratum, reaching a diameter of $12 \mathrm{~mm}$.; hymenium plane or convex, bright-orange; asci cylindric or subcylindric, gradually attenuated below, reaching a length of $300-325 \mu$ and a diameter of $15 \mu$; spores 1 -seriate, at first granular within, later containing one large oil-drop, reaching a diameter of $12-14 \mu$; paraphyses slightly enlarged above, reaching a diameter of $3-4 \mu$ at their apices.

On foliage and bark of species of Abies, Sequoia, and Libocedrus.

Type locality: Germany.

Distribution: California; also in Europe.

Illustrations: Boud. Ic. Myc. pl. 320; Gonnerm. \& Rab. Myc. Eu. 1: 5, f. 4; Pers. Ic. Descr. pl. 11, f. 2; Pat. Tab. Fung. f. 698 .

While this species has been recorded from North America, most of the specimens examined belong with $P$. Cupressi rather than here. The present form is larger and occurs on bark more often than on foliage. The species is less frequent in America than in Europe, so far as we can judge from the specimens examined.

2. Pithya lacunosa (Ellis \& Ev.) Seaver, comb. nov. (PLATE 4, FIG. 2.)

Barlaea lacunosa Ellis \& Ev. Proc. Acad. Nat. Sci. Phila. 1894: 347.

Apothecia sessile, spreading over the substratum and closely adhering to it, except the extreme margin which is free and slightly elevated, circular or more or less irregular in outline, reaching a diameter of $5 \mathrm{~mm}$. to $1.5 \mathrm{~cm}$., externally yellowishwhite and attached to the substratum by a white mycelium; hymenium uneven, undulated or deeply lacunose, bright-orange; asci cylindric above, tapering below into a long stem-like base, reaching a length of $200-225 \mu$ and a diameter of $12-17 \mu$; spores 1-seriate, smooth, reaching a diameter of 12-14 $\mu$, granular within, hyaline; paraphyses gradually thickened above, reaching a diameter of $3-4 \mu$ at their apices.

On the bark of some species of Abies balsamea.

Type Locality: Notre Dame Bay, Newfoundland.

Distributiox: Known only from the type locality. 
Rather closely related to the preceding species but differing in its lacunose hymenium.

3. Pithya Cupressi (Batsch) Rehm in Rab. Krypt.-Fl. $1^{3}: 926$. 1896. (Plate 4, FIG. 1.)

Peziza Cupressi Batsch, Elench. Fung. 1: 119. 1783.

Peziza cupressina Fries, Syst. Myc. 2: 135. 1822.

Pithya cupressina Fuckel, Symb. Myc. 317. 1869.

Humaria cupressina Quél. Ench. Fung. 289. 1886.

Helotium thujinum Peck, Ann. Rep. N. Y. State Mus. 26: 82. 1874.

Phialea cupressina Gill. Champ. Fr. Discom. 107. 1882.

Lachnella Cupressi Phill. Brit. Discom. 240. 1887.

Pithya thujina Sacc. Syll. Fung. 8: 210. 1889.

Apothecia gregarious, sessile or short-stipitate, at first subglobose, expanding, becoming circular in form or elongated and irregular; hymenium plane or slightly concave, deep-orange, darker than the exterior of the apothecium; the cells of the excipulum vertically elongated and subhyaline, giving rise below to white mycelial threads by means of which the apothecia are attached to the substratum; asci cylindric or subcylindric above, tapering below into a long stem-like base, reaching a length of $250 \mu$ and a diameter of $15 \mu$; spores 1 -seriate, granular within and usually containing one large oil-drop, reaching a diameter of 10-12 $\mu$; paraphyses branched below, only slightly enlarged above, reaching a diameter of $2-3 \mu$ at their apices.

On recently killed foliage of various species of Juniperns, Cupressus, Thuja and Sequoia.

TyPe LOCAlity: Europe.

Distribution: Maine to Washington, New Jersey and California, and in the Bermuda Islands; also in Europe.

Illustrations: Grevillea 3: pl. 40, f. 171; Gonne1m. \& Rab. Myc. Eu. 1: pl. 5, f. 9; E. \& P. Nat. Pfl. 1': 205, f. 160, C-D; Phill. Brit. Discom. pl. 8, f. 45.

Exsiccati: N. Am. Fungi 2322; Fungi Columb. 7+1; Ravenel, Fungi Am. 629 (as Pesiza pithya Pers.); Thüm. Mycoth. Univ. 718 (as Pithya cupressina Fuckel).

Commonly collected in Bermuda on foliage of Bermuda cedar. Also fairly common in continental North America.

\section{Excluded Species}

Pithya suecia (DeBary) Fuckel, Symb. Myc. Nacht. 3: 32. 1875. According to Rehm, this is a synonym of Lachnellula chrysophthalma (Pers.) Karst., a species which occurs in North America. The species belongs with the inoperculate discomycetes and is not a true Pithya. 


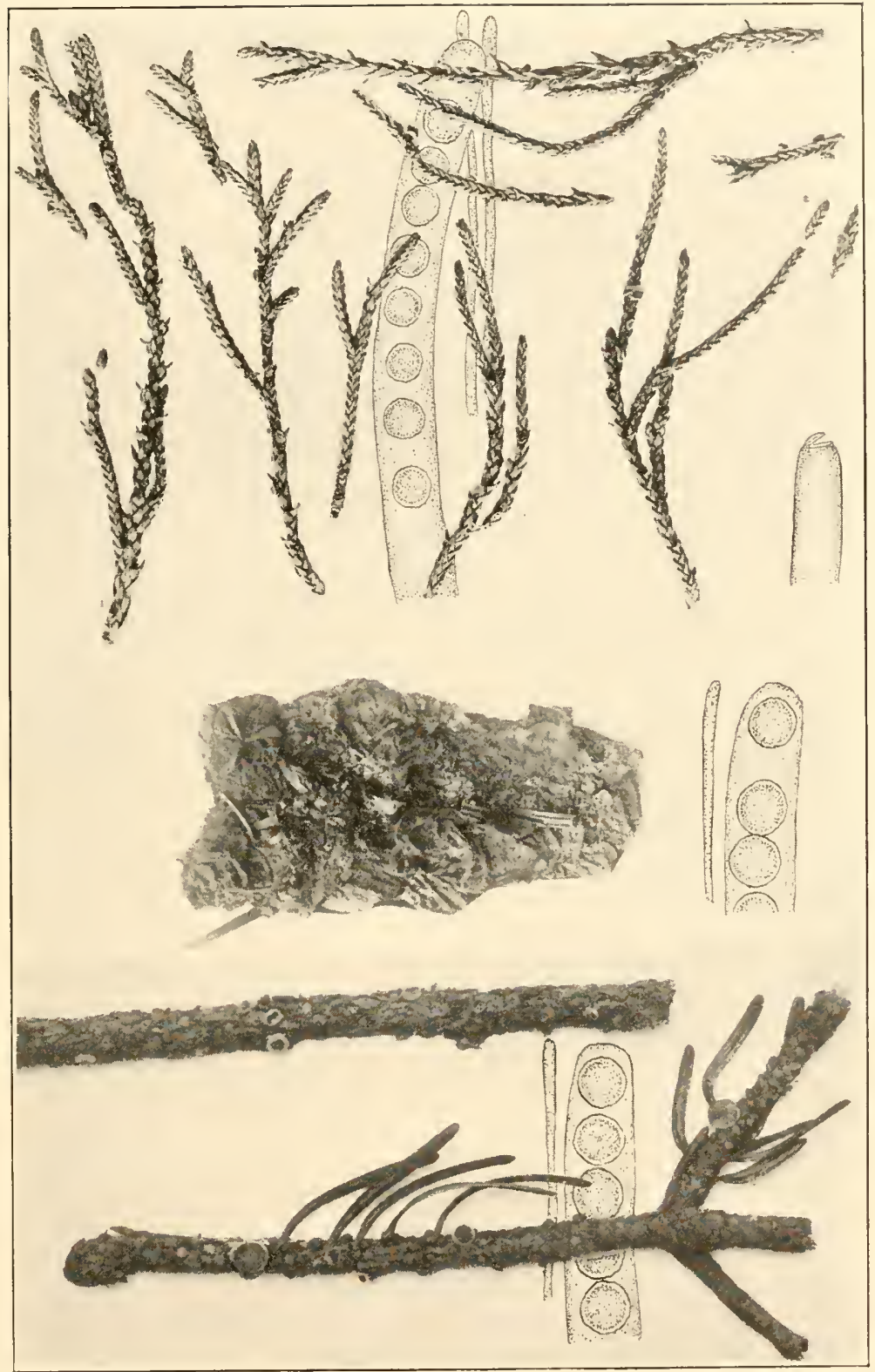

1. PITHYA CUPRESSI

2. PITHYA LACUNOSA

3. PITHYA PITHYA 

7. ASCODESMIS Van Tiegh. Bull. Soc. Bot. Fr. 23:271. 1876.

Ascolobus § Sphaeridiobolus Boud. Bull. Soc. Myc. Fr, 14: 126. 1898. Sphaeridiobolus Boud. Hist. Class. Discom. Eu. 73. 1907.

Apothecia minute, less than $1 \mathrm{~mm}$. in diameter, very simple, consisting of a cluster of asci and paraphyses springing from a clump of basal mycelium; excipulum almost entirely undeveloped; asci comparatively few to each plant, very broad, 8-spored; spores globose or subglobose, hyaline, then pale-brown to blackish, becoming sculptured at maturity; spore-sculpturing consisting of warts or ridges; paraphyses sparse.

Type species, Ascodesmis nigricans Van 'Tiegh.

Spores globose, reticulated.

Spores subglobose, rough but not reticulated.

1. A. microscopica.

2. A. porcina.

1. Ascodesmis microscopica (Crouan) Seaver, Mycologia 8: 3. 1916. (Plate 5, Fig. 1-5.)

Ascobolus microscopicus Crouan, Ann. Sci. Nat. IV. 7: 175. 1857.

?Ascobolus caninus Fuckel, Hedwigia 5: 3. 1866.

A scobolus hyperboreus Karst. Not. Fauna Fl. Fenn. 11:204. 1870.

Ascodesmis nigricans Van Tiegh. Bull. Soc. Bot. Fr. 23:275. 1876.

Boudiera microscopica Cooke, Grevillea 6: 76. 1877.

Ascobolus niveus Quél. Fr. Assoc. Av. Sci. Comp. Rendu 9: 674. 1880.

Sphaeridiobolus hyperboreus lleimerl, Niederosterr. Ascoboleen 12. 1889.

?Boudiera canina Schröt. Krypt.-Fl. Schles. 32: 55. 1893.

Bondiera Claussenii P. Henn. Hedwigia 42: (182). 1903.

?A scodesmis reticulata Bainier, Bull. Soc. Myc. Fr. 23: 137. 1907.

Sphaeridiobolus hyperboreus niveus Boud. Hist. Class. Discom. Eu. 73. 1907.

Apothecia minute, less than $1 \mathrm{~mm}$. in diameter, scattered or thickly gregarious, superficial, consisting of a tuft of asci and very stout paraphyses, at first entirely white, becoming clotted over with black specks, the ends of the asci filled with colored spores, finally becoming entirely black; excipulum almost wanting or consisting of loose mycelium similar to the paraphyses; asci broad-clavate to ovoid, reaching a length of $80 \mu$ and a diameter of $30 \mu, 8$-spored; spores 2 -seriate or irregularly crowded together, perfectly globose, beconing pale-brown and sculptured, reaching a diameter of $10-12 \mu$; spore-sculpturing consisting of net-like reticulations, the meshes reaching a diameter of $3 \mu$, the ridges of the reticulations thin and projecting about the periphery of the spore as minute spines; paraphyses hyaline, stout, scarcely enlarged above, reaching a diameter of 5-6 $\mu$.

On excrement of dogs and tigers, less frequently on that of other animals. 
Type locality : Europe.

Distribution: New York; also in Europe.

Illustrations: Ann. Sci. Nat. IV. 7: pl. 4, f. 20-23; Bull. Soc. Myc. Fr. 23: pl. 19, f. 1-3; Hedwigia 42: (182), f. 1-3; Massee, Brit. Fungus-FI. 4: 12, f. 46; Mycologia 8: pl. 172, f. 1-5; Fr. Assoc. Av. Sci. Comp. Rendu 9: pl. 9, f. 18; Zukal, Mycol. Unters. pl. 2, f. 5-10.

2. Ascodesmis porcina Seaver, Mycologia 8: 3. 1916. (Plate 5, FIG. 6-9.)

Apothecia very small, scarcely visible, scattered or thickly gregarious, at first subglobose, expanding and becoming subdiscoid, externally whitish or pallid, not exceeding $0.5 \mathrm{~mm}$. in diameter; hymenium strongly convex, becoming dark, finally almost black by reason of the dark-colored spores; excipulum almost wanting; asci broad-clavate to ovoid, abruptly narrowed in to a stem-like base, reaching a length of $75-90 \mu$ and a diameter of $25-35 \mu$; spores 2 -seriate or very irregularly bunched near the end of the ascus, subglobose, at first hyaline and smooth, becoming pale-brown sculptured, reaching a diameter of $10-13 \mu$, or occasionally $10-11 \times 12-13 \mu$; spore-sculpturing very variable, consisting of minute rounded wart-like projections, short interrupted ridges, or often with one conspicuous simple or branched ridge extending across the visible surface of the spore; paraphyses stout, gradually enlarged at their apices, reaching a diameter of about $5 \mu$.

On excrement of pigs.

Type Locality: Grown in the laboratories of The New York Botanical Garden on pig dung sent from Porto Rico.

Distribution: Cultivated on pig dung from Porto Rico and New Jersey.

Illustration: Mycologia 8: pl. 172, f. 6-9.

The occurrence of this species on material collected in two such widely separated localities would indicate that the species is more dependent upon the substratum conditions than on climate, assuming that the material collected in Porto Rico was infected before it was received.

8. CUBO NIA Sacc. Syll. Fung. 8: 527. 1889.

Apothecia sessile, convex-hemispheric, naked or clothed with hairs, white or whitish; hymenium plane or convex, roughened 


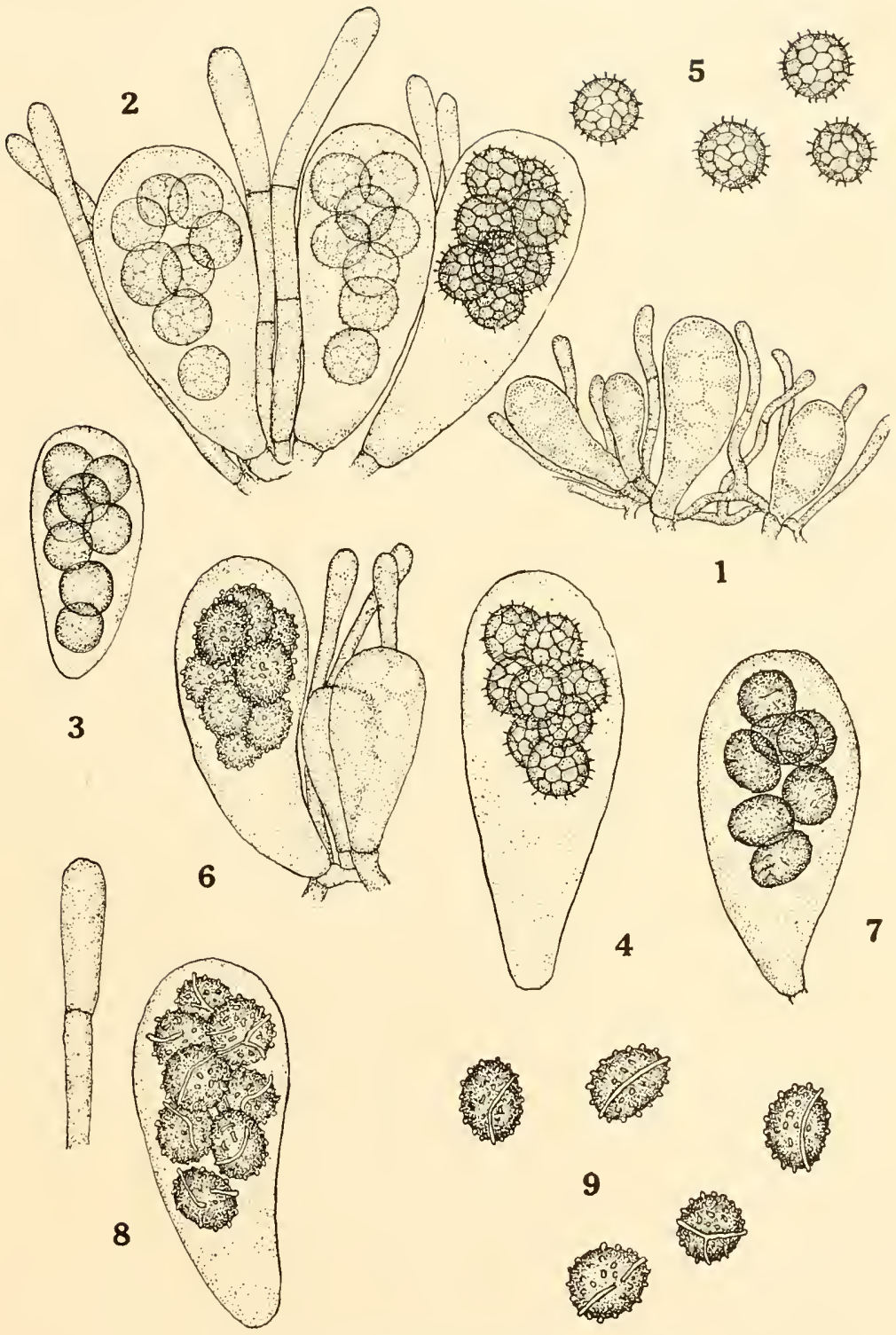

1-5. ASCODESMIS MICROSCOPICA

6-9. ASCODESMIS PORCINA 

by the protruding asci; asci clavate or subpyriform, 8-spored; spores perfectly globose, minutely sculptured, hyaline.

Type species, Lasiobolus brachyascus March.

One unnamed species of this genus has been reported for North America by Dr. B. O. Dodge. This genus contains but three species and in the absence of suitable material it is impossible to determine the identity of the American species. All of the species are coprophilous.

\section{ASCOBOLUS Pers.; J. F. Gmel. Syst. Nat. 1461. 1791.}

Apothecia sessile or substipitate, superficial or partially immersed in the substratum, externally smooth or pilose; hymenium concave, plane or convex; substance soft, fleshy or waxy, usually greenish; asci cylindric to clavate or subovoid, 4-8spored; spores becoming blue or purple, fading to brown or blackish, ellipsoid to subglobose, smooth or becoming sculptured; spore-sculpturing very variable, consisting of warts, ridges or crevices; paraphyses slender and usually adhering together.

Type species, Peziza stercoraria Bull.

Plants growing on the lung of animals.

Apothecia medium or small, not exceeding $5 \mathrm{~mm}$. in diameter.

Apothecia medium large, reaching $5 \mathrm{~mm}$. in diameter.

1. A. stercorarius.

Apothecia not exceeding 1-2 $\mathrm{mm}$. in diameter.

Spores very large, $20-35 \times 50-70 \mu$.

2. A. immersus.

Spores medium large, $25-40 \mu$ long.

Spores densely marked with ridges or crevices.

3. A. glaber.

Spores very minutely roughened.

Spores becoming delicately reticulated. Spores not reticulated.

$$
\begin{aligned}
& \text { Spores } 15-17 \times 30-40 \mu . \\
& \text { Spores } 13-15 \times 24-28 \mu .
\end{aligned}
$$

4. A. Winteri.

5. A. americanus.

6. A. Leveillei.

Spores small, $7-8 \times 12-14 \mu$.

Apothecia greenish.

7. A. viridulus.

Apothecia white.

8. A. candidus.

9. A. magnificus.

Apothecia large, $5 \mathrm{~mm}$. to $2.7 \mathrm{~cm}$. in diameter.

Plants growing on soil.

Restricted to burnt places.

10. A. carbonarius.

On damp soil, not on burnt places.

Apothecia brownish-black.

Spores ellipsoid.

Spores subglobose.

11. A. geophilus.

12. A. subglobosus.

Apothecia white.

13. A. albinus. 
Plants growing on wood.

14. A. xylophilus.

Plants growing on dead leaves.

15. A. striisporus.

Plants growing on fungi or slime-moulds.

16. A. epimyces.

1. Ascobolus stercorarius (Bull.) Schröt. Krypt.-Fl. Schles. $3^{2}$ : 56. 1893. (PLATE 45, FIG. 21.)

Peziza stercoraria Bull. Herb. Fr. pl. 376, f. 1. 1787.

Ascobolus pezizoides Pers.; J. F. Cimel. Syst. Nat. 1461. 1791.

A scobolus furfuraceus Pers. Obs. Myc. 1: 33. 1796.

A scobolus stercorarius retisporus Clements, Bot. Surv. Nebr. 5: 9. 1901.

Apothecia scattered or thickly gregarious, sessile, often partially buried in the substratum, later becoming superficial or subsuperficial, at first globose or subglobose and closed, opening by a circular aperture and expanding, finally scutellate to discoid, reaching a diameter of $5 \mathrm{~mm}$., externally pale-yellow or greenish (whitish in dried specimens), furfuraceous; hymenium concave to plane, at first yellowish or greenish, becoming dotted over with the protruding asci which appear black, finally entirely black; asci clavate, gradually tapering below into a stem-like base, reaching a length of $200-250 \mu$ and a diameter of $30 \mu$, 8 -spored; spores partially 2 -seriate or irregularly disposed, ellipsoid, thick-walled, at first hyaline and more or less granular within, becoming violet, later brown, smooth, becoming sculptured, $11-14 \times 20-30 \mu$; spore-sculpturing taking the form of ridges and crevices which have a tendency to be longitudinally disposed, occasionally anastomosing and then giving the spore a reticulate appearance; paraphyses slender, about $2 \mu$ in diameter, scarcely enlarged above, embedded in golden-yellow mucilaginous substance.

On dung of various kinds.

Type LOCAlity: Europe.

Distribution: Connecticut to California, Louisiana and Bermuda, probably throughout North America; also in Europe and doubtless widely distributed.

Illustrations: Pers. Obs. Myc. 1: pl. 4, f. 3-6; Ann. Sci. Nat. V. 10: pl. 6, f. 6; Bull. Herb. Fr. pl. 376, f. 1; Cooke, Handb. 2: 728, f. 338; Jour. Bot. 2: 150, f. 1; Trans. Linn. Soc. 24: pl. 25, f. 9, 10; Gill. Champ. Fr. Discom. pl. 84, f. 2; E. \& P. Nat. Pfl. $1^{1}$ : 192, f. 154, J-L; Massee, Brit. Fungus-Fl. 4: 162, f. 1-7; Rab. Krypt.-Fl. 13: 1112, f. 1, 2, 3, 6; Bull. Lab. Nat. Hist. State Univ. Iowa 6: pl. 29, f. 2.

Exsiccati: Ravenel, Fungi Am. 312, 632.

Common and widely distributed everywhere. 
2. Ascobolus immersus Pers. Obs. Myc. 1: 35. 1796. (Plate 7, FIG. 5.)

A scobolus macrosporus Crouan, Ann. Sci. Nat. IV. 7: 173. 1857. A scobolus gigasporus De-Not. Comm. Critt. Ital. 1:360. 1863.

Apothecia minute, scattered or thickly gregarious, but not usually crowded, at first immersed or partially immersed in the substratum, expanding and becoming subturbinate, not exceeding 1-2 mm. in diameter, externally greenish-yellow, becoming brownish, pilose; hymenium plane or more often convex, similar in color to the outside of the apothecium; asci comparatively few to each plant, very large, clavate, at maturity projecting half their length above the surface of the hymenium, 3-10 appearing at one time and easily visible with the hand-lens as several black, spike-like protuberances, reaching a length of 500-600 $\mu$ and a diameter of $90-100 \mu, 8$-spored but often with only a part of the spores developed; spores very large, 2-seriate or irregularly disposed, broad-ellipsoid and each surrounded by a hyaline, mucilaginous envelope, at first hyaline, then violet, finally brown, becoming sculptured, $20-35 \times 50-70 \mu$; spore-sculpturing taking the form of sparse reticulations, consisting of one to several anastomosing bands which extend from one end of the spore to the other or diagonally across its surface; paraphyses very slender, scarcely enlarged above and embedded in a greenishyellow mucilaginous substance.

On dung of various kinds, especially after it has weathered for a long time.

Type Locality: Europe.

Distribution: New York to Colorado and Bermuda, probably throughout North America; also in Europe.

Illustrations: Ann. Sci. Nat. IV. $7: p l .4, f . B, 5-8$; Ann. Sci. Nat. V. 10: pl. \&, f. 17; Rab. Krypt.-Fl. 13: 1112, f. +-5; Bull. Lab. Nat. Hist. State Univ. Iowa 6: pl. 31, f. 1; Bull. Torrey Club 39: pl. 11, f. 20-25; Ann. Mag. Nat. Hist. III. 15: pl. 17, f. 33; E. \& P. Nat. Pfl. $1^{1}: 192, f .15+, D-F$.

3. Ascobolus glaber Pers. in Römer's Neues Mag. Bot. 1: 115. 1794.

Apothecia scattered or gregarious, at first subglobose, becoming short-cylindric, finally expanded and more or less discoid, tapering below into a stem-like base, reaching a diameter of 0.5 to $1 \mathrm{~mm}$., externally greenish-yellow, smooth; hymenium 
plane, becoming convex, at first similar in color to the outside of the apothecium, becoming almost entirely black; the component cells of the excipulum roundish or irregularly angular, reaching a diameter of $25 \mu$, the walls hyaline to pale-yellowish; asci clavate, strongly swollen above, tapering rather abruptly below into a short stem-like base, reaching a length of $300-350 \mu$ and a diameter of $40 \mu, 8$-spored; spores 2-seriate or irregularly crowded, ellipsoid, with the ends rather strongly narrowed, hyaline, becoming violet, finally pale-brown, becoming sculptured, $12-13 \times 23-38 \mu$; spore-sculpturing taking the form of longitudinally or irregularly disposed, anastomosing ridges or crevices; paraphyses slender, about $2 \mu$ in diameter, slightly enlarged above.

On dung of various kinds.

Type locality: Europe.

Distribution: New York to Iowa; also in Europe.

Illustrations: Ann. Sci. Nat. IV. 10: pl. 13, f. A; Ann. Sci. Nat. V. 10 : pl. 7, f. 13, 15; Bull. Lab. Nat. Hist. State Univ. Iowa 6: pl. 31, f. 2; E. \& P. Nat. Pfl. 1': 192, f. 15 , G, II.

4. Ascobolus Winteri Rehm in Rab. Krypt.-Fl. $\mathbf{1}^{3}: 1124$. 1896.

Apothecia gregarious or densely crowded, sessile, subglobose, externally yellowish, smooth, reaching a diameter of $0.2-0.4 \mathrm{~mm}$.; hymenium convex, yellowish-brown, finally almost black; asci cylindric or subcylindric to clavate, tapering below rather gradually into a long stem-like base, reaching a length of $180-$ $200 \mu$ and a diameter of $30-33 \mu$, when mature of ten stretching to 300 or $400 \mu$ long; spores 2 -seriate or irregularly disposed, ellipsoid, at first hyaline, then brown, for a long time smooth, becoming sculptured, $12-16 \times 24-33 \mu$; spore-sculpturing consisting of minute warts and reticulations, the reticulations consisting of light lines which give rise to irregular or hexagonal meshes, the meshes ranging from 2 to $5 \mu$ in diameter; paraphyses filiform, septate, about $2.5 \mu$ thick, a little enlarged above, embedded in a yellow mucilaginous substance.

On goose dung.

Type locality : Leipzig, Germany.

Distribution: New York; also in Europe.

Illustrations: Bull. Torrey Club 39: pl. 10, f. 12-17; also pl. 15. 
5. Ascobolus americanus (Cooke \& Ellis) Seaver, sp. nov.

Ascobohus Lereillei americanus Cooke \& Ellis, Grevillea 5: 52. 1876.

Apothecia thickly gregarious, crowded, or more rarely scattered, often nestling in little cavities in the substratum or entirely superficial, at first globose or pyriform with the small end directed downward, gradually expanding and becoming subdiscoid above, never exceeding $1 \mathrm{~mm}$. in diameter, externally yellowish; hymenium plane or convex, at first greenish-yellow. becoming almost black, strongly roughened by the protruding asci; the component cells of the excipulum irregularly 6-sided, reaching a diameter of $12-18 \mu$; asci broad-clavate, gradually tapering below into a stem-like base, reaching a length of 200 $250 \mu$ and a diameter of $35-40 \mu$, when mature often stretching to $400 \mu, 8$-spored; spores 2 -seriate or irregularly disposed, ellipsoid, thick-walled, at first hyaline, becoming violet, then brown, for long time smooth, finally becoming delicately sculptured, $15-17 \times 30-40 \mu$; spore-sculpturing taking the form of minute granules which give to the surface of the spore a minutely warted or pitted appearance; paraphyses about 2 or $3 \mu$ in diameter, scarcely thickened above, embedded in a greenish-yellow mucilaginous substance.

On dung of various kinds.

Type Locality: Newfield, New Jersey.

Distributiox: New Jersey to New York and Kansas.

Exsiccati: N. Am. Fungi 2333 (as Ascobolus glaber Pers.); N. Am. Fungi 2620 (as Ascobolus vinosus Berk.).

6. Ascobolus Leveillei Boud. Ann. Sci. Nat. V. 10:225. 1869. Ascobolus Boudieri Quél. Ench. Fung. 293. 1886.

Apothecia thickly gregarious, minute, sessile, subglobose, with the base partially immersed in the substratum or entirely superficial, externally brownish, slightly roughened, reaching a diameter of $0.5 \mathrm{~mm}$; hymenium becoming convex, at first greenish, finally becoming darker, almost black; the component cells of the excipulum roundish or angular, reaching a diameter of 15-20 $\mu$; asci clavate, tapering below into a stem-like base, reaching a length of $140-160 \mu$ and a diameter of $28-30 \mu$, sspored; spores 2 -seriate or irregularly disposed, at first hyaline, then purple, later brown, ellipsoid, for a long time smooth, becoming minutely sculptured, $13-15 \times 24-28 \mu$; spore-sculpturing taking the form of minute granules which give to the 
surface of the spore a delicately warted or pitted appearance; paraphyses slender, septate, about $3 \mu$ in diameter, slightly thickened above, embedded in a mucilaginous substance.

On dung of different kinds.

Type locality: Europe.

Distribution: New York to Iowa; also in Europe.

Illustrations: Ann. Sci. Nat. V'. 10: pl. 7, f. 16; Bull. Lab. Nat. Hist. State Univ. Iowa 6: pl. 30, f. 2; Bull. Torrey Club 39: pl. 11, f. 27 .

7. Ascobolus viridulus Phill. \& Plow. Crevillea 8: 10.3. 1879.

? A scobolus aerugineus Fries, Obs. Myc. 2: 310. 1818.

? A scobolus crenulatus Karst. Fungi Fenn. Exsicc. 763. 1868.

Apothecia scattered, sessile, at first nearly globose, expanding and becoming discoid, reaching a diameter of $0.5-1 \mathrm{~mm}$., externally pale yellowish-green, coarsely furfuraceous; hymenium at first concave, becoming plane or slightly convex, yellowishgreen, becoming larker as the plants mature on account of the dark-colored spores, roughened by the protruding asci; asci clavate, reaching a length of $75 \mu$ and a diameter of $12-15 \mu, 8$ spored; spores 1 -seriate, or finally becoming 2 -seriate or irregularly crowded, ellipsoid with the ends quite strongly narrowed, hyaline, then violet, finally pale-brown, becoming sculptured, $7-8 \times 12-14 \mu$; spore-sculpturing consisting of anastomosing ridges or crevices which are mostly longitudinal; paraphyses very slender, slightly enlarged above.

On dung of dogs and birds.

Type Locality: Great Britain.

Distribution: New York; also in Europe.

8. Ascobolus candidus Schröt. Krypt.-F1. Schles. 3²: 55.1893.

Apothecia scattered, roundish, becoming subdiscoid, entirely pallid-white; hymenium becoming slightly convex, finally dotted over with the protruding asci and becoming darker with age; the excipular cells irregular and reaching a diameter of $12-15 \mu$ : asci clavate, gradually tapering below into a stem-like base, reaching a length of $100-150 \mu$ and a diameter of $20 \mu, 8$-spored; spores 1 -seriate, 2-seriate or irregularly disposed, ellipsoid, becoming pale-violet, later pale-brown, 8-10 $\times 13-16 \mu$, becoming sculptured; spore-sculpturing consisting of minute warts; paraphyses strongly enlarged above, reaching a diameter of about $4 \mu$ at their apices, hyaline. 


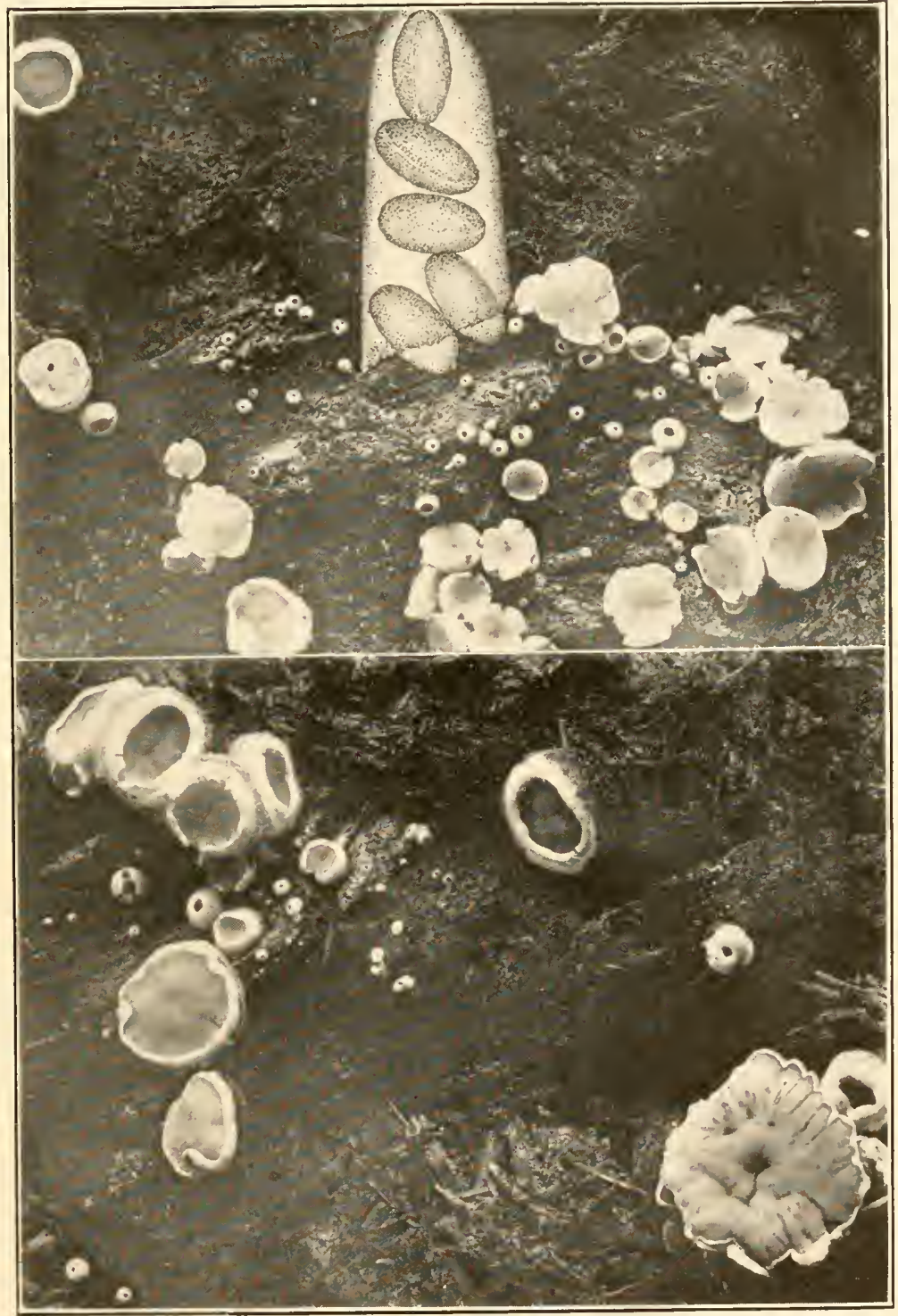

ASCOBOLUS MAGNIFICUS 

On the dung of rabbits and goats.

TrPe LOCAlity: Europe.

Distribution: New York; also in Europe.

9. Ascobolus magnificus Dodge, Mycologia 4: 218. 1912. (Plate 6.)

Apothecia scattered or closely crowded, sessile, at first globose and appearing closed or nearly so, white or whitish, gradually opening, becoming cup-shaped with the smooth margin inrolled, finally becoming subscutellate, externally pruinose from the projecting tips of thin-walled, hair-like hyphal branches which finally become discolored and brownish, reaching a diameter of $0.5-2.7 \mathrm{~cm}$. ; hymenium concave or nearly plane, at first greenish-yellow, roughened by the protruding asci and becoming nearly black at maturity on account of the darkcolored spores; asci cylindric to clavate, reaching a length of $200-300 \mu$ and a diameter of $18-25 \mu, 8$-spored; spores becoming irregularly 2 -seriate, ellipsoid, at first hyaline, then pale-lilac, finally rose-purple or violet, fading to brown in aged specimens, smooth, becoming sculptured, $12-14 \times 20-25 \mu$, germinating by one germ-pore; spore-sculpturing consisting of one faint line extending from one end of the spore to the other or obliquely across its surface; paraphyses filiform, slightly enlarged above, septate, reaching a diameter of $5-7 \mu$ at their apices, filled with a greenish granular content.

On horse dung in damp-chamber cultures.

Type Locality: New York City.

Distribution: New York and Porto Rico.

Illustrations: Mycologia 4: pl. $72, f .1-8$, and pl. 73.

10. Ascobolus carbonarius Karst. (?Fungi Fennici 463. 1866); Not. Fauna Fl. Fenn. 11:202. 1870. (Plate 7, Fig. 4.)

Ascobolus atrofuscus Phill. \& Plow. Grevillea 2: 186. 1873.

Ascobolus carbonicola Boud. Bull. Bot. Soc. Fr. 24:310. 1877.

Phaeopezia Nuttallii Ellis \& Ev. N. Am. Fungi 2908. 1893.

Apothecia scattered or more often crowded into congested masses several cm. in diameter, at first globose or subglobose, expanding and becoming scutellate, reaching a diameter of 4-5 mm., externally yellowish-green, becoming dark-brown, coarsely furfuraceous; hymenium plane or nearly plane with the margin slightly elevated, at first greenish, becoming dotted over with 
the ends of the protruding asci, gradually becoming darker, finally almost black; asci clavate, gradually tapering below into a long, slender, stem-like base, reaching a length of 200-225 $\mu$ and a diameter of 23-27 $\mu, 8$-spored; spores 1-seriate or crowded together so as to become partially 2 -seriate, ellipsoid with the ends rather strongly narrowed, thick-walled, the ends of ten capped with a thickening of the epispore, giving the spore a truncate appearance, hyaline, becoming violet, finally brown or brownish-black, becoming sculptured, 12-14 $\times 20-24 \mu$; sporesculpturing taking the form of wart-like projections, the spaces between appearing lighter, giving rise to reticulate markings; paraphyses about $3 \mu$ in diameter and scarcely thickened above, embedded in greenish-yellow mucilaginous substance.

On burnt places and on charcoal beds.

Type Locality : Finland.

Distribution: New York to Iowa and West Virginia; also in Europe.

Illustrations: Ann. Sci. Nat. V. 10:pl. 5, f. 4 (as Ascobolus viridis Curr.); Bull. Lab. Nat. Hist. State Univ. Iowa 6: pl. 29, f. 1; Bull. Torrey Club 39: pl. 10, f. 9, 10, 11; Mycologia 8: pl. 184, f. 7-8.

Exsiccati: N. Am. Fungi 2908 (as Phaeopezia Nuttallii Ellis \& Ev.).

\section{Ascobolus geophilus Seaver, Mycologia 8: 96. 1916. (Plate 7, Fig. 2.)}

Apothecia scattered, gregarious or more rarely crowded, at first subglobose, expanding, becoming scutellate to discoid, reaching a diameter of $5 \mathrm{~mm}$., externally greenish-yellow, furfuraceous to nearly smooth; hymenium plane or slightly concave, similar in color to the outside of the apothecium, roughened by the protruding asci and becoming darker as the spores mature, finally almost black; asci clavate, gradually tapering below into a stem-like base, reaching a length of $200-250 \mu$ and a diameter of 16-18 $\mu, 8$-spored but of ten with only 4 spores developed; spores 1 -seriate, becoming 2-seriate or irregularly crowded, ellipsoid, at first hyaline, becoming violet, then brown, $12-13 \mu \times 22-25 \mu$, becoming sculptured; spore-sculpturing consisting of verrucose markings and reticulations, the reticulations consisting of light lines which give rise to an irregular network; paraphyses very slender, sparingly branched, reaching a diameter of $2 \mu$, scarcely 
enlarged above, embedded in golden-yellow mucilaginous substance.

On damp soil.

Type Locality: The New York Botanical Garden.

Distribution: New York to Iowa and Colorado.

Illustrations: Bull. Lab. Nat. Hist. State Univ. Iowa 6: pl. 30, f. 1; Mycologia 8: pl. 84, f. 1-2.

This species has been mistaken for Ascobolus viridis of Europe which is very different in spore characters (see PLATE 7).

Since the above account was prepared, a fine specimen of this species has been received from Dr. G. R. Bisby, who collected it on damp soil at the Agricultural College in Winnipeg, Canada.

12. Ascobolus subglobosus Seaver, Mycologia 8: 96.1916. (Plate 7, Fig. 3.)

Apothecia gregarious or thickly crowded, at first nearly globose, expanding and becoming almost discoid, reaching a diameter of 3-5 mm., externally smooth, greenish-yellow; hymenium plane, convex or irregularly convolute, at first similar in color to the outside of the apothecium, becoming dotted over with the ends of the protruding asci, fnally entirely black; asci subcylindric to clavate, gradually tapering below in to a stem-like base, 8 -spored; spores at first 1 -seriate, becoming crowded and partially 2 -seriate as they mature, at first hyaline and containing one oil-drop which is often surrounded by numerous smaller ones, becoming violet, finally almost black and opaque, becoming sculptured, reaching a diameter of $18-20 \mu$ or $18 \times 20 \mu$; sporesculpturing taking the form of numerous vein-like reticulations, which consist apparently of crevices, the spaces between the crevices giving rise to prominent projections visible about the periphery of the spore, the spaces between appearing as notches, giving the spore a very ragged appearance; paraphyses scarcely enlarged above, embedded in golden-yellow mucilaginous substance.

On damp soil in woods and on the margin of a small pond.

Type Locality: Woods near Yonkers, New York.

Distribution: Known only from the type locality.

Illustration: Mycologia 8: pl. $8 t, f .5-6$.

\section{Ascobolus albinus Seaver, Mycologia 8: 95. 1916.}

Apothecia gregarious, at first subglobose, expanding and becoming scutellate, reaching a diameter of 4-5 mm., externally 
pure white, minutely rough; hymenium plane or nearly plane, at first whitish, becoming darkened by the maturing spores; asci cylindric or subcylindric, 8-spored, reaching a length of about $200 \mu$ and a diameter of about $25 \mu$; spores at first obliquely 1 -seriate, becoming 2 -seriate or irregularly crowded, ellipsoid, becoming purple, then brown, becoming sculptured, $12 \times 20-26 \mu$; spore-sculpturing consisting of minute warts; paraphyses very slender, hyaline.

On damp soil in woods.

Type Locality: Woods near Yonkers, New York.

Distribution: Known only from the type locality.

Apparently differing from $A$. carbonarius in color and occurrence on damp soil where there was no trace of fire.

\section{Ascobolus xylophilus Seaver, Mycologia 3: 61. 1911.}

Apothecia gregarious, sessile, at first subglobose, expanding and becoming scutellate to discoid, reaching a diameter of 1-2 mm., externally brownish; hymenium plane or slightly concave, greenish, becoming darker with age, finally almost black; asci cylindric to clavate, tapering below into a stem-like base, reaching a length of $175-235 \mu$ and a diameter of $30-35 \mu$, 8spored; spores 1 -seriate or becoming partially 2 -seriate above, large, ellipsoid, with the ends rather strongly narrowed, at first hyaline, becoming beautifully purple, then brown, smooth, becoming sculptured, $13-15 \times 35-38 \mu$; spore-sculpturing taking the form of minute warts; paraphyses slender, scarcely enlarged above.

On the weathered surface of the wood of some coniferous tree.

Trpe locality: Geneva Creek Canyon, Colorado (elevation about 9,000 feet).

Distribution: Known only from the type locality.

One of the few species of the genus known to occur on wood.

15. Ascobolus striisporus (Ellis \& Dearn.) Seaver, comb. nov.

Chlorosplenium striisporum Ellis \& Dearn. Proc. Acad. Sci. Phila. 1895: 429. 1896.

Apothecia sessile, hemispheric, with the margin incurved and notched, externally greenish-yellow, verrucose-squamose, reaching a diameter of $1-1.5 \mathrm{~mm}$. ; hymenium concave or nearly plane, pale-yellowish, becoming darker in dried specimens; asci clavate, 

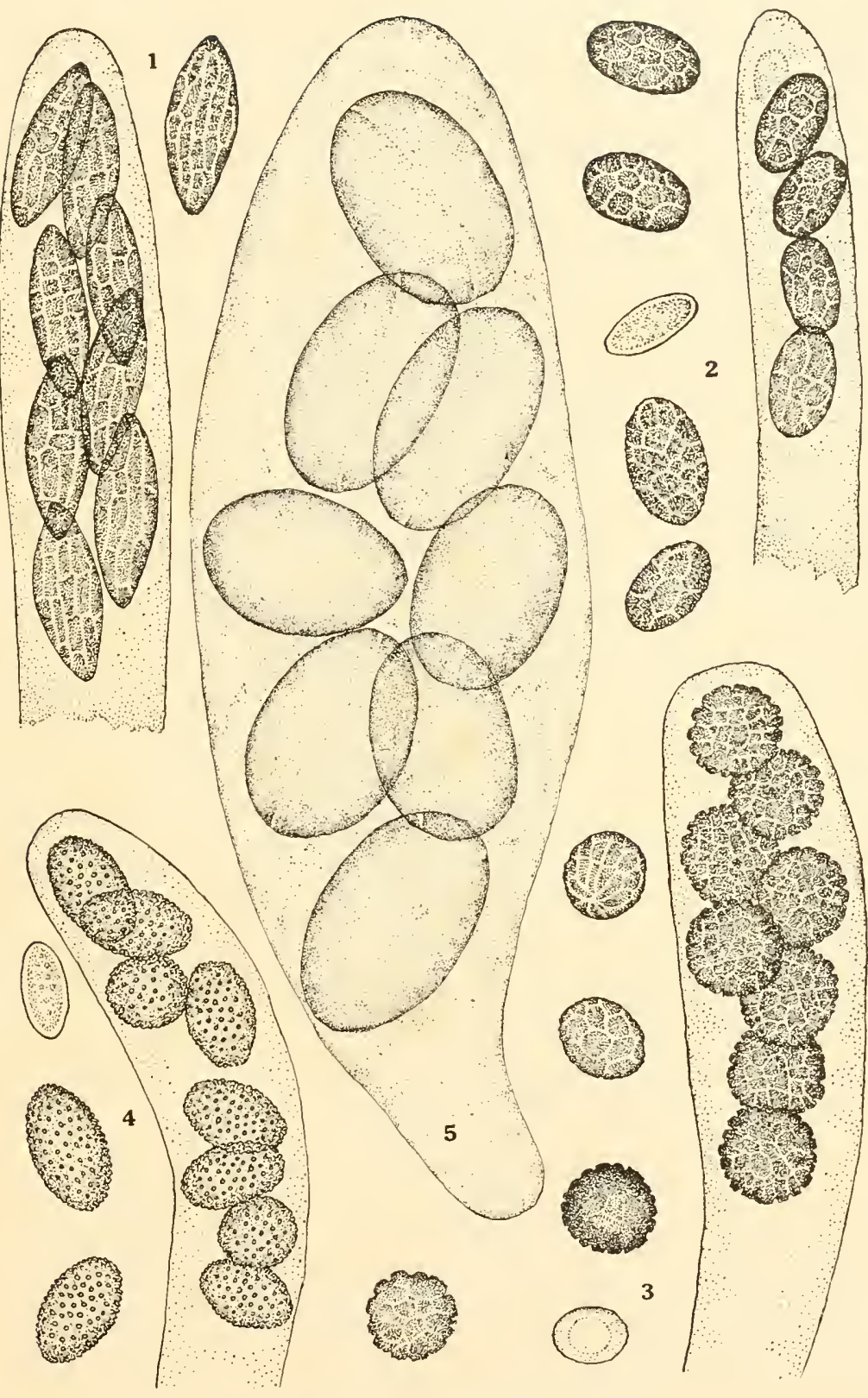

SPECIES OF ASCOBOLUS 

reaching a length of $150-175 \mu$ and a diameter of 15-18 $\mu$; spores at first 1 -seriate, becoming 2 -seriate or irregularly crowded in the upper part of the ascus, at first hyaline, becoming purple, then brown, ellipsoid, about $10-12 \times 20 \mu$ at maturity, becoming sculptured; spore-sculpturing consisting of longitudinal anastomosing ridges; paraphyses about $2 \mu$ in diameter, slightly enlarged above.

On decaying leaves.

Trpe locality: London, Ontario, Canada.

Distribution: Known only from the type locality.

Doubtless on account of its greenish color this was mistaken by Ellis for a Chlorosplenium. Our studies show it to be a true Ascobolus.

Since this work was submitted to the press, the writer has received and examined a specimen of this species collected on old wet leaves at Manitoba Agricultural College, Winnipeg, Canada, by Dr. C. R. Bisby, I. L. Conners, and IV. L. Gordon, No. 3647. So far as we are aware, this is only the second collection of this species on record. The species is rather obscure but is probably more common than would be indicated by the above records.

16. Ascobolus epimyces (Cooke) Seaver, comb. nov.

Chlorosplenium epimyces Cooke, Bull. Buffalo Acad. Sci. 2: 299. 1875.

Apothecia gregarious, sessile, at first nearly globose, expanding and becoming discoid or subdiscoid, scarcely exceeding $1 \mathrm{~mm}$. in diameter, greenish-yellow, then olivaceous, pulverulent, nearly black in dried specimens; hymenium becoming plane, a little lighter in color than the outside of the apothecium; asci clavate, reaching a length of $120 \mu$ and a diameter of $12-15 \mu$, gradually tapering below into a slender stem-like base; spores 2 -seriate above or irregularly crowded, 1 -seriate below, fusoid, at first hyaline (then purple?), finally brown, $8-9 \times 10-18 \mu$, becoming sculptured; spore-sculpturing consisting of delicate lines (apparently ridges) which freely anastomose and give the spore a decidedly striate appearance; paraphyses slender, slightly enlarged above, filled with yellowish-green coloring matter.

Originally reported on old Corlicium, but apparently on the remains of some slime mould. Except for habitat and a slight difference in size and form of the spores, the species is similar to Ascobolus viridulus Phill. \& Plow. 
Type locality: Newfield, New Jersey.

Distribution: Known only from the type locality.

\section{Doubtful and Excluded Species}

Ascobolus atrofuscus Phill. \& Plow.; Harkness \& Moore, Pacific Coast Fungi 38. 1880. This species was listed in the above work as a new species occurring on horse dung. The name is untenable since it was previously used by the same authors for a species occurring on burnt ground which has been made a synonym of Ascobolus carbonarius Karst. The application of the same name to a second species is doubtless due to an oversight. Nothing is known of the plant to which this name was applied in the Harkness and Moore report.

Ascobolus viridis Curr. Trans. Linn. Soc. 24: 154. 1863. This species was reported by the writer from Iowa. Later studies showed that the plant to which this name was applied is quite different from the European species (see Plate 7, Fig. 1) and the American species has therefore been redescribed under the name of Ascobolus geophilus. So far as known the European species has not been collected in America.

Ascobolus purpurascens Pers.; Calkins, Jour. Myc. 2: 106. 1886. This species is listed by Calkins in his report of Florida fungi. We have no knowledge of the nature of the plants reported under this name.

A scobolus brunneus Cooke, Fungi Brit. Exsicc. 3: 87; Hedwigia 6: 154. 1867. American specimens listed under this name have been referred to other species.

Ascobolus cubensis Berk. \& Curt. Jour. Linn. Soc. 10: 370. 1868. No specimen of this species has been seen and its identity is uncertain. From the description it appears to be close to Ascobolus viridulus Phill. \& Plow.

A scobolus vinosus Berk. in Hooker's Engl. F1. 5²: 209. 1836. American specimens referred to this species scarcely differ from Ascobolus stercorarius (Bull.) Schröt.

Ascobolus major Berk. \& Curt. Grevillea 4:6. 1875. No specimen of this species has been seen and the description is so brief and incomplete as to give no clue to its identity.

A scobolus conglomeratus Schw. Trans. Am. Phil. Soc. II. 4: 178. 1832. This is one of the Hysteriaceae and has usually been treated as a synonym of Angelina rufescens (Schw.) Duby.

Ascobolus Trifolii Biv. Stirp. Rar. Sic. 4: 27. 1816. This is not a true Ascobolus. It was made the type of the genus Pseudopeziza by Fuckel.

A scobolus pusillus Boud. Bull. Soc. Bot. Fr. 24: 310. 1877. The species has been reported from North America by Dodge.

10. SACCOBOLUS Boud. Ann. Sci. Nat. Y. 10:228. 1869.

Apothecia minute, sessile, superficial or subsuperficial, externally smooth or pilose; hymenium concave, plane or convex, smooth or becoming roughened by the protruding asci; substance soft, fleshy or waxy, variable in color; asci cylindric to clavate, 4-8-spored; spores hyaline, then purple or bluish, later brown, 
ellipsoid to subglobose, smooth or sculptured; spore-sculpturing consisting of minute warts or faint reticulations, united into a spore-mass; spore-mass elongated or subglobose; paraphyses filiform to clavate.

Type species, Ascobolus Kerverni Crouan.

Apothecia golden-yellow.

Spores ellipsoid to subf usoid.

1. S. Kerverni.

Spores subglobose.

2. S. portoricensis.

Apothecia violaceous to blackish.

Spores $7-8 \times 15 \mu$.

3. S. violascens.

Spores $5 \times 10-12 \mu$.

4. S. depauperatus.

Apothecia white.

5. S. globuliferellus.

1. Saccobolus Kerverni (Crouan) Boud. Ann. Sci. Nat. V. 10: 229. 1869.

Ascobolus Kerverni Crouan, Ann. Sci. Nat. IV. 10: 193. 1858.

Apothecia gregarious or thickly crowded, seated on a rather dense growth of yellowish or whitish mycelium, at first globose, expanding and becoming discoid or subdiscoid, externally goldenyellow, reaching a diameter of 1-2 mm.; hymenium at first concave or plane, becoming strongly convex, at first similar in color to the outside of the apothecium, becoming dotted over with the ends of the protruding asci which appear black on account of the dark-colored spores, entirely black when mature; asci very broad-clavate, gradually narrowed below into a stem. like base, reaching a length of $125 \mu$ and a diameter of $30 \mu$. 8-spored; spore-mass elongated, reaching a length of $50-70 \mu$ and a diameter of $20-27 \mu$; spores ellipsoid, with the ends narrowed, strongly swollen near the center, often subfusoid and slightly unequal-sided, hyaline, becoming violet, later brown, often delicately sculptured, $10 \times 20-23 \mu$; spore-sculpturing taking the form of very delicate reticulations; paraphyses slender, branched rather freely, golden-yellow, thickened above.

On dung of various kinds.

TYPE LOCALITY: Europe.

Distribution: New York to Colorado, Bermuda and Porto Rico, probably common throughout North America; also in Europe.

Illustrations: Ann. Sci. Nat. IV. $10: p l .13, f . B$; Ann. Sci. Nat. V. 10: pl. 8, f. 18; Ann. Mag. Nat. Hist. III. 15: pl. 17, f. 34; Jour. Bot. 2: 15.3, f. 8; Gill. Champ. Fr. Discom. pl. 85, f. 1; Rab. Krypt.-Fl. 13 : 1111, f. 6-7; Massee, Brit. Fungus-Fl. 4: 156, f. 11; Bull. Lab. Nat. Hist. State Univ. Iowa 6: pl. $28, f .2$. 


\section{Saccobolus portoricensis Seaver, sp. nov.}

Apothecia gregarious or scattered, superficial, at first perfectly globose, becoming short-cylindric, finally discoid, smooth, paleamber, reaching a diameter of $1 \mathrm{~mm}$.; hymenium plane, becoming convex, at first similar in color to the outside of the apothecium, dotted over with the protruding asci, finally almost entirely black; hypothecium composed of rather loosely united roundish or angular cells; excipulum poorly developed, consisting of a palisade of mycelium; asci clavate, tapering below into a rather long slender base, reaching a length of 170-200 $\mu$ and a diameter of 35-40 $\mu, 8$-spored; spore-mass at first elongated, finally subglobose, closely compact and opaque or nearly so, surrounded by a mass of purple granules, reaching a length of $40 \mu$ and a diameter of $27-30 \mu$; spores at first subfusoid, finally subglobose, at first hyaline, then purple, finally pale-brown, becoming sculptured, about $17 \times 20 \mu$; spore-sculpturing taking the form of very delicate reticulations, scarcely roughening the surface of the spore; paraphyses about $3 \mu$ thick, scarcely enlarged above, filled with orange granules.

Cultivated on cow dung.

Type grown on dung sent from Porto Rico, autumn, 1915 (Herb. The New York Botanical Garden).

Distribution: Known only from the type locality.

Distinguished by its subglobose spores.

3. Saccobolus violascens Boud. Ann. Sci. Nat. I. 10: 230. 1869.

?Saccobolus neglectus Boud. Ann. Sci. Nat. V. 10: 231. 1869.

Apothecia scattered, superficial, pale-violaceous, with a whitish mycelial grow th about the base, not exceeding $1 \mathrm{~mm}$. in diameter; hymenium becoming strongly convex, roughened by the protruding asci, at first similar in color to the outside of the apothecium, finally almost black; excipulum poorly developed, consisting of loosely interwoven hyphae which, with transmitted light, appear very dilutely violaceous; asci very broad-clavate, gradually tapering below into a stem-like base, reaching a length of $175 \mu$ and a diameter of 30-35 $\mu, 8$-spored; spore-mass densely compact, elongated, reaching a length of $40-60 \mu$ and a diameter of $20 \mu$; spores elongated, slightly unequal-sided or almondshaped, at first hyaline or very dilutely violaceous.

On dung of various kinds, especially on goat dung. 
TyPe LOCALity: Europe.

Distribution: New York to Iowa; also in Europe.

Illustrations: Ann. Sci. Nat. I. 10: pl. 8, f. 19, and pl.9, f. 20; Phill. Brit. Discom. pl. 9, f. 55; Rab. Krypt.-Fl. 13: 1111 , f. 1-5; E. \& P. Nat. Pfl. 1 ${ }^{1}: 192, f .154, B, C$.

4. Saccobolus depauperatus (Berk. \& Br.) Phill. Brit. Discom. 296. 1887.

Ascobolus depauperatus Berk. \& Br. Ann. Mag. Nat. Hist. III. 15: 448. 1865.

Apothecia scattered or gregarious, with a narrowed base which is immersed in the substratum, expanding and becoming discoid, scarcely exceeding $0.3 \mathrm{~mm}$. in diameter; hymenium even with, or slightly elevated above the surface of the substratum, at first whitish with a tinge of violet, finally almost black; the excipular cells angular or rounded and reaching a diameter of 5-7 $\mu$, the walls beautifully lilac, fading to brown, giving rise above to a palisade of mycelia which resemble paraphyses except that they are more deeply colored; asci very broad-clavate, the ends strongly truncate, tapering gradually below into a stem-like base, reaching a length of $65-70 \mu$ and a diameter of 15-17 $\mu$, 8-spored; spore-mass elongated, reaching a length of $30 \mu$ and a diameter of 11-12 $\mu$; spores ellipsoid, the ends strongly narrowed, smooth or minutely sculptured, at first hyaline, becoming deepviolet, finally blackish-brown, $5 \times 10-12 \mu$; paraphyses slender, slightly enlarged above, reaching a diameter of $3-4 \mu$, hyaline, or very faintly colored.

On horse dung.

Type locality : Europe.

Distribution: New York; also in Europe.

Illustration: Ann. Mag. Nat. Hist. III. 15: pl. 1t, f. 6.

\section{Saccobolus globuliferellus Seaver, sp. nov.}

Apothecia widely scattered, minute, scarcely visible, not exceeding $0.3 \mathrm{~mm}$. in diameter, milk-white; hymenium becoming convex, at first white like the outside of the apothecium, finally dotted over with the ends of the asci which appear black on account of the dark-colored spores; asci broad-ovoid above, tapering below into a stem-like base, reaching a length of $60 \mu$ and a diameter of 23-25 $\mu, 8$-spored; spore-mass nearly rounded, about $23 \times 20 \mu$; spores at first loosely disposed in the ascus, finally collecting into the loosely united spore-mass, ellipsoid, at first hyaline, later assuming a faded-blue color which finally 
changes to smoky-blackish, becoming sculptured, $7 \times 12-14 \mu$; spore-sculpturing consisting of minute scattered warts; paraphyses branched, rather strongly enlarged above where they reach a diameter of $7-8 \mu$, hyaline.

On horse dung.

Type locality: New York City.

Distribution: Known only from the type locality.

The species, which was collected during the autumn of 1914 , seems to differ in several particulars from any of the other species of the genus studied. The apothecia are white and very small. The spore masses are nearly rounded and the spores themselves more blue than purple and distinctly warted rather than reticulated. The species has been encountered only once.

\section{Doubtful Species}

Saccobolus obscurus (Cooke) Phill. Brit. Discom. 295. 1887; Ascobolus obscurus Cooke, Grevillea 4: 112. 1876. Specimens were distributed under this name in Clements, Crypt. Form. Colo. 301. No Saccobolus could be found in our copy of this number.

\section{ALEURIA Fuckel, Symb. Myc. 325. 1869.}

Apothecia gregarious, scattered or cespitose, sessile or stipitate, externally smooth or clothed with a delicate white tomentum; hymenium concave or plane, even or lacunose, usually bright-orange or red; asci cylindric or subcylindric, 8-spored; spores ellipsoid, at first smooth, becoming sculptured; sporesculpturing assuming the form of reticulations, often also with apiculi, rings, etc., at the ends of the spores; paraphyses slender, usually strongly enlarged at their apices.

Type species, Peziza aurantia Pers.

Apothecia sessile or subsessile.

Spores apiculate but not marked with a ring at the ends.

Apothecia reaching a diameter of several cm.; spores $18-20 \mu$ long.

1. A. aurantia.

Apothecia not exceeding a diameter of $2 \mathrm{~cm}$; spores $9-15 \mu$ long.

Spores $7 \times 14-15 \mu$. Spores $5 \times 9-10 \mu$.

2. A. wisconsinensis.

3. A. cestrica.

Spores marked with a ring at either end. Apothecia strongly stipitate.

Occurring in coniferous woods; stems springing from a dense mass of mycelium.

4. A. bicucullata.

Occurring usually singly among mosses in deciduous woods.

5. A. rhenana.

6. A. rutilans. 
1. Aleuria aurantia (Pers.) Fuckel, Symb. Myc. 325. 1869. (Plate 8, Fig. 1.)

Elvela coccinea Schaeff. Fung. Bavar. 4: 100. 1774. Not Elvela coccinea Scop. 1772.

Peziza coccinea Bull. Herb. Fr. pl. 47t. 1789.

Peziza aurantia Pers. Obs. Myc. 2: 76. 1797.

Scodellina aurantiaca S. F. Gray, Nat. Arrang. Pl. 668. 1821.

Otidea aurantia Massee, Brit. Fungus-Fl. 4: 448. 1895.

Apothecia gregarious or cespitose, sessile, at first globose, gradually expanding, finally reaching a diameter of $5-6 \mathrm{~cm}$. though of ten smaller, shallow, cup-shaped and usually regular in form when young, becoming irregular and often variously contorted with age or from mutual pressure, occasionally discoid and rarely one-sided and Otidea-like, externally whitish, pruinose; hymenium concave or almost plane, bright-orange, the color fading in dried specimens; asci cylindric or subcylindric, reaching a length of $175-250 \mu$ and a diameter of $12-15 \mu$; spores 1 -seriate, usually obliquely arranged in the ascus, the ends often overlapping, at first smooth and usually containing two large oildrops, finally becoming sculptured, $9-10 \times 18-22 \mu$; sporesculpturing taking the form of reticulations which are regular in form and shallow, except at the ends of the spore where the ridges project, giving rise to apiculi; paraphyses strongly and rather abruptly enlarged at their apices, the ends often subglobose, reaching a diameter of $7-8 \mu$, filled with orange granules.

On damp soil in woods and open places, occasionally on lawns but more often on naked clayey soil.

Týe locality: Europe.

Distribution: Newfoundland to Washington, California and West Virginia; also in Europe.

Illustrations: Bolton, Fungi Halifax pl. 100; Bull. Herb. Fr. pl. 474; Cooke, Mycographia pl. 52, f. 203; Fl. Danici pl. 157; Schaeff. Fung. Bavar. pl. 148; Sow. Engl. Fungi pl. 78; Gill. Champ. Fr. Discom. pl. 37, f. 2; Pat. Tab. Fung.f. 278; E. \& P. Nat. Pfl. $1^{1}: 186, f$. 150, J-L; Phill. Brit. Discom. pl. 3, f. 14; Rab. Krypt.-F1. 13: 920, f. 1-3; Batsch, Elench. Fung. 2: pl. 28, f. 158; Boud. Ic. Myc. pl. 313; Bull. Lab. Nat. Hist. State Univ. Iowa 6: pl. 17, f. 1 .

Exsiccati: N. Am. Fungi 836; Ellis \& Ev. Fungi Columb. 15. One of the commonest and most widely distributed of the 
larger cup-fungi, occurring from the Atlantic to the Pacific and probably throughout temperate North America as well as abroad. Also it is attractive and easily recognized by means of its brightorange color. If there is any doubt of its identity, this can be easily dispelled by an examination of the beautifully reticulated spores.

2. Aleuria wisconsinensis Rehm, Ann. Myc. 2: 34. 1904.

Apothecia gregarious, sessile, becoming discoid, contracted at the base into a slightly stem-like base, the margin thick and entire, at length becoming more or less convolute, externally light-colored, yellowish, tomentose, reaching a diameter of 0.5 $2 \mathrm{~cm}$; hymenium slightly concave or plane, even or convolute, bright orange-red; the excipular cell walls subhyaline; asci cylindric or subcylindric, reaching a length of $200 \mu$ and a diameter of $10 \mu, 8$-spored; spores 1 -seriate, ellipsoid, hyaline, containing two large oil-drops, becoming sculptured, about $7 \times 14-15 \mu$; spore-sculpturing taking the form of reticulations; paraphyses hyaline, filiform, septate, reaching a diameter of $5 \mu$ at their apices and about $3 \mu$ below.

On damp soil.

Trpe locality: Blue mounds, Wisconsin.

Distribution: Misconsin and Minnesota.

3. Aleuria cestrica (Ellis \& Ev.) Seaver, comb. nov.

Pesiza cestrica Ellis \& Ev. Jour. Myc. 1: 152. 1885.

Humaria cestrica Sacc. Syll. Fung. 8: 133. 1889.

Aleurina Lloydiana Rehm, Ann. Myc. 2: 35.1904.

Peziza Commonsii Ellis \& Ev. (in herb.).

Apothecia gregarious or densely crowded, sessile or subsessile, and circular or becoming irregular from mutual pressure, reaching a diameter of $5-6 \mathrm{~mm}$. or rarely $1 \mathrm{~cm}$., externally yellowish-orange; hymenium shallow-concave or becoming nearly plane, orange; asci cylindric or clavate, reaching a length of $150 \mu$ and a diameter of $10 \mu, 8$-spored; spores 1 -seriate, ellipsoid, at first smooth and containing two distinct oil-drops, $5-7 \times 10^{-}$ $11 \mu$, becoming sculptured; spore-sculpturing taking the form of very fine reticulations, with one or two projections at either end and giving the spore an apiculate appearance (the mature spores resembling those of Aleuria aurantia except that they are much smaller), hyaline or subhyaline; paraphyses slender, rather 


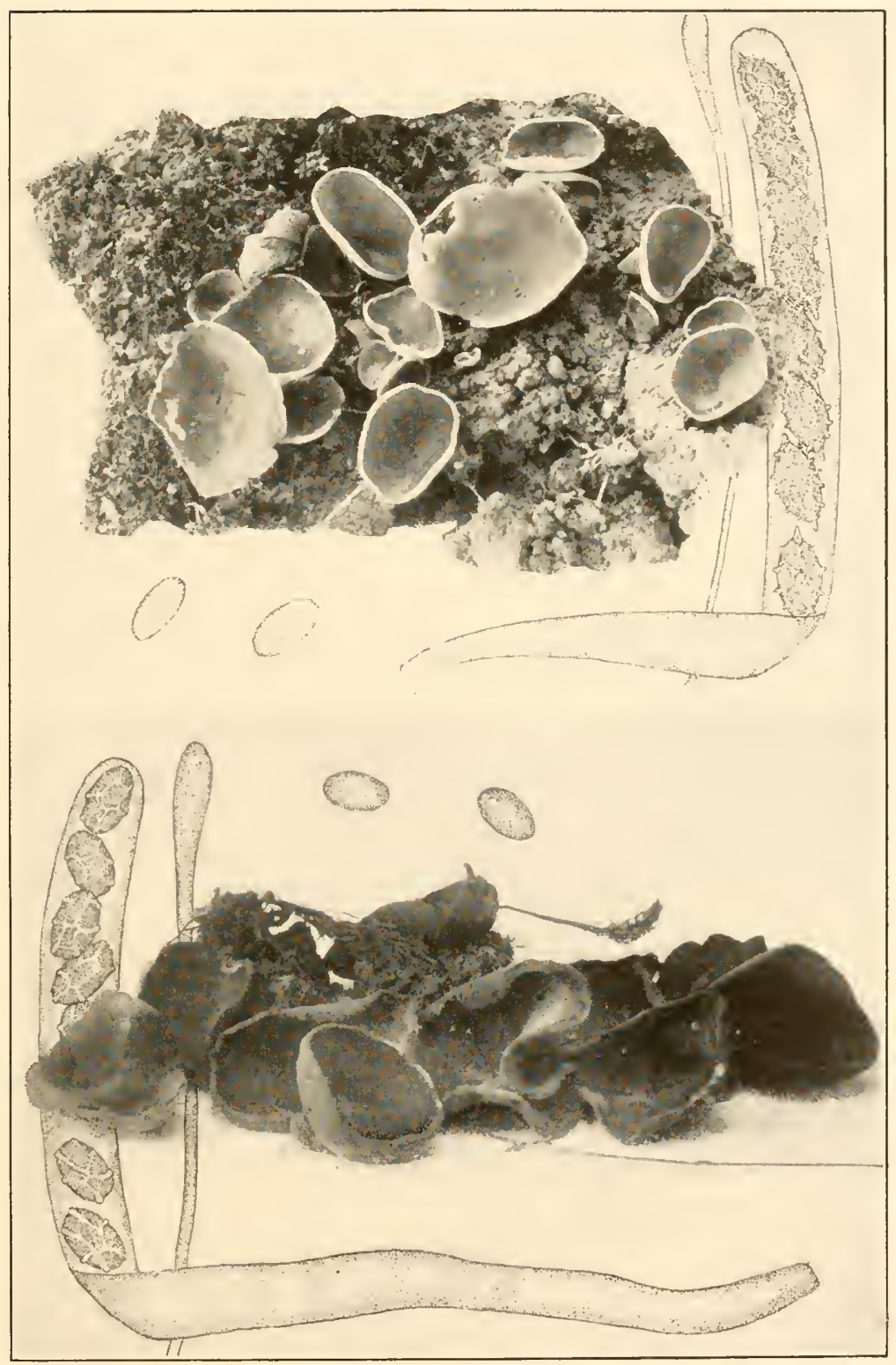

1. ALEURIA AURANTIA

2. ALEURINA ATROVINOSA 

abruptly thickened above, where they reach a diameter of 3$4 \mu$.

On damp ground, usually among mosses.

Type locality: West Chester, Pennsylvania.

Distribution: Known only from the type locality.

Exsiccati : Fungi Columb. 1733.

4. Aleuria bicucullata Boud. Bull. Soc. Bot. Fr. 28: 93. 1881.

Peziza bicucullata Boud. Bull. Soc. Myc. Fr. 1: 103. 1885.

Humaria bicucullata Quél. Ench. Fung. 288. 1886.

Apothecia gregarious or crowded, sessile, at first subglobose, expanding and becoming subdiscoid or irregular from mutual pressure, externally pale-orange or whitish, pruinose, reaching a diameter of $5 \mathrm{~mm}$. to $1 \mathrm{~cm}$.; hymenium concave or nearly plane, bright-orange or yellow; asci cylindric or subcylindric, reaching a length of $200 \mu$ and a diameter of $12-15 \mu$; spores 1 -seriate, obliquely disposed, at first smooth and containing one or two oil-drops, finally becoming sculptured, $10-12 \times 20-23 \mu$, including sculpturing; spore-sculpturing consisting of a ring-like or hood-like process at one or both ends of the spore (especially where the spores come into contact with each other in the ascus) and irregular or often broken reticulations, the ridges of the reticulations conspicuous and giving rise to the rather sharppointed, spine-like projections, the terminal projections larger and giving the spore an apiculate appearance; paraphyses rather strongly enlarged above, where they reach a diameter of $5 \mu$.

On bare ground or among mosses.

Type locality: France.

Distribution: Wisconsin and Ontario; also in Europe.

Illustrations: Bull. Soc. Bot. Fr. 28: pl. 3, f. 1; Boud. Ic. Myc. pl. 318; Mycologia 6: pl. 14t, f. 3; Pat. Tab. Fung. f. 371.

5. Aleuria rhenana Fuckel, Symb. Myc. 325. 1869. (Plate 9, FIG. 2.)

?Pesiza radiculata Sow. Engl. Fungi pl. 11.t (with descr.). 1797.

Peziza splendens Quél. Champ. Jura 388. 1873.

?Peziza sordescens Berk. \& Curt. Grevillea 3: 150. 1875.

Sarcoscypha rhenana Sacc. Syll. Fung. 8: 157. 1889.

?Sarcoscypha radiculata Sacc. Syll. Fung. 8: 156. 1889.

?Geopyxis sordescens Sacc. Syll. Fung. 8: 69. 1889.

Apothecia gregarious or cespitose, stipitate, reaching a diameter of $1-2 \mathrm{~cm}$. and about half as deep, externally white or 
whitish, tomentose, the tomentum consisting of poorly developed hairs; stems very variable in length, reaching $1-2 \mathrm{~cm}$., irregular, often clinging together in clumps, attached at the base by a dense mass of white mycelium which penetrates into the substratum binding together the leaf-mould in which the plants grow, expanding abruptly above in to the apothecium; hymenium concave, bright-orange, the color fading in dried specimens; asci cylindric above, tapering below into a stem-like base, of ten becoming spirally twisted, especially in dried specimens, reaching a length of $300-350 \mu$ and a diameter of $15-17 \mu$; spores 1-seriate, obliquely arranged and with the ends overlapping, ellipsoid, at first smooth, becoming sculptured, $12 \times 20-23 \mu$; spore-sculpturing assuming the form of reticulations, the meshes of the reticulations reaching a diameter of $3 \mu$ or more, rarely 5 or $6 \mu$, the edges of the ridges extending 1-2 $\mu$ beyond the periphery of the spore; paraphyses enlarged above, where they reach a diameter of $6 \mu$, filled with orange granules.

On the ground in coniferous woods.

Type locality: Europe.

Distribution: Pennsylvania to Alabama and west to Washington; also in Europe.

Illustrations: Boud. Ic. Myc. pl. 314; Cooke, Mycographia pl. 112,f.400; Mycologia 6: pl. 142 (lower figure) and pl. 14t,f. 2.

6. Aleuria rutilans (Fries) Gill. Champ. Fr. Discom. 53. 1879.

(Plate 9, Fig. 1; 45, Fig. 22.)

Peziza rutilans Fries, Syst. Myc. 2: 68. 1822.

Leucoloma rutilans Fuckel, Symb. Myc. 318. 1869.

Humaria rutilans Sacc. Syll. Fung. 8: 133. 1889.

Sarcoscypha albovillosa Rehm, Ann. Myc. 2: 33. 1904.

Apothecia gregarious or scattered, stipitate, at first closed and about the same diameter as the stem, gradually expanding and becoming turbinate, the margin crenate and fringed with a few delicate hairs, externally whitish or pale-orange, reaching a diameter of $1 \mathrm{~cm}$; stem rather slender and short, reaching a maximum length of $5 \mathrm{~mm}$., gradually expanding above into the apothecium; hairs delicate, hyaline, septate, reaching a length of $300 \mu$ and a diameter of 10-12 $\mu$; asci cylindric above, tapering below into a stem-like base, reaching a length of 300 $350 \mu$ and a diameter of $20 \mu$; spores 1 -seriate, obliquely arranged and often with the ends overlapping, ellipsoid, containing one or two (usually one) large oil-drops, at first smooth, becoming 
sculptured, $12-14 \times 20-25 \mu$; spore-sculpturing taking the form of reticulations which are of ten interrupted or broken; paraphyses enlarged at their apices, where they reach a diameter of $6 \mu$, filled with orange granules.

On soil among mosses (especially Polytrichum), ap parently growing on the dead leaves and often hidden by the living plants.

Týp locality: Europe.

Distribution: New Hampshire and New Iork to Iowa; also in Europe.

Illustrations: Boud. Ic. Myc. pl. 315; Grevillea 22: 108, f. 1-6; Bull. Lab. Nat. Hist. State Univ. Iowa 6: pl. 17, f. 2; Mycologia 6: pl. 142 (upper figure) and pl. 1tt, f. t.

\section{Doubtful and Excluded Species}

The genus Aleuria is here restricted to those species in which the spores become reticulate as used by Fuckel. The genus has been used in a much broader sense by both Gillet and Boudier, so that many of the species treated as Aleuria by those authors will be included in the present work with the genus Pesiza and other genera of the tribe Pezizeae.

12. ALEURINA Sacc. \& Sydow in Sacc. Syll. Fung. 16: 738. 1902.

Phaeopezia § Aleurina Sacc. Syll. Fung. 8: 472. 1889.

Apothecia medium-sized, of ten reaching a diameter of several cm., cup-shaped to scutellate, fleshy or subfleshy, dark-colored, brownish-black or entirely black, fleshy or subfleshy; asci cylindric to clavate, 8-spored; spores ellipsoid, at first hyaline, becoming smoky-brown, sculptured; spore-sculpturing taking the form of regular or indistinct reticulations; paraphyses rather stout, usually filled with dark granules.

Type species, Pesisa retiderma Cooke.

Spores broad-ellipsoid, $10 \times 15-17 \mu$.

1. A. atrovinosa.

Spores ellipsoid to subfusoid, $10-12 \times 22-25 \mu$.

2. A. aquehougensis.

1. Aleurina atrovinosa (Cooke) Seaver, comb. nov. (PLATE 8, FIG. 2.)

Peziza atrovinosa Cooke, Bull. Buffalo Soc. Nat. Sci. 2:288. 1875.

Peziza retiderma Cooke, Mycographia 176. 1877.

Peziza chlamydospora Ellis \& Ev. Bull. Torrey Club 10: 98. 1883.

Phaeopezia retiderma Sacc. Syll. Fung. 8: 472. 1889.

Aleurina retiderma Sacc. \& Sydow in Sacc. Syll. Fung. 16: 739. 1902.

Apothecia gregarious or occasionally cespitose, rather deep cup-shaped, regular in form or becoming irregularly contorted 
with age or from mutual pressure, at first pale-brown or smoky, becoming darker with age, reaching a diameter of $2-5 \mathrm{~cm}$.; hymenium concave, darker than the outside of the apothecium, becoming almost black with age or with an olive tint from the spores which have dusted out over its surface; asci cylindric or subcylindric, tapering rather abruptly below into a stem-like base, reaching a length of $275 \mu$ and a diameter of $12-14 \mu$; spores 1-seriate, ellipsoid, at first hyaline and smooth, containing one or two oil-drops, finally becoming sculptured and smokybrown, $10 \times 15-17 \mu$; spore-sculpturing usually consisting of one large protuberance at either end of the spore and irregular reticulate markings over the surface of the spore, with irregular lumps at various points on its surface, the ridges of the reticulations so arranged as to give the spore a somewhat striate appearance; paraphyses strongly enlarged above, where they reach a diameter of $8 \mu$, minutely granular within and dilutely colored.

On the ground in woods, of ten among mosses.

Type locality: New Jersey.

Distribution: New York, New Jersey, Maine and Montana.

Illustrations: Cooke, Mycographia pl.79,f. 306; Mycologia 6: pl. 143 (lower figure) and $p l .144, f .6$.

2. Aleurina aquehongensis Seaver, Mycologia 6:278. 1914.

Apothecia gregarious or scattered, sessile, discoid to shallow cup-shaped, externally slightly roughened, pale brownish-black, reaching a diameter of $1 \mathrm{~cm}$.; hymenium concave, dark-brown or becoming almost black or with a slight greenish tinge which seems to be due to the spores which have been dusted out over the hymenium; asci cylindric above, tapering below into an irregular stem-like base, reaching a length of $300-350 \mu$ and a diameter of $15-17 \mu$; spores 1 -seriate or occasionally slightly crowded, ellipsoid to subfusoid, containing one or two oil-drops, at first smooth, becoming sculptured, pale smoky-brown, 10-12 $\times 22-25 \mu$; spore-sculpturing taking the form of irregular reticulations, the ridges of the reticulations strongly projecting, giving the spore a decidedly roughened surface; paraphyses rather strongly enlarged above, reaching a diameter of $6 \mu$ at their apices, pale-brown.

On the ground in damp places.

Type localitr: Staten Island, New York.

Distribution: Known only from the type locality. 


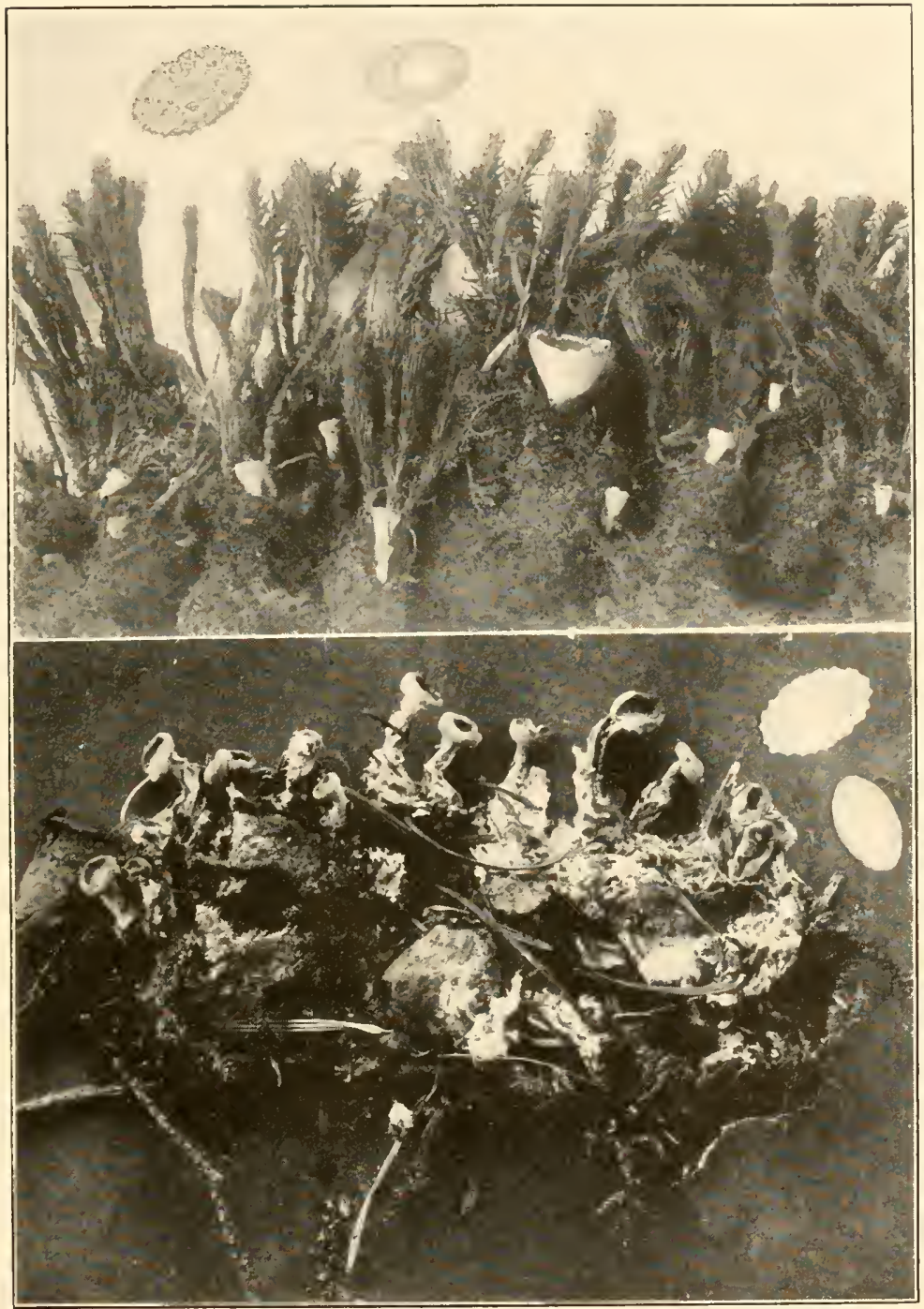

1. ALEURIA RUTILANS

2. ALEURIA RHENANA 

13. MElastizA Boud. Bull. Soc. Myc. Fr. 1: 106. 1885.

Apothecia cup-shaped or scutellate, with the hymenium bright-colored, externally clothed with flexuous or bristle-like hairs; asci 8 -spored; spores hyaline, at first smooth, at maturity sculptured; spore-sculpturing assuming the form of reticulations; paraphyses filiform to clirate.

Type species, Pesisa miniata Fuckel.

Hairs inconspicuous, closely adpressed to the sides of the apothecium.

1. M. Charteri.

I lairs conspicuous, extending far beyond the margin of the apothecium.

Plants tropical; spores $30-35 \mu$ long.

Plants temperate; spores $25-30 \mu$ long.

2. M. asperrima.

3. II. pennsylianica.

1. Melastiza Charteri (W. C. Smith) Boud. Hist. Class. Discom. Eu. 64. 1907. (Plate 45, FIG. 17.)

Peziza Charteri W. G. Smith, Gard. Chron. 1872: 9. 1872.

Iumaria miniata Fuckel, Symb. Myc. Nacht. 3: 32. 1875.

Peziza miniata Cooke, Mycographia 71. 1876. Not Peziza miniata Batsch. 1786.

IIumaria Charteri Rehm, Ascom. 455. 1878.

Lachnea miniata Gill. Champ. Fr. Discom. 210. 1886.

Scutellinia miniata Kuntze, Rev. Gen. PI. 2: 869. 1891.

Melastiza miniata Boud. Ic. Мyc. exp. pl. 1: 16. 1905.

Apothecia scattered, gregarious, or crowded, expanding and becoming nearly plane or more rarely cup-shaped, regular in outline when young, the margin of ten becoming wavy or irregularly convolute with age or from mutual pressure, reaching a diameter of $1.5 \mathrm{~cm}$., though often smaller, externally clothed with clumps of imperfectly dereloped hairs; hymenium concave or nearly plane, bright-red or almost scarlet; the excipular cells roundish or angular, the cell walls pale-brown; hairs usually clinging together in fascicles, flexuous, thin-walled, with blunt ends, 3-4-septate, pale-brown, reaching a length of $150-175 \mu$ and a diameter of $10-12 \mu$; asci cylindric or subcylindric, tapering gradually below, reaching a length of $300 \mu$ and a diameter of 12-14 $\mu$; spores 1 -seriate, parallel with the ascus or more rarely diagonally disposed, ellipsoid, hyaline, usually containing two oil-drops, funally becoming sculptured, $10-13 \times 17-20 \mu$; sporesculpturing assuming the form of reticulations, the reticulations often indistinct and broken in young specimens, and of ten giving rise to an apiculus at either end; paraphyses enlarged above, where they reach a diameter of $6-8 \mu$. 
On bare soil or among mosses.

Type Locality : Europe.

Distribution: New York to Colorado; also in Europe.

Illustrations: Boud. Ic. Myc. pl. 386; Cooke, Mycographia pl. 33, f. 127; Gardner's Chron. 1872: 9, f. 1; Grevillea 1: pl. 8, f. 1, 2; Gill. Champ. Fr. Discom. (suites); Pat. Tab. Fung. f. 276 .

This species has been frequently collected about New York on bare soil in open woods. As this goes to press, specimens of the species have been received from Winnipeg, Canada, with the statement that it is collected there every autumn in abundance on sawdust in an old ice-house after the ice has been removed. The material was collected by A. H. R. Buller and G. R. Bisby.

2. Melastiza asperrima (Ellis \& Ev.) Seaver, comb. nov.

Lachnea barbata Nassee, Jour. Bot. 30: 163. 1892. Not L. barbata (Kunze)

Gill. 1879 .

Lachnea asperrima Ellis \& Ev. (in herb.).

Apothecia scattered or gregarious, scutellate, the margins slightly elevated, regular in form or with the margins wavy, externally sparingly clothed with hairs, reaching a diameter of 5-8 mm.; hymenium slightly concave, bright-red; hairs very long and projecting far out about the margin of the apothecium, dark reddish-brown, septate, thick-walled, gradually tapering above into a bristle-like apex, reaching a length of $2 \mathrm{~mm}$. and a diameter of $35 \mu$ near the base; asci cylindric or subcylindric, reaching a length of $250 \mu$ and a diameter of $17-20 \mu$; spores 1 -seriate, ellipsoid, containing one large oil-drop, $15-17 \times 30-35 \mu$, becoming sculptured; spore-sculpturing assuming the form of very regular, usually hexagonal reticulations, the reticulations consisting of ridges which extend about $2 \mu$ beyond the periphery of the spore, strongly roughening its surface, the meshes of the reticulations about 3 or $4 \mu$ in diameter; paraphyses slender below, rather strongly thickened above.

On rotten wood.

Type Locality: Nicaragua.

Distribution: Nicaragua to Mexico and the West Indies.

Illustration: Jour. Bot. 30: pl. 321, f. 5-8.

\section{Melastiza pennsylvanica Seaver, sp. nov.}

Apothecia scattered or sessile, scutellate, the margin slightly elevated and sparingly clothed with long hairs, reaching a 
diameter of $5-8 \mathrm{~mm}$; hymenium slightly concave, bright-red; hairs dark-brown, thick-walled, septate, reaching a length of more than $1 \mathrm{~mm}$. and a diameter of $35-40 \mu$ near the base, gradually contracted below and often forked at the base, tapering above in to a bristle-like apex; asci cylindric or subcylindric above, reaching a length of $250 \mu$ and a diameter of $20 \mu$; spores 1 -seriate, parallel with the ascus or diagonally disposed, at first smooth, becoming sculptured at an early stage, $14-17 \times 25-30 \mu$; sporesculpturing taking the form of distinct and regular reticulations, the ridges of the reticulations $1-2 \mu$ deep and giving to the spore surface a very rough appearance; paraphyses about $2 \mu$ in diameter below, rather strongly enlarged above.

On old wood.

Type collected in deciduous woods along the Youghiogheny River, Pennsylvania, by IV. A. Murrill (Herb. The New York Botanical Garden).

Distribution: Pennsylvania.

14. PSILOPEZIA Berk. London Jour. Bot. II. 6 : $325.18+7$.

Fleischhakia Rab. Hedwigia 17: 114. 1878.

Peltidium Kalchbr. Hedwigia 2: 58. 1862. Not Peltidium Zollik. 1820.

Apothecia medium-sized, usually not exceeding $1 \mathrm{~cm}$. in diameter, becoming flattened or subdiscoid, closely adhering to the substratum and usually surrounded by a sterile border, occasionally with the margin free and slightly elevated; hymenium slightly concave, plane or more often convex, usually dark-colored, brown or brownish, more rarely bright-colored, yellow or orange; asci cylindric or subcylindric, 8-spored, usually spirally marked; spores ellipsoid, smooth or more rarely sculptured, hyaline or subhyaline; paraphyses stout.

Type species, Psilopesia mummularia Berk.

Apothecia dark-brown or reddish-brown.

Spores smooth.

Spores $12 \times 20-25 \mu$.

1. P. mummularia.

Spores $15-17 \times 22-25 \mu$.

2. P. hydrophila.

Spores $15-17 \times 30-36 \mu$.

3. P. deligata.

Spores becoming rough.

4. P. trachyspora.

Apothecia yellow or orange.

Spores $7 \times 12-14 \mu$.

5. P. flavida.

Spores $12-13 \times 20-24 \mu$.

6. P. aquatica. 
1. Psilopezia nummularia Berk. London Jour. Bot. 6: 325. 1847.

Peziza Babingtonii Berk. \& Br. Ann. Mag. Nat. Hist. II. 7: 179. 1851.

Psiloperia myrothecioides Berk. \& Br. Ann. Mag. Nat. Hist. IV. 15: 39. 1875. Fleischhakia rhizinoides Rab. lledwigia 17: 114. 1878.

Peziza depressa Phill.; Cooke, Mycographia 233. 1879. Not P. depressa Pers. 1796.

IItumaria depressa Sacc. Syll. Fung. 8: 145.1889.

Rhizina myrothecioides Massee, Brit. Fungus-F1. 4: 455. 1895.

Rhizina Babingtonii Massee, Brit. Fungus-F1. 4: 455. 1895.

Peziza nummularia Morgan, Jour. Myc. 8: 190. 1902.

Apothecia gregarious, becoming discoid or subdiscoid and closely adhering to the substratum to the extreme margin and surrounded by a whitish mycelial growth, reaching a diameter of $1-5 \mathrm{~mm}$. or rarely $1 \mathrm{~cm}$; hymenium plane or slightly convex, reddish-brown to brown, almost black in dried specimens, more or less velvety from the protruding paraphyses; asci cylindric above, tapering below and marked with a distinct spiral which appears to be due to thickening or possibly to a twisting of the ascus, reaching a length of $200-250 \mu$ and a diameter of $15-18 \mu$; spores 1 -seriate at maturity, ellipsoid, containing one or two oildrops, hyaline or very faintly yellowish, about $12 \times 20-25 \mu$; paraphyses stout, much thickened above and containing coarse brown granules, pale below, reaching a diameter of $10 \mu$ at their apices.

On rotten wood.

Type Locality: Great Britain.

Distribution: Ontario to New Hampshire and Greenland?; also in Europe.

Illustrations: Ann. Mag. Nat. Hist. IV. 15: pl. 2, f. 5; Cooke, Mycographia pl. 110, f. 392; Phill. Brit. Discom. pl. 5, f. 23; Rab. Krypt.-Fl. $1^{3}$ : $1135, f$. 1-3; Jour. Linn. Soc. $31:$ pl. 16, f. 13 .

2. Psilopezia hydrophila (Peck) Seaver, comb. nov.

Peziza hydrophila Peck, Ann. Rep. N. Y. State Mus. 34: 51. 1881.

Humaria hydrophila Sacc. Syll. Fung. 8: 140. 1889.

?Peziza rivularis Clements, Bot. Surv. Nebr. 3: 8. 1894.

Apothecia scattered, sessile, becoming expanded, at maturity plane or even convex; hymenium reddish-brown when moist, black when dry, reaching a diameter of 2-5 mm.; asci cylindric above, tapering below; spores 1 -seriate, ellipsoid, generally con- 
taining two oil-drops, reaching a diameter of $15-17 \mu$ and a length of 22-25 $\mu$; paraphyses numerous, thickened above, compact and adhering together at their apices.

On decaying wood, lying in the water.

Type locality: Adirondack Mountains, New York.

Distribution: New York and (? Nebraska).

3. Psilopezia deligata (Peck) Seaver, comb. nov.

Bulgaria deligata Peck, Ann. Rep. N. Y. State Mus. 32: 49. 1879. Not Peziza deligata Peck.

Peziza leucobasis Peck, Bull. N. Y. State Mus. 2: 20. 1887.

Pyronema leucobasis Sacc. Syll. Fung. 8: 110. 1889.

Apothecia sessile, closely adhering to the substratum and surrounded by a whitish or yellowish border of superficial mycelium, becoming almost convex-hemispheric, reaching a diameter of $3 \mathrm{~mm}$; hymenium covering all of the exposed surface of the apothecium, convex, brownish-black with a tinge of olive; asci cylindric to subclavate, rather broad; spores 1-seriate, broadellipsoid, thick-walled, smooth, slightly yellowish, usually containing two large oil-drops, reaching a diameter of 15-17 $\mu$ and a length of $30-36 \mu$; paraphyses enlarged above, reaching a diameter of $10 \mu$ at their apices, yellowish or brownish but not usually containing the conspicuous granules characteristic of the other species.

On wet hemlock wood and the bark of an unknown tree.

Trpe locality: Catskill Mountains, New York.

Distribution: New lork and New Hampshire.

Illustration: Bull. N. Y. State Mus. 2: pl. 2, f. 1-3.

4. Psilopezia trachyspora Ellis \& Ev. Erythea 1:200. 1893.

Apothecia gregarious, becoming subdiscoid, adhering closely to the substratum except the extreme margin which is free and slightly elevated, externally pale-brown and becoming slightly wrinkled at least in dried specimens, reaching a diameter of 1-2 cm.; hymenium dark-brown; asci cylindric above, gradually tapering below, reaching a length of $300-325 \mu$ and a diameter of 15-18 $\mu$, becoming spirally marked, the spiral markings extending the whole length of young asci but in older asci restricted to the lower extremity only; spores 1 -seriate or slightly crowded, ellipsoid, at first smooth and containing two oil-drops, beconing sculptured, $13-15 \times 25-28 \mu$; spore-sculpturing taking the form 
of prominent wart-like protuberances; paraphyses stout, much enlarged above, filled with dark-brown coloring matter.

On decaying cedar wood.

Type Locality: North Bend, King County, Washington.

Distribution: Known only from the type locality.

5. Psilopezia flavida Berk. \& Curt. Grevillea 4: 1. 1875.

Apothecia crowded and occasionally confluent, orbicular in form when solitary, reaching a diameter of 3-6 $\mathrm{mm}$., the margin free and often raised when mature; hymenium concave, plane or convex, yellow; asci narrowly cylindric, reaching a length of $120 \mu$ and a diameter of $7-8 \mu$; spores 1 -seriate, hyaline, smooth, ellipsoid, $7 \mu \times 12-14 \mu$, containing two oil-drops; paraphyses stout, scarcely thickened above, not longer than the asci.

On rotten wood of Quercus alba.

Type Locality: Alabama.

Distribution: Alabama.

Illustration: Jour. Limn. Soc. 31 : pl. 16, f. 10.

6. Psilopezia aquatica (DC.) Rehm; Sacc. \& D. Sacc. in Sacc. Syll. Fung. 18: 12. 1906.

Peziza aquatica DC. in Lam. Encyc. 5: 216. 1804.

Peltidium Oocardii Kalch. Hedwigia 2: 58.1862.

Peziza Oocardii lignaria P. Karst. Not. Fauna F1. Fenn. 10: 128. 1869.

Peziza Oocardii Karst. Myc. Fenn. 1: 84. 1871.

Peziza lechithina Cooke, Grevillea 4: 110. 1876.

Peltidium lignarium Karst.; Hazsl. in Oesterr. Bot. Zeits. 32: 7. 1882.

Peltidium Cookei Hazsl. in Oesterr. Bot. Zeits. 32: 7. 1882.

Humaria lechithina Sacc. Syll. Fung. 8: 126. 1889.

Ifumaria Oocardii Sacc. Syll. Fung. 8: 144. 1889.

Humaria aquatica Rehm in Rab. Krypt.-Fl. 13: 954. 1896.

Psilopezia Oocardii Sacc. \& D. Sacc. in Sacc. Syll. Fung. 18: 11. 1906.

Apothecia gregarious, sessile, becoming discoid and closely adhering to the substratum, surrounded about the margin by a white radiating mycelium, reaching a diameter of 3-5 $\mathrm{mm}$.; hymenium plane or slightly convex, bright-orange or becoming dingy with age, blackish when dry; asci cylindric above, gradually tapering below, reaching a length of $275 \mu$ and a diameter of 16-20 $\mu$, becoming strongly spirally twisted; spores ellipsoid, 1 seriate, usually containing two oil-drops or occasionally with numerous smaller ones, hyaline or faintly yellowish, 12-13 $\times 20-24 \mu$, smooth or becoming minutely sculptured; sporesculpturing, when present, consisting of very minute granules; 
paraphyses rather strongly enlarged above, reaching a diameter of $7-8 \mu$.

On stones and water-soaked logs.

Trpe Lochlity : Europe.

Distribution: New York and New Jersey to Minnesota and Utah; also in Europe.

Illustrations: Hedwigia 2: pl. 10,f. 3; Cooke, Mycographia pl. 12, f. 47 and pl. 23, f. 89; Massee, Brit. Fungus-Fl. 4: 290, f. 10-13; Fest. Asch. 483, f. 1-6.

\section{Doubtfil Axd Excluded Species}

Psilopezia mirabilis Berk. \& Curt.; Berk. Jour. Linn. Soc. 10: 364. 1869. The species, which is very imperfectly described, is said to occur on twigs and to look like a Corticium.

\section{PyRonema Carus, Nov. Act. Acad. Nat. Cur.}

\section{$17: 370.1835$.}

Vegetative mycelium superficial, hyaline (white in mass), thin-walled, septate, branched, the branches proceeding almost at right angles to the main hypha, frequently anastomosing, filled with conspicuous vacuoles, giving rise to paired sex organs; sex organs occurring in clusters of several pairs each, each pair consisting of a clavate antheridium and an inflated oögonium surmounted by a slender trichogyne, which at a later stage usually fuses with the oögonium, each cluster of sex organs finally giving rise to a compound apothecium; apothecia open from the first, never enclosed by the excipulum; asci cylindric, 8-spored; spores ellipsoid, hyaline, smooth; paraphyses filiform. Type species, Pyronema Marianum Carus?

1. Pyronema omphalodes (Bull.) Fuckel, Symb. Myc. 319. 1869. (PLATE 10.)

Peziza omphalodes Bull. Herb. Fr. pl. 485, f. 1. 1790. Hist. Champ. 264. 1791.

Peziza confluens Pers. Obs. Myc. 2: 81. 1799.

Pyronema Marianum Carus, Nov. Act. Acad. Nat. Cur. 17:370. 1835.

Pyronema confluens Tul. Fung. Carp. 3: 197. 1865.

Aleuria omphalodes Gill. Champ. Fr. Discom. 48. 1879.

?Pyronema aurantiorubrum Sacc. Syll. Fung. 8: 108. 1889.

Tapesia omphalodes Quél. Ench. Fung. 291. 1886.

II maria omphalodes Massee, Brit. Fungus-F1. 4: 410. 1895.

Apothecia small, not usually exceeding 1-2 $\mathrm{mm}$. in diameter, soon becoming confluent and forming congested masses several 
cm. in diameter; apothecial masses circular or irregular, of ten interrupted, pale-orange, surrounded by a dense superficial white mycelial growth; hymenium usually convex, the color varying greatly with conditions, sometimes only slightly yellowish, to bright-orange, occasionally with a purplish tinge; asci cylindric or subcylindric, $150 \mu$ long and $10-14 \mu$ in diameter; spores 1 seriate, ellipsoid, smooth, hyaline, $5-8 \times 10-13 \mu$; paraphyses rather stout, very slightly enlarged above, reaching a diameter of 6-7 $\mu$ at their apices, filled with orange granules.

Occurring in nature on burned places; in greenhouses on steamed soil or soil which has been sterilized by dry heat.

Type locality: Europe.

Distribution: Throughout North America, Europe and Australia; probably world-wide.

Illustrations: Bull. Herb. Fr. pl. 485, f. 1; Boud. Ic. Myc. pl. 419; Bull. Lab. Nat. Hist. State Univ. Iowa 6: pl. 7, f. 1; Cooke, Mycographia pl. 17, f. 65; Gill. Champ. Fr. Discom. pl. 51; E. \& P. Nat. Pfl. 1': 177, f. 145; Mycologia 1: pl. 9-12; Mycologia 2: pl. 26; Tul. Fung. Carp. 3: pl. 17, f. 11, 12; Pat. Tab. Fung. f. 287; Cooke, Austr. Fung. pl. 19, f. 149; Rab. Krypt.-Fl. $1^{3}$ : 919, f. 1-5; Phill. Brit. Discom. pl. 5, f. 22; Ann. Sci. Nat. V. 6: pl. 11, f. 10-13 and pl. 12; Heidler, Pfl. Marienbad, pl. 2 .

Exsiccati: Fungi Columb. 1308.

Pyronema confuens inigneum W. H. Brown, Am. Jour. Bot. 2: 297. 1915.

This variety according to Brown seems to differ from the species described above through the fact that the plants will develop on soil or pots which have not been sterilized or heated, a condition which has been shown to be absolutely essential to the development of the species. The variety is also said to differ from the species in the entire absence of fusion between the antheridium and trichogyne.

\section{Excluded Species}

Pyronema leucobasis (Peck) Sacc. Syll. Fung. 8: 110. 1889. The only character about this plant which suggests Pyronema is the superficial mycelium which surrounds the apothecia, and it was doubtless due to this resemblance that Saccardo placed the species in that genus. The species is a true Psilopezia. The superficial resemblance of the apothecia in Psilopesia to those of Pyronema was mentioned by Berkeley when he proposed the genus Psilopezia. 


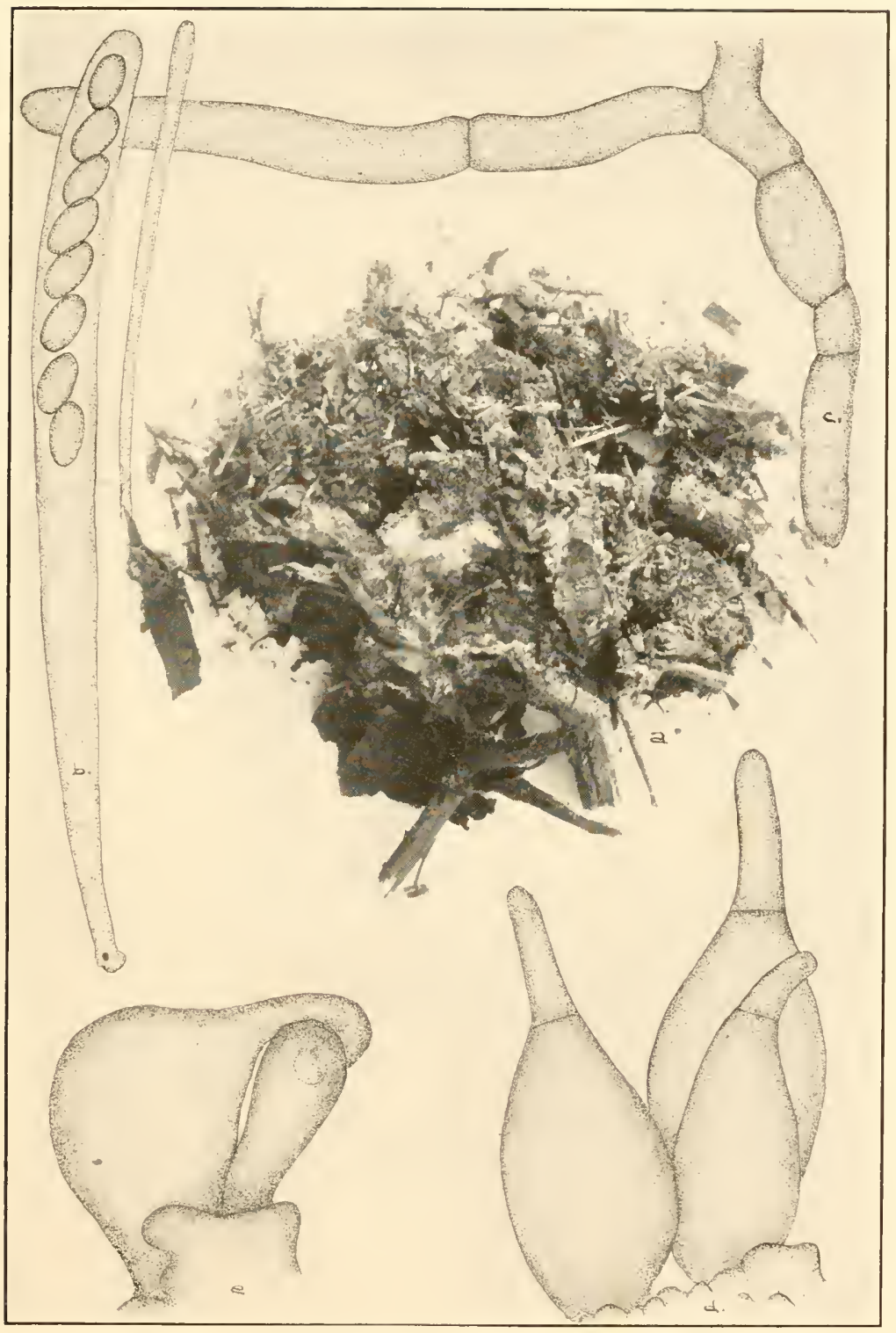

PYRONEMA OMPHALODES 

16. ASCOPHANUS Boud. Ann. Sci. Nat. V. 10:241. 1869.

Coprobia Boud. Bull. Soc. Myc. Fr. 1: 107. 1885.

Plants coprophilous (occurring on the dung of animals or stercoriated mud); apothecia small, rarely exceeding 1-2 mm. in diameter and often less than $1 \mathrm{~mm}$., sessile or short-stipitate, scutellate, externally naked (not clothed with hairs) and smooth or minutely rough, usually bright-colored or more rarely brownish or blackish; hymenium concave, plane or more often strongly convex, leaving the margin indistinct, usually similar in color to the outside of the apothecium; asci cylindric, clavate or ovoid, 4-8-spored; spores 1-2-seriate, hyaline or subhyaline, ellipsoid, smooth or minutely rough, in one species apiculate; paraphyses slender below, their ends clavate to subglobose, hyaline or colored.

Type species, Peziza subfusca Crouan.

Spores large, $25 \mu$ or more in length.

Apothecia white or whitish.

Spores remaining permanently smooth.

Spores apiculate.

Spores not apiculate.

1. A. Holmskjoldii.

2. A. isabellinus.

Spores becoming rough.

Spores $18-20 \times 25-30 \mu$; spore-sculpturing wart-like.

Spores $23-25 \times 33-38 \mu$; spore-sculpturing like tack-heads.

Apothecia ochraceous-carneous.

3. A. sarcobius.

4. A. bermudensis.

5. A. vicinus.

Spores medium-sized, $10-25 \mu$ in length.

Apothecia white.

Asci cylindric; spores 1-seriate.

Asci clavate to subovoid; spores 2-seriate.

6. A. lacteus.

7. A. argenteus.

Apothecia colored, reddish, brown, or lilac.

Apothecia reddish or orange.

Spores 6-8 $\times 10-12 \mu$.

Spores 10-16 × 15-26 $\mu$.

Asci clavate; spores 2-seriate.

Asci cylindric or subcylindric; spores 1seriate.

Apothecia yellowish to ochraceous.

Spores 7-8 × 10-13 $\mu$.

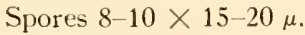

Spores 10-11 $\times 5-6 \mu$.

Apothecia cinereous or blackish.

Spores 10-12 × 20-24 $\mu$.

Spores 7-8 $\times 15-17 \mu$.

Apothecia lilac.

8. A. Aurora.

9. A. carneus.

10. A. granulatus.

11. A. granuliformis.

12. A. ochraceus.

13. A. gallinaceus.

14. A. cinereus.

15. A. tetraonalis.

16. A. lilacinus. 
Spores small, less than $10 \mu$ long.

Apothecia cinereous.

17. A. cinerellus.

Apothecia whitish to yellowish to brown.

Paraphyses globose at their apices.

18. A. microsporus.

Paraphyses only slightly enlarged above.

Apothecia externally brown; hymenium pallid.

Apothecia whitish or yellowish.

19. A. Cesatii.

20. A. glaucellus.

1. Ascophanus Holmskjoldii E. C. Hansen, Vidensk. Medd. 1876:290. Jan. 1877. (Plate 11, Fig. 8.)

Ascobolus incanus Phill. Grevillea 5: 117. Narch, 1877. Ascophanus incanus Sacc. Syll. Fung. 8: 529. 1889.

Apothecia scattered or gregarious, at first turbinate, becoming expanded and reaching a diameter of about $1 \mathrm{~mm}$., grayish; hy'menium plane or nearly so, of the same color as the outside of the apothecium, roughened by the large protruding asci; asci broad-clavate, attenuated below into a stem-like base, reaching a length of $250 \mu$ and a diameter of $40 \mu$; spores 2-seriate or irregularly disposed, ellipsoid, often with a small knob or apiculus at one or both ends, hyaline, granular within and of ten surrounded by an accumulation of granules which give to the outside of the spore a granular appearance but apparently with no true sculpturing, 14-16 $\times 30-36 \mu$; paraphyses slender, scarcely enlarged above, hyaline or subhyaline.

On cow dung.

TYPe LOCALity: Denmark.

Distribution: New York, California; also in Europe.

Illustrations: Grevillea 5: pl. $88, f .10$; Vidensk. Medd. 1876: pl. 6, f. 1-8; Rab. Krypt.-Fl. 13: 1079, f. 1-2; Bull. Soc. Myc. Fr. 34: pl. 3, f. 1 .

2. Ascophanus isabellinus Clements, Bot. Surv. Nebr. 5: 9. 1901. (Plate 11, Fig. 13.)

Apothecia at first nearly doliiform, becoming expanded, white, later becoming dirty-pallid, reaching a diameter of 1-3 mm.; hymenium becoming plane or slightly convex; asci broad-clavate, attenuated below into a stem-like base, reaching a length of $250 \mu$ and a diameter of $30-40 \mu, 8$-spored; spores 2 -seriate, ellipsoid, hyaline, smooth, with a wall $2-3 \mu$ thick, reaching a size of $12-13 \times 27-30 \mu$; paraphyses linear and clavate, the latter reaching a diameter of $3 \mu$ at their apices. 
On stercoriated mud.

Trpe locality: Otawanie woods, Nebraskia.

Distribution: New York to Nebraska.

3. Ascophanus sarcobius Boud. Bull. Soc. Myc. Fr. 18: 14.3. 1902. (PLATE 11, FIG. 4.)

Apothecia gregarious, at first subglobose, smooth, white, gradually expanding, at maturity with the hymenium convex and margin indistinct, reaching a diameter of 1-2 $\mathrm{mm}$.; asci clavate, about 250-300 $\times 35-38 \mu, 8$-spored; spores 2 -seriate or irregularly crowded near the end of the ascus, ellipsoid, at first smooth, becoming sculptured hyaline, about $18-20 \times 25-30 \mu$; spore-sculpturing taking the form of minute warts; paraphyses strongly enlarged above, septate, hyaline, reaching a diameter of 10-12 $\mu$ at their apices.

On cow dlung.

TyPE LOCALITY: France.

Distribution: Bermuda; also in Europe.

Illustrations: Bull. Soc. Myc. Fr. 18: pl. $8, f .2$; Boud. Ic. Myc. pl. +13.

4. Ascophanus bermudensis Seaver, Menl. N. Y. Bot. Gard. 6: 505. 1916. (PLATE 11, FIG. 2.)

Apothecia gregarious or scattered, at first subglobose, expanding and becoming subdiscoid, reaching a diameter of 1-2 mm., white or more often with a delicate pinkish tint; hymenium at first slightly concave, becoming plane, finally convex, roughened by the protruding asci, similar in color to the outside of the apothecium; asci clavate, reaching a length of $325 \mu$ and a diameter of $35-40 \mu, 8$-spored; spores 1 -seriate or partially 2seriate, or occasionally irregularly disposed, at first smooth, becoming rough, $23-25 \times 33-38 \mu$; spore-roughenings assuming the form of scattered protuberances which are enlarged outwards, giving them the appearance of protruding tack-or nail-heads, $2-3 \mu$ long and $2 \mu$ broad; paraphyses strongly enlarged above, hyaline:

On cow dung.

Type collected on cow dung near Harrington Sound, Bermuda, December, 1912 (Herb. The New York Botanical Garden).

Distribution: Known only from the type locality. 
5. Ascophanus vicinus Boud. Ann. Sci. Nat. I. 10:246. 1869.

Apothecia scattered or more rarely aggregated, becoming discoid, reaching a diameter of $0.5-1 \mathrm{~mm}$., ochraceous-carneous; hymenium plane or convex, similar in color to the outside of the apothecium, roughened by the protruding asci; asci broadclavate, attenuated at the base, 8 -spored; spores 2 -seriate or irregularly disposed, hyaline, 20-22 $\times 30-32 \mu$; paraphyses clavate at their apices, septate, hyaline.

On cow dung.

TyPe locality: France.

Distribution: New Jersey; also in Europe.

Illustration: Ann. Sci. Nat. V'. 10: pl. 11,f. 33.

6. Ascophanus lacteus (Cooke \& Phill.) Sacc. Syll. Fung. 8: 528. 1889. (Plate 11, FIG. 1.)

Ascobolus lacteus Cooke \& Phill. Grevillea 5: 119. 1876.

Apothecia small, not exceeding $0.3 \mathrm{~mm}$. in diameter, discoid, tapering below, white or with a very delicate pinkish tinge; hymenium concave, minutely roughened by the protruding asci; the excipular cells irregularly polygonal, hyaline or subhyaline, reaching a diameter of $12-15 \mu$; asci cylindric to clavate, gradually tapering below into a stem-like base, reaching a length of $60-75 \mu$ and a diameter of 12-15 $\mu, 8$-spored; spores usually 1 -seriate or more rarely crowded, ellipsoid, smooth, about $7 \times 10 \mu$; paraphyses about $1 \mu$ thick below, enlarged above, branched and curved at their apices.

On dung of cows and horses.

Type locality: Europe.

Distribution: New York; also in Europe.

Illustrations: Heimerl, Niederöst. Ascoboleen f. 9, 10.

7. Ascophanus argenteus (Curr.) Boud. Ann. Sci. Nat. V. 10: 245. 1869. (Plate 11, Fig. 5.)

Ascobolus argenteus Currey, Trans. Linn. Soc. 24: 496. 1864.

Apothecia gregarious, minute, not exceeding $0.2-0.3 \mathrm{~mm}$. in diameter, sessile, discoid, translucent and silvery-white; hymenium nearly plane or convex, minutely roughened by the protruding asci; excipular cells hyaline, irregularly polygonal and $7-10 \mu$ in diameter; asci broadly clavate to subovoid and abruptly tapering below into a stem-like base, reaching a length of $50-60 \mu$ and a diameter of $20 \mu, 8$-spored, tapering into a short 
stem-like base; spores irregularly 2-seriate, ellipsoid, hyaline, smooth, $6-7 \times 10-12 \mu$; paraphyses slender, septate, hyaline, clavate at their apices.

On cow and horse dung.

Tripe locality: Europe.

Distribution: New York to Colorado and Porto Rico; also in Europe.

Illustrations: Trans. Linn. Soc. 24 : pl. 51, f. 21; Ann. Mag. Nat. Hist. III. 15: pl. 17, f. 32; Ann. Sci. Nat. V. 10: pl. 11, f. 32; Jour. Bot. 2: 152, f. 6 .

8. Ascophanus Aurora (Crouan) Boud. Ann. Sci. Nat. V. 10: 248. 1869. (Plate 11, Fig. 7.)

Periza A urora Crouan, Fl. Finist. 53. 1867. Aleuria A urora Gill. Champ. Fr. Discom. 54. 1879.

Apothecia scattered, sessile, at first subglobose, becoming subdiscoid, reaching a diameter of 0.5-1.5 mm., externally smooth, bright-orange; hymenium at first concave, becoming plane, similar in color to the outside of the apothecium but a little brighter, roughened by the protruding asci; asci cylindric to clavate, 8 -spored; spores 1 -seriate or becoming irregularly 2seriate, ellipsoid, hyaline, 6-7 7 10-12 $\mu$; paraphyses slender, septate, simple or branched, usually curved at their apices, scarcely enlarged above, filled with orange granules.

On dung of various kinds.

Type locality: Europe.

Distribution: Delaware and Nebraska; also in Europe.

Illustration: Ann. Sci. Nat. V. 10:pl. 11, f. 36.

9. Ascophanus carneus (Pers.) Boud. Ann. Sci. Nat. I. 10: 250. 1869.

Ascobolus carneus Pers. Syn. Fung. 676. 1801.

A scobolus saccharinus Berk. \& Curt.; Berk. Outl. Brit. Fungol, 374. 1860.

Ascophanus saccharinus Boud. Ann. Sci. Nat. V. 10: 251. 1869.

Peziza humosoides Peck, Ann. Rep. N. Y. State Mus. 32: 46. 1879.

Ascophanus humosoides Peck, Bull. N. Y. State Mus. 2: 22. 1887.

Ascophanus carneus saccharinus Phill. Brit. Discom. 309. 1887.

Pyronema carneum Schrüt. Krypt.-F1. Schles, 32: 34. 1893.

Ascophanus carneus difformis Clements, Bot. Surv. Nebr. 5: 22. 1901. Not Periza difformis Karst.

Apothecia gregarious or occasionally crowded in clusters of variable size, minute, usually not exceeding $1 \mathrm{~mm}$. in diameter 
or rarely as large as $2 \mathrm{~mm}$., flesh-colored, the color becoming brighter in dried specimens; hymenium at first concave, becoming convex, similar in color to the outside of the apothecium but a little brighter, roughened by the protruding asci; excipulum giving rise above to a palisade of mycelium the loose ends of which form a very delicate fringe-like border, the ends of the peridial mycelium reaching a diameter of $12-15 \mu$; asci rather broad-clavate, reaching a length of $200-300 \mu$ and a diameter of $25-40 \mu$, tapering below into a stem-like base, 8-spored; spores 2-seriate above or becoming irregularly crowded, ellipsoid, hyaline, at first smooth, becoming sculptured, 11-12 × 17-20 $\mu$, or rarely $14-16 \times 24-26 \mu$; spore-sculpturing consisting of very minute warts barely roughening the surface of the spore; paraphyses septate, stout, enlarged at their apices, where they reach a diameter of $7-8 \mu$, densely filled with orange granules.

On dung of various kinds.

Type locality: Europe.

Distribution: New York to North Dakota, Florida, Colorado, Bermuda and Porto Rico; also in Europe.

Illustrations: Ann. Mag. Nat. Hist. III. 15: pl. 14, f. 5; Ann. Sci. Nat. V. 10: pl. 12, f. 38-40; Rab. Krypt.-Fl. 133: 1080, f. 1-5; Pat. Tal). Fung. f. 379; Trans. Linn. Soc. 24: p!. 51 , f. 20 .

A specimen grown on dung from Porto Rico shows asci 40 $\times 300 \mu$ and spores $14 \times 26 \mu$; otherwise it appears to be typical of A. carneus.

10. Ascophanus granulatus (Bull.) Speg. Michelia 1:235. 1879. (Plate 11, FiG; 12.)

?Peziza scabra Müll. Fl. Dan. 11: 7. 1775.

Peziza granulata Bull. Herb. F. pl. 438, f. 3. 1789.

Peziza granulosa Pers. Syn. Fung. 667. 1801.

Ascobolus granulatus Fuckel, Symb. Myc. 287. 1869.

Aleuria granulata Gill. Champ. Fr. Discom. 56. 1879.

Humaria granulata Quél. Ench. Fung. 290. 1886.

Coprobia granulata Boud. Hist. Class. Discom. Eu. 69. 1907.

Apothecia gregarious or crowded, at first closed and subglobose, expanding and becoming scutellate to subdiscoid, externally pale-orange, coarsely granulose, reaching a diameter of 1-3 mm., color fading in dried specimens to nearly white; hymenium slightly concave to plane, orange, brighter than the outside of the apothecium; asci cylindric or subcylindric, gradu- 
ally tapering below, reaching a length of $175-200 \mu$ and a diameter of $15-17 \mu, 8$-spored; spores 1 -seriate, diagonally arranged in the ascus, narrow-ellipsoid, smooth, $7-9 \times 14-18 \mu$; paraphyses stout, strongly thickened above, reaching a diameter almost equal to that of the ascus.

On cow dung.

Type locality: Europe.

Distribution: Connecticut to Iowa, South Carolina and Mexico; also in Europe.

Illustrations: Bull. Herb. Fr. pl. 438, f, 3; Gill. Champ. Fr. Discom. pl. 47, f. 1; Cooke, Mycographia pl. 15, f. 59; ?Fl. Dan. pl. 655, f. 2.

Exsiccati: Rav. Fungi Am. Exsicc. 630; N. Am. Fungi 2037 .

11. Ascophanus granuliformis (Crouan) Boud. Ann. Sci. Nat. $\mathrm{T}$. 10: 245. 1869. (Plate 11, Fig. 10.)

Ascobolus granuliformis Crouan, Ann. Sci. Nat. IV. 10: 195. 1858.

Apothecia minute, usually less than $1 \mathrm{~mm}$. in diameter, sessile, at first globose, becoming discoid; hymenium pale yellow-ochraceous; asci broad-clavate to ovoid, tapering below, 8-spored; spores hyaline, smooth, ellipsoid, $7-8 \times 10-13 \mu$; paraphyses either simple or branched, hyaline, septate, pearshaped at their apices.

On cow dung.

Trpe locality: France.

Distribution: Iowa and Colorado; also in Europe.

Illustrations: Ann. Sci. Nat. IV. 10: pl. 13, f. F; Ann. Sci. Nat. V. 10: pl. 10, f. 31; Ann. Mag. Nat. Hist. III. 15: pl. 17, f. 31; Jour. Bot. 2: 152, f. 5; Pat. Tab. Fung. f. 173.

Exsiccati: Clements, Crypt. Form. Colo. 300.

12. Ascophanus ochraceus (Crouan) Boud. Ann. Sci. Nat. V. 10: 247. 1869.

Ascobolus ochraceus Crouan, FI. Finist. 57. 1867. ?Peziza cremoricolor Berk. Grevillea 3: 151. 1875.

Ascophanus subgranuliformis Rehm; Voss, Yerh. Zool.-Bot. Ges. Wien 37: 224. 1887.

Ascophanus flavus Karst. Medd. Soc. Fauna Fl. Fenn. 16: 105. 1889. ?Humaria cremoricolor Sacc. Syll. Fung. 8: 136. 1889.

Apothecia thickly gregarious, sessile, at first globose or subglobose, expanding and becoming subdiscoid, pale-yellow, ex- 
ternally smooth, reaching a diameter of 0.3-1 mm.; hymenium plane or a little concave, finally convex, the color a little brighter than that of the outside of the apothecium, roughened by the protruding asci; asci cylindric above, slightly tapering below, reaching a diameter of $12-14 \mu, 8$-spored; spores 1 -seriate, parallel with the ascus or diagonally disposed, more rarely crowded, ellipsoid, smooth, subhyaline or faintly yellowish, $8-10 \times 15-20 \mu$; paraphyses slender, enlarged above, where they reach a diameter of 5-6 $\mu$.

On dung of various kinds.

Type locality: Europe.

Distribution: New York to West Virginia and Bermuda; also in Europe.

Illustrations: Verh. Zool.-Bot. Ges. Wien 37: pl. 5, f. 7; Ann. Sci. Nat. I. 10: pl. 11, f. 34; E. \& P. Nat. Pfl. 1': 189, f. $152, D$.

\section{Ascophanus gallinaceus (Peck) Seaver, comb. nov.}

Peziza gallinacea Peck, Ann. Rep. N. Y. State Mus. 31: 46. 1879. Humaria gallinacea Sacc. Syll. Fung. 8: 135. 1889.

Apothecia gregarious or scattered, yellowish to ochraceous, sessile or with the base slightly projected below, externally slightly furfuraceous, the margin of ten wavy or irregular, reaching a diameter of 2-3 mm.; hymenium smooth, similar in color to the outside of the apothecium; asci cylindric, reaching a length of $150 \mu$ and a diameter of $10 \mu, 8$-spored; spores ellipsoid, smooth, 1 -seriate, occupying the upper part of the ascus only, about 5-6 $\times 10-11 \mu$; paraphyses slender, enlarged above at their apices.

On partridge dung.

Type Locality: Oneida, New York.

Distribution: Known only from the type locality.

14. Ascophanus cinereus (Crouan) Boud. Ann. Sci. Nat. V. 10: 249. 1869. (Plate 11, Fig. 11.)

A scobolus cinereus Crouan, Ann. Sci. Nat. IV. 10: 194. 1858.

Peziza cinerea Karst. Myc. Fenn. 1: 59. 1871.

Ascophanus crustaceus Starb. Bot. Not. 1898: 216. 1898.

Apothecia gregarious or closely crowded, at first subglobose or pyriform, becoming short-cylindric, finally expanding to discoid or subdiscoid and narrowed below into a stem-like base, 
at first grayish or cinereous, but at maturity darker and appearing almost black and so closely resembling the substratum in color that they are detected with difficulty, reaching an extreme diameter of 2 mm.; hymenium becoming plane, finally strongly convex, roughened by the protruding asci, of ten surrounded by a slightly elevated margin; excipular cells rounded or angular, the walls smoky-brown, variable in size but reaching a diameter of $12-15 \mu$, giving rise above to a palisade of mycelium, the ends of which are enlarged, reaching a diameter of 15-17 $\mu$, the palisade mycelium often appearing as rudimentary hairs; asci clavate, gradually tapering below into a stem-like base, with an abrupt swelling at the extreme base, reaching a length of $250-300 \mu$ partly due to stretching at maturity and a diameter of $15-17 \mu$; spores at first 1 -seriate, finally becoming partially to entirely 2 -seriate, each spore surrounded by a granular protoplasm which sometimes collects about the outer surface, so as to give them a roughened appearance, ellipsoid, with the ends strongly narrowed, perfectly hyaline, $10-12 \times 20-24 \mu$; paraphyses very slender, about $1.3 \mu$ thick, rather strongly enlarged above, where they reach a diameter of $4 \mu$, smoky-brown above, hyaline below.

On excrement of horses.

Týe locality: Europe.

Distribution: New York to Colorado; also in Europe.

Illustrations: Ann. Sci. Nat. IV. 10: pl. 13, f. D; Ann. Sci. Nat. V. 10: pl. 11, f. 37; Bull. Lab. Nat. Hist. State Univ. Iowa 6: pl. 28,f. 1; Ann. Mag. Nat. Hist. III. 15: pl. 17, f. 30.

15. Ascophanus tetraonalis Peck, Bull. N. Y. State Mus. 2: 22. 1887.

Peziza tetraonalis Peck, Ann. Rep. N. Y. State Mus. 32: 46. 1879.

Apothecia sessile, externally cinereous, the margin often wavy or flexuous, reaching a diameter of 1-3 $\mathrm{mm}$.; hymenium blackish or blackish-brown; asci cylindric, truncate at the apex, 8 -spored; spores 1 -seriate, ellipsoid, smooth, colorless, reaching a length of $7-8 \times 15-17 \mu$; paraphyses filiform, slightly enlarged above.

On the excrement of partridge or grouse.

Type Locality: Catskill Mountains.

Distribution: Known only from the type locality. 
16. Ascophanus lilacinus Cooke, Grevillea 21: 74. 1893.

Apothecia minute, gregarious, smooth, reaching a diameter of 0.3-0.8 mm.; hymenium slightly concave, pale-lilac, roughened by the protruding asci; asci rather fusoid-clavate, 8-spored; spores ellipsoid, hyaline, smooth, $10 \times 20 \mu$; paraphyses filiform, scarcely thickened above, longer than the asci.

On horse dung.

Type Locality : New York.

Distribution: Known only from the type locality.

17. Ascophanus cinerellus (Karst.) Speg. Anal. Soc. Ci. Argent. 10: 29.1880 .

Peziza cinerella Karst. Myc. Fenn. 1: 51.1871.

Apothecia scattered or subgregarious, sessile, cinereous-pallid, reaching a diameter of $0.3-0.4 \mathrm{~mm}$.; hymenium convex, similar in color to the outside of the apothecium; asci cylindric-clavate, reaching a length of $38-42 \mu$ and a diameter of $6-7 \mu, 8$-spored; spores 1 -seriate or 2-seriate, ellipsoid or globose-ellipsoid, not containing oil-drops, 3-4 $\times 5-7 \mu$; paraphyses not visible.

On cow dung.

TyPe Locality: Finland.

Distribution: Greenland; also in Europe.

18. Ascophanus microsporus (Crouan) Phill. Brit. Discom. 307. 1887. (Plate 11, Fig. 9.)

Ascobolus microsporus Berk. \& Br. Ann. Mag. Nat. Hist. III. 15: 449. 1865. ?Ascophanus mimutissimus Boud. Ann. Sci. Nat. V. 10: 243. 1869. ?Ascophanus Coemansii Ann. Sci. Nat. V. 10:244. 1869.

Apothecia gregarious but not usually crowded, at first globose, expanding and becoming discoid, $w$ th the hymenium plane or a little concave and the margin slightly elevated, externally dark brownish-black, when dry entirely black and appearing as minute black specks on the substratum, entire plant not exceeding $0.2-0.5 \mathrm{~mm}$. in diameter; hymenium paler, reddish-brown; excipu'um pseudoparenchymatous, the component cells $2-5 \mu$ in diameter; asci clavate, $7-10 \times 50-70 \mu$, tapering gradually below ; spores minute, usually 2 -seriate or partially 2 -seriate, ellipsoid, smooth, perfectly hyaline, $4 \times 6-7 \mu$; paraphyses very slender below, about $1 \mu$ thick, abruptly expanding above into a subglobose head which is filled with golden-yellow coloring matter, reaching a diameter of $7-9 \mu$. 


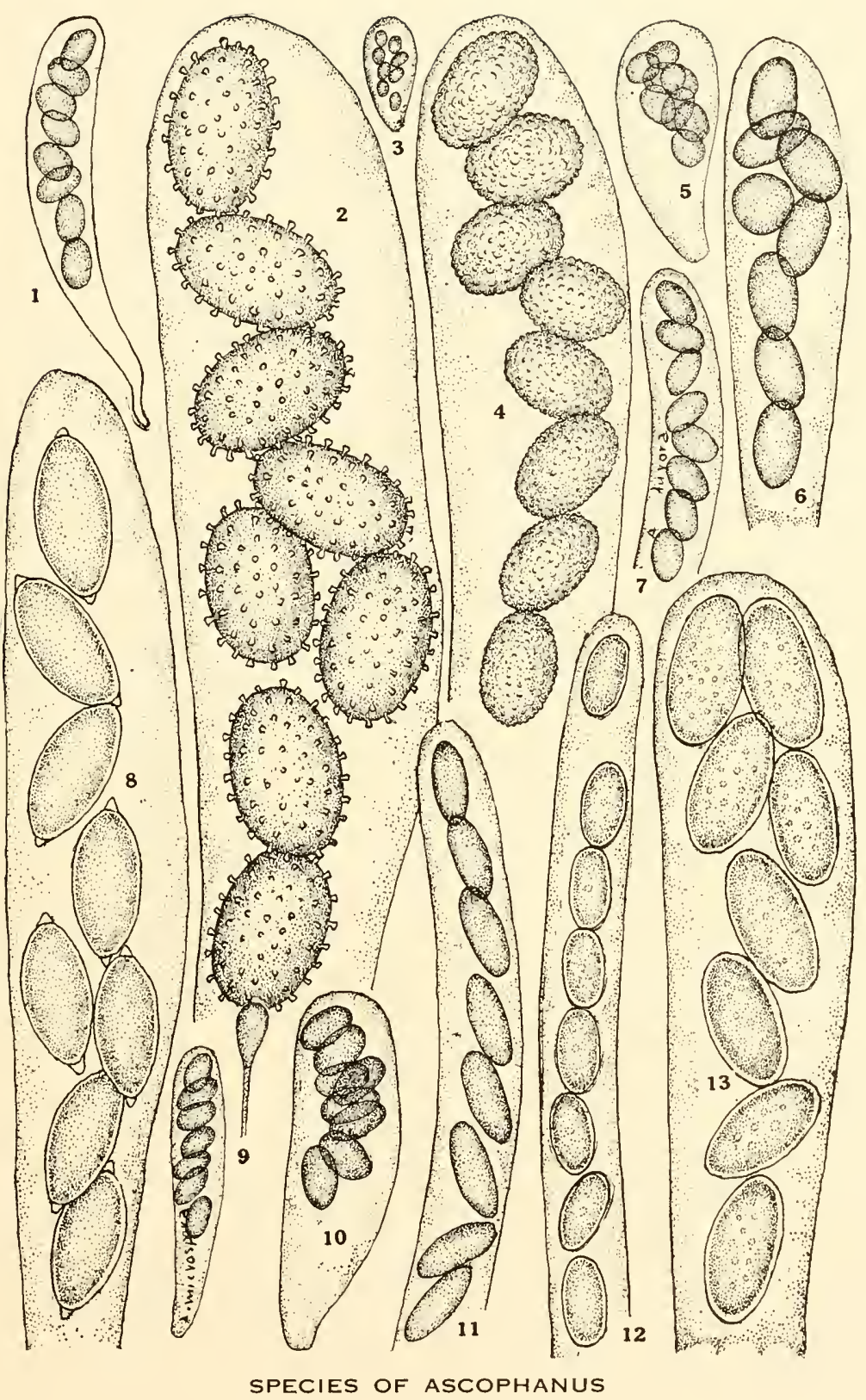



()n cow dung.

Trpe Localiti: Europe.

Distribution: New York to Colorado; also in Europe.

Illustrations: Ann. Mag. Nat. Hist. III. 15: pl. 16, f. 28; An1. Sci. Nat. Y'. 10: pl. 27, f. 29-30; Bull. Lab. Nat. Hist. State Lniv. Iowa 6: pl. 27, f. 2 .

19. Ascophanus Cesatii (Carest) Sacc. Syll. Fung. 8: 533. 1889.

Ascobolus Cesatii Carest in Rab. Fungi Eu. 976. 1866.

Pezizula Cesatii Karst. Myc. Fenn. 1: 83. 1871.

Apothecia becoming discoid, externally brownish; hymenium pallid, nearly plane; asci clavate, 8-spored, reaching a length of $32 \mu$ and a diameter of $8 \mu$; spores hyaline, ovoid, reaching a length of $8 \mu$; paraphyses simple, straight.

On bird dung.

Type locality: Europe.

Distribution: Greenland; also in Europe.

20. Ascophanus glaucellus Rehm in Rab. Krypt.-Fl. 13: 1086. 1896.

Apothecia gregarious or scattered, sessile, becoming discoid, white or whitish, reaching a diameter of $0.2-0.5 \mathrm{~mm}$.; asci clavate or subovoid, reaching a length of $40-50 \mu$ and a diameter of $8-12 \mu$; spores 2 -seriate, ellipsoid, smooth, hyaline, $3 .=-4.5$ $\times 6-9 \mu$; paraphyses slender, reaching a diameter of $1.5 \mu$ below and $2.5 \mu$ above, hyaline or yellowish, strongly curved at their apices.

On dung.

Type Locality: Germany.

Distribution: New York; also in Europe.

Illustration: Rab. Krypt.-F1. $1^{3}: 1080, f .5$.

17. HUMARINA Seaver, Mycologia 19: 87. 1927.

Pesiza § IIunaria Fries, Syst. Myc. 2: 42. 1822.

IIumaria Sacc. Syll. Fung. 8: 118. 1889. Not Humaria Fuckel. 1869. Leucoloma Fuckel, Symb. Myc. 317. 1869. Not Lencoloma Brid. 1827.

Apothecia minute to medium-sized, usually less than $1 \mathrm{~cm}$. in diameter and often less than $1 \mathrm{~mm}$., usually light-colored, white, yellow, orange, or purple, more rarely dark-colored, brownish or blackish, usually discoid or more rarely cup-shaped, 
occurring on humus often among mosses, or more rarely on the stems and leaves of the higher plants; asci clavate, 4-8-spored; spores 1-2-seriate, ellipsoid to fusoid or fusiform, smooth or becoming sculptured, hyaline; paraphyses slender or stout, usually containing a granular coloring matter.

Type species, Octospora leucoloma Hedw.

It is difficult to separate this from the preceding genus on morphological characters, while it is doubtful if they should be separated on any other. However, as the coprophilous forms have usually been segregated, in this case, we follow precedent and leave the reader to satisfy himself in the matter.

Apothecia light-colored, white, yellow, red, lilac, or violaceous.

Spores ellipsoid, usually not more than twice as long as broad.

Growing on the living stems of mosses and liverworts.

Occurring in the axils of the leaves of mosses.

Occurring on the thallus of Marchantia.

1. H. axillaris.

2. H. ithacaensis.

Growing on soil and on decaying plant remains.

Apothecia white or dirty-whitish.

Apothecia rounded or discoid.

Apothecia hysteriform, partially closed.

Apothecia orange, yellow, or lilac.

Occurring on old paper, cloth, twine, etc.

Occurring on soil, usually among mosses.

Apothecia minute, rarely exceeding

$1 \mathrm{~mm}$. in diameter.

Spores becoming rough.

Spores remaining permanently smooth.

Apothecia orange.

Spores 6-7 $\times 12 \mu$.

Spores $10-12 \times 16-18 \mu$.

Spores $12-14 \times 20-25 \mu$.

Apothecia with a lilac tinge.

3. H. pallens.

4. H. clausa.

5. H. testacea.

6. If. orthotricha.

Apothecia medium-sized, 2-10 $\mathrm{mm}$. in diameter.

Spores broad-ellipsoid, usually containing one large oildrop or none.

Apothecia bright-orange or red.

Apothecia entirely sessile. 11. H. leucoloma. 
Apothecia short-stipitate. 12. II. araneosa. Apothecia yellow to paleorange.

Apothecia sessile, partially immersed.

13. II. semiimmersa.

Apothecia short-stipitate, superficial.

14. II. ochroleuca.

Spores narrow-ellipsoid, contain-

ing two oil-drops.

Occurring on decaying plant remains.

Spores minute, $3 \times 6-7 \mu$, on Carex. Spores medium-sized, 12-20 $\mu$ long.

Apothecia $1 \mathrm{~mm}$. or less in diameter.

On brassicaceous plants.

On unknown herbaceous plants.

Apothecia 1 to several $\mathrm{mm}$. in di-

15. H. rufa.

16. II. wisconsinensis. ameter.

Spores 10-11 $\times 20 \mu$; on chaff. 19. II. glumarum.

Spores $8 \times 12 \mu$; on damp hay. 20. II. Peckii.

Spores $12 \times 18-20 \mu$; on

leaves.

17. H. nectrioides.

18. II. deligata.

21. II. phyllogena.

Spores fusoid, approximately three times as long as broad.

Asci 4-spored.

22. II. tetraspora.

Asci 8-spored.

Apothecia with a rose-colored hymenium.

Apothecia with an orange hymenium.

Apothecia reaching a diameter of 5-8 mm.

23. II. permuda.

Apothecia not exceeding $2-3 \mathrm{~mm}$, in diameter.

Spores 22-25 $\mu$ long; on burned areas. Spores 25-35 $\mu$ long.

Occurring on soil, but not on

burned areas.

Spores almost fusiform.

Spores fusoid, but with ends

blunt.

26. II. fusispora.

24. II. ollaris.

25. II. aggregata.

Occurring on dearl sticks.

27. II. coccinea.

28. II. Cookeina.

Apothecia violaceous.

29. II. Gerardi.

Apothecia dark-colored, brown, brownish-black or more rarely purplish.

Spores becoming rough; apothecia purplish.

30. II. purpurea.

Spores remaining permanently smooth.

Apothecia liver-colored.

31. II. hepatica.

Apothecia dark but not liver-colored.

32. II. trachyderma 
1. Humarina axillaris (Nees) Seaver, comb. nov.

Peziza axillaris Nees, Syst. Pilze 258. 1817.

Leucoloma axillaris Fuckel, Symb. Myc. 318. 1869.

IIumaria axillaris Sacc. Syll. Fung. 8: 130. 1889.

Helotium axillaris Boud. Hist. Class. Discom. Eu. 114. 1907.

Apothecia sessile, subglobose, becoming slightly depressed, reaching a diameter of $1 \mathrm{~mm}$., externally pale-orange, surrounded at the base by coarse mycelium which attaches the apothecia to the moss plants on which they grow; hymenium plane or nearly so, a little darker than the outside of the apothecium; asci cylindric above, narrowed below into a stem-like base, 8-spored; spores obliquely 1 -seriate, hyaline, smooth, ellipsoid, containing one or two large oil-drops, $7-10 \times 17-24 \mu$; paraphyses numerous, slender, slightly enlarged above.

Growing from the axils of leaves of mosses.

Trpe Localitr: Europe.

Distribution: Colorado; also in Europe.

Illustrations: Nees, Syst. Pilze pl. 37, f. 267; Cooke, Mycographia $p l .23, f .91$.

Exsiccati: Clements, Crypt. Form. Colo. 112.

\section{Humarina ithacaensis (Rehm) Seaver, comb. nov.}

Humaria ithacaensis Rehm, Ann. Myc. 2: 35. 1904.

Apothecia scattered, sessile, at first globose and closed, then cup-shaped, finally expanded, flesh-red, reaching a diameter of $0.5-1 \mathrm{~mm}$., smooth, attached to the substratum by a coarse white mycelium; hymenium becoming plane or slightly convex; asci cylindric, reaching a length of $150-180 \mu$ and a diameter of $15 \mu, 8$-spored; spores 1 -seriate, ellipsoid, containing two large oil-drops, hyaline, $8-9 \times 15-17 \mu$, becoming minutely sculptured; spore-sculpturing consisting of minute warts; paraphyses filiform, septate, hyaline, $3 \mu$ in diameter below, enlarged above, reaching a diameter of $4 \mu$ at their apices.

On the living thallus of Marchantia polymorpha.

Type Locality: I thaca, New York.

Distribution: Known only from the type locality.

\section{Humarina pallens (Boud.) Seaver, comb. nov.}

Ascophanus pallens Boud. Bull. Soc. Myc. Fr. 4: XLVIII. 1888.

Apothecia gregarious but not crowded, at first subglobose, expanding and becoming discoid or subdiscoid, entirely white or 
dirty-white, becoming darker when dry, reaching a diameter of 2-3 mm.; hymenium plane or strong y convex, roughened by the large protruding asci; asci clavate, reaching a length of $350-400 \mu$ and a diameter of $35-50 \mu$ at their apices, tapering below into a slender stem-like base, 8-spored; spores 1-3-seriate or more of ten irregularly crowded together, granular within and usually surrounded by a hyaline membrane, large, narrowellipsoid or with the ends rather abruptly narrowed, about $15-20 \times 35-45 \mu$, hyaline; paraphyses slender, strongly enlarged above.

On sandy soil which is sparingly overrun with algae.

Type locality: France.

Distributiox: New York; also in Europe.

Illustrations: Bull. Soc. Myc. Fr. 4: pl. 2, f. 2; Boud. Ic. Myc. pl. $41+$.

4. Humarina clausa (Clem.) Seaver, comb. nov. Humaria clausa Clements, Bot. Surv. Nebr. 4: 10. 1896.

Apothecia cespitose, fleshy, subglobose or nearly hemispheric, pruinose, reaching a diameter of $2 \mathrm{~mm}$.; hymenium somewhat hysteriform, gaping slightly, drab; asci clavate, reaching a length of $250 \mu$ and a diameter of $35 \mu, 8$-spored; spores large, ellipsoid, smooth, devoid of oil-drops, $12.5-16 \times 32-37 \mu$; paraphyses abundant, filiform, scarcely enlarged at their apices.

On moist ground.

Type Locality: Otawaine woods, Lancaster County, Nebraska.

Distribution: Known only from the type locality.

5. Humarina testacea (Moug.) Seaver, comb. nov.

Peziza testacea Moug.; Fries, Elench. Fung. 2: 11. 1828.

Helotium testaceum Berk. Outl. Brit. Fungol. 372. 1860.

Ascobolus testaceus Berk. Ann. Nag. Nat. Hist. III. 15: 447. 1865.

Ascophanus testaceus Phill. Brit. Discom. 310. 1887.

Humaria testacea Schröt. Kŕryt.-Fl. Schles. 3²:36. 1893.

Ascophanus carneus testaceus Massee, Brit. Fungus-FI. 4: 178. 1895.

Apothecia gregarious or densely crowded, at first subglobose, becoming discoid or subdiscoid, flesh-red, not usually exceeding 1-2 $\mathrm{mm}$. in diameter; hymenium at first slightly concave, becoming plane or more often convex, roughened by the protruding asci, similar in color to the outside of the apothecium or a little brighter; the excipular cells irregular and reaching a 
diameter of $12-15 \mu$, giving rise above to palisade-like fascicles of club-shaped mycelial threads; asci rather broad-clavate, reaching a length of $200 \mu$ and a diameter of $20-25 \mu, 8$-spored; spores at first quite regularly 2 -seriate, becoming irregularly disposed, ellipsoid, hyaline, smooth or very minutely sculptured, 10-12 $\times 17-20 \mu$; spore-sculpturing consisting of minute granules; paraphyses slightly enlarged above, reaching a diameter of 7 $8 \mu$ at their apices, filled with orange granules.

On old building paper, sacking, cloth, twine, leather, and on weathered fibers of Yucca leaves.

Type locality : Europe.

Distribution: Massachusetts to New Jersey, Louisiana and North Dakota; also in Europe.

Illustrations: Phill. Brit. Discom. pl. 9, f. 58; Ann. Mag. Nat. Hist. III. 15: pl. 14, f. 5; Bull. Lab. Nat. Hist. State Univ. Iowa 6: pl. $27, f .1$.

On morphological characters it is difficult, if not impossible, to separate this species from Ascophamus carneus, its nearest coprophilous relative. In fact, Massee treats this species as a variety of the latter. While some workers seem to see a difference in spore measurements, such a difference is scarcely apparent so far as our observations go.

The habitat of this species is unique. The persistence with which it occurs on cloth, string, and building paper is interesting. It was first encountered by the writer early in his studies on the Discomycetes at Lafayette, Indiana, where it was found in abundance on old burlap sacking, the search for it having been prompted by Phillips' illustration of the species in his British Discomycetes. About the same time it was found on old rag carpet at Pocahontas, Iowa. In 1905 it was found in abundance around Mt. Pleasant, Iowa, on old paper and sacking, and in 1907 on a similar habitat in Fargo, North Dakota. In 1913 it was collected at Portland, Connecticut, on old paper, twine and sacking.

In 1916, a fine collection was made at Yonkers, New York, on decaying paper and the surrounding soil in a dumping ground. This collection showed unusually large spores, measuring 16-18 $\times 28-30 \mu$, and was listed as a new variety under the name IItmarina testacea macrospora. The spores in this form were decidedly rough.

Further study is necessary in order to determine whether 
this species and Ascophanus carneus are really distinct but for the present they are allowed to stand.

6. Humarina orthotricha (Cooke \& Ellis) Seaver, comb. nov. Peziza orthotricha Cooke \& Ellis; Cooke, Grevillea 6: 7. 1877.

Humaria orthotricha Sacc. Syll. Fung. 8: 119. 1889.

Apothecia widely scattered, at first globose and closed, opening and at maturity becoming scutellate or subdiscoid, reaching a diameter of $1 \mathrm{~mm}$., externally pale-orange; hymenium plane or a little concave, orange-vermillion; asci cylindric or subcylindric to clavate, 8 -spored, reaching a length of $200-250 \mu$ and a diameter of $18-20 \mu$; spores 1 -seriate or becoming irregularly crowded, ellipsoid, becoming sculptured, 10-12 × 18-22 $\mu$; spore-sculpturing taking the form of minute warts not exceeding $1 \mu$ in diameter; paraphyses gradually thickened above, reaching a diameter of $5 \mu$ at their apices, of ten strongly curved.

On soil and bark among mosses, especially Orthotrichum.

Trpe locality: New Jersey.

Distribution: New York to New Jersey and Colorado.

Illustrations: Grevillea 6: pl.96,f. 33; Cooke, Mycographia pl. $98, f .355$.

\section{Humarina Clementsii Seaver, nom. nov.}

Iumaria phycophila Clements, Bot. Surv. Nebr. 4: 10. 1896. Not Humaria phycophila Oudem. Beih. Boı. Centı. 11: 526. 1902.

Apothecia very minute, gregarious, sessile, scutellate, finally becoming subdiscoid, reaching a diameter of $0.3-0.5 \mathrm{~mm}$.; hymenium at first concave, finally becoming convex, orange to reddish, darker than the outside of the apothecium; asci clavatecylindric, obliquely operculate, 8-spored, reaching a length of $60-67 \mu$ and a diameter of $9-15 \mu$; spores ellipsoid, obliquely 1 -seriate or often becoming 2 -seriate, usually containing one oildrop, smooth, hyaline, $6-7.5 \times 10-12.5 \mu$; paraphyses filiform, filled with orange granules, strongly curved at their apices, reaching a diameter of $1-2 \mu$.

Among filaments of Lyngbya on moist ground.

Type locality: Beatrice, Nebraska.

Distribution: Known only from the type locality.

8. Humarina rubens (Boud.) Seaver, comb. nov.

Humaria rubens Boud. Bull. Soc. Myc. Fr. 12: 13. 1896.

Apothecia gregarious but not usually crowded, at first subglobose, expanding and becoming discoid or subdiscoid, reaching 
a diameter of 1-3 mm., externally pale-orange; hymenium becoming plane or occasionally a little convex, orange to brightred; asci cylindric above, gradually tapering below into a rather short stem-like base, reaching a length of $200 \mu$ and a diameter of $16 \mu, 8$-spored; spores 1 -seriate, ellipsoid or ovoid, each containing one large oil-drop, hyaline, smooth, 10-12 $\times 16-18 \mu$; paraphyses rather stout, simple or branched, of ten swollen near the joints, reaching a diameter of $8-9 \mu$ at their apices.

On damp soil among mosses.

TyPe LOCAlity: Europe.

Distribution: New York and Colorado; also in Europe.

Illustration: Bull. Soc. Myc. Fr. 12: pl. 3, f. 3.

9. Humarina convexula (Pers.) Seaver, comb. nov.

Peziza convexula Pe1s. Obs. Myc. 2: 85. 1799.

Letucoloma convexula Fuckel, Symb. Myc. 318. 1869.

Pesiza chrisophthalma Ger. Bull. Torrey Club 4: 48. 1873. Not Peziza chrysophthalma Pers. 1822.

Aleuria convexula Gill. Champ. Fr. Discom. 55. 1879.

IHumaria convexula Sacc. Syll. Fung. 8: 139. 1889.

Apothecia gregarious but not usually crowded, at first globose or short-cylindric, soon opening, pale- to bright-orange, rarely exceeding 1-2 $\mathrm{mm}$. in diameter and often less; hymenium becoming convex, similar in color to the outside of the apothecium; asci cylindric above, tapering rather abruptly below, reaching a length of $200 \mu$ and a diameter of $18-20 \mu, 8$-spored; spores obliquely or irregularly disposed, broad-ellipsoid, hyaline, smooth, containing either one or two large oil-drops which reach a diameter of about $10 \mu$, entire spore $12-14 \times 22-25 \mu$; paraphyses straight or very slightly curved, rather stout, about 2 or $3 \mu$ thick below, strongly enlarged above, where they reach a diameter of $7-8 \mu$, filled with rather coarse orange granules.

On bare soil or among mosses.

Type locality: Europe.

Distribution: New York; also in Europe.

Illustrations: Cooke, Mycographia pl. 9, f. 36; Grevillea 3: pl. 31, f. 81; Gill. Champ. Fr. Discom. pl. 56, f. 1 .

\section{Humarina lilacina Seaver, sp. nov.}

Apothecia rather thickly gregarious or rarely with several in close contact but not usually congested, at first globose or subglobose, expanding and becoming subdiscoid, reaching a diameter 
of $0.5 \mathrm{~mm}$. or rarely as large as $1 \mathrm{~mm}$., reddish, with a decided lilac tinge; hymenium at first concave, finally plane or convex, the margin becoming indistinct, roughened by the protruding asci, the color similar to that of the outside of the apothecium; asci clavate or subclavate, reaching a length of $200 \mu$ and a diameter of $15-17 \mu, 8$-spored; spores 1 -seriate or becoming irregularly crowded, ellipsoid, usually containing one large often eccentric oil-drop half the diameter of the spore, $10 \times 15-17 \mu$; paraphyses strongly enlarged above, septate, filled with coarse granules which are subhyaline or with a pale-lilac tinge.

On the ground which has been overrun with mosses and algae.

Type collected in the New York Botanical Garden, September 5, 1912 (Herb. The New York Botanical Garden).

Distribution: New York and New Jersey.

11. Humarina leucoloma (Hedw.) Seaver, comb. nov.

Octospora leucoloma Hedw. Descr. 2: 13. 1788.

Pesiza leucoloma Rebent. Fl. Neom. 386. 1804.

Peziza humosa Fries, Obs. Myc. 2: 308. 1818.

Leucoloma Hedwigii Fuckel, Symb. Myc. 317. 1869.

Aleuria humosa Gill. Champ. Fr. Discom. 56. 1879.

Aleuria leucoloma Gill. Champ. Fr. Discom. 56. 1879.

Humaria humosa Quél. Ench. Fung. 289. 1886.

Humaria leucoloma Quél. Ench. Fung. 289. 1886.

Neottiella leucoloma Massee, Brit. Fungus-F1. 4: 374. 1895.

Leucoscypha excipulata Clements, Crypt. Form. Colo. 117. 1906.

Apothecia gregarious or scattered, sessile and of ten with the base nestling in the substratum, at first globose and closed, expanding and becoming scutellate to subdiscoid, reaching a diameter of 2-5 mm., externally pale-orange; hymenium concave or often becoming plane or a little convex, bright-orange; asci cylindric or subclavate, gradually tapering below into a long stem-like base, reaching a length of $200-250 \mu$ and a diameter of $20 \mu, 8$-spored; spores 1 -seriate or occasionally crowded, usually diagonally disposed, ellipsoid or with one or both ends slightly narrowed, $12-15 \times 18-24 \mu$, a few often larger, smooth. usually containing one large oil-drop surrounded by several smaller ones; paraphyses $3-4 \mu$ in diameter below, enlarged above, reaching a diameter of $8-9 \mu$ at their apices, branched, of ten curved and filled with numerous granules.

On the ground among mosses. 
Type locality: Europe.

Distribution: New York to Delaware and Colorado; also in Europe.

Illustrations: Hedw. Descr. 2: pl. 4, f. 1-7; Cooke, Mycographia pl. 7, f. 28; Boud. Ic. Myc. pl. 391 and 395; Gill. Champ. Fr. Discom. pl. 56, f. 2; Nees, Syst. Pilze pl. 37, f. 268; Ann. Mag. Nat. Hist. III. 18: pl. 3, f. 16.

Exsiccatr: Fungi Columb. 3815; Sydow, Fungi Exotici Exsicc. 139; Clements, Crypt. Form. Colo. 117 (as Leucoscypha excipulata).

12. Humarina araneosa (Peck) Seaver, comb. nov.

Peziza araneosa Bull. Herb. Fr. pl. 280. 1785.

Leucoloma araneosa Fuckel, Symb. Myc. Nacht. 1: 50. 1871.

Pesiza rubra Peck, Ann. Rep. N. Y. State Mus. 24: 95.1872.

Aleuria araneosa Gill. Champ. Fr. Discom. 55. 1872.

Humaria araneosa Sacc. Syll. Fung. 8: 122.1889.

Apothecia subglobose, finally becoming hemispheric, the mouth constricted and often slightly irregular, short-stipitate, externally pale-whitish or reddish, reaching a diameter of 4-5 $\mathrm{mm}$.; stem short, stout; hymenium bright-red, concave; asci cylindric or subcylindric, 8-spored; spores 1-seriate, ellipsoid and containing no oil-drops, hyaline, $7 \times 14 \mu$; paraphyses filiform, clavate.

On damp soil and on burnt ground.

Type Locality: Highlands, New York.

Distribution: New York; also in Europe.

Illustrations: Ann. Rep. N. Y. State Mus. 24: pl. 2, f. 20 , 21; Sow. Engl. Fungi pl. 369, f. 5; Bull. Herb. Fr. pl. 280.

13. Humarina semiimmersa (Karst.) Seaver, comb. nov.

Peziza semiimmersa Karst. Not. Fauna Fl. Fenn. 10: 117. 1869.

Humaria semiimmersa Sacc. Syll. Fung. 8: 143. 1889.

Sepultaria semiimmersa Massee, Brit. Fungus-Fl. 4: 391. 1895.

Apothecia gregarious, sessile and partially immersed in the ground, at first subglobose and closed, expanding and becoming shallow cup-shaped to scutellate, reaching a diameter of $1 \mathrm{~cm}$., externally pale-yellow, more or less floccose or tomentose, the margin irregular and often torn; hymenium concave, brightyellow to pale-ochraceous; asci cylindric or subcylindric above, reaching a diameter of $17-20 \mu, 8$-spored; spores 1-seriate, obliquely arranged in the ascus or occasionally parallel with 
the ascus, ellipsoid, hyaline or very faintly yellowish, smooth, 10-11 $\times 18-20 \mu$; paraphyses slender, slightly enlarged above, where they reach a diameter of $2 \mu$, yellowish.

On bare ground.

Trpe locality : Europe.

Distribution: Delaware and Kentucky; also in Europe.

Illustrations: Cooke, Mycographia pl. 12, f. 46; Grevillea 3: pl. 31, f. 75 .

\section{Humarina ochroleuca (Clements) Seaver, comb. nov.}

IIumaria ochroleuca Clements, Bull. Torrey Club 30: 91.1903.

Apothecia solitary, sessile or contracted below into a stemlike base, cupulate, finally expanded, reaching a height of 2-6 $\mathrm{mm}$. and a diameter of 3-6 mm., yellowish-white, margin crenulate; hymenium at first concave, becoming plane or occasionally convex, the color similar to that of the outside of the apothecium; asci cylindric above, long-stipitate below, reaching a length of $275 \mu$ and a diameter of 11-12 $\mu, 8$-spored; spores irregularly 1 -seriate, ellipsoid, smooth, hyaline, $11 \times 19 \mu$; paraphyses slender, about $3 \mu$ in diameter, slightly enlarged above.

Among mosses.

Type locality : Engelmann Canyon, Colorado.

Distribution: Colorado.

Exsiccati: Clements, Crypt. Form. Colo. 113.

15. Humarina rufa (Pers.) Seaver, comb. nov.

Peziza rufa Pers. Obs. Myc. 2: 79. 1799.

Peziza rubricosa Fries, Syst. Myc. 2: 72. 1822.

Leucoloma rubricosa Fuckel, Symb. Myc. 318. 1869.

Humaria rubricosa Sacc. Syll. Fung. 8: 138.1889.

Apothecia scattered, sessile or tapering below into a stemlike base, externally rough, orange, reaching a diameter of $1-4$ mm.; hymenium a little concave to nearly plane, orange, a little darker than the exterior of the apothecium, excipulum giving rise to a palisade of mycelium above, the loose ends of which form a fringe-like border, are clavate and reach a diameter of $10 \mu$, hyaline; asci rather broad-cylindric or clavate, reaching a length of $75 \mu$ and a diameter of $20 \mu$ at their apices, 8-spored; spores 2 -seriate or irregularly crowded above, partially 1 -seriate below, narrow-ellipsoid, often curved or unequal-sided, containing two oil-drops, hyaline, 9-10 $\times 20-23 \mu$; paraphyses enlarged above, reaching a diameter of $7-8 \mu$. 
Among mosses.

TYPE locality: Europe.

Distribution: Delaware; also in Europe.

Illustrations: Cooke, Mycographia pl. 18, f. 71 ; Boud. Ic. Myc. pl. 397; Rab. Krypt.-F1. 133:916, f. 5.

16. Humarina wisconsinensis (Rehm) Seaver, comb. nov.

Humaria wisconsinensis Rehm, Ann. Myc. 3: 517. 1905.

Apothecia gregarious, sessile, at first globose and closed. expanding and becoming discoid, externally pale-yellow, smooth, attached to the substratum by conspicuous white mycelium, reaching a diameter of $5 \mathrm{~mm}$.; hymenium plane or nearly plane, orange-yellow; asci clavate, the apex rounded, reaching a length of $40-45 \mu$ and a diameter of 5-6 $\mu, 8$-spored; spores 2-seriate, ellipsoid, hyaline, $3 \times 6-7 \mu$; paraphyses filiform, septate, reaching a diameter of $2-2.5 \mu$, scarcely enlarged above, yellow.

On decaying Carex.

Type locality: Blue Mountains, Wisconsin.

Distribution: Known only from the type locality.

\section{Humarina nectrioides Seaver, sp. nov.}

Apothecia scattered or gregarious, sessile, almost globose, becoming somewhat discoid, bright-orange, not exceeding $1 \mathrm{~mm}$. in diameter and closely resembling a Nectria; hymenium plane or slightly concave; asci clavate, 8-spored, reaching a length of $150 \mu$ and a diameter of $20 \mu$; spores 2 -seriate or irregularly disposed, ellipsoid, hyaline, smooth, about $12 \times 20 \mu$; paraphyses stout, septate, thickened above, reaching a diameter of $10 \mu$ at their apices, filled with minute orange granules.

Type collected on old cabbage stems associated with Psendombrophila deerata (Karst.) Seaver, Kulm, North Dakota, July 4, 1911 (Herb. The New York Botanical Garden).

Distribution: Known only from the type locality.

Exsiccatı: Brenckle, Fungi Dakotenses 140 (in part).

18. Humarina deligata (Peck) Seaver, comb. nov.

Peziza deligata Peck, Ann. Rep. N. Y. State Mus. 30: 61. 1879. Humaria deligata Sacc. Syll. Fung. 8: 123. 1889.

Apothecia gregarious, minute, sessile, with radiating, hyaline mycelial threads at the base, at first subglobose, then opening and becoming scutellate to subdiscoid, externally pale-reddish; 
hymenium slightly concave or plane, reddish, a little brighter than the outside of the apothecium; asci subcylindric to clavate, reaching a length of $150 \mu$ and a diameter of $20 \mu, 8$-spored; spores 2-seriate above or irregularly disposed, smooth, hyaline, 10-12 $\times 18-20 \mu$; paraphyses very slender, reaching a diameter of about $3 \mu$ below, slightly enlarged at their apices.

On dead herbs lying on the ground.

Trpe locality: Bethlehem, New York.

Distributiox: Known only from the type locality.

19. Humarina glumarum (Desm.) Seaver, comb. nov.

Peziza glumarum Desm. Ann. Sci. Nat. II. 15: 129. 1841.

Aleuria glumarum Gill. Champ. Fr. Discom. 55. 1879.

Humaria glumarum Sacc. Syll. Fung. 8: 130. 1889.

Apothecia gregarious, at first closed, gradually expanding and becoming scutellate, reaching a diameter of $+-8 \mathrm{~mm}$., orange; hymenium concave or nearly plane, a little darker than the outside of the apothecium; asci cylindric above, tapering below, reaching a length of $235 \mu$ and a diameter of 15-16 $\mu, 8$-spored; spores ellipsoid, 1 -seriate or partially 2 -seriate, smooth, hyaline or very faintly yellowish, $10-11 \times 20 \mu$; paraphyses slender, enlarged above, reaching a diameter of $7-8 \mu$.

On chaff and straw.

Type locality : Europe.

Distributiox: Iowa; also in Europe.

Illustratiox: Cooke, Mycographia pl. 10, f. 39.

20. Humarina Peckii (House) Seaver, comb. nov.

IIumaria Peckii House, Bull. N. Y. State Mus. 205-206: 38. 1919.

Apothecia at first closed, finally opening and becoming shallow cup-shaped to scutellate, externally pallid, subpruinose, surrounded at the base with a mass of white mycelium, reaching a diameter of $4 \mathrm{~mm}$.; hymenium slightly concave, pale-yellow or subochraceous; asci cylindric or subcylindric, reaching a length of $160 \mu$ and a diameter of $12 \mu$, attenuated below into a rather long stem-like base; spores ellipsoid or ovoid, 1-seriate, each containing one oil-drop, about $8 \times 12 \mu$; paraphyses not exceeding $2 \mu$ in diameter, scarcely thickened above.

On damp decaying hay accompanied by a Sclerotium.

Type locality: Menandos, Albany County, New York, April, 1890 (C. H. Peck).

Distribution: Known only from the type locality. 


\section{Humarina phyllogena Seaver, comb. nov.}

Humaria phyllogena Seaver, Mycologia 17: 46. 1925.

Apothecia sessile or subsessile, discoid or with the margin slightly elevated, reaching a diameter of $3-5 \mathrm{~mm}$., flesh-red, brighter when dry; asci clavate, operculate, reaching a length of $200 \mu$ and a diameter of $12 \mu$; spores broad-ellipsoid, $12 \times 18-$ $20 \mu$, usually containing two oil-drops, smooth.

On dead leaves.

Type locality: El Yunque, Porto Rico.

Distribution: Known only from the type locality.

\section{Humarina tetraspora (Fuckel) Seaver, comb. nov.}

Ascobolus tetrasporus Fuckel, Hedwigia 5: 4. 1866.

Leucoloma tetraspora Fuckel, Symb. Myc. 317. 1869.

Peziza tetraspora Cooke, Grevillea 3: 73. 1874.

Aleuria tetraspora Gill. Champ. Fr. Discom. 207. 1886.

Humaria tetraspora Sacc. Syll. Fung. 8: 121. 1889.

Humaria silvosa Clements, Bot. Surv. Nebr. 5: 7. 1901.

Apothecia gregarious or scattered, sessile, at first closed and subglobose, expanding and becoming subdiscoid, reaching a diameter of 2-3 $\mathrm{mm}$; hymenium at first concave, becoming nearly plane or slightly convex, surrounded by a delicate fringelike border, bright-orange; asci clavate, reaching a length of $150-200 \mu$ and a diameter of 15-22 $\mu, 4$-spored; spores 1-seriate, with the ends strongly overlapping, narrow, ellipsoid to subfusoid, containing two or three oil-drops, $10-12 \times 22-26 \mu$, or rarely reaching a length of $30 \mu$, hyaline; paraphyses strongly enlarged at their apices, where they reach a diameter of $7-8 \mu$, filled with orange granules.

On the ground usually among mosses.

Type locality: Europe.

Distribution: New York to Iowa and Minnesota; also in Europe.

Illustrations: Hedwigia 5: pl. $1, f .5 ;$ Bull. Lab. Nat. Hist. State Univ. Iowa 6: pl. 13, f. 1; Boud. Ic. Myc. pl. 393; Cooke, Mycographia pl. 12, f. 45; Gill. Champ. Fr. Discom. pl. 52, f. 1; Pat. Tab. Fung. f. 482 .

23. Humarina permuda (Cooke) Seaver, comb. nov.

Peziza fusispora var. permuda Cooke, Mycographia 209. 1878. Pesiza permuda Cooke, Mycographia 209. 1878 (as synonym). IIumaria permuda Sacc. Syll. Fung. 8: 134. 1889. 
Apothecia gregarious or scattered, at first cup-shaped, expanding and becoming discoid, whitish with a tinge of pink, reaching a diameter of $1-2 \mathrm{~mm}$.; hymenium slightly concave or nearly plane; asci cylindric or subcylindric, \&-spored; spores obliquely 1 -seriate, fusoid, each containing one or two oil-drops, reaching a size of $10 \times 30 \mu$; paraphyses slender, only slightly enlarged above.

On the ground.

Trpe locality: South Carolina.

Distribution: Known only from the type locality.

Illustration: Cooke, Mycographia pl. 9\&, f. 353.

\section{Humarina ollaris (Fries) Seaver, comb. nov.}

Peziza ollaris Fries, Syst. Myc. 2: 68. 1822.

Aleuria ollaris Gill. Champ. Fr. Discom. 51. 1879.

Itumaria ollaris Sacc. Syll. Fung. 8: 131. 1889.

Neottiella ollaris Clements, Bot. Surv. Nebr. 5: 22. 1901.

Apothecia gregarious or more commonly crowded, sessile, at first closed and hemispherical, finally expanding and becoming scutellate, reaching a diameter of $5-8 \mathrm{~mm}$.; excipulum giving rise above to a palisade of parallel mycelial threads, the ends of which give to the border of the apothecium a minutely downy appearance, the ends of the mycelium; hymenium orange, a little darker than the exterior; asci cylindric above, tapering below into a stem-like base, 8 -spored; spores obliquely 1 -seriate, hyaline, smooth, containing one or two oil-drops, fusoid, 8-11 $\times 26-30 \mu$; paraphyses septate, strongly enlarged above, reaching a diameter of $8-10 \mu$ at their apices.

On the ground among mosses and in plant-pots.

Type Locality: Europe.

Distribution: Nebraska and New York; also in Europe.

Illustrations: Cooke, Mycographia pl. 14, f. 56; Gonnerm. \& Rab. Myc. Eu. 2: pl. 2, f. 2.

The species described under this name has been reported by Clements from Nebraska. A fine collection obtained March 19, 1928, on well-manured soil in pots in greenhouse of The New York Botanical Garden has been referred here. Our plants reach a diameter of $5 \mathrm{~mm}$. and as they expand they split so that the margin appears crenulate with a whitish border but scarcely pubescent. The spores are a little broader than usually indicated for this species. The color of the hymenium is a dirty- 
orange. The paraphyses are strongly enlarged and several times branched.

There seems to be some confusion regarding this species in Europe and of course the question arises as to whether we have the same thing here. Perhaps future study will add to our knowledge of this form. Our specimens are preserved in the herbarium of The New York Botanical Garden.

25. Humarina aggregata (Berk. \& Br.) Seaver, comb. nov.

Peziza aggregata Berk. \& Br. Ann. Mag. Nat. Hist. III. 18: 123. 1866.

IIumaria aggregata Sacc. Syll. Fung. 8: 134. 1889.

Apothecia gregarious or more often crowded together into confluent masses, subcylindric or turbinate, externally whitish or pale-orange, reaching a diameter of 2-3 $\mathrm{mm}$., seated on a conspicuous mycelial growth; hymenium slightly concave or nearly plane, surrounded by a delicate fringe-like border, brightorange; asci cylindric to clavate, tapering rather abruptly below, reaching a length of $200-225 \mu$ and a diameter of $10-12 \mu, 8$ spored; spores 1 -seriate, often with the ends strongly overlapping or irregularly crowded and partially 2 -seriate, fusoid, containing two oil-drops, $8-9 \times 22-25 \mu$, hyaline; paraphyses rather strongly enlarged above.

On the ground, on burned places and on humus in coniferous woods.

Type Locality: Great Britain.

Distribution: New Hampshire and Indiana; also in Europe.

Illustrations: Grevillea 3 : pl.50,f. 236; Cooke, Mycographia pl. 8, f. 31; E. \& P. Nat. Pf. $1^{1}: 184, f .149$, F-II.

26. Humarina fusispora (Berk.) Seaver, comb. nov.

Peziza fusispora Berk. London Jour. Bot. 5: 5. 1846.

Humaria fusispora Sacc. Syll. Fung. 8: 133. 1889.

Leucoloma fusispora Rehm, Ascom. 1053; Hedwigia 31: 301. 1892.

Apothecia gregarious or crowded, at first subglobose, becoming scutellate to discoid, reaching a diameter of $2-3 \mathrm{~mm}$., externally pale-orange, surrounded at the base by a rather conspicuous mycelial growth; hymenium concave or nearly plane, bright-orange; asci subcylindric to clavate, 8 -spored, reaching a length of about $250 \mu$ and a diameter of $12 \mu$; spores 1 -seriate, with the ends overlapping or becoming partially 2 -seriate, fusoid or almost fusiform, containing one or more commonly two oildrops, $8-10 \times 30-33 \mu$, hyaline; paraphyses filiform, slightly enlarged above. 
On the ground.

Type LocAlity: 'Tasmania.

Distribution: New Jersey to South Carolina; also in Europe and Tasmania.

Illustration: Cooke, Mycographia $p l .8, f .32$.

Exsiccati: Ravenel, Fungi Am. Exsicc. 174.

27. Humarina coccinea (Crouan) Seaver, comb. nov.

Ascobolus coccineus Crouan, Ann. Sci. Nat. IV. 7: 174. 1857.

Lencoloma coccinea Fuckel, Symb. Myc. 318. 1869.

Peziza corallina Cooke, Mycographia 19. 1875.

Aleuria corallina Gill. Champ. Fr. Discom 51. 1879.

Peziza muralis Quél. Grevillea 8: 116. 1880.

II umaria coccinea Sacc. Syll. Fung. 8: 119. 1889.

Humaria muralis Sacc. Syll. Fung. 8: 127. 1889.

Neotticlla corallina Nassee, Brit. Fungus-FI. 4: 372. 1895.

Plicaria muralis Rehm in Rab. Krypt.-Fl. 133: 1006. 1896.

Apothecia gregarious or scattered, at first closed and subglobose, later expanding and becoming nearly discoid, reaching a diameter of 2-3 $\mathrm{mm}$; hymenium slightly concave or nearly plane, surrounded by a delicate ragged fringe-like border, bright-orange, brighter than the outside of the apothecium; asci clavate, 8 -spored; spores 2-seriate above or irregularly crowded, fusoid, with the ends strongly narrowed but not acute, containing two or three oil-drops, rarely one, $7-10 \times 25-35 \mu$; paraphyses strongly enlarged above, reaching a diameter of 6 $10 \mu$ at their apices.

On sandy soil among mosses.

TyPe Locality: France.

Distribution: Iowa; also in Europe.

Illustrations: Ann. Sci. Nat. 7 : pl. 4, f. 15-19; Boud. Ic. Myc. pl. 392; Bull. Lab. Nat. Hist. State Univ. Iowa 6: pl. 13, f. 2; Cooke, Mycographia pl. 8, f. 30; Proc. Assoc. Fr. Av. Sci. 12: pl. 7, f. 7; Gill. Champ. Fr. Discom. (suites); Massee, Brit. Fungus-Fl. 4: 290, f. 33-35; E. \& P. Nat. Pfl. 1': 184, f. 149, E; Rab. Krypt.-Fl. 13: 917,f. 1-4; Phill. Brit. Discom. pl. 4, f. 21; Grevillea 3: pl. 31, f. 83 .

28. Humarina Cookeina Seaver, comb. nov.

IIumaria Cookeina Seaver, Mycologia 17: 46. 1925.

Apothecia short-stipitate or subsessile, with the hymenium slightly concave, reaching a diameter of $2-3 \mathrm{~mm}$., bright-orange, a little paler outside, the stem slightly grooved or furrowed; 
asci clavate, 8-spored, $14-15 \times 160 \mathrm{~mm}$; spores partially 2seriate, fusoid, $6 \times 30 \mu$.

On decaying sticks.

Trpe locality: El Yunque, Porto Rico.

Distribution: Known only from the type locality.

29. Humarina Gerardi (Cooke) Seaver, comb. nov.

Pesiza Gerardi Cooke, Hedwigia 14: 81. 1875.

Peziza violacea Ger.; Cooke, Hedwigia 14: 81 (as synonym). 1875. Not Peziza violacea Pers. 1797.

Peziza ionella Quél. Bull. Soc. Bot. Fr. 24: 328. 1877.

Aleuria ionella Gill. Champ. Fr. Discom. 51. 1879.

Humaria ionella Sacc. Syll. Fung. 8: 149. 1889.

Humaria Gerardi Sacc. Syll. Fung. 8: 150. 1889.

Galactinia ionella Boud. Hist. Class. Discom. Eu. 47. 1907.

Apothecia gregarious, at first closed and subglobose, expanding and becoming scutellate or nearly discoid, sessile or substipitate, reaching a diameter of $4-5 \mathrm{~mm}$., externally paleviolaceous and slightly roughened; hymenium slightly concave or nearly plane, violaceous; asci clavate, 8-spored; spores 1seriate or partially 2 -seriate above, occasionally becoming irregularly crowded, fusoid, smooth, containing one to several oildrops, $9-10 \times 30-35 \mu$, hyaline; paraphyses rather stout, enlarged above.

On the ground.

Type LOCality: New York.

Distribution: New York and Minnesota; also in Europe.

Illustrations: Cooke, Mycographia pl. 11, f. Ht; (?) Bull. Soc. Bot. Fr. 24: pl. 6, f. 4; Grevillea 3: pl. 43, f. 206; Boud. Ic. Myc. pl. 301.

30. Humarina purpurea Seaver, sp. nov.

Apothecia gregarious or closely crowded and of ten irregular from mutual pressure, sessile, becoming scutellate, externally rough and dark reddish-purple to blackish-brown, the margin crenate, reaching a diameter of $2-3 \mathrm{~mm}$. hymenium concave, reddish-purple, lighter than the outside of the apothecium; excipular cells elongated, rectangular or polyhedral, reaching a diameter of $25-30 \mu$, with brown walls, giving rise to fascicles of dark-brown hair-like structures which project and give rise to the crenate margin; asci cylindric or subcylindric, reaching a length of 150-175 $\mu$ and a diameter of 11-12 $\mu, 8$-spored; spores 1 -seriate, parallel with the ascus or slightly oblique, fusoid, at 
first smooth and containing one oil-drop about half the diameter of the spore or rarely with two, 8-10 $\times 13-20 \mu$, becoming delicately sculptured at maturity; spore-sculpturing consisting of minute warts or very short irregular ridges, often with a minute apiculus at each end; paraphyses slender and often adhering together at their apices, purplish.

On damp soil.

Type collected in Colorado by E. Bethel (1914?) (Herb. The New York Botanical (rarden).

Distribution: Known only from the type locality.

31. Humarina hepatica (Batsch) Seaver, comb. nov.

Peziza hepatica Batsch, Elench. Fung. Contin. 1: 199. 1786.

Aleuria hepatica Gill. Champ. Fr. Discom. 208. 1886.

IIumaria hepatica Sacc. Syll. Fung. 8: 140. 1889.

A scophanus hepaticus Boud. Hist. Class. Discom. Eu. 76. 1907.

Apothecia gregarious or scattered, at first closed and subglobose, opening and becoming scutellate or subdiscoid, reaching a diameter of 2-4 mm., externally reddish-brown or liver-colored and minutely granular, the margin becoming irregularly crenate; hymenium concave or nearly plane, similar in color to the outside of the apothecium; excipular cells rounded or polygonal and reaching a diameter of $30-40 \mu$, the walls pale-brown or with a purplish tinge; asci broad-cylindric, reaching a length of $200 \mu$ and a diameter of $20 \mu, 8$-spored; spores 1 -seriate or irregularly crowded, ellipsoid, smooth, hyaline, rather thick-walled, 10-12 $\times 22-26 \mu$; paraphyses septate, enlarged at the septa, giving them a knotted appearance, enlarged at their apices, where they reach a diameter of $6 \mu$, pale-brown or purplish.

On soil and fire clay.

TyPE LOCALITY : Europe.

Distribution: Colorado; also in Europe.

Illustratioss: Batsch, Elench. Fung. Contin. 1: pl. 26, f. 138; Ann. Mag. Nat. Hist. III. 15: pl. 15, f. 19; Cooke, Mycographia pl. 22, f. 85; Pat. Tab. Anal. Fung. f. 485.

32. Humarina trachyderma (Ellis \& Ev.) Seaver, comb. nov.

?Peziza tapeina Cooke, Mycographia 157. 1877.

?Peziza pertenuis Cooke, Mycographia 157. (as synonym). 1877.

Peziza trachyderma Ellis \& Ev. Am. Nat. 31:426. 1897.

Humaria trachyderma Sacc. \& Syd. in Sacc. Syll. Fung. 14: 752. 1899.

Apothecia sessile, becoming shallow cup-shaped or nearly plane, externally furfuraceous-verrucose, when fresh nearly the 
color of the substratum, with the hymenium darker when dry, margin incurved, reaching a diameter of 2-4 mm.; asci cylindric or subcylindric, about $12-14 \times 200 \mu$, 8-spored; spores 1 -seriate, ellipsoid, hyaline, smooth, $10-12 \times 18-20 \mu$; paraphyses thickened at their apices.

On decaying and partially buried wood.

Type Locality: Valentine, Nebraska.

Distributiox: Nebraska and ?South Carolina.

Illustration: Cooke, Mycographia pl. 70, f. 268.

\section{Doubtful and Excluded Species}

IIumaria bella (Berk. \& Curt.) Sacc. Syll. Fung. 8: 135. 1889; Peziza bella Berk. \& Curt.; Berk. Jour. Linn. Soc. 10:366. 1868. This species is reported from Cuba by Berkeley and Curtis. No specimens have been seen, but the general description of the species suggests Humarina leucoloma (Hedw.) Seaver.

IIumaria scatigena (Berk. \& Curt.) Sacc. Syll. Fung. 8: 147. 1889; Peziza scatigena Berk. \& Curt.; Berk. Jour. Linn. Soc. 10: 366. 1868. This species is also reported from Cuba by Berkeley and Curtis. No specimens have been seen, but both the description and habitat suggest an Ascobolus.

IIumaria salmonicolor (Berk. \& Br.) Sacc. Syll. Fung. 8: 123. 1889; Peziza salmonicolor Berk. \& Br. Ann. Mag. Nat. Hist. III. 18: 124. 1866. This species is reported from Nebraska by Clements. No specimens have been found available for study.

Humaria olivatra (Ellis \& Holw.) Sacc. Syll. Fung. 8: 148. 1889; Peziza olivatra Ellis \& Holw.; Arth. Bull. Geol. Nat. Hist. Surv. Minn. 3: 36. 1887. This is an inoperculate species and therefore not a member of the present genus, which belongs to the operculate section of discomycetes.

Humaria fuscocarpa (Ellis \& Holw.) Morgan, Jour. Myc. 8: 189. 1902; Peziza fuscocarpa Ellis \& Holw. Jour. Myc. 1: 5. 1885. This also belongs to the inoperculate series of discomycetes. It is apparently a synonym of Peziza olivacea Batsch and belongs to the monotypic genus Catinella established by Boudier in 1907.

IIumaria vitigena Massee \& Morgan; Morgan, Jour. Myc. 8: 189. 1902. This is not a member of this genus and probably also belongs with the inoperculate section of discomycetes.

Humaria subcrenulata Clements, Bot. Surv. Nebr. 4: 11. 1896. The type of this species could not be located, so that the identity of the species is uncertain.

Humaria secreta (Phill.) Sacc. Syll. Fung. 8: 123. 1889; Peziza secreta Phill. Grevillea 7: 21. 1878. This species was described from material collected in California by Harkness. We have no knowledge of the species except that gained from the original description.

Humaria groenlandica Rostr. Medd. Groenland 18: 55. 1896. This small blackish species is reported from Jamesons Land, Greenland. No specimen has been seen, but the description suggests a close relationship with Peziza spissa Berk. 
IHumaria microspora (Berk. \& Curt.) Sacc. Syll. Fung. 8: 131. 1889; Peziza micraspora Berk. \& Curt.; Berk. Grevillea 3: 150. 1875. This species was first reported from South Carolina. Specimens collected in Pennsylvania which appear to agree with the original description are more closely related to the genus Plectania than to IIumarina.

Humaria xanthomela americana (Rehm) Sacc. \& Trott. in Sacc. Syll. Fung. 22: 626. 1913; Melachroia xanthomela americana Rehm, Ann. Myc. 3: 230. 1905. The American form of this species was reported by Rehm from Tacoma Park, Washington, D. C. No specimen has been seen.

Peziza elachroa Berk. \& Curt.; Cooke, Mycographia 160. 1877. The species which is described from Cuban material is about one-fourth of an inch broacl and of an olivaceous color. No specimen has been seen.

IIumaria subgranulata (Berk. \& Curt.) Sacc. Syll. Fung. 8: 129. 1889; Peziza subgranulata Berk. \& Curt.; Berk. Jour. Linn. Soc. 10: 366.1868. A Cuban species said to be closely related to Ascophanus granulaius.

\section{PSEU DOMBROPHILA Boud. Hist. Class. Discom.} Eu. 65. 1907.

Apothecia subsessile or short-stipitate, less than $1 \mathrm{~cm}$. in diameter; substance rather tough and resembling an Ombrophila; asci cylindric or subcylindric, usually 8-spored; spores ellipsoid, hyaline; paraphyses delicate.

Type species, IIelotium Pedrottii Bres.

1. Pseudombrophila deerrata (Karst.) Seaver, comb. nov.

Pesiza deerrata Karst. Not. Fauna F1. Fenn. 10: 119. 1869.

Peziza rufescens Schröt.; Rab. Fungi Eu. 2311. 1878.

Peziza Schroteri Cooke, Grevillea 6: 110. 1878.

Helotium Pedrottii Bres. Fungi Trid. 1: 14. 1881.

IIumaria deerrata Sacc. Syll. Fung. 8: 140. 1889.

Geoscypha Schröteri Rehm, Ascom. 901; Hedwigia 27: 163. 1888.

IIumaria Schröteri Sacc. Syll. Fung. 8: 141. 1889.

Pseudombrophila Pedrottii Boud. Hist. Class. Discom. Eu. 65. 1907.

Apothecia gregarious or crowded, sessile or short-stipitate, at first closed and subglobose, opening and becoming discoid or shallow cup-shaped, reaching a diameter of 3-4 mm., externally dark-brownish and subtomentose or squamulose; hymenium plane or slightly concave, pale-reddish or reddish-purple; asci cylindric or subcylindric, 8-spored; spores ellipsoid, 1-seriate, parallel with the ascus and apparently adhering together but easily detached, occasionally containing one central oil-drop, hyaline or slightly yellowish, $8-9 \times 12-14 \mu$; paraphyses slender, rather strongly enlarged above, where they reach a diameter of $4 \mu$.

On dead herbaceous stems, especially on Brassicaceae. 
Type Locality: Finland.

Distribution: North Dakota; also in Europe.

Illustrations: Boud. Ic. Myc. pl. 390; Bres. Fungi Trid. 1: pl. 15; Cooke, Mycographia pl. 110, f. 393.

Exsiccati: Brenckle, Fungi Dakotenses 170.

19. STREPTOTHECA Vuill. Jour. de Bot. 1:33. 1887.

Ascobolus § Ascozonus Renny, Jour. Bot. 12: 355. 1874. Ascozonus Boud. Hist. Class. Discom. Eu. 79. 1907.

Apothecia minute, scarcely visible to the unaided eye, externally naked or clothed with poorly developed hyaline hairs, white or whitish; hymenium plane or convex, roughened by the large protruding asci; asci broad-clavate to ovoid, with a distinct collar near their apices, more or less attenuated at the apex, opening by a transverse slit which gives the open ascus a bilabiate appearance, many-spored; spores hyaline or subhyaline, small, ellipsoid, often enveloped in a mucilaginous material; paraphyses slender, scant.

Type species, Streptotheca Boudieri V'uill.

Asci 32-spored.

1. S. Crouani.

Asci 64-spored.

Spores 6-7 $\times 12-14 \mu$.

Spores $4 \times 8 \mu$.

2. S. woolhopensis.

3. S. obscura.

1. Streptotheca Crouani (Renny) Seaver, comb. nov.

Ascobolus Crouani Renny, Jour. Bot. 12: 356. 1874.

Streptotheca Boudieri Vuill. Jour. de Boi. 1: 34. 1887.

Ryparobius Crouani Sacc. Syll. Fung. 8: 543. 1889.

Ascozonus Boudieri Boud. Hist. Class. Discom. Eu. 79. 1907.

Ascozonus Crouani Boud. Hist. Class. Discom. Eu. 79. 1907.

Apothecia minute, scarcely visible to the unaided eye, gregarious or widely scattered, at first subcylindric, becoming expanded and more or less discoid, not exceeding $0.5 \mathrm{~mm}$. in diameter, white or whitish, externally clothed with a few hairlike hyphae; hymenium plane or convex, of about the same color as the outside of the apothecium; asci clavate, marked near the apex with a distinct thickened ring which projects inward, 32-spored, reaching a length of $120 \mu$ and a diameter of $22 \mu$, opening by a transverse slit; spores ellipsoid, smooth, hyaline, $3 \times 12 \mu$; paraphyses very slender.

On dung of different kinds. 
Type locality: Europe.

Distribution: New York; also in Europe.

Illustrations: Jour. de Bot. 1: 3t, f. A-G; E. \& P. Nat. Pfl. $1^{1}: 191$, f. 153, A-B; Jour. Bot. 12: pl. 154, f. 6-10.

2. Streptotheca woolhopensis (Renny) Seaver, comb. nov. (Plate 12, Fig. 2-3.)

Ryparobius woolhopensis Renny; Berk. \& Br. Ann. Mag. Nat. Hist. IV. 11:

348. 1873.

Ascobolus woolhopensis Renny, Jour. Bot. 12: 356. 1874.

Apothecia minute, less than $1 \mathrm{~mm}$. in diameter, white, sessile or subsessile, externally clothed with minute whitish hairs; hymenium plane or nearly so, roughened by the large protruding asci; hairs blunt, thin-walled, septate, hyaline, reaching a length of $40-60 \mu$ and a diameter of $8-20 \mu$; asci clavate, attenuated above in to a rather acute apex, short-stipitate, reaching a length of $100-200 \mu$ and a diameter of $20-22 \mu$ (broader when under pressure), 64-spored; spores at first collected into a rather compact mass, becoming more or less separated in the older asci, ellipsoid to fusoid, hyaline, $6-7 \times 12-14 \mu$; paraphyses rather stout, hyaline.

On the dung of birds and mice.

Type LOCAlity: Great Britain.

Distribution: New York; also in Europe.

Illustrations: Ann. Mag. Nat. Hist. IV. 11: pl. 9, f. 12; Jour. Bot. 12: pl. 153.

3. Streptotheca obscura Seaver, sp. nov. (PLATE 12, FIG. 4.)

Apothecia minute, scarcely visible to the naked eye, cinereous under the lens and scarcely differing in color from the substratum; hymenium convex, dull; excipular cells irregular and the walls pale yellowish-brown; asci broad, clavate, stipitate below, slightly constricted above near the apex, the constriction marking the position of the ring or collar, reaching a length of $80 \mu$ and a diameter of 20-22 $\mu$, 64-spored; spores ellipsoid, hyaline, $4 \times 8 \mu$; paraphyses slender, septate.

Type collected on rabbit dung at Tarrytown, New York, May, 1916 (Herb. The New York Botanical Garden).

Distributiox: Known only from the type locality. 
20. RYPAROBIUS Boud. Ann. Sci. Nat. V. 10:237. 1869.

?Thelebolus Tode, Fungi Meckl. 1: 41. 1790.

Pezizula Karst. Myc. Fenn. 1: 81. 1871.

Apothecia minute, of ten scarcely visible, sessile, externally smooth or clothed with poorly developed hairs, white to whitish or yellowish; excipulum of ten remaining closed until ruptured by the maturing asci; hymenium concave, plane or more often convex, usually roughened by the protruding asci; asci large, broad-clavate to ovoid, opening by a circular lid or in a few cases the method of dehiscence uncertain, many-spored; spores hyaline or subhyaline, small, ellipsoid, often enveloped in a mucilaginous material with which they are discharged from the ascus; paraphyses usually very delicate.

Type species, Ryparobius brunneus Boud.

Asci 16-spored.

1. R. sexdecimsporus

Asci 6t-spored.

2. R. crustaceus.

Asci 72-spored.

3. R. hyalinellus.

Asci more than 72-spored.

Apothecia always having more than one ascus.

Apothecia usually having a single ascus.

4. R. polysporus.

5. R. monascus.

1. Ryparobius sexdecimsporus (Crouan) Sacc. Syll. Fung. 8: 541. 1889. (Plate 12, Fig. 1.)

Ascobolus sexdecimsporus Crouan, Ann. Sci. Nat. IV. 10: 195. 1858. Ascophanus sexdecimsporus Boud. Ann. Sci. Nat. V. 10: 247. 1869.

Apothecia scattered or gregarious, sessile, at first subglobose, expanding and becoming subdiscoid, smooth, at first white or whitish, finally dull, pallid or yellowish, reaching a diameter of 1-2 mm., or occasionally less than $1 \mathrm{~mm}$.; hymenium at maturity plane or convex, roughened by the protruding asci, similar in color to the outside of the apothecium; excipular cells irregularly polygonal, reaching a diameter of $12-15 \mu$, giving rise above to a palisade of mycelium with loose, club-shaped ends; asci broadly clavate, reaching a length of $75-125 \mu$ and a diameter of $20-25 \mu$, tapering below in to a short stem-like base, 16-spored; spores 2 -seriate or becoming irregularly crowded, ellipsoid, containing one central oil-drop, $7-10 \times 11-14 \mu$, hyaline; paraphyses very slender, not usually exceeding $2 \mu$ in diameter and scarcely thickened above.

On dung of various kinds.

Trpe locality: France. 


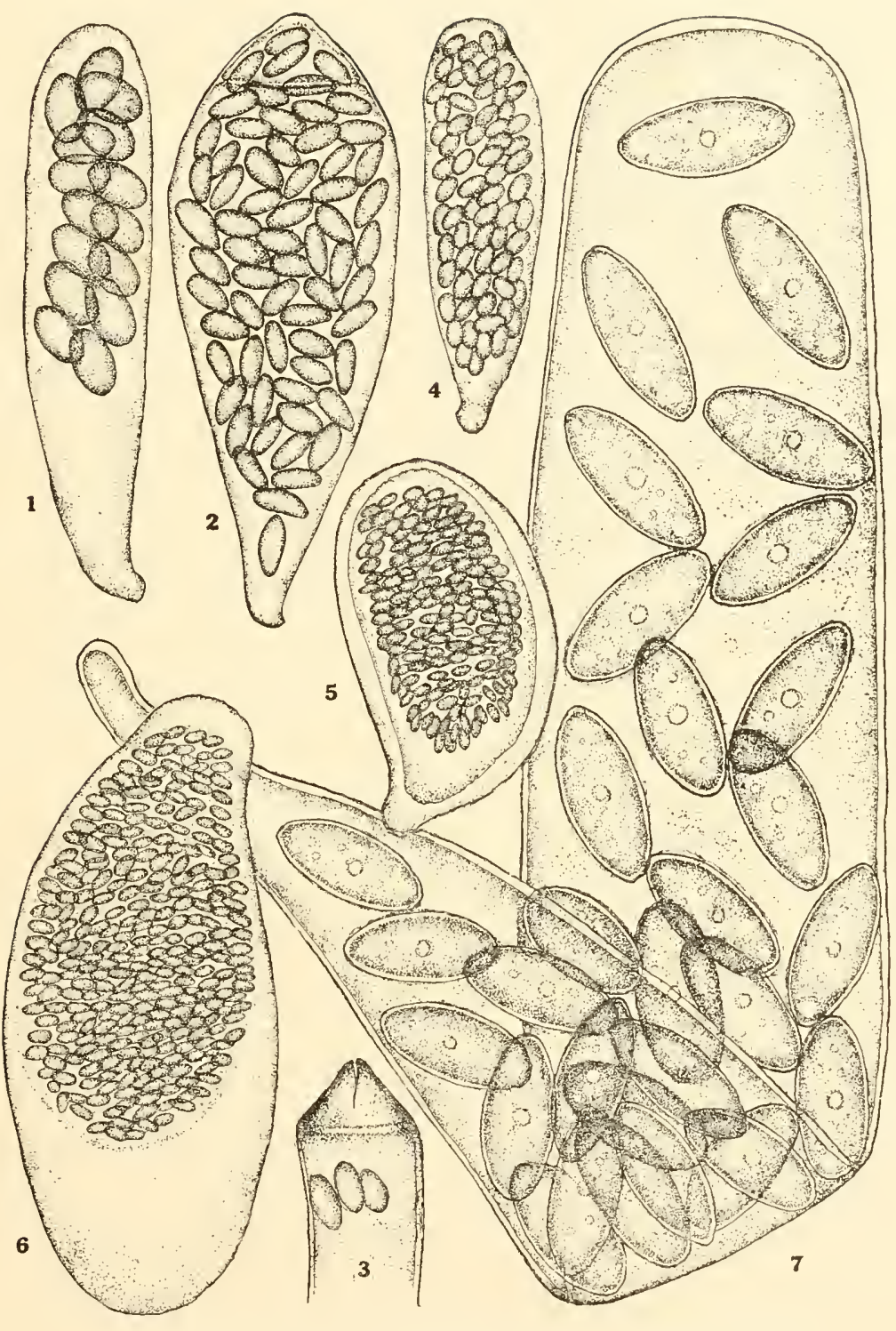

RYPAROBIUS, STREPTOTHECA, AND THECOTHEUS 

Distribution: New York to North Dakota; also in Europe.

lluustratrons: Ann. Sci. Nat. IV. 10: pl. 13, f. 21-26; Anı. Sci. Nat. V'. 10: pl. 11, f. 35; Ann. Mag. Nat. Hist. III. 15: pl. 17, f. 35; Rab. Krypt.-Fl. 13: 1082, f. 5; E. \& P. Nat. Pfl. $1^{1}: 189, f .152, E-F$; Bull. Lab. Nat. Hist. State Univ. Lowa 6: pl. 3t, f. 1 .

2. Ryparobius crustaceus (Fuckel) Rehm, Ber. Naturh. Ver. Augsburg 26: 17. 1881.

Ascobolus crustaceus Fuckel, Hedwigia 5: 4. 1866. Ascobolus Cookei Crouan, Fl. Finist. 56. 1867. Ascobolus polysporus Auersw. Hedwigia 7: 51. 1868. Ryparobius Cookei Boud. Ann. Sci. Nat. V. 10:238. 1869. Pesizula crustacea Karst. Myc. Fenn. 1: 81. 1871.

Apothecia gregarious or scattered, very minute and scarcely visible to the unaided eye, at first subglobose, then becoming expanded and more or less discoid, at first white or whitish, becoming dull-pallid or dirty-white, not usually exceeding 0.5 nm. in diameter; hymenium convex and roughened by the strongly protruding asci; asci comparatively few to each plant and very broad-clavate to subovoid, many-spored, the exact number of the spores difficult to make out with certainty, but usually 64, entire ascus reaching a length of $90-100 \mu$ and a diameter of about $25 \mu$, rather abruptly tapering below into a short stem-like base; spores ellipsoid, crowded together in the ascus with no apparent order, hyaline, often with one small oildrop or with none apparent, above $4-6 \times 7-10 \mu$; paraphyses sparse, slender and very slightly thickened above.

On dung of different kinds.

Tyé locality: Europe.

Distribution: New York to Colorado; also in Europe.

Illustrations: Ann. Sci. Nat. V. 10 :pl. 9, f. 27; Hedwigia 5: pl. 1, f. 6; Crouan Fl. Finist. pl. (Suppl.), f. 3; Massee, Brit. Fungus-F1. 4: 156, f. 34-35; Phill. Brit. Discom. pl. 9, f. 57; Rab. Krypt.-Fl. $1^{3}: 1083, f .1-4 ;$ Bull. Lab. Nat. Hist. State Univ. Iowa 6: pl. 33, f. 2.

3. Ryparobius hyalinellus (Karst.) Sacc. Syll. Fung. 8: 542. 1889.

Peziza hyalinella Karst. Myc. Fenn. 1: 83. 1871.

Apothecia gregarious, subglobose, smooth, whitish, reaching a diameter of $100 \mu$; hymenium strongly convex, similar in color 
to the outside of the apothecium; asci clavate, reaching a length of 55-100 $\mu$ and a diameter 18-28 $\mu, 72$-spored; spores ellipsoid, hyaline, reaching a length of $5 \mu$ and a diameter of $3 \mu$; paraphyses slender, enlarged above, reaching a diameter of $6 \mu$ at their apices.

On bird dung.

Type LocAlıty: Finland.

Distribution: Greenland; also in Europe.

4. Ryparobius polysporus (Karst.) Sacc. Syll. Fung. 8: 539. 1889. (Plate 12, FIG. 5.)

Ascobolus polysporus Karst. Fungi Fenn. 655. 1867; Not. Fauna Fl. Fenn. 11: 208. 1870 .

Peziza polyspora Karst. Myc. Fenn. 1: 82. 187 .

Ryparobius pachyascus Zukal; Rehm, Ascom. 91 ; Hedwigia 27: 167. 1888. Ascozonus oligoascos Heimerl, Niederöst. Ascoboleen 27. 1889.

Apothecia gregarious or scattered, subglobose, becoming more or less expanded at the top, very minute, scarcely visible to the unaided eye and difficult to find even with a lens, often partially immersed in the substratum, yellowish to yellowishbrown, not exceeding $100-150 \mu$ in diameter; excipulum for a long time entirely enclosing the apothecium, finally rupturing irregularly and exposing the asci and paraphyses, which constitute a poorly developed hymenium; asci comparatively few to each plant, not usually exceeding 3-5, broad-clavate to subovoid, the small end directed downward, reaching a length of $70-150 \mu$ (often stretching when mature) and a diameter of $35-50 \mu$, with a faint suggestion of a ring near the apex, many-spored; spores irregularly disposed, small, ellipsoid, the exact number in each ascus difficult to determine with certainty, $3 \times 5-7 \mu$; paraphyses minute and indistinct.

On dung of different kinds, especially abundant on goat dung.

Type locality: Europe.

Distribution: New York to Colorado; also in Europe.

Illustrations: Rab. Krypt.-Fl. $1^{3}$ : 1083, f. 1-3; Bull. Lab. Nat. Hist. State Univ. Iowa 6: pl. 3f, f. 2; Heimerl, Niederöst. Ascoboleen pl. 1, f. 1 . 
5. Ryparobius monascus Mouton, Bull. Soc. Royale Bot. Belg. 25: 141. 1886. (Pl.ATE 12, Fig. 6.)

?Thelebolus stercoreus Torle, Fungi Meckl. 1: 41.1790.

Thelebolus nanus Heimerl, Nielleröst. Ascoboleen 30. 1889.

Thelebolus monascus Boud. Hist. Class. Discom. Eu. 79. 1907.

? Thelebolus lignicola Lloyd, Myc. Notes 52: 738. 1917.

Apothecia gregarious or scattered, at first globose, then broad-ovoid, externally smooth, yellowish to brown, entirely closed, finally bursting open by a rupture of the excipulum through which the ascus protrudes, reaching a diameter of 200-300 $\mu$; asci usually one to each apothecium, but occasionally two or three, ellipsoid to ovoid, often slightly constricted near the upper end and with a faint suggestion of a ring, reaching a length of $200-260 \mu$ and a diameter of $150-175 \mu$, each containing a large number of spores, the exact number difficult to determine but exceeding one hundred, method of dehiscence uncertain since they do not dehisce readily but usually burst open irregularly; spores ellipsoid, hyaline, $3-3.5 \times 5-7 \mu$; paraphyses slender, septate.

On dung of various kinds, especially abundant on goat dung; more rarely on wood.

Týe LOCALity: Europe.

Distribution: New York; also in Europe.

Illustrations: ?Tode, Fungi Meckl. 1: pl. 7, f. 56; Rab. Krypt.-Fl. $1^{3}: 1080, f .1-4$; Ann. Bot. 15: pl. 18, f. 41-4t, 66; Heimerl, Niederöst. Ascoboleen pl. 1, f. 2.

This and the preceding species differ from the other members of the genus examined in that they are for a long time enclosed in a surrounding sheath here referred to as the excipulum. Perhaps these forms should have been referred to the genus Thelebolus in which there is no true apothecium, although they are referred to as such by systematists.

\section{Doubtful ind Excluded Species}

Ryparobius nizeus (Fuckel) Rehm in Rab. Krypt.Fl. 13: 1102. 1896; Ascobolus nivens Fuckel, Hedwigia 5: 4. 1886. This species has been reported for North America by Dodge. No specimens have been seen. The species is closely related to $R$. crustaceus (Fuckel) Rehm.

\section{THECotheUS Boud. Ann. Sci. Nat. V. 10: 235.1869.}

Apothecia sessile, short-cylindric, at least when young, white or whitish, minute, substance soft and waxy; asci very large, 
broad-clavate, usually truncate at the apex, many-spored; spores ellipsoid or subellipsoid, smooth, each usually surrounded by a mucilaginous envelope; paraphyses present, slender.

Type species, Ascobolus Pelletieri Crouan.

1. Thecotheus Pelletieri (Crouan) Boud. Ann. Sci. Nat. V. 10: 236. 1869. (Plate 12, Fig. 7.)

Ascobolus Pelletieri Crouan, Ann. Sci. Nat. IV. 7: 173. 1857. Ryparobius Pelletieri Sacc. Syll. Fung. 8: 542. 1889.

Apothecia gregarious or scattered, sessile, at first subconical, the top gradually expanding, finally short-cylindric or rarely approaching discoid, reaching a diameter of 1-2 $\mathrm{mm}$. and of about the same height, white or whitish, externally more or less pruinose; hymenium plane or slightly convex, similar in color to the outside of the apothecium, roughened by the protruding asci; the excipular cells roundish, loosely united, reaching a diameter of $20 \mu$, the cell walls hyaline; asci comparatively few to each apothecium, very large, strongly exserted and easily visible with the hand lens, broad-cylindric to clavate, tapering below into a stem-like base, reaching a length of $300-350 \mu$ and a diameter of 50-60 $\mu, 32$-spored; spores 3-4-seriate or irregularly disposed, ellipsoid, the ends strongly narrowed, containing one central nucleus-like body or a number of small oil-drops, 23-24 $\times 35-38 \mu$, each surrounded by a mucilaginous envelope which is rather thick and of irregular outline; paraphyses very slender.

On dung of various kinds.

Type Locality: France.

Distribution: Massachusetts to North Dakota and Bermuda; also in Europe.

Illustrations: Ann. Sci. Nat. IV. $7: p l .4, f . A$; Ann. Sci. Nat. V. 10: pl. 9, f. 22; E. \& P. Nat. Pfl. $1^{1}$ : 189, f. 152, G-J; Massee, Brit. Fungus-Fl. 4: 156, f. 38; Rab. Krypt.-Fl. 13 : 1082, f. 1-4; Phill. Brit. Discom. pl. 9, f. 56; Bull. Lab. Nat. Hist. State Univ. Iowa 6: pl. 33, f. 1; Pat. Tab. Fung. f. 172.

\section{SEPUlTARIA Massee, Brit. Fungus-F1. 4: 389. 1895.}

Peziza § Sepultaria Cooke, Mycographia 259. 1879.

Apothecia medium-sized, reaching a diameter of $2-3 \mathrm{~cm}$., cup-shaped or rarely subscutellate with age, clothed with flexuous or bristly hairs, partially to entirely buried in the ground, of ten becoming subsuperficial with age, entire or splitting Geaster- 
like; hymenium concave, whitish or orange to red; asci 8 -spored; spores ellipsoid; paraphyses present and variable.

Type species, Pezist sepulla Fries.

Apothecia large, $1-4 \mathrm{~cm}$. in diameter, entirely buried and appearing as a hole in the ground.

Spores ellipsoid, $15-17 \times 25-30 \mu$.

1. S. arenicola.

Spores subglobose, $18-20 \times 20-22 \mu$.

2. S. Longii.

Apothecia medium-sized, seldom exceeding $1 \mathrm{~cm}$., partially buried.

Hymenium white or whitish.

3. S. arenosa.

Hymenium orange or redclish.

Spores $8-10 \times 18-25 \mu$; hairs rigid.

4. S. aurantiaca.

Spores $12-14 \times 25-33 \mu$; hairs entirely flexuous.

5. S. pellita.

1. Sepultaria arenicola (Lév.) Massee, Brit. Fungus-Fl. 4: 390. 1895.

?Peziza lanuginosa Bull. Herb. Fr. pl. 396, f. 2. 1788.

Peziza arenicola Lév. Ann. Sci. Nat. III. 9: 140. 1848.

Peziza sepulta Fries; Berk. \& Br. Ann. Mag. Nat. Ilist. II. 13: 463.1854.

Peziza Geaster Berk. \& Br. Ann. Nag. Nat. Ilist. III. 18: 125. 1866.

Peziza lanuginosa Sumneri Berk. Trans. Linn. Soc. 25: 432. 1866.

Lachnea arenicola Gill. Champ. Fr. Discom. 77. 1879.

Lachnea Sumneriana Phill. Brit. Discom. 213. 1887.

Lachnea lanuginosa Sacc. Syll. Fung. 8: 167. 1889.

Lachnea Geaster Sacc. Syll, Fung. 8: 172. 1889.

Lachnea sepulta Sacc. Syll. Fung. 8: 170. 1889.

Scutellinia Geaster Kuntze, Rev, Gen. PI. 2: 869. 1891.

Scutellinia sepulta Kuntze, Rev. Gen. P'1. 2: 869. 1891.

Scutellinia Sumneriana Kuntze, Rev. Gen. Pl. 2: 869. 1891.

Scutellinia arenicola Kuntze, Rev. Gen. P1. 2: 869. 1891.

?Scutellinia lanuginosa Kuntze, Rev. Gen. Pl. 2: 869. 1891.

Sarcosphaera arenicola Lindau in E. \& P. Nat. Pfl. 1 1 : 182. 1897.

Sarcosphaera Sumneriana Lindau in E. \& P. Nat. Pfl. $1^{1}: 182.1897$.

Sarcosphaera Geaster Lindau in E. \& P. Nat. Pfl. 1' ${ }^{1}$ : 182. 1897.

Sepultaria heterothrix Clements, Bull. Torrey Club 30: 91. 1903.

Lachnea heterothrix Sacc. \& D. Sacc. in Sacc. Syll. Fung. 18: 33. 1906.

Sepultaria Sumneri Boud. Hist. Class. Discom. Eu. 59. 1907.

Sepultaria sepulta Boud. Hist. Class. Discom. Eu. 59. 1907.

Sepultaria Geaster Boud. Hist. Class. Discom. Eu. 59. 1907.

Apothecia gregarious, at first closed and entirely immersed in the ground, at maturity opening and appearing as a hole in the ground, sometimes becoming semisuperficial, margin incurved and entire or splitting ir regularly, reaching a diameter of $1-4 \mathrm{~cm}$., externally brown and densely clothed with brown flexuous hairs which bind the substratum together so that the whole exterior of the apothecium is encrusted with sand, the exterior of the cup 
woolly when the soil has been washed away; hymenium pallid, becoming yellowish or brownish when old or when dried; hairs thin-walled, sparingly septate, often branched, reaching a diameter of 10-15 $\mu$, externally minutely roughened; asci cylindric or subcylindric, reaching a diameter of $20 \mu$; spores ellipsoid, often narrowed at the ends, smooth, usually containing one large oil-drop, or rarely two, $12-17 \times 25-30 \mu$, usually about $12 \times 25 \mu$; paraphyses slender, slightly enlarged at their apices. On rather sandy soil.

Type locality: Europe.

Distribution: New York to Colorado, and California; also in Europe and Africa.

Illustrations: Cooke, Mycographia pl. 29, f. 111, 112, 114; Bull. Lab. Nat. Hist. State Univ. Iowa 6: pl. 9, f. 2; Trans. Linn. Soc. 25: pl. 55, f. 1; Boud. Ic. Myc. p'. 358; Phill. Brit. Discom. pl. 6, f. 39; Rab. Krypt.-Fl. $1^{3}$ : 1036, f. 1-5; E. \& P. Nat. Pfl. $1^{1}: 181, f .147, H$; Ann. Mag. Nat. Hist. III. 18: pl. 4, f. $25-27$.

\section{Exsiccatr: Fungi Columb. 2377.}

Since this manuscript was submitted to the printers, the writer has received from Dr. John Axel Nannfeldt of Sweden a collection, under the name of Sepultaria sepulta (Fries) Rehm, which he reports growing abundantly on (or rather in or under) the sidewalks in a suburb of Upsala just outside the Botanical Garden and only a few hundred meters from the type locality. He also states that it looks very insignificant like holes from earthworms.

Nannfeldt also states that after examination of the authentic specimens of Peziza arenosa Fuckel, he is convinced that this is identical with the above. Sepultaria arenosa has been treated as distinct in this work, the American specimens referred to this species having smaller apothecia which are only partially submerged. It is possible that this is only a form of Sepultaria arenicolt.

2. Sepultaria Longii Seaver, Mycologia 7: 199. 1915.

Apothecia densely gregarious or cespitose, at first closed and entirely buried, finally opening to the surface by an elongated or compressed aperture, or when the substratum is not too compact spreading so as to expose the hymenium, never protruding above the surface of the substratum but causing the soil to become 


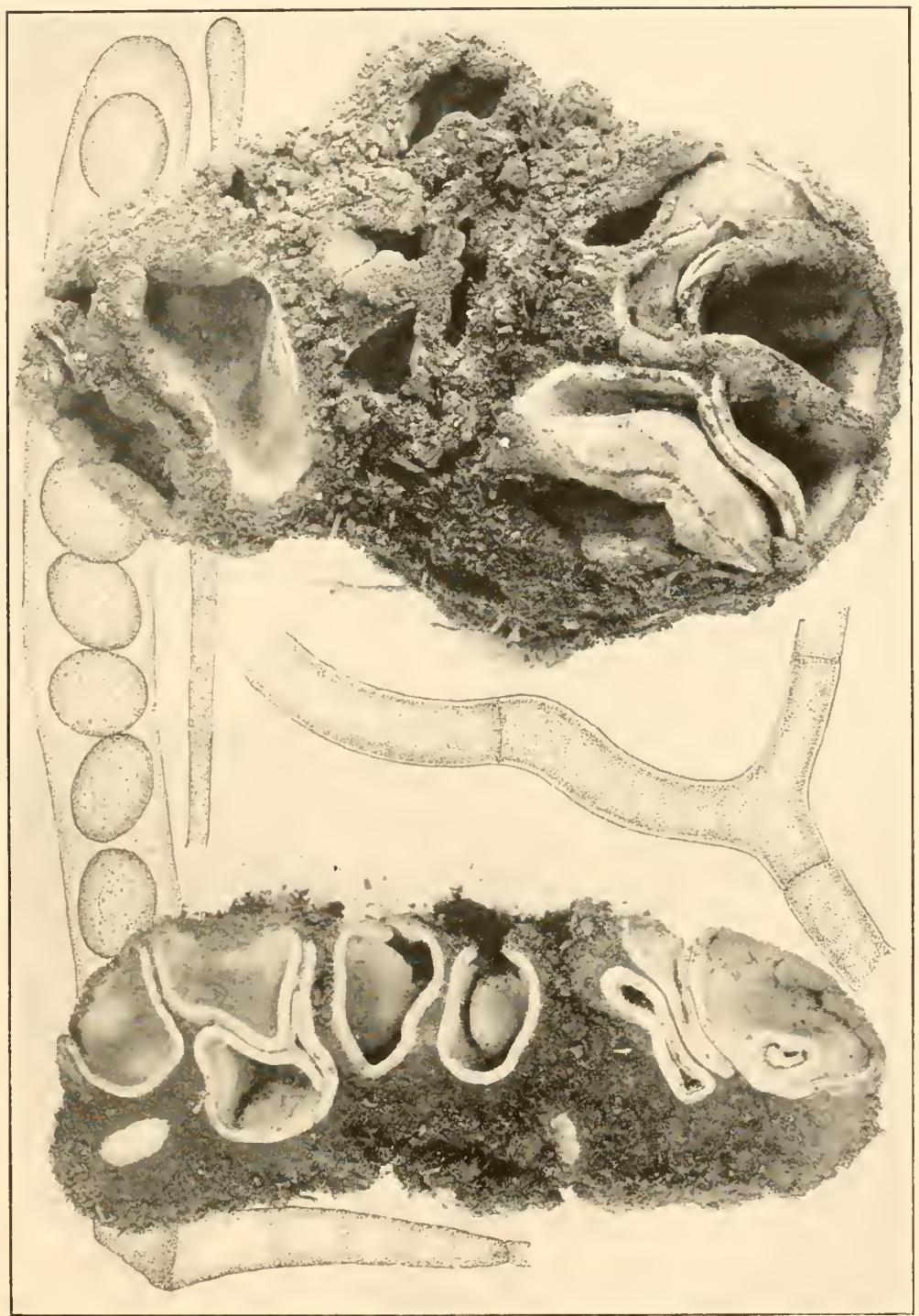

SEPULTARIA LONGII 

slightly elevated as they mature, reaching a cliameter of $4 \mathrm{~cm}$., regular in form or becoming very much contorted from mutual pressure, clothed with hairs which extend into the substratum, binding the surrounding soil to the outside of the apothecium; hymenium deeply concave, nearly smooth, almost white; hairs flexuous, septate, brown, and of nearly uniform thickness throughout their entire length; asci subcylind ric above, tapering gradually below into a stem-like base, reaching a length of $250-300 \mu$ and a diameter of 20-22 $\mu$; spores 1 -seriate, short-ellipsoid or subglobose, at first containing one small oil-drop which gradually enlarges until it nearly fills the spore, about $18-20 \times 20-22 \mu$; paraphyses stout, gradually enlarged above, where they reach a diameter of $4-6 \mu$, filled with numerous vacuoles or oil-drops, hyaline.

On bare ground.

Type Locality: Albuquerque, New Mexico.

Distribution: Known only from the type locality.

Illustration: Mycologia $7:$ pl. 161.

3. Sepultaria arenosa (Fuckel) Boud. Hist. Class. Discom. Eu. 59. 1907.

Peziza arenosa Fuckel, Fung. Rhen. 1212. 1865; Hedwigia 5: 15. 1866. Humaria arenosa Fuckel, Symb. Myc. 321. 1869.

Lachnea arenosa Sacc. Syll. Fung. 8: 167. 1889.

Scutellinia arenosa Kuntze, Rev. Gen. P1. 2: 869. 1891.

?Sepultaria grisea Clements, Bot. Surv. Nebr. 4: 13. 1896.

?Lachnea grisea Sacc. \& Sydow in Sacc. Syll. Fung. 14: 756. 1899.

Sarcosphaera arenosa Lindau in E. \& P. Nat. Pfl. 1'1 182.1897.

Apothecia scattered, sessile and partially immersed in the ground, finally becoming subsuperficial, cup-shaped or occasionally subscutellate, reaching a diameter of $1 \mathrm{~cm}$., the margin entire or splitting, externally clothed with hairs which are often tufted; hymenium white or whitish; hairs flexuous or crooked, more rarely straight and subrigid on the exposed parts, often swollen at the base, reaching a length of $200 \mu$ and a diameter of $9 \mu$, the hairs on the lower part of the cup giving rise to rhizoidlike hyphae which extend into the surrounding soil; asci subcylindric above, reaching a length of 200-225 $\mu$ and a diameter of $15-18 \mu$; spores 1 -seriate or partially 2 -seriate, ellipsoid, the ends slightly narrowed, usually containing two oil-drops, 13-18 $\times 23-25 \mu$, smooth; paraphyses gradually enlarged above, where they reach a diameter of $7-9 \mu$. 
()n sandy soil.

TYPE LOCALity: Europe.

Distribution: New Jork to Colorado; also in Europe.

Illustrations: Boud. Ic. Myc. pl. 361; Cooke, Mycographia pl. $30, f .117$.

4. Sepultaria aurantia Clements, Bot. Surv. Nebr. 4: 12.1896. ?Peziza hybrida Sow. Engl. Fungi 369. 1803.

?Scutellinia hybrida Kuntze, Rev. Gen. Pl. 2: 869. 1891.

Lachnea aurantia Sacc. \& Sydow in Sacc. Syll. Fung. 14: 757. 1899.

Apothecia scattered or crowded, sessile, concave-hemispheric, subsuperficial, reaching a diameter of $1-2 \mathrm{~cm}$., externally clothed with hairs; hymenium concave, reddish or orange; hairs flexuous near the base, those on the exposed parts rigid, septate, darkbrown; asci cylindric or subcylindric; spores 1 -seriate, ellipsoid, containing one or two oil-drops, smooth, 8-10 $\times 18-25 \mu$; paraphyses slightly enlarged above, filled with orange granules.

()n damp ground.

Type locality: Bellevue, Nebraska.

Distribution: Known only from the type locality.

Illustrations: ?Sow. Engl. Fungi pl. 369, f. 1; Boud. Ic. Myc. pl. 356; Cooke, Mycographia pl. 32, f. 126, b.

5. Sepultaria pellita (Cooke \& Peck) Seaver, comb. nov.

Peziza pellita Cooke \& Peck, Grevillea 1: 5. 1872.

Lachnea pellita Sacc. Syll. Fung. 8: 169. 1889.

Scutellinia pellita Kuntze, Rev. Gen. Pl. 2: 869. 1891.

Apothecia scattered or gregarious, sessile and at first entirely immersed in the soil, the margin of the cup appearing above the surface of the soil when expanded, entire or splitting, reaching a diameter of 1-2 cm., externally clothed with flexuous hairs which penetrate into the substratum, binding together the particles of sand and humus on which they grow; hymenium concave, yellowish to pale-orange; hairs brown, sparingly septate, of nearly uniform thickness throughout their entire length, reaching a diameter of $7-8 \mu$; asci cylindric above, reaching a length of $300 \mu$ and a diameter of $20 \mu$; spores 1 -seriate or occasionally slightly crowded in the upper part of the ascus; ellipsoid, the ends rather strongly narrowed, containing one or two large oildrops, $12-14 \times 25-33 \mu$; paraphyses rather strongly enlarged above, reaching a diameter of $7-8 \mu$, filled with yellow granules.

On sandy soil among mosses and humus. 
Type locality: Adirondack Mountains.

Distrinution: New York to Wisconsin.

Illustr.itions: Grevillea 1: pl. $1, f .3$; Cooke, Mycographia pl. 31, f. 119 .

\section{PSEUDOPITHYELLA Seaver, Mycologia 19: 87. 1927.}

Apothecia stipitate or subsessile, rather tough, not shrinking much in drying, in general appearance and in habitat resembling a Pithy' $a$; hymenium scarlet; asci 8-spored, marked near the apex by a prominent thickened ring; spores ellipsoid, hyaline; paraphyses filiform.

Type species, Surcoscypha minuscula Boud. \& Torrend.

1. Pseudopithyella minuscula (Boud. \& Torrend) Seaver, comb. nov.

Sarcoscypha minuscula Boucl. \& Torrend, Bull. Soc, Myc. Fr. 27: 128. 1911.

Apothecia minute, not exceeding 1-2 $\mathrm{mm}$. in diameter, usually stipitate, at first nearly globose, becoming discoid or subdiscoid, externally whitish and more or less tomentose; hymenium concave or nearly plane, scarlet, becoming paler in dried plants; stem slender and very variable in length, when springing from the under side of the substratum, short or almost wanting, seldom exceeding $1 \mathrm{~mm}$. in length, gradually expanding above into the apothecium; asci cylindric or subcylindric above, gradually tapering below into a long stem-like base, reaching a length of $600 \mu$ and a dianeter of $12-15 \mu$, marked by two little ear-like protuberances where the thickened ring passes around near the apex, the point of dehiscence about $3 \mu$ inside of the ring; operculum circular, $3-4 \mu$ in diameter; spores smooth, containing two oil-drops, $10-11 \times 15-17 \mu$; paraphyses filiform, scarcely enlarged above, branched, reaching a diameter of $2 \mu$ at their apices.

On clecaying foliage of cedar.

Type locality: Portugal.

Distribution: Bermuda Islands; also in Europe.

Illustration: Bull. Soc. Myc. Fr. $27: p l .4, f .3$.

The only specimens of this species known on this side of the Atlantic were collected by the writer, and later by H. H. Whetzel, in Bermuda. Our specimens agree splendidly with the illustration cited. 
24. PERROTiA Boud. Bull. Soc. Myc. Fr. 17: 24. 1901.

Apothecia minute, sessile, clothed with hairs, the general appearance being like that of Lachnella except that the asci are operculate; asci clavate, 8 -spored; spores allantoid, at first simple, later apparently 1 -septate, or pseudoseptate; paraphyses present.

Type species, Peziza flammea Alb. \& Schw.

1. Perrotia flammea (Alb. \& Schw.) Boud. Hist. Class. Discom. Eu. 66. 1907.

Peziza flammea Alb. \& Schw. Consp. Fung. 319. 1805.

?Peziza cinnabarina Schw. Trans. Am. Phil. Soc. II. 4: 173. 1832.

?Peziza maculincola Schw. Trans. Am. Phil. Soc. II. 4: 174. 1832.

Laclnella flammea Fries, Summa Veg. Scand. 365. 1849.

Ifelotium flammenm Karst. Myc. Fenn. 1: 157. 1871.

?Peziza Mfeleagris Ellis, Bull. Torrey Club 8: 123. 1881.

? Lachnella cinnabarina Sacc. Syll. Fung. 8: 399. 1889.

?Lachnella incurnescens Sacc. Syll. Fung. 8: 399. 1889.

?Lachnella maculincola Sacc. Syll. Fung. 8: 400. 1889.

Dasyscypla allantospora Earle in Greene, Pl. Baker. 2: 5. 1901.

Lachnella rhoina Earle in Greene, PI. Baker. 2: 6. 1901.

Apothecia gregarious or crowded, at first subglobose, with the margin strongly incurved, becoming scutellate, externally clothed with cinnabar-red hairs which give to the whole apothecium a brick-red color, varying in old specimens to dark-brown, reaching a diameter of $2 \mathrm{~mm}$; hymenium concave, reddish. much paler than the outside of the apothecium; hairs flexuous, of nearly uniform thickness throughout their entire length, reaching a diameter of 3-5 $\mu$, sparingly septate, externally densely covered with coarse red granules; asci reaching a length of $100 \mu$ and a diameter of $10-12 \mu$, gradually tapering below; spores 2 -seriate or irregularly crowded, hyaline, reaching a length of $20 \mu$ and a diameter of 3-4 $\mu$; paraphyses rather stout, reaching a thickness of $4 \mu$.

On dead branches and twigs of deciduous and coniferous trees.

Type locality : Europe.

Distribution: Pennsylvania to Montana and Colorado; also in Europe.

Illustrations: Alb. \& Schw. Consp. Fung. pl. $1, f .6$; Boud. Ic. Myc. pl. 321; E. \& P. Nat. Pf. $1^{1}$ : 202, pl. 159, F-G; Rab. Krypt.-Fl. $1^{3}: 828, f .1-5$.

Exsiccati: N. Am. Fungi 2323; Fungi Columb. 1221, 2733. 
25. LASIOBOLUS Sacc. Bot. Centr. 18:220. 1884.

Apothecia becoming scutellate to discoid, externally clothed with very conspicuous hairs; substance soft and fleshy or waxy; hairs hyaline or subhyaline (white to the naked eye), rigid, nonseptate; asci strongly protruding, cylindric to clavate, 8 -spored; spores ellipsoid, hyaline; paraphyses filiform to clavate, simple or branched.

Type species, Peziza papillala Pers.

Apothecia hyaline to pale-orange; spores $12-14 \times 20-24 \mu$. Apothecia bright-red; spores 12-14 $\times 24-30 \mu$.

1. L. equinus.

2. L. ruber.

1. Lasiobolus equinus (Müll.) Karst. Act. Soc. Fauna Fl. Fenn. $2: 122.1885$.

Elvela equina Müll. Fl. Dan. 13: 8. 1778.

Peziza papillata Pers. Tent. Disp. Fung. 34. 1797.

A scobolus ciliatus $\mathrm{K}$ unze \& Schmidt, Myc. Heft. 1:90. 1817.

Ascobolus pilosus Fries, Syst. Myc. 2: 164. 1822.

Peziza cervina Pers. Myc. Eu. 1:254. 1822.

Peziza diversicolor Fries, Syst. Myc. 2: 88. 1822.

A scobolus papillatus Wallr. F1. Crypt. Ger. 2: 514. 1833.

A scophanus ciliatus Boud. Ann. Sci. Nat. V. 10:254. 1869.

A scobolus diversisporus Fuckel, Symb. Myc. 289. 1869.

Ascophanus pilosus Boud. Ann. Sci. Nat. Y. 10:254. 1869.

IH umaria diversispora Speg. Michelia 1:236. 1878.

Lasiobolus pilosus Sacc. Bot. Centr. 18: 220. 1884.

.1 scophanus pilosus ciliatus Phill. Brit. Discom. 312. 1887.

Lasiobolus diversisporus Sacc. Syll. Fung. 8: 538. 1889.

Apothecia gregarious or crowded, often forming congested masses of considerable extent, at first closed, expanding and becoming discoid or short-cylindric, rarely reaching a diameter of $1 \mathrm{~mm}$, externally clothed with very conspicuous hairs; hymenium concave, plane or slightly convex, roughened by the protruding asci, the color varying from almost hyaline to paleyellow or orange; hairs swollen near the base, where they reach a diameter of $30-35 \mu$, tapering above into a sharp-pointed apex, reaching a length of $375 \mu$, thick-walled, non-septate, hyaline or faintly yellowish; asci cylindric or subcylindric above, tapering rather abruptly below into a stem-like base, reaching a length of $200 \mu$ and a diameter of $20-24 \mu$; spores 1 -seriate or irregularly crowded, smooth, hyaline, or slightly yellowish, ellipsoid, 12-14 $\times 20-24 \mu$; paraphyses slender, septate, slightly enlarged above, reaching a diameter of $2-3 \mu$, often branched. 
On dung of various kinds.

TYPe localitY: Europe.

Distribution: Massachusetts to South Carolina, North Dakota, Colorado, California, and the Bermuda Islands; also in Europe.

Illustrations: Fl. Dan. pl. 779, f. 3; Ann. Sci. Nat. V. 10: pl. 12, f. 42-4t; E. \& P. Nat. Pfl. $1^{1}: 189, f$. 152, A-C; Bull. Lal). Nat. Hist. State Univ. Iowa 6: pl. 32, f. 1; Rab. Krypt.-Fl. $1^{3}$ : 1081, f. 1-4; Pat. Tab. Fung. pl. 487.

Exsiccatı: N. Am. Fungi 233t; Ravenel, Fungi Car. 5: 37 ; Clements, Crypt. Form. Colo. 122.

\section{Lasiobolus ruber (Quél.) Sacc. Syll. Fung. 8: 537. 1889.}

Ascophanus ruber Quél. Grevillea 8: 117. 1880.

Apothecia gregarious or crowded in small congested masses, at first subglobose, becoming discoid or subdiscoid, reaching a diameter of $0.5-1 \mathrm{~mm}$., externally densely clothed with hairs; hymenium concave, plane or convex, bright-red; hairs swollen just above the base and contracted at the point of attachment, tapering above into a bristle-like apex, hyaline or subhyaline, reaching a length of $500 \mu$ and a diameter of $30 \mu$; asci cylindric to clavate, reaching a length of $200 \mu$ and a diameter of 25-30 $\mu$, tapering rather abruptly below into a stem-like base; spores at first 1 -seriate, obliquely arranged with the ends overlapping, often becoming 2-seriate or irregularly crowded, ellipsoid, 12-14 $\times 24-30 \mu$; paraphyses about $3 \mu$ in diameter, enlarged upwards, reaching a diameter of $5-6 \mu$ at their apices.

(On cow dung.

Type Locality: Jura Mountains.

Distribution: Colorado; also in Europe.

Illustrations: Grevillea 8: pl. 131, f. 8 ; Assoc. Fr. Av. Sci. Compte Rendu 12: pl. 7, f. 13; Boud. Ic. Myc. pl. 415.

26. PATELLA Weber; Wiggers, F1. Hols. 106. 1780.

Humaria Fuckel, Symb. Myc. 320. 1869. Not IIumaria Sacc.

Lachnea Gill. Champ. Fr. Discom. 57. 1879. Not Lachnaea L. 1762. (Lachnea, 1753.)

Peziza \$ Scutellinia Cooke, Mycographia 260. 1879.

Peziza $\$$ Neottiella Cooke, Mycographia 261. 1879.

Octospora Hedwig, Descr. 2: 4, 10. 178s. (in part.)

Ciliaria Quél.; Boud. Bull. Soc. Myc. Fr. 1: 105. 1885. See Bull. Soc. Bot.

Fr. 26: 235. 1879. Not Ciliaria Stackh., 1809, nor Ciliaria Haworth, 1821 . 
Cheilymenia Boud. Bull. Soc. Myc. Fr. 1: 105. 1885.

Tricharia Boud. Bull. Soc. Myc. Fr. 1: 10t. 1885.

Trichophaea Boud. Bull. Soc. Myc. Fr. 1: 105. 1885.

Neottiel!a Sace. Syll. Fung. 8: 190. 1889.

Scutellinia Kuntze, Rev. Gen. Pl. 2: 868. 1891.

Humariella Schröt. Krypt.-Fl. Schles, 32:36. 1893.

Pelodiscus Clements, Bot. Surv. Nebr. 5: 7. 1901.

Neottiopezis Clements, Bull. Torrey Club 30:89. 1903.

Apothecia sessile, scattered, gregarious or congested, superficial, at least when fully matured, scutellate to discoid, more rarely concave-hemispheric, externally setose; hymenium red, yellow to brown, or white, concave or plane; hairs septate, hyaline or colored, flexuous or more often rigid; asci variable, usually 8-spored; spores ellipsoid to fusoid, smooth or rough, hyaline or subhyaline; paraphyses filiform or more commonly strongly clavate.

Type species, Elvela ciliata Schaeff.

Hymenium red, yellow, or brown, never white.

Occurring on soil, rotten wood or decaying plant materials.

Hairs simple (not forked or branched).

Hairs well developed, bristly.

Spores becoming distinctly sculptured.

Apothecia clothed with brown hairs.

Spores for a long time sinooth, becoming only minutely rough.

Spores $12-15 \times 20-2+\mu$.

Spores $16-18 \times 30 \mu$.

1. P. scutellata.

2. P. piliseta.

Spores becoming strongly roughened.

Apothecia medium large, $5 \mathrm{~mm}$. or more in diameter.

Plants tropical; spores about $20 \mu$ long.

3. P. cubensis.

Plantstemperate; spores $23 \mu$ or more long.

Occurring on soil among mosses; spores $12-1+$ $\times 23-24 \mu$.

t. P. umbrorum.

Occurring on rotten wood; spores $14-16$ $\times 22-26 \mu$.

5. P. Lusatiae.

Apothecia small, 1-2 mm. in diameter.

6. P. miniata.

7. P. albocincta.

Apothecia clothed with hyaline hairs. Spores remaining permanently smooth or indistinctly and minutely sculptured. 
Hairs hyaline, white to the naked eye.

Spores fusiform, very large.

Spores ellipsoid, medium-sized.

Spores $12 \times 18 \mu$.

Spores $18 \times 24-26 \mu$.

Hairs brown.

Spores small, $7-9 \times 10-12 \mu$.

Spores medium large, $14-22 \mu$ long.

Occurring on burnt ground.

Occurring on old wood.

On deciduous wood; spores

$11-12 \times 20-24 \mu$.

On wood of Sequoia; spores

$$
12-13 \times 17-20 \mu \text {. }
$$

8. P. ovilla.

9. P. Hetieri,

10. P. ricciophila.

11. P. punicea.

12. P. gilia.

Hairs poorly developed, blunt, adpressed.

llairs stellately branched.

Occurring on the dung of animals.

Spores permanently smooth.

Apothecia clothed with stellate hairs.

Apothecia clothed with simple hairs.

Apothecia medium to large, reaching a diameter of $1 \mathrm{~cm}$.

Apothecia bright-yellow.

Hairs small, subhyaline.

Hairs very large, dark-brown.

Apothecia ochraceous-brown.

Apothecia small, not exceeding $1 \mathrm{~mm}$. in diameter.

Apothecia short-cylindric.

Apothecia discoid or subdiscoid

Spores becoming minutely sculptured.

Hymenium white or bluish-white.

Spores becoming sculptured.

Spore-sculpturing consisting of coarse tubercles.

Spores 22-25 $\mu$ long.

Spores 30-35 $\mu$ long.

Spore-sculpturing consisting of minute warts or papillae.

Apothecia reaching a diameter of $2-3 \mathrm{~cm}$.

Apothecia not exceeding a diameter of 5$10 \mathrm{~mm}$.

Spores fusoid, $10-13 \times 20-27 \mu$.

Spores ellipsoid, $8 \times 15 \mu$.

18. P. theleboloides.

19. $P$. coprinaria.

20. P. maculosa.

21. P. pulcherrima.

22. P. raripila.

23. P. fimetaria.

24. P. paludosa.

25. P. tuberculata.

26. P. albida.

27. $P$. gregaria.

28. P. irregularis.

Syores remaining permanently smooth.

Apothecia exceeding $1 \mathrm{~mm}$. in diametcr.

Plants restricted to burned areas.

29. P. abundans.

Plants growing on damp soil or wood.

Occurring on old wood.

Occurring on damp soil.

30. P. Erinaceus.

31. P. altospadicea.

Apothecia less than $1 \mathrm{~mm}$. in diameter.

32. P. pygmaea. 
1. Patella scutellata (L.) Morgan, Jour. Myc. 8: 187. 1902. (Plate 14, Fig. 2; 45, Fig. 19.)

Peziza scutellata L. Sp. Pl. 1181.1753.

Elvela ciliata Schaeff. Fung. Bavar. 4: 112. 1774.

Patella ciliata Weber; Wiggers, FI. Hols. 106. 1780.

Peziza aurantiaca Bull. Herb. Fr. pl. 10. 1780.

Octospora scutellata Hedw. Descr. 2: 10. 1788.

Peziza ciliata $1 \mathrm{loffm}$. Veg. Crypt. 2: 25. 1790.

IItumaria scutellata Fuckel, Symb. Myc. 321. 1869.

?Peziza laeticolor Karst. Myc. Fenn. 1: 66. 1871.

Lachnea scutellata Gill. Champ. Fr. Discom. 75. 1879.

Scutellinia scutellata Kuntze, Rev. Gen. Pl. 2: 869. 1891.

?Scutellinia laeticolor Kuntze, Rev. Gen. 1'l. 2: 869 1891.

II umariella scutellata Schröt. Krypt.-Fl. Schles. 3²:37. 1893.

Ciliuria scutellata Boucl. 1list. Class. Discom. Eu. 61. 1907.

Apothecia gregarious or occasionally crowded, at first globose, closed and appearing dark-brown by reason of the hairs with which the exterior is covered, expanding and becoming scutellate at maturity, with the margin slightly elevated and fringed with hairs which may be very short or may extend beyond the margin a length of $1 \mathrm{~mm}$; hymenium bright-red, almost vermillion, fading in dried specimens to pale-yellow or almost white; hairs swollen just above the base and rather abruptly constricted below at the point of attachment, gradually tapering above to a bristly-like apex, thick-walled, several septate, reaching a diameter of $35-40 \mu$ at the thickest point and a length of $1 \mathrm{~mm}$.; asci cylindric or subcylindric, reaching a diameter of $12-15 \mu$ and a length of 200-225 $\mu$; spores 1 -seriate or irregularly crowded at first densely filled with oil-drops and smooth, the surface finally becoming delicately sculptured, $12-15 \times 20-24 \mu$; sporesculpturing consisting of minute warts; paraphyses strongly enlarged above, reaching a diameter of $7-10 \mu$ at their apices.

On rotten wood or more rarely on soil and leaf-mould.

Type locality: Europe.

Distribution: Maine to Washington and Mexico; also in Europe.

Illustrations: Boud. Ic. Myc. pl. 368; Bull. Lab. Nat. Hist. State Univ. Iowa 6: pl. 10, f. 1; Bull. Herb. Fr. pl. 10; Schaeff. Fung. Bavar. pl. 28t; Cooke, Mycographia pl. 34, f. 131; Pat. Tab. Fung. f. 81; E. \& P. Nat. Pfl. $1^{1}$ : 181, f. 147, $A-B$; Massee, Brit. Fungus-F1. 4: 290, f. 20, 21; Rab. Krypt.-Fl. $1^{3}$ : 1034, f. 1-t; Sow. Engl. Fungi pl. 2t; Gill. Champ. Fr. Discom. (suites); Bolton, Geschichte 3: pl. 108, f. 1 . 
Exsiccati: Clements, Crypt. Form. Colo. 119; N. Am. Fungi 1310 .

2. Patella piliseta (Clem.) Seaver, comb. nov.

Pelodiscus pilisetus Clements, Bot. Surv. Nebr. 5: 8. 1901.

Lachnea piliseta Sacc. \& Sydow in Sacc. Syll. Fung. 16: 1147. 1902.

Apothecia at first closed and subglobose, expanding and becoming scutellate to discoid, reaching a diameter of $1 \mathrm{~cm}$.; hymenium plane or concave, yellowish-brown; hairs scattered, rigid, pointed, brown, 2-3-septate, attenuated at the base, reaching a length of $300-400 \mu$ and a diameter of $25 \mu$; asci cylindric or subcylindric, reaching a length of $250 \mu$ and a diameter of $25 \mu$; spores obliquely 1 -seriate, broad-ellipsoid, densely filled with granules, smooth, becoming indistinctly sculptured, $16-18 \times 30 \mu$; paraphyses clavate, septate, subhyaline, reaching a diameter of $8 \mu$ at their apices.

On wet wood.

Trpe locality: Barney Creek, Keya Paha County, Nebraska. Distribution: Nebraska and Colorado.

3. Patella cubensis (Berk. \& Curt.) Seaver, comb. nov. Peziza cubensis Berk. \& Curt.; Berk. Jour. Linn. Soc. 10:366. 1868. Peziza stictica Berk. \& Curt.; Berk. Jour. Linn. Soc. 10:367. 1868. Peziza texensis Berk. \& Curt.; Berk. Grevillea 3: 154. 1875.

Lachnea cubensis Sacc. Syll. Fung. 8: 176. 1889.

Lachnea stictica Sacc. Syll. Fung. 8: 177. 1889.

Lachnea texensis Sacc. Syll. Fung. 8: 182. 1889.

Scutellinia stictica Kuntze, Rev, Gen. P1. 2: 869. 1891.

Scutellinia terensis Kuntze, Rev. Gen. Pl. 2: 869. 1891.

Apothecia sessile, expanding, becoming scutellate, reaching a diameter of 3-6 mm. externally, especially about the margin clothed with long bristly hairs; hymenium slightly concave or nearly plane, bright-red, fading in dried specimens; hairs thickwalled, septate, bristly, tapering above into a bristle-like apex, dark-brown, reaching a length of $1 \mathrm{~mm}$. and a diameter of 25-30 $\mu$, intermixed with much shorter hairs which are occasionally clavate at the apex; asci cylindric, about $14-15 \times 200-$ $220 \mu$; spores 1 -seriate, ellipsoid, hyaline, becoming sculptured, 11-13 $\times 16-21 \mu$; spore-sculpturing consisting of rather coarse warts; paraphyses slender below, strongly enlarged at their apices.

On rotten wood, more rarely on herbaceous stems.

Trpe locality: Cuba. 


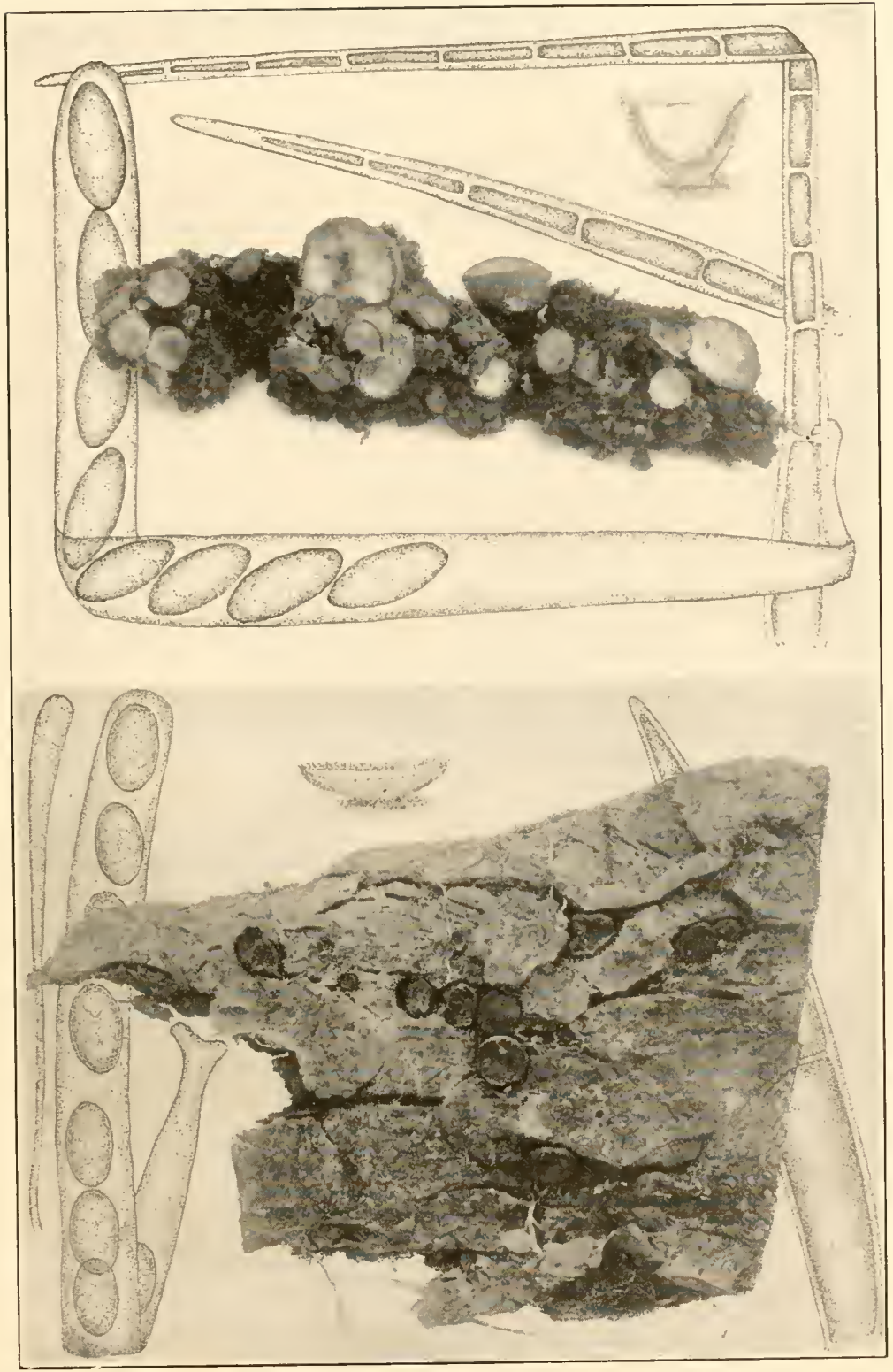

1. PATELLA ALBIDA

2. PATELLA SCUTELLATA 

Distribution: Cuba to Jamaica and Texas; also in Trinidad and South America.

Illustrations: Cooke, Mycographia pl. 37, f. 14t, 145; Jour. Lim. Soc. $31:$ pl. $18, f .2$.

4. Patella umbrorum (Fries) Seaver, comb. nov.

Peziza umbrosa Fries, Syst. Myc. 2: 85. 1822. Not P. umbrosa Schr. Peziza umbrorum Fries, Syst. Myc. 2: 612. 1823.

II umaria umbrortm Fuckel, Symb. Nyc. 323. 1869.

Lachnea umbrorum Gill. Champ. Fr. Discom. 209. 1886.

Scutellinia umbrarum Kuntze, Rev. Gen. P'l. 2: 869. 1891.

?Sepultaria rubropurpurea Clements, Bot. Surv. Nebr. 4: 15. 1896.

? Lachnea rubropurpurea Sacc. \& Sydow in Sacc. Syll. Fung. 14: 755. 1899.

?Scutellinia heterospora Clements, Bull. Torrey Club 30:90. 1903.

?Scutellinia dispora Clements, Bull. Torrey Club 30: 90. 1903.

?Lachnea heterospora Sacc. \& 1. Sacc. in Sacc. Syll. Fung. 18:36. 1906.

?Lachnea dispora Sacc. \& D. Sacc. in Sacc. Syll. Fung. 18: 37. 1906.

Ciliaria umbrorum Boud. Hist. Class. Discom. Eu. 61. 1907.

Apothecia gregarious or densely crowded, at first closed and globose, at maturity scutellate, reaching a diameter of $5 \mathrm{~mm}$. to $1 \mathrm{~cm}$., externally appearing brown from the dark-colored hairs; hymenium slightly concave, almost plane or occasionally slightly convex, bright-red, almost scarlet; excipulum composed of large roundish or slightly angular cells which form a palisade near the margin, the loose ends of which project, giving rise to a fringe-like border of club-shaped hyphae; hairs ranging from a few pale cells when young to long rigid setae at maturity, dark reddish-brown, reaching a length of $1 \mathrm{~mm}$. and a diameter of $35 \mu$ at the broadest point, closely septate, the walls $3-4 \mu$ thick, constricted below near the point of attachment; asci cylindric above, gradually tapering below into a stem-like base, reaching a length of $325-350 \mu$ and a diameter of $26-27 \mu, 8$-spored but part of the spores often remaining undeveloped; spores 1-seriate, usually obliquely arranged in the ascus, at first smooth and usually containing one large oil-drop, $12-14 \times 23-24 \mu$, hyaline, at maturity becoming sculptured; spore-sculpturing consisting of rather coarse warts; warts about $2 \mu$ in diameter; paraphyses rather stout, about 3-4 $\mu$ in diameter below, strongly and rather abruptly enlarged above, reaching a diameter of $10 \mu$ at their apices, densely filled with minute orange granules.

On very damp soil, more rarely on rotten wood.

Type locality : Europe. 
Distribution: New York to Colorado, New Mexico and West Virginia; also in Europe.

Illustrations: Cooke, Mycographia pl. 35, f. 138; Boud. Ic. Myc. 369; Gill. Champ. Fr. Discom. pl. 68.

Exsiccati: N. Am. Fungi 2321, 2911.

5. Patella Lusatiae (Cooke) Seaver, comb. nov.

Peziza Lusatiae Cooke, Mycographia So. 1875.

?Peziza badioberbis Berk.; Cooke, Grevillea 8: 61. 1879.

?Lachnea badioberbis Sacc. Syll. Fung. 8: 173. 1889.

Lachnea Lusatiae Sacc. Syll. Fung. 8: 178. 1889.

Scutellinia Lusatiae Kuntze, Rev. Gen. Pl. 2: 869. 1891.

Scutellinia badeoberbis Kuntze, Rev. Gen. Pl. 2: 869. 1891.

Ciliaria Lusatiae Boud. Hist. Class. Discom. Eu. 62. 1907.

Apothecia gregarious, at first globose, gradually expanding and at maturity scutellate, reaching a diameter of $5 \mathrm{~mm}$., externally densely clothed with hairs; hymenium plane or slightly concave, bright-red; hairs very long and forming a conspicuous fringe about the border of the apothecium, dark-colored, septate, swollen near the base and often forked below, gradually tapering above to a bristle-like apex, often reaching a length of more than $1 \mathrm{~mm}$.; asci cylindric above, reaching a diameter of 15-18 $\mu$; spores 1 -seriate, broad-ellipsoid or slightly narrowed toward the ends, containing one or two oil-drops, at first smooth, becoming sculptured, hyaline or faintly yellowish, 14-16 $\times 22-26 \mu$; sporesculpturing consisting of rather prominent warts; paraphyses strongly enlarged above, reaching a diameter of $\delta-9 \mu$ at their apices.

On rotten wood.

Type locality: Germany.

Distribution: New York; also in Europe and New Zealand.

Illustration: Cooke, Mycographia pl. 37, f. 146.

\section{Patella miniata (Clem.) Seaver, comb. nov.}

Pelodiscus miniatus Clements, Bot. Surv. Nebr. 5: 8. 1901.

Lachnea Clementsi Sacc, \& Sydow in Sacc. Syll. Fung. 16:1147. 1902.

Apothecia occurring singly or in groups of two or three, reaching a diameter of $1-2 \mathrm{~mm}$. and $0.5 \mathrm{~mm}$. high, margin naked, externally except the base clothed with very short hairs; hymenium concave or nearly plane, circular in form, red; hairs short, continuous, flexuous, pale-yellow; spores 1-seriate, parallel with the ascus or obliquely arranged, ellipsoid, of ten only four 
developed, the other four remaining abortive, $12-14 \times 26-28 \mu$, hyaline, at maturity beautifully sculptured; spore-sculpturing consisting of papillae 2-3 $\mu$ high; paraphyses septate, enlarged above, reaching a diameter of $9-12 \mu$ at their apices.

On stercoriated mud.

Type locality: Beal's slough, Otawaine woods, Nebraska.

Distribution: Known only from the type locality.

7. Patella albocincta (Berk. \& (urt.) Seaver, comb. nov.

(PLATE

45, FIr. 11, 12.)

?Peziza Polytrichi Schum. Enum. Pl. Saell. 423. 1803.

Peziza albocincta Berk. \& Curt. Crevillea 3: 154. 1875.

Neottiella albocincta Sacc. Syll. Fung. 8: 190. 1889.

Neottiella ovilla flavodisca Cooke \& Massee, Grevillea 21: 71. 1895.

Neottiella Polytrichi Massee, Brit. Fungus-F1. 4:370. 1895.

Apothecia gregarious or scattered, at first closed and subglobose, gradually expanding, at maturity turbinate to subscutellate, sessile or short-stipitate, reaching a diameter of 10-12 mm. but often much smaller, externally clothed with hyaline (white to the naked eye) hairs which form a delicate fringe about the margin of the apothecium; marginal hairs often in dense fascicles, individual hairs $4-5 \mu$ in diameter at the base, gradually tapering toward the apex, which is blunt and about $2 \mu$ in diameter, reaching a length of $275 \mu$, hyaline; asci cylindric or subcylindric, reaching a length of $200 \mu$ and a diameter of 14-16 $\mu$; spores 1 -seriate at maturity or with the ends slightly overlapping, ellipsoid, with the ends strongly narrowed, containing one large oil-drop, finally becoming sculptured, 10-12 $\times 24-28 \mu$; spore-sculpturing consisting of minute warts; paraphyses slightly enlarged above, reaching a diameter of $4-5 \mu$ at their apices.

On the ground in woods, of ten among mosses.

Tyie locality: South Carolina.

Distrubution: New York to South Carolina; also in Europe.

Illustrations: Massee, Brit. Fungus-Fl. 4: 371, f. 1-t; Grevillea 22: 109, f. 1-5; Cooke, Mycographia pl. 40, f. 157.

8. Patella ovilla (Peck) Seaver, comb. nov.

Peziza orilla Peck, Ann. Rep. N. Y. State Nus. 28: 66. 1879.

Neottiella orilla Sacc. Syll. Fung. 8: 194. 1889.

Humaria rhodolenca Bres. Fungi Trid. 2: 79. 1898.

Neottiopezis macrospora Clements, Bull. Torrey Club 30: 89. 1903.

Neottiella macrospora Sacc. \& D. Sacc. in Sacc. Syll. Fung. 18: 39. 1906. 
Apothecia subglobose or hemispheric, slightly attenuated below, the margin crenate, reaching a diameter of $5 \mathrm{~mm}$. to $1 \mathrm{~cm}$., externally whitish and clothed with tomentose hairs; the excipular cells reaching a diameter of $20 \mu$; hairs blunt, rather thin-walled, septate and slightly constricted at the septa, reaching a diameter of $15 \mu$; asci cylindric above, tapering below into a stem-like base, reaching a length of $280-350 \mu$ and a diameter of $14-16 \mu, 8$-spored; spores fusnid, containing one to three oil-drops, $10-14 \times 32-40 \mu$, smooth or very minutely sculptured; spore-sculpturing consisting of minute warts; paraphyses branching, septate, $3.5-4 \mu$ in diameter, enlarged above, where they reach a diameter of $4-7 \mu$.

On the ground in woods.

Trpe Locality: Sageville, New York.

Distribution: New York to Minnesota and Nebraska; also in Europe.

Illustration: Bres. Fungi Trid. 2: pl. 193, f. 2.

\section{Patella Hetieri (Boud.) Seaver, comb. nov.}

Neottiella Hetieri Boud. Bull. Soc. Myc. Fr. 12: 12. 1896.

Apothecia gregarious or scattered, at first subglobose, opening and gradually expanding, finally becoming scutellate or subdiscoid, reaching a diameter of $2 \mathrm{~mm}$., externally pale-orange and clothed with delicate white hairs; hymenium slightly concave or nearly plane, bright orange-red; hairs fairly abundant but not conspicuous to the unaided eye, rigid, blunt when young, sharp-pointed when mature, hyaline, septate, reaching a length of $150-200 \mu$ and a diameter of $4-6 \mu$; asci cylindric above, gradually tapering below into a short stem-like base, reaching a length of $200-225 \mu$ and a diameter of $16-20 \mu$, 8-spored; spores 1 -seriate, ellipsoid or more often ovoid, containing one large oildrop or very rarely two, hyaline, about $12 \times 18 \mu$; paraphyses stout, rather freely branched, septate, often swollen near the septa, filled with orange granules, reaching a diameter of $8 \mu$ at their apices.

On old burnt place which has been overrun with mosses, or occasionally where there is no trace of fire.

Type LOCAlity: Europe.

Distribution: New York and Connecticut; also in Europe.

Illustration: Bull. Soc. Myc. Fr. 12: pl. 3, f. 2. 
10. Patella ricciophila Seaver, sp. nov. (PLATE 45, FI(i. 15, 16.)

Apothecia gregarious or scattered, at first globose, becoming expanded and sulpdiscoid, reaching a diameter of $1.5 \mathrm{~mm}$., paleorange, surrounded by a pale-orange or whitish border, and rather densely clothed with white hairs; hymenium plane, slightly concave, or convex, a little brighter in color than the outside of the apothecium, becoming roughened or pitted; hairs perfectly hyaline, thick-walled, tapering into an acute apex, reaching a length of $150-200 \mu$ and a diameter of 16-18 $\mu$; asci cylindric or subcylindric, with a short stem-like base, reaching a length of $180-200 \mu$ and a diameter of $20 \mu$, 8-spored; spores 1 -seriate or rarely crowded, decidedly ovoid, the small end directed either upward or downward, usually containing one large oil-drop, hyaline, smooth, about $18 \times 24-26 \mu$; paraphyses stout, slightly enlarged above, reaching a diameter of 5-6 $\mu$, filled with orange granules.

Closely associated with and apparently growing on the living thallus of Riccia nigrella brought from Texas and grown in the propagating house of The New York Botanical Garden, December 6,1915 .

Distribution: Known only from the type collection.

\section{Patella punicea (Clem.) Seaver, comb. nov.}

Sepultaria punicea Clements, Bot. Surv. Nebr. 4: 14. 1896.

Lachnea punicea Sacc. \&. Sydow in Sacc. Syll. Fung. 14: 759. 1899.

Apothecia subgregarious, superficial or nearly so, at first subglobose, expanding and becoming scutellate to discoid, reaching a diameter of $2 \mathrm{~mm}$., externally densely clothed with hairs; hymenium bright-red, concave; hairs brown, septate, sharppointed, reaching a length of $300-400 \mu$ and a diameter of $16-20 \mu$; asci cylindric or subcylindric, reaching a length of $225-2.30 \mu$ and a diameter of 10-14 $\mu$; spores 1 -seriate, ellipsoid, smooth, hyaline, 7-9 $\times 10-12 \mu$; paraphyses filiform, clavate, densely filled with orange granules.

On wet, decaying wood.

Type Lochlity: Bluffs of the Missouri River, Otoe County, Nebraska.

Distribution: Known only from the type locality. 


\section{Patella gilva (Boud.) Seaver, comb. nov.}

Peziza gilva Boud.; Cooke, Mycographia 240. 1879.

Tricharia gilva Boud. Hist. Class. Discom. Eu. 57. 1907.

Lachnea gilva Sacc. Syll. Fung. 8: 18t. 1889.

Scutellinia gilva Kuntze, Rev. Gen. Pl. 2: 869. 1891.

Apothecia scattered or occasionally closely crowded, at first globose or subglobose, gradually expanding and becoming shallow cup-shaped, reaching a diameter of 5-6 mm., externally ochraceous-brown and clothed with rather inconspicuous hairs; hymenium concave, ochraceous or brownish; hairs blunt when young, sharp-pointed when mature, septate, pale-yellowish, reaching a length of $200 \mu$ and a diameter of $8 \mu$; asci cylindric above, gradually tapering below into a stem-like base; spores 1-seriate, ellipsoid, hyaline, containing no oil-drops, about 8-10 $\times 14-18 \mu$, smooth; paraphyses rather stout, gradually enlarged above, reaching a diameter of $4-5 \mu$ at their apices.

On an old burnt place which had been overrun with mosses.

Type locality: Europe.

Distribution: New York; also in Europe.

Illustrations: Cooke, Mycographia pl. 113, f. 406; Boud. Ic. Myc. pl. 347.

13. Patella setosa (Nees) Seaver; Brenckle, Fungi Dakot. 458. 1920.

Peziza setosa Nees, Syst. Pilze 260. 1817.

Humaria setosa Fuckel, Symb. Myc. 321. 1869.

Lachnea setosa Gill. Champ. Fr. Discom. 75. 1880.

Scutellinia setosa Kuntze, Rev. Gen. P1. 2: 869. 1891.

Ciliaria setosa Boud. Hist. Class. Discom. Eu. 62. 1907.

?Lachnea subcrinita Rehm, Ann. Nyc. 7: 535. 1909.

Apothecia thickly gregarious but seldom crowded, at first globose or subglobose and bristling with a dense covering of dark-colored setae, expanding and becoming discoid or subdiscoid, reaching a diameter of $2-3 \mathrm{~mm}$.; hymenium plane or nearly so, dull-red; hairs reaching a length of $500 \mu$ and a diameter of $25 \mu$ at the broadest point near the base, forked and rooting at the extreme base, thick-walled, dark-brown, subacute at their apices; asci cylindric or subcylindric, reaching a length of $300-325 \mu$ and a diameter of $12-15 \mu$; spores 1 -seriate, parallel with the ascus or slightly oblique, ellipsoid, smooth, filled with numerous oil-drops which become more or less broken up in dried plants, 11-13 $\times 20-22 \mu$; paraphyses enlarged at their apices, where they reach a diameter of $4-5 \mu$. 
On dead and often partially rotted wood of deciduous trees. Type locality: Europe.

Distribution: New York to North Dakota, Colorado and Nicaragua; also in Europe.

Illustrations: Boud. Ic. Myc. pl. 370; Cooke, Mycographia pl. 37, f. 133; Nees, Syst. Pilze pl. 37, f. 275; Cill. Champ. Fr. Discom. (suites); Proc. Ohio Acad. Sci. 5: pl. 1, f. 1-7.

Exsiccsti: N. Am. Fungi 2033, 2910 (as Pesisa vitellina Pers.); Seaver, North Dakota Fungi 27; Brenckle, Fungi Dakot. 458 .

\section{Patella Sequoiae (Phill.) Seaver, comb. nov.}

Peziza Sequoiae Phill. Grevillea 7:22. 1878.

Lachnea Sequoiae Sacc. Syll. Fung. 8: 176. 1889.

Scutellinia Sequoiae Kuntze, Rev. Gen. Pl. 2: 869. 1891.

Apothecia gregarious, sessile, reaching a diameter of $3-5 \mathrm{~mm}$, externally clothed with hairs; hymenium concave, reddish or flesh-colored; hairs short near the base, the marginal ones reaching a length of $600 \mu$ long, straight and subacute, sparingly septate; asci cylindric or subcylindric; spores 1 -seriate, ellipsoid, smooth, hyaline, $12-13 \times 17-20 \mu$; paraphyses filiform, slightly enlarged above.

On dead twigs of Sequoia gigantea.

Type Locality: California.

Distribution: Known only from the type locality.

Illustration: Cooke, Mycographia pl. 113, f. 403.

15. Patella melaloma (Alb. \& Schw.) Seaver, comb. nov. (PLATE 15, FIG. 2.)

IIumaria melaloma Massee, Brit. Fungus-F1. 4: 411. 1895.

Peziza melaloma Alb. \& Schw. Consp. Fung. 336. 1805.

Peziza intermixta Karst. Not. Fauna Fl. Fenn. 10: 119. 1869.

Pyronema melalonum Fuckel, Symb. Myc. 319. 1869.

Peziza adusta Cooke \& Peck; Peck, Ann. Rep. N. Y. State Mus. 27: 107.

1875.

Aleuria melaloma Gill. Champ. Fr. Discom. 5t. 1879.

IIumaria melalomoides Rehm in Sydow, Mycoth. March.778. 1884.

Laclnea melaloma Sacc. Syll. Fung. 8: 181. 1889.

?II maria macrocystis Sacc. Syll. Fung. 8: 122, 1889.

?Pyronema subhirsutum Sacc. Syll. Fung. 8: 108. 1889.

Scutellinia melaloma Kuntze, Rev. Gen. Pl. 2:869. 1891.

II umariella melaloma Schröt. Krypt.-Fl. 3²:37. 1893.

Lachnea intermixta Rehm in Rab. Krypt.-Fl. 13 $\mathbf{1}^{3}$ 1047. 1896.

II umaria adusta Sace. Syll. Fung. 8: 1+1. 1889. 
IIumaria flavoaurantiaca Rehm, Ann. Myc. 2:35. 1904. Anthracobia melaloma Boud. Hist. Class, Discom. Eu. 65. 1907.

Apothecia gregarious or more often densely crowded, forming continuous masses often several $\mathrm{cm}$. in diameter, at maturity scutellate with the margin slightly elevated, externally dark reddish-brown and clothed with hairs which are closely adpressed and not extending above the margin of the apothecium, reaching a diameter of $3-5 \mathrm{~mm}$. or rarely $1 \mathrm{~cm}$. ; hymenium slightly concave, plane or convex, very variable in color, ranging from paleto bright-orange or dark-brown; hairs flexuous, brow11, sparingly septate, the ends blunt, of variable length; excipular cells large, rounded or angular, with brown cell walls, reaching a diameter of $35 \mu$; asci cylindric or subcylindric, reaching a length of 150-200 $\mu$ and a diameter of $12-14 \mu$, rather abruptly narrowed below; spores 1 -seriate, parallel with the ascus or slightly oblique, or occasionally irregularly disposed, containing one or more, commonly two oil-drops, ellipsoid, smooth, hyaline, $7-10 \times 16-$ $21 \mu$; paraphyses enlarged upwards, reaching a diameter of $4-6 \mu$ at their apices, reddish.

On burnt ground and charcoal beds.

Type Locality: Europe.

Distribution: New York to Iowa, Texas, California and Jamaica; also in Europe.

Illustrations: Alb. \& Schw. Consp. Fung. pl. 2, f. 5; Boud. Ic. Myc. pl. 307; Bull. Lab. Nat. Hist. State Univ. Iowa 6: pl. 10, f. 2; Gill. Champ. Fr. Discom. pl. 55, f. 2; Pat. Tab. Fung. f. 275; Cooke, Mycographia pl. 17, f. 67; Rab. Krypt.-Fl. $1^{3}: 1032, f .1-5$.

16. Patella crucipila (Cooke \& Phill.) Seaver, comb. nov.

Peziza crucipila Cooke \& Phill.; Cooke, Mycographia 136. 1876.

Lachnea crucipila Phill. Brit. Discom. 229. 1887.

Neottiella crucipila Sacc. Syll. Fung. 8: 192. 1889.

Apothecia gregarious or crowded, at first subglobose, expanding and becoming scutellate to discoid, the margin of the apothecium even or irregularly wavy, externally pale-yellow and clothed with a mass of rather pale hairs, attached to the substratum by a mass of coarse, white mycelium, reaching a diameter of about $5 \mathrm{~mm}$; hymenium concave or plane, bright-orange, brighter than the outside of the apothecium (the type described as pale-scarlet), becoming paler in dried specimens; excipular cells large and irregularly polygonal, reaching a diameter of 
$50-75 \mu$, the walls hyaline or very faintly yellowish; hairs 2-4pronged or more rarely with five or six rays springing from nearly the same point, the basal cell often enlarged and irregularly rectangular, the rays reaching a diameter of $20 \mu$ at their bases and a length of $500-600 \mu$, sharp-pointed, pale-brown; asci cylindric or subcylindric, reaching a length of $200-225 \mu$ and a diameter of $12-14 \mu$; spores 1 -seriate, ellipsoid, smooth, thinwalled and easily collapsing, $9 \times 15-20 \mu$; paraphyses clavate, filled with orange granules.

On rich sandy soil in coniferous woods, occasionally on bits of wood.

Type Locality: Great Britain.

Distributios: Washington; also in Europe.

Illustrations: Cooke, Mycographia pl. 60, f. 237; Gill. Champ. Fr. Discom. pl. 71; Pat. Tab. Fung. f. 481.

17. Patella stercorea (Pers.) Neber; Niggers, F1. Hols. 106. 1780 .

?Elvela lutea Scop. F1. Carn. 2: 481. 1772.

Peziza stercorea Pers. Obs. Myc. 2: 89. 1799.

Peziza ciliata Bull. Champ. Fr. 1:257. 1809.

IH maria stercorea Fuckel, Symb. Myc. 321. 1869.

IIumaria alpina Fuckel, Symb. Myc. Nacht. 3:32. 1875.

Lachnea stercorea Gill. Champ. Fr. Discom. 76. 1880.

Lasiobolus stercoreus Karst. Act. Fauna F1. Fenn. 2: $122 . \quad 1885$.

?Lachnea alpina Sacc. Syll. Fung. 8: 180. 1889.

?Scutellinia alpina Kuntze, Rev. Gen. Pl. 2: 869. 1891.

Scutellinia stercorca Luntze, Rev. Gen. P1. 2: 869. 1891.

Humariella stercorea Schröt. Krypt.-F1. Schles, 32: 37. 1893.

Patella lutea Morgan, Jour. Myc. 8: 188. 1902.

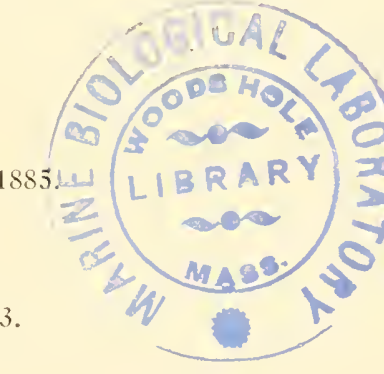

Cheilymenia stercorea Boud. Hist. Class. Discom. Eu. 63. 1907.

Apothecia gregarious or crowded, expanding and becoming scutellate to discoid, externally pale-yellowish, clothed with hairs of two kinds, simple and compound, reaching a diameter of $2 \mathrm{~mm}$; hymenium plane or concave, bright-orange; the simple hairs confined mainly to the margin of the apothecium, giving rise to a conspicuous fringe-like border, reaching a length of $1 \mathrm{~mm}$. and a diameter of $25-50 \mu, 2-5$-septate, thick-walled, acute at the apex and with an enlarged and often forked base, dark-brown; stellate hairs usually not extending above the margin of the apothecium, consisting of a triangular or rectangular basal portion with 2-5 rays which are straight, acute at their apices, and reach a maximum length of $200 \mu$, the rays 
similar in color and appearance to the simple hairs but smaller; asci cylindric or subcylindric, reaching a length of $225-300 \mu$ and a diameter of $15-20 \mu$; spores 1 -seriate, parallel with the ascus or oblique, ellipsoid, smooth, pale-yellow, 9-14 $\times 18-24 \mu$; paraphyses clavate, reaching a diameter of $7-8 \mu$ at their apices.

On cow dung.

Type Locality: Europe.

Distribution: New York to California; also in Europe.

Illustrations: Boud. Ic. Myc. pl. 384; Cooke, Mycographia pl. 38, f. 147, 148; Gill. Champ. Fr. Discom. pl. 63, f. 1; Bull. Herb. Fr. pl. 438, f. 2; Sow. Engl. Fungi pl. 352.

18. Patella theleboloides (Alb. \& Schw.) Seaver, comb. nov.

?Peziza fimetaria Schum. Pl. Saell. 2: 426. 1803.

Peziza theleboloides Alb. \& Schw. Consp. Fung. 321. 1805.

?Pyronema subhirsutum Fuckel, Symb. Myc. 320. 1869. Excl. syn.

Peziza dalmeniensis Cooke, Grevillea 3: 66. 1874.

Alenria subhirsuta Gill. Champ. Fr. Discom. 49. 1879.

Lachnea theleboloides Gill. Champ. Fr. Discom. 74. 1879.

Humaria theleboloides Quél. Ench. Fung. 285. 1886.

Lachnea dalmeniensis Sacc. Syll. Fung. 8: 180. 1889.

Scntellinia theleboloides Kuntze, Rev. Gen. Pl. 2: 869. 1891.

Scutellinia dalmeniensis Kuntze, Rev. Gen. Pl. 2: 869. 1891.

Lachnea Lojkaena Rehm in Rab. Krypt.-Fl. 13 : 1045. 1896.

Lachnea diplotricha Rehm, Ann. Myc. 2: 34. 1904.

Cheilymenia theleboloides Boud. Hist. Class. Discom. Eu. 62. 1907.

Cheilymenia subhirsuta Boud. Hist. Class. Discom. Eu. 62. 1907.

Cheilymenia fimetaria Boud. Hist. Class. Discom. Eu. 63. 1907.

Cheilymenia dalmeniensis Boud. Hist. Class. Discom. Eu. 63. 1907.

Apothecia gregarious or closely crowded, forming congested masses, at first subglobose or short-cylindric, expanding and becoming scutellate to discoid, reaching a diameter of 3-5 $\mathrm{mm}$. or rarely as large as $1 \mathrm{~cm}$., externally pale-yellow, sparingly clothed with hairs; hymenium concave or plane, bright-yellow; the excipular cells rounded or angular, reaching a diameter of $35 \mu$, the cell walls pale-yellow; hairs rigid, hyaline or very paleyellow, enlarged at the base, tapering into a bristle-like apex, $2-4$-septate, reaching a length of $200-500 \mu$ and a diameter of $10 \mu$ at their bases, very rarely branched; asci cylindric above, abruptly tapering at the base, reaching a length of 225-275 $\mu$ and a diameter of $12-14 \mu$; spores 1 -seriate, parallel with the ascus or oblique, ellipsoid, smooth, hyaline or faintly yellowish, thin-walled, often collapsing on one side, $7-10 \times 14-20 \mu$; pa- 
raphyses slightly enlarged at their apices, reaching a diameter of $3-4 \mu$, filled with yellow granules.

On cow dung or occasionally on rich soil, rubbish, paper, cloth, etc.

TyPE LOCALITY: Europe.

Distrimution: Connecticut to Delaware, North Dakota, California and Bermuda; also in Europe.

Illustrations: Alb. \& Schw. Consp. Fung. pl. 12, f. 4; Boud. Ic. Myc. pl. 380, 381; Gill. Champ. Fr. Discom. pl. 50, f. 1; Cooke, Mycographia pl. 39, f. 151, 153; Bull. Lab. Nat. Hist. State [niv. Iowa 6: pl. $8, f .2$.

Exsiccati: N. Am. Fungi 2035; Brenckle, Fungi Dakotenses $1+1$ (as IIumaria subhirsuta (Schum.) Karst.).

19. Patella coprinaria (Cooke) Seaver, comb. nov. (PlATE 45, FIG. 18.)

Peziza coprinaria Cooke, Grevillea 4:91. 1875.

Pesizu scubalonta Cooke \& Gerard; Cooke, Grevillea 4:92. 1875.

Lachnea coprinaria Phill. Brit. Discom. 224. 1887.

Lachnea scubalonta Sacc. Syll. Fung. 8: 179. 1889.

Scutellinia coprinaria Kuntze, Rev. Gen. l'l. 2: 869. 1891.

Sepultaria pediseta Clements, Bot. Surv. Nebr. 4:13. 1896.

Scutellinia scubalonta Kuntze, Rev. Gen. Pl. 2: 869. 1891.

Lachnea pediseta Sacc. \& Sydow in Sacc. Syll. Fung. 14: 758. 1899.

Cheilymenia coprinaria Boud. Hist. Class. Discom. Eu. 63. 1907.

Apothecia gregarious or scattered, at first closed, expanding and becoming scutellate to discoid, the margin slightly wavy, pale-yellow, sparingly clothed with hairs, reaching a diameter of $3 \mathrm{~mm}$. to $1 \mathrm{~cm}$; hymenium plane or concave, bright-yellow to pale-orange; the excipular cells very large, reaching a diameter of $75-80 \mu$, irregularly polygonal, thin-walled, the walls subhyaline; hairs conspicuous, those about the margin projecting into a sparse fringe-like border, pale-brown, sparingly septate, the base often once or several times divided, giving rise to rootlike branches, tapering above into a bristle-like apex, reaching a length of $600 \mu$ and a diameter of $20-30 \mu$ at the base; asci cylindric or subcylindric, reaching a length of $200 \mu$ and a diameter of 12-14 $\mu$; spores 1 -seriate, ellipsoid, smooth, hyaline, 8-10 $\times 17-20 \mu$; paraphyses clavate, reaching a diameter of 5-7 $\mu$ at their apices.

On dung of various kinds.

TyPE LOCAlity: Rannock, Scotland. 
Distribution: New York to Nebraska and California; also in Europe.

Illustratioss: Cooke, Mycographia pl. 38, f. 149, 150; Boud. Ic. Myc. pl. 383.

20. Patella maculosa (Phill.) Seaver, comb. nov.

Peziza maculosa Phill. Grevillea 5: 116. 1877.

Lachnera maculosa Sacc. Syll. Fung. 8: 171. 1889.

Apothecia sessile, superficial or semi-immersed, fleshy, brown, reaching a diameter of $1 \mathrm{~cm}$., externally marked with brown spots and clothed with flexuous hairs; hymenium slightly concave, brownish; hairs slender, septate, blunt, pale-brown, minutely sculptured; asci cylindric, 8-spored; spores ellipsoid, smooth, hyaline, $7 \times 14 \mu$; paraphyses filiform, septate.

On cow dung.

Type Locality: Blue Canyon, Sierra Nevada Mountains, California.

Distribution: Known only from the type locality.

Illustrations: Grevillea 5: pl. 89, f. 11; Cooke, Mycographia pl. $99, f .358$.

\section{Patella pulcherrima (Crouan) Seaver, comb. nov.}

Ascobolus pulcherrimus Crouan, Ann. Sci. Nat. N. 10: 196. 1858.

Pesiza pulcherrima Cooke, Nycographia 84. 1876.

IIumaria pulcherrima Speg. Michelia 1:237. 1878.

Lachnea pulcherrima Gill. Champ. Fr. Discom. 76. 1880.

Cheilymenia pulcherrima Boud. Hist. Class. Discom. Eu. 63. 1907.

Scutellinia pulcherrima Kuntze, Rev. Gen. Pl. 2: 869. 1891.

Lasiobolus pulcherrimus Schröt. Krypt.-Fl. Schles. 3²: 54. 1893.

Apothecia gregarious or congested, of ten forming dense masses several $\mathrm{cm}$. in diameter, short-cylindric, scarcely exceeding $1 \mathrm{~mm}$. in diameter and reaching a height of $1 \mathrm{~mm}$., externally paleyellow and sparingly clothed with hairs; hymenium plane or concave, bright-yellow; hairs small, rigid, enlarged at their bases, acute at their apices, 2-4-septate, pale-brown, reaching a length of $100-200 \mu$ and a diameter of $15 \mu$ at their bases; asci cylindric or subcylindric, reaching a length of $200-235 \mu$ and a diameter of $20 \mu$; spores 1 -seriate, ellipsoid, hyaline or very slightly yellowish, smooth, thin-walled, often collapsing on one side, 10-12 × 20-22 ; paraphyses filiform, slightly enlarged above, yellow.

On cow dung. 
TyPE LOCALITY : France.

Distribution: Bermuda Islands and reported from Nebraska; also in Europe.

Illustratioxs: Ann. Sci. Nat. IV. 10: pl. 13, f. 32-37; Cooke, Mycographia pl. 39, f. 15t; Gill. Champ. Fr. Discom. pl. $63, f .2$.

\section{Patella raripila (Phill.) Seaver, comb. nov.}

A scobolus raripilus Phill. Grevillea 7:23. 1878.

Lasiobolus ruripilus Sacc. Syll. Fung. 8: 537. 1889.

Apothecia gregarious or closely crowded, of ten forming congested masses of considerable extent, reaching a diameter of 1-2 mm., pale-yellow, externally scantily clothed with hairs; hymenium at first concave, becoming plane or a little convex, bright-yellow, a little brighter than the outside of the apothecium; hairs pale-yellow or subhyaline, rigid, tapering into a bristlelike apex; asci broad-clavate; spores 1-seriate or irregularly disposed, ellipsoid, hyaline, $10-14 \times 25-30 \mu$; paraphyses slender, slightly enlarged above.

On the dung of animals and on the surrounding soil.

Type locality: California.

Distribution : California and Iowa.

Illustration: Bull. Lab. Nat. Hist. State Univ. Iowa 6: pl. 32, f. 2 .

\section{Patella fimetaria Seaver, sp. nov.}

Apothecia gregarious or scattered, at first globose, expanding and becoming discoid, reaching a diameter of $5 \mathrm{~mm}$., externally densely clothed with hairs; hymenium plane or slightly concave, yellowish to orange; hairs rigid, reaching a length of $1 \mathrm{~mm}$. and a diameter of $30 \mu$, thick-walled, septate, attenuated above into a very sharp-pointed apex, the base forked and root-like, darkbrown; asci cylindric or subcylindric, reaching a length of 200-225 $\mu$ and a diameter of $15 \mu$; spores 1-seriate, ellipsoid, hyaline, containing two large oil-drops, becoming minutely sculptured, about $12 \times 20 \mu$; spore-sculpturing consisting of minute papillae or warts; paraphyses strongly enlarged above, reaching a diameter of $7-8 \mu$ at their apices, nearly hyaline.

On cow dung.

Type collected east of Tripoli along Halifax Brook, Wash- 
ington County, New York, by Stewart H. Burnham (Herb. The New York Botanical Garden).

Distribution: Known only from the type locality.

\section{Patella paludosa (Boud.) Seaver, comb. nov.}

Ciliaria paludosa Boud. Bull. Soc. Myc. Fr. 10:65. 1894.

Lachnea paludosa Sacc. Syll. Fung. 11: 400. 1895.

Lachnea gregaria pseudogregaria Rick in Oester. Bot. Zeitschr. 48: 62. 1898. Lachnea pseudogregaria Rehm, Ascom. 1268; Herlwigia 38: (243). 1899.

Trichophaea pseudogregaria Boud. Hist. Class. Discom. Eu. 60. 1907.

Trichophaea paludosa Boud. Hist. Class. Discom. Eu. 60. 1907.

Apothecia closely gregarious, at first subglobose, finally becoming scutellate to discoid, reaching a diameter of 1-2 $\mathrm{mm}$., externally clothed with dark-colored hairs which project about the margin of the apothecium giving rise to a fringe-like border; hymenium concave or nearly plane, whitish or bluish-white; hairs rigid, sharp-pointed, sparingly septate, but the septa often indistinct, so that the hairs often appear to be non-septate, reddish-brown, reaching a length of $500 \mu$ and a diameter of $20 \mu$ at the broadest point; asci cylindric or subcylindric above, gradually tapering below, reaching a length of $300 \mu$ and a diameter of 15-17 $\mu$; spores 1 -seriate, ellipsoid, containing two oil-drops which become more or less obscured at maturity, becoming sculptured, reaching a length of 22-25 $\mu$ and a diameter of 15-17 $\mu$; spore-sculpturing taking the form of tubercles $2-3 \mu$ in diameter, giving to the spore a scalloped appearance; paraphyses slender, slightly enlarged above, hyaline.

On soil in swampy places.

Type locality: Montmorency, France.

Distribution: New York to Iowa; also in Europe.

Illustrations: Bull. Soc. Myc. Fr. 10: pl. 2, f. t; Bull. Lab. Nat. Hist. State Univ. lowa 6: pl. 11, f. 1 .

\section{Patella tuberculata Seaver, sp. nov.}

Apothecia gregarious but not usually crowded, at first globose and closed, the light-colored exterior concealed by the dense covering of dark-brown hairs, expanding and becoming scutellate to discoid, reaching a diameter of 1-2 $\mathrm{mm}$.; hymenium white or whitish, plane or very slightly concave; hairs reddish-brown, sparingly septate, straight or nearly so, thick-walled, tapering into a bristle-like apex, varying in length according to age, but reaching an extreme of $500 \mu$ and a diameter of $20 \mu$; asci cylindric 
or subcylindric above, tapering into a stem-like base, reaching a length of $300-500 \mu$ and a diameter of $25-27 \mu$; spores 1 -seriate, at first smooth, containing two oil-drops, soon becoming sculptured, reaching a length of $30-35 \mu$ and a diameter of $20-22 \mu$, hyaline; spore-sculpturing taking the form of numerous tubercles which reach a diameter of $3 \mu$ or rarely as large as $4-5 \mu$, the tubercles rounded and giving the spore a scalloped appearance; paraphyses slender below, enlarged above, reaching a diameter of $7-9 \mu$ at their apices.

On damp sandy soil among mosses.

Type Locality: The New York Botanical Garden.

Distribution: Known only from the type locality.

Distinguished from the preceding by the larger spores and coarser tubercles.

26. Patella albida (Schaeff.) Seaver; Brenckle, Fungi Dakot. 407. 1916. (Plate 14, Fig. 1.)

Elvela albida Schaeff. Fung. Bavar. 4: 101. 1774.

Peziza hemisphaerica Veber; Wiggers, F1. Hols. 105. 1780.

Peziza labellum Bull. Champ. Fr. pl. 20t. 1784. Octospora fasciculata Hedw. Descr. 2: 14. 1788. Peziza hispida Sow. Engl. Fungi pl. 1+7. 1798.

Humaria hemisphaerica Fuckel, Symb. Myc. 322. 1869.

Lachnea hemispherica Gill. Champ. Fr. Discom. 73. 1879.

Scutellinia hemisphaerica Kuntze, Rev. Gen. P1. 2: 869. 1891.

Sepultaria albida Morgan, Jour. Myc. 8: 188. 1902.

?Scutellinia chaetoloma Clements, Bull. Torrey Club 30: 89. 1903.

?Lachnea chaetoloma Sacc. \& D. Sacc. in Sacc. Syll. Fung. 18: 34. 1906.

Apothecia gregarious or scattered, at first globose and closed, gradually expanding and becoming concave-hemispheric, or occasionally shallow cup-shaped, reaching a diameter of $2-3 \mathrm{~cm}$. and about one-half or one-third as deep, the margin wavy or regular, externally entirely clothed with tufted hairs which project and form a fringe about the margin of the apothecium; hymenium white or whitish, becoming yellowish or yellowishbrown in dried specimens; hairs enlarged at the base, tapering above into a bristle-like apex, reaching a diameter of $15-20 \mu$ at the base and a length of $400-500 \mu$, dark-brown, septate, the walls about $3 \mu$ thick; asci cylindric or subcylindric above, tapering rather abruptly below into a stem-like base, reaching a length of $325 \mu$ and a diameter of $15-18 \mu$; spores 1 -seriate, ellipsoid, $12-15 \times 25-27 \mu$, hyaline or subhyaline, usually containing two large oil-drops which become more or less broken 
up in dried specimens, becoming delicately sculptured; sporesculpturing consisting of minute papillae often indistinct in dried specimens; paraphyses slender, rather strongly enlarged at their apices, reaching a diameter of $7-8 \mu$.

On soil and more rarely on rotten wood.

TYPE locality: Europe.

Distribution: Maine to Winnipeg, Kansas and North Carolina; also in Europe.

Illustrations: Bull. Herb. Fr. pl. 204; Hedw. Descr. 2: pl. 4,f. B; Gill. Champ. Fr. Discom. pl. 61,f. 1; Rab. Krypt.-F1. $1^{3}$ : 1033, f. 1-4; Sow. Engl. Fungi pl. 147; E. \& P. Nat. Pfl. $1^{1}$ : 181, f. 147, C-D; Bull. Lab. Nat. Hist. State Univ. Iowa 6: pl. 9, f. 1; Pat. Tab. Fung. f. 82; Cooke, Mycographia pl. 30, f. 115; Massee, Brit. Fungus-Fl. 4: 290, f. 5-9; Schaeff. Fung. Bavar. 2: pl. 151 .

Exsiccati: N. Am. Fungi 837; Brenckle, Fungi Dakotenses 407; Clements, Crypt. Form. Colo. 118.

27. Patella gregaria (Rehm) Seaver, comb. nov. (Plate 15, FIG. $1 ; 45$, FIG. 13, 14.)

?Peziza proximella Karst. Not. Fauna F1. Fenn. 10: 125. 1869.

IIumaria gregaria Rehm; Winter, Flora 55: 508. 1872.

Lachnea gregaria Phill. Brit. Discom. 214. 1887.

Scutellinia gregaria Kuntze, Rev. Gen. Pl. 2: 869. 1891.

Lachnea amphidoxa Rehm in Rab. Krypt.-Fl. 13:1048. 1896.

Trichophaea gregaria Boud. Hist. Class. Discom. Eu. 60. 1907.

Apothecia gregarious or more densely crowded, at first globose, becoming concave-hemispheric and resembling in gross characters $P$. albida but much smaller, occasionally becoming expanded and scutellate, reaching a diameter of $4-5 \mathrm{~mm}$.; hymenium concave, becoming nearly plane, white or whitish; the excipular cells rounded or angular, giving rise to hairs which are usually borne in clusters; hairs closely adpressed to the sides of the apothecium, the marginal ones projecting, giving rise to a delicate fringe-like border, septate, blunt at their apices when young, becoming sharp-pointed as they mature, reaching a length of $150-300 \mu$ and a diameter of $10-12 \mu$, pale-brown; asci cylindric or subcylindric above, reaching a length of $300 \mu$ and a diameter of $17 \mu$; spores 1 -seriate, the ends overlapping, ellipsoid to fusoid, filled with oil-drops, becoming sculptured, reaching a length of $20-27 \mu$ and a diameter of $10-13 \mu$; spore- 


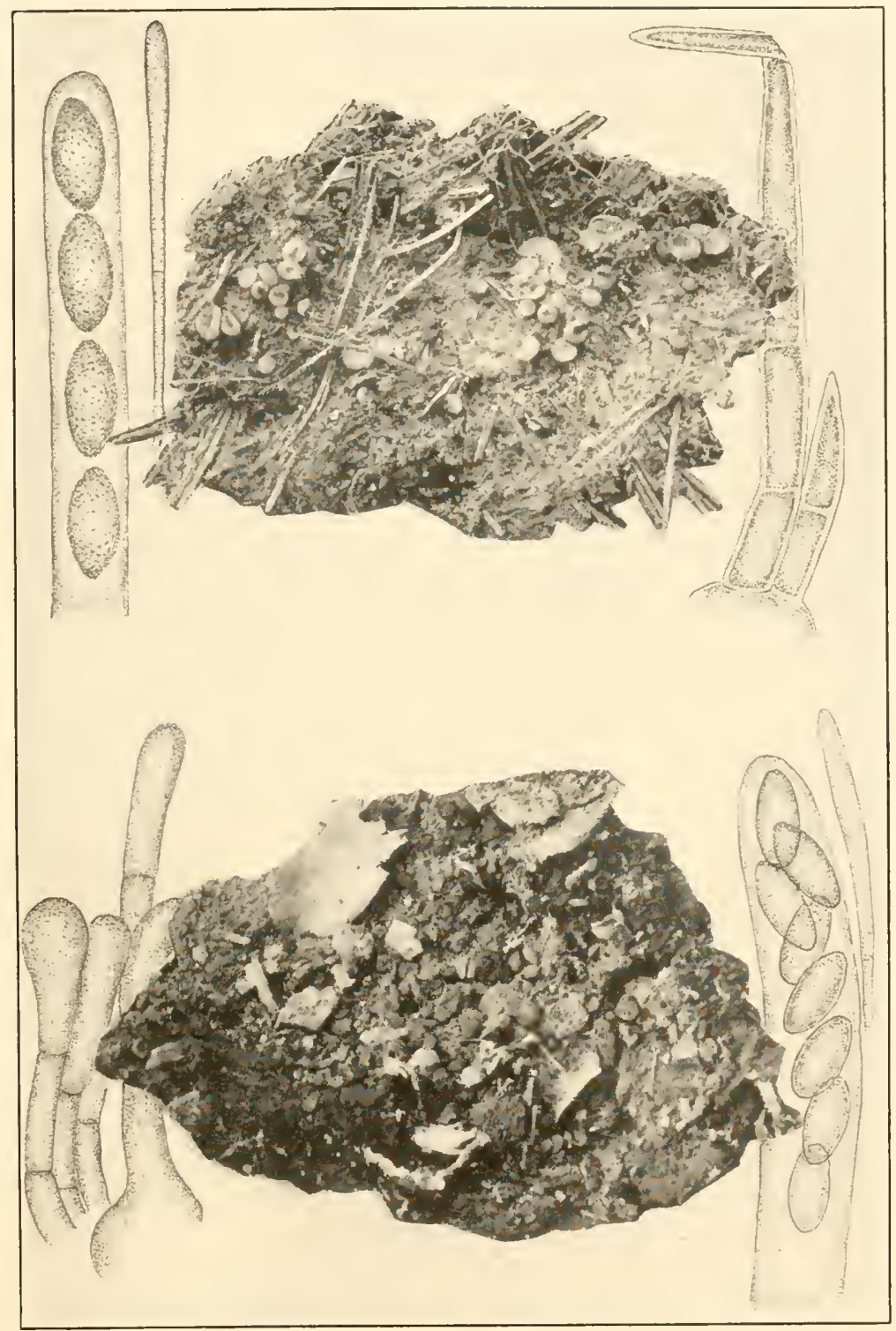

1. PATELLA GREGARIA

2. PATELLA MELALOMA 

sculpturing taking the form of minute warts; paraphyses slender, slightly enlarged above, where they reach a diameter of $6 \mu$.

On rather sandy soil in woods and open places, often under pines.

Type locality: Europe.

Distribution: New York to Delaware; also in Europe.

Illustrations: Cooke, Mycographia pl. 32, f. 123; Boud. Ic. Myc. pl. 364; Grevillea 3: pl. 32, f. 98.

28. Patella irregularis (Clements) Seaver, comb. nov.

Scutellinia irregularis Clements, Bull. Torrey Club 30:90. 1903.

Lachnea irregularis Sacc. \& D. Sacc. in Sacc. Syll. Fung. 18: 36.1906.

Apothecia gregarious, sessile, irregularly cup-shaped, finally subscutellate, reaching a diameter of 4-10 $\mathrm{mm}$., externally whitish but appearing dark on account of the brown hairs with which they are clothed; hymenium concave, whitish; hairs septate, rigid, reaching a length of $325 \mu$ and a diameter of $8 \mu$; asci cylindric or subcylindric, reaching a length of $200 \mu$ and a diameter of $16 \mu$; spores 1 -seriate, ellipsoid, containing two oildrops, becoming rough, $\delta \times 15 \mu$; paraphyses clavate, slightly enlarged above, where they reach a diameter of $3 \mu$.

On decaying Picea.

Type Locality: Jack Brook, Minnehaha, Colorado.

Distribution: Linown only from the type locality.

\section{Patella abundans (Karst.) Seaver, comb. nov.}

Pesiza abundans Karst. Not. Fauna Fl. Fenn, 10: 12t. 1869.

?Peziza cretea Cooke, Trans. Bot. Soc. Edinburgh 13: 46. 1877.

?Lachnea cretea Sacc. Syll. Fung. 8: 184. 1889.

Lachnea abundans Sacc. Syll. Fung. 8: 186. 1889.

?Scutellinia cretea Kuntze, Rev. Gen. P1. 2: 869. 1891.

Scutellinia abundans Kuntze, Rev. Gen. Pl. 2:869. 1891.

Trichophaea abundans Boud. Ilist. Class. Discom. Eu. 61. 1907.

Apothecia gregarious or more of ten densely crowded, at first globose or subglobose, expanding and becoming discoid or subdiscoid, reaching a diameter of $1-3 \mathrm{~mm}$., externally clothed with pale-brown hairs; hymenium concave or plane, whitish, becoming yellowish in dried specimens; hairs sparingly septate, usually subglobose at the base, tapering above into a bristle-like apex, reaching a length of $100-150 \mu$ and a diameter of $7 \mu, 1-3$-septate when mature, subhyaline to pale-brown; asci cylindric or subcylindric above, abruptly tapering below, reaching a length of 
$150 \mu$ and a diameter of $10 \mu$; spores 1 -seriate, with the ends slightly overlapping, ellipsoid, the ends strongly narrowed, containing one or two conspicuous oil-drops, hyaline, $8-9 \times 15-17 \mu$; paraphyses rather strongly enlarged above, reaching a diameter of 5-6 $\mu$ at their apices.

On ashes in burned places and on plaster walls.

Type locality: Finland.

Distribution: New York to Iowa; also in Europe.

Illustrations: Trans. Bot. Soc. Edinburgh 13: pl. 3, f. $k-o$; Cooke, Mycographia pl. 100, f. 362; Grevillea 6: pl. 97, f. 4-7; Bull. Lab. Nat. Hist. State Univ. Iowa 6: pl. 11, f. 3 .

\section{Patella Erinaceus (Schw.) Morgan, Jour. Myc. 8: 188. 1902.}

Peziza Erinaceus Schw. Schr. Nat. Ges. Leipzig 1:119. 1822.

Lachnea Erinaceus Sacc. Syll. Fung. 8: 182.1889.

Scutellinia Erinaceus Kuntze, Rev. Gen. Pl. 2: 869. 1891.

?Lachnea chrysotricha Rehm, Ann. Myc. 5: 520. 1907.

Apothecia gregarious, at first subglobose, expanding and becoming scutellate to discoid, reaching a diameter of $2-5 \mathrm{~mm}$., externally densely clothed with hairs; hymenium concave or nearly plane, whitish; hairs long, rigid, brown, reaching a length of $300-500 \mu$ and a diameter of $14-18 \mu$, tapering rather abruptly into a bristle-like apex; asci cylindric or subcylindric above; spores 1-seriate, ellipsoid, smooth, hyaline, $10-11 \times 18-20 \mu$; paraphyses slender, enlarged at their apices.

On decaying wood of deciduous trees.

Type locality: Pennsylvania.

Distribution: New York to Ohio and ? Michigan.

Illustration: Cooke, Mycographia pl. $36, f .140$.

\section{Patella albospadicea (Crev.) Seaver, comb. nov.}

Peziza albospadicea Grev. Fl. Edin. 420. 1824.

Peziza Woolhopeia Cooke \& Phill. Grevillea 6: 75. 1877.

Lachnea Woolhopeia Sacc. Syll. Fung. 8: 185. 1889.

Scutellinia albospadicea Kuntze, Rev. Gen. Pl. 2: S69. 1891.

Scutellinia Woolhopeia Kuntze, Rev. Gen. Pl. 2: S69. 1891.

Sepultaria bryophila Clements, Bot. Surv. Nebr. 4: 13. 1896.

Sepultaria pseudocrenulata Clements, Bot. Surv. Nebr. 4: 14. 1896.

Lachnea pseudocrenulata Sacc. \& D. Sacc. in Sacc. Syll. Fung. 14: 755.1899. Lachnea bryophila Sacc. \& D. Sacc. in Sacc. Syll. Fung. 14: 757. 1899.

Trichophaea albospadicea Boud. Hist. Class. Discom. Eu. 61. 1907. 
Apothecia gregarious, sessile, at first globose, becoming concave-hemispheric, finally almost entirely discoid, reaching a diameter of $6 \mathrm{~mm}$., externally clothed with dense covering of hairs when young, the hairs appearing more scant at maturity; hymenium concave or plane, whitish or grayish; hairs often swollen at the base, tapering into a sharp-pointed apex, rather closely septate, pale-brown, reaching a length of $350 \mu$ but of ten much shorter, and a diameter of $12 \mu$; asci cylindric or subcylindric. gradually tapering below in to a stem-like base, reaching a length of $235 \mu$ and a diameter of $10 \mu$; spores 1-seriate, ellipsoid, the ends slightly narrowed, containing one or two oil-drops, 9-12 $\times 14-20 \mu$, smooth, hyaline; paraphyses straight, very slightly enlarged at their apices, reaching a diameter of $3 \mu$.

On the ground in shady places, of ten among mosses.

Trpe locality: Europe.

Distribution: New lork to Nebraska; also in Europe.

Illustrations: Cooke, Mycographia $p l .36, f .1+1$ and $p l$. 113, f. 404; Boud. Ic. Myc. pl. 365; Gill. Champ. Fr. Discom. (suites); Pat. Tab. Fung. f. 171.

\section{Patella pygmaea (Clements) Seaver, comb. nov.}

Sepultaria pygmaea Clements, Bot. Surv. Nebr. 4: 14. 1896. Lachnea pygmaea Sacc. \& Sydow in Sacc. Syll. Fung. 14: 755. 1899.

Apothecia gregarious, at first closed and suloglobose, becoming scutellate to subdiscoid, reaching a diameter of $0.5-0.75 \mathrm{~mm}$. or rarely as large as $1 \mathrm{~mm}$., externally clothed with hairs; hymenium plane or concave, gray, becoming slightly brownish when old; hairs rigid, the ends blunt or becoming acute, septate, brown, reaching a length of $175-250 \mu$ and a diameter of $12.5 \mu$; asci cylindric or subcylindric; spores ellipsoid, smooth, hyaline, $7 \times 12 \mu$; paraphyses numerous, filiform.

On rich ground among filaments of Lyngbya.

Trpe Locality: Otawaine Woods, Lancaster county, Nebraska.

Distributiox: Known only from the type locality.

\section{Doubtful and Excludei Species}

Lachnea vitellina (Pers.) Sacc. Syll. Fung. 8: 179. 1889; Peziza vitellina Pers. Myc. Eu. 1: 257. 1822. Specimens distributed under this name in N. Am. Fungi 2910 are Putella setosa (Nees) Seaver.

Lachnea crispata (Berk. \& Curt.) Sacc. Syll. Fung. 8: 169. 1889; Pezisa crispata Berk. \& Curt.; Berk. Jour. Linn. Soc. 10:367. 1868. No specimen of this species has been and its identity is uncertain. 
Neottiella Spraguei (Berk. \& Curt.) Sacc. Syll. Fung. 8: 190. 1889; Peziza Spraguei Berk. \& Curt.; Cooke, Bull. Buffalo Acad. Sci. 2: 289.1875. Examination of a specimen of this species in the herbarium of The New York Botanical Garden shows it to be a small specimen of Peziza but its eyact identity is uncertain.

Lachnea livida (Schum.) Gill. Champ. Fr. Discom. 73. 1880; Peziza livida Schum. Enum. P1. Saell. 2: 422. 1803. American specimens referred to this name do not differ from Patella Erinaceus (Schw.) Seaver.

Neottiella albotecta (Berk. \& Curt.) Sacc. Syll. Fung. 8: 191. 1889; Peziza albotecta Berk. \& Curt.; Berk. Jour. Linn. Soc. 10:367. 1868. No specimen of this species has been seen and its identity is uncertain.

Lachnea hirta (Schum.) Gill. Champ. Fr. Discom. 75. 1880; Peziza hirta Schum. Enum. Pl. Saell. 2:422. 1803. Nost of the specimens examined under this name have been found to be either Patella umbrormm or Patella scutellata. In 1881, Rehm described IIumaria hirtella as intermediate between Peziza hirta and $P$. scutellata. Later this species was made a synonym of Lachnea hirta (Schum.) Gill. We have no means of knowing just what Scumacher's species really was and since in current literature the name has been interpreted differently no species can be found to which the name can be applied with certainty.

Neottiella sericeovillosa Rehm; Kellerm. Jour. Nyc. 14: 6. 1908. No specimen of this species has been seen and its identity is in doubt. The species was described from material collected in Guatemala.

Lachnea fissilis (Sacc. \& Cooke) Sacc. Syll. Fung. 8: 169. 1889; Peziza fissilis Sacc. \& Cooke, Michelia 2: 257. 1881. The specie; was reported from Nebraska by Clements, placed in the subgenus Sepultaria and said to be closely related to $S$. Geaster, $S$. tenuis and $S$. arenosa.

Neottiella callichroa (Boud.) Sacc. Syll. Fung. 8: 190. 1889; Humaria callichroa Boud. Bull. Soc. Bot. Fr. 28:93. 1881. Reported from Nebraska by Clements. No specimen has been seen.

Neottiopezis macrospora Clements, Bull. Torrey Club 30: 89. 1903 Apothecia described as 3-6 $\mathrm{mm}$. in diameter and spores $16-18 \times 40-42 \mu$. No specimen has been seen.

27. WYNNEA Berk. \& Curt. Jour. Linn. Soc. 9: 424. 1867.

Apothecia usually cespitose and branched at the base, springing from a sclerotium buried in the substratum, thick, firm, subcartilaginous, tough and subcoriaceous in drying, erect, elongate ear-shaped or spoon-shaped, simple or proliferous; asci cylindric or subcylindric, 8-spored; spores ellipsoid to fusoid, unequalsided; paraphyses stout, simple or branched.

Type species, Wynnea gigantea Berk. \& Curt.

Spores $12 \times 25-30 \mu$.

Spores $15-16 \times 32-40 \mu$.
1. $11^{\top}$, gigantea.

2. II. americana. 


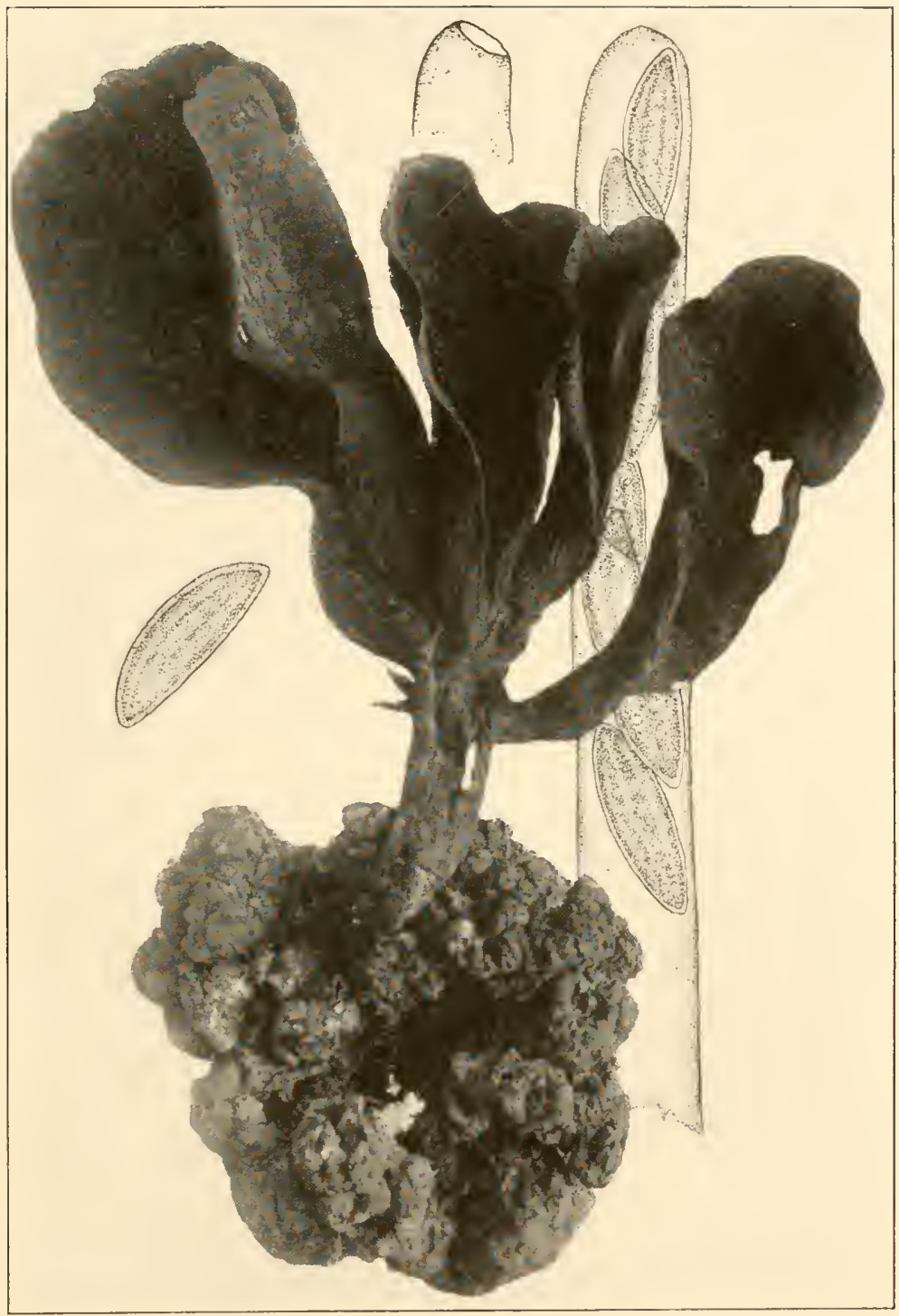

WYNNEA AMERICANA 

1. Wynnea gigantea Berk. \& Curt. Jour. Linn. Soc. 9:424. 1867.

?Peziza macrotis Berk. Jour. Bot. and Kew Misc. 3: 203. 1851.

? Ilynnea macrotis Berk. Jour. Linn. Soc. 9: 424. 1867.

? Midotis macrotis Sace. Syll. Fung. 8: 547 . $188 \%$.

Midotis gigantea Sacc. Syll. Fung. 8: $5+7.1889$.

Apothecia cespitose and springing from a common stem which is about $6-7 \mathrm{~cm}$. long and $2 \mathrm{~cm}$. thick, deeply rugose and cracked, the individual apothecia smooth, externally becoming wrinkled when dry but not cracked like the stem, reaching a length of $5-7 \mathrm{~cm}$. with the margins incurved, simple or occasionally proliferous; asci cylindric or subcylindric; spores subcymbiform,

$12 \times 25-30 \mu$; paraphyses slightly enlarged above.

Habitat unknown, but probably on the ground.

Type Locality: Orizaba, Mexico.

Distribution: Mexico and (India?).

Illustrations: Jour. Linn. Soc. 9: pl. 12; Cooke, Mycographia pl. 24, f. 93.

2. Wynnea americana Thaxter, Bot. Gaz. 39: 246.1905. (Plate 16.)

Sclerotium tough, subgelatinous, coriaceous on drying, irregularly lobed, variable in size, reaching a diameter of $4-5 \mathrm{~cm}$., brown, the main axis becoming variously divided almost immediately after emerging from the ground, the divisions giving rise to clusters of apothecia of variable size and number; apothecia from a few to twenty-five from a single sclerotium, simple or more rarely proliferous, erect, elongate ear-shaped, very variable in size, reaching an extreme length of $6-13 \mathrm{~cm}$., the average about $8 \mathrm{~cm}$., the margins somewhat incurved on drying, the external surface rich blackish-brown, finely verrucose, the roughness due to projecting cells which become hair-like near the margin; hymenium even, dark purplish-red or brown; asci elongate, reaching a length of $500-540 \mu$ and a diameter of $18 \mu$; spores subcymbiform, $15-16 \times 32-40 \mu$, with the extremities apiculate, striately marked, the striations consisting of about 8 alternately light and dark bands extending the length of the spore, the entire spore when fresh filled with oil-drops; paraphyses septate, enlarged above and pale-brown.

On the ground in rich woods.

Trpe Locality: Burbank, East Tennessee.

Distributiox: North Carolina to Tennessee and Ohio.

Illustration: Thaxter, Bot. Gaz. 39: pl. + and 5 (opposite p. 246). 
28. PHILliPSIA Berk. Jour. Linn. Soc. 18: 388. 1881.

Apothecia usually eccentric, attached by a very broad base which is of ten extended in to a rather long, thick stem; hymenium concave or plane, bright-colored, the substance not shrinking much in drying; asci cylindric or subcylindric, 8-spored; spores usually striate, subhyaline; paraphyses very slender.

Type species, Peziza domingensis Berk.

Apothecia cup-shaped, reddish-purple.

Apothecia not exceeding a diameter of $2 \mathrm{~cm}$.

1. P. domiangensis.

Apothecia reaching a diameter of $4-6 \mathrm{~cm}$.

Cup-shaped; substance thick.

2. P. gigantea.

Orbicular; substance thin.

3. P. Chardoniana.

Apothecia spoon-shaped, yellowish-brown.

4. P. dochmia.

1. Phillipsia domingensis Berk. Jour. Linn. Soc. 18: 388.1881. (Plate 17, Fig. 2.)

Peziza domingensis Berk. Ann. Mag. Nat. Hist. II. 9: 201. 1852.

IIelotium purpuratum Kalchbr. in Thüm. Myc. Univ. 161t. 1880.

?Peziza Harmoge Berk. \& Br. Jour. Linn. Soc. 14: 104. 1875.

?Peziza cordovensis Cooke, Hedwigia 14:81. 1875.

Phillipsia kermesina Kalchbr. \& Cooke, Grevillea 9:25. 1880.

Phillipsia subpurpurea Berk. \& Br. Trans. Linn. Soc. II. 2: 69. 1883.

Lachnea crispata Sacc. Syll. Fung. 8: 169.1889.

Otidea domingensis Sacc. Syll. Fung. 8: 97. 1889.

Apothecia shallow cup-shaped or subdiscoid usually unequalsided or occasionally regular in form, attached by a broad base which is often extended into a thick stem, externally nearly white or with a pinkish tinge, fading when dry, more or less tomentose, especially near the base, reaching a diameter of 1-2 cm. the substance tough and corky when dry; hymenium concave or nearly plane, dark reddish-purple, becoming pitted as a result of shrinkage in drying which gives it the appearance of a resupinate polypore; stem often reaching a length of $1 \mathrm{~cm}$. and several $\mathrm{mm}$. thick, or nearly wanting; asci cylindric above, reaching a length of $300-360 \mu$ and a diameter of $15-20 \mu$, gradually tapering below into a stem-like base; spores 1 -seriate or with the ends slightly overlapping, ellipsoid, unequal-sided, the ends blunt or rarely narrowed, striated, the striations consisting of a few bands extending the length of the spore, containing one or two large oil-drops and of ten several smaller ones; paraphyses filiform, slightly enlarged above.

On old wood and bark. 
Type locality : Santo Domingo.

Distribution: West Indies and (Mexico?); also in Africa, Australia and Japan.

Illustrations: Cooke, Austr. Fungi, pl. 19, f. 151; Grevillea 9: pl. 136, f. 21; Jour. Linn. Soc. 31: pl. 16, f. 7-9; Mycologia 5: pl. 89 (lower figure) and $p l .90, f .7$.

2. Phillipsia gigantea Seaver, sp. nov. (Plate 17, fig. 1.)

Apothecia occurring singly or in clusters of 3 or 4 each with their bases more or less fused together, the individual apothecia infundibuliform, tapering below into a rather thick, stem-like base, elongated on one side or nearly symmetrical, the margin often more or less lobed, reaching a diameter of $4-6 \mathrm{~cm}$. and a depth of 3-4 cm., externally nearly white or with a pinkish tinge which is somewhat darker below, delicately tomentose, the substance tough so that the apothecia maintain their form fairly well in drying; hymenium bright-purple or purplish-red, splitting into numerous vein-like markings when dry; stem thick, often reaching a length of $1-2 \mathrm{~cm}$. but not clearly defined; asci cylindric above, rounded at the apex, with the operculum opening a little to one side of the center, gradually tapering below into a stem-like base, reaching a length of $500 \mu$ and a diameter of $17-18 \mu$ at the broadest point, 8-spored, but of ten with only four or five of the spores developed; spores 1 -seriate, ellipsoid, unequal-sided with the ends bluntly attenuated, containing two oil-drops which of ten merge into one, longitudinally marked with light and dark bands, 12-14 × 25-27 $\mu$, hyaline; paraphyses very slender, reaching a diameter of $2-3 \mu$ at their apices.

On decaying wood of some monocotyledon.

Type Locality: Castleton Gardens, Jamaica.

Distribution: Known only from the type locality.

Differing from the preceding mainly in its larger size.

3. Phillipsia Chardoniana Seaver, Mycologia 17: 48.1925. (Frontispiece.)

Apothecia orbicular or nearly so, subsessile, reaching a diameter of 3-5 cm., eccentrically attached, the hymenium brick-reddish, the substance thin (about 1-2 mm., not thick or corky as in other species); asci cylindric or subcylindric, reaching a length of $300 \mu$ and a diameter of $14 \mu, 8$-spored; spores ellipsoid, 
unequal-sided, usually containing two large oil-drops, longitudinally striated with light and dark bands, about $12 \times 26 \mu$.

On decaying wood.

Type Locality: Ajuntas, Porto Rico.

Distribution: Known only from the type locality.

Illustration: Mycologia 17: pl. 4.

4. Philiipsia dochmia (Berk. \& Curt.) Seaver, comb. nov.

Pesiza dochmia Berk. \& Curt.; Berk. Jour. Linn. Soc. 10: 36t. 1869.

?Peziza hirneoloides Berk. \& Curt.; Berk. Jour. Linn. Soc. 10:365. 1869.

Otidea dochmia Sacc. Syll. Fung. 8: 95. 1889.

?Otidea hirneoloides Sacc. Syll. Fung. 8: 96. 1889.

Apothecia subsessile and attached by a rather thick, stemlike base, at maturity decidedly spoon-shaped, yellowish to yellowish-brown, reaching a diameter of 2-4 cm.; hymenium a little darker than the outside of the apothecium; asci cylindric above, tapering below; spores 1-seriate, or with the ends slightly overlapping, ellipsoid, strongly unequal-sided, usually containing two large oil-drops and numerous smaller ones, the striations consisting of rather broad light and dark bands extending the length of the spore; $12-15 \times 25-33 \mu$; paraphyses slender, slightly enlarged above, adhering closely together.

On rotten wood.

Type locality: Cuba.

Distribution: Cuba.

Illustration: Cooke, Mycographia pl. 56, f. 220, 221.

29. SCODEllina S. F. Gray, Nat. Arrang. Brit. Pl. 1: 668. 1821.

Otidea Fuckel, Symb. Myc. 329. 1869.

IYynnella Boud. Bull. Soc. Myc. Fr. 1: 102. 1885.

Apothecia scattered or crowded, often cespitose and occasionally fused together at the base or branched, usually large or medium sized, substipitate, rarely with a well-developed stem, usually unsymmetrical, split on one side or elongated and inclined to ear-shaped, externally usually furfuraceous; asci typically cylindric, 8-spored; spores smooth, usually containing one or two oil-drops; paraphyses filiform or very slightly enlarged above, simple or branched, straight or more often hooked at their apices.

Type species, Peziza leporina Batsch. 

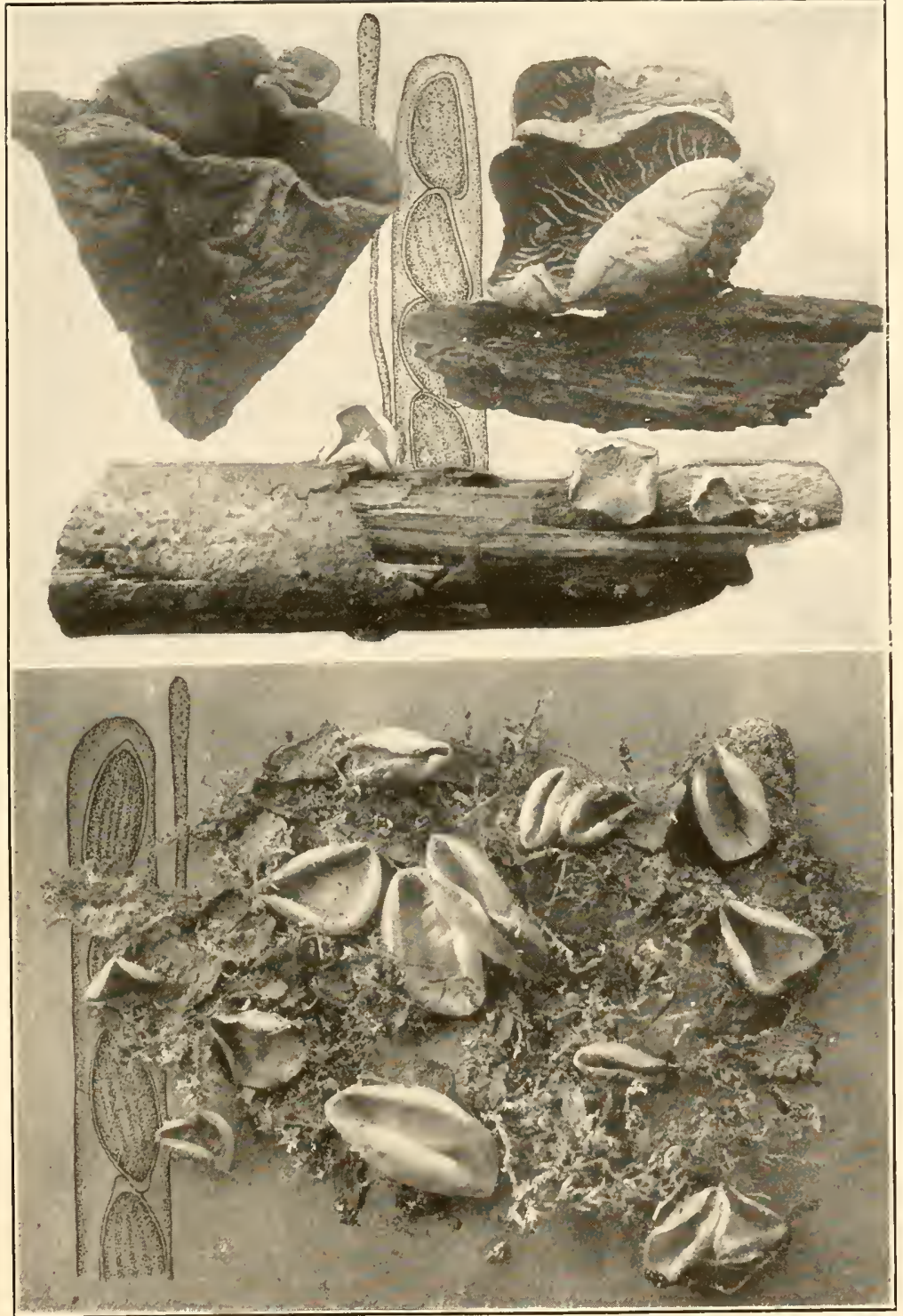

1. PHILLIPSIA GIGANTEA

2. PHILLIPSIA DOMINGENSIS

3. COOKEINA COLENSOI 

Spores remaining permanently smooth.

Spores $7-8 \times 12-14 \mu$, containing two oil-drops.

1. S. leporina.

Spores $12-13 \times 20-24 \mu$, containing one large oil-

(lrop.

Spores becoming minutely rough.

2. S. aluricula.

3. S. grandis.

1. Scodellina leporina (Batsch) S. F. Gray, Nat. Arrang. Brit. Pl. 1:668. 1821.

Pesisa leporina Batsch, Elench. Fung. 117. 1783.

Pesizu onotica Pers. Syn. Fung. 637. 1801.

Scodellina onotica S. F. Gray, Nat. Arrang. Brit. PI. 1: 66\$. 1821.

Pesiza onotica ochracea Fries, Syst. Myc. 2: 48. 1822.

Otidea onotica Fuckel, Symb. Myc. 329. 1869.

Otidea leporina Fuckel, Symb. Myc. 329. 1869.

Peziza unicisa Peck, Ann. Rep. N. Y. State Mus. 26: 81. 1874.

Aleuria leporina Gill. Champ. Fr. Discom. 40. 1879.

Aleuria onotica Gill. Champ. Fr. Discom. 40. 1879.

Otidea ochracea Seaver, Bull. Lab. Nat. Ilist. State Univ. lowa 5: 45. 1904.

Apothecia gregarious or scattered, strongly elongated on one side and split on the opposite side to the base, externally rather bright-yellow to yellowish-brown, often becoming dull with age or when dry, reaching a height of $4-5 \mathrm{~cm}$. and about half as broad; hymenium similar in color to the outside of the apothecium; asci cylindric or subcylindric, reaching a length of $200 \mu$ and a diameter of $10-12 \mu$; spores 1 -seriate, narrowellipsoid, each containing two small oil-drops, $7-8 \times 12-14 \mu$; paraphyses slender, usually strongly curved or hooked at their apices.

On soil in woods.

Type locality: Europe.

Distribution: New York to Mashington and California; also in Europe.

Illustrations: Schaeff. Fung. Bavar. pl. 156 (in part); Sow. Engl. Fungi pl. 79; Bres. Fungi Trid. pl. 182; Cooke, Mycographia pl. 53, f. 210 and pl. 5f, f. 211; Fl. Dan. pl. 1077, f. 2; Gonnerm. \& Rab. Myc. Eu. 3: pl. 2, f. 4; Nees, Syst. Pilze pl. 37, f. 278; Rab. Krypt.-Fl. 133: 1022, f. 1-4; Bull. Lab. Nat. Hist. State Univ. Iowa $5:$ pl. 10.

2. Scodellina auricula (Schaeff.) Seaver, comb. nov.

Eliela auricula Schaefi. Fung. Bavar. Ind. 103. 1774.

Pesiza auricula Cooke, Mycographia 124. 1876.

Aleuria auricula Gill. Champ. Fr. Discom. 40. 1879.

Otidea auricula Rehm, lledwigia 22:34. 1883. 
Wynnella auricula Boud. Hist. Class. Discom. Eu. 51. 1907. Otidea neglecta Massee, Grevillea 22: 66. 1893.

Apothecia gregarious or scattered, spoon-shaped or earshaped, elongated on one side and entirely split to the base of the opposite side, the margin even or more or less crenate, externally bright-yellow or becoming yellowish-brown, remaining lighter toward the base, reaching a height of $4-5 \mathrm{~cm}$. and half as broad; hymenium a little darker than the outside of the apothecium, often becoming brownish-black with age; asci cylindric or subcylindric, attenuated below into a stem-like base, reaching a length of $250 \mu$ and a diameter of $20 \mu$; spores 1-seriate, broad-ellipsoid, each containing one large oil-drop and numerous small ones, $12-13 \times 20-24 \mu$, paraphyses slender, strongly enlarged above where they reach a diameter of $10 \mu$, filled with yellowish granules.

On the ground in woods.

Trpe locality: Europe.

Distribution: Florida to Wisconsin and Alberta; also in Europe.

Illustrations: Schaeff. Fung. Bavar. pl. 156 (in part); Bres. Fungi Trid. pl. 73; Boud. Ic. Myc. pl. 250; Cooke, Mycographia pl. 5t, f. 213.

\section{Scodellina grandis (Pers.) Seaver, comb. nov.}

Peziza grandis Pers. Obs. Myc. 1: 27. 1796.

Otidea grandis Massee, Brit. Fungus-F1. 4: 446. 1895.

?Otidea Harperiana Rehm, Ann, Myc. 2: 34. 1904.

Apothecia cespitose or solitary, sessile or substipitate, shallow cup-shaped, the margin incurved, usually split on one side to near the base and with the split edge rolled inward, externally yellowish to dark-brownish, with a tinge of olive, pruinose above and whitish tomentose toward the base, reaching a diameter of 5-6 cm. and about half as deep; hymenium paleyellow, lighter than the outside of the apothecium; asci cylindric above, gradually tapering below, reaching a length of $280 \mu$ and a diameter of $12-13 \mu$ at the widest point, 8-spored; spores 1 -seriate, parallel or obliquely disposed, ellipsoid, with the ends quite strongly narrowed, containing two oil-drops, hyaline, smooth, or at maturity very minutely roughened, about $8 \times 15-$ $18 \mu$; paraphyses rather stout, reaching a diameter of $7-8 \mu$, strongly curved or hooked at their apices and densely filled with minute granules. 
On soil in coniferous or mixed woods.

Type LOCALity: Europe.

Distribution: Connecticut to Pennsylrania and Wisconsin; also in Europe.

Illustrations: Boud. Ic. Myc. pl. 328; Cooke, Mycographia pl. 105, f. 376; Pat. Tab. Fung. f. 480.

\section{DOUBTFLL SPEC1ES}

Otidea obtecta (Schw.) Sace. Syll. Fung. 8: 98. 1889; Peziza obtecta Schw. Trans. Am. I'hil. Soc. II. 4: 170. 1832. The iclentity of this species is uncertain.

30. COOKEINA Kuntze, Rev. Gen. P1. 2: 849. 1891.

Peziza \$ Trichoscypha Cooke, Mycographia 252. 1879.

Trichoscypha Sacc. Syll. Fung. 8: 160. 1889. Not Trichoscypha Hooker, 1862.

Pilocratera P. Henn. in Engler, Bot. Jahr. 14:363. 1892.

Apothecia stipitate or substipitate, bright-colored, some shade of red or yellow (especially the hymenium), externally hairy or tomentose or occasionally pruinose, the substance tough, not shrinking much in drying; hairs when present fasciculate; asci cylindric or subcylindric, usually with an abrupt stem at the base, 4-8-spored; spores hyaline or subhyaline, ellipsoid to fusoid, usually striate, the striations consisting of light and dark bands extending the length of the spore; paraphyses usually very slender.

Type species, Peziza Tricholoma Mont.

Apothecia clothed with well-developed hairs.

Hairs long and conspicuous, covering the outside of the apothecium.

1. C. Tricholoma.

Hairs short and inconspicuous, mostly near the margin. Asci 8-spored.

Asci t-spored.

2. C. sulcipes.

3. C. tetraspora.

Apothecia pruinose but with no well-developed hairs.

4. C. Colensoi.

1. Cookeina Tricholoma (Mont.) Kuntze, Rev. Gen. Pl. 2: 849. 1891. (Plate 18, I IG. 2.)

Peziza Tricholoma Mont. Ann. Sci. Nat. II. 2: 77.1834.

Peziza Ilystrix Berk. Ann. Mag. Nat. 1list. 1I. 9: 201.1852.

Trichoscypha Tricholoma Sacc. Syll. Fung. 8: 160. 1889.

Pilocratera Tricholoma P. Henn. in Engler, Bot. Jahr. 14: 364. 1892.

Peziza striispora Ellis \& Ev. Bull. Lab. Nat. Hist. State Univ. Iowa 4: 69. 1896.

Sarcoscypha striispora Sacc. Syll. Fung. 14: 75t. 1899. 
Apothecia stipitate or substipitate, cup-shaped with the margin slightly incurved, reaching a diameter of $1-1.5 \mathrm{~cm}$. and a depth of $1 \mathrm{~cm}$., externally clothed with long hairs which are more numerous around the margin, forming an incurved fringe, deep-red, fading in drying; hymenium bright-red, almost scarlet; stem often so short that the apothecia appear to be sessile and again, often $2-3 \mathrm{~cm}$. long and about $2 \mathrm{~mm}$. in diameter; hairs often 2-3 mm. long and $100-175 \mu$ in diameter at the base, gradually tapering upward, whitish or pale-brown, composed of a dense fascicle of mycelial threads; asci cylindric above, reaching a length of $350-37+\mu$ and a diameter of $20 \mu$, abruptly narrowed below into a short, appendage-like base; spores ellipsoid to fusoid, $12-14 \times 27-33 \mu$, hyaline or subhyaline, containing one or two large oil-drops, usually marked with delicate, longitudinal striations; paraphyses filiform, slender, slightly enlarged upwards.

On old wood and bark.

Type locality: Central America.

Distribution: West Indies, Mexico, Central America; also in South America, Australia and the Philippine Islands.

Illustratioss: Ann. Sci. Nat. II. 2: pl. 4, f. 2; Cooke, Mycographia pl. 51, f. 202; E. \& P. Nat. Pfl. 1': 195, f. 155, $C-E$; Mycologia 5: pl. 88 (lower figure) and pl. 90, f. 1-2.

2. Cookeina sulcipes (Berk.) Kuntze, Rer. Gen. Pl. 2: 849. 1891. (Plate 18, Fig. 1.)

Peziza sulcipes Berk. London Jour. Bot. $1: 141.18+2$.

Pezisa Hindsii Berk. London Jour. Bot. 1: 456.1842.

?Peziza Afzelii Fries, Nor. Acta Reg. Soc. Scient. Upsal. III. 1: 121.1855.

Trichoscypha Hindsii Sacc. Syll. Fung. 8: 161. 1889.

Trichoscypha sulcipes Sacc. Syll. Fung. 8:161. 1889.

?Trichoscypha Afzelii Sacc. Syll. Fung. 8: 161. 1889.

Cookeina Hindsii Kuntze, Rev. Gen. Pl. 2: 849. 1891.

?Cookeina Afzelii Kuntze, Rev. Gen. Pl. 2: 849. 1891.

?Pilocratera Engleriana P. Henn. in Engler, Bot. Jahr. 14:363. 1892.

Pilocratera Hindsii Lindau in E. \& P. Nat. Pfl. 1: 195. 1897.

Geopyxis elata Massee, Bull. Royal Gardens Kew, 1898: 123. 1898.

Apothecia stipitate or substipitate, cup-shaped, reaching a diameter of $1-2 \mathrm{~cm}$. and a depth of $1 \mathrm{~cm}$., or sometimes more shallow, externally often marked with several concentric rings near the margin which is fringed with very short hairs, yellowish; hymenium deep-orange to nearly scarlet, faded in dried specimens; stems often so short that the cups appear to be sessile, 


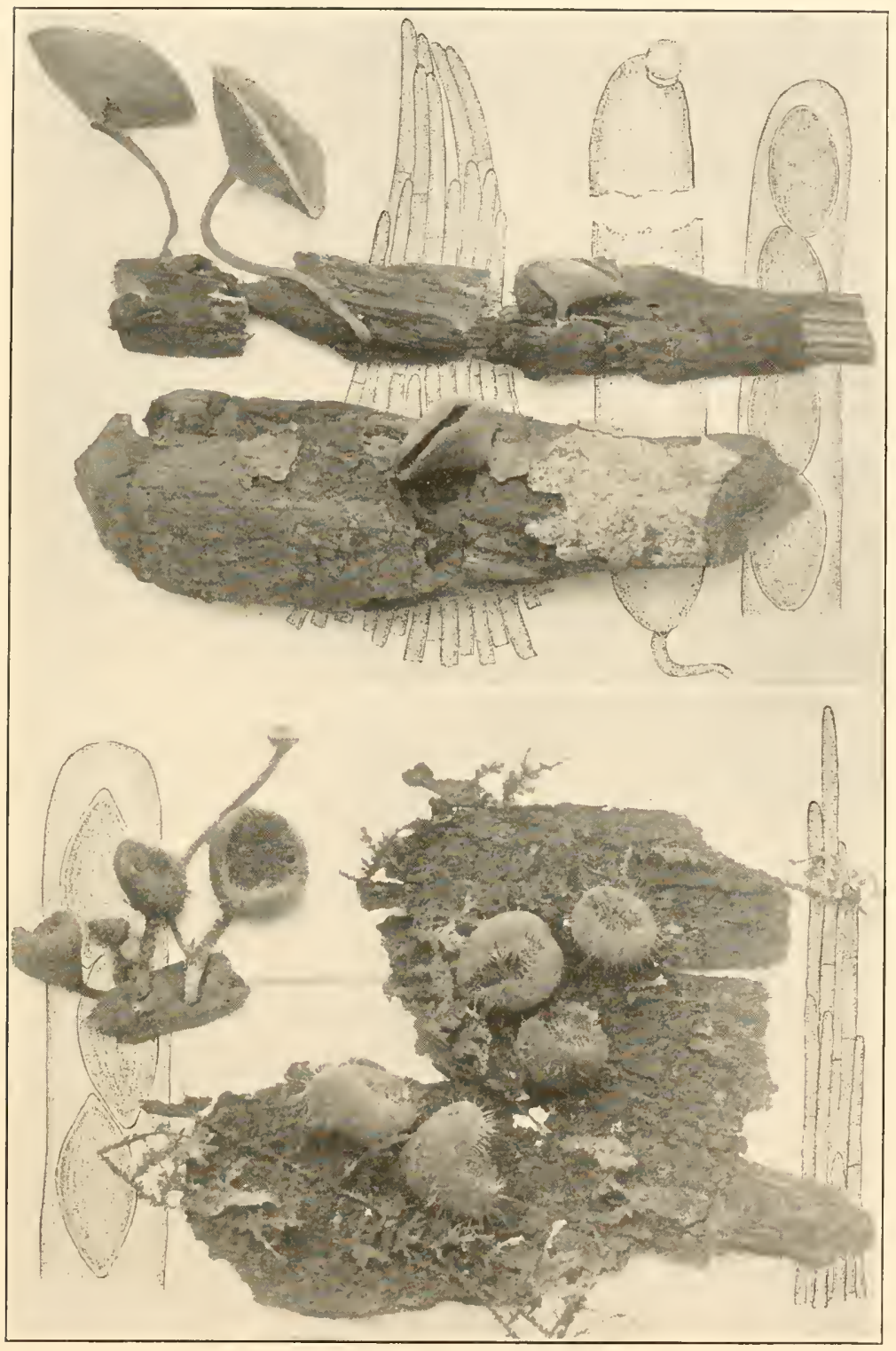

1. COOKEINA SULCIPES

2. COOKEINA TRICHOLOMA 

but occasionally reaching a length of $3 \mathrm{~cm}$, and about $2 \mathrm{~mm}$. in diameter; hairs comparatively short, subconical in form, reaching a length of $400-500 \mu$ and a diameter of $75-100 \mu$ at the base, gradually tapering upwards, composed of a fascicle of mycelial threads, pale-yellow; asci cylindric, reaching a length of 300 $350 \mu$ and a diameter of $20 \mu$, with a short appendage-like base; spores ellipsoid, with the ends slightly narrowed, hyaline or subhyaline, containing one or two oil-drops, $14-18 \times 27-33 \mu$, marked with delicate, longitudinal striations; paraphyses filiform, slightly enlarged above.

On old wood and bark.

Type locality: Surinam, South America.

Distribution: Nest Indies and New Mexico; also reported from South America and Australia.

Illustrations: London Jour. Bot. 1: pl. 15 (in part); Cooke, Mycographia pl. 51, f. 199, 200; Cooke, Australian Fungi pl. 20, f. 153; E. \& P. Nat. Pfl. 11: 195, f. 155, F-G; Engler, Bot. Jahr. 14: pl. 6, f. 9; Mycologia 5: pl. 88 (upper figure), pl. 90, f. 3-5.

3. Cookeina tetraspora Seaver; Stevenson, Jour. Depart. Agr. Porto Rico 2: 160. 1918. (hyponym); Mycologia 17: 45. 192.5 .

Apothecia gregarious, closely crowded, or occasionally becoming confluent with age, at first short-stipitate and turbinate, gradually expanding, hecoming slightly concave or nearly plane, externally whitish and slightly tomentose, becoming strongly wrinkled when dry, reaching a diameter of 4 mm. and a height of $2 \mathrm{~mm}$., yellowish or orange the margin fimbriate; fimbriae consisting of conical, fasciculate masses of delicate hairs, each reaching a length of $150 \mu$ and a diameter of $100 \mu$ at the base, hyaline; asci clavate, gradually tapering below into a slender stem, reaching a length of $200 \mu$ and a dianeter of $12-14 \mu$, 4-spored; spores ellipsoid, unequal-sided, usually containing two large oil-drops, appearing to have a long slender apiculus at the basal end which usually disappears when removed from the ascus, $10-11 \times 24-27 \mu$, often showing faint striations; paraphyses filiform, slightly enlarged above.

On decaying leaves of some palm.

Trie locality: El Yunque, Porto Rico.

Distributiox: Known only from the type locality. 
4. Cookeina Colensoi (Berk.) Seaver, Mycologia 5 : 191. 1913. (Plate 17, Fig. 3.)

Peziza Colensoi Berk. in Hooker's F1. New Zealand 2: 200. 1855.

Peziza aluticolor Berk. Proc. Linn. Soc. 13:176. 1873.

Phillipsia Venezuelae Berk. \& Curt.; Cooke, Mycographia 120. 1870.

Geopyxis aluticolor Sacc. Syll. Fung. 8: 64. 1889.

Surcoscypha Colensoi Sacc. Syll. Fung. 8: 157. 1889.

Pesiza Venezuelae Massee, Jour. Linn. Soc. 31: 473. 1896.

Apothecia stipitate or substipitate, shallow cup-shaped, reaching a diameter of 1-2 cm. and a depth of about $5 \mathrm{~mm}$., dried specimens pale-yellow (probably much brighter when fresh), marked with concentric rings about the margin, externally covered with loose cells which sometimes approach rudimentary hairs but with no well-developed hairs, strongly wrinkled when dry especially near the base of the apothecium; stem very short and sometimes almost wanting, of ten not more than $1 \mathrm{~mm}$. in length, never long as in other species; asci cylindric above, reaching a length of $400-475 \mu$ and a diameter of $20 \mu$, gradually tapering below; spores 1 -seriate or with the ends slightly overlapping, fusoid, with the ends quite strongly narrowed, containing one or two large oil-drops and granular within, the striations consisting of several broad, longitudinal bands extending the length of the spore, $12-15 \times 30-40 \mu$; paraphyses filiform, scarcely enlarged above.

On wood and bark.

Type locality: New Zealand.

Distribution: West Indies; also in New Zealand, Australia and Africa.

Illustrations: Hooker's Fl. New Zealand 2: pl. 105, f. 5; Cooke, Mycographia pl. 50, f. 198; pl. 52, f. 206; Jour. Linn. Soc. 31: pl. 16, f. 4-5; Hedwigia 39: pl. 11, f. 21; Mycologia 5: pl. 89 (upper figure) and pl. 90,f. $\delta$.

31. PLECTANiA Fuckel, Symb. Myc. 323. 1869.

Microstoma Milde, Bot. Zeit. 10: 208. 1852. Not Microstoma Bruch. 1846.

Anthopeziza Wettst. Verh. Zool.-Bot. Wien 35: 383. 1886. Sarcoscypha Sacc. Syll. Fung. 8: 153. 1889.

Apothecia at first subglobose, expanding but with the margin of ten incurved and even or laciniate, usually stipitate but with the stem very variable in length or sometimes almost wanting, externally more or less hairy; hymenium bright-colored; inclined 


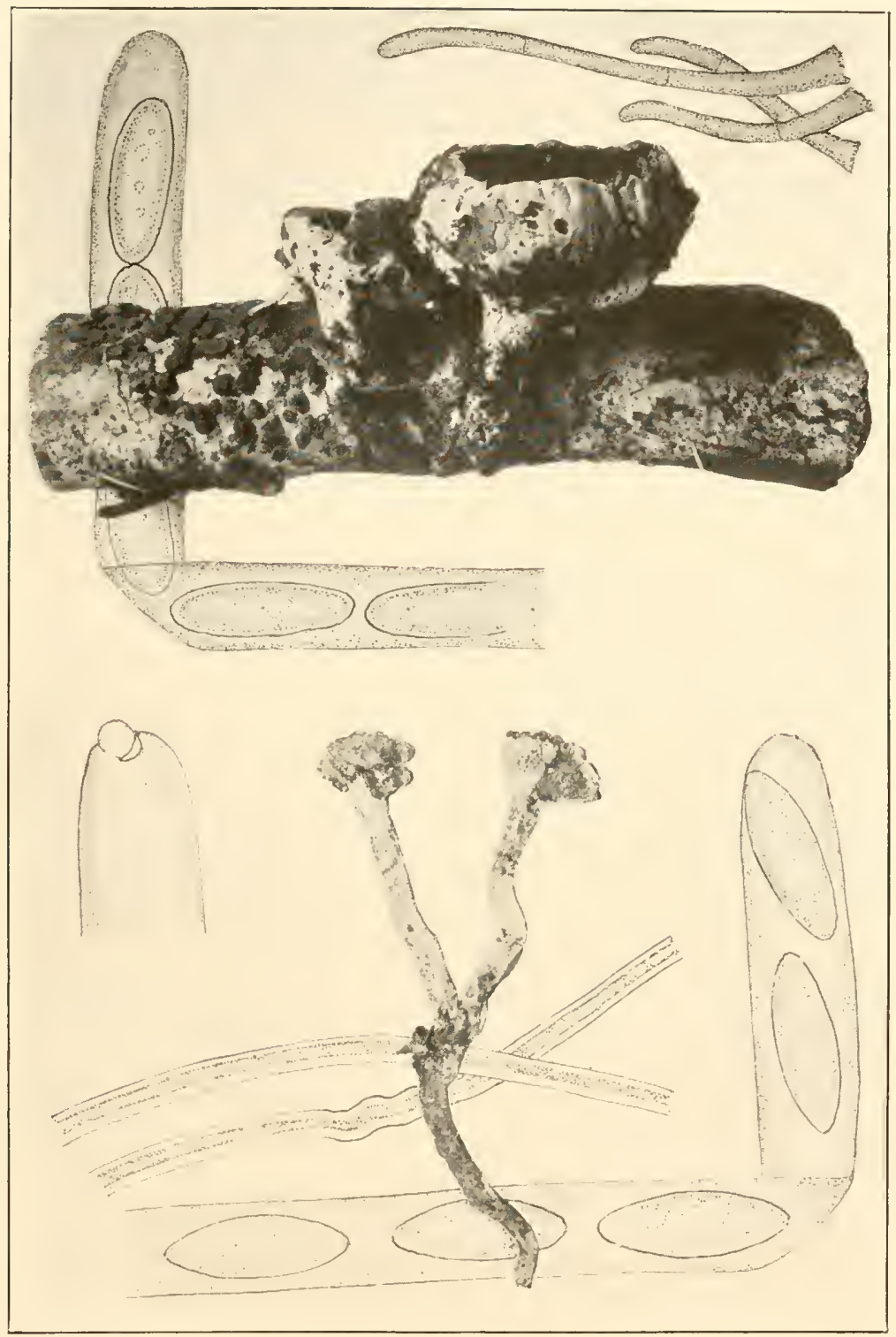

1. PLECTANIA COCCINEA

2. PLECTANIA HIEMALIS 

to scarlet; hairs when present hyaline or very slightly yellowish; asci 8-spored; spores ellipsoid, hyaline or subhyaline, smooth; paraphyses filiform and slender.

Type species, Peziza coccinea Scop.

Apothecia large, $2-3 \mathrm{~cm}$. in diameter.

1. P. coccinea.

Apothecia rarely exceeding a diameter of $1 \mathrm{~cm}$.

Hairs long, bristly and very conspicuous.

2. P. floccosa.

Hairs inconspicuous, consisting of delicate tomentum.

Tomentum scant; spores $10-12 \times 20-22 \mu$.

3. P. occidentalis.

Tomentum abundant; spores $13-16 \times 35-50 \mu$.

4. P. hiemalis.

1. Plectania coccinea (Scop.) Fuckel, Symb. Myc. 32t. 1869. (PLATE 19, Fig. 1.)

Elrela coccinea Scop. F1. Car. 2: 479.1772.

Peziza coccinea Jacq. F1. Austr. 2: pl. 163. 177 t.

Peziza epidendra Bull. Herb. Fr. pl. 467, f. 3. 1789.

Peziza poculiformis Hoffm. Veg. Crypt. 2: 27. 1790.

?Peziza pulcherrima Raf. Med. Rep. II. 5: 362. 1808.

Macroscyphus coccineus S. F. Gray, Nat. Arrang. Brit. PI. 1:pl.672. 1821.

Lachnea coccinea Gill. Champ. Fr. Discom. 66. 1880.

Sarcoscypha coccinea Sacc. Syll. Fung. 8: 15t. 1889.

Peziza Dudleyi Peck, Amn. Rep. N. Y. State Mus. 47:23. 1894.

Geopyxis coccinea Massee, Brit. Fungus-Fl. 4:377. 1895.

Apothecia rather deep cup-shaped or infundibuliform, stipitate or rarely subsessile, the margin of the cup usually strongly incurved, externally nearly white and more or less floccose with hyaline, flexuous mycelial hairs; hymenium deeply concave, scarlet, fading when dry; stem stout, 4-5 $\mathrm{mm}$. thick and of variable length, often 2-3 cm. long and again almost wanting, the length of the stem varying according to the depth at which the sticks are buried; asci very long, cylindric, gradually tapering into a stem-like base, reaching a length of $400-500 \mu$ and a diameter of 12-14 $\mu$; spores mostly 1-seriate, long-ellipsoid, often containing two large oil-drops and numerous small ones, $10-12 \times 26-40 \mu$; paraphyses slightly enlarged above, containing numerous red granules.

On buried or partially buried sticks, early spring.

Type locality: Europe.

Distribution: New York to Washington and West Virginia; also in Europe.

Illustrations: Boud. Ic. Myc. pl. 322, 323; Bull. Herb. Fr. pl. 467, f. 3; Cooke, Mycographia pl. 25, f. 95; E. \& P. Nat. Pfl. $1^{1}$ : 195, f. 155, A-B; Gill. Champ. Fr. Discom. pl. 58, f. 1; Hoffm. Veg. Crypt. 2 : pl. 7, f. 5; Bull. Soc. Myc. Fr. pl. 1,f. 1. 
Melvin R. Gilmore of the Museum of the American Indian, New York City writes: The Scarlet Cup-Fungus, Sarcoscypha coccinea (Jacq.) Sacc., is used medicinally by the Oneida, and probably by the other tribes of the Iroquois Six Nations. In such use this fungus is dried, pulverized, and applied as a styptic. Most particularly this is the medicament used for application to the navel of a newborn child when the umbilical cord is cut, and is not healing well. In old times this pulverized fungus was kept in place on the part under a bandage of soft-tanned deerskin.

2. Plectania floccosa (Schw.) Seaver, comb. nov. (Plate 20, FIG. 1.)

Peziza floccosa Schw. Trans. Am. Phil. Soc. II. 4: 172. 1832.

Geopyxis floccosa Morgan, Jour. Myc. 8: 188. 1902.

Sarcoscypha floccosa Sacc. Syll. Fung. 8: 156. 1889.

Apothecia gregarious or occasionally cespitose, stipitate, infundibuliform, with the margin usually strongly curved especially in young plants, reaching a diameter of 5-8 $\mathrm{mm}$. and a depth of $1 \mathrm{~cm}$., externally clothed with very long, rigid, hyaline hairs which give to the apothecium a very shaggy appearance; stem slender, gradually expanding into the apothecium above, very short or reaching a length of several cm., the length varying with the depth at which the sticks on which the plants grow are buried in the ground; hairs about $15-18 \mu$ in diameter at the base, gradually tapering into a bristle-like apex, reaching a length of more than $1 \mathrm{~mm}$., septate, thick-walled; asci cylindric or subcylindric, rather abruptly narrowed into a long stem-like base, reaching a length of $300-325 \mu$ (not including the constricted portion below) and a diameter of $20 \mu$ at the apex; spores 1 -seriate or with the ends partially overlapping, ellipsoid, with the ends rather strongly narrowed, smooth, hyaline or slightly yellowish, $15-17 \times 20-35 \mu$; paraphyses slender, slightly enlarged above, reaching a diameter of $3 \mu$ at their apices.

On buried sticks in woods.

Type locality: Nazareth, Pennsylvania.

Distribution: Massachusetts to Iowa, Missouri and Virginia.

Illustrations: Grevillea 1: pl. 1, f. 2; Bull. Lab. Nat. Hist. State Univ. Iowa 6: pl. 22, f. 1; Atkinson, Mush. f. 222.

Exsiccati: N. An. Fungi 435; Rab.-Winter, Fungi Eu. 3171. 


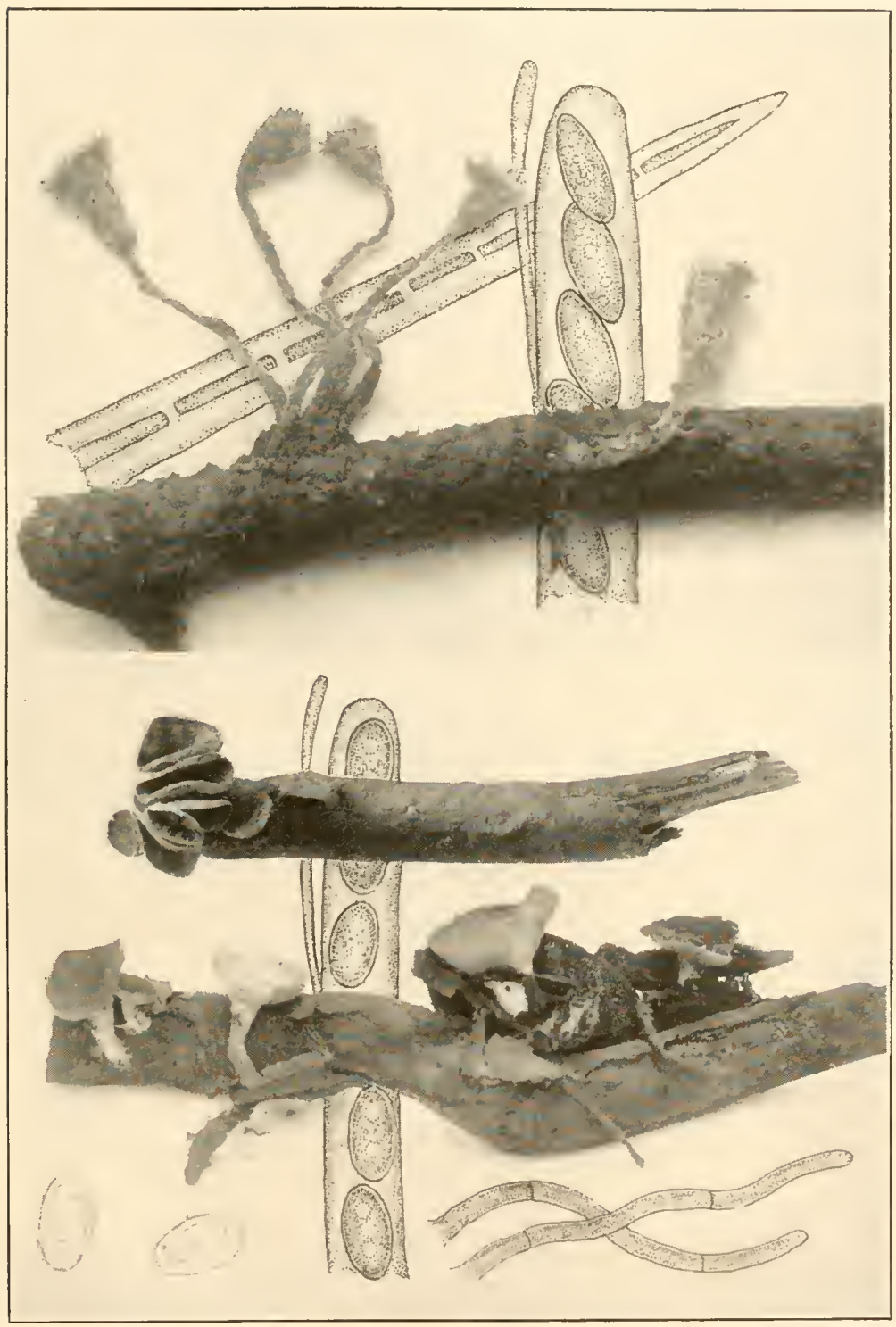

1. PLECTANIA FLOCCOSA

2. PLECTANIA OCCIDENTALIS 

The hairy cups of this species are rather common in woods in early spring.

3. Plectania occidentalis (Schw.) Seaver, coml), nov. (PLATE 20 , FIG. $2 ; 45$, FIG. 23.)

Peziza occidentalis Schw. Trans. Am. Phil. Soc. I1. 4: 171. 1832.

Peziza hesperidea Cooke \& P'eck, Grevillea 1: 5. 1872.

Geopyxis occidentalis Morgan, Jour. Myc. 8: 188. 1902.

Sarcoscypha occidentalis Sacc. Syll. Fung. 8: 154. 1889.

Geopyxis hesperidea Sacc. Syll. Fung. 8: 63. 1889.

Apothecia gregarious or cespitose, shallow cup-shaped to discoid, stipitate, externally whitish, reaching a diameter of 1 cm.; hymenium usually concave, bright-red, almost scarlet; stem varying in length according to the depth at which the sticks on which the plants grow are buried in the ground but often reaching a length of $2-3 \mathrm{~cm}$. and a diameter of $2 \mathrm{~mm}$.; asci cylindric or subcylindric, reaching a diameter of $15-18 \mu$ at the apex, tapering below into a long stem-like base; spores 1 -seriate, parallel with the ascus or oblique and with the ends slightly overlapping, ellipsoid, usually with two oil-drops one in either end which are often surrounded with smaller oil-drops and granules, hyaline or slightly yellowish, $10-12 \times 20-22 \mu$; paraphyses slender, slightly thickened above, reaching a diameter of $3-4 \mu$ at their apices.

On buried or partially buried sticks in wood.

TyPE LocAlity: Muskingum, Ohio.

Distribution: Connecticut to Iowa, Kansas and I.ouisiana.

Illustrations: Grevillea 1: pl. 1, f. 1; Cooke, Mycographia pl. 50, f. 195; Bull. Lab. Nat. Hist. State Univ. Iowa 6: pl. 22, f. 2 .

Exsiccati: N. Am. Fungi 436 .

Rather common but not abundant in woods in midsummer.

4. Plectania hiemalis (Nees \& Bernst.) Seaver, comb. 110V.

(Plate 19, FIG. 2.)

Microstoma hiemale Nees \& Bernst.; Milde, Bot. Zeit. 10: 208. 1852.

Peziza cruciata Fries, Nov. Symb. Myc. 229. 1855.

Peziza prostrata Fries, Nor. Symb. Myc. 230. 1855.

Peziza mirabilis Borszcz. Beit. Pflanzenkunde 10: 61. 1857.

Sclerotinia baccata Fuckel, Symb. Myc. 331. 1869.

Anthopeziza Winteri Wettst. Verh. Zool.-Bot. Wien 35: 383. 1886.

Sarcoscypha alpina Ellis \& Ev. Bull. Torrey Club 24: 281. 1897.

Sarcoscypha cruciata Sacc. Syll. Fung. 8: 154. 1889. 
Sarcoscypha prostrata Sacc. Sy 11. Fung. 8: 155. 1889.

Lachnea mirabilis Phill. Grevillea 18: 83. 1890.

Apothecia solitary or cespitose, stipitate, at first infundibuliform, becoming expanded and at maturity shallow cup-shaped, the margin lobed and of ten reflexed, reaching a diameter of $1 \mathrm{~cm}$., externally clothed with soft, white, flexuous hairs; hymenium bright-red, almost scarlet; stem slender, reaching a length of $3-4 \mathrm{~cm}$. and a diameter of 1-2 mm., gradually expanding into the cup; hairs hyaline, blunt, and of about the same diameter throughout their entire length, reaching a diameter of $6-7 \mu$; asci cylindric, reaching a length of $200-250 \mu$ and a diameter of 20-22 $\mu$; spores 1-seriate, ellipsoid, subinequilateral, narrowed toward either end, usually containing one large oil-drop and one or two smaller ones, $13-16 \times 25-50 \mu$, smooth; paraphyses slender, slightly enlarged above.

On the ground in woods.

Trpe locality: Near Breslau, Germany.

Distribution: Minnesota to Colorado; also in Europe.

Illustrations: Verh. Zool.-Bot. Wien 35: pl. 16; Cooke, Mycographia, pl. 25,f. 89; Beit. Pflanzenkunde 10: pl. 4, 5.

The only North American specimen of this species seen is a single plant, the type of Sarcoscypha alpina. The accompanying photograph is from a plant in the Torrey collection from an unknown locality.

\section{Doubtfll Species}

Sarcoscypha roseotincta Clements, Boc. Surv. Nebr. 4: 11. 1896. A delicate rose-colored species with spores $5 \times 10 \mu$ described from material collected on horse dung. Nothing is known of the species in addition to that given in the original description.

\section{BULGARIA Fries, Syst. Myc. 2: 166. 1822.}

Burcardia Schmidel, Ic. Pl. 261. 1797. Not Burcardia Schreb. 1789. Sarcosoma Casp; Rehm in Rab. Krypt.-F1. $\mathbf{1}^{3}: 497.1896$.

Apothecia stipitate or sessile, externally hairy or tomentose, the tissue gelatinous, when dry becoming coriaceous or corky; hymenium partly or entirely covering the upper surface, lighter than the exterior which is black or blackish, the entire apothecium becoming strongly wrinkled when dry; asci cylindric or subcylindric, 8-spored; spores ellipsoid or subellipsoid; hyaline or subhyaline; paraphyses slender. 
Type species, Burcurdia globosa Schmidel.

The genus Bulgaria was established by Fries and based on an operculate form as indicated above. Howerer, at the same time he included in the genus Pesisa inquinans Pers. which is an inoperculate species and according to present notions not congeneric with the type of the genus. Unfortunately Saccardo in his "Sylloge Fungorum" has treated Bulgariu inquinans first so that it has come to be looked upon by collectors as the typical Bulgaria, especially since it is much more commonly collected than the authentic type. We are therefore using the genus Bulgaria in the restricted, and morphologically correct sense for the operculate forms. Since the inoperculate species are not treated in this work, Bulgaria inquinans (Pers.) Fries is left out of consideration, but will be properly dealt with under the Inoperculates when these are monographed.

Apothecium strongly swollen below into a large globose

base.

1. B. globosa.

Apothecium not swollen into a globose base below the hymenium.

Hymenium light-colored when fresh, with a reddish tinge.

Hymenium dark-colored, blackish.

2. B. rufa.

3. B. melastoma.

1. Bulgaria globosa Fries, Syst. Myc. 2:166. 1822. (Text Fig. 2.)

Burcardia globosa Schmiclel, Ic. Pl. 261. 1797.

Peziza Burcardia Pers. Syn. Fung. 632. 1801.

Burckhardia globosa Kuntze, Rev. Gen. Pl. 2: 845. 1891.

Sarcosoma globosa Casp.; Rehm in Rab. Krypt.-Fl. 1³:498. 1896.

Apothecia gregarious, at first nearly globose, ranging in size from 1-5 cm. or rarely larger, at length ovoid with the hymenium appearing as a depression in the upper surface, becoming expanded but usually much narrower than the gelatinous base which remains strongly swollen and bulged out below the hymenium, externally, brownish-black, the substance consisting of a tough outer rind and a thick, gelatinous interior which shrinks much in drying, giving the exterior a peculiar wrinkled appearance, minutely brownish-tomentose; hymenium slightly concave, darker than the outside of the apothecium; asci cylindric or subcylindric above; spores 1-seriate, ellipsoid, about 10-12 $\times 23-26 \mu$; paraphyses dark-brown adhering together in masses, slender below, enlarged above.

On the ground among mosses in fir woods.

Type Lochlity: Europe. 
Distribution: Ontario, Canada; also in Europe.

Illustratiox: Schmidel, Ic. Pl. 69, f. 1-13.

On May 23, 1919 an excellent specimen of this species was received from Prof. J. H. Faull of the Iniversity of Toronto, Toronto, Canada. Although previously recorded from Ottawa, this is the only fresh specimen of the species seen by the writer. American specimens agree well with Schmidel's excellent illustrations except that the hymenium in our specimen is much more expanded which is probably due to a more advanced stage of development. This is a part of the material reported in Mycologia (11:293. 1919) as Bulgaria platydiscus Casp. which is said to differ from $B$. globosa in the size of the spores. The writer has had no opportunity to study living material of either species.

2. Bulgaria rufa Schw. Trans. Phil. Soc. II. 4: 178. 1832.

Apothecia gregarious or cespitose, sessile or more of ten shortstipitate, attaining a diameter of $2-3 \mathrm{~cm}$. at first closed, finally opening and becoming shallow cup-shaped, with the margin incurved, externally blackish-brown and covered over with clusters of hairs, the substance tough, internally with a gelatinous layer several $\mathrm{mm}$. thick, giving to the fresh plants a rubbery consistency, on drying becoming coriaceous and strongly wrinkled as a result of the gelatinous tissue within; hymenium slightly concave, pale-reddish or reddish-brown; stem reaching a length of $1 \mathrm{~cm}$. and a diameter of $45 \mathrm{~mm}$., attached below by means of a dense mass of black mycelium which reaches a diameter of $7-8 \mu$; hairs blackish-brown, similar to the mycelium at the base of the stem but shorter; asci cylindric above, gradually tapering below into a long stem-like base, reaching a length of 275-300 $\mu$ and a diameter of $12-14 \mu$; spores 1 -seriate, ellipsoid, with the ends strongly narrowed, hyaline, granular within, $10 \times 20 \mu$; paraphyses filiform, scarcely enlarged above.

On the ground in woods attached to sticks which are buried under leaf-mould and soil.

Trpe locality: Bethlehem, Pennsylvania.

Distribution: New York to Minnesota, Missouri and North Carolina.

Illustration: Bull. Lab. Nat. Hist. State L'niv. Iowa 6: pl. $37, f .1$. 
Exsicciti: N. Am. Fungi 449; Fungi Columb. 248; Rav. Fungi Car. 4: 23; Rab.-Winter, Fungi Eu. $3+67$ (as Pesisa pellita Cooke \& Peck).

Frequent in woods in midsummer.

\section{Bulgaria melastoma (Sow.) Seaver, comb. nov.}

Peziza melastoma Sow. Engl. Fungi pl. 149 (with descr.). 1799.

Pesiza rhizopus Alb. \& Schw. Consp. Fung. 317. 1805.

Calycina melastoma S. F. Gray, Nat. Arrang. Brit. Pl. 670. 1821.

Peziza atrorufa Grev. Scot. Crypt. Fl. 315 (with rlescr.). 1828

Peziza cremulata Fuckel, Bot. Zeit. 19: 250. 1861.

Plectania melastoma Fuckel, Symb. Myc. 324. 1869.

Peziza hirtipes Cooke, Bull. Buff. Acad. Sci. 2: 290. 1875.

Lachnea melastoma Gill. Champ. Fr. Discom. 66. 1880.

Peziza rhizomorpha Ellis \& Ev. Jour. Myc. 4: 98. 1888.

Plectania hirtipes Sacc. Syll. Fung. 8: 163. 1889.

Plectania rhizomorpha Sacc. Syll. Fung. 8: 164. 1889.

Lrmula melastoma Boud. Hist. Class. Discom. Eu. 55. 1907.

Sarcoscypha melastoma Hone, Minn. Bot. Studies 4: 97. 1909.

Scutellinia melastoma Kuntze, Rer. Gen. Pl. 33: 520. 1898.

Scutellinia hirtipes Kuntze, Rev. Gen. Pl. $3^{3}: 520.1898$.

Scutellinia rhizomorpha Kuntze, Rev. Gen. Pl. 33: 520. 1898.

Apothecia gregarious or cespitose, short-stipitate or sessile, at first globose or subglobose, gradually opening with a circular aperture, but with the margin remaining incurved, entirely black or brownish-black, externally tomentose, the substance tough outside with an internal gelatinous layer, becoming much wrinkled in drying, reaching a diameter of $1-2 \mathrm{~cm}$. and of about the same depth; hymenium deeply concave, a little paler than the outside of the apothecium, smooth and glistening, splitting into vein-like markings when dry; stem when present, short and stout, attached to the substratum by a dense tuft of black mycelium which penetrates into the humus and binds it together; hairs brown, flexuous, long, about $7 \mu$ in diameter, often interspersed with brick-red granules; asci cylindric, reaching a length of $500-600 \mu$ and a diameter of $15-18 \mu$, tapering below into a long, slender, stem-like base; spores ellipsoid, with the ends strongly narrowed, smooth, hyaline, 9-10 × 20-25 $\mu$; paraphyses filiform, scarcely enlarged above, yellowish-brown.

Attached to sticks and twigs in woods.

TrPe locality: Great Britain.

Distributiox: Maine to Manitoba, Washington, Mexico and the West Indies; also in Europe, New Zealand and Australia. 
Illustrations: Alb. \& Schw. Consp. Fung. pl. 1, f. 7; Boud. Ic. Myc. pl. 342; Cooke, Mycographia pl. 27, f. 103, 104; Gill. Champ. Fr. Discom. pl. 58, f. 3; Grev. Scot. Crypt. F1. pl. 315; Sow. Engl. Fungi pl. 149.

The generic position of this species is very uncertain as indicated by the synonymy. It shows affinities with both Bulgaria and Urmula but does not seem to fit either genus particularly well. What appears to be this species is very abundant in Bermuda on the bark of Bermuda cedar, Juniperus bermudiana, but never on anything else. Since the host is an endemic species the fungus may also be found to differ and be itself endemic. The writer has not yet had the opportunity to clear up this point but reference will be made to it in later publications.

\section{Doubtful Species}

Peziza aurantiopsis Ellis, Bull. Torrey Club 9: 18. 1882; Lachnea aurantiopsis Sacc. Syll. Fung. 8: 180. 1889; Scutellinia aurantiopsis Kuntze, Rev. Gen. Pl. 2: 869.1891 . Apothecia gregarious, sessile, attached to the substratum by the entire under surface except the extreme margin which is free and slightly elevated and more or less incurved, externally brownishblack, the under side covered with numerous projecting folds, clothed with a dense growth of black mycelium, the substance within white, several mm. thick and in dried plants decidedly corky; hymenium pale-yellow, darker in dried plants; mycelium pale-brown, thin-walled, branched, septate, and externally often minutely rough; asci cylindric above, gradually tapering below into a stem-like base, reaching a length of $300 \mu$ and a diameter of $17-18 \mu$; spores 1 -seriate or with the ends slightly overlapping, broad-ellipsoid, granular within, hyaline or slightly yellowish, $16-18 \times 27-33 \mu$; paraphyses slender, slightly enlarged above and hyaline or nearly so, reaching a diameter of $3-4 \mu$.

On bare soil and on decaying wood and leaves in low sandy oak and pine woods.

In general appearance this species resembles a Bulgaria. Dried specimens examined show the substance to be thick and decidedly corky and in this closely resembling a Phillipsia, although in other respects it does not seem to fit the genus well. Its generic position is therefore uncertain. In addition to the type, excellent dried specimens have been sent by Dr. L. O Overholts from Pennsylvania. No living plants have been seen by the writer.

\section{URNULA Fries, Summa V'eg. Scand. 364. 1849.}

Cenangium \& Microcrater Endl. Gen. Pl. 32. 1836.

Chorioactis Kupfer, Bull. Torrey Club 29: 142. 1902.

Apothecia opening with a stellate aperture or by a number of transverse slits through the apex, leaving the margin crenate 


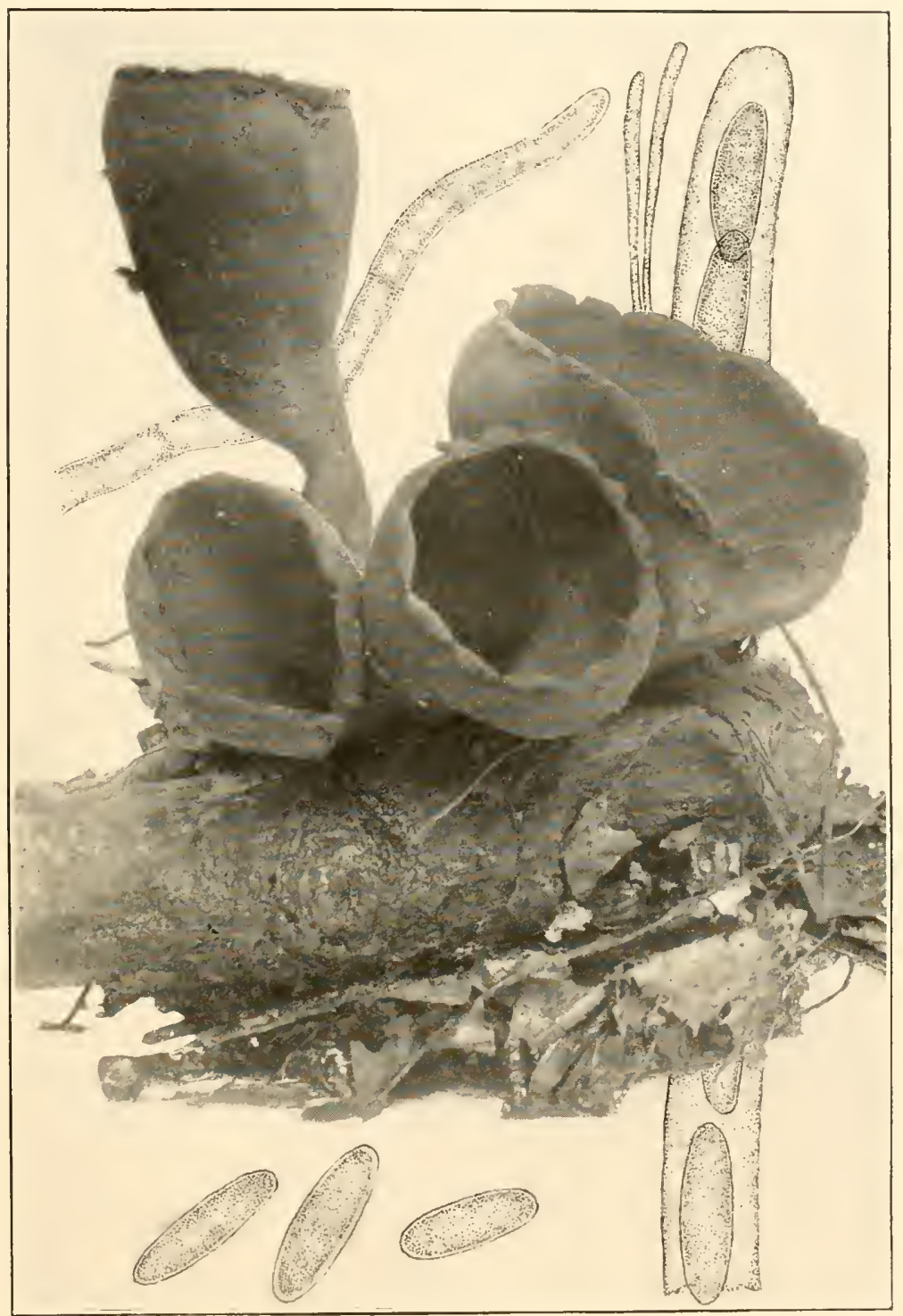

URNULA CRATERIUM 

or split into a number of rays, externally tomentose; asci cylindric or subcylindric, 8-spored; spores ellipsoid to fusoid, hyaline or subhyaline; paraphyses very slender, of ten branched.

Type species, Peziza Craterium Schw.

Apothecium with a crenate margin, not splitting Geaster-

like.

Apothecium splitting Geaster-like into rays.

1. U. Craterium.

2. U. Geaster.

1. Urnula Craterium (Schw.) Fries, Nowa Acta Soc. Sci. Upsal. III. 1: 122. 1851. (PlATE 21.)

Peziza Craterium Schw. Schr. Nat. Ges. Leipzig 1: 117. 1822.

Cenangium Craterium Fries, Elench. Fung. 2: 21. 1827.

Dermea Craterium Schw. Trans. Am. Phil. Soc. II. 4: 237. 1832.

Peziza adusta Schulz. Verh. Zool.-Bot. Wien 16: 62. 1866.

Craterium microcrater Haszl. Verh. Zool. Bot. Wien 37: 167. 1887.

Scutellinia adusta Kuntze, Rev. Gen. Pl. 33: 520. 1893.

Geopyxis Craterium Rehm in Rab. Krypt.-Fl. 13: 974. 1896.

Plectania adusta Sacc. Syll. Fung. 8: 16t. 1889.

Apothecia at first closed above, finally opening by a starshaped aperture which leaves the margin notched and infolded, externally black or brownish-black and clothed with a lense covering of tomentum, reaching a diameter of $3-4 \mathrm{~cm}$. and a depth of 4-6 cm., the substance tough and leathery; hymenium brownish-black, a little paler than the outside of the apothecium; stem reaching a length of $3-4 \mathrm{~cm}$. and a diameter of 5-8 $\mathrm{mm}$., even or very slightly lacunose near the base, black or brownishblack and attached to the substratum by a dense mass of black mycelium, gradually expanding above into the apothecium; hairs variable in length, thin-walled sparingly septate. flexuous, about $10 \mu$ in diameter and of nearly uniform thickness throughout their entire length; asci cylindric above, tapering below into a long stem-like base, reaching a length of $600 \mu$ and a diameter of $15-17 \mu$; spores 1 -seriate, broad-ellipsoid, smooth, hyaline, $12-1+\times 25-35 \mu$; paraphyses filiform, slightly enlarged above, pale-brown.

On the ground in deciduous woods, attached to buried or partially buried sticks.

TyPE Locality: North Carolina.

Distribution: New York to North Dakota, Alabama and Mississippi; also in Europe.

Illustritions: Boud. Ic. Myc. pl. 341; Bull. Lab. Nat. Hist. State Univ. Iowa 6: pl. 39, f. 2; Bull. Soc. Myc. Fr. 14: 
pl. 11, f. 3; Freeman, Minn. Pl. Diseases f. 61-62; Minn. Bot. Studies 4: pl. 16; Nees \& Henry, Syst. Pilze pl. 20, f. 1-t (as IIicrocrater); Schr. Nat. Ges. Leipzig 1: pl. 1, f. 7-11.

Exsiccati: N. Am. Fungi 982; Fungi Columb. 1890; Rab.Winter, Fungi Eu. 2968; Rav. Fungi Am. Exsicc. 633; Rav. Fungi Car. 1: 39; Rehm, Ascom. 2002.

Common and conspicuous in woods in early spring.

2. Urnula Geaster Peck, Ann. Rep. N. Y. State Mus. 46: 39. 1893. (Plate 22.)

Chorioactis Geaster Bull. Torrey Club 29: 142. 1902.

Apothecia at first elongated and closed or nearly closed at the top, reaching a diameter of $5 \mathrm{~cm}$. and a depth of $10 \mathrm{~cm}$., opening by several transverse fissures and finally splitting Geaster-like into 3-6 rays, the clefts extending nearly to the base of the apothecium, externally clothed with a dense covering of brownish tomentum, reaching a diameter of $10-12 \mathrm{~cm}$. when expanded, substance tough and leathery, soft and spongy when dry; hymenium at first white or whitish, becoming yellowish with age; stem $1-2 \mathrm{~cm}$. in diameter, and reaching a length of $1-3 \mathrm{~cm}$., similar in color to the outside of the apothecium; hairs straight or bent and twisted into various forms, reaching a diameter of $\delta \mu$ and of nearly uniform thickness throughout their entire length, rather thin-walled, sparingly septate, deeply colored and minutely roughened on their outer surface, blunt at their apices, variable in length; asci cylindric or subcylindric, reaching a length of $600-700 \mu$ and a diameter of $20-23 \mu$; spores 1 -seriate, fusoid, often unequal-sided, hyaline or subhyaline, $12-16 \times 50-70 \mu$; paraphyses strongly thickened above.

Attached to sticks of Llmus crassifolia on the ground.

Type locality: Austin, Texas.

Distribution: Texas.

Illustration: Bot. Gaz. 49: 184, f. 1; 185, f. 2; 186, f. 3 and $\mathrm{pl}$. 12.

\section{Excluded Species}

Urnula terrestris (Niessl) Sacc. Syll. Fung. 8: 550. 1889; Podophacidium terrestre Niessl in Rab. Fungi Eu. 1152. 1868; Phacidium terrestre Phill. Grevillea 18: 86. 1890. While this species has been placed in the genus Urmula by Saccardo, examination of cotype material gives no indication that the asci are operculate as is true of other species of the genus Urmula. The genus Podophacidium was founded by Niessl on this species and the genus has been placed in the Phacidiaceae, a family of inoperculate ascomycetes where it doubtless belongs. North American specimens collected by Dr. B. O. Dodge in Wisconsin have been examined. 


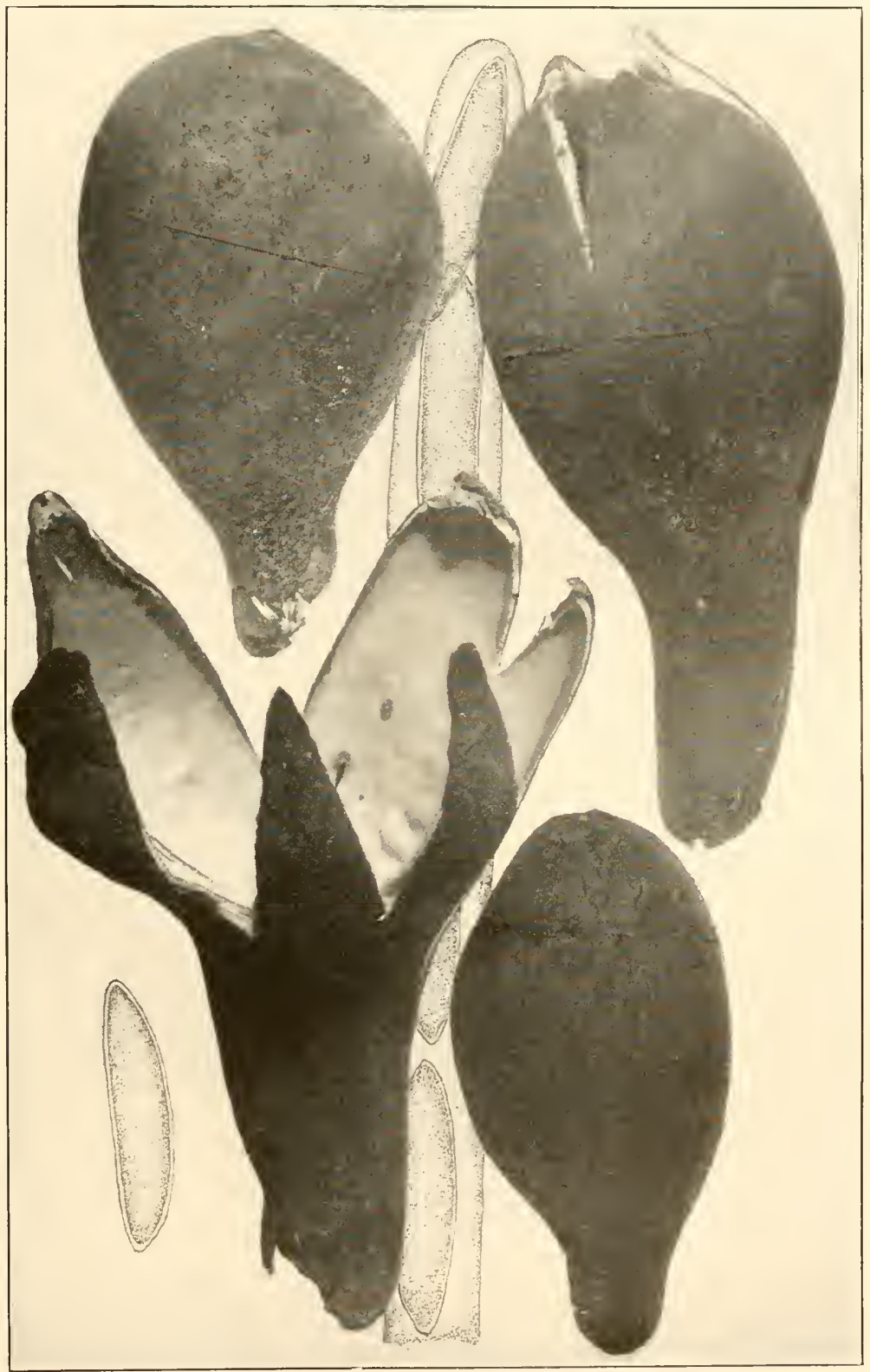

URNULA GEASTER 

34. PAXINA Kuntze, Rer. Cien. Pl. 2: 86t. 1891.

Acetabula Fuckel, Symb. Myc. 330. 1869. Not Acetabulum BoehmerLudwig, 1760.

Macropodia Fuckel, Symb. Myc. 331. 1869. Not Macropodia R. Brown, 1812.

Fuckelina Kuntze, Rev. Gen. Pl. 2: 852. 1891. Not Fuckelina Sacc, 1875. Phleboscyphus Clements, Bull. Torrey Club 30: 93. 1903.

Cyathipodia Boud. I Iist. Class. Discom. Eu. 39. 1907.

Apothecia stipitate or substipitate, cup-shaped, usually regular or occasionally slightly contorted, externally hairy or tomentose, the substance tough and approaching leathery; stem slender or, more often stout, long or very short and immersed in the ground when the apothecia appear sessile, eren or irregularly lacunose; asci cylindric to clavate, 8-spored; spores ellipsoid to fusiform, smooth or rough, hyaline or at most slightly yellowish; paraphyses rather stout.

Type species, Pesisa Acetabulum L.

Spores remaining permanently smooth.

Stem thick and strongly lacunose or corrugated.

Corrugations extending up the sides of the apothecium nearly to the margin.

1. P. Acetabulum.

Corrugations extending only to the base of the apothecium.

Stem long, reaching a length of $4-5 \mathrm{~cm}$.

2. P. macropus.

Stem short, not exceeding $2-3 \mathrm{~cm}$. in length.

Stem flattened.

3. P. platypodia.

Stem rounded or angular, not flattened.

Stem and outside of the apothecium nearly white; stem short, rarely reaching a diameter of $1 \mathrm{~cm}$.

4. P. leucomelas.

Stem and outside of the apothecium cinereous to brown; stem reaching a length of $2-3 \mathrm{~cm}$.

Stem and outside of the apothecium olivaceous; stem reaching a length of $2-3 \mathrm{~cm}$.

6. P. Barlae.

Stem slender, even or only slightly corrugated.

Apothecia and stems cinereous to brown; hairs hyaline.

Stems even, at least usually so.

Reaching a length of $3-4 \mathrm{~cm}$.

7. P. lispida.

Reaching a length of scarcely $1 \mathrm{~cm}$.

8. P. subclavipes.

Stems slightly corrugated.

9. P. Dupainii.

Apothecia and stems black or blackish.

Spores $10-12 \times 18-20 \mu$.

10. P. Corium.

Spores $15 \times 30-35 \mu$.

11. P. nigrella. 
Spores becoming rough at maturity.

Spores fusiform; apothecia brown.

Apothecia 2-3 cm. broad and high; stem strongly corrugated.

12. P. semitosta.

Apothecia scarcely exceeding $2 \mathrm{~cm}$. broad and high; stem not strongly corrugated.

Spores ellipsoid; apothecia olivaceous.

13. P. fusicarpa.

14. P. olivacea.

1. Paxina Acetabulum (L.) Kuntze, Rev. Gen. Pl. 2: 864. 1891. (Plate 23.)

Peziza Acetabulum L. Sp. Pl. 1181. 1753.

Macroscyphus acetabuliforme S. F. Gray, Nat. Arrang. Brit. Pl. 672. 1821.

Acetabula vulgaris Fuckel, Symb. Myc. 330. 1869.

Aleuria Acetabulum Gill. Champ. Fr. Discom. 36. 1879.

Elvela Acetabulum Quél. Enchir. Fung. 275. 1886.

Phleboscyphus Acetabulum Clements, Crypt. Form. Colo. 298. 1907.

Acetabula Acetabulum Underw. \& Earle, Bull. Alab. Exp. Sta. 80: 200. 1897.

Apothecia rather deep cup-shaped, reaching a depth of 2-3 cm. or more rarely expanded and shallow, externally cinereous to brownish, minutely tomentose and conspicuously ribbed, reaching a diameter of $3-5 \mathrm{~cm}$., stipitate; hymenium darker than the exterior of the apothecium, brown to brownish-black; stem short and thick, reaching a length of $1-1.5 \mathrm{~cm}$. and a diameter of $1 \mathrm{~cm}$., deeply lacunose, the ribs of the stem being continuous with those of the apothecium, the stem not sharply defined but gradually expanding into the apothecium; tomentum consisting of bunches or fascicles of poorly developed, hyaline hairs, the component cells of which are strongly swollen but contracted at the point of union; asci cylindric above; spores obliquely 1 -seriate, ellipsoid, hyaline, each containing one oildrop, smooth, $12-14 \times 18-22 \mu$; paraphyses straight, enlarged above, reaching a diameter of 5-6 $\mu$ at their apices.

On the ground in woods and open places.

Type locality: Europe.

Distribution: New York to Minnesota, Colorado, Texas and Alabama; also in Europe.

Illustrations: Bull. Herb. Fr. pl. 485, f. 4; Vaill. Bot. Paris pl. 13, f. 1; Gill. Champ. Fr. Discom. pl. 32, f. 1; Bres. Fungi Trid. pl. 213, f. 1; Cooke, Mycographia pl. 47, f. 183; Massee, Brit. Fungus-F1. 4: 290, f. 15, 16; Phill. Brit. Discom. pl. 3, f. 11; Rab. Krypt.-F1. 13 : 923, f. 1-3; Sow. Engl. Fungi pl. 59; Bull. Lab. Nat. Hist. State Univ. Iowa 6: pl. 19, f. 3; Bull. Soc. Myc. Fr. 3: pl. 5, f. 1 . 


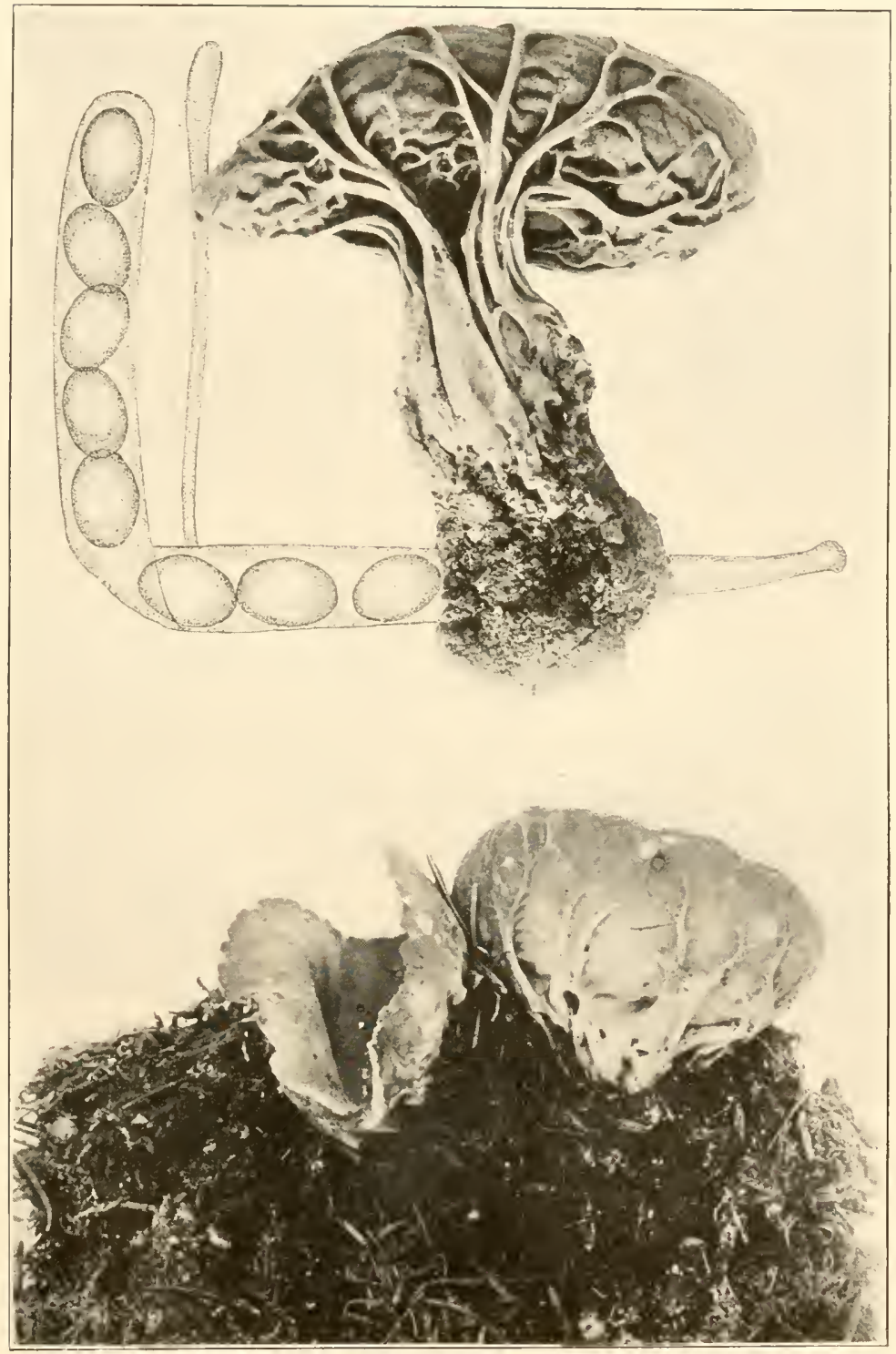

PAXINA ACETABULUM 

Exsiccati: Rav. Fungi Am. Exsicc. 764; Fungi Columb. 1801; Clements Crypt. Form. Colo. 298.

\section{Paxina macropus (Clements) Seaver, comb. nov.}

Phleboscyphus macropus Clements, Bull. Torrey Club 30: 93. 1903. Acetabula macropus Sacc. Syll. Fung. 18: 13. 1906.

?Cyathipodia longipes Boud. Hist. Class. Discom. Eu. 39. 1907.

Apothecia reaching a diameter of $3-4 \mathrm{~cm}$. and a depth of $1 \mathrm{~cm}$., externally cinereous-whitish, clothed, especially about the margin with short, septate hairs; hymenium darker than the exterior of the apothecium, brownish; stem solid, long, rather tough, lacunose, usually with three or four longitudinal ribs, reaching a length of $4-5 \mathrm{~cm}$. and a diameter of $7 \mathrm{~mm}$.; asci cylindric, reaching a length of $300 \mu$ and a diameter of $20 \mu$, tapering below into a stem-like base; spores irregularly 1-seriate, broad-ellipsoid, hyaline, each containing one large oil-drop which nearly fills the spore, about $12-14 \times 20-22 \mu$; paraphyses enlarged above where they reach a diameter of $9 \mu$.

On damp soil.

Trpe Locality: Minnehaha, Colorado.

Distribution: Wisconsin to Colorado; also in (Europe?).

\section{Paxina platypodia (Boud.) Seaver, comb. nov.}

Cyathipodia platypodia Boud. Hist. Class. Discom. Eu. 39. 1907.

Macropodia platypodia Dodge, Trans. Wisc. Acad. Sci. 17: 1041. 1914.

Apothecia scattered, rather shallow and more or less irregular, reaching a diameter of $2-3 \mathrm{~cm}$. and usually a depth of $1 \mathrm{~cm}$., externally cinereous and clothed with subconic fascicles of rather poorly developed hairs; hymenium darker than the exterior of the apothecium, almost black in dried specimens; stem much flattened and more or less costate or grooved on the two opposite sides, reaching a length of $2-3 \mathrm{~cm}$. and a diameter of $4-5 \mathrm{~mm}$., clothed with poorly developed hairs which give a pruinose appearance; hairs hyaline or subhyaline, consisting of loosely united cells which are strongly swollen in the center but contracted at the point of union; asci cylindric above, gradually tapering below, reaching a length $100-135 \mu$ and a diameter of $15-17 \mu$; spores 1 -seriate, usually diagonally disposed with the ends overlapping, fusoid, $10-11 \times 21-27 \mu$, usually containing one large oil-drop and two smaller ones; paraphyses $3-4 \mu$ in diameter below, rather strongly enlarged above where they reach a diameter of $7-9 \mu$. 
On the ground.

TrPE LOCALITY : France.

Distribution: Wisconsin; also in Europe.

4. Paxina leucomelas (Pers.) Kuntze, Rev. Gen. Pl. 2: 864. 1891.

Peziza leucomelas Pers. Myc. Eu. 1:219. 1822.

Aleuria lencomelas Gill. Champ. Fr. Discom. 37. 1879.

Acetabula leucomelas Boud. Hist. Class. Discom. Eu. 40. 1907.

Apothecia gregarious or scattered, rather deep cup-shaped, reaching a diameter of 2-3 cm. and a depth of $2 \mathrm{~cm}$. or occasionally expanded and more shallow, externally whitish or cinereous and rather conspicuously tomentose; hymenium darker than the outsicle of the apothecium, brownish-black; stem short and thick, not usually exceeding $1 \mathrm{~cm}$. in length and 5-8 $\mathrm{mm}$. thick, deeply lacunose, the ribs extending to the base of the apothecium; tomentum consisting of fascicles of hyaline hairs which are made up of rather loosely united and strongly swollen cells; asci cylindric above tapering below; spores ellipsoid, smooth, each containing one large oil-drop which nearly fills the spore, $12-13 \times 21-23 \mu$; paraphyses straight, enlarged above, reaching a diameter of 5-6 $\mu$.

On the ground.

TyPe LOCAlity : Europe.

Distribution: Wisconsin to California; also in Europe.

Iluestrations: Pers. Myc. Eu. pl. 30, f. 1; Gill. Champ. Fr. Discom. pl. 32, f. 2; Cooke, Mycographia pl. 47, f. 186; Boud. Ic. Myc. pl. 2+9; Bull. Soc. Myc. Fr. 3 : pl. 5, f. 2.

5. Paxina sulcata (Pers.) Kuntze, Rev. Gen. Pl. 2: 864. 1891. (Plite 24, Fig. 2.)

Peziza sulcata Pers. Syn. Fung. 643. 1801.

Acetabula sulcata Fuckel, Symb. Myc. 330. 1869.

Acetabula Calyx Sacc. Myc. Ven. 168. 1873.

Apothecia gregarious or scattered, shallow cup-shaped or occasionally expanded or nearly plane, reaching a diameter of 2-3 cm. and a depth of $1-1.5 \mathrm{~cm}$, externally minutely rough, the roughenings consisting of poorly developed hairs, the color varying from cinereous to brown; the hymenium darker than the outside of the apothecium, brownish-black; stem usually short, seldom exceeding a length of $1 \mathrm{~cm}$. or rarely $2 \mathrm{~cm}$., deeply lacunose, paler than the outside of the apothecium, whitish to 


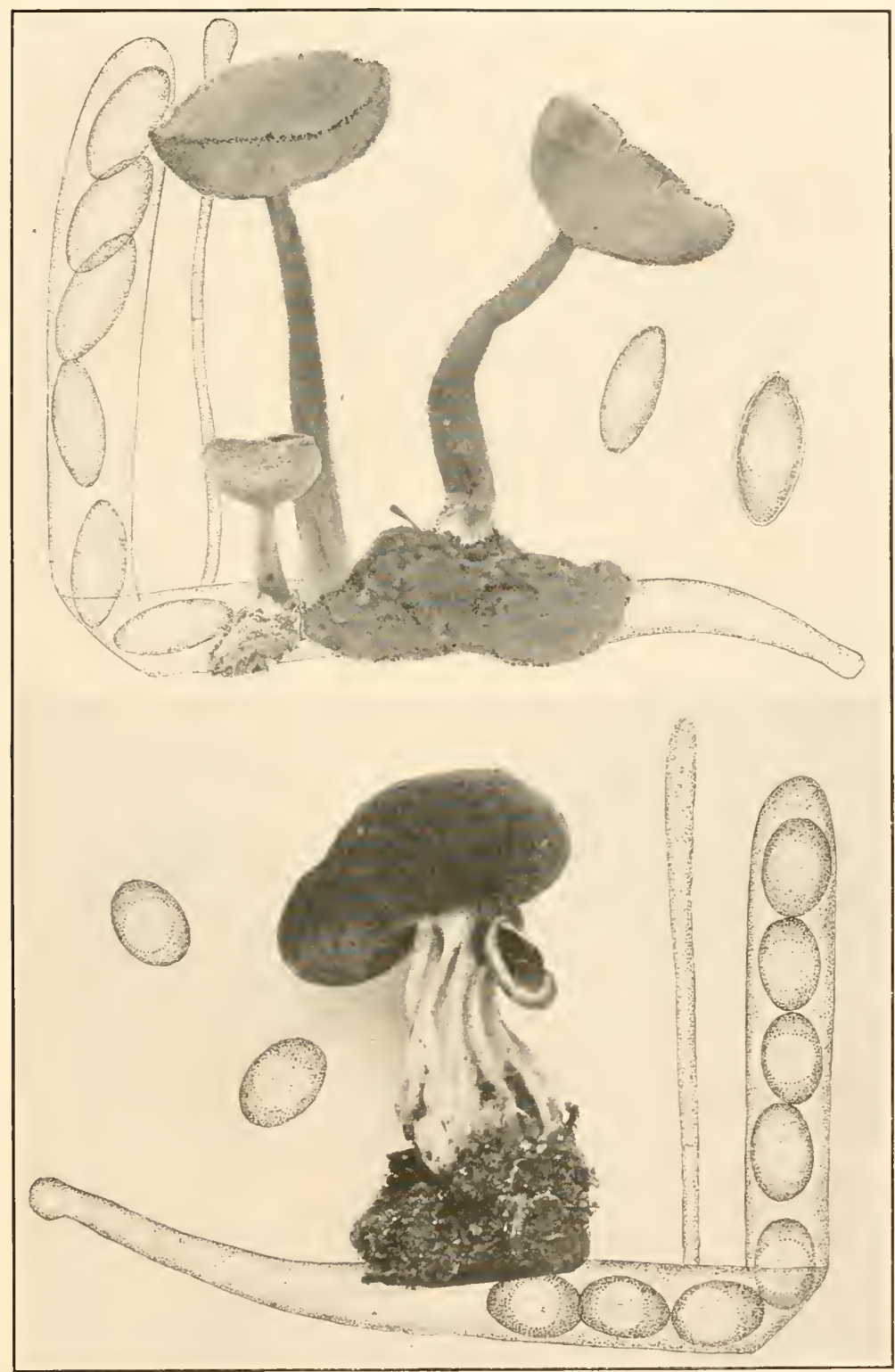

1. PAXINA HISPIDA

2. PAXINA SULCATA 

yellowish; hairs hyaline to subhyaline, each consisting of a few loosely united cells; asci cylindric or subcylindric, reaching a length of $300 \mu$ and a diameter of $15-18 \mu$; spores 1-seriate, broad-ellipsoid, containing one large oil-drop, $12-14 \times 15-20 \mu$; paraphyses rather stout, reaching a diameter of $7 \mu$, yellowish.

On the ground in woods.

Trpe LOCAlity: Europe.

Distribltiox: New Jersey to Iowa; also in Europe.

Illustrations: Pers. Sym. Fung. pl. 5, f. 1; Sacc. Myc, Ven. pl. 8, f. 14-18; Boud. Ic. Myc. pl. 246; Cooke, Mycographia pl. 47, f. 185; E. \& P. Nat. Pfl. $1^{1}: 186, f .150, E-F$; Bull. Lab. Nat. Hist. State Univ. Iowa 6: pl. 19, f. 2.

\section{Paxina Barlae (Boud.) Seaver, comb. nov.}

Acetabula Barlae Boud. Hist. Class. Discom. Eu. 40. 1907.

Apothecia gregarious deep cup-shaped, externally brownishtomentose or with a faint olive tint, reaching a diameter of 2-4 cm. and about the same depth; stem short, scarcely exceeding a length of $5 \mathrm{~mm}$., paler than the outside of the apothecium, deeply lacunose; hairs consisting of loosely united cells, hyaline or faintly yellowish; asci cylindric above, gradually tapering below, reaching a length of $300-325 \mu$ and a diameter of $20 \mu$; spores ellipsoid, hyaline, containing one large oil-drop, 12-13 $\times 20-23 \mu$; paraphyses gradually enlarged above, reaching a diameter of $7 \mu$, pale olive-brown.

On the ground.

TYPE LOCALITY: Europe.

Distribution: Alabama to California; also in Europe.

Illustration: Boud. Ic. Myc. pl. 245.

7. Paxina hispida (Schaeff.) Seaver, comb. nov. (Plate 24, FIG. 1.)

Elvela hispida Schaeff. Fung. Bavar. 4: 108. 177 t.

Octospora villosa Hedw. Descr. 2: 64. 1788.

Peziza macropus Pers. Obs. Myc. 1: 26. 1796.

Peziza stipitata Huds. Fl. Angl. 636. 1798.

Macroscyphus macropus S. F. Gray, Nat. Arrang. Brit. Pl. 672. 1821.

?Elvela ephippium Lév. Ann. Sci. Nat. II. 16:240. 1841.

Macropodia macropus Fuckel, Symb. Myc. 331. 1869.

Elvela macropus Karst. Myc. Fenn. 1: 37. 1871.

Aleuria macropus Gill. Champ. Fr. Discom. 35. 1875.

Lachnea macropus Phill. Brit. Discom. 207. 1887. 
Fuckelina villosa Kuntze, Rev. Gen. PI. 2: 852. 1891.

? Macropodia urceolata Clements, Bull. Torrey Club 30: 91. 1903.

Apothecia scattered or gregarious, reaching a diameter of 2-3 cm. and a depth of $1 \mathrm{~cm}$., externally grayish or densely whitish-tomentose; hymenium darker than the exterior of the apothecium, light-colored when young, becoming brownish with age; stem slender, reaching a length of $3-4 \mathrm{~cm}$. and a diameter of $3-4 \mathrm{~mm}$. at the base, gradually tapering upward toward the base of the cup where it is reduced to about $2 \mathrm{~mm}$., sharply distinguished from the apothecium, even or irregularly and sparingly lacunose, tomentose; tomentum consisting of conical bunches of hairs which cling together in fascicles, the individual hairs made up of a chain of loosely united, hyaline cells which are strongly swollen in the center and contracted at the point of union; asci cylindric or slightly clavate above, reaching a length of $250-275 \mu$ and a diameter of $17-20 \mu$, gradually tapering below into a stem-like base; spores 1-seriate, obliquely disposed in the ascus, narrow-ellipsoid to fusoid, smooth, containing one to three large oil-drops and numerous smaller ones, 12-14 $\times 25-30 \mu$, paraphyses gradually enlarged above where they reach a diameter of $8 \mu$.

On the ground in woods.

Type Locality: Europe.

Distribution: Massachusetts to Minnesota and Colorado (probably throughout North America); also in Europe.

Illustrations: Schaeff. Fung. Bavar. pl. 167; Bolton, Hist. Fung. 3: pl. 96; Boud. Ic. Myc. pl. 239; E. \& P. Nat. Pfl. $1^{1}$ : 186, f. 150, G-L; Gill. Champ. Fr. Discom. pl. 31; Hedw. Descr. 2: pl. 19,f. 1-4; Pers. Obs. Myc. pl. 1,f. 2; Underw. Molds Mild. \& Mush. pl. 4, f. 9-10; Bull. Lab. Nat. Hist. State Univ. Iowa 6: pl. 19, f. 1 .

Exsiccati: Clements, Crypt. Form. Colo. 297.

Rather common in midsummer.

8. Paxina subclavipes (Phill. \& Ellis) Seaver, comb. nov.

Pesiza subclavipes Phill. \& Ellis, N. Am. Fungi 985. 1887.

?Peziza brachypus Ellis \& Ev. Jour. Мyc. 4: 55. 1888.

?Geopyxis brachypus Sacc. Syll. Fung. 8: 68.1889.

Elvela macropus brevis Peck, Bull. Torrey Club 29: 74. 1902.

Macropodia subclavipes Rehm, Ann. Myc. 2: 35t. 1904.

Apothecia gregarious, reaching a diameter of $2 \mathrm{~cm}$. and a depth of about $1 \mathrm{~cm}$., externally cinereous to yellowish or more 
rarely olivaceous-brown, rough, the roughenings consisting of bunches of hairs; hymenium darker than the outside of the apothecium, brownish; stem slender, even or nearly so, reaching an extreme length of $1 \mathrm{~cm}$. but often not over a few mm., about $2 \mathrm{~mm}$. thick, covered like the outside of the apothecium with tufts of hairs; hairs clining together in conical clumps, each individual hair made up of a chain of loosely united cells the cells swollen in the center but contracted at the point of union, hyaline or faintly yellowish; asci cylindric, reaching a length of $250 \mu$ and a diameter of $15 \mu$; spores 1-seriate or slightly crowded near the apex of the ascus, ellipsoid, simple, containing one large oil-drop and occasionally a few smaller ones, smooth, hyaline, 9-10 $\times 18-23 \mu$; paraphyses filiform, about $3 \mu$ in diameter below, enlarged above where they reach a diameter of $7 \mu$, yellowish-brown.

On the ground in woods.

Trpe locality: Newfield, New Jersey.

Distribution: New York to Iowa, Texas and South Carolina. Exsiccati: Rav. Fungi Am. Exsicc. 760 (as Pezisa Corium); N. Am. Fungi $98+$ (as Pesisa Corium).

9. Paxina Dupainii (Boud.) Seaver, comb. nov.

Acetabula Dupainii Boud. Bull. Soc. Myc. Fr. 14: 17. 1898.

Elvela Faulknerae Copeland, Ann. Myc. 2: 509. 1904.

Cyathipodia Dupainii Boud. Hist. Class. Discom. Eu. 39. 1907.

Apothecia gregarious, cup-shaped, regular or occasionally compressed, reaching a diameter of $2-3 \mathrm{~cm}$. and a depth of $1 \mathrm{~cm}$., externally rough, the roughenings consisting of conical tufts of hairs, yellowish to yellowish-brown; hymenium darkbrown to blackish; stem slightly swollen near the base and narrowed upward toward the base of the apothecium, yellowish, lighter than the outside of the apothecium; asci cylindric above, gradually tapering below, reaching a length of $300-325 \mu$ and a diameter of $15 \mu$; spores ellipsoid, containing one large oil-drop which is nearly as large as the small diameter of the spore, hyaline, $12-15 \times 20-23 \mu$; paraphyses strongly enlarged above where they reach a diameter of $8-10 \mu$.

On the ground.

Trpe LOCALity : Europe.

Distribution: Wisconsin; also in Europe.

Illustrations: Bull. Soc. Myc. Fr. 14: pl. 3, f. 1; Boud. Ic. Myc. pl. 242; Ann. Myc. 2: pl. 12, f. 6-7. 
10. Paxina Corium (Weberb.) Seaver, comb. nov.

Peziza Corium Weberb. Pilze Norddeutsch. pl. 3, f. 7. 1873.

Aleuria Corium Gill. Champ. Fr. Discom. 39. 1879.

Lachnea Corium Phill. Brit. Discom. 204. 1887.

Macropodia Corium Sacc. Syll. Fung. 8: 159. 1889.

Fuckelina Corium Kuntze, Rev. Gen. P1. 2: 852. 1891.

Sarcoscypha Corium Schröt. Krypt.-Fl. Schles. 32: 59. 1893.

Elvela nigra Perk, Bull. Torrey Club 26: 70. 1899.

Cyathipodia Corium Boud. Hist. Class. Discom. Eu. 39. 1907.

Leptopodia Corium Boucl. Ic. Myc. 6: 1, 6. 1909.

Apothecia rather shallow cup-shaped or infundibuliform, with the margin more or less wavy, reaching a diameter of $3-5 \mathrm{~cm}$. and a depth of 1-2 cm., externally blackish, with a brownish tomentum, the substance tough, becoming very hard when dry (white when broken); hymenium black or blackish; stem 2-3 cm. long and nearly $1 \mathrm{~cm}$. in diameter at the base, tapering upward to a diameter of $3-4 \mathrm{~mm}$. near the base of the apothecium then gradually expanding into the apothecium, irregularly and rather sparingly lacunose, tomentose; tomentum consisting of hairs which are composed of a chain of rather loosely united cells, often branched, pale-brown; asci cylindric above, reaching a diameter of $20 \mu$; spores 1-seriate, ellipsoid, smooth, usually containing one large oil-drop which nearly fills the spore, 10-12 $\times 18-20 \mu$; paraphyses strongly enlarged above where they reach a diameter of $7-9 \mu$, pale-brown.

On the ground.

Type locality : Europe.

Distribution: Nebraska to Colorado and Idaho; also in Europe.

Illustrations: Weberb. Pilze Norddeutsch. pl. 3, f. 7; Cooke, Mycographia pl. 48, f. 187; Boud. Ic. Myc. pl. 239 bis.

Exsiccati: Fungi Columb. 2329; Clements, Crypt. Form. Colo. 536 .

\section{Paxina nigrella Seaver, sp. nov.}

Apothecia scattered, shallow cup-shaped, with the margin more or less wavy, externally brownish-black, clothed with inconspicuous hairs, reaching a diameter of 2-3 cm. and a depth of about $1 \mathrm{~cm}$. or less, becoming strongly wrinkled when dry (externally closely resembling Pseudoplectania vogesiaca); hymenium concave, black; stem reaching a length of $3-4 \mathrm{~cm}$. and a diameter of 2-3 $\mathrm{mm}$. of nearly uniform thickness throughout 
its entire length, roundish or angular, clothed like the outside of the apothecium with brown hairs and attached at the base with a dense mass of coarse, black mycelium; hairs pale-brown, septate, thin-walled, flexuous, reaching a diameter of $10 \mu$; asci cylindric above, gradually tapering below, reaching a length of $500 \mu$ and a diameter of $20 \mu$; spores 1 -seriate, parallel with the ascus, ellipsoid, usually containing two small oil-drops and numerous granules, hyaline or faintly yellowish, $15 \times 30-35 \mu$; paraphyses numerous slightly enlarged at their apices, darkbrown, reaching a diameter of $4-5 \mu$.

On rotten wood in coniferous woods.

Type LocAlity: Tolland, Colorado.

Distribution: Tolland and Caribou, Colorarlo.

This very characteristic species which externally very closely resembles Pseudoplectania rogesiaca is based on material collected June 30, 1914, by Dr. L. O. Overholts in Boulder Canyon, Colorado. A second collection was made by the late Professor E. Bethel at Caribou, Colorado, July 19, 1914. It differs from Paxina Corium, its closest ally, in the much larger size of its spores.

\section{Paxina semitosta (Berk. \& Curt.) Seaver, comb. nov.} (Plate 25, FIG. 2.)

Peziza semitosta Berk. \& Curt. Grevillea 3: 153. 1875.

Peziza Hainesii Ellis, Bull. Torrey Club 8: 65. 1881.

Lachnea Hainesii Sacc. Syll. Fung. 8: 186. 1889.

Fuckelina semitosta Kuntze, Rev. Gen. Pl. 2: 852. 1891.

Scutellinia Hainesii Kuntze, Rev. Gen. P1. 2: 869. 1891.

Sepultaria gigantea Clements, Bot. Surv. Nebr. 5: 8. 1901.

Sepultaria semitosta Morgan, Jour. Myc, 8: 188. 1902.

Lachnea gigantea Sacc. \& D. Sacc. in Sacc. Syll. Fung. 18: 33. 1906.

Macropodia semitosta Durand, Jour. Myc. 12: 31. 1906.

Apothecia gregarious or cespitose, rather deep cup-shaped, reaching a diameter of $2-5 \mathrm{~cm}$. and a depth of $2-3 \mathrm{~cm}$., externally brown and densely clothed with a soft tomentum; hymenium creamy-white when fresh, becoming brown when old or in drying; stem usually about $1 \mathrm{~cm}$. long and $1-2 \mathrm{~cm}$. in diameter, often immersed or partially immersed, deeply lacunose, brown and covered like the outside of the apothecium with tomentum; tomentum consisting of brown, rather thin-walled, sparingly septate, flexuous hairs which reach a diameter of $18-20 \mu$, of nearly uniform thickness throughout their entire length, ends 
blunt, the length very variable; asci cylindric to clavate, reaching a length of $300-325 \mu$ and a diameter of $15 \mu$; spores obliquely 1 -seriate, with the ends overlapping, fusoid to fusiform, becoming sculptured when mature, containing two large oil-drops, 10-12 $\times 25-33 \mu$; spore-sculpturing consisting of coarse warts; paraphyses clavate, reaching a diameter of $7-8 \mu$ at their apices.

On rich soil or more rarely on rotten wood.

Type Locality: Pennsylvania.

Distribution: New York to Wisconsin and Iowa.

Illistrations: Cooke, Mycographia pl. 28,f. 109; Grevillea 3: pl. 44, f. 225; Jour. Linn. Soc. 31 : pl. 16, f. 19.

13. Paxina fusicarpa (Ger.) Seaver, comb. nov. (Plate 25, FIG. 1.)

Pesiza fusicarpa Ger. Bull. Torrey Club 4: 64. 1873.

Peziza pubida Berk. \& Curt. Grevillea 3: 153. 1875.

Macropodia pubida Sacc. Syll. Fung. 8: 159. 1889.

Lachnea fusicarpa Sacc. Syll. Fung. 8: 172.1889.

Fuckelina pubida Kuntze, Rev. Gen. Pl. 2: 852. 1891.

Scutellinia fusicarpa Kuntze, Rev. Gen. Pl. 2: 869. 1891.

Sepultaria aspera Clements, Bot. Surv. Nebr. 4:12. 1895.

Lachnea aspera Sacc. \& Sydow in Sacc. Syll. Fung. 14: 757. 1899.

Peziza Morgani Massce; Morgan, Jour. Myc. 8: 190. 1902.

Macropodia fusicarpa Durand, Jour. Myc. 12: 29. 1906.

Apothecia gregarious or cespitose, rather deep cup-shaped, reaching a diameter of $2-3 \mathrm{~cm}$. and a depth of $1 \mathrm{~cm}$., externally brown and densely clothed with a soft tomentum; hymenium creamy-white when fresh, becoming brown when old or in drying; stem short, rarely exceeding $5 \mathrm{~mm}$. in length and about $3-5 \mathrm{~mm}$. in diameter, nearly even or in some cases deeply lacunose, clothed with tomentum similar to that on the outside of the apothecium, often immersed so that the apothecia appear to be sessile; tomentum consisting of thin-walled, flexuous, sparingly septate, brown hairs $12-15 \mu$ in diameter and of nearly uniform thickness throughout their entire length, or occasionally enlarged at the base, slightly roughened on the outside, ends blunt; asci cylindric or clavate above, reaching a diameter of $20-22 \mu$ and a length of $300-325 \mu$; spores 1 -seriate, diagonally disposed and with the ends strongly overlapping, or becoming partially 2-seriate above, hyaline or slightly yellowish, fusiform, containing two large oil-drops, often slightly curved or unequalsided, $10-12 \times 30-45 \mu$, becoming sculptured; spore-sculpturing 


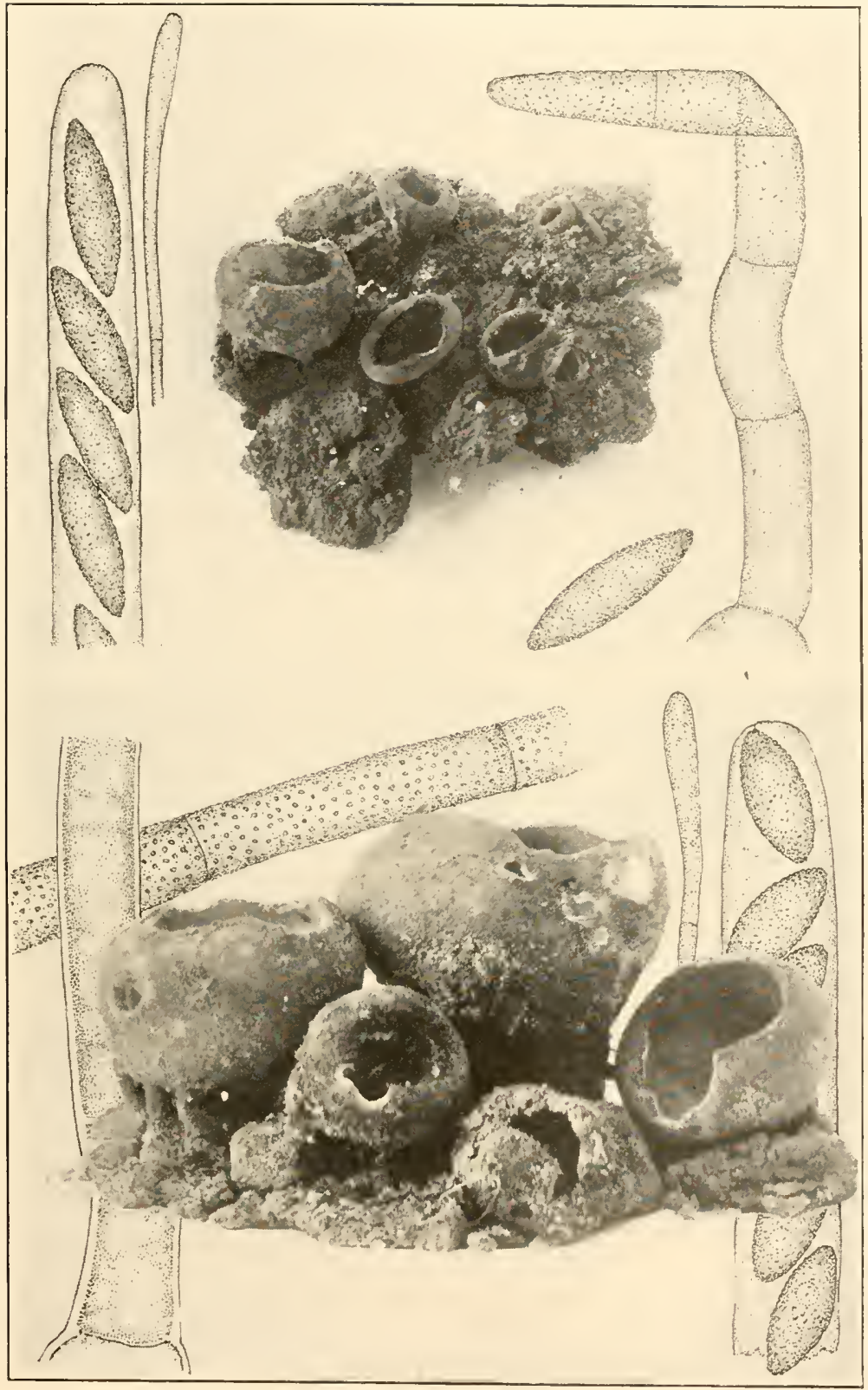

1. PAXINA FUSICARPA

2. PAXINA SEMITOSTA 

consisting of coarse warts; paraphyses cylindric or slightly clavate, reaching a diameter of $6-8 \mu$ at their apices.

On soil in woods or more rarely on rotten wood.

Typr locality: Poughkeepsie, New York.

Distribution: Connecticut to Iowa and Virginia.

Illustrations: Cooke, Mycographia pl. 28,f. 110 and pl. 29, f. 113; Grevillea 3: pl. .4, f. 226; Bull. Lab. Nat. Hist. State Univ. Iowa 6: pl. 21, f. 1.

Exsiccatı: N. Am. Fungi 1269; Fungi Columb. 1307; Rab.Winter, Fungi Eu. 325 (in part).

This and the preceding are frequently collected in midsummer.

14. Paxina olivacea (Clements) Seaver, comb. nov.

Phleboscyphus olivaceus Clements, Bull. Torrey Club 30: 93. 1903. Icetabula olivacea Sacc. \& D. Sacc. in Sacc. Syll. Fung. 18: 13. 1906.

Apothecia cespitose, cup-shaped, reaching a diameter of $4-5$ cm. and a depth of $2-2.5 \mathrm{~cm}$., margin becoming lacerate, externally brownish-olivaceous, furfuraceous-tuberculate; hymenium greenish-olivaceous; stem 1-2-sulcate or lacunose, furfuraceous, reaching a length of $2-2.5 \mathrm{~cm}$. and a diameter of $1.5-2 \mathrm{~cm}$; asci cylindric, short-stipitate, reaching a length of $350 \mu$ and a diameter of $14 \mu$; spores 1 -seriate, ellipsoid, becoming sculptured, hyaline, $8 \times 19 \mu$; spore-sculpturing consisting of minute warts: paraphyses slender, septate, hyaline, reaching a diameter of 3-4 $\mu$ at their apices.

On moist soil.

Type LocAlity: Jack Brook, Minmehaha, Colorado.

Distributiox: Known only from the type locality.

\section{Doubtful Species}

Macropodia Schweinitzii Sacc. Syll. Fung. 8: 160. 1889; Peziza tomentosa Schw. Trans. Am. Phil. Soc. II. 4: 171. 1832; Fuckelina Schreeinitzii Kuntze, Rev. Gen. Pl. 2: 852. 1791. The identity of this species is uncertain.

Plectania rimosa Peck, Bull. Torrey Club 30: 100. 1903. This may be Paxina Corium. No specimen has been seen.

35. GEOPYXIS (Pers.) Sacc. Syll. Fung. 8: 63. 1889. Peziza § Geopyxis Pers. Myc, Eu. 1:224. 1822.

Pustularia Fuckel, Symb. Myc. 328. 1869. Noc Pustularia Roussel, 1806.

Apothecia medium sized, usually deep cup-shaped, externally pustulate, stipitate; stem usually slender and short; asci 8- 
spored; spores ellipsoid, with or without oil-clrops; paraphyses slender.

Type species, Pesiza carbonaria Alb. \& Schw.

Plants confined to burned places or rocky ledges.

1. G. cupularis. Plants not confined to burned places.

On damp soil; spores containing two conspicuous oildrops.

Apothecia bright-yellow, very coarsely verrucose.

Apothecia dull-yellow, minutely verrucose.

Among mosses; spores without oil-drops.

2. G. Eronca.

3. G. Catinus.

4. G. vulcanalis.

1. Geopyxis cupularis (L.) Sacc. Syll. Fung. 8: 72. 1889. (Plate 26, Fig. 1.)

Peziza cupularis L. Sp. Pl. 1181. 1753.

Peziza carbonaria Alb. \& Schw. Consp. Fung. 31t. 1805.

Pustularia cupularis Fuckel, Symb. Myc. 328. 1869.

Pesiza suburceolata Phill. Grevillea 7: 21. 1878.

Aleuria cupularis Gill. Champ. Fr. Discom. 39. 1879.

Peziza crenata Bull. Herb. Fr. pl. 396. 1788.

Geopyxis carbonaria Sacc. Syll. Fung. 8: 71. 1889.

Geopyxis suburceolata Sacc. Syll. Fung. 8: 72. 1889.

Apothecia gregarious reaching a diameter of $3 \mathrm{~mm}$. to $1 \mathrm{~cm}$. (rarely larger) and of about the same depth, the mouth of the cup slightly constricted, at least in the younger specimens, and the margin crenate, the whole plant resembling a small acorncup, externally pustulate or nearly smooth, dull-yellowish; stem short, usually $2-3 \mathrm{~mm}$. long and about $1 \mathrm{~mm}$. thick, rather variable both in length and diameter, expanding rather abruptly into the apothecium; hymenium concare, a little paler than the outside of the apothecium; asci cylindric, reaching a length of $200 \mu$ and a diameter of $10 \mu$; spores 1 -seriate, obliquely arranged in the ascus when young and usually parallel when mature, ellipsoid, with the ends slightly narrowed, rather thick-walled, hyaline, smooth, about $9-10 \times 18 \mu$, without conspicuous oildrops; paraphyses enlarged above, reaching a diameter of $7 \mu$ at their apices.

On the ground in burnt places.

Type locality: Europe.

Distribution: New York to Washington, West Virginia and Colorado; also in Europe.

Illustrations: Boud. Ic. Myc. pl. 338, in part; Bull. Herb. Fr. pl. 396, f. 3; E. \& P. Nat. Pfl. 1' ${ }^{1}:$ 186, f. 150, A. \& B.; Gill. Champ. Fr. Discom. pl. 36; Alb. \& Schw. Consp. Fung. pl. $4, f .2$. 


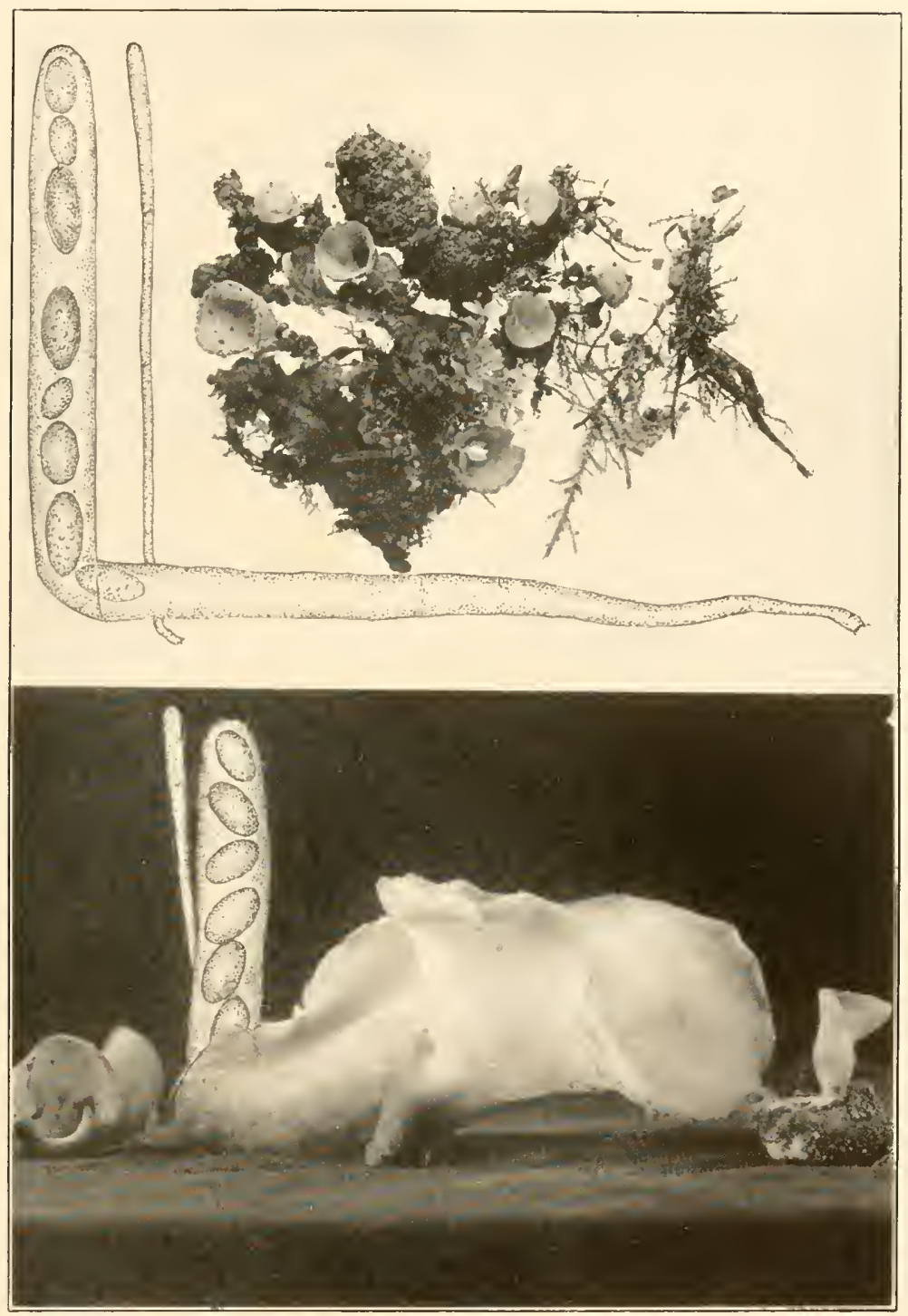

1. GEOPYXIS CUPULARIS

2. PEZIZA DOMICILIANA 

Exsiccati: N. Am. Fungi 2909.

A specimen of Peziza suburceolata in the herlarium of The New York Botanical Garden collected by Dr. Harkness in California seems to be identical with the above.

\section{Geopyxis bronca (Peck) Seaver, comb. nov.}

Peziza bronca Peck, Ann. Rep. N. Y. State Mus. 29: 54. 1878.

Aleuria humicola Boud. Hist. Class. Discom. Eu. 45. 1907.

Peziza humicola Sacc. \& Trav. in Sacc. Syll. Fung. 22: 614. 1913.

Apothecia gregarious or crowded, sessile or substipitate, at first subhemispheric, becoming more or less expanded with age, externally pale-yellow to bright lemon-yellow, the margin finely crenate and the entire exterior covered with coarse warts which give the apothecia a beautiful verrucose appearance, reaching a diameter of 2-3 cm. and of about half that depth; hymenium similar in color to the outside of the apothecium; asci cylindric or subcylindric, reaching a length of $400 \mu$ and a diameter of 24-28 $\mu$; spores 1 -seriate, ellipsoid, hyaline, smooth, 12-14 $\times 20$ $24 \mu$, containing two conspicuous oil-drops; paraphyses rather strongly enlarged above.

On the ground.

Type locality: Knowersville, New York.

Distribution: New York; also in Europe.

Illustrations: Ann. Rep. N. Y. State Mus. 29: pl. 2, f. 10-12; Boud. Ic. Myc. pl. 262.

3. Geopyxis Catinus (Holmsk.) Sacc. Syll. Fung. 8: 71. 1899.

Peziza Catinus Holmsk. Otia 2: 22. 1799.

Pustularia Catinus Fuckel, Symb. Myc. 328. 1869.

Aleuria Catinus Gill Champ. Fr. Discom. 39. 1879.

Apothecia rather deep cup-shaped, externally dull-yellow, strongly but finely pustulate, the margin crenate and usually infolded, reaching a diameter of $2-3 \mathrm{~cm}$. and nearly as deep; hymenium similar in color to the outside of the apothecium or a little lighter; stem reaching a length of $5 \mathrm{~mm}$. to $1 \mathrm{~cm}$. and usually 3-4 $\mathrm{mm}$. thick, lacunose or nearly even; asci cylindric above, gradually tapering below, reaching a diameter of $15 \mu$; spores 1-seriate, broad-ellipsoid, rarely with the ends slightly narrowed, containing two large oil-drops, more or less granular, 10-12 $\times 20 \mu$; paraphyses about $2 \mu$ in diameter, slightly enlarged above.

On the ground. 
Type locality : Europe.

Distribution: New York and California; also in Europe.

Illustrations: Holmsk. Otia 2: pl. 8 ; Boud. Ic. Myc. pl. 336 .

4. Geopyxis vulcanalis (Peck) Sacc. Syll. Fung. 8: 65. 1889.

?Peziza majalis Fries, Nova Acta Soc. Sci. Upsal. III. 1: 120. 1855.

Peziza vulcanalis Peck; Coulter, Rep. U. S. Geol. Surv. Terr. 6: 792. 1873.

Peziza pulchra Ger. Bull. Torrey Club 4: 64. 1873.

Geopyxis pulchra Sacc. Syll. Fung. 8: 65. 1889.

Phleboscyphus radicatus Clements, Bull. Torrey Club 30: 94. 1903.

Sarcoscypha dawsonensis Peck, Bull. Torrey Club 33: 220. 1906.

Acetabula radicata Sacc. Syll. Fung. 18: 13. 1906.

Apothecia gregarious, short-stipitate, subinfundibuliform with the margin usually incurved and crenate, externally covered with an evanescent, pruinose or subtomentose coat, especially when young, often becoming entirely smooth with age, whitish or yellowish-white, darker when naked, reaching a diameter of 1-2 cm. and about half as deep; stem 1-2 mm. thick and of variable length up to $5 \mathrm{~mm}$. but of ten so short that the apothecia appear sessile; hymenium pale-orange; asci cylindric above, tapering below into a long stem-like base, reaching a length of $275 \mu$ and a diameter of $15-17 \mu$ at the broadest point; spores ellipsoid, with the ends strongly narrowed, $8-10 \times 14-18 \mu$; paraphyses slightly thickened above, reaching a diameter of $4 \mu$ at their apices.

Nestling among mosses and leaf-mould in coniferous woods.

Type Locality: Snake River, Wyoming.

Distribution: New York to Wyoming and Colorado.

Illustration: Cooke, Mycographia pl. 74,f. 285.

Exsiccat1: Clements, Crypt. Form. Colo. 126 (as Phleboscyphus radicatus (lements).

\section{Doubtful and Excluded Species}

Geopyxis nebulosa (Cooke) Sacc. Syll. Fung. 8: 70. 1889; Peziza nebulosa Cooke, Mycographia 163. 1877. This is an inoperculate species and should be referred to the genus Ciboria.

Geopyxis nebulosoides Peck, Bull. Torrey Club 32: 80. 1905. Probably not distinct from Geopyxis nebulosa.

Geopyxis cinerascens (Rehm) Sacc. Syll. Fung. 18: 14. 1906; Tarzetta cinerascens Rehm, Ann. Myc. 2: 352. 1904. This is also undoubtedly a Ciboria.

Geopyxis verruculosa (Berk. \& Curt.) Sacc. Syll. Fung. 8: 68. 1889; 
Pesiza verruculosa Berk. \& Curt. Proc. Am. Acarl. 4: 127. 1860. This may be a Psendoplectania.

Geopyxis IIicksii Peck, Ann. Rep. N. Y. State Mus. 46: 38. 1893. This is probably a Sclerotinia. Type could not be found in the Peck collection at Albany.

36. RHIZINA Fries, Obs. Myc. 1: 161. 1815.

Apothecia expanded, attached to the substratum by numerous root-like processes, the substance fleshy or subfleshy, rather tough when dry; asci cylindric to clavate, 8-spored; spores fusoid; paraphyses stout.

Type species, Rhisina undulata Fries.

1. Rhizina inflata (Schaeff.) Karst. Act. Fauna Fl. Fenn. 2: 112. 1885. (Plate 27.)

Elvela inflata Schaeff. Fung. Bavar. 4: 102. 1774.

Elvela acoulis Pers. Obs. Myc. 2: 29. 1799.

Phallus acaulis Batsch, Elench. Fung. 130. 1783.

Peziza rhizophora Willd. F1. Berol. 402. 1787.

Octospora rhizophora Hedw. Descr. 2: 15. 1788.

Rhizina undulata Fries, Obs. Myc. 1: 161. 1815.

Rhizina laevigata Fries, Obs. Myc. 1: 162. 1815.

Apothecia sessile, discoid or nearly so, attached to the substratum by root-like processes which cover the lower surface to near the margin, the substance firm, more or less spongy, becoming tough or rather corky when dry, reaching a diameter of 5-6 cm.; hymenium plane or slightly convex, even or undulated, brownish-black, the margin lighter; asci cylindric to clavate, reaching a length of about $300 \mu$ and a diameter of 12-18 $\mu$; spores 1-seriate or partially 2 -seriate above, with the ends overlapping, fusiform, usually with an apiculus $3-4 \mu$ long on either end, containing two oil-drops and occasionally with a pseudoseptate appearance, hyaline, about $10 \times 35-43 \mu$; paraphyses enlarged and clinging together at their apices, brown, intermixed with brown, thick-walled, non-septate, hair-like structures.

Rare on the ground where it has recently been burned over. TYPE locality: Europe.

Distribution: Connecticut to Alabama and Montana; also in Europe.

Illustritions: Boud. Ic. Myc. pl. 251; E. \& P. Nat. Pfl. $1^{1}$ : 172, f. 1+3; Cill. Champ. Fr. Discom. pl. 30, f. 1; Hedw. 
Descr. pl. 5, A; Phill. Brit. Discom. pl. 2, f. 10; Rab. Krypt.Fl. 13: 1136, f. 1-4; Schaeff. Fung. Bavar. pl. 153.

Exsiccati: N. Amr. Fungi 2739.

\section{DoubtFul Species}

Rhizina spongiosa Berk. \& Curt.; Berk. Jour. Linn. Soc. 10: 364. 1869. Described as one and one-half inches in diameter with spores $20 \times 60 \mu$. Growing vertically on bushes.

\section{DISCINA Fries, Summa Veg. Scand. 348. 1849.}

Apothecia medium to large, sessile or short-stipitate, fleshy or waxy, light-or dark-colored; asci cylindric or subcylindric, very long, usually showing a tendency to become spirally twisted; spores ellipsoid, appendiculate and of ten sculptured, hyaline or faintly colored; spore appendages apiculate or truncate; paraphyses rather stout.

Type species, Discina perlata Fries. Apothecia dark-colored; spore appendages apiculate.

Apothecia large, $6-7 \mathrm{~cm}$. or more in diameter.

1. D. ancilis.

Apothecia medium sized, not exceeding $5 \mathrm{~cm}$. in diameter.

Apothecia bright-colored; spore appendages truncate.

Hymenium strongly convolute.

2. D. apiculata.

llymenium even or only slightly undulated.

3. D. convoluta.

4. D. lencoxantha.

1. Discina ancilis (Pers.) Sacc. Syll. Fung. 8: 103. 1899. (Plate 28, Fig. 2.)

Peziza ancilis Pers. Myc. Eu. 1: 219. 1822.

Peziza perlata Fries, Syst. Myc. 2: 43. 1822.

Discina perlata Fries, Summa Veg. Scand. 348. 1849.

Rhizina helvetica Fuckel, Symb. Myc. Nacht. 2: 66. 1873.

Peziza Warnei Peck, Ann. Rep. N. Y. State Mus. 30: 59. 1878.

Aleuria ancilis Gill. Champ. Fr. Discom. 36. 1879.

Acetabula ancilis Lamb. Fl. Myc. Belg. 2: 573.1880.

Discina Warnei Sacc. Syll. Fung. 8: 102. 1889.

Discina ancilis Sacc. Syll. Fung. 8: 103.1889.

Discina helvetica Sacc. Syll. Fung. 8: 103. 1889.

Apothecia gregarious or scattered, more rarely congested, short-stipitate, at first subglobose, soon becoming discoid, finally repand, at first regular in form, becoming irregular and of ten angular as the margin rolls back, externally whitish or pallid, reaching a diameter of $7-8 \mathrm{~cm}$., or in rare cases as large as 20-25 cm.; hymenium uncven, of ten beautifully veined or convolute, plane or convex, usually umbilicate, dark-brown, finally 


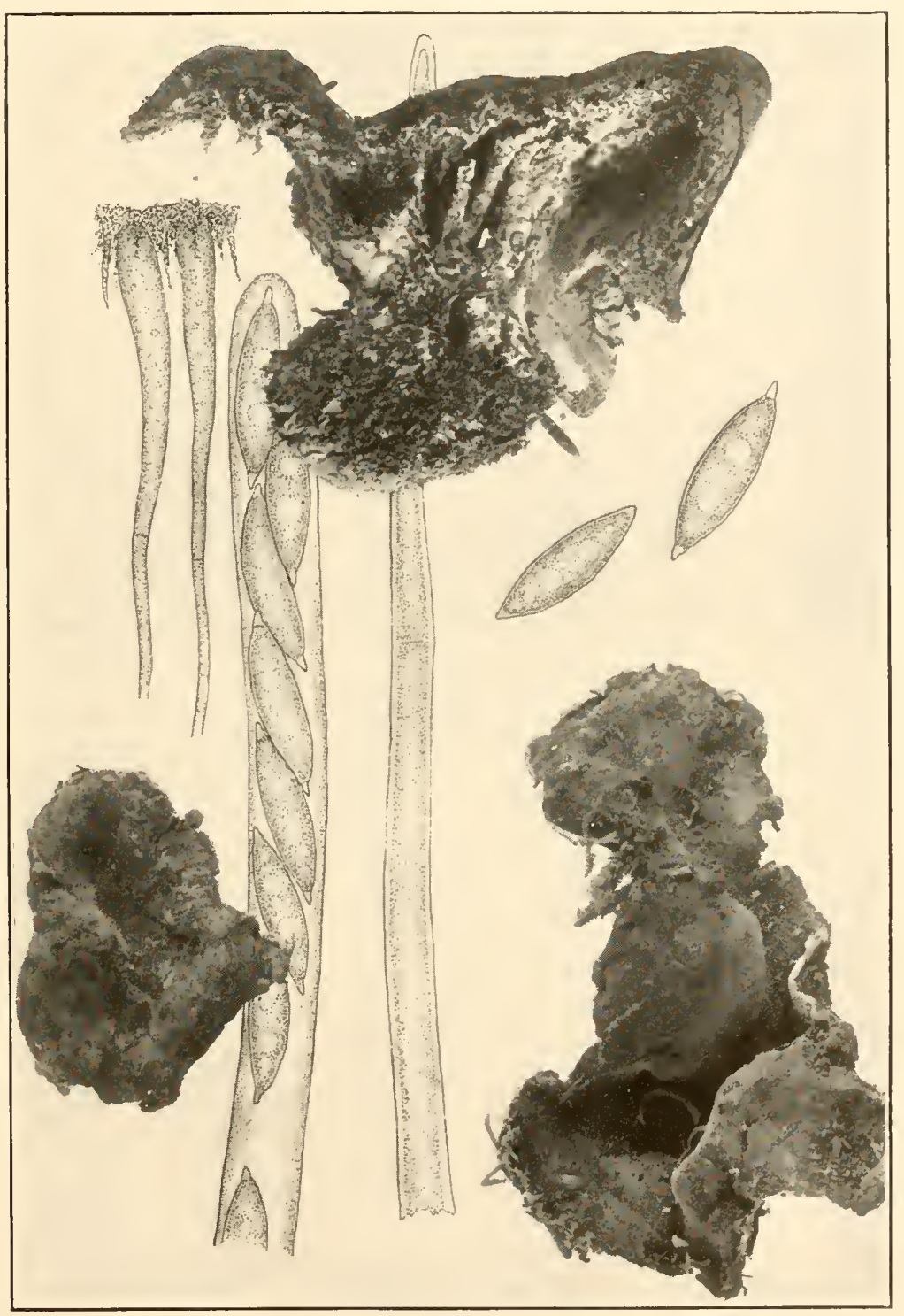

RHIZINA INFLATA 

almost black; stem very short and stout, often $1-3 \mathrm{~cm}$. in diameter and rarely exceeding $1 \mathrm{~cm}$. in length, or entirely wanting, more or less lacunose, whitish or overcast with a pinkish tint; asci cylindric or subcylindric, reaching a length of $300-350 \mu$ and a diameter of $12-18 \mu, 8$-spored; spores obliquely 1 -seriate, very large, ellipsoid, hyaline, $12-14 \times 30-35 \mu$, or occasionally as long as $40 \mu$ including apiculi; at first smooth, becoming sculptured; spore-sculpturing consisting of minute warts; spore appendages consisting of a minute apiculus $4-5 \mu$ long and $3-4 \mu$ broad at the base, one at either end of the spore; paraphyses strongly enlarged above, closely adhering together, dark yellowish-brown reaching a diameter of $8 \mu$.

On the ground in coniferous woods, more rarely on rotten wood.

Trpe Locality : Europe.

Distributiox: New York to Manitoba, Washington, Oregon, and Colorado; also in Europe.

Illustrations: Ann. Rep. N. Y. State Mus. 30: pl. 1, f. 19-21; Boud. Ic. Myc. pl. 252; Fuckel, Symb. Myc. Nacht. 2: f. 24; Pat. Tab. Fung. f. 596; Cooke, Mycographia pl. 103, f. 371; Rab. Krypt.-F1. $1^{3}: 922, f .1-4$.

Exsiccati: Shear, New lork Fungi 324; N. Am. Fungi 2622. Rather frequently collected but scarcely common.

2. Discina apiculata (Cooke) Seaver, Mycologia 13: 70. 1921.

Peziza apiculata Cooke, Mycographia 175. 1877.

Phaeopezia apiculata Sacc. Bot. Centr. 18: 218. 1884.

Aleuria a piculata Boud. Hist. Class. Discom. Eu. 47. 1907.

?Peziza elacodes Clements, Bot. Surv. Nebr. 5: 6. 1901.

Apothecia scattered, sessile, at first cup-shaped, soon becoming discoid, fleshy, circular in outline not usually exceeding $1.5 \mathrm{~cm}$. in diameter; hymenium dark brownish-black, slightly concave or nearly plane; asci cylindric or subcylindric, reaching a length of $200 \mu$ and a diameter of $18 \mu$, 8-spored; spores obliquely 1 -seriate, with the ends overlapping, narrow-ellipsoid to fusoid, often with a small apiculus at either end, becoming pale-brownish and often delicately sculptured, about $10 \times 2+\mu$, containing two large oil-drops; spore-sculpturing consisting of minute warts; paraphyses slender, adhering together at their apices, darkbrow11.

On damp soil.

TyPE LoCALITY: Italy. 
Distribution: (Nebraska?) and (Bermuda?); also in Europe. Illustration: Cooke, Mycographia pl. 79, f. 305.

A small specimen collected in Bermuda by B. O. Dodge seems to belong here so far as spore characters are concerned. However, the material was so limited that it was impossible to make a careful study of the gross characters. Also Pesiza elaeodes of Clements seems to fit Cooke's description but here again it was impossible to be certain for lack of material. So the species must remain doubtful so far as its record from North America is concerned.

3. Discina convoluta Seaver, Mycologia 13: 70. 1921. (PLATE 28, FIr. 1.)

Apothecia gregarious or cespitose, very short-stipitate, becoming shallow cup-shaped or subdiscoid, externally whitish at the base, becoming yellowish upwards toward the margin, reaching a diameter of $6 \mathrm{~cm}$; hymenium yellowish-brown, very deeply convolute, the convolutions consisting of more or less radiating ribs or veins, resembling those of Perisa venosa but more distinct; stem very short and stout, $1 \mathrm{~cm}$. or more thick and usually not more than $1 \mathrm{~cm}$. long, whitish, deeply corrugated; asci cylindric or subcylindric, reaching a length of $400-500 \mu$ and a diameter of $20 \mu, 8$-spored but a part of the spores often remaining undeveloped; spores 1 -seriate, with the ends usually overlapping, ellipsoid, becoming sculptured and appendiculate 12-14 $\times 35-40 \mu$; spore-sculpturing consisting of warts or short interrupted ridges which of ten approach very fine reticulations; spore appendages consisting of a cup-like structure at each end; paraphyses stout, usually straight, reaching a diameter of $8 \mu$ at their apices, densely filled with yellow granules.

On the ground in woods.

Type collected in the woods near Yonkers, New York, May 22, 1916, by F. J. Seaver.

Distribution: Known only from the type locality.

4. Discina leucoxantha Bres. Rev. Myc. 4:212. 1882.

Pesiza leucoxantha Bres. Fungi Trid. 1: 42.1883.

Apothecia gregarious or substipitate, at first subglobose, expanding and becoming hemispheric or nearly plane, externally whitish, reaching a diameter of $4-7 \mathrm{~cm}$., the margin regular or lobed; hymenium concave or nearly plane, even or undulated, 


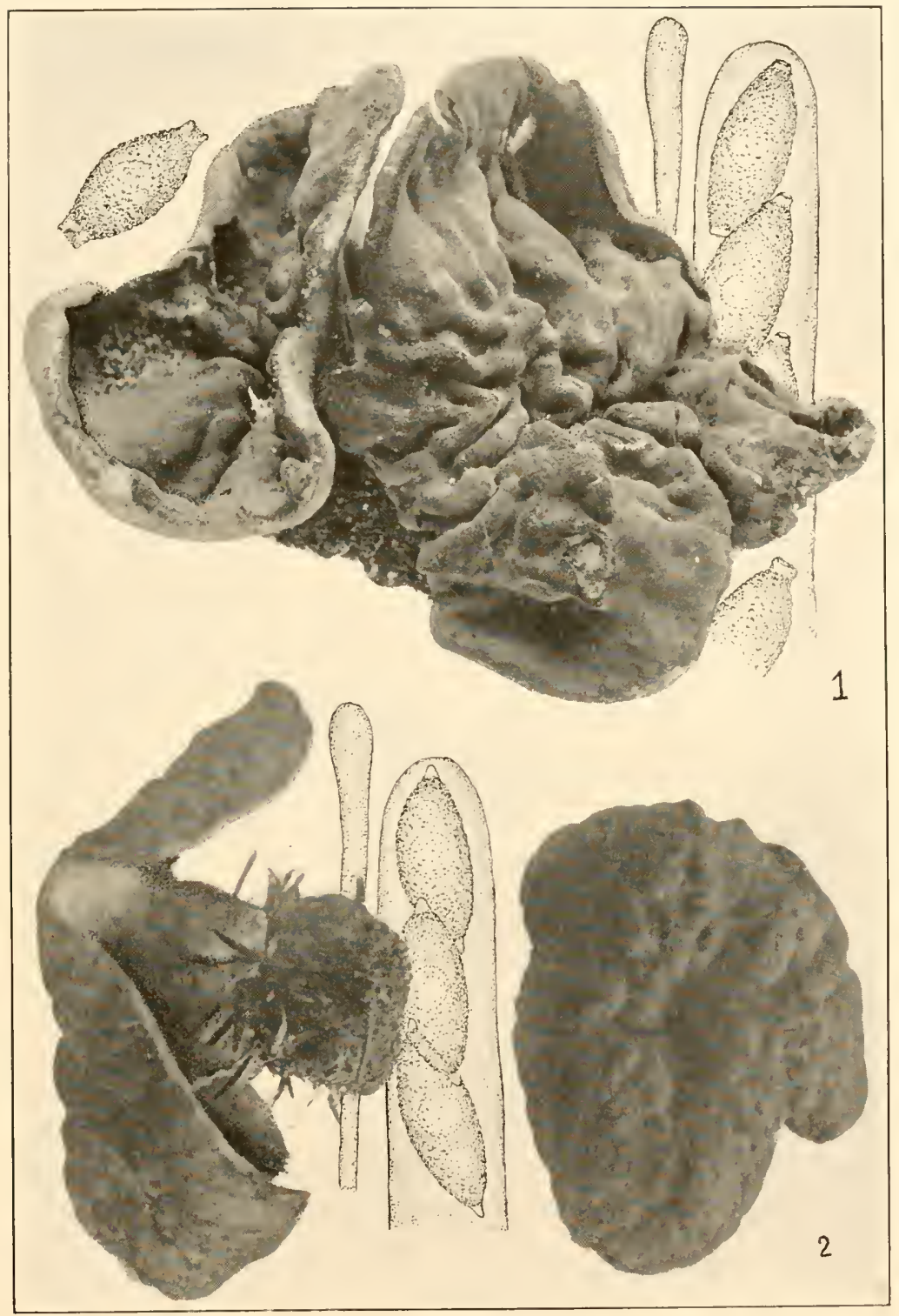

1. DISCINA CONVOLUTA

2. DISCINA ANCILIS 

bright-yellow or becoming yellowish-brown with age; stem about 1 cm. in diameter and scarcely exceeding $5 \mathrm{~mm}$. in length, irregularly corrugated at the base, the flesh thick and brittle; asci cylindric or subcylindric, attenuated at the base, reaching a length of $400 \mu$ and a diameter of $20 \mu$, becoming twisted, \&spored; spores ellipsoid, smooth, containing one large oil-rlrop and several smaller ones, becoming minutely sculptured, 10-15 $\times 27-35 \mu$; spore-sculpturing consisting of minute warts or occasionally minute ridges or indistinct reticulations; spore appendages consisting of truncate protuberances, one at either end of the spore; paraphyses slender, septate, branched, slightly enlarged above, filled with orange granules.

Rare on the ground in coniferous woods.

TyPl: Locality: France.

Distribution: New York to Maryland; also in Europe.

Illustrations: Bres. Fungi 'Trid. pl. tt; Bull. Soc. Myc. Fr. 3: pl. 12; Boud. Ic. Myc. pl. 253; Rab. Krypt.-Fl. 13: 922, f. 5 .

38. PEZIZA (Dill.) L. Sp. Pl. 1180. 1753.

Plicaria Fuckel, Symb. Myc. 325. 1869 (in part).

Pustularia Fuckel, Symb. Myc. 328. 1869 (in part).

Otidea Fuckel, Symb. Myc. 329. 1869 (in part).

Pezisa § Galactinia Cooke, Mycographia 253. 1879.

Galactinia Sacc. Syll. Fung. 8: 106. 1889.

Aleuria Authors, not Fuckel Symb. Myc. 325. 1869.

Heteroplegma Clements, Bull. Torrey Club 30: 92. 1903.

Disciotis Bourl. Hist. Class. Discon. Eu. 42. 1907.

Pseudotis Boud. Hist. Class. Discom. Eu. 52. 1907.

Pachyella Boud. Hist. Class. Discom. Eu. 50. 1907.

Apothecia medium sized or large, usually not less than $1 \mathrm{~cm}$. in diameter and occasionally reaching a diameter of $15-20 \mathrm{~cm}$., usually cup-shaped or occasionally discoid or repand, the color variable; asci cylindric to clavate, usually 8 -spored; spores, ellipsoid, hyaline or faintly colored, smooth or sculptured; sporesculpturing consisting of minute papillae to rather coarse warts or short interrupted ridges, never truly reticulate; paraphyses variable.

Type species, Pesisa cochleata L.

Spores at maturity sculptured; spore-sculpturing varying from minute papillae to coarse warts.

Hymenium becoming brown, brownisb-black or olivaceous. 
Apothecia also dark-colored, the color being similar to that of the hymenium.

Apothecia large, reaching a diameter of $8-10 \mathrm{~cm}$.

1. P. badia.

Apothecia small, not exceeling 1 or $2 \mathrm{~cm}$. in diameter.

Spores $10-11 \times 20-22 \mu$.

Spores $12-14 \times 25-27 \mu$.

Apothecia externally light-colored, white, whitish, golden-yellow, or occasionally dingy with age.

Flesh when broken turning golden-yellow.

Flesh when broken not turning goldenyellow.

Iymenium ochraceous-brown.

Apothecia externally pustulate; on burnt ground.

Not strongly pustulate; on wood.

Hymenium nearly black.

Spores $8-9 \times 17-21 \mu$.

Spores $10 \times 14 \mu$.

Hymenium violaceous, becoming very dark with age; occurring on burnt ground.

Hymenium white or whitish, more rarely rosaceous or faintly violet.

Hymenium rosaceous.

Hymenium white, becoming smoky or faintly

violet; on burnt ground.

2. P. brunneoatra.

3. P. spissa.

4. P. succosa.

5. P. pustulata.

6. P. Emileia.

7. P. melaleuca.

8. P. melaleucoides.

9. P. violacea.

10. P. griseorosea.

11. P. proteana.

Spores remaining permanently smooth.

Apothecia externally reddish-brown, similar in color to the hymenium.

Apothecia marked with concentric rings, sessile.

Apothecia not marked with concentric rings, substipitate.

Apothecia externally white or pallid, rarely dingy with age.

Apothecia cup-shaped or repand, not adhering to the substratum except at the central point of attachment.

Hymenium becoming venose-reticulate; spores very large, $12-17 \times 22-30 \mu$.

11. P. venosa.

liymenium not becoming venose-reticulate; spores rarely over $20 \mu$ long.

Apothecia becoming repand at maturity.

Occurring about cavesand cellass; flesh often turning yellow when broken.

12. $P$. concentrica.

13. P. abietina.

Occurring on rotten wood; flesh not turning yellow when broken.

15. P. domiciliana.

16. P. repanda.

Apothecia normally remaining cup-shaped. 
Occurring on manure or heavily fertilized soil.

Apothecia large; spores 10-11 $\times$ 20-23 $\mu$.

Apothecia small; spores $8 \times 16 \mu$.

Occurring on humus in woods.

Apothecia becoming discoid, closely adhering to the substratum.

17. P. vesiculosa.

18. P. fimeti.

19. P. sylvestris.

20. P. clypeata.

\section{Peziza badia Pers. Obs. Myc. 2: 78.1799.}

?Peziza cochleata L. Sp. Pl. 1181. 1753.

?Elvela cochleata Bolton, Fungi Halifax 3: 99 (in part). 1789.

Scodellina badia S. F. Gray, Nat. Arrang. Brit. Pl. 1: 669. 1821.

Plicaria badia Fuckel, Symb. Myc. 327. 1869.

Aleuria badia Gill. Champ. Fr. Discom. 43. 1879.

Galactinia badia Boud. Ilist. Class. Discom. Eu. 48. 1907.

Apothecia scattered, gregarious, or more commonly cespitose, sessile, at first globose, expanding and becoming deep cupshaped, regular in form, or infolded and cochleate or auricular, occasionally one-sided, rarely Otidea-like, externally varying from tan-colored when young to dark-brown with age, whitish near the base, pustulate, the pustules reddish or reddish-purple, becoming dark with age, reaching a diameter of $10 \mathrm{~cm}$.; hymenium usually concave, dark-brown; asci tapering below and often forked at the base, cylindric above; spores 1-seriate, usually obliquely arranged and often irregularly crowded, ellipsoid, becoming sculptured, hyaline or faintly colored, 8-10 $\times 17-23 \mu$; spore-sculpturing consisting of rather coarse warts or short interrupted ridges; paraphyses rather strongly enlarged above, yellowish.

On the ground in deciduous woods and open places.

Type locality: Europe.

Distribution: New York to Oregon, California and Alabama; also in Europe. Probably widely distributed.

Illustrations: Bolton, Fungi Halifax, pl. 99; Boud. Ic. Myc. pl. 283; Bull. Lab. Nat. Hist. State Univ. Iowa 6: pl. 1t, f. 2; pl. 15, f. 1; Cooke, Mycographia pl. 57, f. 226; Gill. Champ. Fr. Discom. pl. 42; Mycologia 7: pl. 155 (lower figure); (?) Sow. Engl. Fungi pl. 5.

Exsiccati: N. Am. Fungi 981.

The species is rather common and of ten abundant. 
2. Peziza brunneoatra Desm. Ann. Sci. Nat. II. 6:244. 1836.

?Peziza macrospora Wallr. Fl. Crypt. Germ. 2: 500. 1833.

?IIumaria macrospora Fuckel, Symb. Myc. 323. 1869.

Aleuria brunneoatra Gill. Champ. Fr. Discom. 53. 1879.

Plicaria brunneoatra Rehm in Rab. Krypt.-Fl. 13: 1010. 1896.

?Phaeopezia vinacea Clements, Bot. Surv. Nebr. 4: 16. 1896.

?.1leurina vinacea Sacc. \& Sydow in Sacc. Syll. Fung. 16: 740. 1902.

?Peziza nana Massee \& Morgan, Jour. Myc. 8: 190. 1902.

Galactinia brunneoatra Boud. Hist. Class. Discom. Eu. 49. 1907.

Apothecia scattered or gregarious, sessile, expanding, and at maturity becoming scutellate to discoid, not usually exceeding 1-2 cm. in diameter; hymenium at first concave, becoming plane. finally a little convex, of ten umbilicate, brownish-black with a slight tinge of green; asci cylindric above, tapering rather abruptly below into a stem-like base, reaching a length of 300-350 $\mu$ and a diameter of $15-17 \mu, 8$-spored; spores 1 -seriate or occasionally slightly crowded, parallel with the ascus or oblique, at first smooth, becoming sculptured, very faintly yellowish or olive, containing two conspicuous oil-drops or more rarely one, $10-11 \times 20-22 \mu$; spore-sculpturing taking the form of rather conspicuous warts about $2 \mu$ in diameter; paraphyses rather strongly enlarged above, reaching a diameter of $7-8 \mu$ at their apices, yellowish-brown.

On the ground in damp places.

Type Locality : Europe.

Distribution: New York to Iowa; also in Europe.

Illustrations: Boud. Ic. Myc. pl. 298; Cooke, Mycographia pl. 20, f. 78; Bull. Lab. Nat. Hist. State Univ. Iowa 6: pl. 14, f. 3 .

3. Peziza spissa Berk. Grevillea 3: 152. 1875.

Humaria spissa Sacc. Syll. Fung. 8: 141. 1889.

Apothecia gregarious, at first shallow cup-shaped, becoming discoid, attached to the substratum by a short stem-like base which is obscured at maturity, reaching a diameter of 1-2 cm.; hymenium concave, becoming convex, dark-brown; asci cylindric or subcylindric above, tapering below into a stem-like base, becoming spirally twisted when young, reaching a length of $260-275 \mu$ and a diameter of $2.3-24 \mu$; spores 1-seriate, obliquely or irregularly disposed, ellipsoid, usually containing two large oil-drops and often several smaller ones, granular within and slightly yellowish, smooth, then becoming very minutely sculp- 
tured, $12-14 \times 25-27 \mu$; spore-sculpturing consisting of minute warts; paraphyses stout, strongly enlarged above where they reach a diameter of $10-12 \mu$, filled with a mass of dark-brown coloring matter which often separates in such a way as to give the tip of the paraphyses a septate or muriform appearance, hyaline below, often spirally twisted like the ascus.

On damp soil.

Type locality: Alabama.

Distributiox: Alabama and Washington.

Illustratiox: Cooke, Mycographia pl. 20, f. 79 .

Except in habitat and mode of attachment, resembling a Psilopesia.

4. Peziza succosa Berk. Ann. Mag. Nat. Hist. I. 6: 358.1841.

Aleuria succosa Gill. Champ. Fr. Discom. 45. 1879.

Otidea succosa Thüm. Mycoth. Univ. 1+11. 1879.

Galactinia succosa Sacc, Syll. Fung. 8: 106. 1889.

Plicaria succosa Rehm in Rab. Krypt.-Fl. $1^{3}: 1016.1896$.

Apothecia gregarious or scattered, sessile, at first hemispheric, expanding and becoming shallow cup-shaped or more rarely sul)discoid, regular in outline or irregularly contorted, the margin even or occasionally more or less lobed, externally whitish or yellowish with a slight shade of olive, reaching a diameter of 3-4 cm.; hymenium concave or occasionally nearly plane, even, brown, becoming darker with age, often with an olivaceous tint apparently from the spores which have dusted out over its surface; asci cylindric or subcylindric, reaching a length of 200-225 $\mu$ and a diameter of 12-15 $\mu, 8$-spored; spores obliquely 1 -seriate, ellipsoid, usually containing two distinct oil-drops, hyaline or very faintly yellowish (olivaceous in mass), finally becoming sculptured, $8-12 \times 16-20 \mu$; spore-sculpturing consisting of rather conspicuous warts $1-2 \mu$ in diameter; paraphyses slender, septate, enlarged above, filled with yellowish coloring matter.

On damp soil in woods.

Type locality: Europe.

Distrubution: New York to Iowa and Wisconsin; also in Europe.

Illustrations: Ann. Mag. Nat. Hist. I. 6: pl. 10, f. 5-7; Gill. Champ. Fr. Discom. pl. 46; Boud. Ic. Myc. pl. 287; Cooke, Mycographia pl. 63, f. 243; Pat. Tab. Fung. f. 166; Phill. Brit. 
Discom. pl. 4, f. 16; Bull. Lab. Nat. Hist. State Univ. Iowa 6: pl. $16, f .2$.

Quite frequently found in midsummer.

5. Peziza pustulata (Hedw.) Pers. Syn. Fung. 646. 1801. (Plate 29, Fig. 1.)

Octospora pustulata Hedw. Descr. 2: 19. 1787.

Scodellina pustulata S. F. Gray, Nat. Arrang. Brit. Pl. 1: 668. 1821.

Plicaria pustulata Fuckel, Symb. Myc. 327. 1869.

Peziza assimilata Karst. Not. Fauna Fl. Fenn. 10:113. 1869.

?Peziza echinosperma Karst. Not. Fauna F1. Fenn. 10: 115. 1869.

Pesiza Petersii Berk. Grevillea 3: 150. 1875.

Aleuria pustulata Gill. Champ. Fr. Discom. 45. 1879.

Peziza umbrina Boud.; Cooke, Mycographia 226 (in part). 1879.

Aleuria umbrina Gill. Champ. Fr. Discom. 42. 1879.

Galactinia pustulata Boud. Hist. Class. Discom. Eu. 48. 1907.

Apothecia gregarious, scattered, or cespitose, at first closed and globose, gradually expanding, reaching a diameter of 3-5 $\mathrm{cm}$., regular, or much contorted, externally whitish and densely pustulate, the pustules giving rise to bran-like particles as the plant matures, becoming dingy with age, margin usually crenate; hymenium pale- to dark-brown; asci cylindric above, reaching a length of $275 \mu$ and a diameter of $12-14 \mu$; spores 1 -seriate, ellipsoid, becoming minutely sculptured, hyaline to faintly yellowish, $8-10 \times 15-17 \mu$; spore-sculpturing consisting of very minute warts; paraphyses strongly enlarged above and reaching a diameter of $7-8 \mu$ at their apices.

On charcoal and burned areas.

TYPE LOCALITY: Europe.

Distribution: New York to Wisconsin and Wyoming; also in Europe.

Illustrations: Boud. Ic. Myc. pl. 279; Cooke, Mycographia pl. 64, f. 246, pl. 106, f. 378; Grevillea 2: pl. 24, f. 2; Hedw. Descr. 2: pl. 6, f. 1-4; Gill. Champ. Fr. Discom. pl. 47, f. 2; Mycologia $7:$ pl. 156 (upper figure).

The species is quite common in midsummer.

6. Peziza Emileia Cooke, Mycographia 226. 1879.

Aleuria Emileia Boud. Hist. Class. Discom. Eu. 46. 1907.

Apothecia gregarious or scattered, sessile, large, at first cupshaped, becoming expanded and often irregularly repand, the margin even or more or less lobed, regular in form or contorted, externally white or whitish-farinose, reaching a diameter of 


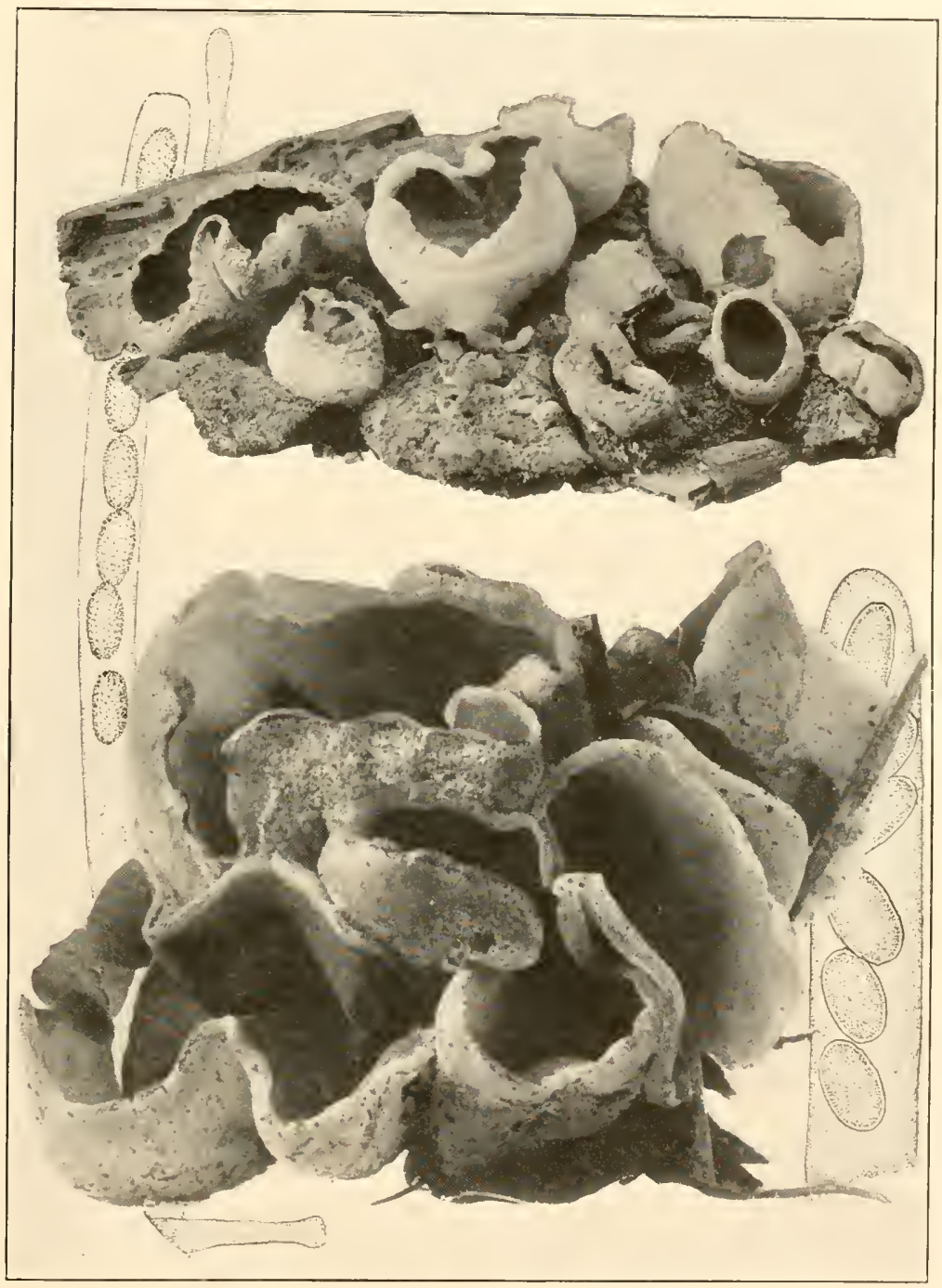

1. PEZIZA PUSTUlLATA

2. PEZIZA VESICULOSA 

8-10 cm.; hymenium concave, plane or occasionally convex, even or undulated; asci cylindric or subcylindric, reaching a length of $200 \mu$ and a diameter of $12-15 \mu$; spores 1-seriate, ellipsoid, hyaline, becoming sculptured, $8 \times 16-18 \mu$; spore-sculpturing consisting of very minute warts or papillae; paraphyses slencler, septate, strongly enlarged above.

On damp soil in woods.

Type Locality : France.

Distribution: IVisconsin; also in Europe.

Illustrations: Cooke, Mycographia pl. 106, f. 379; Boud. Ic. Myc. pl. 280.

7. Peziza melaleuca (Bres.) Seaver, comb. nov.

Discina metalenca Bres. Fungi Trid. 2: 74. 1898.

?Heteroplegma caeruleum Clements, Bull. Torrey Club 30: 92. 1903.

?Peziza caerulea Sacc. \& D. Sacc. in Sacc. Syll. Fung. 18: 20. 1906.

Apothecia gregarious, soon becoming expanded, finally often repand or with the extreme margin slightly elevated, the center usually depressed or umbilicate, externally white or whitish, reaching a diameter of 2-4 cm., narrowed below into a stemlike base; hymenium concave, becoming plane or slightly convex, brownish-black, when dry entirely black; asci cylindric or subcylindric, reaching a length of $360-400 \mu$ and a diameter of 16-18 $\mu$; spores 1 -seriate, ellipsoid, containing 1-3 (usually 2) oil-drops, $8-9 \times 17-21 \mu$, becoming sculptured; spore-sculpturing consisting of papillae or minute warts; paraphyses rather stout, enlarged above where they reach a diameter of $6-8 \mu$.

On the ground in coniferous woods.

Type Locality: Europe.

Distribution: Colorado; also in Europe.

Illustration: Bres. Fungi Trid. pl. 186.

Exsiccati: Clements, Crypt. Form. Colo. 12t? (as Plicaria Fuckelii caerulescens).

\section{Peziza melaleucoides Seaver, sp. nov.}

Apothecia sessile or short-stipitate, reaching a diameter of $10 \mathrm{~cm}$., cup-shaped, becoming somewhat repand, usually whitish near the base, brownish above or occasionally with a lavender tint; stem when present lacunose, very short; lymenium concave, often umbilicate, becoming dark-brown or tinted with olive; asci cylindric or subcylindric, reaching a length of $250 \mu$ and a diameter of $12-15 \mu$; spores 1 -seriate, ellipsoid, each containing 
two oil-drops, $10 \times 14 \mu$, hyaline or subhyaline, becoming sculptured; spore-sculpturing consisting of minute papillae; paraphyses about $4 \mu$ in diameter below, enlarged above where they reach a diameter of $\delta \mu$, filled with brown coloring matter.

On the ground or more often on rotten wood in coniferous woods.

Type collected by Dr. L. O. Overholts at Tolland, Colorado, June, 1914.

Distribution: Colorado.

This species differs from the preceding, which it resembles externally, in the broad-ellipsoid spores.

9. Peziza violacea Pers. Syn. Fung. 639. 1801. (Plate 30, FIG. 2.)

Peziza Boltoni Quél. Bull. Soc. Bot. Fr. 25: 290. 1878.

Aleuria violacea Gill. Champ. Fr. Discom. 47. 1879.

Pesiza ampelina Quél. Grevillea 8: 116. 1880.

Humaria violacea Sacc. Syll. Fung. 8: 149.1889.

Aleuria Boltoni Gill. Champ. Fr. Discom. 206. 1886.

Galactinia Boltoni Boud. Hist. Class. Discom. Eu. 48. 1907.

Apothecia gregarious, sessile or substipitate when young, at first closed and subglobose, gradually expanding and becoming shallow cup-shaped, discoid, or occasionally repand, at first regular in form, becoming irregular, the margin often splitting, externally at first white, finally becoming pale-violaceous, reaching a diameter of 3-4 cm., although often much smaller; hymenium concave, plane or convex, pale-riolet when young, becoming deep-violet with age, finally almost black, even or slightly undulated, usually umbilicate; asci cylindric or subcylindric, gradually attenuated below, reaching a length of 200-250 $\mu$ and a diameter of 12-15 $\mu, 8$-spored; spores 1-seriate, or irregularly disposed, ellipsoid, usually containing two small oil-drops, hyaline, becoming sculptured, $8 \times 12-13 \mu$; sporesculpturing consisting of very minute warts; paraphyses slender, septate, enlarged above, usually curved and filled with violet granules, reaching a diameter of $8 \mu$ at their apices.

On burnt ground and charcoal beds.

TyPe LOCALitY: Europe.

Distribution: New York to Wisconsin and Colorado; also in Europe.

Illustrations: Grevillea 8: pl. 131, f. 4; Boud. Ic. Myc. pl. 276; Gill. Champ. Fr. Discom. (suites). 


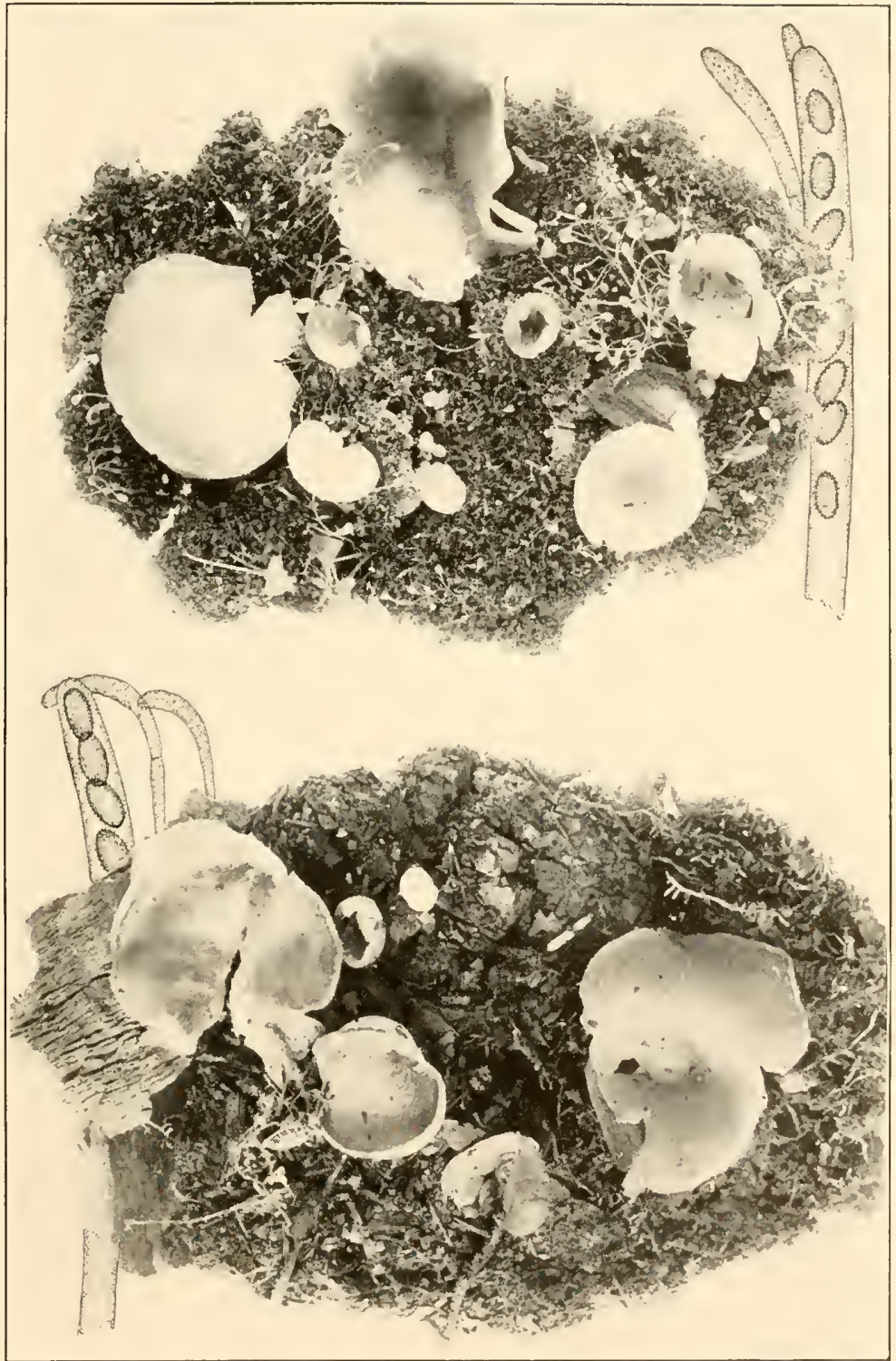

1. PEZIZA PROTEANA

2. PEZIZA VIOLACEA 

Quite common on burned places and rather attractive because of its violet color, although not very conspicuous.

10. Peziza griseorosea Ger. Bull. Torrey Club 6:31. 1875.

Apothecia shallow cup-shaped, externally whitish-pruinose, sessile, the flesh rather thin, the color grayish-ochraceous; reaching a diameter of $2-4 \mathrm{~cm}$; hymenium concave, palerosaceous to subochraceous; asci cylindric or subcylindric; spores 1 -seriate, ellipsoid, becoming sculptured, $7-10 \times 15-18 \mu$, hyaline or slightly yellowish; spore-sculptured taking the form of minute warts; paraphyses slightly enlarged at their apices.

On the ground.

Type locality: Poughkeepsie, New York.

Distribution: New York and Connecticut to Wisconsin and Virginia.

Illustration: Cooke, Mycographia pl. 65, f. 249.

An authentic specimen of this species from the herbarium of Gerard is deposited in our collection at The New York Botanical Garden. A number of specimens from various localities have been referred to this species but always with more or less doubt, since it is difficult to determine the exact color from the dried specimens and the species was originally distinguished chiefly on that character. When possible, color records should be preserved in such cases as this in connection with field records.

11. Peziza proteana (Boud.) Seaver, Mycologia 9: 1. 1917. (Plate 30, Ficr. 1.)

Aleuria proteana Boud. Bull. Soc. Myc. Fr. 15: 50. 1899.

Galactinia proteana Sacc. Syll. Fung. 16: 709. 1902.

Apothecia sessile, cup-shaped, finally becoming expanded and often more or less repand, entirely white when young, becoming overcast with a faint reddish or lilac tint, reaching a diameter of 3-6 cm.; hymenium concave, becoming plane or convex and usually umbilicate, the color varying from white when young to rosy, pale-lilac or slightly brownish, becoming darker with age; asci cylindric or subcylindric, reaching a length of $225-250 \mu$ and a diameter of $10 \mu$; spores 1 -seriate or becoming slightly crowded, small, ellipsoid, usually containing two small oil-drops, at first smooth, becoming sculptured, 5-7 $\times 12-13 \mu$; sporesculpturing assuming the form of minute warts or papillae; paraphyses slender, septate, enlarged above where they reach a diameter of $7-8 \mu$. 
On old burnt places which have been overrun with mosses.

Trpe locality: France.

Distribution: New York and Texas; also in Europe.

Illustrations: Bull. Soc. Myc. Fr. 15: pl. 3, f. 1; Boud. Ic. Myc. pl. 293; Mycologia 9: pl. 1 (upper figure).

In habitat and spore characters this species resembles Peziza violacea but differs much in color.

\section{Peziza concentrica Seaver, sp. nov.}

Apothecia subglobose, becoming more or less widely expanded, externally pale-brownish, reaching a diameter of $2-4$ cm., both externally and internally marked with concentric rings consisting of depressions and elevations which somewhat resemble ripple-marks; hymenium concave or nearly plane, showing the same concentric markings found on the exterior of the apothecium, similar in color to the outside of the apothecium or a little darker, often slightly olivaceous; asci cylindric above, tapering below rather abruptly into a stem-like base with an enlargement at the extreme base, reaching a length of $300 \mu$ and a diameter of $16 \mu$; spores 1 -seriate, ellipsoid, hyaline or subhyaline, remaining smooth, $10 \times 18-20 \mu$; paraphyses reaching a diameter of $2 \mu$ below and a diameter of $4 \mu$ at their apices, yellowish-olive.

On the ground.

Type locality: Humboldt County, California.

Distribution: California.

This species is based on material submitted to the writer by the late C. C. Lloyd. The specimens were collected by Mrs. H. E. Wilder, January 22, 1914, in the locality indicated above.

\section{Peziza abietina Pers. Syn. Fung. 637. 1801.}

Otidea abietina Fuckel, Symb. Myc. 320. 1869.

Aleuria abietina Gill. Champ. Fr. Discom. 41. 1879.

Discina abietina Rehm in Rab. Krypt.-Fl. 13:977. 1896.

Heteroplegma crenatum Clements, Bull. Torrey Club 30: 92. 1903.

Peziza crenata Sacc. \& D. Sacc. in Sacc. Syll. Fung. 18: 19. 1906.

Pseudotis abietina Boud. Hist. Class. Discom. Eu. 52. 1907.

Plicaria rubrofusca Rehm, Ann. Myc. 3: 517. 1905.

Peziza rubrofusca Sacc. \& Trott. in Sacc. Syll. Fung. 22: 619. 1913.

Apothecia gregarious or cespitose, stipitate or substipitate, cup-shaped, regular in form or becoming irregular with age, the margin entire or crenate, externally pale- to dark-brownish, 


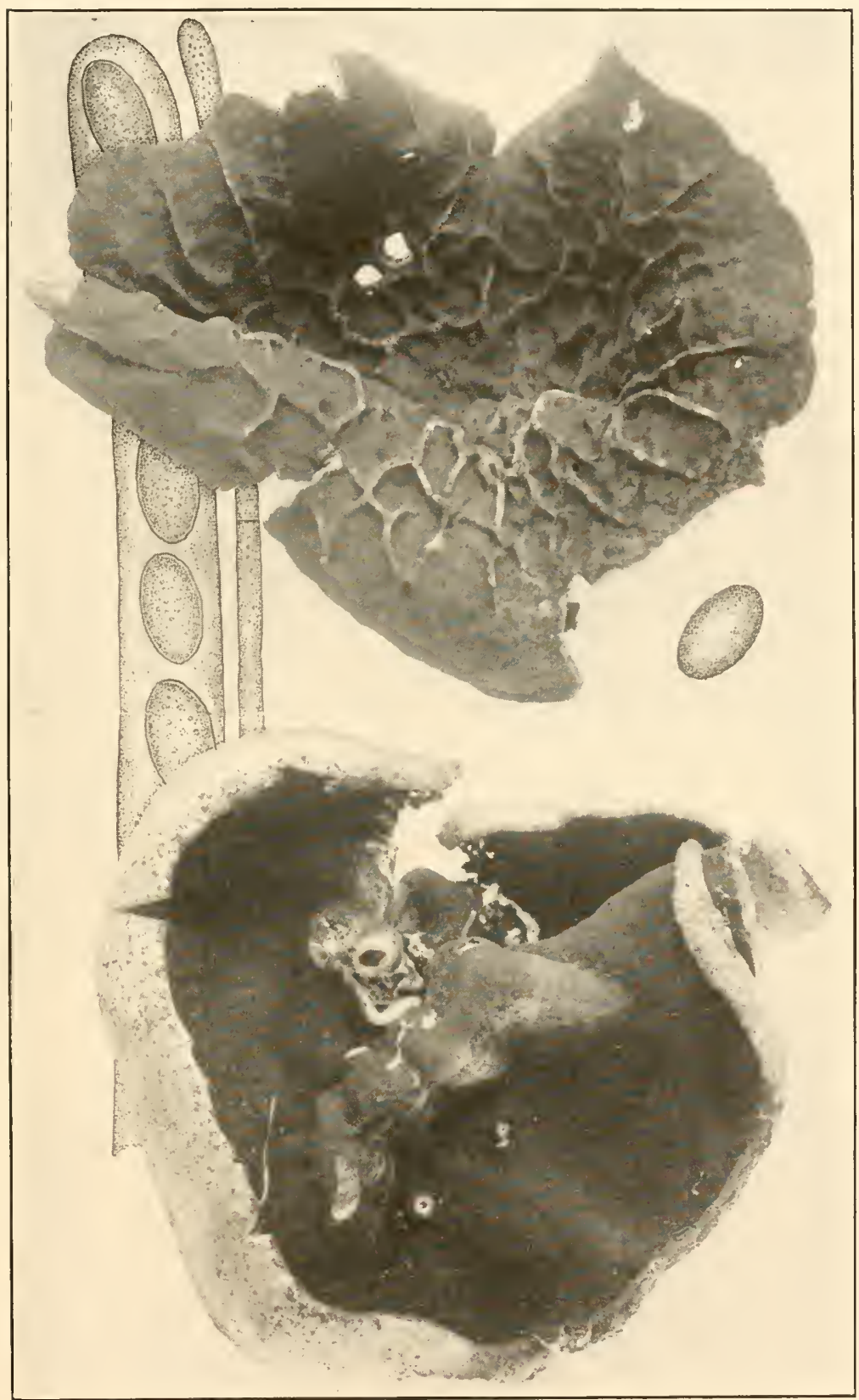

PEZIZA VENOSA 

reaching a diameter of $3-5 \mathrm{~cm}$. and a depth of $2-3 \mathrm{~cm}$.; hymenium concave, brown, of nearly the same shade as the outside of the apothecium or a little darker; stem very short, stout, not exceeding $1 \mathrm{~cm}$. in length and about $5 \mathrm{~mm}$. thick, or of ten nearly wanting, the substance rather tough, not shrinking much in drying; asci cylindric or subcylindric, reaching a length of $200 \mu$ and a diameter of 12-15 $\mu, 8$-spored; spores ellipsoid, smooth, usually containing two large oil-drops and numerous smaller ones, 9-12 $\times 18-20 \mu$; paraphyses filiform, septate, enlarged above, with numerous small knots or branches near their apices, filled with coarse granules, reaching a diameter of $7 \mu$ at their tips.

()n the ground in coniferous woods.

Trpe locality: Europe.

Distribution: Colorado; also in Europe.

Illustrations: Boud. Ic. Myc. pl. 333; Bres. Fungi Trid. pl. 183, f. 2; Cooke, Mycographia pl. 57, f. 223; Gonnerm. \& Rab. Myc. Eu. 3: pl. 1, f. 7; Fl. Dan. pl. 1853, f. 1; Payer, Bot. Crypt. 89, f. 401.

14. Peziza venosa Pers. Syn. Fung. 638. 1801. (excl. syn.) (Plate 31.)

Peziza reticulata Grev. Scot. Crypt. F1. 156. 1825.

Plicaria reticulata Fuckel, Symb. Myc. 328. 1869.

Aleuria venosa Gill. Champ. Fr. Discom. 37. 1879.

Acetabula venosa Lamb. F1. Myc. Belg. 2: 57t. 1880.

Discina reticulata Sacc. Syll. Fung. 8: 100. 1889.

Discina venosa Sacc. Syll. Fung. 8: 104. 1889.

Peziza convoluta Peck, Bull. Torrey Club 30: 101. 1903.

Disciotis venosa Boud. Hist. Class. Discom. Eu. 42. 1907.

Apothecia solitary or gregarious, substipitate with the base lacunose, at first shallow cup-shaped, soon becoming depressed and finally resting on the substratum with the extreme margin slightly elevated, when young entire but often irregularly radially splitting at maturity, externally whitish or dingy, slightly pruinose or scurfy, reaching a diameter of $20 \mathrm{~cm}$.; hymenium reddish-brown, dried specimens of ten dusted over with the spores which are rust-colored in mass, at first even, becoming convolute, the convolutions either radial or giving a reticulate appearance; asci cylindric or subcylindric clavate, reaching a diameter of $25 \mu$; spores 1 -seriate or slightly crowded together, ellipsoid, smooth, pale-yellowish, $12-17 \times 22-30 \mu$; paraphyses clinging 
together in masses, enlarged above, reaching a diameter of $8 \mu$, yellowish-brown.

On the ground in deciduous woods.

Type locality: Europe.

Distribution: New York to Ohio; also in Europe.

Illustrations: Boud. Ic. Myc. pl. 25t; Rab. Krypt.-FI. $1^{3}$ : 922, f. $1-3$.

Exsiccati: N. Am. Fungi 2621.

Very distinct with its reticulated hymenium but not very commonly collected.

15. Peziza domiciliana Cooke, Gardner's Chronicle 41: 793. 1877. (Plate 26, Fig. 2.)

?Octospora varia Hedw. Descr. 2: 22. 1788.

Peziza Adae Sadler; Cooke, Trans. Bot. Soc. Edinburgh 13: 45. 1877.

Pesiza odorata Peck, Bull. Torrey Club 23: 420. 1896.

Pesiza varia f. typica Bres. Fungi Trid. 2: 75. 1898.

Apothecia gregarious or occasionally cespitose, usually shortstipitate when young, at first concave, soon becoming repand, leaving a depression in the center, at first rounded, becoming irregular and often decidedly angular in outline, externally white, the margin entire or occasionally splitting, reaching a diameter of $10 \mathrm{~cm}$., the substance when broken turning goldenyellow (it is uncertain whether this character is constant but it is very conspicuous in some cases); hymenium at first concave, becoming plane or convex and distinctly umbilicate, at first white, becoming dingy-buff or brownish; stem not exceeding $1 \mathrm{~cm}$. in length, thick, irregular, white, becoming obsolete with age; asci cylindric or subcylindric, reaching a length of $225-250 \mu$ and a diameter of $15 \mu$; spores ellipsoid, hyaline when young, of ten containing two small oil-drops, $8-10 \times 13-15 \mu$; paraphyses slender, septate, slightly enlarged above.

In cellars, mushroom caves, and occasionally in greenhouses, usually growing on plaster, sand, gravel, or coal-dust.

Type locality : Europe.

Distribution: New York to Iowa and Missouri; also in Europe.

Illustrations: Trans. Bot. Soc. Edinburgh 13: pl. 3, f. $a-i$; Cooke, Mycographia, pl. 97, f. 349; Bres. Fungi Trid. pl. 188; Bull. Lab. Nat. Hist. State Univ. Iowa 6: pl. 15, f. 2 (as Pezizn repanda).

Rather frequently encountered. 


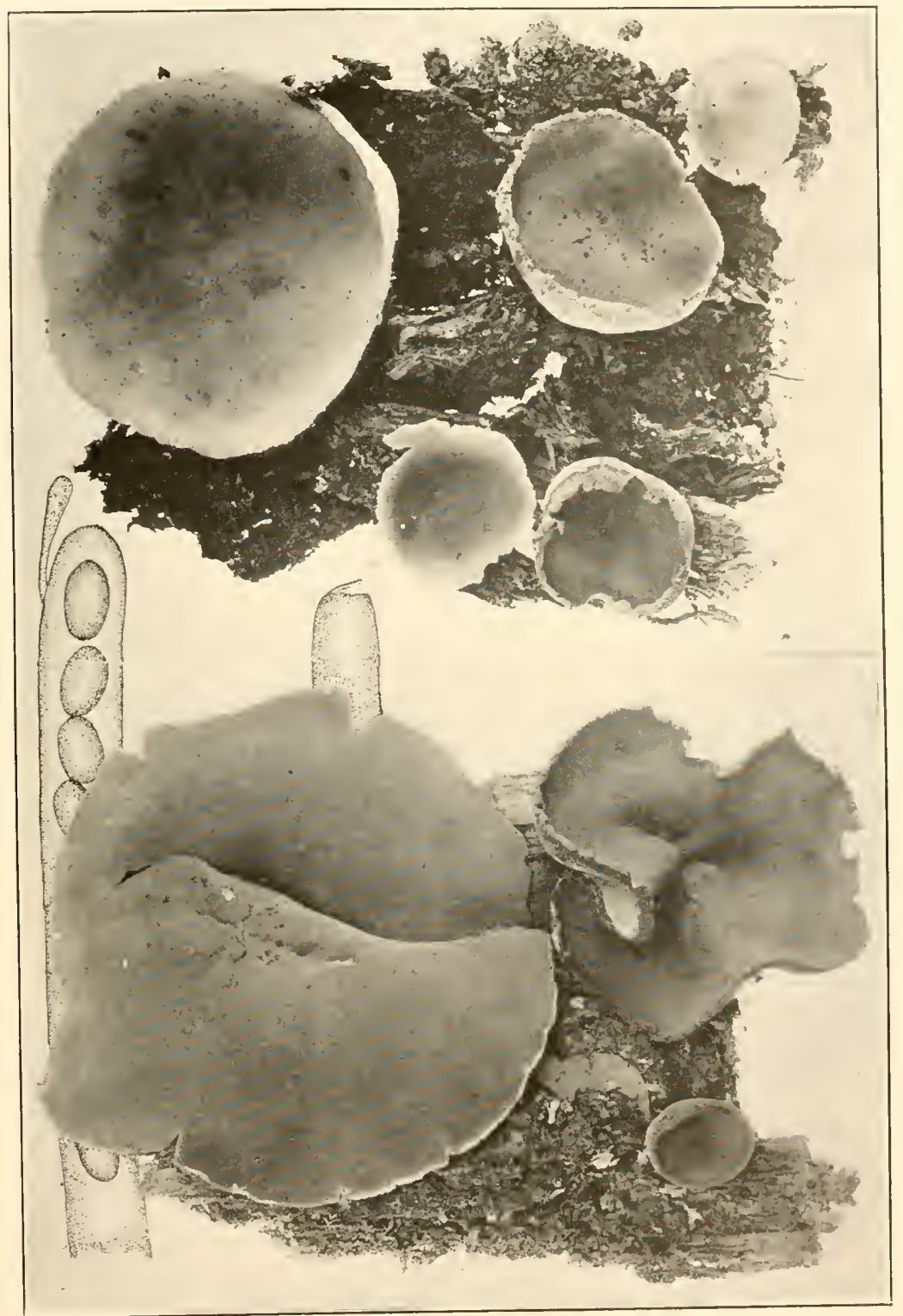

PEZIZA REPANDA 

16. Peziza repanda Pers. Ic. Pict. Fung. 49. 1806.

?Peziza micropus Pers. Ic. \& Descr. Fung. 30. 1800.

Peziza pullida Cooke \& Peck; Cooke, Buff. Acad. Sci. 2: 288. 1875.

Peziza repanda amplispora Cooke \& Peck; Cooke, Bull. Buff. Acad. Sci. 2: 288. 1875.

Peziza truncicomes Ger.; Cooke, Mycographia 147. 1877.

Peziza amplispora Cooke, Mycographia 167. 1877.

Aleuria repanda Gill. Champ. Fr. Discom. 43. 1879.

Peziza Stevensoniana Ellis; Rehm, Ascom. Lojk. 3. 1882. (as synonym.)

Geopyxis pallidula Sacc. Syll. Fung. 8: 70. 1889.

Geopyxis amplispora Sacc. Syll. Fung. 8: 71. 1889.

Discina repanda Sacc. Syll. Fung. 8: 100. 1889.

Plicaria repanda Rehm in Rab. Krypt.-Fl. 13: 1007. 1896.

Pustularia Stevensoniana Rehm in Rab. Krypt.-Fl. 13: 1019. 1896.

Peziza varia f. lignicola Bres. Fungi Trid. 2: 76. 1898.

Apothecia sessile or very short-stipitate, at first cup-shaped, the margin even or crenate, externally white or whitish, expanding and becoming repand, the margin remaining entire or splitting, regular in outling or irregularly revolute, reaching a diameter of 8-10 cm.; hymenium concave, becoming plane or convex, pale-brown, becoming darker with age, even or convolute; stem short, stout, usually only a few mm. long or entirely wanting; asci cylindric or subcylindric, reaching a length of $225 \mu$ and a diameter of $12-15 \mu$; spores ellipsoid, hyaline, smooth, 8-10 $\times 14-16 \mu$; paraphyses slender, slightly enlarged above, yellowish or brownish.

On rotten logs or occasionally on soil or chip-piles.

TYPE LOCALITY: Europe.

Distribution: New York to Iowa and Maryland; also in Europe.

Illustrations: Pers. Ic. Pict. pl. 20, f. 2; ? Pers. Ic. Descr. Fung. pl. $8, f .3$; Cooke, Mycographia pl. 62, f. 2to; Bres. Fungi Trid. pl. 189; Minn. Bot. Studies 4: pl. 15; Freeman, Minn. Pl. Diseases $f .64$.

One of the most conspicuous species on rotten logs in woods, its variability in form at different ages probably accounting for its numerous synonyms. When young it appears short-stipitate but when mature the stem is inconspicuous or obsolete.

17. Peziza vesiculosa Bull. Herb. Fr. pl. 457, f. 1. 1789. (Plate 29, Ficr. 2.)

Scodellina vesiculosa S. F. Gray, Nac. Arrang. Brit. Pl. 669. 1821.

?Eliela cochleata Bolton, Hist. Fung. 3: 99 (in part). 1789.

Pustularia vesiculosa Fuckel, Symb. Myc. 329. 1869.

Aleuria vesiculosa Gill. Champ. Fr. Discom. 45. 1879. 
Apothecia gregarious or more often densely cespitose, at first closed and globose, gradually expanding and becoming deep cup-shaped, regular in form or irregularly contorted, sessile or with a very stout stem-like base, externally whitish or yellowish, with minute wart-like pustules, reaching a diameter of $7-8 \mathrm{~cm}$; hymenium pale-brown, paler than the outside of the apothecium; asci cylindric or subcylindric; spores obliquely 1-seriate, ellipsoid, smooth, hyaline, 10-11 $\times 20-23 \mu$; paraphyses enlarged above granular within, subhyaline.

On manure piles and heavily fertilized soil.

Type locality: Europe.

Distribution: New York to Washington, California, Alabama and probably throughout North America; also in Europe.

Illustrations: Bull. Herb. Fr. pl. 457, f. 1; Boud. Ic. Myc. pl. 257; Cooke, Mycographia pl. 63, f. 242; Gill. Champ. Fr. Discom. pl. 4t; Rab. Krypt.-F1. 13 : 992, f. 1-t; Bull. Lab. Nat. Hist. State Univ. Iowa 6: pl. 16, f. 1; Sow. Engl. Fungi pl. 4; Massee, Brit. Fungus-F1. 4: 290, f. 22; Mycologia 7 : pl. 155 (upper figure).

Very common on manure piles and on account of its large size conspicuous and attractive. It occurs less commonly on soil in greenhouses and occasionally in richly manured gardens. The cups are often regular in form or may become beautifully contorted or crimped.

18. Peziza fimeti (Fuckel) Seaver, comb. nov.

IHumaria fimeti Fuckel, Symb. Nyc. Nacht. 1: 50. 1871. ?Peziza fimetaria Schum. Pl. Saell. 2: 426.1803.

?Peziza chlorophysa Sacc. \& D. Sacc. in Sacc. Syll. Fung. 18: 18. 1906.

Apothecia scattered, sessile, or substipitate, at first subglobose, becoming expanded and reaching a diameter of $2 \mathrm{~cm}$., externally granulose, pallid-brown; hymenium concave to nearly plane, similar in color to the outside of the apothecium; asci cylindric or subcylindric, reaching a length of $280 \mu$ and a diameter of $18 \mu$; spores ellipsoid, $8 \times 16 \mu$; paraphyses abundant, slender, reaching a diameter of $8 \mu$.

On cow dung.

TrPe LOCAlitY: Europe.

Distribution: Kentucky to Iowa and Colorado; also in Europe.

Illustration: Bres. Fungi Trid. pl. 192, f. 2. 


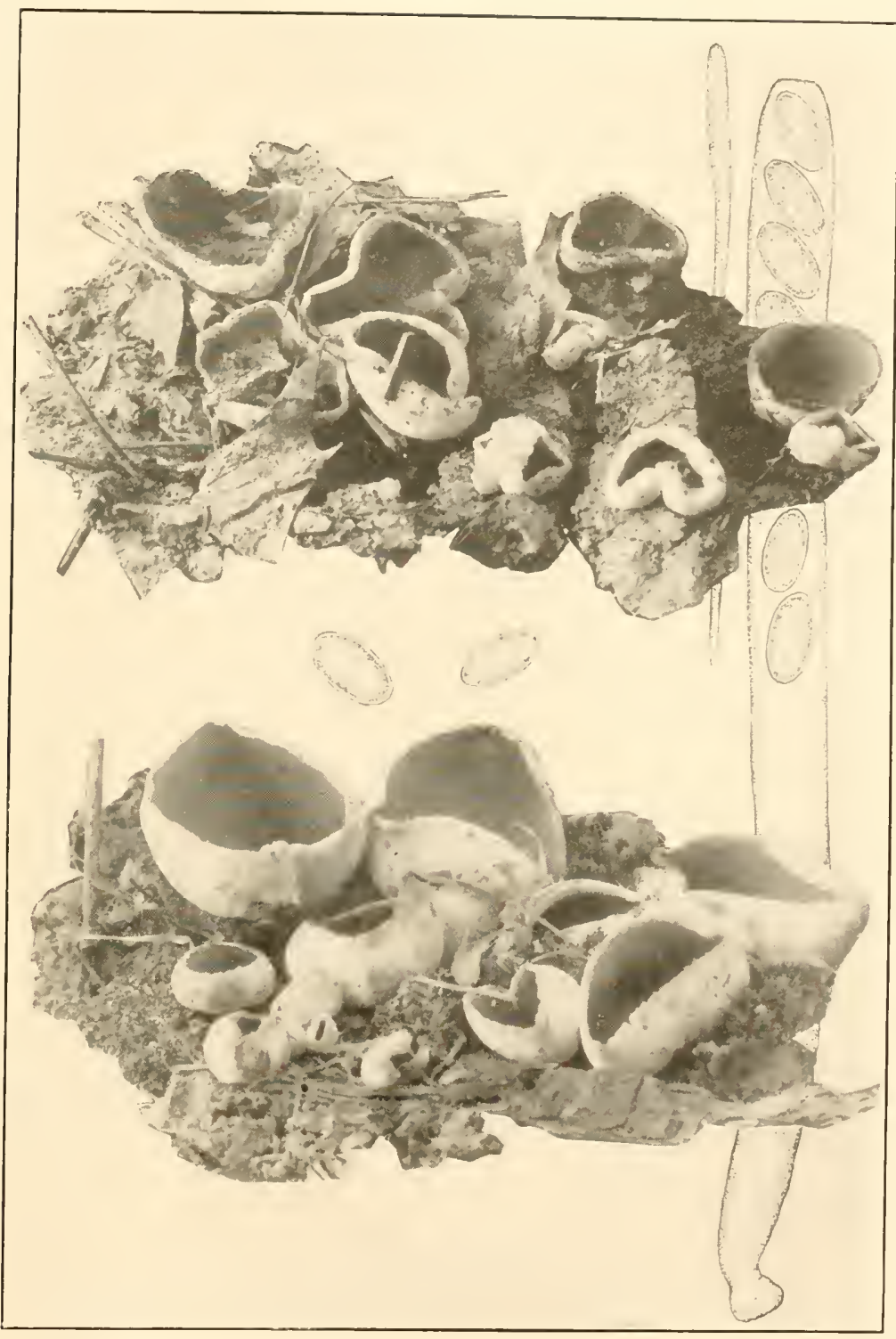

PEZIZA SYLVESTRIS 

Similar in habitat to the preceding but apparently distinguished by the small size of both apothecia and spores. The plants occur more on isolated cow clung than on manure piles as does the preceding.

19. Peziza sylvestris (Boud.) Sacc. \& Trott. in Sacc. Syll. Fung. 22: 612. 1913. (Plate 33.)

Peziza varia f. terrestris Bres. Fungi Trid. 2: 76. 1898. Aleuria sylvestris Boud. Hist. Class. Discom. Eu. 44. 1907.

Apothecia gregarious, sessile, deep cup-shaped to subdiscoid, externally whitish, nearly smooth or minutely pustulate, the margin even or slightly wavy and crenate, reaching a diameter of 3-8 cm.; hymenium umber-brown; asci cylindric above, gradually tapering below, reaching a length of $200-235 \mu$ and a diameter of $13-15 \mu$; spores 1 -seriate, with the ends slightly overlapping, hyaline, smooth, $9-10 \times 15-20 \mu$; paraphyses strongly enlarged above, reaching a diameter of $7-8 \mu$ at their apices.

On rubbish piles and soil in woods.

Type locality : Europe.

Distribution: New York to California; also in Europe.

Illustrations: Boud. Ic. Myc. pl. 261; Bres. Fungi Trid. pl. 190; Mycologia 7: pl. 156 (lower figure).

This may be Peziza cerea Sow. the identity of which seems to be uncertain. The species is common in woods and often approaches Peziza repanda in size and general appearance. The latter seems to differ however in its more repand habits as well as in habitat, occurring on rotten logs.

20. Peziza clypeata Schw. Schr. Nat. Ges. Leipzig 1: 117. 1822. (Plate 34.)

Bulgaria bicolor Peck, Ann. Rep. N. Y. State Mus. 32: 49. 1879.

Peziza orbicularis Peck, Bull. N. Y. State Mus. 2: 20. 1887.

Discina clypeata Sacc. Syll. Fung. 8: 101. 1889.

?Peziza Barleana Bres. Fungi Trid. 2: 74. 1898.

?Peziza paraphysata Clements, Bot. Surv. Nebr. 4: 9.1896.

Psilopezia juruensis P. Henn. Hedwigia 43: 273. 1904.

?Pachyella Barleana Boud. Hist. Class. Discom. Eu. 50. 1907.

Psilopezia orbicularis Dodge, Trans. Wisc. Acad. Sci. 17: 1052. 1914.

Apothecia gregarious but not usually crowded, at first globose, gradually expanding, soon becoming shallow cup-shaped, finally discoid, regular in outline or occasionally more or less distorted when old, becoming closely adnate to the substratum on the under surface, except the extreme margin which is free and 
often slightly upturned, varying in size from a few mm. when young to 3 or $4 \mathrm{~cm}$. when mature; hymenium at first dark reddishbrown, smooth and glistening, later assuming an olive tint and losing its luster, when old greenish-black (almost entirely black when dried), splitting in dried specimens, giving rise to whitish vein-like markings where the whitish interior is exposed through the crevices, the substance soft, inclined to waxy; asci cylindric, reaching a diameter of $17 \mu$, often spirally twisted when dry; spores 1 -seriate, ellipsoid, smooth, hyaline, containing one or two large oil-drops, $12-14 \times 25-27 \mu$ or rarely $30-35 \mu$; paraphyses adhering together, septate, strongly enlarged above, reaching a diameter of $7-8 \mu$, densely filled with yellowish-brown coloring matter.

On much decayed deciduous logs of various kinds, especially where they are saturated with water.

Type locality: North Carolina.

Distribution: New York to Wisconsin and North Carolina; also in South America.

Illustrations: Bull. N. Y. State Mus. 2: pl. 2, f. 4-6; Hedwigia 43: 273, f. 1-3; (?) Boud. Ic. Myc. pl. 310; (?) Bres. Fungi Trid. pl. 187.

Exsiccati: N. Am. Fungi 568 (as Psilopezia mummularia Berk.).

Very distinct with its adnate, dark-colored, discoid apothecia. This species has been collected in New York City year after year in the same place on the decaying trunk of a large tree, occurring in the late summer or autumn.

\section{DoubtFul Species}

Peziza caeruleomaculata (Rehm) Sacc. \& D. Sacc. in Sacc. Syll. Fung. 18: 19. 1906; Plicaria caeruleomaculata Rehm, Ann. 1lyc. 2: 351. 1904. This may be an abnormal specimen of Peziza pustulata (Hedw.) Pers.

Humaria lacteocinerea Rehm, Ann. Myc. 3: 517. 1905. A whitish species reaching a diameter of $2 \mathrm{~cm}$. and with coarsely verrucose spores 7-8 $\times 12-13 \mu$. On a pine drain in greenhouse at Madison, Wisconsin. The identity of the specimens is uncertain.

Peziza brunneovinosa Clements, Bot. Surv. Nebr. 4:8. 1896. A brownish or wine-colored species, with discoid apothecia reaching a diameter of $1.5 \mathrm{~cm}$. and with smooth spores $10 \times 16-20 \mu$. On soil, Keya Paha County, Nebraska. No specimen has been seen.

Peziza chrysopela Cooke, Mycographia 156. 1877. A small species described as one-half inch in diameter, subdiscoid, with pale-orange hymenium and smooth spores $6 \times 12 \mu$. On the ground in South Carolina. No specimen has been seen. 


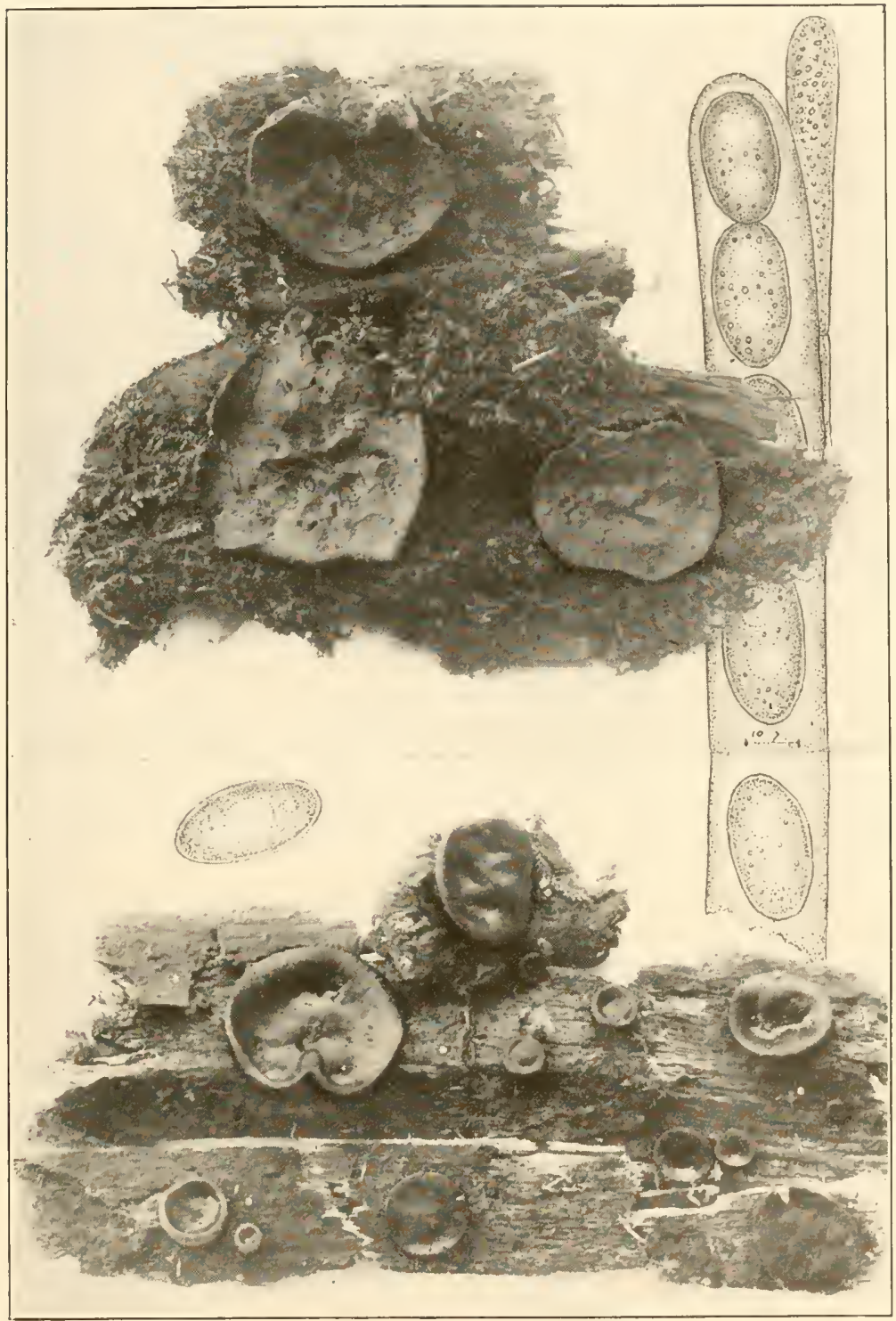



Peziza roseolilacina Clements, Bot. Surv. Nebr. 5: 7. 1901. Described as yellowish-ochraceous with a rose-lilac hymenium, reaching a diameter of $1.5 \mathrm{~cm}$., cup-shaped, with smooth spores $10 \times 17-18 \mu$. On wet soil among mosses, Keya Paha County, Nebraska. No specimens seen.

Peziza caligans Cooke, Mycographia 149. 187 7 . The description suggests a small specimen of Peziza badia. Its identity however is uncertain.

Peziza irrorata Berk. \& Curt.; Berk. Grevillea 3: 150. 1875. This species is described as applanate, fuligineous, $2-3 \mathrm{~cm}$. in diameter, with spores $12 \times 18-20 \mu$. On soil in Texas. No specimen seen.

Peziza repandoides (Rehm) Sacc. \& Trott. in Sacc. Syll. Fung. 22: 614. 1913; Plicaria repandoides Rehm, Ann. Myc. 3: 518. 1905. This appears from the description to be a small specimen of Peziza repanda.

Peziza irregularis Berk. \& Curt.; Berk. Jour. Linn. Soc. 10: 365. 1868. This species is clescribed as $6-8 \mathrm{~cm}$. in diameter, with an orange hymcnium and spores $12 \times 25 \mu$. Both the size of the apothecia and the size and form of the spores are strongly suggestive of a large Phillipsia which occurs in the West Indies. The color of the Phillipsia is reddish-purple, however, rather than orange as described and illustrated by Cooke. No authentic specimen has been seen.

Peziza convoluta Peck, Bull. Torrey Club 30: 101. 1903. Apothecia yellowish or tawny-brown with a wavy margin and a contorted hymenium, the spores $12-15 \times 20-22 \mu$. On sandy soil in California. No specimens have been seen.

39. SARCOSPHAERA Auersw. Hedwigia 8: 82. 1869.

Apothecia gregarious or scattered, at first entirely immersed in the substratum, the margin splitting Geaster-like at maturity; asci 8-spored; spores smooth or nearly so, ellipsoid or subellipsoid, hyaline; paraphyses filiform.

Type species, Peziza macrocalyx Reiss.

1. Sarcosphaera coronaria (Jacq.) Schröt. Krypt.-Fl. Schles. 3\%: 49. 1893.

Peziza coronaria Jacq. Misc. Austr. 1: 140. 1778.

Pesiza amplissima Fries, Summa V'eg. Scand. 349. 1849.

Peziza Geaster Rab. Sitzber. Nat. Ges. Isis. 1867: 22. 1867.

Sarcosphaera macrocalyx Auersw. Hedwigia 8: 82. 1869.

?Peziza sicula Inzenga, Fung. Sic. 2: 39. 1869.

Peziza Clissoni Ripart. Bull. Soc. Bot. Fr. 23: 309. 1876.

Aleuria eximia Gill. Champ. Fr. Discom. 48. 1879.

Pustularia gigantea Rehm, Ann. Myc. 3: 517.1905.

Peziza gigantea Sacc. \& Trott. in Sacc. Syll. Fung. 22: 611. 1913.

Apothecia occurring singly or two to five closely crowded together, at first buried, later becoming partially exposed, subglobose or more or less irregularly contorted, splitting from the top downward into $7-10$ pointed rays, externally dirty-pallid and 
at first clothed with a transient mycelium, at length naked, reaching a diameter of $6 \mathrm{~cm}$. and a depth of $8-10 \mathrm{~cm}$. when expanded, extended below into a short stem-like base; hymenium at first pallid, becoming bluish or violaceous; asci cylindric or subcylindric, reaching a length of about $200 \mu$ and a diameter of 10-12 $\mu$; spores 1 -seriate, smooth or very minutely roughened, usually containing two oil-drops, $8-9 \times 15-18 \mu$; paraphyses enlarged and branched above, filled with bluish coloring matter when fresh, the color fading when dry.

In coniferous woods, on or under humus.

Type locality: Europe.

Distribution: British Columbia to Michigan and New York; also in Europe and North Africa.

Illustrations: Boud. Ic. Myc. pl. 302; Cooke, Mycographia pl. 61; E. \& P. Nat. Pfl. 1'1 181, f. 147, F-G; Fres. Beit. Myk. pl. 9, f. 7-11; Cill. Champ. Fr. Discom. pl. 48; Gonnerm. \& Rab. Myc. Eu. Pez. pl. 3, f. 5; Inzenga, Fung. Sic. 2: pl. 8, f. 4; Jacq. Misc. Austr. 1: pl. 10; Jour. Bot. 7: pl. 98; Bull. Torrey Club 45: pl. 3; Lloyd, Myc. Notes 56, f. 1255; Sitzber. Nat. Ges. Isis. 1867: pl. 1 .

A most beautiful species but seldom collected. The only freshly collected material examined was that collected by $\mathrm{Mr}$. Stewart H. Burnham in Washington county, New York. Recognized by its semisubterranean habits and the splitting of the apothecia.

\section{Family 2. ELVELACEAE}

Ascophores consisting of a distinct stem and pileus; pileus bell-shaped, saddle-shaped, subglobose or entirely covering the outside of the stem when it assumes a columnar form, the surface of the hymenium even, lacunose or costate, the margin of the pileus either free or partially to entirely attached to the stem; stem very slender or stout, even, lacunose, or distinctly fluted, naked or pubescent, usually hollow within; asci cylindric or subcylindric, 2-8-spored; spores ellipsoid, smooth or sculptured, hyaline or faintly colored; paraphyses variable in form, hyaline or slightly colored.

Upper surface of the pileus costate.

With a sterile stem and fertile head.

1. Morchella.

Without stem and fertile to the base.

2. Durandiomyces.

Upper surface of the pileus even, lacunose, or gyrose, not costate. 
Pileus bell-shaped.

Pileus saddle-shaped or iriegularly subglobose.

Pileus columnar.
3. Verpa.

4. Elvela.

5. Underwoodia.

1. MORChella (Dill.) Pers. Tent. Disp. Fung. 36. 1797. Morchella Dill. App. Cat. Pl. 74. 1719.

Phalloboletus Adlans. Fam. Pl. 9. 1763. Hyponym.

Morilla Quél. Ench. Fung. 270. 1886.

Phalloboletus Kuntze, Rev. Gen. Pl. 2: 86t. 1891.

Pileus subglobose or elongated, obtuse or acute at the apex, the margin closely adnate or rarely free from the stem at the base, the surface irregularly costate, the rounded or elongated pits entirely lined within by the hymenium; the ribs irregularly anastomosing; hymenium yellow to brown; asci cylindric or subcylindric, usually 8 -spored; spores ellipsoid, smooth, hyaline or faintly colored; paraphyses few, usually stout.

Type species, Phallus esculentus L.

Pileus adnate to the stem at the base.

Ribs of the pileus similar in color to the interior of the pits or lighter.

Pileus large, reaching a length of $4-8 \mathrm{~cm}$. at maturity.

Pits large, usually shallow; ribs thin; stem strongly enlarged at the base.

1. M. crassipes.

Pits small, deep; ribs thick; stem only slightly enlarged at the base.

Pileus subglobose or only slightly elongated. Pileus elongated or strongly attenuated upwards.

Pileus small, not exceeding $2-3 \mathrm{~cm}$. in length.

2. M. esculenta.

3. M. conica.

4. M. deliciosa.

Ribs of the pileus much darker than the interior of the pits, becoming smoky-brown.

Pileus free from the stem at the base.

5. M. angusticeps.

6. M. hybrida.

1. Morchella crassipes (Vent.) Pers. Syn. Fung. 621. 1801. (Plate 35.)

Phallus crassipes Ventenat, Mem. Inst. 509. 1798.

Phalloboletus crassipes Kuntze, Rev. Gen. Pl. 2: 865. 1891.

Pileus usually elongated and often subconic, reaching a length of 6-8 cm. and a diameter of 5-6 cm.; pits roundish or irregularly elongated, reaching a diameter of $1 \mathrm{~cm}$., yellowish within; ribs irregularly anastomosing, thin, of ten sharp-edged; stem stout, reaching a length of $10-11 \mathrm{~cm}$. and a diameter of 5-6 cm. at the base, tapering upwards to a diameter of $4 \mathrm{~cm}$., yellowish or whitish, more or less lacunose, or nearly even, 
slightly pubescent; asci cylindric or subcylindric, reaching a length of $200 \mu$ and a diameter of $20 \mu$; spores 1-seriate, ellipsoid, hyaline or subhyaline, $12-14 \times 20-22 \mu$; paraphyses stout, clavate, hyaline or subhyaline.

On the ground in open places, of ten in margins of wooded areas.

Type locality: Europe.

Distribution: New York to Montana and Iowa; also in Europe.

Illustrations: Atkinson, Stud. Am. Fungi ed. 2, pl. 86; Boud. Ic. Myc. pl. 197; Cooke, Mycographia pl. 84, f. 319; Gill. Champ. Fr. Discom. pl. 14; Krombh. Abbild. pl. 16, f. 1-2; Hedwigia 25: 136; Mem. Inst. 509, f. 2.

2. Morchella esculenta (L.) Pers. Syn. Fung. 618. 1801. (Plate 36, Fig. 2.)

Phallus esculentus L. Sp. Pl. 1178.1753.

MIorchella esculenta rotunda Pers. Syn. Fung. 619. 1801.

Morchella esculenta vulgaris Pers. Syn. Fung. 619. 1801.

Morchella continua Tratt. Fungi Austr. 67. 1830 (in part).

Morchella esculenta fulva Fries, Syst. Myc. 2: 7. 1822.

Morchella esculenta longipes Peck, Ann. Rep. N. Y. State Mus. 28: 87. 1876. Phalloboletus esculentus Kuntze, Rev. Gen. Pl. 2: 865. 1891.

Morchella rotunda Boud. Soc. Myc. Fr, 13: 135. 1897.

Morchella vulgaris Boud. Bull. Soc. Myc. Fr. 13: 139. 1897.

Morilla esculenta Quél. Ench. Fung. 271. 1886.

Pileus subglobose, ovoid, or elongated, occasionally attenuated upwards but obtuse at the apex, varying much in size but of ten reaching a diameter of $4-5 \mathrm{~cm}$. and a length of $7-9 \mathrm{~cm}$.; pits rounded, irregular, or occasionally longitudinally elongated, yellowish within, becoming brownish or blackish when dry, reaching a diameter of $5 \mathrm{~mm}$. to $1 \mathrm{~cm}$.; ribs irregularly anastomosing, not longitudinally disposed, the edges rounded, about $1 \mathrm{~mm}$. thick and lighter colored than the interior of the pits, usually whitish or yellowish; stem stout but not usually exceeding two-thirds the diameter of the pileus, usually a little enlarged at the base and irregularly lacunose, nearly even above, whitish to yellowish, lighter than the pileus, delicately pubescent, reaching a length of $200-250 \mu$ and a diameter of $18-20 \mu$; spores 1 -seriate, ellipsoid, hyaline, yellowish in mass, $12-14 \times 20-24 \mu$; paraphyses strongly enlarged above, where they reach a diameter of $15 \mu$, faintly colored. 


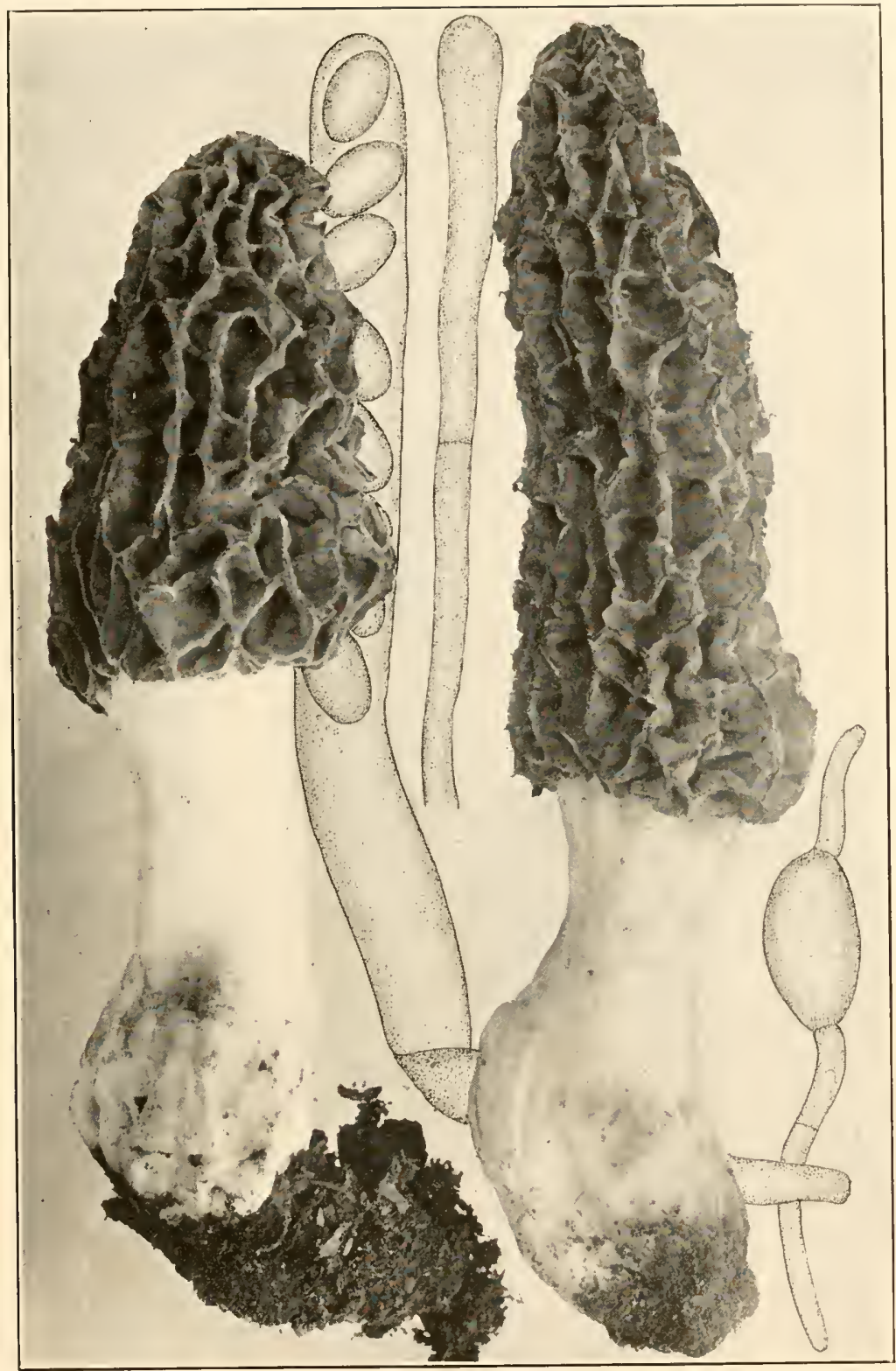

MORCHELLA CRASSIPES 

On the ground in woods and open places.

Type locality: Europe.

Distribution: Massachusetts to Michigan and Colorado, south to South Carolina; probably throughout North America; also in Europe.

Illustrations: Sow. Engl. Fungi pl. 51 (in part); Bolton, Hist. Fung. pl. 91; Boud. Ic. Myc. pl. 195, 196 and 202; Bull. Herb. Fr. pl. 216; Cooke, Mycographia pl. 81 (in part); Grev. Scot. Crypt. Fl. 2: pl. 68; Gill. Champ. Fr. Discom. pl. 13; Massee, Brit. Fungus-F1. 4: 188, f. 1-3; Phill. Brit. Discom. pl. 1, f. 1; Schaeff. Fung. Bavar. pl. 298, 299; Krombh. Abbild. pl. 19, f. 6-7.

Exsiccati: N. Am. Fungi 979.

3. Morchella conica Pers. Champ. Comest. 257. 1819.

?Phallus acuminatus Batsch. Elench. Fung. 133. 1783.

? Morchella continua Tratt. Fungi Austr. 67.1830 (in part).

Morchella esculenta conica Fries, Syst. Myc. 2: 7. 1822.

Morilla conica Quél. Ench. Fung. 271. 1886.

Phalloboletus conicus Kuntze, Rev. Gen. Pl. 2: 865. 1891.

Pileus elongated, subconic, acute at the apex or subobtuse, reaching a length of $6-8 \mathrm{~cm}$. and a diameter of $4 \mathrm{~cm}$.; pits elongated and more or less inclined to rectangular in form, yellowish within, becoming brown or blackish when dry, reaching a length of $5 \mathrm{~mm}$. to $1 \mathrm{~cm}$. and about half as broad; ribs more or less longitudinally disposed, anastomosing or connected by cross ribs, the edges about $1 \mathrm{~mm}$. thick, rounded and lighter in color than the interior of the pits; stem about two-thirds the diameter of the base of the pileus, irregularly lacunose below, nearly even above, whitish to yellowish, lighter than the pileus, delicately pubescent, reaching a length of $4-7 \mathrm{~cm}$.; asci cylindric or subcylindric, reaching a length of $200-250 \mu$ and a diameter of $18-20 \mu$; spores 1 -seriate, ellipsoid, hyaline, yellowish in mass, $12-14 \times 20-24 \mu$; paraphyses strongly enlarged above, where they reach a diameter of $12-15 \mu$, faintly colored.

On the ground in woods and open places in the margins of woods.

Type locality : Europe.

Distribution: New York to Washington and Iowa; also in Europe.

Illustritions: Tratt. Fungi Austr. pl. 6, f. 11; Rab. Krypt.Fl. 13: 1178, f. 1-4; Atkinson, Stud. Am. Fungi ed. 2, 218, f. 217; 
Gill. Champ. Fr. Discom. pl. 16, f. 1; Krombh. Abbild. pl. 16, f. $7-12$.

The species is regarded by many as only a form of M. esculenla.

4. Morchella deliciosa Fries, Syst. Myc. 2: 8. 1822.

Morchella conica deliciosa Phill. Brit. Discom. 5. 1887.

Phalloboletus deliciosus Kuntze, Rev. Gen. Pl. 2: 865. 1891.

Pileus conic or subconic, reaching a length of $2-3 \mathrm{~cm}$. and a diameter of 1-1.5 cm.; pits usually elongated, cinereous to blackish within; ribs inclined to be longitudinally disposed, irregularly anastomosing, the edges rounded and about $1 \mathrm{~mm}$. thick, much lighter than the interior of the pits, whitish; stem half to two-thirds as thick as the base of the pileus, of ten enlarged at the base and irregularly lacunose, lighter than the pileus, whitish or yellowish; asci cylindric or subcylindric, reaching a length of about $200 \mu$ and a diameter of $12-15 \mu$; spores 1 -seriate, ellipsoid, hyaline, yellowish in mass, $10 \times 20 \mu$; paraphyses enlarged at their apices and slightly colored.

On the ground in grassy places, usually in the edges of wooded places.

Type locality: Europe.

Distribution: New York to Pennsylvania, Iowa and Colorado; also in Europe.

Illustrations: Trans. Bot. Soc. Edinburgh 10: 441, f. 1; Cooke, Mycographia pl. 84, f. 320; Gill. Champ. Fr. Discom. pl. 15; Massee, Brit. Fungus-Fl. 4: 188, f. 31; Bull. Lab. Nat. Hist. State Univ. Iowa 6: pl. 2, f. 2; Krombh. Abbild. pl. 16, f. $17-19$.

5. Morchella angusticeps Peck, Ann. Rep. N. Y. State Mus. 32 : 44. 1879.

?Morchella elata Fries, Syst. Myc. 2: 8. 1822.

? Morilla elata Quél. Ench. Fung. 271. 1886.

?Phalloboletus elatus Kuntze, Rev. Gen. Pl. 2: 865. 1891.

Phalloboletus angusticeps Kuntze, Rev. Gen. Pl. 2: 865. 1891.

Pileus elongated, subobtuse or narrowly conic and acute at the apex, reaching a length of $2-5 \mathrm{~cm}$. and about half as broad at the base; pits elongated, reaching a length of $5-10 \mathrm{~mm}$. and about half as broad, yellowish within, becoming smoky-brown at the margins; ribs inclined to be longitudinally disposed, irregularly anastomosing, usually less than $1 \mathrm{~mm}$. thick and often almost sharp-edged, black at the extreme edge, lighter 


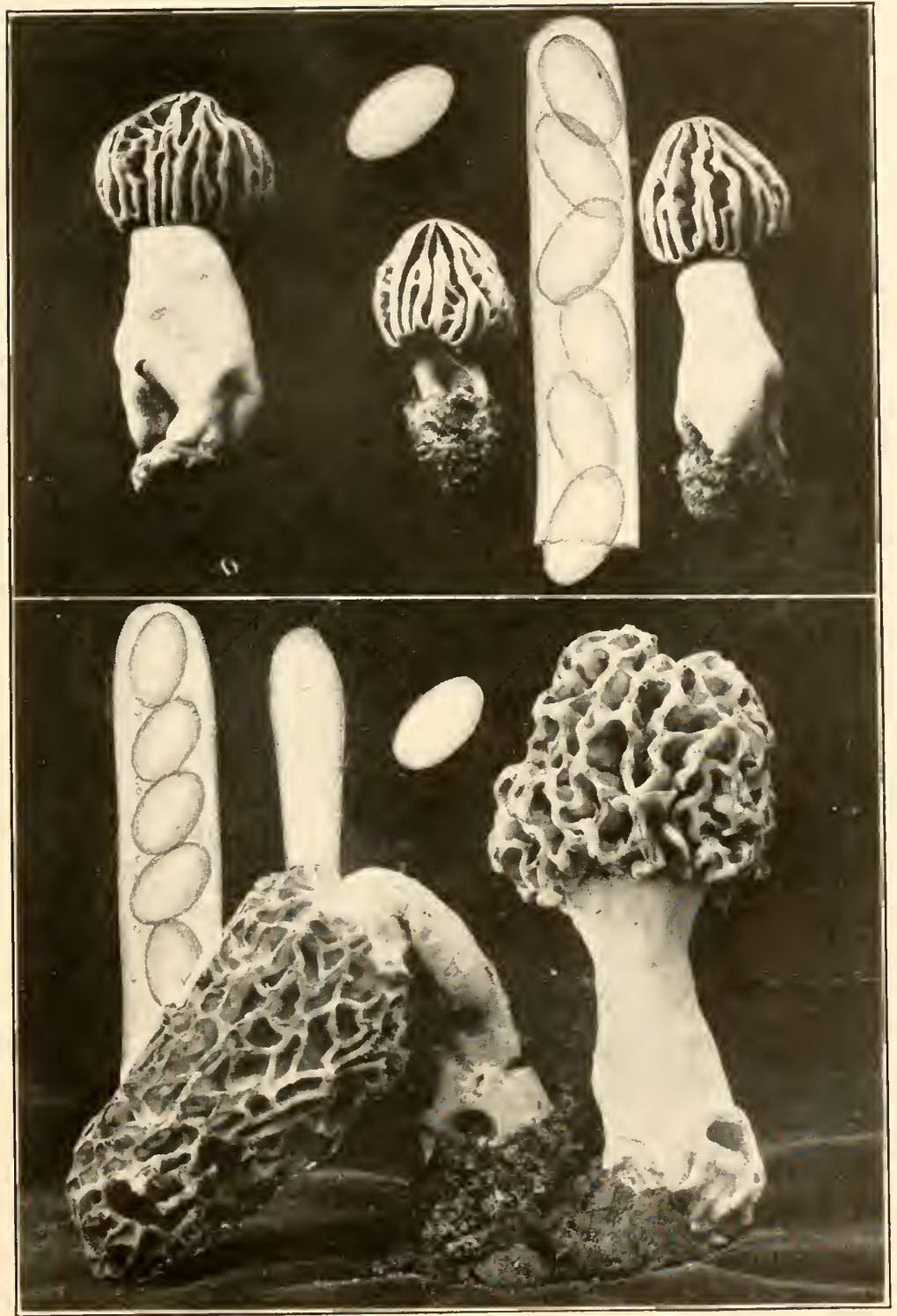

1. MORCHELLA HYBRIDA

2. MORCHELLA ESCULENTA 

below; stem of almost uniform thickness throughout its entire length, the diameter almost equal to that of the pileus, irregularly lacunose near the base, nearly even above, delicately pubescent; asci cylindric or subcylindric, reaching a length of $275 \mu$ and a diameter of $20 \mu$; spores 1 -seriate, ellipsoid, hyaline or very faintly colored, yellowish in mass, $12-14 \times 24-28 \mu$; paraphyses enlarged upwards.

On sandy soil in the borders of woods and open places.

True Locality: West Albany, New York.

Distributiox: New York to Pennsylvania and Michigan; also in Europe.

Iliustrations: Bull. N. I. State Mus. 12: pl. 1, f. 19-2(); Ann. Rep. N. Y. State Mus. 48: pl. 4, f. 5-9; Boud. Ic. Myc. pl. 206 and (? 213).

6. Morchella hybrida (Sow.) Pers. Syn. Fung. 621. 1801. (Plate 36, Fig. 1.)

?Phallus Rete Batsch. Elench. Fung. 131. 1783.

Elvela hybrida Sow. Engl. Fungi pl. 238. 1799.

?.Morchella patula Pers. Sỹn. Fung. 619. 1801.

Morchella rimosipes DC. Fl. Fr. 2: 21t. 1815.

? Morchella Rete Pers. Myc. Eu. 1: 205. 1822.

Mitrophora semilibera Lév. Ann. Sci. Nat. III. 5: 250. 1846.

? Mitrophora patula Lév. Ann. Sci. Nat. III. 5: 250. 1846.

Mitrophora rimosipes Lév. Ann. Sci. Nat. III. 5: 250. 1840.

Morilla semilibera Quél. Ench. Fung. 271. 1886.

Morchella Mitra Lenz, Schwamme 103. 1831.

Phalloboletus Rete Kuntze, Rev. Gen. Pl. 2: 865. 1891.

Morchella hybrida rimosipes P. Henn. Verh. Bot. Brandenb. 36: 68. 1895.

Phalloboletus rimosipes Kiuntze, Rev. Gen. Pl. 2: 865. 1891.

Morchella punctipes Peck, Bull. Torrey Club 30: 99. 1903.

Mitrophora hybrida Bourl. Hist. Class. Discom. Eu. 33. 1907.

Pileus bell-shaped or subconic, reaching a length of $2 \mathrm{~cm}$. and a diameter of $1.5 \mathrm{~cm}$., the margin free about half way up; pits irregularly rounded or elongated, reaching a diameter of 5-10 mm., yellowish within; ribs inclined to be longitudinal or irregularly anastomosing, about $1 \mathrm{~mm}$. thick, whitish, lighter than the interior of the pits; stem thick, at first very short, finally reaching a length of $8-10 \mathrm{~cm}$. and a diameter of $2 \mathrm{~cm}$. at the base, gradually tapering upward to about half that diameter, delicately pubescent, whitish or yellowish, often irregularly lacunose at the base, nearly even above; asci cylindric or subcylindric, reaching a length of $250 \mu$ and a diameter of $20 \mu$; 
spores 1 -seriate, ellipsoid, $12-14 \times 22-26 \mu$, hyaline or faintly colored; paraphyses enlarged upwards, hyaline or subhyaline.

On the ground, usually in the margins of woods.

Type locality : Europe.

Distribution: New York to Iowa and Oregon; also in Europe.

Illustrations: Boud. Ic. Myc. pl. 216; Bull. Lab. Nat. Hist. State Iniv. Iowa 6: pl. 3, f. 2; Cooke, Mycographia pl. 85; Minn. Bot. Studies 3: pl. $48, f .7,8$; Lenz, Schwamme pl. 16, f. 67; Mycologia 19: 141, f. 3 .

Exsiccati: N. Am. Fungi 2628, 2907.

\section{DURANDIOMYCES Seaver, gen. nov.}

Ascophores large, consisting of numerous contorted and frequently anastomosing ribs resembling a Sparassis, the numerous cavities lined everywhere with the hymenium, the color ranging from white to rosy or faintly violaceous; flesh very brittle; asci 8 -spored; spores minutely sculptured; spore-sculpturing consisting of minute warts or papillae.

Type species, Gyromitra Phillipsii Massee.

Originally thought and still maintained by some to be an anomalous form of Peziza proteana which it resembles in spore characters and in color. Although familiar with Peziza proteana, I have never seen any tendency to assume this form and therefore regard it as a well-defined genus. It is here dedicated to the late Dr. E. J. Durand, to whom we are indebted for the excellent photograph. (Plate 37.)

Durandiomyces Phillipsii (Massee) Seaver, comb. nov.

(Plate 37.)

Gyromitra Gigas Phill. Jour. Bot. 31:129. 1893. Not G. Gigas Krombh. Gyromitra Phillipsii Massee, Brit. Fungus-Fl. 4: 478. 1895.

Aleuria proteana sparassoides Boud. Bull. Soc. Myc. Fr. 15: 51. 1899. Galactinia proteana sparassoides Boud. Ic. Мyc. 162. 1911. Peziza proteana sparassoides Durand, Mycologia 11:1. 1919.

Ascophores large, reaching a height of $20-25 \mathrm{~cm}$. and a diameter of $15-20 \mathrm{~cm}$; asci cylindric or subcylindric, scarcely attenuated at the base, reaching a length of $250-300 \mu$ and a diameter of $10-11 \mu$; spores ellipsoid, usually containing two oildrops, becoming minutely sculptured, $7 \times 11-12 \mu$; spore-sculpturing consisting of minute warts or papillae; paraphyses enlarged upwards, reaching a diameter of $5-7 \mu$ at their apices. 


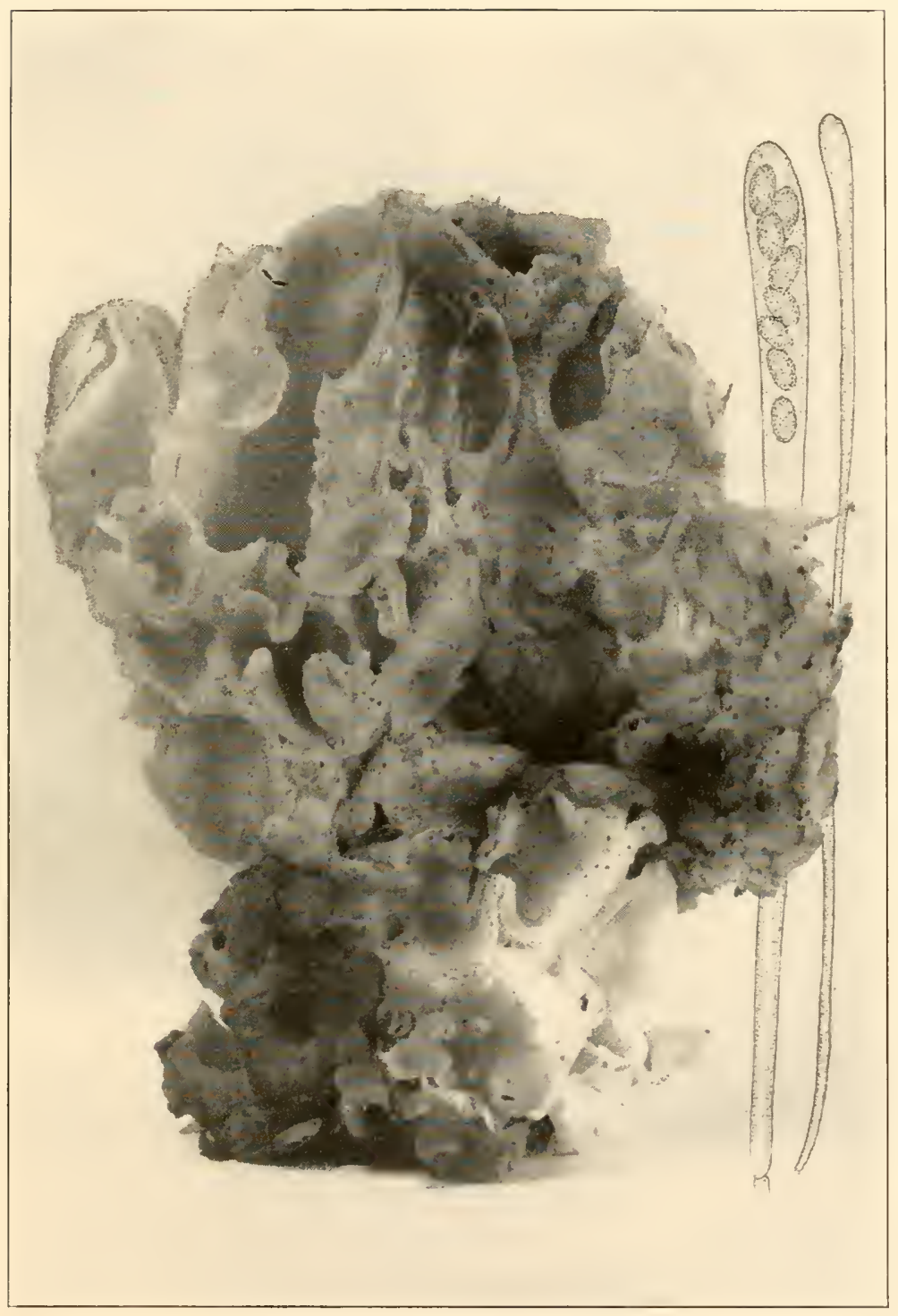

DURANDIOMYCES PHILLIPSII 

On the ground in burnt places.

Type locality: Europe.

Distributiox: New York to Washington and Oregon; also in Europe.

Illustrations: Bull. Soc. Myc. Fr. 15: pl. 3, f. 2; Bold. Ic. Myc. pl. 294; Jour. Bot. 31 : pl. 334; Mycologia 11: pl. 1.

3. VERPA Swartz, Sv. Vet. Akad. Handl. 1815: 129.

Pileus bell-shaped, with the stem attached to the center of the under surface; hymenium covering the entire outside of the pileus, varying in color from yellow to dark-brown, even or more or less lacunose; stem rather stout, hollow or loosely stuffed, lighter colored than the hymenium, usually even or very slightly lacunose, naked or delicately pubescent; asci cylindric or clavate, 2-8-spored; spores ellipsoid, smooth, medium sized to very large; paraphyses rather stout.

Type species, Phallus conicus Mïller.

Asci 8-spored; spores medium sized.

1. I. conica.

Asci typically 2 -spored; spores very large.

2. Ir. bohemica.

1. Verpa conica (Müll.) Swartz, Sv. Vet. Akad. Handl. 1815: 136. 1815. (PLATE 38, FIG. 2.)

Phallus conicus Müller, F1. Dan. pl. 65t,f.2. 1777.

Leotia conica Pers. Syn. Fung. 613. 1801.

Verpa digitaliformis l'ers. Myc. Eu. 1: 202. 1822.

Verpa Krombholzii Corda in Sturm, Deutsch. F1. 2: 5.1829.

Verpa helvelloides Krombh. Abbild. 1:76. 1831.

Phalloboletus conicus Kuntze, Rev. Gen. Pl. 2: 865. 1891.

Terpa chicoensis Copeland, Ann. Myc. 2: 508. 1904.

Pileus bell-shaped or subconic, whitish beneath, the margin often slightly reflexed, exposing a whitish border, entirely free from the stem, reaching a depth of $2 \mathrm{~cm}$. and a diameter of 1-2 cm.; hymenium becoming dark-brown, even or slightly lacunose; stem cylindric or subcylindric, slightly narrowed above, whitish or slightly floccose or scaly, the scales giving a transversely striate appearance, hollow or very loosely stuffed, reaching a length of 5-6 cm.; asci cylindric or subcylindric, gradually tapering below into a more or less contorted, stem-like base, reaching a length of $300 \mu$ and a diameter of $20 \mu, 8$-spored; spores 1 -seriate or irregularly crowded, ellipsoid, slightly yellowish at maturity, $12-16 \times 22-26 \mu$; paraphyses stout, sparingly septate, reaching a diameter of $10 \mu$. 
On the ground.

Type locality: Europe.

Distribution: New York to Colorado; also in Europe.

Illustrations: Boud. Ic. Myc. pl. 220; Cooke, Mycographia pl. 101, f. 364; F1. Dan. pl. 654, f. 2; Pers. Myc. Eu. 1: pl. 7, f. 1-3; Sturm, Deutsch. Fl. 2: pl. 1; Ann. Myc. 2: pl. 12, f. 1-5; Rab. Krypt.-Fl. $1^{3}: 1175, f .2-3$.

2. Verpa bohemica (Krombh.) Schröt. Krypt. Fl. Schles. $3^{2}$ : 25. 1893. (Plate 38, Fig. 1.)

Morchella bohemica Krombh. Abbild. 3: 3. 1834.

Morchella gigaspora Cooke, Trans. Bot. Soc. Edinb. 10: 442. 1870.

Morchella bispora Sorokin, Mycol. Unters. 21. 1872.

Morchella bohemica bispora Cooke, Mycographia 188. 1878.

Morilla bohemica Quél. Ench. Fung. 271. 1886.

Morilla gigaspora Quél. Ench. Fung. 271. 1886.

Phalloboletus bohemicus Kuntze, Rev. Gen. Pl. 2: 865. 1891.

Phalloboletus gigasporus Kuntze, Rev. Gen. Pl. 2: 865. 1891.

Phalloboletus bisporus Kuntze, Rev. Gen. Pl. 2: 865. 1891.

Morchella bispora truncata Peck, Ann. Rep. N. Y. State Mus. 46: 38. 1893.

Pileus bell-shaped or subconic, white underneath, often with the margin slightly reflexed, exposing a white border below, $2-3 \mathrm{~cm}$. deep and reaching a diameter of 1-2 cm.; hymenium folded into longitudinal and rather freely anastomosing ribs, yellowish to brownish; stem almost cylindric, hollow or loosely stuffed, externally white or slightly floccose, not wrinkled or lacunose, reaching a length of 6-8 cm.; asci cylindric or subcylindric, tapering below into a much contorted stem-like base, the entire ascus reaching a length of $300-325 \mu$ and a diameter of 20-22 $\mu$, typically 2-spored; spores ellipsoid, straight or slightly curved, smooth externally, and minutely granular within, 15-18 $\times 60-80 \mu$, subhyaline or slightly yellowish; paraphyses clavate, stout, reaching a diameter of $7-8 \mu$ at their apices.

On the ground.

Type locality : Europe.

Distributiox: New York to Minnesota; also in Europe.

Illustrations: Boud. Ic. Myc. pl. 218; Krombh. Abbild. pl. 15, f. 1-13; Minn. Bot. Studies 3: pl. 49, f. 7-9; Trans. Bot. Soc. Edinb. 10: 442, f. 2; Rab. Krypt.-Fl. 133 1176, f. 1-3; Cooke, Mycographia pl. 87, f. 324-326; Bot. Zeit. 34: pl. 10; E. \& P. Nat. Pfl. $1^{1}: 168, f .1+1, E-F$ and $169, f .1+2, G$. 


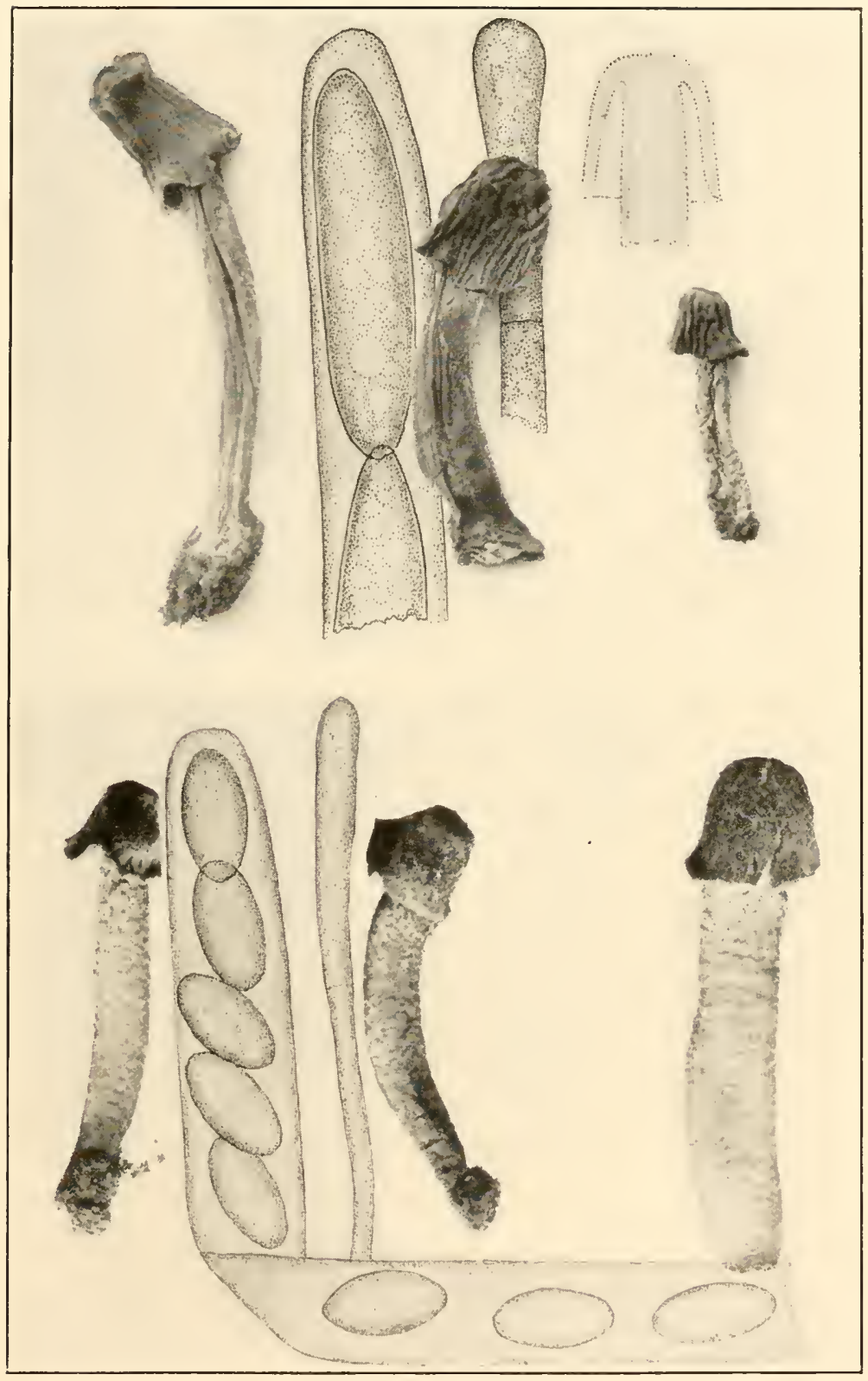

1. VERPA BOHEMICA

2. VERPA CONICA 



\section{Doubtfil Species}

Verpa atroalba Fries, Syst. Myc. 2: 23. 1822. A specimen referred to this name was collected at Jamesville, New York, Mlay 17, 1890. The specimen is identical with T'erpa conica. No authentic specimen of Fries' species has been seen and its identity is therefore uncertain.

Terpa perpusilla Rehm, Ann. Myc. 7: 526. 1909. Specimens of this species distributed by Rehm in his Asconycetes 1857 appear to be identical with Elrela elastica Bull.

\section{ElVELA L. Sp. Pl. 1180. 1753. (Often written Helvella.)}

Gyromitra Fries, Summa Veg. Scand. 346. 1849.

Leptopodia Boud. Bull. Soc. Myc. Fr. 1: 99. 1885.

Physomitra Boud. Hist. Class. Discom. Eu. 35. 1907.

Pileus mitrate, saddle-shaped or sulgglobose, even or irregularly convolute, the convolutions often taking the form of gyrose ridges, the margin reflexed and free or more or less adnate to the stem; stem very slender or stout, even, lacunose, or strongly fluted, white, yellow, or smoky; asci cylindric or subcylindric, 8-spored; spores 1- or 2-seriate, ellipsoid, of ten apiculate, smooth or rough; paraphyses slender, more or less enlarged above.

Type species, Elvela Mitra L.

Stem distinctly fluted, i.e. with sharp-cornered ridges which extend almost the entire length of the stem.

Stem stout and usually strongly swollen at the base.

Pileus becoming dark-colored and stem smoky.

Pileus and stem remaining light-colored, almost white.

Stem very slender and of nearly uniform thickness.

Stem not distinctly fluted but even or irregularly lacunose.

Stem very slender, rarely exceeding $5 \mathrm{~mm}$. in diameter.

Pileus and stem entirely black.

Pileus and stem not entirely black.

Pileus entirely free from the stem.

Stem very long.

Stem very short.

P'ileus adnate to the stem.

1. E. Mitra.

2. E. crispa.

3. E. palustris.

4. E. atra.
5. E. elastica.
6. E. Klotzschiana.
7. E. adhaerens.

Stem stout, usually 1 to several $\mathrm{cm}$. in liameter. Spores ellipsoirl to fusoirl.

Spores small, smooth, not exceeding 20 $24 \mu$ long. 
Pileus large and umbrella-like; spores small, $8-9 \times 17 \mu$.

Stem long, reaching a length of $10 \mathrm{~cm}$.

8. E. californica.

Sten short, reaching a length of $3-5 \mathrm{~cm}$.

9. E. umbraculiformis.

Pileus not widely spreading or umbrella-like.

Spores narrow-cllipsoid, containing two oil-drops.

Pileus medium large; stem reaching a length of 6-8 $\mathrm{cm}$.

Pileus very small; stem not exceeding $1-2 \mathrm{~cm}$. in length.

Spores broad-ellipsoid, containing one oil-drop.

Spores large, rough, $12-14 \times 30-35 \mu$.

Spores fusoid, strongly apiculate.

Spores ellipsoid, not strongly apiculate.

10. E. infulu.

11. E. brerissima.

12. E. albipes.

13. E. caroliniana.

14. E. Underwoodii.

Spores globose.

15. E. sphaerospora.

1. Elvela Mitra L. Sp. P1. 1180. 1753. (Plate 39, Fig. 1.)

Elvela nigricans Schaeff. Fung. Bavar. 4: Ind. 102. 177 t.

Elrela lacunosa Afz. Sr. Vet. Akall. Handl. 304. 1783.

Elvela sulcata Afz. Sr. Vet. Akad. Handl. 305. 1783.

'Elvela grisea Clements, Bot. Surv. Nebr. 4: 8. 1896.

Leptopodia elastica Boud. Hist. Class. Discom. 37. 1907.

Pileus mitrate, irregularly saddle-shaped or occasionally subglobose, the margin reflexed and adnate with the stem at various points, occasionally extending down the stem for some distance, reaching a diameter of $2-5 \mathrm{~cm}$; hymenium even or irregularly convolute, dark brownish-black; stem reaching a length of 10 $\mathrm{cm}$. and a diameter of $2 \mathrm{~cm}$., usually enlarged below and gradually attenuated above, deeply fluted, yellowish, becoming smoky; asci cylindric, 8-spored, reaching a length of $200 \mu$ and a diameter of $16 \mu$; spores ellipsoid, usually containing one large oil-drop which almost fills the spore, about $12 \times 20 \mu$; paraphyses enlarged at their apices, reaching a diameter of $5 \mu$, pale yellowishbrown.

On damp soil.

Type lochlity: Europe.

Distribution: New York to British Columbia and south to Mexico; also in Europe.

Illustrations: Micheli, Nov. Pl. Gen. pl. 86, f. 7; Schaeff. 


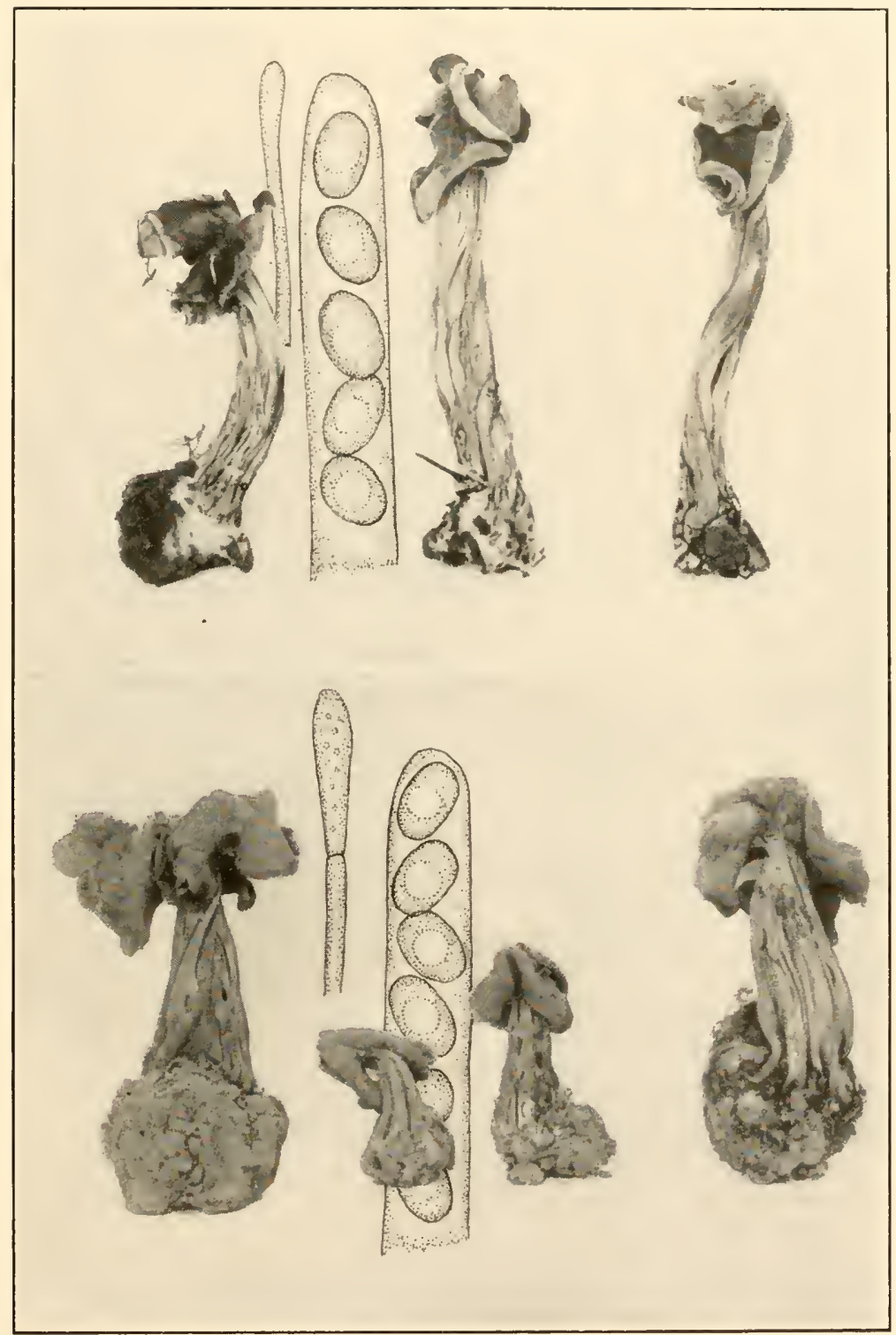

1. ELVELA MITRA

2. ELVELA CRISPA 

Fung. Bavar. pl. 154; Boud. Ic. Myc. pl. 228; Cooke, Mycographia pl. 41, f. 160; Gill. Champ. Fr. Discom. pl. 2, f. 1 and pl. 3; Bull. Herb. Fr. pl. 466, f. B; Minn. Bot. Studies 3: pl. $48, f .11-13$.

Exsiccati: Clements, Crypt. Form. Colo. 130, 302; N. Am. Fungi 3039; Fungi Columb. 1931.

2. Elvela crispa (Scop.) Fries, Syst. Myc. 2: 14. 1822. (Plıte 39, FIG. 2.)

?Elvela pallida Schaeff. Fung. Bavar. 4:112. 1770.

Phallus crispus Scop. Fl. Carn. 2: 475.1772.

Elvela nivea Schrad. Jour. Bot. Schracl. 2: 66. 1799.

Elvela leucophaea Pers. Obs. Myc. 2: 19. 1799.

Elvela fusca Gill. Champ. Fr. Discom. 9. 1879.

Pileus mitrate or more often saddle-shaped, reflexed and usually irregularly lobed, reaching a diameter of $4-5 \mathrm{~cm}$; hymenium white, becoming cream or yellowish with age and especially when dried, even or more or less convoluted; stem reaching a length of $6-7 \mathrm{~cm}$. and a diameter of 2-3 cm., deeply fluted, entirely white when fresh, becoming cream or yellowish with age, still darker when dry; asci cylindric or subcylindric, reaching a length of $300 \mu$ and a diameter of 15-18 $\mu$; spores 1 seriate, ellipsoid, containing one large oil-drop, about $12 \times 20 \mu$; paraphyses enlarged above, where they reach a diameter of $\delta \mu$.

On soil usually in wooded places.

Type LOCALITY: Europe.

Distribution: New York to Alberta and California; also in Europe.

Illustrations: Boud. Ic. Myc. pl. 225; Cooke, Mycographia pl. 41, f. 159; Gill. Champ. Fr. Discom. pl. 2, f. 2; Krombh. Abbild. pl. 19, f. 27-29; Massee, Brit. Fungus-F1. 4: 188, $f$. 17-18; E. \& P. Nat. Pfl. $1^{1}: 168, f .141, G-H$; Bull. Lab. Nat. Hist. State Univ. Iowa 6: pl. 5, f. 1; Bull. Herb. Fr. pl. 466, f. A; Minn. Bot. Studies 3: pl. 49, f. 10; Schaeff. Fung. Bavar. pl. 282 .

Exsiccati: Fungi Columb. 3329.

3. Elvela palustris Peck, Ann. Rep. N. Y. State Mus. 33: 31. 1880 .

?Elvela pallescens Schaeff. Fung. Bavar. 4: Ind. 11t. 177 t.

Pileus widlely expanded, the margin reflexed, at first slightly adnate with the stem but at maturity entirely free, reaching a 
diameter of 2-3 cm., light-colored and rugose underneath; hymenium even or slightly undulated, the color varying from brown to blackish; stem slender, of nearly uniform diameter throughout its entire length or very slightly enlarged at the base, deeply fluted throughout its entire length, dark, the color similar to that of the hymenium, reaching a length of $4-5 \mathrm{~cm}$. and a diameter of 5-6 $\mathrm{mm}$. at the base; asci cylindric or subcylindric, reaching a length of $200 \mu$ and a diameter of $16 \mu$; spores ellipsoid, containing one large oil-drop which often breaks up in dried specimens, about $9 \times 18 \mu$; paraphyses enlarged at their apices, where they reach a diameter of $6-8 \mu$.

Among mosses and liverworts in swamp.

Type Locality: Manilius Center, New York.

Distribution: New York; also in Europe?

Illustrations: Ann. Rep. N. Y. State Mus. 33: pl. 2, f. 16-18; ? Schaeff. Fung. Bavar. pl. 322; Cooke, Mycographia pl. $9+, f .3+1$.

Little is known of this species and it is possible that it is only a slender form of Elvela Mitra.

\section{Elvela atra Oed. Fl. Dan. 9: 7.1770.}

Elvela nigricans Pers. Obs. Myc. 1: 72. 1796.

?Leptopodia atra Boud. Hist. Class. Discom. 37. 1907.

Pileus mitrate or more often saddle-shaped, the margin free from the stem, at least when mature and irregularly lobed, the color underneath smoky-brown, becoming almost black when mature, especially when dry; hymenium nearly even or slightly undulated, entirely black; stem slender, slightly enlarged at the base, entirely smoky-black except the base, which is whitish, slightly pruinose or tomentose, reaching a length of $4-5 \mathrm{~cm}$. and a diameter of 2-3 mm.; asci cylindric or subcylindric, reaching a length of $230 \mu$ and a diameter of $16 \mu$; spores 1 -seriate, ellipsoid, containing one large oil-drop, about $12 \times 20 \mu$; paraphyses strongly enlarged at their apices, where they reach a diameter of $8-10 \mu$, smoky-brown.

On the ground, usually in woods.

Týe locality: Europe.

Distribution: Wisconsin to Montana; also in Europe.

Illustrations: Fl. Dan. pl. 534; Boud. Ic. Myc. pl. 238; Cooke, Mycographia pl. 43, f. 167; Gill. Champ. Fr. Discom. pl. 7; Krombh. Abbild. pl. 21, f. 18-20; Rab. Krypt.-Fl. 133:1173, f. $S$. 


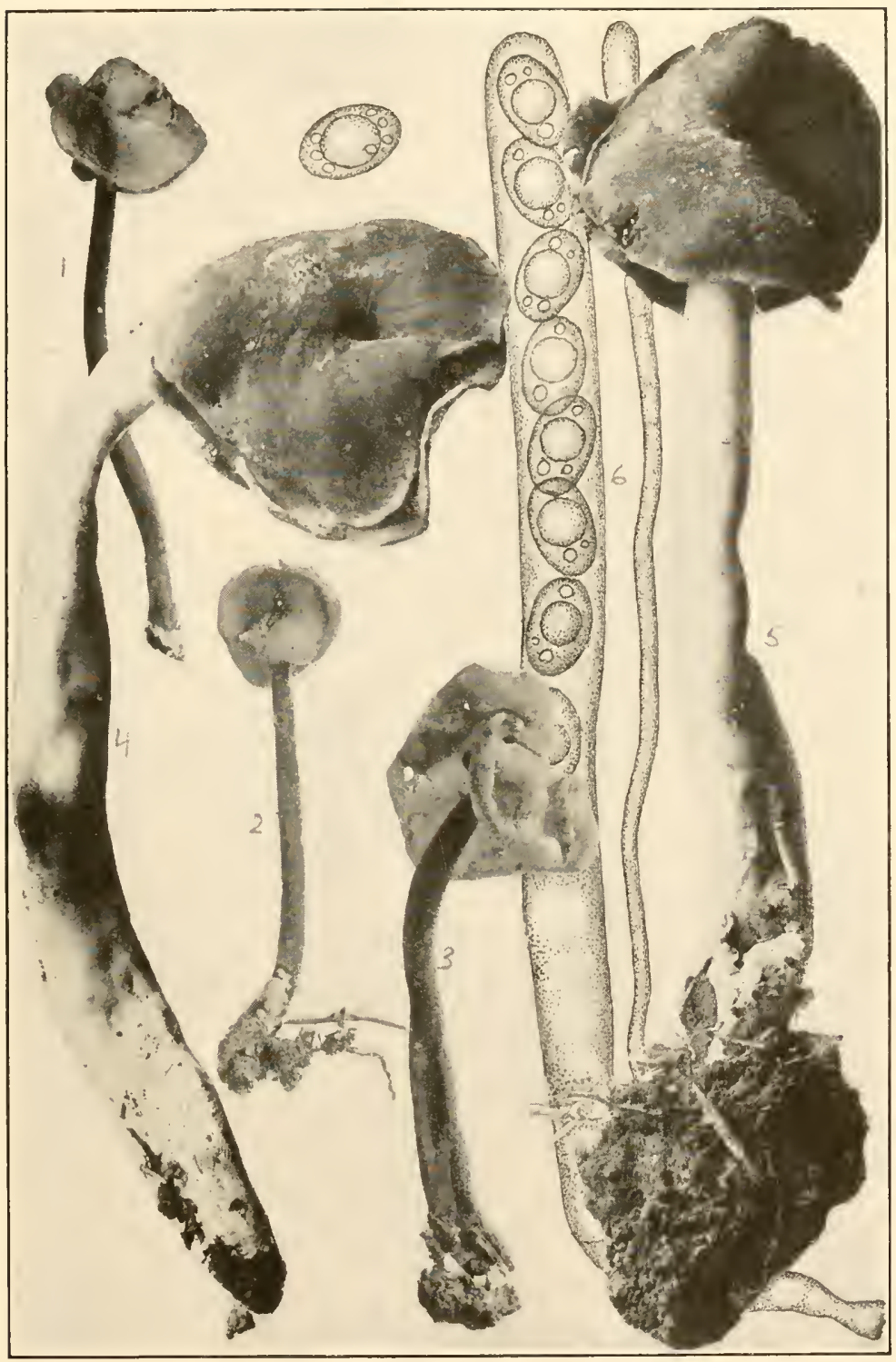

1-3. ELVELA ELASTICA

4-5. ELVELA ELASTICA GIGANTEA 

This species although listed separately here scarcely differs from E. elastica except in color; whether the species is well founded is difficult to say without more extended observations in the field. This is made difficult through the fact that the plants are not often collected.

5. Elvela elastica Bull. Herb. Fr. pl. 242. 1785. (Plate 40.)

?Elvela capucinoides Peck, Bull. N. Y. State Mus. 157:27. 1912.

Elvela gracilis Peck, Ann. Rep. N. Y. State Mus. 24: 94. 1872.

?Elvela fistulosa Alb. \& Schw. Consp. Fung. 299. 1805.

?Elvela fuliginosa Pers.; Cooke, Mycographia 92. 1876.

Elvela Stevensii Peck, Bull. Torrey Club 31: 182. 1904.

Pileus irregularly saddle-shaped, the margin reflexed and usually free from the stem, reaching a diameter of $2-3 \mathrm{~cm}$.; hymenium even or more or less convolute, the color varying from yellowish to dark-brown or nearly black; stem slender, 3-10 $\mathrm{mm}$. thick, reaching a length of 5-10 $\mathrm{cm}$., even or slightly lacunose, never fluted, yellowish, paler than the hymenium; asci cylindric or subcylindric, reaching a length of $200-250 \mu$ and a diameter of $20 \mu$; spores 1-seriate, ellipsoid, containing one large oildrop which often becomes indistinct in dried specimens, 10-12 $\times 18-20 \mu$; paraphyses strongly enlarged above, where they reach a diameter of $10 \mu$, faintly colored.

On the ground, usually in woods.

Type locality: Europe.

Distributiox: New York to California, Idaho and Texas; also in Europe.

Illustrations: Bull. Herb. Fr. pl. 242; Boud. Ic. Myc. 232; Cooke, Mycographia pl. 42, f. 163, 164; Gill. Champ. Fr. Discom. pl. 11, 12; Rehm, Krypt.-Fl. 13: 1173, f. 6-7; Krombh. Abbild. pl. 21,f. 21; Pat. Tab. Fung. f. 100; E. \& P. Nat. Pfl. 11: 168, f. 141, J; Bull. Lab. Nat. Hist. State Univ. Iowa 6: pl. 5, f. 2; Minn. Bot. Studies 3: pl. 49, f. 14, 15.

Exsiccati: Underw. \& Cook, Illust. Fungi 81; Clements, Crypt. Form. Colo. 129.

The large specimens shown on the accompanying plate were collected and photographed by C. G. Lloyd. It is unusually large and might be regarded as a different form.

6. Elvela Klotzschiana Corda; Sturm, Deutsch. FI. 3 : 121. 1837. ?Leptopodia Klotzschiana Boud. Hist. Class. Discom. 37. 1907.

Pileus mitrate, saddle-shaped or irregularly lobed, reaching a diameter of $2 \mathrm{~cm}$, the color underneath bright-yellow or tan; 
hymenium even or more or less undulated, dark brownish-black; stem short, slender, of nearly uniform diameter throughout its entire length, or slightly enlarged at the base, reaching a length of $1.5 \mathrm{~cm}$. and a diameter of 3-4 mm., similar in color to the under side of the pileus; asci cylindric or subcylindric, reaching a length of $300 \mu$ and a diameter of $16 \mu$; spores 1 -seriate, ellipsoid, containing one large oil-drop, $10 \times 17-18 \mu$; paraphyses enlarged above, where they reach a diameter of $\delta \mu$, slightly colored.

On soil, usually in woods.

Type Locality: Europe.

Distribution: Idaho; also in Europe.

Illustration: Sturm, Deutsch. Fl. 3: pl. 57.

7. Elvela adhaerens Peck, Bull. N. Y. State Mus. 54: 956. 1902.

Pileus thin, irregularly reflexed and more or less saddleshaped, reaching a diameter of $2-3 \mathrm{~cm}$., the margin adhering to the stem, underneath whitish or yellowish; hymenium even or very slightly undulated, whitish to tan, becoming brownish with age; stem slender, reaching a diameter of $5 \mathrm{~mm}$. and a length of 6-8 cm., similar in color to the outside of the pileus; asci cylindric or subcylindric, 8 -spored; spores ellipsoid, usually containing one large oil-drop, about $12 \times 18-20 \mu$; paraphyses strongly thickened at their apices.

On the ground in woods.

Type Locality: Bolton, New York.

Distribution: New York.

Illustration: Bull. N. Y. State Mus. 54: pl. L, f. 11-14.

8. Elvela californica Phill. Trans. Linn. Soc. II. 1: 423.1880.

Pileus strongly spreading, reflexed or occasionally irregularly saddle-shaped, reaching a diameter of $10 \mathrm{~cm}$., strongly inflated, the substance very thin and papery when dry; hymenium even or irregularly convoluted, light- to dark-brown; stem stout, reaching a diameter of $3 \mathrm{~cm}$. and a length of $10 \mathrm{~cm}$., deeply and irregularly lacunose, with the ribs extending out on the under side of the pileus like the ribs of an umbrella, the entire stem white or occasionally with a pinkish tint, becoming yellowish with age; asci clavate or subcylindric, reaching a length of $200 \mu$ and a diameter of $12 \mu$; spores 1 -seriate or partially 2seriate above, narrow-ellipsoid, containing two small oil-drops, 


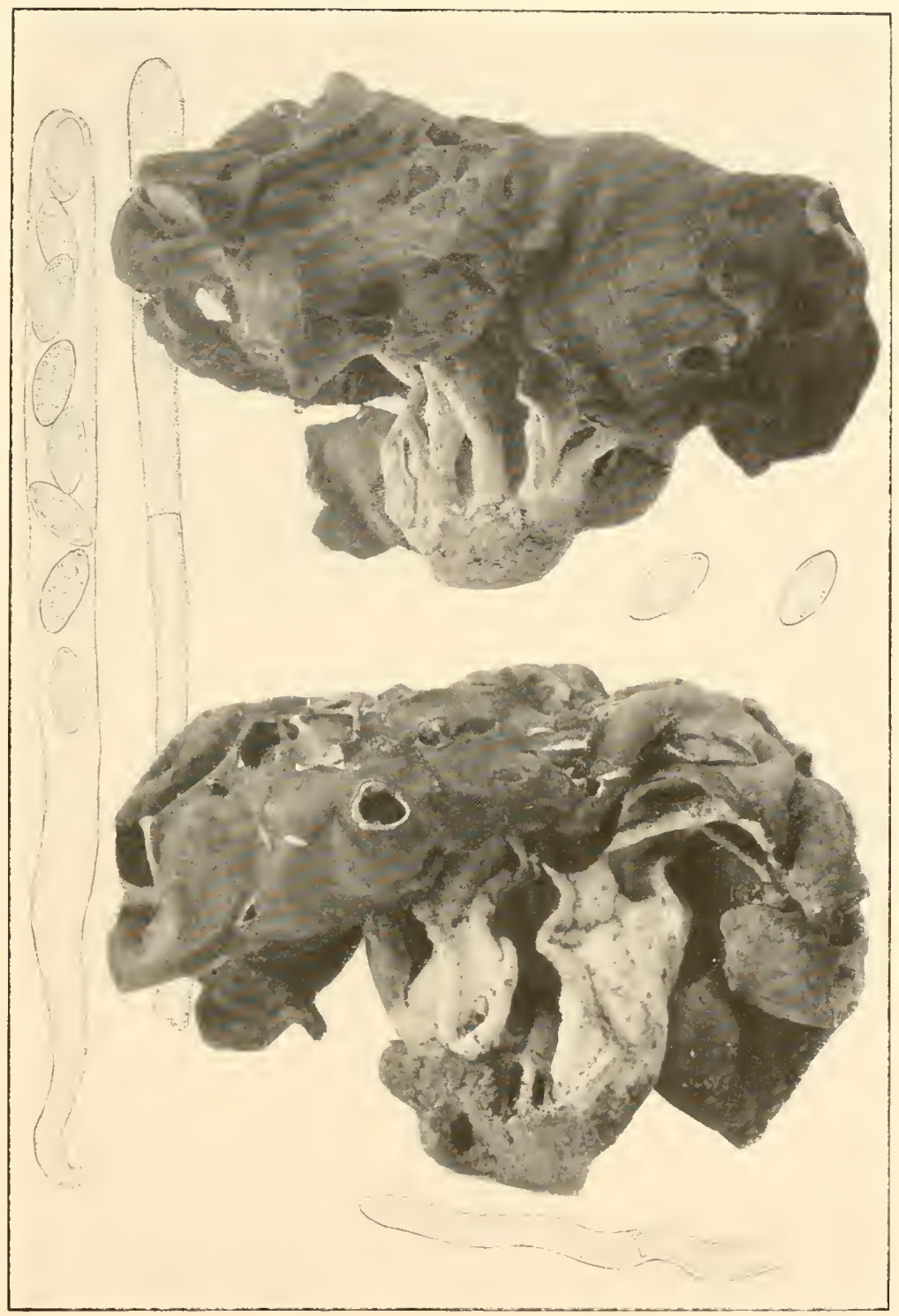

ELVELA UMBRACULIFORMIS 

about $8-9 \times 17 \mu$; paraphyses rather stout, enlarged above, reaching a diameter of $\delta \mu$ at their apices.

On soil, usually in woods.

Type locality: Sierra Nevada Mountains, California.

Distribution: California and Nevada.

Illustration: Trans. Linn. Soc. II. 1: pl. 78.

Exsiccati: N. Am. Fungi 2737.

\section{Elvela umbraculiformis Seaver, sp. nov. (Plate 41.)}

Pileus inflated and widely expanded and reflexed, the margin free or attached to the stem at various points, reaching a diameter of $10 \mathrm{~cm}$; hymenium light-brown or tan to dark-brown or brownish-black, even or irregularly undulated to convolute; stem stout, deeply and irregularly lacunose, reaching a length of 4-5 cm. and a diameter of 3-4 cm., the ribs of the stem extending out on the under side of the pileus like the ribs of an umbrella, the color white, whitish or pinkish; asci cylindric or subcylindric, reaching a length of $225 \mu$ and a diameter of $10 \mu$; spores 1-seriate, each containing two small oil-drops, ellipsoid, the ends narrowed, about $7-8 \times 16-17 \mu$; paraphyses clavate, enlarged at their apices, where they reach a diameter of $10 \mu$.

On damp soil.

Type Locality: Morgan Hill, Yosemite Park, California, elevation 7,000 feet.

Distribution: California and Idaho.

This species resembles the preceding but differs in its much shorter stem as well as in other minor points.

10. Elvela infula Schaeff. Fung. Bavar. 4: Ind. 105. 1774. (Plate 42.)

?Phallus Monacellus Scop. Fl. Carn. ed. 2, 2: 476.1772.

Elvela Mitra Schaeff. Fung. Bavar. 4: Ind. 105. 177t. Not E. Mitra L.

Elvela brunnea L. Syst. Nat. 1450. 1796.

Elvela esculenta Pers. Comm. Fung. Bavar. 64. 1800.

Elvela infula Pers. Syn. Fung. 617. 1801.

Elvela rlodopus Krombh. Abbild. 3: 23. 1834.

Gyromitra esculenta Fries, Summa Veg. Scand. 346. 1849.

Gyromitra infula Quél. Ench. Fung. 272. 1886.

Gyromitra esculenta crispa Peck, Ann. Rep. N. Y. State Mus. 51: 299. 1898. Physomitra infula Boud. Hist. Class. Discom. Eu. 35. 1907.

Physomitra esculenta Boud. Hist. Class. Discom. Eu. 35. 1907.

Pileus reaching a diameter of 6-8 cm., reflexed and more or less adnate to the stem, very irregular, mitrate, saddle-shaped or 
occasionally subglobose, even or variously contorted or convoluted, the color varying from reddish-brown to dark-brown and occasionally almost black; stem reaching a length of $6-8 \mathrm{~cm}$. and a diameter of 5-15 mm., even or more or less lacunose, never strongly fluted, the color varying from whitish to yellowish or occasionally with a pinkish tint; asci cylindric or subcylindric, reaching a length of $200 \mu$ and a diameter of 12-14 $\mu, 8$-spored; spores 1 -seriate or partially 2 -seriate, rather narrow-ellipsoid, containing two oil-drops, about $8-12 \times 18-24 \mu$; paraphyses strongly enlarged at their apices, reaching a diameter of $10 \mu$.

On the ground or occasionally on rotten wood, usually summer and autumn.

TYPE locality : Europe.

Distribution: Maine to British Columbia and California; also in Europe.

Illustrations: Schaeff. Fung. Bavar. 4: pl. 159, 161; Rab. Krypt.-F1. 13 : 1174, f. 1-3; Boud. Ic. Myc. pl. 223, 224; Pers. Champ. Comest. pl. 4; Cooke, Hand. Brit. Fungi 2: 657, f. 322; Cooke, Mycographia pl. $89, f .328$ and pl.90,f. 330; Gill. Champ. Fr. Discom. pl. 19; Massee, Brit. Fungus-Fl. 4: 188, f. 14; Phill. Brit. Discom. pl. 1,f. 2; E. \& P. Nat. Pfl. $1^{1}: 168, f$. 1+1, B; Fries, Sv. Aetl. Svamp. pl. 82 and 83; Krombh. Abbild. pl. 20, f. 6-12 and pl. 21, f. 12-17; Minn. Bot. Studies 3: pl. 49, f. 1-3.

Exsiccati: N. Am. Fungi 1267; Clements, Crypt. Form. Colo. 141 .

The writer regards Gyromitra esculenta as only a gyrose form of Elvela infula, although there may be some difference of opinion on this point.

\section{Elvela brevissima Peck, Bull. Torrey Clul, 30: 100. 1903.}

Pileus irregularly undulated or convolute, with the margin reflexed and usually free, whitish or pallid beneath, reaching a diameter of 1-2 cm.; hymenium dark-brown, becoming blackish when dry; stem very short and rather stout, even, solid, whitish or pallid, reaching a length of $1-1.5 \mathrm{~cm}$. and a diameter of 3-4 $\mathrm{mm}$.; asci cylindric or subcylindric, 8-spored; spores 1-seriate, ellipsoid, usually containing two small oil-drops, about 10-12 $\times 15-20 \mu$; paraphyses slender, enlarged above and colored.

On the ground.

Type locality: California.

Distribution: Known only from the type locality. 


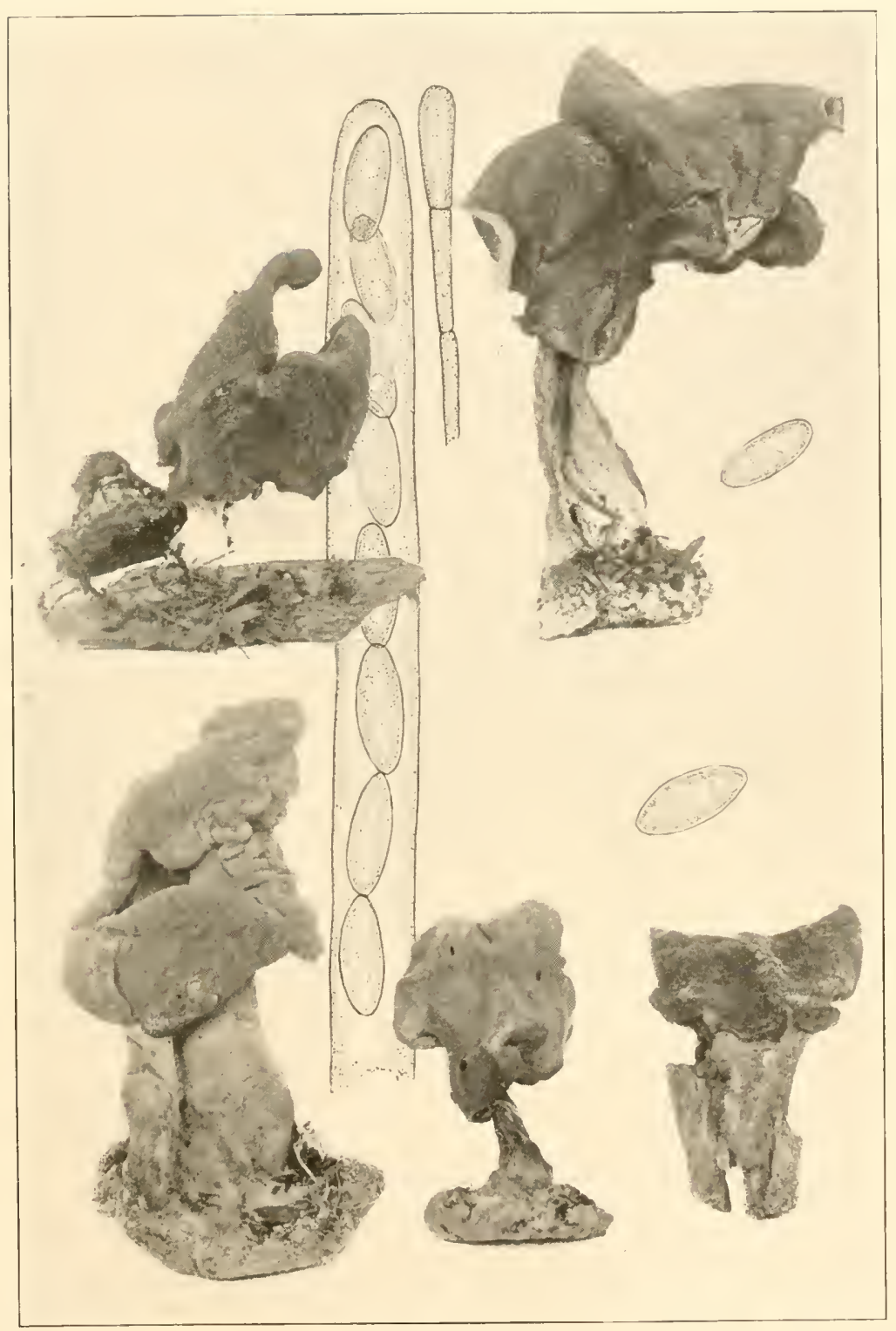

ELVELA INFULA 

12. Elvela albipes Fuckel, Symb. Myc. 334. 1869.

Elvela Hegani Copeland, Ann. Myc. 2: 510. 1904.

Pileus lobate, deflexed, the lobes subreniform, reaching a diameter of $2 \mathrm{~cm}$. or more, whitish or yellowish outside; hymenium brown, becoming blackish with age; stem white or whitish, subpubescent, even or scarcely lacunose, reaching a diameter of $1 \mathrm{~cm}$. and a length of $3-4 \mathrm{~cm}$.; asci cylindric or subcylindric, reaching a length of $300 \mu$ and a diameter of 16-18 $\mu$; spores 1 -seriate, ellipsoid, each containing one large oil-drop, 12-14 $\times 20-22 \mu$; paraphyses enlarged above, where they reach a diameter of $7-8 \mu$, yellowish.

On damp soil.

Type locality: Europe.

Distribution: California and Idaho; also in Europe.

Illustrations: Fuckel, Symb. Myc. pl. 5, f. 2; Boud. Ic. Myc. pl. 231; Ann. Myc. 3: pl. 12, f. \&, 9.

\section{Elvela caroliniana (Bosc) Nees, Syst. Pilze 176. 1817.}

Morchella caroliniana Bosc Ges. Nat. Freunde Berlin Mag. 5: 86. 1811.

?Elvela costata Schw. Schr. Nat. Ges. Leipzig 1: 114. 1822.

Elvela Gigas Krombh. Abbild. 3: 28. 1834.

Mitrophora caroliniana Lév. Ann. Sci. Nat. III. 5: 250. 1846.

Gyromitra curtipes Fries, Sv. Aetl. Svamp. 34. 1861.

Gyromitra caroliniana Fries, Ofv. Sv. Yet.-Akad. Förh. 28: 173. 1871.

Gyromitra Gigas Cooke, Mycographia 191. 1878.

Pileus irregularly lobed and plicate and in places more or less gyrose, the ridges often anastomosing and giving to the surface a reticulate appearance, whitish underneath, the margin adhering to the stem in various places, reaching a diameter of 5-12 cm.; hymenium brown to brownish-black; stem rather short and stout, more or less enlarged at the base, reaching a diameter of $2-5 \mathrm{~cm}$. and a length of $8-10 \mathrm{~cm}$., rather deeply lacunose, the color white or whitish; asci clavate or subcylindric; spores 1-seriate, narrow-ellipsoid and often apiculate, usually containing one large oil-drop and often two smaller ones, at first smooth, becoming sculptured; spore-sculpturing assuming the form of minute warts or occasionally reticulations; paraphyses thickened above and colored.

On the ground.

Type Locality: Carolina.

Distribution: West Virginia to Colorado; also in Europe. 
Illustrations: Krombh. Abbild. pl. 20, f. 1-5; Boud. Ic. Myc. pl. 221; Hard, Mush.f. 419 and (? f. 418 as G. esculenta); Ges. Nat. Freunde Berlin Mag. 5: pl. 5,f. 6; Cooke, Mycographia pl. $90, f .330$.

\section{Elvela Underwoodii Seaver, nom. nov. (PLATE 43.)}

Gyromitra brunnea Underw. Proc. Ind. Acad. Sci. 1893: 33. 1894.

Pileus much contorted, irregularly lobed and plicate, in places faintly marked into areas by indistinct anastomosing ridges, adhering to the stem at various points, whitish underneath, reaching a diameter of $5-12 \mathrm{~cm}$. in the widest point; hymenium chocolate-brown (lighter when covered by leaves); stem reaching a length of $8-13 \mathrm{~cm}$. and a diameter of $2-5 \mathrm{~cm}$., rarely slightly lacunose, hollow or loosely stuffed, white; asci cylindric or subcylindric; spores ellipsoid, $14 \times 28-30 \mu$, usually containing two rather large oil-drops, becoming sculptured; spore-sculpturing consisting of small warts or faint reticulations; paraphyses slender, enlarged above.

In rich woods on leaf-mould.

Týpe Locality: Putnam County, Indiana.

Distribution: Indiana and Ohio.

Illustration: Hard, Mush. f. 419.

The name assigned by Underwood is untenable in this genus since the Elvela brunnea was used by Linnaeus for an entirely different species. The name Eliela Underwoodii is therefore adopted.

15. Elvela sphaerospora Peck, Ann. Rep. N. Y. State Mus. 27: 106. 1875.

Gyromitra sphaerospora Sacc. Syll. Fung. 8: 16. 1889.

Pileus rather widely spreading, the margin quite evenly reflexed and usually free from the stem, whitish underneath and slightly tomentose, reaching a diameter of $6-8 \mathrm{~cm}$.; hymenium nearly even or slightly undulated, the color varying from brown to brownish-black; stem stout, reaching a diameter of $2-3 \mathrm{~cm}$. and a length of $4-8 \mathrm{~cm}$., whitish or slightly pinkish, deeply lacunose or fluted, the ribs extending up underneath the pileus like the ribs of an umbrella; asci cylindric or subcylindric, reaching a length of $150 \mu$ and a diameter of $10-12 \mu$; spores 1 -seriate, globose, reaching a diameter of $10 \mu$; paraphyses slightly enlarged above, where they reach a diameter of $4 \mu$. 


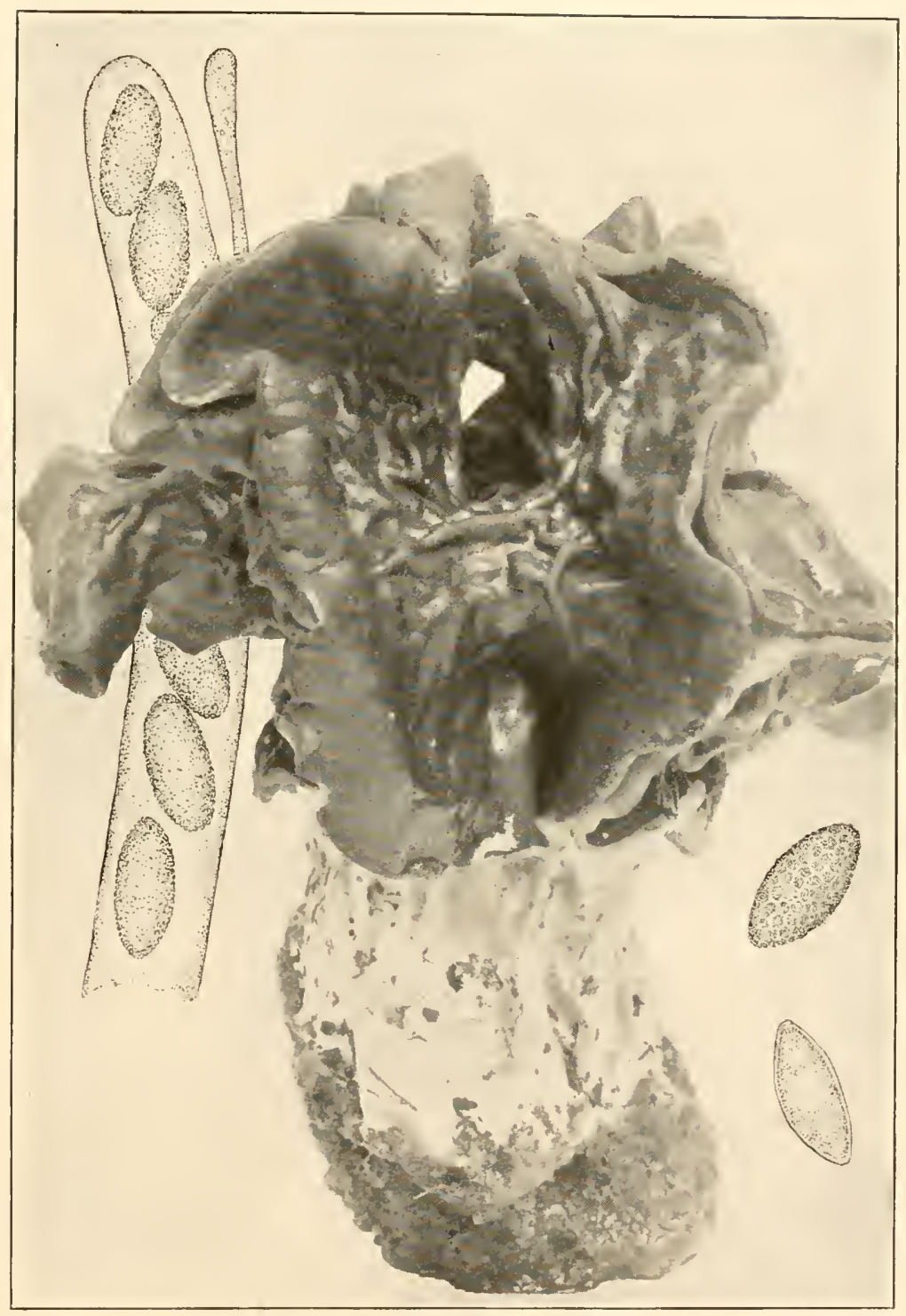

ELVELA UNDERWOODII 

On old stumps in woods.

Type locality: Indian Lake, New York.

Distribution: Vermont to Wisconsin and Manitoba.

Illustration: Ann. Rep. N. Y. State Mus. 51: pl. B, $f$. $21-25$.

\section{Doubtful Species}

Elvela pileata Clements, Bull. Torrey Club 30:94. 1903. The description of this species suggests that it may be a Terpa. No specimen has been seen.

5. UNDERWOODIA Peck, Ann. Rep. N. Y. State Mus. $43: 32.1890$.

Pileus fleshy, more or less elongated or columnar, entirely covering the stem; hymenium covering the entire outer surface of the pileus, even or undulated; stem externally lacunose or fluted, internally containing several longitudinal cavities; asci cylindric above, 8-spored; paraphyses slender below, clavate above.

Type species, Underwoodia columnaris Peck.

1. Underwoodia columnaris Peck, Ann. Rep. N. Y. State Mus. 43: 32. 1890. (PLATE 44.)

Pileus clavate, columnar, or slightly tapering above, straight or curved and often horn-shaped, entirely overspreading the stem; hymenium at first light-colored, becoming brownish, the entire fruiting body like the stem of an Elvela entirely overspread and surrounded by the pileus, reaching a height of $10 \mathrm{~cm}$. and a diameter of 2-3 cm.; asci reaching a length of $350 \mu$ and a diameter of $20 \mu$, tapering below into a stem-like base with an abrupt enlargement at the extreme base; spores 1-seriate or occasionally crowded, ellipsoid, at first smooth, becoming sculptured, $12-14 \times 25-27 \mu$; spore-sculpturing taking the form of rather coarse warts or small tubercles; paraphyses rather strongly thickened above, brownish.

On soil among leaves.

Tyé Locality: Kirkville, New York.

Distributiox: New York to Michigan and Manitoba.

Illustration: Ann. Rep. N. Y. State Mus. 43: pl. 4, $f, 1-4$.

Since this manuscript was submitted to the printers, excellent specimens of Underwoodia columnaris and Elvela sphaerospora have been received from (r. R. Bisby of Winnipeg, Manitoba. 
These additional specimens have materially extended the range of the species northward.

\section{Excluded Gexus}

Spragueola Massee, Jour. Bot. 34: 149. 1896. This genus was founded by Massee on Spragueola americana, which according to Durand is Mitrula irregularis (Peck) Durand, a species which becomes irregularly distorted as indicated by its name.

\section{BIBLIOGRAPHICAL NOTE}

Since most of the citations in this work are familiar to mycologists, it hardly seems necessary at this time to append a complete bibliography. If a second volume is eventually published on the Inoperculates, it would be much more fitting that the bibliography, if one is thought necessary, should appear at that time. 


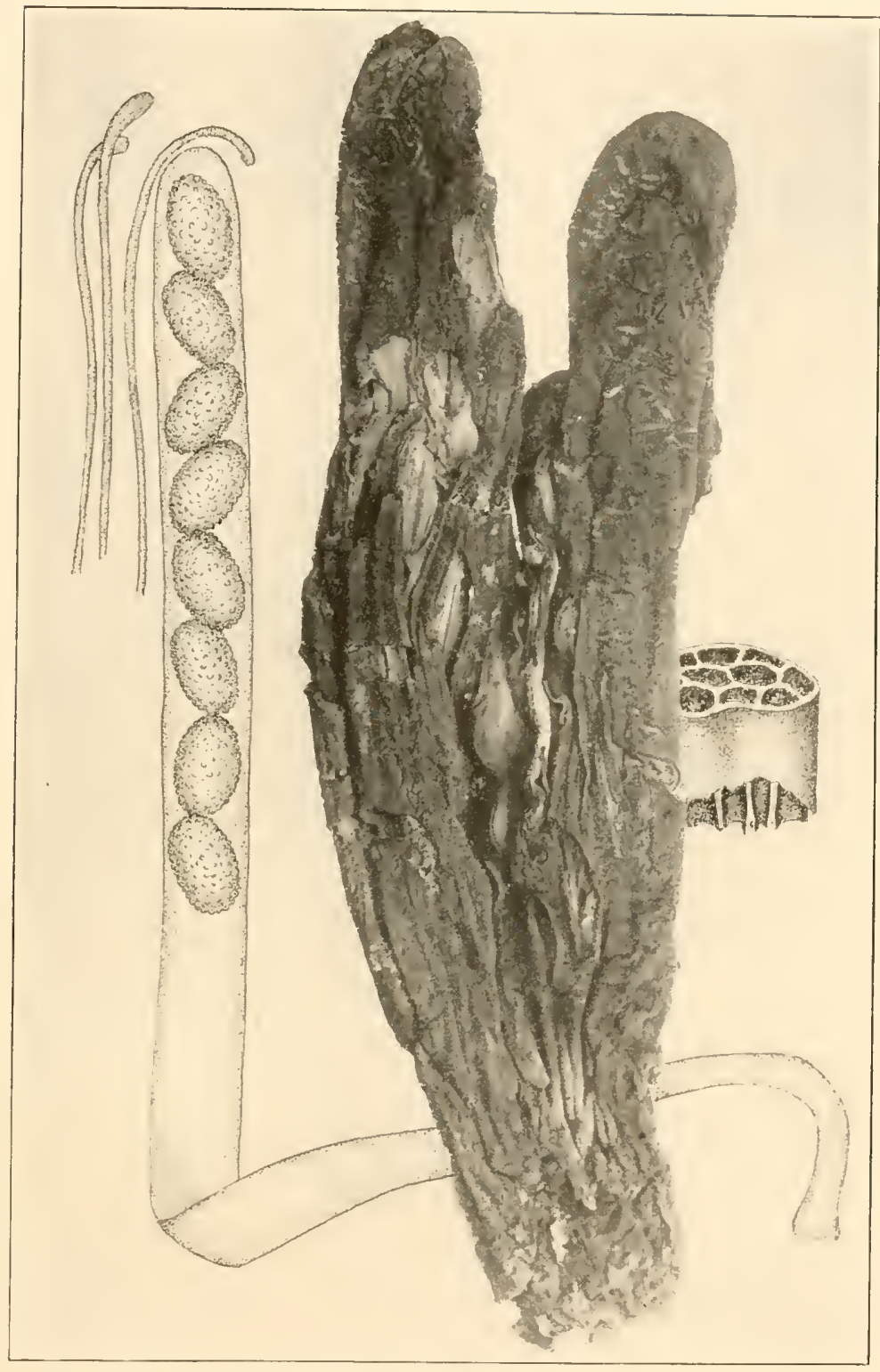

UNDERWOODIA COLUMNARIS 



\section{EXPLANATION OF PLATES}

The plates accompanying this work consist of colored drawings made from living plants, photographs, and drawings of spores and other microscopic characters. All spore drawings are made with the aid of the camera lucida and are drawn to a common scale. The reduction is also approximately equal so that the proportionate sizes are kept throughout. Other microscopic characters such as the hairs from the apothecia are also drawn with the aid of the camera lucida but occasionally it became necessary to use a lower magnification. If desired, the exact magnification can be determined by comparing reproductions with sizes indicated in descriptions. An especial effort has been made to keep drawings of spores approximately proportionate throughout the work.

Since the plates are distributed through the body of the work, instead of being bunched at the end, as a matter of convenience the page opposite which the plate appears is placed in parenthesis directly after the plate number.

In order to save space and bring the various characters together, a combination of photographs and drawings has been used. Where not otherwise indicated, the photographs of a pothecia and ascophores are approximately natural size, although they may not indicate the maximum size which the apothecia may attain.

\section{FroNTISPIECE}

Phillipsia Chardoniana. Vertical view of two plants showing the expanded apothecia, about natural size. Drawn and colored from life by Mr. Mario Brau of the Department of Agriculture of Porto Rico and the plate furnished by the courtesy of that Department.

\section{Plate I (p. 48)}

Upper figure (1). Psendoplectania vogesiaca. Three apothecia, about natural size. Also drawing of a portion of an ascus with spores; one of the branching and hooked paraphyses; and a portion of one of the hairs from the outside of the apothecium.

Lower Figure (2). Psendoplectania nigrella. Sereral apothecia, about natural size, showing the habitat among Sphagnum moss. At the left, drawing of a portion of an ascus with spores and a paraphysis. Below, two of the coiled and twisted hairs from the outside of the apothecia.

$$
\text { Plate } 2 \text { (p. 52) }
$$

Figure 1. Boudiera areolata. Portion of an ascus with spores and a tip) of one of the much thickened paraphyses. Drawn with the aid of the camera lucida from material collected in Maine by Dr. Roland Thaxter and compared with authentic material collected in Europe. The spores are marked with long spines or interrupted reticulations.

Figure 2. Boudiera echinulata. Drawn from material collected in lowa and originally described as Sphaerosoma echinulatum by the author. 
Spores scarcely differ from those of the preceding except that they are slightly larger.

Figure 3. Sphaerosoma fuscescens. A portion of an ascus with spores, showing the definite reticulations in contrast with the indefinite reticulations of the two preceding.

$$
\text { Plate } 3 \text { (p. 64) }
$$

Drawings of a portion of the ascus and spores of various species of Lamprospora: 1, L. Crec'hqueraultii; 2, L. Crouani; 3, L. areolata; 4, L. spinulosa; 5, L. tuberculatella; 6, L. tuberculata; 7, L. ascoboloides; 8, L. annulata; 9, L. Wrightii; 10, L. lobata.

\section{Plate 4 (p. 78)}

UpPer figure (1). Pithya Cupressi. Photographs of a large number of apothecia on the twigs of Bermuda cedar, Juniperus bermudiana, collected in Bermuda by the writer. Also drawing of a portion of an ascus with spores, and the tips of two of the slender paraphyses. Lower right-hand corner, the end of an ascus showing the operculum.

Central figure (2). Pithya lacunosa. Photograph of the type collected in Newfoundland by Waghorne. Also drawing of a portion of the ascus with spores, and a tip of a paraphysis.

Lower Figure (3). Pithya pithya. Photographs of several apothecia on some fir. Also drawing of a portion of an ascus with spores, and a tip of a paraphysis.

\section{Plate 5 (p. 80)}

Figures 1-5. Ascodesmis microscopica. 1, cluster of immature asci and paraphyses; 2, asci and paraphyses with spores, in various stages of maturity; 3 , ascus with immature spores; 4 , ascus with mature spores; 5 , mature spores removed from the ascus, showing the regular character of the reticulations.

Figures 6-9. Ascodesmis porcina. 6, cluster of asci and paraphyses in various stages of development; 7 , isolated ascus with immature spores; 8 , ascus with mature spores and a tip of one of the paraphyses; 9 , mature spores removed from ascus, showing character of the sculpturing.

\section{Plite 6 (p. 86)}

Ascobolus magnificus. Photographs of a large number of apothecia in various stages of development, the photographs made by Dr. B. O. Dodge, the author of the species. Above, a drawing of a portion of an ascus with several spores, showing the characteristic marking.

\section{Plate 7 (p. 90)}

Drawings of the asci and spores of various species of Ascobolus: $1, A$. viridis. Drawing of a portion of an ascus with spores for comparison with A. geophilus, the American form with which it has been confused; $2, A$. geophilus. Drawing of a portion of an ascus with a part of the spores undeveloped; also isolated spores in various stages of development; $3, A$. subglobosus. Drawing of a portion of an ascus with spores and several isolated 
spores in various stages of development; 4 , A. carbonarizs. Drawing of a portion of an ascus with isolated spores; 5 , A. immersus. Drawing of an ascus with spores.

\section{PL.1TE 8 (P. 98)}

UPPER Figure (1). Aleuria aurantia. Photograph of a number of apothecia, about natural size. At the right, a drawing of an ascus with mature spores showing reticulate markings and a paraphysis with rather strongly enlarged tip. Below, two immature spores.

Lower figure (2). Aleurina atrovinosa. Photograph of a cluster of apothecia, about natural size. At the left, a drawing of an ascus with mature spores showing irregular reticulations and a paraphys with enlarged tip. Above, two immature spores.

$$
\text { Plate } 9 \text { (p. 102) }
$$

UPPER FIGLRE (1). Aleuria rutilans. Photograph of several apothecia at different stages in their development and showing habitat among mosses. Above, drawing of a mature and an immature spere, the former showing the regular and fine reticulate markings.

Lower figtre (2). Aleuria rhenana. Photograph of several apothecia showing habitat in coniferous woods and dense mycelial growth which binds the substratum together. Above at the right, a mature and an immature spore, the former showing the typical reticulate markings.

\section{Pl.tTE 10 (p. 110)}

Pyronema omphalodes. Photograph of a mass of mycelium and apothecia, showing the natural habitat on charcoal (a). Upper right-hand corner, a germinating ascospore showing the very coarse mycelium (c). Lower righthand corner, cluster of öigonia with trichogynes (d). Lower left-hand corner, antheridium and oögonium with the connecting trichogyne (e). Upper lefthand corner, an ascus with spores and a paraphysis (b).

\section{PLATE 11 (p. 120)}

Drawings of asci and spores of various species of 1 scophanus: 1,1 . lacteus; 2, A. bermudiensis; 3, A. minutissimus (later referred to A. microsporus?); 4, A. sarcobius; 5 , A. argentius; 6, A. glumarum = IIumarinu glumarum; 7, A. Aurora; 8, A. Holmskjoldii; 9, A. microsporus with paraphysis showing enlarged tip; 10, A.granuliformis; 11 , A. cinereus; 12, A. granulatus; 13, A. isabellinus.

Plate 12 (p. 144)

Drawings of asci and spores of various species: 1, Ryparobius sexdecimsporus; 2-3, Streptotheca woolhopensis, the latter showing the method of dehiscence of the ascus; 4, Streptotheca obscura; 5, Ryparobius polysporus; 6, Ryparobius monascus; 7, Thecotheus Pelletieri, showing the large size of the asci and spores. 
Plate 13 (p. 150)

Sepultaria Longii. Upper figure, a vertical view of a cluster of apothecia which make their appearance as a series of holes in the surface of the ground. Lower figure, a section through such a cluster, giving some idea of the subterranean habits of the species. At the left, a drawing of an ascus with spores and a paraphysis. In the center, a portion of the mycelium which clothes the outside of the apothecia and binds the soil together.

\section{Plite 14 (p. 160)}

Upper figure (1). Photograph of several apothecia of Patella albida, made by Dr. F. E. Clements under the name of Lachnea chaetoloma. Upper right-hand corner, sketch of a section through one of the apothecia, showing gencral form of cup, also drawings of hairs from outside of apothecia. Lower left-hand corner, drawing of an ascus with spores.

Lower Figure (2). Patella scutellata. Several apothecia on the bark of a dead stump. Above, a sketch of a section through an apothecium. Right, a drawing of a hair from outside of apothecium. Lefc, a drawing of an ascus with spores and a paraphysis with its enlarged tip.

$$
\text { PLATE } 15 \text { (p. 176) }
$$

UPPer figure (1). Patella gregaria. Photograph of group of apothecia, showing natural habitat under pine trees. Right, drawings of hairs from outside of apothecia. Left, drawing of a portion of an ascus with spores and a paraphysis.

Lower figure (2). Patella melaloma. Photograph of a group of apothecia, showing natural habitat on charcoal. Right, drawing of portion of an ascus with spores and a paraphysis. Left, cluster of club-shaped hairs from outside of apothecia.

\section{Plate 16 (p. 180)}

Wynnea americana. Photograph of a sclerotium with a branched apothecium. Right, drawing of a portion of an ascus with spores, showing the longitudinal striations. Left, an isolated spore showing its unequal-sided character. Above, sketch of the end of an ascus, showing the eccentricity of the ascostome.

\section{Plate 17 (p. 184)}

Upper figure (1). Phillipsia gigantea. Three apothecia photographed from dried specimens but about natural size. Also drawing of a portion of an ascus with spores and a paraphysis.

Central figure (2). Phillipsia domingensis. Several apothecia on a dead stick. Spores apparently identical with those of the preceding.

Lower figure (3). Cookeina Colensoi. Photograph of a number of apothecia on moss-covered bark, made from dried specimens, which, however, shrink little in drying. Left, drawing of a portion of an ascus with spores, showing characteristic striations. Also the tip of a paraphysis. 


\section{PLATE 18 (p. 188)}

UPPER FIGLRE (1). Cookeina sulcipes. Photograph of several apothecia on dead wood, showing variation in the length of the stem, from dried specimens which shrink little in drying. Right, drawing of a portion of an ascus with spores, showing characteristic striations. Also empty ascus showing eccentric position of ascostome and operculum and the abrupt tail-like stem at the base of the ascus. Near the center, a drawing of one of the fasciculate hairs to be found about the margin of the cup.

Lower FIGURE (2). Cookeina Tricholoma. Photograph of a cluster of apothecia on moss-covered bark, made from dried specimens which shrink little in drying. Near the left, a cluster of apothecia showing the variation in the length of the stem; also the conspicuous hairs which clothe the outside of the cup. Left, a drawing of a portion of an ascus with spores, showing characteristic striations. Right, drawing of tip of one of the long fasciculate hairs from the outside of the apothecium.

\section{Plate 19 (p. 190)}

Upper figure (1). Plectania coccinea. Photograph of two apothecia growing from a partially buried stick. Photograph by C. G. Lloyd. Left, drawing of a portion of an ascus with spores. Upper right-hand corner, drawing of hairs from the outside of the apothecium.

Lower figure (2). Plectania hiemalis. Photograph of two apothecia, showing long stems and crenate margins. Photograph by C. G. Lloyd. Lower right-hand corner, drawing of a portion of an ascus with spores. Upper left-hand corner, tip of ascus showing the eccentricity of the ascostome and operculum. Near the center, two hairs from outside of the apothecium.

$$
\text { Plate } 20 \text { (p. 192) }
$$

Upper figure (1). Plectania floccosa. Cluster of apothecia, showing long stems and densely hairy exteriors. Also a drawing of a portion of an ascus with spores and the tip of one of the very long hairs from the outside of the apothecium.

Lower figure (2). Plectania occidentulis. Photographs of several apothecia from dead sticks, showing the variation in the length of the stems and the comparatively smooth exterior of the apothecia. Near the center, drawing of a portion of an ascus with spores and a slender paraphysis. Lower righthand corner, drawing of hairs from exterior of cups.

\section{Plate 21 (p. 198)}

Urnula Craterium. Phoiograph of a cluster of apothecia from a partially buried stick, with their notched margins. Photograph by C. G. Lloyd. Right, drawing of a portion of an ascus with spores and tips of two paraphyses. Upper left-hand corner, drawing of a portion of hair from exterior of cup. Below, three isolated spores.

$$
\text { Plate } 22 \text { (p. 200) }
$$

Urnula Geaster. Photographs of several apothecia in different stages of development, showing the Geaster-like method of dehiscence of the apothecia. 
Near the center, drawing of a portion of an ascus with spores. Lower lefthand corner, one spore isolated. Photograph by Dr. W. H. Long.

\section{Plite 23 (p. 202)}

Paxina Acctabulum. Upper figure, photograph of an isolated apothecium, showing the vein-like markings on the outside of the cup. Also drawing of an ascus with spores and the tip of a paraphysis. Lower figure, two apothecia showing habitat. Lower figure from photograph by Dr. F. E. Clements.

\section{Plate 24 (p. 204)}

Upper figure (1). Paxina hispida. Photograph of several apothecia, showing long stems. Left, drawing of an ascus with spores and a paraphysis with its enlarged tip. Right, two spores isolated.

Lower figure (2). Paxina sulcata. Photograph of apothecium, showing thick, corrugated stem. Lower right-hand corner, drawing of an ascus with spores and the tip of a paraphysis. Left, two spores isolated.

$$
\text { Plate } 25 \text { (p. 210) }
$$

UpPer figure (1). Paxina fusicarpa. Photograph of a cluster of apothecia, showing habitat on the ground. Left, drawing of a portion of an ascus with spores and the tip of a paraphysis. Right, drawing of a hair from outside of apothecium; also one spore isolated.

Lower figure (2). Paxina semitosta. Photograph of a cluster of apothecia, showing comparatively large cups with short, thick, furrowed stems. Right, drawing of a portion of an ascus with spores; also the tip of a paraphysis. Left, drawings of portions of hairs from outside of cups.

$$
\text { Plate } 26 \text { (p. 212) }
$$

UPPER figure (1). Geopyxis cupularis. Photograph of several apothecia. Photograph by W. R. Fisher. Left, drawing of ascus with spores; also tip of paraphysis.

Lower figure (2). Peziza domiciliana. Photograph of several apothecia in different stages of development, showing the short, stem-like base in young specimens. Left, drawing of a portion of an ascus with spores; also tip of a paraphysis.

\section{Plate 27 (p. 216)}

Rhizina inflata. Upper figure, photograph of a section through one of the apothecia, showing expanded hymenium and root-like attachment. Lower figure, vertical views of apothecia. Photographs by Dr. J. R. Weir. Left, drawing of a portion of an ascus with spores; also tips of paraphyses. Center, drawing of one of hairs from hymenium. Right, two spores, showing apiculate ends.

Plate 28 (p. 218)

Upper figure (1). Discina convoluta. Photograph of type specimen, showing two apothecia with their convoluted hymenia. Right, drawing of a 
portion of an ascus with spores; also the tip of a paraphysis. Left, drawing of one spore isolated, showing peculiar truncate ends.

Lower figure (2). Discina ancilis. Photographs of two apothecia with side and vertical view. Photographs by Dr. J. R. Weir. Center, drawing of a portion of an ascus with spores; also the tip of a paraphysis.

Plite 29 (p. 224)

Upper figure (1). Peziza pustulata. Photograph of group of apothecia, showing habitat on charcoal. Left, drawing of an ascus with spores; also the tip of a paraphysis.

Lower figure (2). Peziza zesiculosa. Photograph of a cluster of apothecia. Right, drawing of a portion of an ascus with spores.

Plite 30 (p. 226)

IPPer figure (1). Peziza proteana. Photograph of several apothecia, showing habitat on old burnt place which has been subsequently overrun with mosses. Right, drawing of a portion of an ascus with spores; also tip of a paraphysis.

Lower figure (2). Peziza violacea. Photograph of several apothecia, showing habitat on charcoal. Left, drawing of a portion of an ascus with spores; also tips of paraphyses. Note similarity in size and markings of the spores of this and the preceding.

Plate 31 (p. 228)

Peziza venosa. Upper figure, an expanded apothecium, showing the veinlike folds characteristic of the hymenium. Lower figure, a younger specimen in which the veins are not apparent. Left, drawing of a portion of an ascus with spores; also a paraphysis. Right, an isolated spore.

\section{Plate 32 (p. 230)}

Peziza repanda. Photographs of a number of apothecia in different stages of development, on rotten wood which has been partially overrun with mosses. Left, drawing of a portion of an ascus with spores; also tip of a paraphysis. Center, drawing of tip of an ascus, showing operculum.

\section{Plate 33 (p. 232)}

Peziza syluestris. Photographs of a number of apothecia in different stages of development, and about natural size, athough they are often much larger. Right, drawing of an ascus with spores; also tip of paraphysis. Center, drawing of two spores isolated.

\section{PLATE 34 (p. 234)}

Peziza clypeata. Photographs of a number of apothecia at different stages of development, from a rotten $\log$ which was partially overgrown with mosses. Right, drawing of a portion of an ascus with spores; also tip of one of the stout paraphyses. Left, drawing of one spore isolated. Note the unusually large size of the spores of this species. 
Plate 35 (p. 238)

Morchella crassipes. Photograph of two ascophores, showing the enlarged bases and rather thin, almost sharp ribs. Lower right-hand corner, a germinating spore. Near center, drawing of an ascus with spores; also a part of one of the stout paraphyses.

Plate 36 (p. 240)

UPPER Figure (1). Morchella hybrida. Photograph of three ascophores of different ages. The stems elongate much as the plants mature. Near center, drawing of a portion of an ascus with spores and an isolated spore.

Lower figure (2). Morchella esculenta. Photograph of two ascophores, one bent over. Upper left-hand corner, drawing of a portion of an ascus with spores; also the tip of one of the stout paraphyses and an isolated spore.

\section{Plate 37 (p. 242)}

Durandiomyces Plillipsii. Photograph of the ascophore which appears like a compound apothecium. Photograph obtained from the late Dr. E. J. Durand. Right, drawing of an ascus with spores; also a paraphysis. Note the similarity of the spores to those of Peziza proteana and Peziza violacea (PLATE 29).

Plate 38 (p. 244)

UPPER figure (1). Verpa bohemica. Photograph of three ascophores from dried specimens. Near center, drawing of a portion of an ascus with spores; also tip of paraphysis and sketch of section through pileus.

Lower Figure (2). T'erpa conica. Photograph of three ascophores from fresh material. Left, drawing of portion of an ascus with spores; also tip of a paraphysis.

\section{Plate 39 (p. 246)}

UPPER figure (1). Elvela Mitra. Photograph of three ascophores from dried material. Also drawing of a portion of an ascus with spores and tip of a paraphysis.

Lower Figure (2). Elvela crispa. Photograph of several ascophores at different stages of development, from dried material. Also drawing of a portion of an ascus with spores and tip of a paraphysis.

$$
\text { Plate } 40 \text { (p. 248) }
$$

Figures 1-3. Elvela elastica. Photographs of ascophores in different stages of development. Right, drawing of an ascus with spores; also a paraphysis and an isolated spore.

Figures 4-5. Elvela elastica gigantea. Unusually large specimens of this species which might be regarded as a different form. Photographed by C. G. Lloyd.

$$
\text { Plate } 41 \text { (p. 250) }
$$

Elvela umbraculiformis. Photographs of two ascophores, showing the large pilei and the short, corrugated stems. Left, drawing of an ascus with 
spores; also a paraphysis. Right, isolated spores. Lower right-hand corner, a bit of a hair from outside of stem.

\section{Plate 42 (p. 252)}

Elvela infula. Photographs of ascophores at different stages of development and showing different degrees of gyrosity. Center, drawing of a portion of an ascus with spores; also tip of a paraphysis. Right, two isolated spores.

$$
\text { Plate } 43 \text { (p. 254) }
$$

Elvela Underwoodia. Photograph of a large ascophore by C. G. Lloyd. Left, drawing of a portion of an ascus with spores; also tip of a paraphysis. Lower right-hand corner, drawing of a mature and an immature spore, showing the faintly reticulate character of the markings.

$$
\text { Plate } 44 \text { (p. 256) }
$$

Underwoodia columnaris. Photograph of a double ascophore, consisting of a corrugated stem overspread with the hymenium; also a sketch of a section of the ascophore. Left, drawing of an ascus with spores; also tips of several paraphyses.

\section{Plate 45 (p. 266)}

1, Lamprospora haemastigma; 2-3, Lamprospora Crouani; 4, Lamprospora discoidea; 5-6, Lamprospora spinulosa; 7, Lamprospora Constellatio; 8, Lamprospora Crec'hqueraultii; 9-10, Lamprospora tuberculatella; 11-12, Patella albocincta; 13-14, Patella gregaria; 15-16, Patella ricciophila; 17, Melastiza Charteri; 18, Patella coprinaria; 19, Patella scutellata; 20, Pesiza violacea; 21, Ascobolus stercorarius; 22, Aleuria rutilans; 23, Plectania occidentalis. 



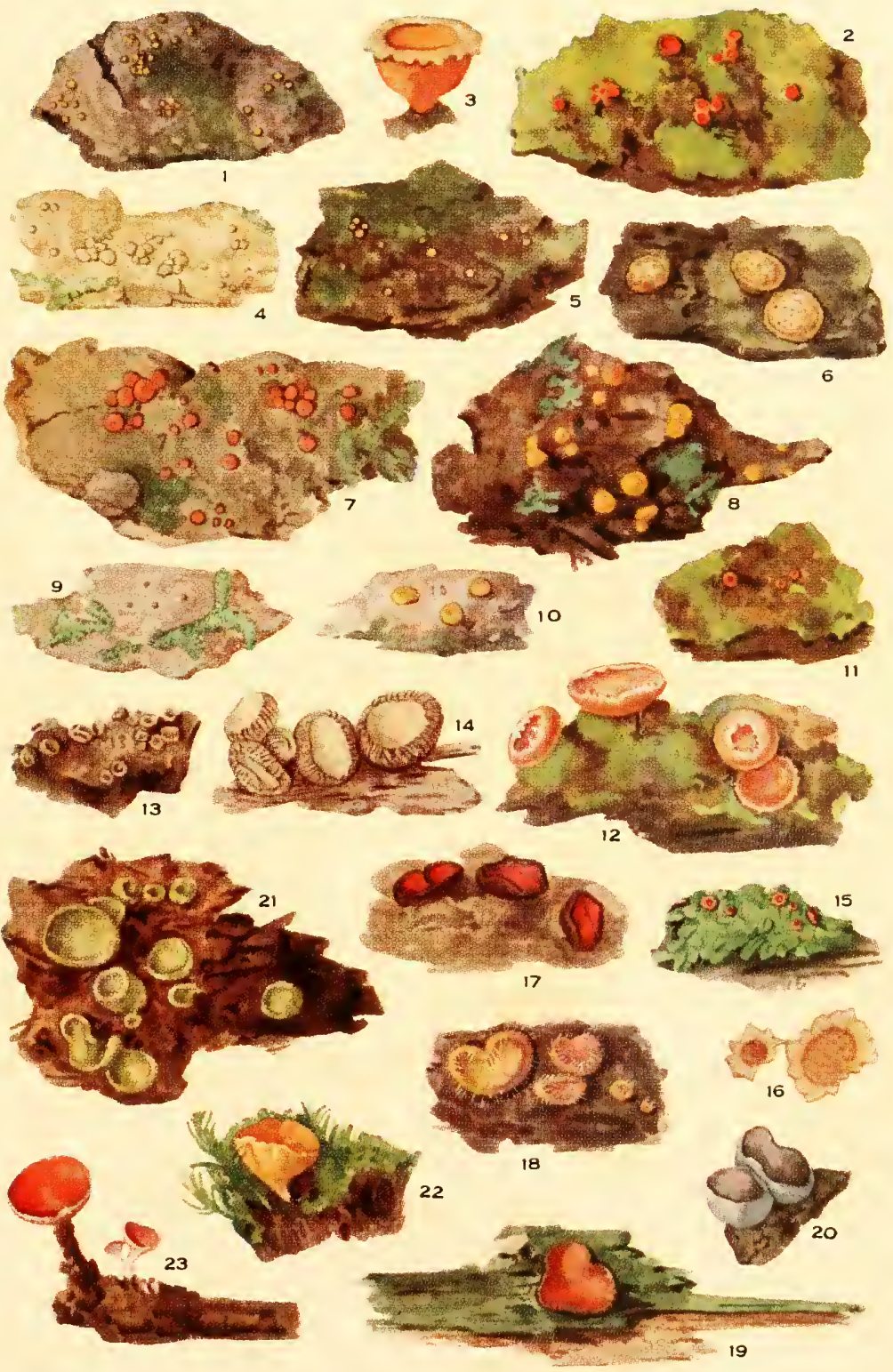





\section{INDEX TO RECOGNIZED GENERA}

Aleuria, 96

Aleurina, 101

Ascobolus, 81

Ascodesmis, 79

Ascophanus, 111

Boudiera, 51

Bulgaria, 194

Cookeina, 187

Cubonia, 80

Discina, 216

Durandiomyces, 242

Elvela, 245

Geopyxis, 211

Humarina, 121

Lamprospora, 54

Lasiobolus, 155

Melastiza, 103

Morchella, 237

Patella, 156

Paxina, 201

Perrotia, 154

Peziza, 219
Phillipsia, 182

Pithya, 76

Plectania, 190

Pseudombrophila, 141

Pseudopithyella, 153

Pseudoplectania, 47

Psilopezia, 105

Pyronema, 109

Rhizina, 215

Ryparobius, 144

Saccobolus, 92

Sarcosphaera, 235

Scodellina, 184

Sepultaria, 148

Sphaerosoma, 51

Sphaer ospora, 43

Streptotheca, 142

The otheus, 147

Underwoodia, 255

Urnula, 198

Verpa, 243

Wynnea, 180

\section{INDEX TO GENERA AND SPECIES}

Acetabula, 201

Acetabulum, 202

ancilis, 216

Barlae, 205

Calyx, 204

Dupainii, 207

leucomelas, 204

macropus, 203

olivacea, 211

radicata, 214

sulcata, 204

venosa, 229

vulgaris, 202

Aleuria, 40, 96, 101, 219

abietina, 228

Acetabulum, 202

ancilis, 216

\section{(Symonyms in italics)}

apiculata, 217

araneosa, 130

aurantia, 96-98

auricula, 185

auriflava, 62

A urora, 115

badia, 221

bicucullata, 96, 99

Boltoni, 226

brunneoatra, 222

Catinus, 213

cestrica, 96, 98

Constellatio, 69

convexula, 128

corallina, 137

Corium, 208

Cronani, 56 
cupularis, 212

Emileia, 224

eximia, 235

fulgens, 50

glumarum, 133

granulata, 116

hepatica, 139

humicola, 213

humosa, 129

ionella, 138

leiocarpa, 73

leporina, 185

leucoloma, 129

leucomelas, 204

macropus, 205

melaloma, 167

ollaris, 135

omphalodes, 109

onotica, 185

proteana, 227

proteana sparassoides, 242

pustulata, 224

repanda, 231

rhenana, 96, 99

rutilans, 96, 100

subhirsuta, 170

succosa, 223

sylvestris, 233

tetraspora, 134

trachycarpa, 71

umbrina, 224

venosa, 229

vesiculosa, 231

violacea, 226

wisconsinensis, 96, 98

Aleurina, 40, 101

aquehongensis, 101, 102

atrovinosa, 101

Lloydiana, 98

retiderma, 101

vinacea, 222

Angelina rufescens, 92

Anthopeziza, 190

IVinteri, 193

Anthracobia melaloma, 168

Ascobolus, 10, 16, 26, 40, 55, 60, 79,

$81,91,140,142$

aerugineus, 86

albinus, 81,89 americanus, 81,85

argenteus, 114

atrofuscus, 87, 92

Boudieri, 85

brunneus, 92

candidus, 81, 86

caninus, 79

carbonarius, $8,12,25,26,81,87$,

90,92

carbonicola, 87

carneus, 115

Cesatii, 121

ciliatus, 155

cinereus, 118

coccineus, 137

conglomeratus, 92

Cookei, 145

Crec'hqueraultii, 62

crenulatus, 86

Crouani, 56, 142

crustaceus, 145

cubensis, 92

depauperatus, 95

diversisporus, 155

epimyces, 82, 91

furfuraceus, 8,82

geophilus, 81, 88, 92

gigasporus, 83

glaber, $81,83,85$

granulatus, 116

granuliformis, 117

hyperborews, 79

immersus, 14, 81, 83

incanus, 112

Kerverni, 93

lacteus, 114

Leveillei, 81, 85

Leveillei americanus, 85

macrosporus, 83

magnificus, 9, 12, 81, 87

major, 92

microscopicus, 79

microsporus, 120

miniatus, 54, 56

niveus, 79,147

obscurus, 96

ochraceus, 117

papillatus, 155

Pelletieri, 148 
pezizoides, 82

pilosis, 155

polysporus, 145,146

pulcherrimus, 172

purpurascens, 92

pusillus, 92

raripilus, 173

saccharinus, 115

sexdecimsporus, 144

stercorarius, $81,82,92$

stercorarius retisporus, 82

striisporus, 82,90

subglobosus, 81,89

testaceus, 125

tetrasporus, 134

Trifolii, 92

vinosus, 85,92

viridis, $88,89,92$

viriclulus, 81, 86, 91, 92

Winteri, 81,84

woolhopensis, 143

xylophilus, 82, 90

Ascodesmis, 39, 54, 79

microscopica, 79

nigricans, 79

porcina, 25, 79, 80

reticulata, 79

Ascophanus, 16, 41, 111

argenteus, 111, 114

Aurora, 111, 115

bermudensis, 111, 113

carneus, 111, 115, 116, 126, 127

carnews difformis, 115

carneus saccharinus, 115

carneus testaceus, 125

Cesatii, 112, 121

cinerellus, 112, 120

cinereus, 111,118

Coemansii, 120

crustaceus, 118

flavus, 117

gallinaceus, 111, 118

glaucellus, 112, 121

granulatus, 111, 116, 141

granuliformis, 111,117

hepaticus, 139

Holmskjoldii, 111, 112

humosoides, 115

incumus, 112 isabellinus, 111,112

lacteus, 111, 114

lilacinus, 111, 120

microsporus, 112,120

minutissimus, 120

ochraceus, 111, 117

pallens, 124

pilosus, 155

ruber, 156

saccharinus, 115

sarcobius, 111, 113

sexdecimsporus, 144

subgranuliformis, 117

testaceus, 125

tetraonalis, 111, 119

vicinus, 111,114

Ascozonus, $1+2$

Boudieri, 142

Crouani, 142

oligoascos, 146

Barlaea, 34, 54

amethystina, 67

areolata, 52

asperella, 62

carbonaria, 67

cinnabarina, 58

Constellatio minuta, 69

convexella, 68

Crec'hqueraultii, 62

discoidea, 70

exasperata, 75

fulgens, 50

fuliginea, 76

gemmea, 70

hinmulea, 46

lacunosa, 77

laeterubra, 69

lobata, 74

miniata, 57

modesta, 62

Polytrichi, 75

schizospora, 46

verrucosa, 65

Wrightii, 66

Barlaeina, 34, 54

carbonicola, 67

Constellatio, 69

Constellatio minuta, 69)

Crec'hqueraultii, 62 
dictydiola, 58

discoidea, 70

scutellata, 159

laeterubra, 69

setosa, 166

trechispora, 44

Botrytis, 22

Boudiera, 11, 39, 51

areolata, 52, 54

canina, 79

Clanssenii, 79

echinulata, 52

marginata, 53

microscopica, 79

Bulgaria, 35, 42, 194, 198

bicolor, 233

carbonaria, 71

deligata, 107

globosa, 5, 195, 196

inquinans, 195

melastoma, 195, 197

platydiscus, 196

rufa, 195, 196

spongiosa, 48

Burcardia, 194

globosa, 195

Burckhardia globosa, 195

Caloscypha, 47

fulgens, 50

Calycina melastoma, 197

Catinella, 140

Cenangium, 198

Craterium, 199

Cheilymenia, 157

coprinaria, 171

dalmeniensis, 170

fimetaria, 170

pulcherrima, 172

stercorea, 169

subhirsuta, 170

theleboloides, 170

Chlorosplenium, 91

epimyces, 91

striispormm, 90

Chorioactis, 198

Geaster, 200

Ciboria, 214

Ciliaria, 156

asperior, 44

confusa, 46

Lusatiae, 162

paludosa, 174

umbrorum, 161

Cookeina, 17-19, 42, 187

Afzelii, 188

Colensoi, 18, 19, 187, 190

Hindsii, 188

sulcipes, 187,188

tetraspora, 187, 189

Tricholoma, 187

Coprobia, 111

grannlata, 116

Craterium microcrater, 199

Cronania, 34, 54

asperella, 62

carbonaria, 67

cinnabarina, 58

humosa, 69

miniata, 56

Cubonia, 39, 80

Curreyella, 54

foveata, 73

trachycarpa, 71

Cyathipodia, 201

Corium, 208

Dupainii, 207

longipes, 203

platypodia, 203

Dasyscypha allantospora, 154

Dermea Craterium, 199

Detonia, 34, 54

Constellatio, 69

convexella, 68

foreata, 73

fulgens, 50

laeterubra, 69

leiocarpa, 73

miniata, 57

modesta, 63

nigrans, 72

polytrichina, 75

trachycarpa, 71

Discina, 43, 216

abietina, 228

ancilis, 216

apiculata, 216, 217

clypeata, 233

convoluta, 216, 218 
helvetica, 216

leucoxantha, 216, 218

melaleuca, 225

perlata, 216

repanda, 231

reticulata, 229

trachycarpa, 71

renosa, 229

Ilarnei, 216

Disciotis, 219

renosa, 229

Durandiomyces, 236, 242

Phillipsii, 242

Elvela, 237, 245, 255

acaulis, 215

Acetabulum, 202

adhaerens, 245, 250

albida, 175

albipes, 246, 253

atra, 245,248

auricula, 185

brevissima, 246,252

brunnea, 251, 254

californica, 246, 250

capucinoides, 249

caroliniana, 246, 253

ciliata, 159

coccinea, 97, 191

cochleata, 221, 231

costata, 253

crispa, 245,247

elastica, 245, 249

ephippium, 205

equina, 155

esculenta, 251

Faulknerae, 207

fistulosa, 249

fuliginosa, 249

fusca, 247

Gigas, 253

gracilis, 249

grisea, 246

Hegani, 253

hemisphaerica, 49

hispida, 205

hybrida, 241

inflata, 215

infula, $27,28,246,251,252$

Klotzschiana, 245, 249 lacunosa, 246, 248

leucophaea, 247

lutea, 169

macropus, 205

macropus brevis, 206

Nitra, 245, 246, 251

nigra, 208

nigricans, 246, 248

nivea, 247

pallescens, 247

pallida, 247

palustris, 245,247

pileata, 255

rhodopus, 251

sphaerospora, 246, 254, 255

Sterensii, 249

sulcata, 246

umbraculiformis, 246, 251

Underwoodii, 246, 254

Fleischhakia, 105

rhizinoides, 106

Fuckelina, 201

Corium, 208

pubida, 210

Schweinitzii, 211

semitosta, 209

villosa, 206

Galactinia, 219

badia, 221

Boltoni, 226

brunneoatra, 222

ionella, 138

proteana, 227

proteana sparassoides, 242

pustulata, 224

succosa, 223

Geopyxis, 43, 211

aluticolor, 190

amplispora, 231

brachypus, 206

bronca, 212, 213

carbonaria, 212

Catinus, 212, 213

cinerascens, 214

coccinea, 191

Craterium, 199

cupularis, 212

elata, 188

floccosa, 192 
hesperidea, 193

Hicksii, 215

nebulosa, 214

nebulosoides, 214

occidentalis, 193

pallidula, 231

pulchra, 214

sordescens, 99

suburceolata, 212

verruculosa, 214

vulcanalis, 212, 214

Geoscypha Schröteri, 141

Gyromitra, 245

brunnea, 254

caroliniana, 253

curtipes, 253

esculenta, 27, 28, 251, 252

esculenta crispa, 251

Gigas, 242, 253

infula, 251

Phillipsii, 242

sphaerospora, 254

\section{Helotium}

a.xillaris, 124

flammeum, 154

Pedrottii, 141

pith yum, 76

purpuratum, 182

testacenm, 125

thijinum, 78

Helvella, 4, 245

Heteroplegma, 219

caeruleum, 225

crenatum, 228

Humaria, 121, 156

adusta, 167

aggregata, 136

alpina, 169

aquatica, 108

araneosa, 130, 151

axillaris, 124

bella, 140

bicucullata, 99

callichroa, 180

cestrica, 98

Charteri, 103

clausa, 125

coccinea, 137

convexula, 128

Cookeina, 137
Crec'hqueraultii, 62 .

cremoricolor, 117

cupressina, 78

deerrata, $1+1$

deligata, 132

depressa, 106

diversispora, 155

echinosperma, 62

fimeti, 232

flavoantrantiaca, 168

fuscocarpa, 140

fusispora, 136

gallinacea, 118

Gerardi, 138

glumarum, 133

granulata, 116

gregaria, 176

groenlandica, 140

haemastigma, 68

hemisphaerica, 175

hepatica, 139

hirtella, 180

humosa, 129

hydrophila, 106

ionella, 138

ithacaensis, 124

lacteocinerea, 234

lechithina, 108

leucoloma, 129

macrospora, 222

macrocystis, 167

melaloma, 167

melalomoides, 167

microspora, 141

miniata, 103

muralis, 137

ochroleuca, 131

olivatra, 140

ollaris, 135

omphalodes, 109

Oocardii, 108

orthotricha, 127

Peckii, 133

permuda, 134

Persoonii antethystina, 67

phycophila, 127

phyllogena, 134

pityina, 76

pulcherrima, 172 
rhodoleuca, 163

rubens, 127

rubricosa, 131

rutilans, 100

salmonicolor, 140

scatigena, 140

Schröteri, 141

scutellata, 159

secreta, 140

semiimmersa, 130

setosa, 166

silvosa, 134

spissa, 222

stercorea, 169

subcrenulata, 140

subgranulata, 141

subhirsuta, 171

testacea, 125

tetraspora, 134

theleboloides, 170

trachyderma, 139

umbrorum, 161

vialacea, 226

vitigena, 140

wisconsinensis, 132

I'rightii, 66

xanthomela americana, 141

Iumarina, 16, 22, 41, 121, 141

aggregata, 123, 136

araneosa, 123, 130

axillaris, 22, 122, 124

clausa, 122,125

Clementsii, 127

coccinea, 123,137

convexula, 122, 128

Cookeina, 123, 137

deligata, 123, 132

fusispora, 123, 136

Gerardi, 123, 138

glumarum, 123, 133

hepatica, 123, 139

it hacaensis, 22, 122, 124

leucoloma, 122, 129, 140

lilacina, 122, 128

nectrioides, 123, 132

ochroleuca, 123, 131

ollaris, 123,135

orthotricha, 122, 127

pallens, 122, 124
Peckii, 123, 133

permuda, 123, 134

phycophila, 122

phyllogena, 123, 134

purpurea, 123, 138

rubens, 122, 127

rufa, 123, 131

semiimmersa, 123,130

testacea, 122, 125

testacea macrospora, 126

tetraspora, 123, 134

trachyderma, 123, 139

wisconsinensis, 123, 132

Humariella, 157

melaloma, 167

scutellata, 159

stercorea, 169

Lachnea, 35, 156

abundans, 177

alpina, 169

amphidoxa, 176

arenicola, 149

arenosa, 151

aspera, 210

asperrima, 104

aurantia, 152

aurantiopsis, 198

badioberbis, 162

barbata, 104

bryophila, 178

chaetoloma, 175

chrysotricha, 178

Clementsi, 162

cocrinea, 191

confusa, 46

coprinaria, 171

Corium, 208

cretea, 177

crispata, 179

crucipila, 168

cubensis, 160

dălmeniensis, 170

diplotricha, 170

dispora, 161

Erinaceus, 178

fissilis, 180

fusicarpa, 210

Geaster, 149

gigantea, 209 
gilva, 166

gregaria, 176

gregaria pseudogregaria, 174

grisea, 151

Hainesii, 209

hemispherica, 175

heterospora, 161

heterothrix, 149

hinnulea, 46

hirta, 180

intermixta, 167

irregularis, 177

lanuginosa, 149

livida, 180

Lojkaeana, 170

macropus, 205

maculosa, 172

melaloma, 167

melastoma, 197

miniata, 103

mirabilis, 194

nigrella, 49

paludosa, 174

pediseta, 171

pellita, 152

piliseta, 160

pseudocrenulata, 178

pseudogregaria, 174

pulcherrima, 172

punicea, 165

pygmaea, 179

rubropurpurea, 161

scubalonta, 171

scutellata, 159

sepulta, 149

Sequoiae, 167

setosa, 166

stercorea, 169

stictica, 160

subcrinita, 166

Sumneriana, 149

texensis, 160

theleboloides, 170

trechispora, 43

umbrorum, 161

vitellina, 179

Woolhopeia, 178

Lachnella, 154

cinnabarina, 154
Cupressi, 78

flammea, 154

incarnescens, 154

maculincola, 154

rhoina, 154

Lachnellula chrysophthalma, 78

Lamprospora, 15, 16, 23, 31, 32, 34, $35,39,54$

amethystina, 55, 67

annulata, 55, 60

areolata, 55, 59

areolata a ustralis, 32, 59

ascoboloides, 55, 60

brevispinosa, 55, 63

carbonaria, 56, 67

carbonicola, 67, 68

Constellatio, 56, 69

Crec'hqueraultii, 11, 45, 55, 62, 64

Crec'hqueraultii macrantha, 63

Crouani, 54, 56

Detonia, 56, 72

dictydiola, $\mathbf{5 5 , 5 8}$

discoidea, 56, 70

exasperata, 56, 75

genmea, 56, 70

haemastigma, 56, 68

laetirubra, $\mathbf{5 4 , 5 8}$

leiocarpa, 56, 73

lobata, 56, 74

macrantha, 55,63

Maireana, 32, 55, 65

miniata, 56

nigrans, 56, 72

Planchonis, 32, 56, 74

polytrichina, 56,75

salmonicolor, 56, 71

spinulosa, 55, 61

trachycarpa, 56, 71, 72

tuberculata, $32,55,64,65$

tuberculatella, $32,55,66$

wisconsinensis, 56, 69

Wrightii, 55, 66

Lasiobolus, 41, 155

brachyascus, 81

diversisporus, 155

equinus, 155

pilosus, 155

pulcherrimus, 172

raripilus, 173 
ruber, 155,156

stercoreus, 169

Leotia conica, 243

Leptopodia, 245

atra, 248

Corium, 208

elastica, 246

Klotzschiana, 249

Leucoloma, 121

araneosa, 130

asperior, 43

axillaris, 124

coccinea, 137

Constellatio, 69

convexula, 128

fusispora, 136

Iledwigii, 129

rubricosa, 131

rutilans, 100

tetraspora, 134

Leucoscypha excipulata, 129, 130

Macropodia, 201

Corium, 208

fusicarpa, 210

macropus, 205

platypodia, 203

pubida, 210

Schweinitzii, 211

semitosta, 209

subclavipes, 206

urceolata, 206

Macroscyphus, 202

acetabuliforme, 202

coccineus, 191

macropus, 205

Melachroia, 141

xanthomela americana, 141

Melascypha, 47

melaena, 48

Melastiza, 40, 103

asperrima, 103, 104

Charteri, 103

miniata, 103

pennsylvanica, 103, 104

Microcrater, 198, 200

Microstoma, 190

hiemale, 193

Midotis, 181

gigantea, 181 macrotis, 181

Mitrophora, 253

caroliniana, 253

hybrida, 241

patula, 241

rimosipes, 241

semilibera, 241

Mitrula irregularis, 256

Mollisia, 62

Crec'hqueraultii, 62

Morchella, 29, 236, 237

angusticeps, 237, 240

bispora, 244

bispora truncata, 244

bohemica, 244

bohemica bispora, 244

caroliniana, 253

conica, 237, 239

conica deliciosa, 240

continua, 238, 239

crassipes, 237

deliciosa, 237, 240

elata, 240

esculenta, 27, 237, 238

esculenta conica, 239

esculenta fulva, 238

esculenta longipes, 238

esculenta rotunda, 238

esculenta vulgaris, 238

gigaspora, 244

hybrida, 237, 241

hybrida rimosipes, $2+1$

Mitra, 241

patula, 241

punctipes, 241

Rete, 241

rimosipes, 241

rotunda, 238

vulgaris, 238

Morilla, 237

bohemica, 244

conica, 239

elata, 240

esculenta, 238

gigaspora, 244

semilibera, 241

Neottiella, 156, 157

albotecta, 180

callichroa, 180 
corallina, 317

crucipila, 168

Hetieri, 164

leucoloma, 129

macrospora, 163

ollaris, 135

ovilla, 163

ovilla flavodisca, 163

Polytrichi, 163

sericeovillosa, 180

Spraguei, 180

Neottiopezis, 157

macrospora, 163, 180

Octospora, 156

fasciculata, 175

haemastigma, 68

leucoloma, 122, 129

pustulata, 224

rhizophora, 215

scutellata, 159

varia, 230

villosa, 205

Ombrophila, 141

Otidea, 97, 184, 219, 221

abietina, 228

aurantia, 97

auricula, 185

dochmia, 184

domingensis, 182

grandis, 186

Harperiana, 186

hirneoloides, 184

leporina, 185

neglecta, 186

obtecta, 187

ochracea, 185

onotica, 185

succosa, 223

Otidella, 47

fulgens, 50

fuscocana, 48

nigrella, 49

Pachyella, 219

Barleana, 233

Patella, 21, 35, 41, 156

abundans, 21, 22, 158, 177

albida, 158, 175, 176

albocincta, 157, 163

albospadicea, 158, 178 ciliata, 159

coprinaria, 158, 171

crucipila, 158, 168

cubensis, 157, 160

Erinaceus, 158, 178, 180

fimetaria, 158, 173

gilva, 158, 166

gregaria, 158, 176

Hetieri, 158, 164

irregularis, 158, 177

Lusatiae, 157, 162

Iutea, 169

maculosa, 158, 172

melaloma, 158, 167

miniata, 157, 162

ovilla, 158,163

paludosa, 158, 174

piliseta, 157,160

pulcherrima, 158, 172

punicea, 158, 165

pygmaea, 158, 179

raripila, 158, 173

ricciophila, 158, 165

scutellata, $35,157,159,180$

Sequoiae, 158, 167

setosa, 158, 166, 179

stercorea, 158, 169

theleboloides, 158,170

tuberculata, 158, 174

umbrorum, 157, 161, 180

Paxina, 42, 201

Acetabulum, 201, 202

Barlae, 201, 205

Corium, 201, 208, 211

Dupainii, 201, 207

fusicarpa, 202, 210

hispida, 201, 205

leucomelas, 201, 204

macropus, 201, 203

nigrella, 201, 208

olivacea, 202, 211

platypodia, 201, 203

semitosta, 202, 209

subclavipes, 201

sulcata, 4, 201, 204

Pelodiscus, 157

miniatus, 162

pilisetus, 160

Peltidium, 105 
Cook?i, 108

lignanium, 108

Oocaraiii, 108

Perrotia, 41, 154

flammea, 154

Plectania adusta, 199

Peziza, 15, 43, 121, 148, 156, 21s

abietina, 220, 228

abundans, 177

Acetabulum, 201, 202

Adae, 230

adusta, 167, 199

Afzelii, 188

aggregata, 136

albocincta, 163

albospadicea, 178

albotecta, 180

aluticolor, 190

ampelina, 226

amplispora, 231

amplissima, 235

ancilis, 216

apiculata, 217

aquatica, 108

araneosa, 130

arenicola, 149

arenosa, 150, 151

asperior, 43

assimilata, 224

atrorufa, 197

atrospora, 71

atrovinosa, 101

aurantia, 96, 97

aurantiaca, 159

aurantiopsis, 198

auricula, 185

auriflava, 62

Aurora, 115

axillaris, 124

Babingtonii, 106

badia, 32, 220, 221, 235

badioberbis, 162

Barleana, 233

bella, 140

bicucullata, 99

Boltoni, 226

brachypus, 206

bronca, 213

brunnea, 46 brunneoatra, 220, 222

brunneovinosa, 234

Burcardia, 195

caerulea, 225

caeruleomaculata, 234

caligans, 235

carbonaria, 212

Catinus, 213

cerea, 233

cervina, 155

cestrica, 98

Charteri, 103

chlamydospora, 101

chlorophysa, 232

chrisophthalma, 128

chrysopela, 234

ciliata, 157, 159, 169

cinerea, 118

cinerella, 120

cinnabarina, 154

Clissoni, 235

clypeata, 221, 233

coccinea, 97, 191

cochleata, 219, 221

Colensoi, 190

Commonsii, 98

concentrica, 220, 228

confuens, 109

confusa, 46

Constellatio, 69

convexella, 68

convexula, 128

convoluta, 229, 235

coprinaria, 171

corallina, 137

cordovensis, 182

Corium, 207, 208

coronaria, 235

Craterium, 199

cremoricolor, 117

crenata, 212, 228

crenulata, 197

cretea, 177

crispata, 179

Crouani, 56

cruciata, 193

crucipila, 168

cubensis, 160

Cupiessi, 78 
cupressina, 78

cupularis, 212

cyanoderma, 50

dalmeniensis, 170

deerrata, 141

deligata, 107, 132

depressa, 106

difformis, 115

diversicolor, 155

dochmia, 184

domiciliana, 220, 230

domingensis, 182

Dudleyi, 191

echinosperma, 62, 63, 224

elachroa, 141

elaeodes, 217, 218

Emileia, 220, 224

epidendra, 191

Erinaceus, 178

exasperata, 75

fimetaria, 170, 232

fimeti, 221, 232

flammea, 154

flavovirens, 44

floccosa, 192

fulgens, 50

fuliginea, 76

fuscocana, 48

fuscocarpa, 140

fusicarpa, 210

fusispora, 136

fusispora permuda, 134

gallinacea, 118

Geaster, 149, 235

gemmea, 70

Gerardi, 138

gigantea, 235

gilva, 166

globifera, 76

glumarum, 133

grandis, 186

granulata, 116

granulosa, 116

griseorosea, 220, 227

Hainesii, 209

Harmoge, 182

hemisphaerica, 49, 175

hepatica, 139

hesperidea, 193
Hindsii, 188

hinnulea, 46

hirneoloides, 184

hirta, 180

hirtipes, 197

hispida, 175

humicola, 213

humosa, 129

humosoides, 115

hyalinella, 145

hybrida, 152

hydrophila, 106

Hystrix, 187

inquinans, 195

intermixta, 167

ionella, 138

irregularis, 235

irrorata, 235

labellum, 175

laeticolor, 159

laetirubra, 58

lanuginosa, 149

lanuginosa Sumneri, 149

lechithina, 108

Leineri, 76

leiocarpa, 73

leporina, 184, 185

leucobasis, 107

leucoloma, 75, 129

leucomelas, 204

leucoxantha, 218

livida, 180

lobata, 74

Lusatiae, 162

macrocalyx, 235

macropus, 205

macrospora, 222

macrotis, 181

maculincola, 154

maculosa, 172

majalis, 214

melaena, 48

melaleuca, 220, 225

melaleucoides, 220, 225

melaloma, 167

melania, 48

melastoma, 197

Meleagris, 154

micropus, 231 
microspora, 141

miniata, 103

mirabilis, 193

modesta, 62, 63

monilifera, 47

Morgani, 210

muralis, 137

nana, 222

nebulosa, 214

nigrans, 72

nigrella, 48, 49

nummularia, 106

obtecta, 187

occidentalis, 193

odorata, 230

olivacea, 140

olivatra, 140

ollaris, 135

omphalodes, 109

onotica, 185

onotica ochracea, 185

Oocardii, 108

Oocardii lignaria, 108

orbicularis, 233

orthotricha, 127

ovilla, 163

pallida, 231

papillata, 155

paraphysata, 233

pellita, 152, 197

perlata, 216

permuda, 134

pertenuis, 139

Petersii, 224

pithya, 76, 78

pithyna, 76

poculiformis, 191

polyspora, 146

Polytrichi, 75, 163

prostrata, 193

proteana, 220, 227, 242

proteana sparassoides, 242

proximella, 176

pubida, 210

pulcherrima, 172, 191

pulchra, 214

pustulata, 220, 224, 234

radiculata, 99

repanda, 21, 220, 230, 231, 233, 235 repanda amplispora, 231

repandoides, 235

reticulata, 229

retiderma, 101

rhizomor pha, 197

rhizophora, 215

rhizopus, 197

rivularis, 106

roseolilacina, 235

rubra, 130

rubricosa, 131

rubrofusca, 228

rufa, 131

rufescens, $1+1$

rutilans, 100

salmonicolor, 140

sanguinaria, 67

scabra, 116

scabrosa, 71

scatigena, 140

schizospora, 46

Schröteri, 141

scubalonta, 171

scutellata, 159,180

scutelloides, 46

secreta, 140

semiimmersa, 130

semitosta, 209

sepulta, 149

Sequoiae, 167

setosa, 166

sicula, 235

sordescens, 99

sphaeroplea, 46

spissa, 140, 220, 222

splendens, 99

spongiosa, 48

Spraguei, 180

stercoraria, 81, 82

stercorea, 169

Sterensoniana, 231

stictica, 160

stipitata, 205

striispora, 187

stygia, 49

subclavipes, 206

subf usca, 111

subgranulata, 141

suburceolata, 212, 213 
succosa, 220, 223

sulcata, 204

sulcipes, 188

sylvestris, 221, 233

tapeina, 139

testacea, 125

tetraonalis, 119

tetraspora, 134

texensis, 160

theleboloides, 170

tomentosa, 211

trachycarpa, 71

trachyderma, 139

trechispora, 43

Tricholoma, 187

truncicomes, 231

umbrina, 224

umbrorum, 161

umbrosa, 161

unicisa, 185

raria lignicola, 231

varia terrestris, 233

varia typica, 230

Venezuelae, 190

venosa, 218, 220, 229

verruculosa, 215

vesiculosa, 21, 221, 231

violacea, 138, 220, 226, 228

vitellina, 179

vogesiaca, 48

vulcanalis, 214

IVarnei, 216

Woolhopeia, 178

IVrightii, 66

Pezizula, 144

Cesatii, 121

crustacea, 145

Phacidium terrestre, 200

Phaeopezia, 54, 101

apiculata, 217

atrospora, 71

elaeodes, 44

Nuttallii, 87, 88

retiderma, 101

scabrosa, 71

vinacea, 222

Phalloboletus, 237

angusticeps, 240

bisporus, 244 bohemicus, 244

conicus, 239, 243

crassipes, 237

deliciosus, 240

elatus, 240

esculentus, 238

gigasporus, 244

Rete, 241

rimosipes, 241

Phallus, 215

acaulis, 215

acuminatus, 239

conicus, 243

crassipes, 237

crispus, 247

esculentus, 237, 238

Monacellus, 251

Rete, 241

Phialea cupressina, 78

Phillipsia, 17-19, 42, 182, 198, 235

Chardoniana, 18, 182, 183

dochmia, 182, 184

domingensis, 182

gigantea, 182, 183

kermesina, 182

subpurpurea, 182

Venezuelae, 190

Phleboscyphus, 201

Acetabulum, 202

macropus, 203

olivaceus, 211

radicatus, 214

Physomitra, 245

esculenta, 251

infula, 251

Pilobolus, 26

Pilocratera, 187

Engleriana, 188

Hindsii, 188

Tricholoma, 187

Pithya, 39, 76

Cupressi, 22, 76-78

cupressina, 78

lacunosa, 76, 77

pithya, 76

suecica, 78

thujina, 78

vulgaris, 76

Plectania, 42, 141, 190 
coccinea, 191

floccosa, 191, 192

hiemalis, 17, 19, 191, 193

hirtipes, 197

melastoma, 197

nigrella, 49

occidentalis, 191, 193

rhizomorpha, 197

rimosa, 211

Plicaria, 54, 219

badia, 221

brunneoatra, 222

caeruleomaculata, 234

carbonaria, 71

ferruginea, 71

favovirens, 44

foreata, 73

Fuckelii caerulescens, 225

muralis, 137

Planchonis, 74

pustulata, 224

repanda, 231

repandoides, 235

reticulata, 229

rubrofusca, 228

succosa, 223

tracheia, 52

Plicariella, 34, 54

Constellatio, 69

fulgens, 50

leiocarpa, 73

miniata, 57

modesta, 62

Polytrichi, 75

trachycarpa, 71

P'odophacidium terrestre, 200

Pseudombrophila, 41, 141

deerata, 132, 141

Pedrottii, 141

Pseudopeziza, 92

Pseudopithyella, 41, 153

minuscula, 153

I'seudoplectania, 39, 47, 215

fulgens, 48, 50

melaena, 48

nigrella, 48,49

stygia, 49

vogesiaca, 48, 208, 209

Pseudotis, 219 abietina, 228

Psilopezia, 40, 105, 110, 223

aquatica, 105, 108

deligata, 107

flavida, 105, 108

hydrophila, 105, 106

juruensis, 233

mirabilis, 109

myrothecioides, 105, 106

nummularia, 105, 106, 234

Oocardii, 108

orbicularis, 233

trachyspora, 105, 107

Pulparia spongiosa, 48

Pulvinula, 54

carbonaria, 67

Constellatio, 69

haemastigma, 68

Pustularia, 211, 219

Catinus, 213

cupularis, 212

gigantea, 235

Sterensoniana, 231

vesiculosa, 231

Pyronema, 3, 6-8, 11, 23-25, 27, 40,

109

aurantionubrum, 109

carneum, 115

confluens, 109

confluens inigneum, 110

haemastigma, 68

leucobasis, 107, 110

Marianum, 109

melalomum, 167

omphalodes, 6, 12, 27, 109

subhirsutum, 167, 170

Pyronemella monilifera, 47

Rhizina, 43, 215

Babingtonii, 106

helvetica, 216

inflata, 215

laevigata, 215

myrothecioides, 106

spongiosa, 216

undulata, 215

Ruhlandiella, 51

berolinensis, 51

hesperia, 51

Ryparobius, 41, 144 
brunneus, 144

Cookei, 145

Crouani, 142

crustaceus, 144, 145, 147

hyalinellus, 144, 145

monascus, 144, 147

niveus, 147

pachyascus, 146

Pelletieri, 148

polysporus, 144, 146

sexdecimsporus, 144

woolhopensis, 143

Saccobolus, 40, 92, 96

depauperatus, 93, 95

globuliferellus, 93, 95

Kerverni, 93

neglectus, 94

obscurus, 96

portoricensis, 93, 94

violascens, 93, 94

Sarcoscypha, 190

albovillosa, 100

alpina, 193, 194

coccinea, 191, 192

Colensoi, 190

Corinm, 208

cruciata, 193

dawsonensis, 214

floccosa, 192

melastoma, 197

minuscula, 153

occidentalis, 193

prostrata, 194

radiculata, 99

rhenana, 99

roseotincta, 194

striispora, 187

Sarcosoma, 194

globosa, 195

Sarcosphaera, 43, 235

arenicola, 149

arenosa, 151

coronaria, 235

Geaster, 149

macrocalyx, 235

Sumneriana, 149

Sclerotinia, 13, 21, 215

baccata, 193

Sclerotium, 133
Scodellina, 42, 184

aurantiaca, 97

auricula, 185

badia, 221

grandis, 185, 186

leporina, 185

onotica, 185

pustulata, 224

vesiculosa, 231

Scutellinia, 156, 157

abundans, 177

adusta, 199

albospadicea, 178

alpina, 169

arenicola, 149

arenosa, 151

aurantiopsis, 198

badeoberbis, 162

brunnea, 46

chaetoloma, 175

coprinaria, 171

cretea, 177

dalmeniensis, 170

dispora, 161

Erinacens, 178

fusicarpa, 210

Geaster, 149

gilva, 166

gregaria, 176

Hainesii, 209

hemisphaerica, 175

heterospora, 161

hirtipes, 197

hybrida, 152

irregularis, 177

laeticolor, 159

lanuginosa, 149

Lusatiae, 162

melaloma, 167

melastoma, 197

miniata, 103

pellita, 152

pulcherrima, 172

rhizomorpha, 197

scubalonta, 171

scutellata, 159

sepulta, 149

Sequoiae, 167

setosa, 166 
stercorea, 169

stictica, 160

Sumneriana, 149

texensis, 160

theleboloides, 170

umbrarum, 161

Woolhopeia, 178

Sepultaria, 41, 148

albida, 175

arenicola, 149, 150

arenosa, 149-151, 180

aspera, 210

aurantia, 152

aurantiaca, 149

bryophila, 178

Geaster, 149, 180

gigantea, 209

grisea, 151

heterothrix, 149

Longii, 149, 150

pediseta, 171

pellita, 149, 152

pseudocrenulata, 178

punicea, 165

pygmaea, 179

rubrupurpurea, 161

semiimmersa, 130

semitosta, 209

sepulta, 149, 150

Sumneri, 149

tenuis, 180

Sphaeridiobolus, 79

hyperboreus, 79

hyperboreus niveus, 79

Sphaerosoma, 39, 51

alveolatum, 53

echinulatum, 11, 52

fuscescens, 51

hesperium, 51

Sphaerospora, 39, 43

asperior, 44

brunnea, 43,46

confusa, 46

Durandi, 44

flavovirens, 43,44

hinnulea, 43, 46

monilifera, 43, 47

nigrella, 49 perplexa, 43, 45

scutelloides, 46

trechispora, 43

Sphacrosporula, 43

asperior, 44

conf $u$ sa, 46

flavovirens, 44

scutclloides, 46

trechispora, 44

Sphaerozosma, 51

Spragueola, 256

Streptotheca, 16, 41, 142

Boudieri, 142

Crouani, 142

obscura, 142, 143

wool hopensis, 142, 143

Tapesia omphalodes, 109

Tarzetta cinerascens, 214

Thecotheus, 41, 147

Pelletieri, 148

Thelcbolus, 144, 147

lignicola, 147

monascus, 147

nanus, 147

stercoreus, 147

Tricharia, 157

gilva, 166

Trichophaea, 157

abundans, 177

albospadicea, 178

gregaria, 176

paludosa, 174

psendogregaria, 174

Trichoscypha, 187

Afzelii, 188

IIindsii, 188

sulcipes, 188

Tricholoma, 187

Underwoodia, 237, 255

columnaris, 255

Urnula, 42, 198

Craterium, 199

Geaster, 199, 200

melastoma, 197

terrestris, 200

Verpa, 237, 243

atroalba, 245

bohemica, 243, 244 
chicoensis, 243

conica, 243, 245

digitaliformis, 243

helvelloides, 243

Krombholzii, 243

perpusilla, 245
Wynnea, 4, 17-19, 42, 180 americana, 19, 180, 181 gigantea, 180,181 macrotis, 181

Wynnella, 184

auricula, 186 


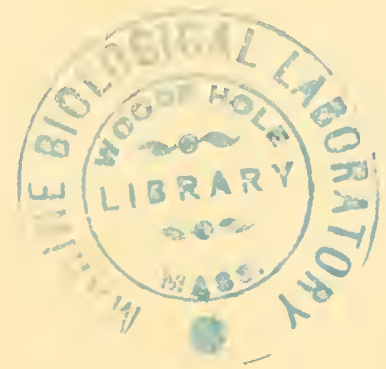




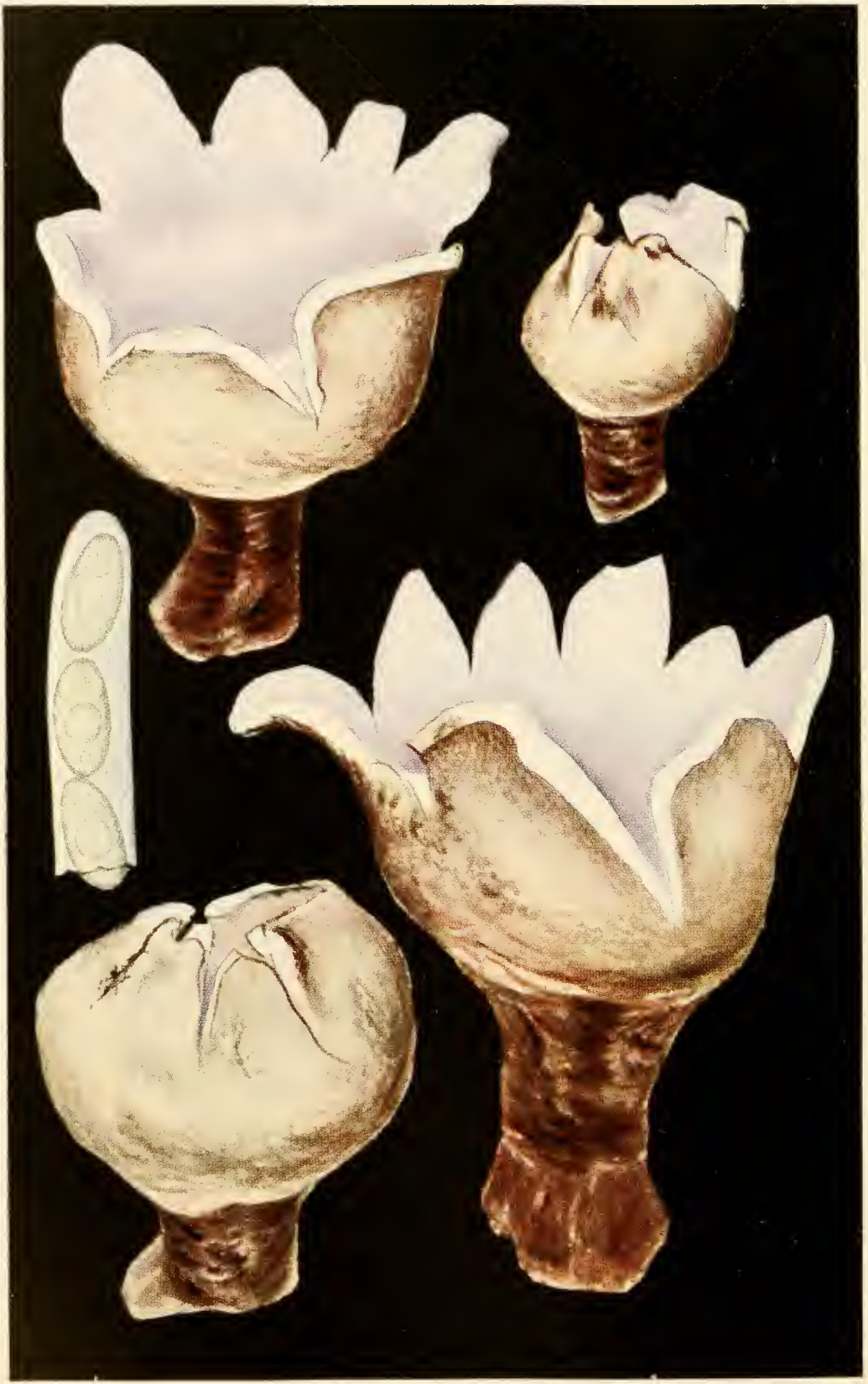

SARCOSPHAERA CORONARIA 


\section{GENERAL FEATLRES OF THE GROLP}

The general features of this group were treated under a number of subheadings in the first edition of this work. Additional information is treated here under the same subheadings, the page number in parentheses indicating the place where the first treatment occurred. If no number is given it is a new subtitle.

\section{Heterothallism (page 12)}

Recently heterothallism has been reported in Ascobolus stercorarius and in a recentiy described European species, Ascobolus strobilinus. In 1938, Edwin M. Betts and Samuel L. Neyer reported heterothallism for Ascobolus geophilus. These authors after extensive studies (Am. Jour. Bot. 26:619. 1939) conclude:

"Ascobolus geophilus Seaver is heterothallic since the mycelium for a single spore will not develop apothecia unless crossed with the mycelium from a spore of the opposite strain.

"Four spores from a single ascus are of one strain while four are of the opposite strain.

"Segregation of sexual strains takes place at either the first or second division of the zygote nucleus."

This is as much as is known at the present of heterothallism in the operculate cup-fungi.

\section{Spore Discharge (page 13)}

In our first edition the writer reproduced from II. R. Fisher a photograph of a cloud of spores as they were being ejected from the asci of Sclerotinia, one of the inoperculate disconycetes. The phenomenon of spore puffing, so far as we are aware, is restricted to the stomatous discomycetes, but characterizes the operculate and inoperculate alike. Some time ago the writer received from G. IV. Coldsmith of Texas a photograph of the same phenomenon in Urmula Geaster, an operculate species, which is here reproduced (FIG. 16). In this species Goldsmith states that the spores are discharged with an audible sound which can be heard several feet away.

In Urnula Geaster the apothecia are at first entirely closed and before the spores can be discharged it is necessary for the 
apothecia to dehisce. In this case they split into several Geasterlike rays, hence the name. These roll back so that the hymenium is frecly exposed at maturity. In a previous paper the writer has called attention to the peculiar bladder-like swelling of the cells of the paraphyses which seems to be a device for expanding the hymenium in order to facilitate the discharge of the spores (Plate 60). This has not been observed in any other species.

On the question of spore discharge K. B. Boedijn (see bibliography) seems to differ with the writer. The difference is,

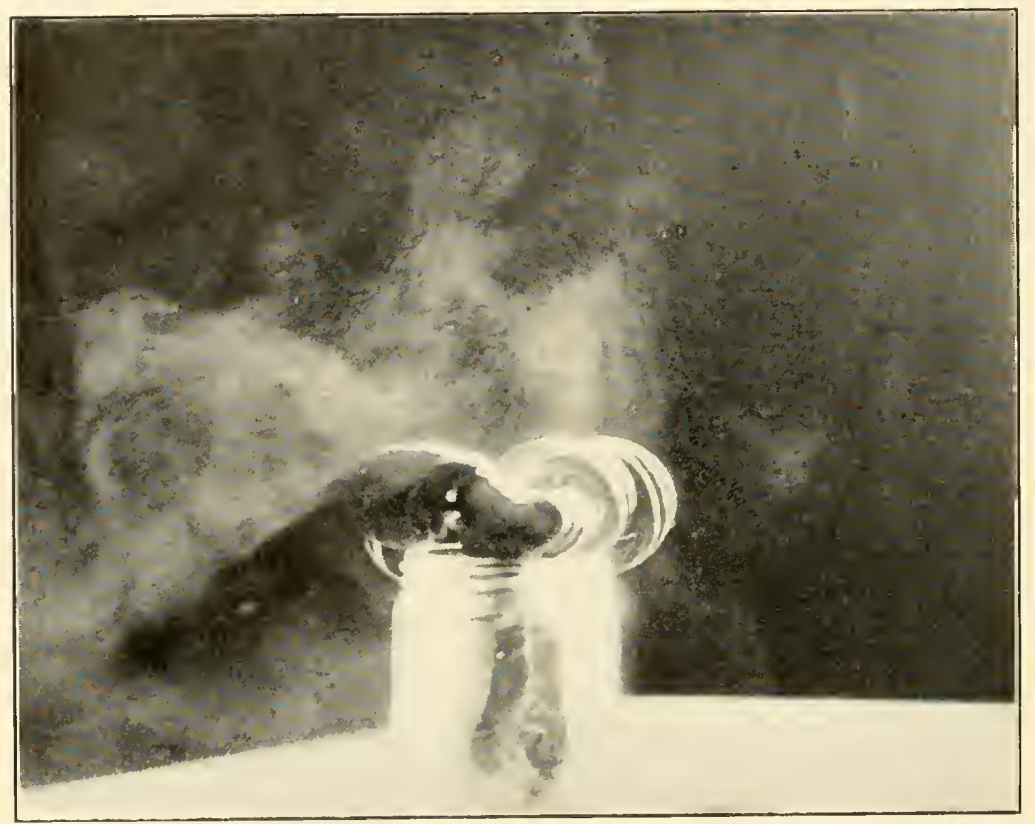

Fig. 16. Photograph of spore discharge in an operculate discomycete, Urnula Geaster. Photo by C. IV. Goldsmith.

however, apparently due to misunderstanding rather than to conflicting observations. The writer claimed (p. 20) that since the ascostome is much narrower than the spore which has passed through it, the ascostome must have stretched and contracted as the spore passed through, and that this expansion and contraction tends to accelerate the force with which the spore is ejected or "snapped out" of the ascus.

In answer to this Boedijn states: "A contraction between each spore ejection, as suggested by Seaver (p. 21), does never 
take place. Seaver drew his conclusions from preserved material in which there is a great discrepancy between the size of the ascostome and that of the spores. But as I have shown such material is materially altered by contraction and swelling of the ascus wall. The ascusporus which in living asci is just wide enough for the passing of the spores shrinks considerably after cjection."

While Boedijn appears to differ with the writer in matters of spore discharge, both his statements and figures, some of which are here reproduced (FIG. 17), prove rather than disprove our previous statements. Before the spore is discharged there is no ascostome, but the original size of the ascostome is indicated approximately by the diameter of the operculum or lid which is usually left hanging at the lower side of the ascostome. Referring to Boedijn's own illustrations (FIG. $17 \mathrm{f}, \mathrm{g}$ ) it will be noted that the operculum is scarcely half the diameter of the spore, and in our own observations sometimes even less. Also (FIG. 17, g) a spore is seen in the process of passing through the ascostome which is already stretched much beyond its original size, as indicated by the attached operculum or lid. In this case the spore is said to have been stuck in the ascostome. Why did it stick? Because the ascostome was not large enough for the spore to pass through without stretching, and there was not sufficient force behind the spore to complete the process.

Boedijn claims that the ascus jet passes through the ascostome at once. So do the bullets from a machine gun pass out in a continuous jet but there is an explosion behind each one. The writer did not claim that there was a pause between each spore ejection, as implied by Boedijn. but that there was an expansion and contraction between each spore ejection, and this must be true even though the spores pass out in a continuous jet end to end.

Even if we admit for the sake of argument that the ascostome was originally as wide as the spore, but contracted after spore ejection, we might ask when does it contract? Does it contract after all the spores have been ejected, or after each spore ejection? Again Boedijn's own illustration (FIG. 17) proves that the ascostome does contract before all the spores are ejected. If not, why did the last spore (FIG. 17, g) stick in the ascostome? If the ascostome contracted after the seventh spore why should it not have contracted after each discharge? The fact that the 
process is ton rapid to be followed with the eye does not alter the facts.

This process might be compared to the potato-gun which consists of a quill which is large at the base and narrow at the tip. When a plug of raw potato is put in at the large end and

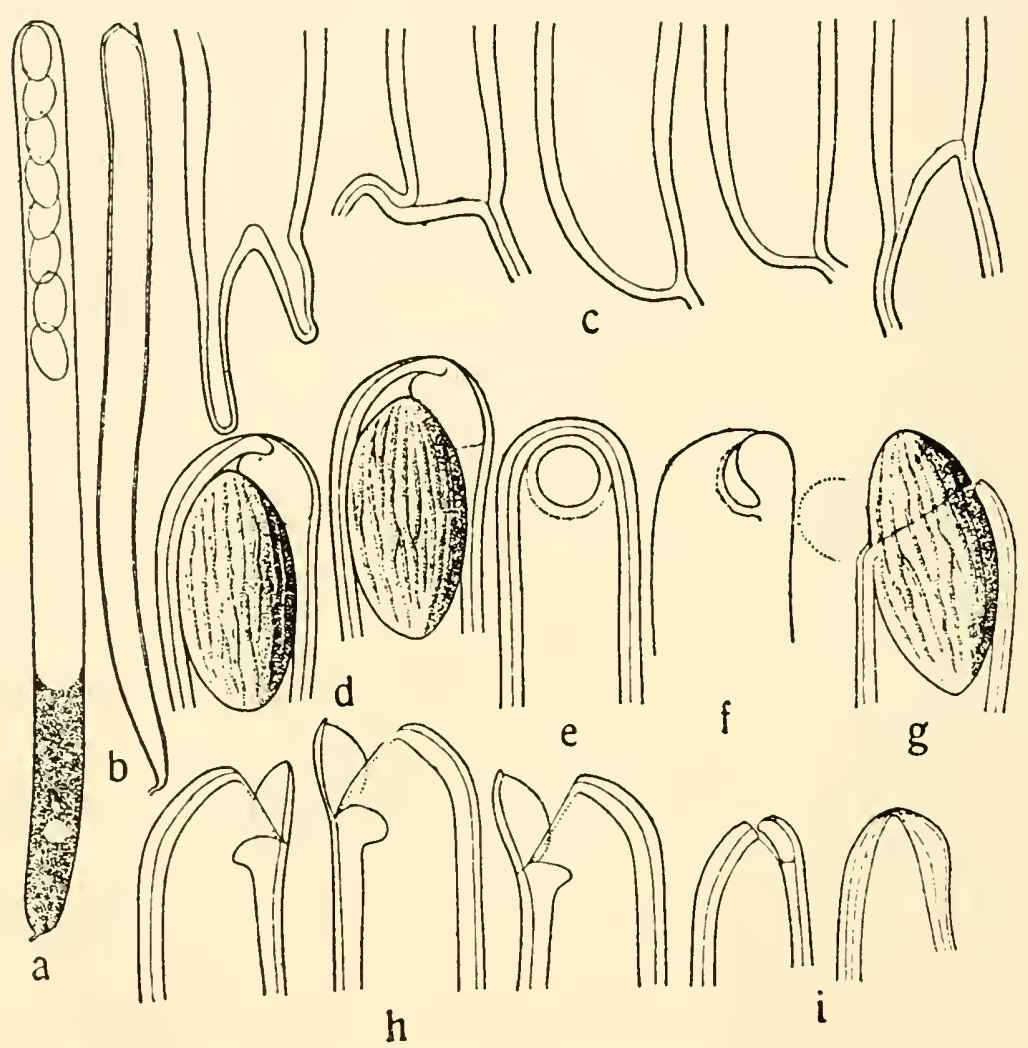

FIG. 17. a-h, Cookeina sulcipes, i, C. insititia. a, living ascus; b, the same after spore discharge; $c$, bases of asci; $d$, apices of asci closed; e, idem opened, front view; $\mathrm{f}$, idem, side view; $\mathrm{g}$, spore sticking in ascostome; $\mathrm{h}$, apices of asci, opened; i, idem of C. insititia, opened and closed. From K. B. Boedijn.

by means of a ram rod crowded into the small end, it fits very tightly. When another potato plug is crowded up behind it the first one sticks in the small end of the quill. As the second plug is pushed up with a ram rod the air is compressed and when the first plug is finally released it is fired out with a loud bang and great force. 
The process here is exactly the same except that in the fungus the ascostone stretches in order to produce a tight fit, while in the potato gun the potato plugs contract for the same reason. In the potato gun the force is applied by the human muscle while in the ascus it is supplied by osmotic pressure. And again the form of the spore is such that, as previously suggested, after the spore has passed its center the contraction of the stretched ascostome accelerates the force with which it is shot out, as a lemon seed may be shot from between the fingers.

Recently Miss Ellys Butler (Mycologia 31: 612-623. f. 1-2. 1939) has noted the same method of spore discharge in Patellaria, one of the inoperculate discomycetes. In that case, however, the process takes place by slow motion so that it can easily be followed (FIG. 22). A more complete discussion of this is under the subtitle Classification (page 296).

According to Boedijn the writer seems to have been the first to call attention to the constancy of the delicate striate markings on the spores of the species of these two genera. He clains, however, that there are delicate longitudinal ridges. These marks are suggestive of the rifling of a gun barrel, and it may be that they too are concerned with the methods of spore discharge.

\section{Dehiscence of the Ascus (page 15)}

In the introductory chapter it was stated that there were three lypes of ascus dehiscence. A fourth type has since been discovered in the disconycetes, and this will be treated more in detail under the subheading Classification.

\section{Eccentricity of the ascostome (page 17)}

In our first edition the writer having discussed the eccentricity of the ascostome finally concluded from numerous observations that this was a fixed character in the asci of species of certain tropical genera, especially Phillipsia and Cookeina. Thus two theories have been offered:

Dr. A. H. R. Buller noted this character in a Canadian species described in this work as Plectania hiemalis (p. 193, pl. 19, f. 2). Since the cups of this species happen for the most part to be deep funnel-shaped he concludes that the eccentricity of the ascostome is an adaptation to this character and designed to throw the spores up through the mouth of the cup instead of shooting them across into the opposite wall. This is a very 
plausible explanation in so far as it applies to the species mentioned above. The only difficulty is that it does not agree with the writer's observations on species of some genera in which the apothecia are often shallow cup-shaped or entirely flat.

The writer claims that the eccentricity of the ascostome is an absolutely fixed character in certain genera, especially Phillipsia and Cookeina, and has no relation to the concavity of the cup or to the direction of the light. Unfortunately, these genera are confined to the tropics. If Dr. Buller had had the opportunity of examining and observing these forms in the field, the writer is certain that he would have modified his views on this point.

Since the publication of these views, Boedijn (1.c.) has published a paper on "The genera Phillipsia and Cookeina in Netherlands India" in which he bears out the observations of the writer as to the eccentricity of the ascostome in the asci of the species of these genera. He states "Mostly the ascus jet takes a somewhat oblique direction owing to the eccentricity of the ascusporus. In this connection it may be noted that on a radial section of a fruit body all opercula are pointing to the border of the apothecium." "This is in Cookeina sulcipes in which the cups are shallow. In Phillipsia, in which the apothecia are defined as "concave or plane," he also indicates "Operculum eccentric."

Thus we conclude that the eccentricity has nothing to do with the concavity of the cup. If Boedijn's conclusions are correct the eccentricity of the ascostome, since it is always directed toward the outside of the apothecium, is a device for scattering the spores as shot are scattered when fired from a gun instead of shooting them straight up in the air. If the ascostomes are directed toward the outer margin of the apothecium and the cup is cleeply depressed the spores will be shot upward as indicated by Buller. Again if Boedijn's conclusions are correct the ascostomes are eccentric anyway even though the apothecia are flat. These conclusions bear out the writer's observations.

\section{Mycophagy (page 18)}

While none of the cup-fungi are deadly poisonous and most of them are usable as food, if collected in sufficient quantity, the spring mushroom (Morchella esculenta) is probably the most widely used in this connection. In our earlier pages we published some records as to the profusion in which this species often occurs. Although the writer has frequently collected the morel 
in the vicinity of New Jork (ity, never until 1937 was it collected in great abundance. On May 23 while collecting near his home in Elmsford the writer encountered an especially fine group of fruiting bodies of this species. About 75 were collected, filling an entire basket (FIG. 18), and more might have been found had the writer been attempting to break any records. The colored illustration accompanying this article was made from

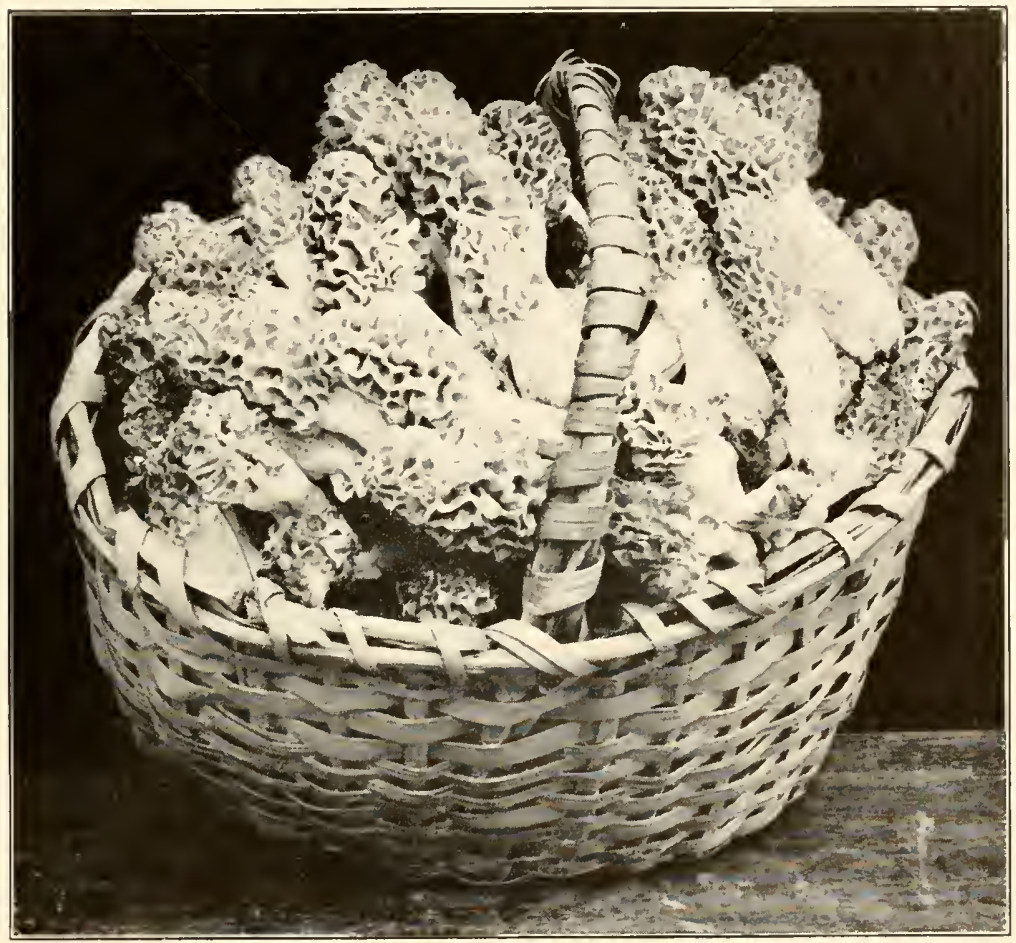

Fig. 18. A basketful of morels, an unusual quantity to be found in one spot in the woods.

this material (Plate 65). All these were dried and kept for scientific purposes. The following week-end the place was again visited with the hope of getting a fresh supply to be used for culinary purposes. We were surprised, however, at this time in not finding a single fruiting body, indicating that the fruiting bodies occur in one great burst and then disappear for the season.

The following spring the writer again visited this ravine hoping for a reoccurrence of the species in large numbers. In- 
fortunately, however, the entire ravine had in the meantime been filled many feet deep with crushed rock and debris from the New York City Aqueduct which was being constructed through this section, thus preventing us from repeating our observations. It would be interesting to have other records as to the abundance with which this fungus occurs in other localities.

\section{Asexual Reproduction (page 21)}

In the early chapters of this work the writer referred to the fact that the conidial stage was absent in many of the species of this group, or at least had never been observed. Where the conidial stages are known they seem to take quite a variety of forms. In addition to those already reported the following should be added.

\section{CHLAMYDOSPORES}

M. Woronin (Beitr. Morph. Phyz. Pilze 2:1-11. pl. t. 1866) has reported chlanydospores in Ascobolus pulcherrimus (Fig. 19),

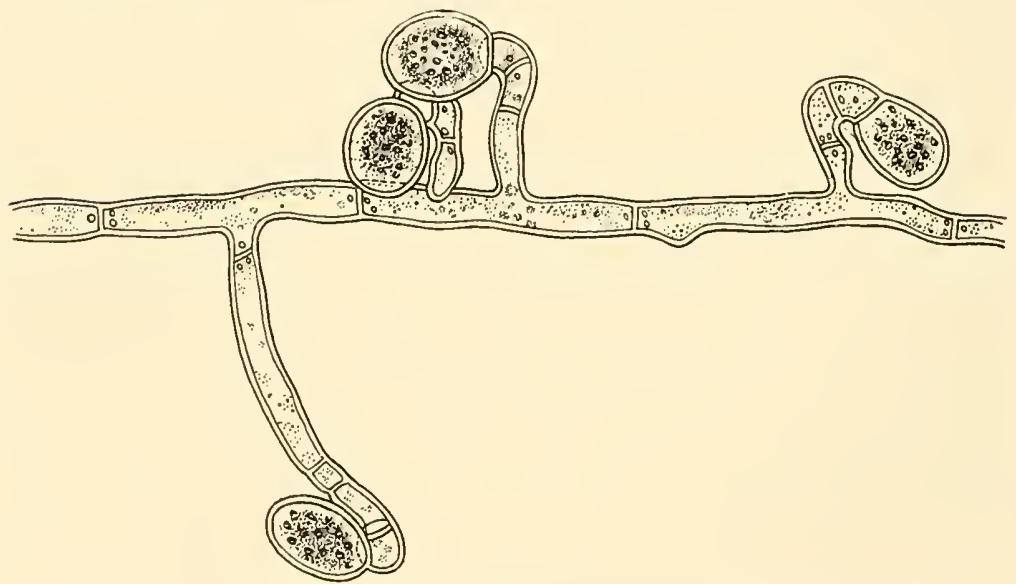

Fig. 19. Chlamydospores in Patella pulcherrima (Crouan) Seaver.

From Woronin.

recorded here as Patella pulcherrima. The presence of chlamydospores in this species has been confirmed by Dr. B. O. Dodge in single spore cultures. Woronin states that no similar chlamydospores were known to him in any other discomycete.

\section{PAPULASPORA}

The term "bulbil" has been employed to designate a certain type of sclerotium-like growth capable of reproducing the plant. 
Such growths have been found associated with some of the operculate discomycetes. These have been ascribed to several genera of the Fungi Imperfecti, among them the genus Papulaspora. Many of the "bulbils" have been regarded as miniature perithecia or apothecia, but in some this is not the case.

In 1915 (Science N.S. 41: 173) B. O. Dodge reported a Papulaspora closely associated with Ascobolus mannificus, either as a parasite or as an asexual spore of the Ascobolus. In 1917 (Bot. Gaz. 64:265) J. IV. Hotson was unable to prove that what he designated as Papulaspora magnifica was the asexual stage of Ascobolus magnificus.

In 1920 (Mycologia 12: 115-1.34) Dodge proved by singleascospore cultures that Papulaspora magnifica Hotson is not a parasite, but represents the asexual stage of the Ascobolus with which it is associated (FIG. 20). This has been confirmed by H. C. I. Gwrnne-Yaughan and H. S. Williamson (Ann. Bot. 46: 653-670. pl. 21-23. 1932).

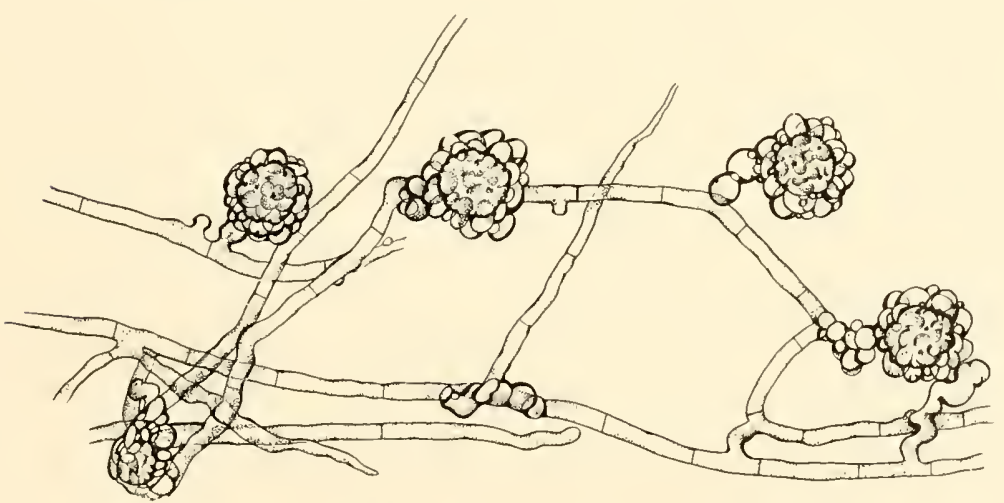

Fiti. 20. Papulaspora stage of .1scobolus magnificus Dodge.

Drawn from photographs by Dodge.

\section{OIDICM}

Oidia have been reported in a number of species of Ascobolus, among them $A$. stercorarius. In this connection E. S. Dowding (Ann. Bot. 45: 627. 1931) states: "In $A$. stercorarius oidia are constantly and abundantly produced by all mycelia of monosporous origin, and they continue to be produced by two mycelia of opposite sex which have been mated.

"A mycelium which is about to produce oidia gives rise to a number of relatively slender acrial hyphae which grow out per- 
pendicularly from the surface of the culture medium (Textfig. 5). Then each hypha, beginning at its apex and proceeding downwards, breaks up into a series of short cylindrical cells which become the oidia (Text-fig. 4). These oidia, when fully formed, are loosely attached to one another and a chain of oidia may be readily detached from the nuycelium by a puff of air blown from the mouth. The oidia adhere to any object which is brought into contact with them. Those shown in Plate XIX, Fig. 4,

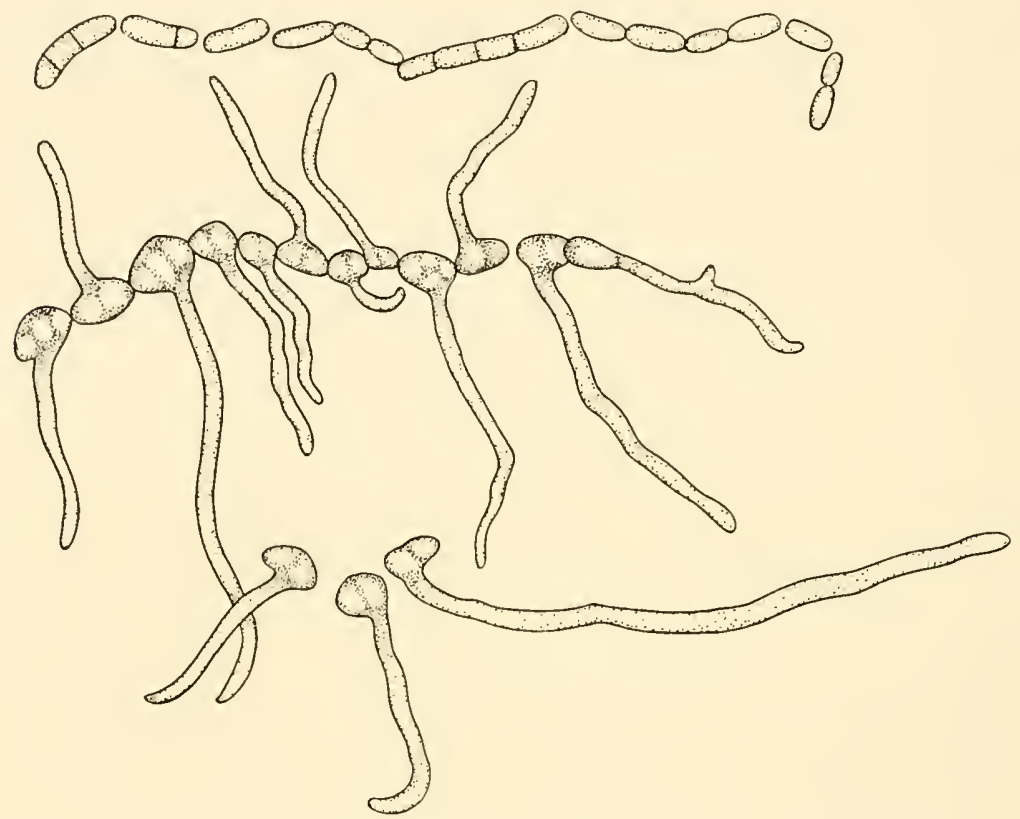

Fic. 21. Oidia in Ascobolus stercorarius (Bull.) Schröt. From Dowding.

adhered to a glass slide which was lowered gently on to the surface of a mycelium.

"The oidia of $A$. stercorarius germinate readily in water, dung, dung agar, or air saturated with water vapour, and in all these media germination begins within twelve hours after the oidia have been sown.

"On germinating, an oidium first swells up to about eight times its original volume and, in so doing, becomes barrel-shaped and vacuolated (Text-fig. 6). Then it puts out either one or two germ-tubes from its sides or ends (Text-figs. 6-10). In a 
nutrient solution the germ-tubes soon develop into a branched and septate mycelium which, after growing for two or three days, gives rise to a new set of aerial hyphae which break up in their turn into oidia. Sometimes, as shown in Text-fig. 10, the germtube itself breaks up into oidia.

"The germ-tube of an oidium readily fuses with any other hypha with which it comes into contact (Text-fig. 9). Thus such a germ-tube has been observed to fuse with the germ-tube of another oidium of the same or of opposite sex and with a hypha of a mycelium derived from an ascospore of the same or of opposite sex.",

\section{OEDOCEPHALUH}

In a recent paper (Mycologia 29: 651) B. (). Dodge describes "The conidial stage of Pesisa pustuluta." Twenty-five years ago he noted the Oedocephalum stage of this fungus on a heated soil extract agar, but at that time it was thought to be of little importance. So far as known no record of this was published.

In June 1937, the writer made a fine collection of this species in the woods east of the Museum Building of the New York Botanical Garden. At the request of Dr. Dodge this was turned over to him for study. The species grows on burned spots and charcoal, and is therefore referred to as a pyrophilous or fireloving species. Ascospores were planted on plates or cormmeal agar and heated to a temperature of $58^{\circ}$ for one hour, since heating often stimulates the spore germination.

Dodge states "Practically all the spores germinated. On the second day characteristic condiophores bearing heads of conidia developed from the surface hyphae. The conidiophores (FIr. 22) are usually about $150-350 \mu$ long, 3 or 4 celled, and end in an Oedocephalum head which varies greatly in shape and sizenarrow clavate, oval to spherical $12-20 \times 20-40 \mu$. Conidiophores may be much longer, sometimes even $1200 \mu$ long with 10 or 15 cells.

"The conidia are very slightly colored and probably would be described as hyaline with a slightly roughened or warted surface, elliptical, $2.5-3 \times 6-9 \mu$. Some are larger, $4 \times 12 \mu$. The point where the conidium was originally attached usually shows as a little papilla on the conidiophore head, and as a little knob on the lower end of the conidium." 
The writer is glad to add this description of the conidial stage to that of the perfect stage already described in early chapters of this work (p. 224, pl. 29,f. 1).
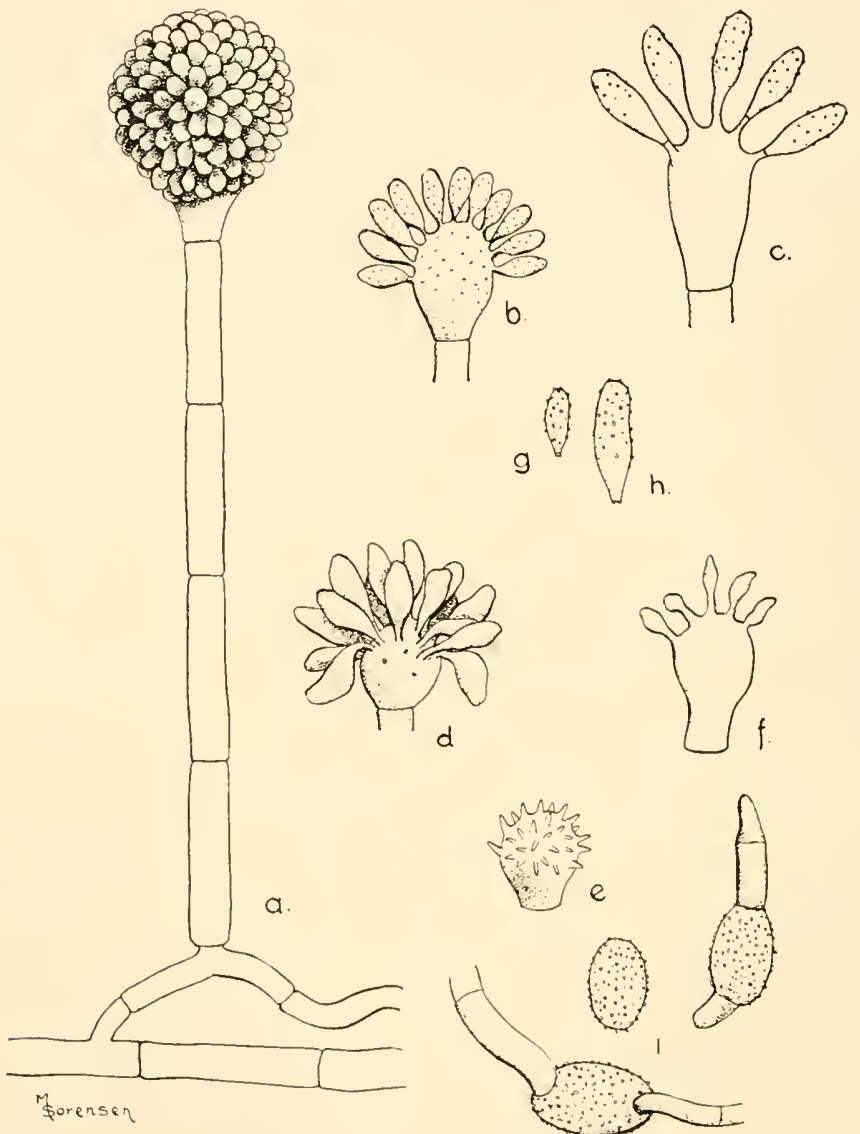

\section{h.}

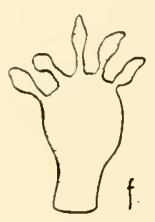

FIG. 22. a-h, stages in the development of Oedocephalum, the conidial stage of

Pesiza pustulata; i, ascospores showing germination. From Dodge.

\section{Classification (page 29)}

A discussion of the classification of the discomycetes should rightfully follow that of ascus dehiscence, since the former is based largely on the latter, i.e. the type of ascus dehiscence is the primary basis on which the disconycetes are separated into groups. Formerly two groups of disconycetes were recognized, 
the Operculates and the Inoperculates. Now a third must be added.

Early in the writer's work on the disconycetes it was noted that Patellaria atrata, one of the xerophytic species commonly. collected in the west, seemed to be an exception to the general rule, so far as the discharge of its spores is concerned, in that no pore or ascostome had ever been olsserved through which the spores could have escaped. Instead a third of the ascus was broken off and these remained in the field as detached thimbles.

It remained for Miss Elly's Butler to determine the method of spore discharge in Patellaria (Lecanidion) and its allies. It was discovered by her in fresh material collected by the writer in Bermuda that Patelluria possesses a double ascus, a character that had been observed in some of the pyrenonycetes but never before in the discomycetes. Inder proper conditions the inner ascus, which is termed by her the endoascus, elongates and extends through the outer ascus, termed by her the ectoascus, about one-third of its length carrying with it the ascospores which are discharged one by one not directly through the ascostome of the ectoascus but through the end of the endoascus.

The spores are ejected from the endoascus in the same manner described by the writer for certain of the operculate cup-fungi, in which the ascostome is much smaller than the spore. In Patellaria, however, the process takes place in "slow motion" so that it can be easily observed. The process has been described by Miss Butler as follows: "The first four spores were shot out in rapid succession, the last ones more slowly, so that the process could be followed easily (FIG. 23). A spore pushed forward to the apex and, stretching the contracted pore, slowly squeezed through the opening to the point of maximum width of the spore and then was shot out quickly and forcefully. Thus the shape of the spore seems to play an important part in its discharge. Seaver described this process of stretching and contracting in the operculates, but he was unable to follow the discharge closely as there then was no pause between spore ejections and the motion was too rapid."

One point has not yet been cleared up. It has not yet been determined how the endoascus makes its exit through the ectoascus. Does it pass through a definite opening at the end of the ascus, or does it push off the end of the ectoascus in the form of a thimble? If the latter were true some of the thimbles should 


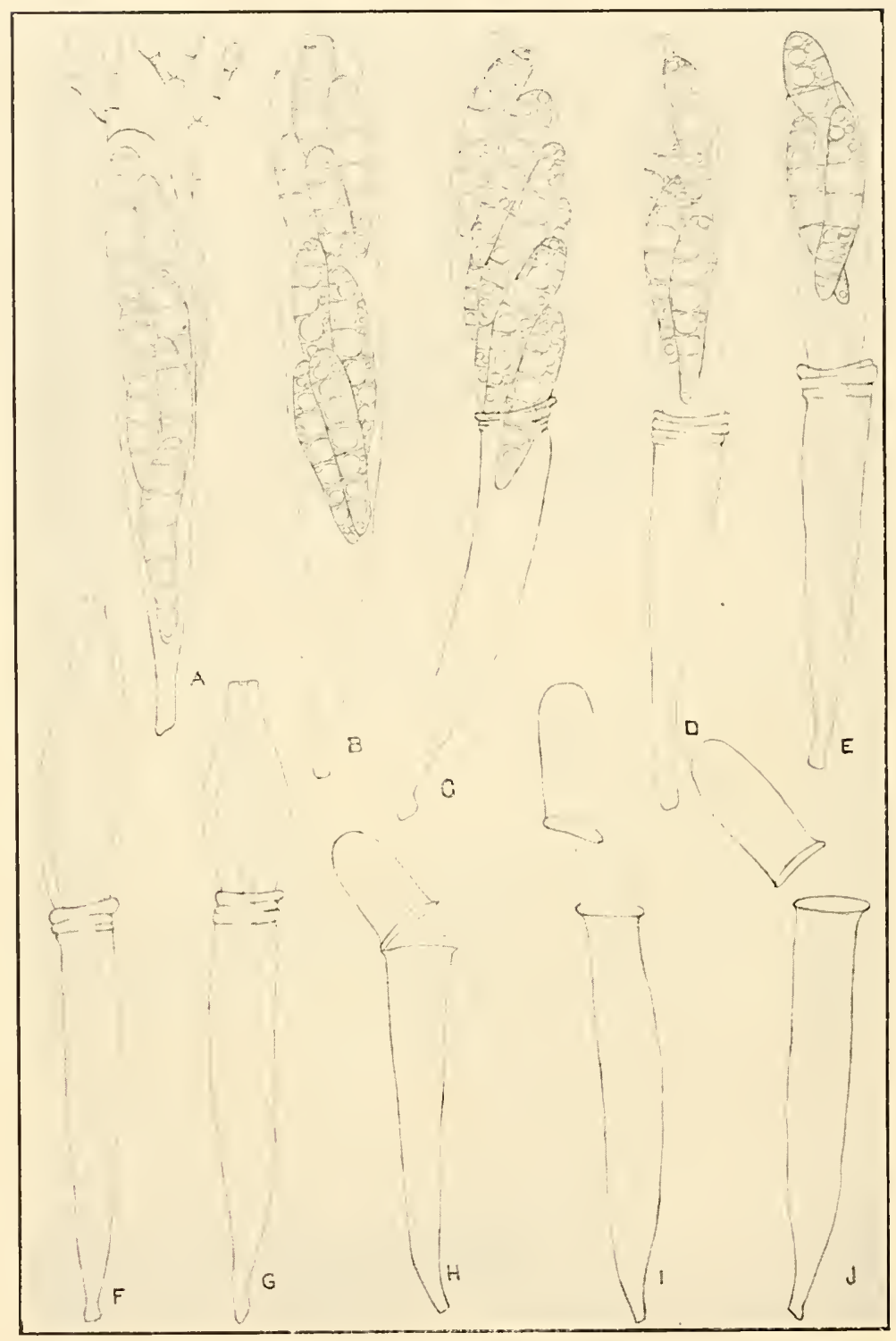

FIG. 23. Various stages in the discharge of the spores from the extrucled endoascus in Iecanidion atratum (Patellaria atrata). From E. T. Butler. 
have been found capping the endoascus. If this is not true, what is the significance of the thimbles always found in the field or making an examination of the species. Perhaps more field study may serve to answer this question.

From her studies Mliss Butler concludes that the Patellariaceae do not belong with the stomatous discomycetes, but are more closely related to the disco-lichens on the one hand and the pyrenomycetes on the other. The following suggestions are offered:

\section{I)iscomicetots Fuxgl}

Spores discharged directly through a definite pore (ascostome) in the ascus wall.

Stonatae.

Ascostome provided with a lid (operculum).

Ascostome without lid.

Operculatac. Inoperculatae. Spores not discharged directly through a definite pore or ascostome but from the encl of the protruding endoascus. AstonataE.

The Astomatae would include Patellaria and a number of genera now placed in the Patellariaceae and possibly the discolichens. The absence of a definite ascostone may be a morphological character on which to separate so-called disco-lichens from the other discomycetes or cup-fungi as now known.

The writer has been criticized and justly, on several points in his proposed classification. Nannfeldt claims that Phillipsica, Cookeina and Wynnea should be brought together because of the several characters which they share in common, i.e. the inordinately small and eccentrically placed ascostones, and the unequal sided, fusoid, longitudinally striated spores. We agree that these characters do indicate a close relationship and perhaps should take precedence over the external characters, such as the symmetrical or one-sided character of the apothecia, which were used in the proposed classification. Any classification adopted now is only tentative and doubtless many changes will be made as our knowledge advances.

\section{Nomenclature (page 33)}

When the original text of this work was published the writer followed the old American Code of Nomencłature, as indicated in the introduction. Since that time, however, in the interests of international harmony we have subscribed to the International Rules of Botanical Nomenclature, as adopted by the Cambridge Congress in 1930. Should these rules be applied throughout to 
the present work sone of the conclusions atopted would need to be reversed. Since, however, this work has been in general use throughout the world since 1928, such a reversal would not be in the interests of stability, and those conclusions are allowed to stand in the main as they were. However, in this supplementary work an attempt has been made to follow the International Rules, even though some of them, in our opinion, are not all that could be desired. A few illustrations will be given:

Chapter III, Section 3, Article 20 reads: "Legitimate botanical nomenclature begins for the different groups of plants at the following dates:

(d) Lichenes, 1753 (Linnaeus, Species Plantarum, ed. 1).

(e) Fungi: Uredinales, Ustilaginales and Gasteromycetes, 1801 (Persoon, Synopsis methodica fungorum).

(i) Fungi caeteri, 1821-32 (Fries, Systema mycologicum)."

From the above it will be seen that we have several different dates for the starting points of the nomenclature of the different groups of fungi, and under " $f$ " it will be noted that we have a sliding date 1821-32 for certain groups. This, in the opinion of the writer, is very bad and can only lead to confusion. It will be noted that the lichens, which are regarded as a highly specialized group of fungi, have as the starting point for their nomenclature 1753 , while the other ascomycetes have dates varying from 1821-32.

In carrying on studies of the Patellariaceate, under the writer's supervision, it was found after extended observations by Miss Ellys Butler that this family, which had usually been placed with the Pezizales, showed a much closer relationship with certain genera of the so-called lichens than with the non-algicolous discomycetes. If the plants of this family are placed with the lichens they have as the starting point for their nomenclature 1753. If, on the other hand, they are regarded as non-algicolous discomycetes they will have as the starting point 1822. Theoretically at least the nomenclature of this family would be entirely overturned if they are regarded as lichens. This, in the writer's opinion, is an unfortunate condition of affairs. Every individual fungus in the last analysis has its own starting point, and we believe that the first name applied to a fungus since the binomial system of nomenclature was adopted should be used. If it is necessary to use any other date than 1753 we believe that there should at least be one date for the starting point for all fungi. 
In the Amsterdam Congress of 1935 an amendment was proposed by C. II. Dodge (Ann. Missouri Bot. Gard. 21: 709-712. 1934) whereby this could be accomplished, and the date 1821 adopted as the starting point for the nomenclature of the fungi. Some discussion followed but no action was taken.

In 1821 S. F. Gray, in his Natural Arrangement of British Plants, adopted a number of fungus genera which were used for the first tine with binomial combinations. One of these chanced to be a genus of the operculate cup-fungi, the genus Scodellina, the name having been taken up from Micheli. The first species mentioned under this genus was $S$. leporina, which would be regarded as the type. When Fries' Systema Mycologicum was published in 1822 no mention was made of this genus, and the type species was listed as a species of Pesiza. Vears later, in 1869, Fuckel established the genus Otidea on the same type used by S. F. Gray in 1821. If we applied the International Rules of Nomenclature in this case, Scodellina of S. F. Gray, adopted in 1821 and used in the present work, would need to be replaced with Fuckel's genus Otidea, published 48 years later, and all this merely because S. F. Gray used the genus a year before Fries' Systema Mycologicum was published, and perhaps he was not even aware of S. F. Cray's work. Under the circumstances it would seem to the writer that the name Scodellina should be validated for this genus by the Congress.

Not only would a strict application of the International Rules affect some of the genera, as indicated above, but a number of the specific names likewise would need to be altered. To illustrate-Fries in 1815 established the genus Rhizina with Elvela inflate as the type. This was taken up in his Systema Mycologicum with Rhisina undulata as the type species and Elvela inflata Schaeffer cited as a synonym. Just why he replaced the name inflata with undulata is not apparent. However, Rhisina inflata is the combination used in this work and also previously used by Saccardo in his Sylloge Fungorum. If we wish to follow the International Rules the name influta would need to be replaced by undulata, upsetting both priority and current usage. Such a procedure would seem inexcusable. Of course such names could be retained in nomina conservanda but this to be legal would need action of the Congress which would require years. In the meantince what is the poor monographer to do? 
As another illustration let us take the well known species Lasiobolus equinus founded on Elvela equina proposed by Müller in 1778. The first name used by Fries for this species was Ascobolus pilosus, notwithstanding the fact that three specific names had been proposed for this species before Fries published this part of his Systema Mycologicum in 1822. Under the International Rules the Friesian name would have to be used and the other three discarded, and that in spite of the fact that the binomial used in this work more than a dozen years ago had previously been employed in all recent monographs of the group.

Still another case is Pesiza ancilis Pers. and Pesisa perlata Fries, here regarded as synonyms. The specific name ancilis not only has priority but has been used here and in other monographs of the group. Again application of the International Rules would require that the prior name proposed by Persoon be replaced by the one given by Fries.

The above examples will serve to illustrate the fact that the adoption of a recent date or sliding dates as a starting point for the nomenclature of the fungi has not been one hundred per cent efficient in bringing about stability of nomenclature. In fact, it is a question whether it has any advantage whatsoever and in many cases, such as cited above, has defeated the very end for which it was devised. The adoption of a multiplicity of starting points for the nomenclature of the various groups of fungi is the weakest link in the whole chain of International Rules.

\section{Parasitism}

In sharp contrast with the inoperculate cup-fungi parasitism is almost unknown among the operculate forms, few species being even under suspicion, while many of the inoperculates are destructive parasites. As there are exceptions to every rule, so there is at least one to this. Rhizina inflata while appearing to be strictly a saprophyte may become at least a facultative parasite. James R. Weir seems to have been one of the first in this country to call attention to the destructive work of the fungus. In the Journal of Agricultural Research (4: 93-95. 1915) he writes:

"Considerable doubt exists regarding the parasitism of Rhisina inflata (Schäff.) Sacc. (R. undulata Fr.). This peculiar fungus (Pl. VIII, figs. 1, 2, and 3) occurs quite abundantly on the ground in the forest-fire areas of the Northwest. Usually 
found as a saprophyte on the burned forest soil, it attracted little attention until the close proximity of the fruiting bodies to dead coniferous seedlings was noted to be of frequent occurrence. A close examination of the roots of the dead seedlings showed the mass of white mycelium clinging to and ramifying in the cortical tissues of the root to be in connection with the near-by fruiting structures of Rhisina inflata. In some cases the sporophores of this fungus surrounded the stem of the seedling."

From his own experiments Weir concludes that the species is an active parasite on the seedlings of a number of conifers in the Northwest.

In Mycologia (27: 452. 1935) S. M. Zeller writes:

"Associated with and parasitic in roots of Pinus contorta in Sandy Hummocks near the ocean beach at Big Creek, Lincoln County. There were great quantities of the fruiting bodies in the sand covering an area about 30 feet in diameter. If this fungus is not parasitic it at least smothers seedlings 2 to 3 years old. This is the first report of the species west of Idaho."

It is not unlikely that other species which have been considered harmless saprophytes may be found under proper conditions to be parasitic or at least to become facultative parasites. 


\section{ADDITIONS AND CORRECTIONS}

Numbers in the extreme left margin preceding the names in heavy type refer to pages in original text.)

46. Sphaerospora brunnea.

Range extended north to New Hampshire (F. J. Seaver).

\section{Pseudoplectania vogesiaca.}

Range extended to Oregon (F. P. Sipe), Manitoba (G. R. Bisby \& A. H. R. Buller), British Columbia (J. Macoun), and south to Tennessee (L. R. Hesler).

\section{Pseudoplectania nigrella.}

Add: Exsiccati: Clements, Crypt. Form. Colo. 121.

Range extended west to Washington State (J. R. Hardison), north to New Hampshire (F. A. Molf), Mississippi (H. C. Eno, P. Spaulding \& J. R. Hansbrough), and south to Florida (E. IVest).

\section{Pseudoplectania fulgens.}

Add the synonym: Lamprospora fulgens Snyder, Mycologia 28: 484.1936.

Range extended to Manitoba (G. R. Bisby), Ontario (J. IV. Groves \& S. M. Pady), Washington (L. C. Snyder), and British Columbia (J. Macoun).

\section{Insert:}

3. Boudiera Walkerae Seaver, Mycologia 31:501. 1939. (Plate 47.)

Apothecia gregarious, sessile, at first subdiscoid soon expanding and becoming rounded and cushion-like with the ends of the huge asci protruding and giving the surface a roughened appearance, entirely white, reaching a diameter of $1 \mathrm{~mm}$; asci clavate, reaching a length of $225 \mu$ and a diameter of $40 \mu, 8$-spored; spores at first irregularly disposed, finally becoming 1 -seriate, at first smooth and filled with large oil-drops, the surface gradually becoming roughened, the roughenings finally assuming the form of long spines, reaching a diameter of $25-30 \mu$ including spines, or $18-20 \mu$ exclusive of spines, hyaline; paraphyses clavate reaching a diameter of $15 \mu$. 


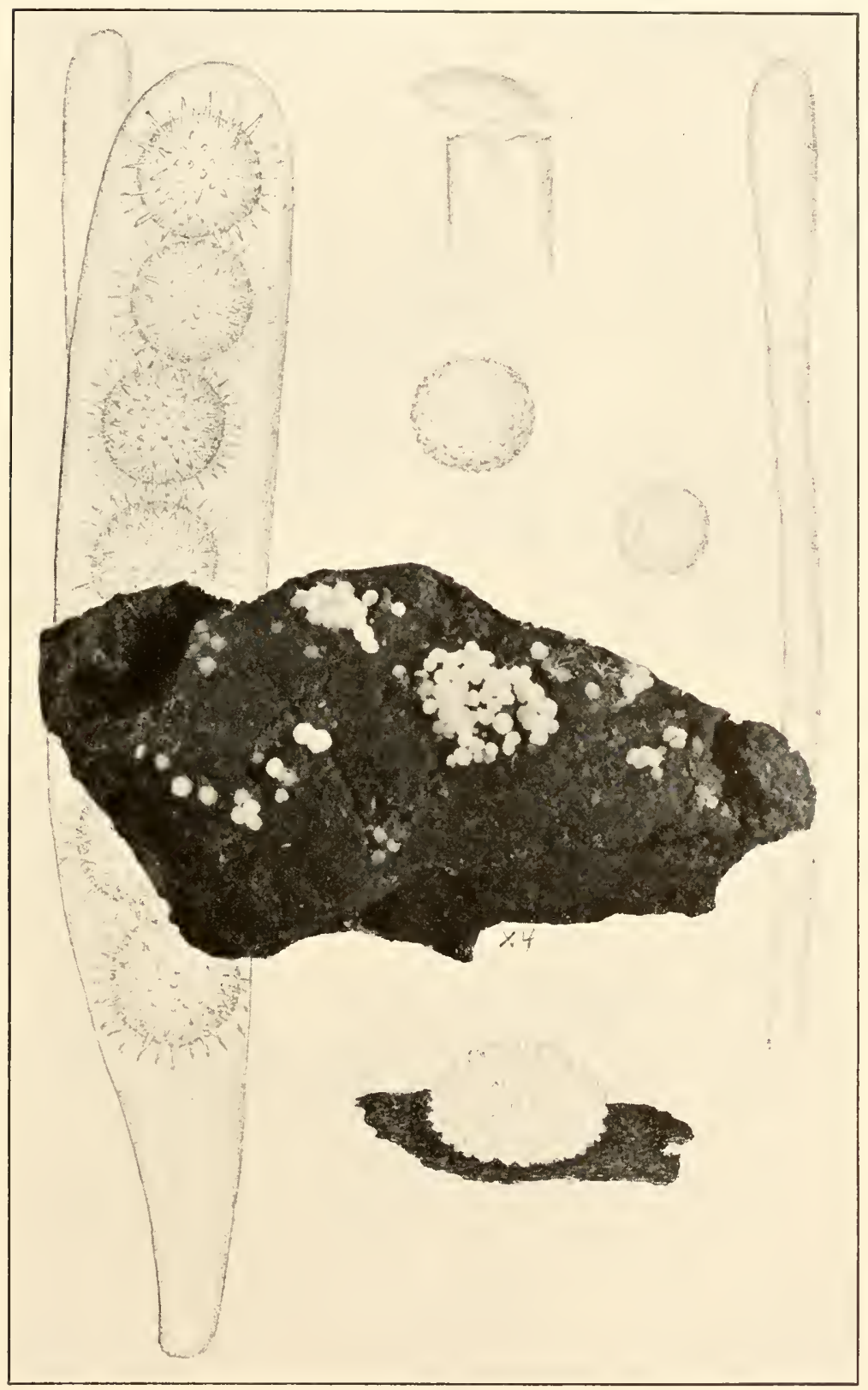

BOUDIERA WALKERAE 

On bare soil in the laboratory.

Type locality: Lincoln, Nebraski.

Distribution: Known only from the type locality.

In this species the asci open by means of an operculum, characteristic of the group. After the discharge of the spores the asci themselves partially collapse while the operculum seems to keep approximately its original size; so that the lid of the emptied asci appears to be too large for the ascus, as indicated in the sketch. This is just the reverse of conditions found in some of the other operculates in which the lid is very much smaller than the diameter of the ascus. even after the spores are discharged.

\section{Lamprospora spinulosa.}

Range extended to Iowa (G. IV. Martin), with a doubtful specimen from Oregon (J.R. Kienholz).

\section{Lamprospora Crec'hqueraultii.}

Range extended north to New Hampshire (F. J. Seaver) and west to Oregon (J. R. Kienholz).

\section{Lamprospora Wrightii.}

Range extended north to North Carolina (F. A. Wolf).

66. Lamprospora tuberculatella.

Range extended from New York to Maine (Roland Thaxter).

\section{Lamprospora haemastigma.}

Range extended to Iowa (B. Shimck) and ()regon (J. R. Kienholz).

69. Lamprospora Constellatio.

Range extended to Manitoba (G. R. Bisby) and Oregon (J. R. Kienholz).

\section{Lamprospora trachycarpa.}

Range extended to Panama (C. IV. Martin).

\section{Lamprospora Detonia.}

Add the synonym: Phaeopezin Detonia Sacc. Syll. Fung. 24: 1206.1928.

\section{Lamprospora leiocarpa.}

This species has been reported from Japan (Bot. Mag. Tokyo 52: 362. 1938). 


\section{Lamprospora Planchonis.}

This species has been collected in Africa, R. Maire, Mỵc. Bor.-Africana 192. 1914.

76. Insert:

31. Lamprospora sphagnicola Seaver, Mycologii 26: 102. 1934. (Plate 48.)

Apothecia sessile at first globose and solid, reaching a diameter of $1 \mathrm{~cm}$., gradually expanding and becoming subdiscoid finally reaching a diameter of $3 \mathrm{~cm}$., externally whitish; hymenium strongly convoluted, at first light colored gradually assuming a lavender tint; asci cylindric or subcylindric, tapering into a rather abrupt stem-like base, 8-spored, reaching a length of $215 \mu$ and a diameter of $15 \mu$, spores at first irregularly disposed, finally becoming definitely 1 -seriate, hyaline or subhyaline, at first smooth, soon becoming sculptured reaching a diameter of 12-15 $\mu$; spore-sculpturing taking the form of tubercles or very short elongated ridges; paraphyses filiform rather strongly cnlarged above reaching a diameter of $4-5 \mu$.

On Sphagnum moss, in storage.

Trpe locality: Experiment Station, Georgia.

Distribution: Known only from the type locality.

The above species has not been enconntered since its publication in 1934. It should be included as no. 31 in the Key (page 56).

32. Lamprospora pyrophila Snyder, Mycologia 28:

$$
\text { 484. } 1936 .
$$

Apothecia scattered to gregarious, sessile, at first globose, becoming expanded and discoid, with an even margin, reaching a diameter of 3-5 $\mathrm{mm}$, externally smooth, salmon-pink; excipulum consisting of interwoven, swollen-celled hyphae; hymenium plane, smooth, salmon-pink; asci cylindrical, $150-200 \times 10-12 \mu$, 8 -spored; spores 1-seriate, globose, 7-9 $\mu$ in diameter, smooth; paraphyses filiform, hooked at their apices, often forked.

On burnt ground.

Type Locality: Canyon Park, Bothell, Washington.

Distripution: Known only from the type locality.

ILLustrations: Mycologia 28: $485, f .1 b$.

Said to be distinguished from $L$. carbonaria by its much smaller spores and absence of oil-drop.

\section{Pithya pithya.}

Add: Exsiccati: W. B. Cooke, Mycol. N. Am. 92 (as Pithya anlgaris Fuckel). 


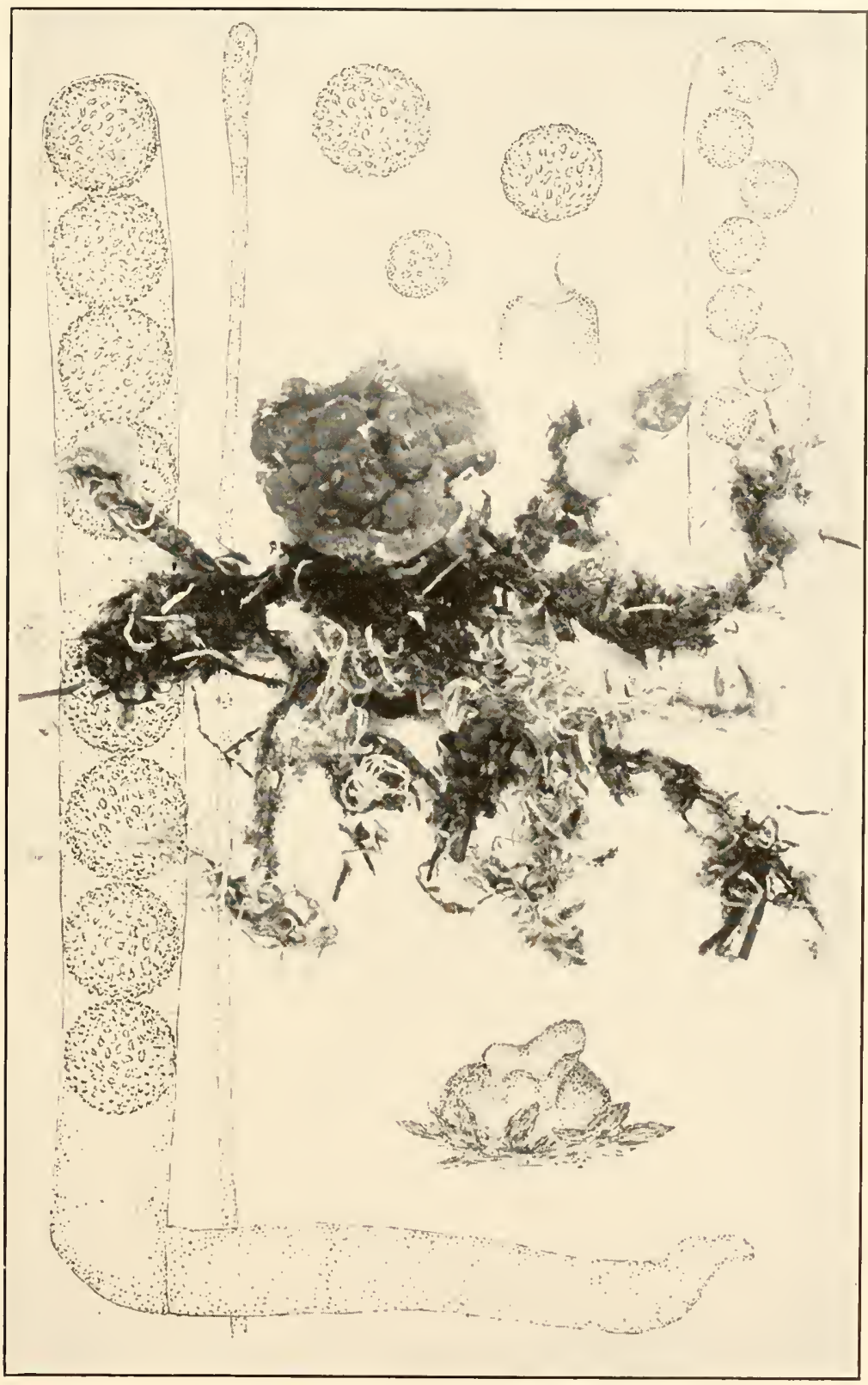

LAMPROSPORA SPHAGNICOLA 

Add the note: IV. B. Cooke has used the name Pithya vulguris Fuckel instead of Pithyo pithye (P'ors.) Gill., the International Congress having ruled out duplicate binomials. Since the name used by the writer was also pre-Friesian perhaps it is preferable to adopt the name used by Cooke, Pithya vulgaris Fuckel.

\section{Pithya Cypressi.}

Range extended to North Carolina (F. A. Wolf).

81. Insert:

Cubonia bulbifera Hotson, Proc. Am. Acad. 48: 242. 1912 .

"Plants single or gregarious, often crowded, sessile or narrowed to a stem-like base, turbinate, 3-10 $\mathrm{mm}$. in diameter. Disk cupulate or saucer-shaped, the hymenium pale fawn-color, even when young, but in old specimens wrinkled in a cerebriform manner, externally much darker, becoming almost black with age, smooth or grumous; margin irregularly lacerate-dentate. Consistency subgelatinous, excipulum pseudoparenchymatous throughout, of nearly rounderl cells, $20-25 \mu$ in diameter, the cortical cells blackish, often protruding in groups. Asci clavate, apex rounded, not blue with iodine, $125 \times 15 \mu$. Spores 8 , uniseriate, hyaline, smooth, spherical, $12 \mu$ diameter. Paraphyses slender, hyaline, only slightly thickened upward. Mycelium giving rise to numerous rounded, black bulbils, 75-100 $\mu$ diameter, composed of rounded cells about $20 \mu$ diameter."

"Cultivated on nutrient agar. Found on dog dung from Jamaica, Paestum (Italy), Guatemala and California, and pig dung from Guatemala."

The writer has no personal knowledge of this species.

\section{Ascobolus.}

Add the synonym: Dasyobolus Sacc. Syll. Fung. 11: 421. 1896.

\section{Ascobolus viridulus.}

Range extended to Florida (E. W'est), and Quebec (Myc. Foray).

\section{Ascobolus magnificus.}

Add the synonym: Papulaspora magnifica Hotson, Bot. Gaz. 64: 277. 1917. For illustration see introduction.

Range extended to Connecticut (G. S. Torrey), Bermuda (F. J. Seaver \& J. M. Waterston), Dominican Republic, Colombia 
(C. E. Chardon) and China (C. K. Lin). Probably will be found to be widely distributed.

87. Ascobolus carbonarius.

Range extended to Oregon (J. R. Kienholz), and Quebec (Myc. Foray).

\section{Ascobolus geophilus.}

Range extended to Virginia (E. M. Betts).

Add the note: Heterothallism was demonstrated in this species and fully discussed by E. M. Betts and S. L. Meyer (Am. Jour. Bot. 26: 617-619. 1939.). See introduction.

\section{Ascobolus striisporus.}

Range extended to Ohio on dead leaves (IV. B. Cooke), Colorado on poplar bark (F. J. Seaver \& P. F. Shope), and Michigan on decaying leaves (G. B. Cummins).

\section{Saccobolus Kerverni.}

Range extended to Quebec (Myc. Foray).

\section{Saccobolus depauperatus.}

Range extended to Quebec (Myc. Foray).

\section{Aleuria aurantia (Plate 49).}

Add the note: Specimens collected by C. IV. Dodge and IV. S. Thomas in Costa Rica appear to be this species, so far as one can judge from the spores. Notes on the specimens, however, seem to indicate a brighter color "hymenium flame scarlet" than is usual for this species. It is possible that the tropical material is different.

\section{Aleuria wisconsinensis.}

Range extended to North Carolina (L. R. Hesler), and Michigan (A. H. IV. Povah).

\section{Aleuria cestrica.}

Range extended to Kentucky (F. T. McFarland), North Carolina (L. R. Hesler), and Panama (G. W. Martin). It had also been collected in New York State and reported from Tennessee.

\section{Aleuria bicucullata.}

Range extended to include New Jersey (F. J. Seaver) and Florida (G. F. Weber) with a doubtful specimen from Now York (S. H. Burnham). 


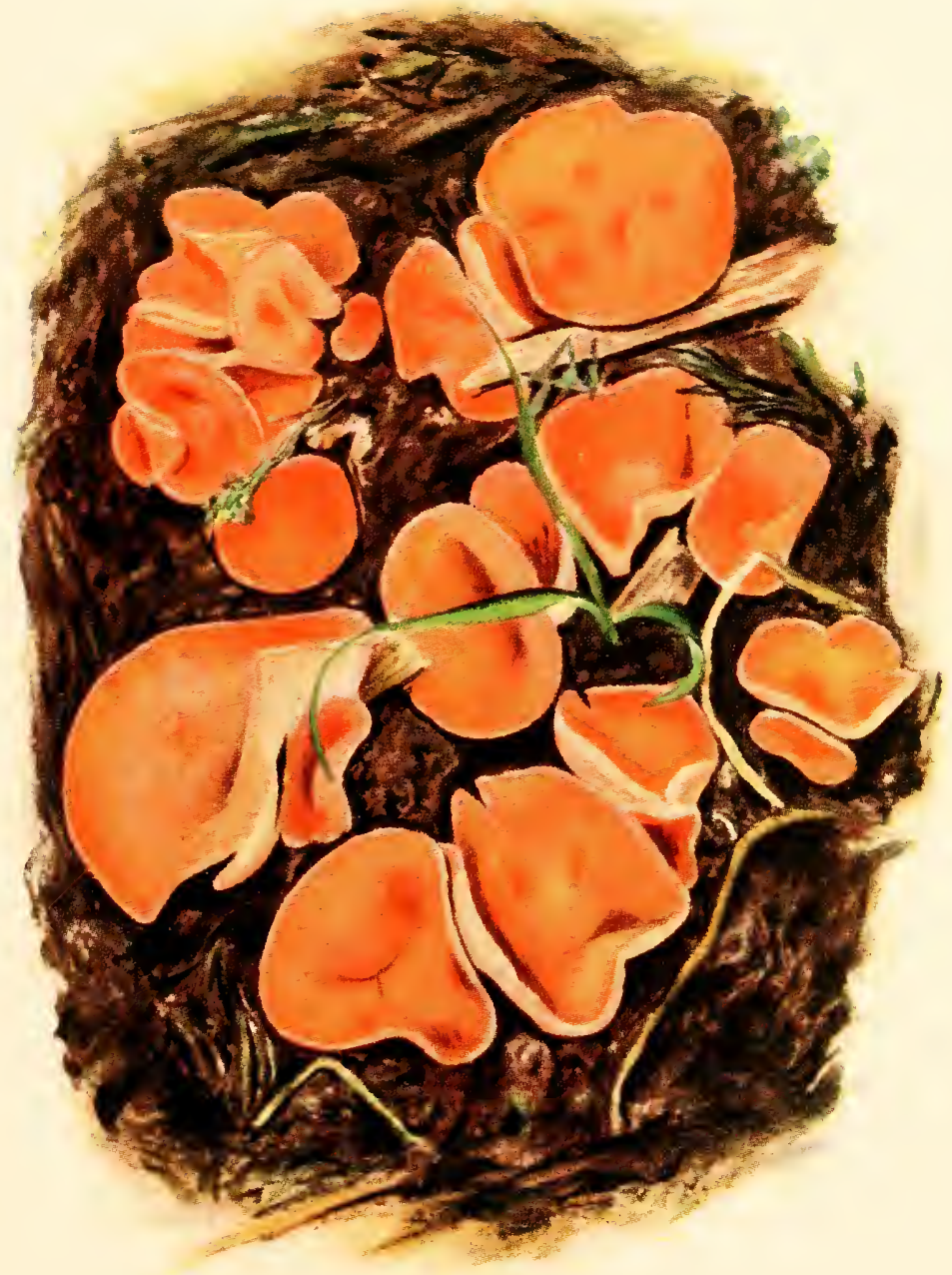

ALEURIA AURANTIA 

99. Aleuria rhenana.

Range extended to New York (F. S. Boughton), and New Hampshire (Myc. Foray); also a doubtful specimen from Japan (A. Yasuda).

\section{Aleuria rutilans.}

Range extended to Washington State (J. F. Flett), and Puerto Rico (C. E. Chardon); also a doubtful specimen from Colorado (L. O. Overholts).

\section{Aleurina atrovinosa.}

Range extended to Tennessee (L. R. Hester), Virginia (IT. A. Murrill), New Hampshire (F. J. Seaver), Vermont (C. IV. Dodge), Massachusetts (S. Davis), and Connecticut (F. J. Seaver).

\section{Melastiza Charteri.}

Range extended to Winnipeg (G. R. Bisby).

\section{Melastiza asperrima.}

Range extended to Costa Rica apparently on banana stems

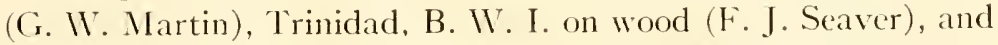
Canal Zone on petioles of Panama oil palm (M. A. Howe).

\section{Melastiza pennsylvanica.}

Range extended to Kentucky (H. Bishop).

\section{Psilopezia nummularia.}

Range extended to Michigan (A. H. W. Povah), and Costa Rica (C. IV. Dodge, G. Catt \& II. S. Thomas). Costa Rican specimens reach a diameter of $2 \mathrm{~cm}$.

\section{Psilopezia hydrophila.}

Range extended to New Hampshire (Myc. Foray).

\section{Psilopezia aquatica.}

Range extended to Utah (A. O. Carrett).

\section{Pyronema omphalodes.}

Range extended to Bermuda (F. J. Seaver), the Bahamas (L. J. K. Brace), Dutch East Indies (K. B. Boedijn), and China (C. T. Wei) where the fungus was reported on soil which had been heated to high temperature. 


\section{Ascophanus Holmskjoldii.}

Range extended to Oregon (J. R. Kienholz); also on rabbit dung in Bermuda (F. J. Seaver).

\section{Ascophanus isabellinus.}

Collected on soil in conservatory of The New York Botanical Garden (B. O. Dodge).

\section{Ascophanus sarcobius.}

Add the note: Specimens collected in Bermuda on old banana leaves lying on the ground, a very unusual habitat.

\section{Ascophanus bermudensis.}

Range extended to Florida (E. West).

\section{Ascophanus lacteus.}

Range extended to Quebec (Myc. Foray).

\section{Ascophanus argenteus.}

Range extended to Michigan (A. H. II. Povah).

\section{Ascophanus Aurora.}

Add the synonym: Ascophanus cervinus Povah, Papers Mich. Acad. 13: 175. 1930.

\section{Ascophanus carneus.}

Range extended to Colombia and Venezuela (C. E. Chardon), Ontario (R. F. Cain), and Quebec (Myc. Foray).

\section{Ascophanus granulatus.}

Range extended to Winnipeg (G. R. Bisby), California (C. F. Baker), Puerto Rico (B. Fink), Dominican Republic and Venezuela (C. E. Chardon), and Bermuda (F. J. Seaver).

\section{Ascophanus granuliformis.}

Range extended to Oregon (J. R. Kienholz), and Bermuda (F. J. Seaver).

\section{Ascophanus ochraceus.}

Range extended to Ontario (R. F. Cain).

\section{Ascophanus cinereus.}

Range extended to Oregon (J. R. Kienholz). 


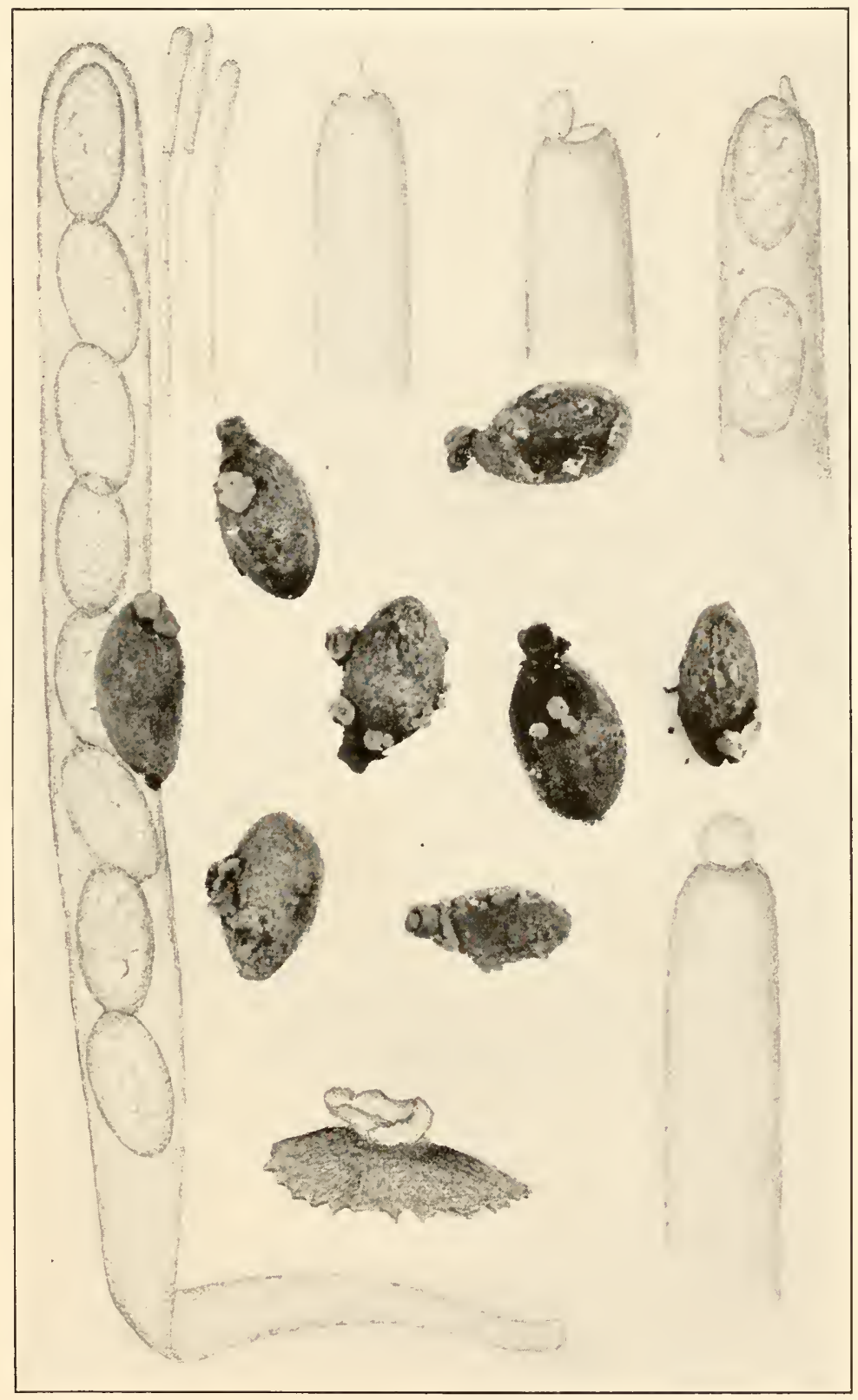

HUMARINA WATERSTONII 



\section{Humarina testacea.}

Add: Exsiccati: Rav. Fungi Am. Exsicc. 176. (Is Ascobolus carneus P.)

Range extended to Oregon (I. R. Kienholz).

\section{Humarina convexula.}

Range should include New Jersey and Halifax.

129. Humarina leucoloma.

Range extended to Ontario (G. R. Bishy), and Oregon (J. R. Kienholz).

\section{Humarina araneosa.}

One doubtful specimen from Ontario (G. R. Bisby).

\section{Humarina semiimmersa.}

Range extended to Ohio (IV. B. Cooke), California (E. E. Morse), Winnipeg (G. R. Bisby \& IV. L. Gordon), and Oregon (J. R. Kienholz).

\section{Humarina ochroleuca.}

See Geopyris rulcanilis (p. 214) for discussion.

\section{Humarina aggregata.}

Range extended to Virginia (C. R. Orton), and Manitoba (G. R. Bisby).

\section{Humarina coccinea.}

Range extended to Washington State (T. C. Frye).

\section{Humarina hepatica.}

Range extended to Oregon (J. R. Kienholz).

\section{Humarina trachyderma.}

Range extended to Manitoba (C. R. Bisby).

140. Insert:

33. Humarina Waterstonii Seaver, Mycologia 31:

$$
\text { 533. 1939. (PLATE 50.) }
$$

Apothecia occurring singly or in cespitose clusters, sessile or subsessile, early expanding and becoming shallow cup-shaped or subdiscoid, reaching a diameter of $4-5 \mathrm{~mm}$., externally whitish; hymenium slightly concave, bright red, almost scarlet; asci cylindric or subcylindric, reaching a length of $300 \mu$ and a 
dianeter of $16 \mu$, tapering leclow into a stem-like base 8 -spored; spores 1-seriate cllipsoid, slightly narrowed toward either end denscly filled with oil-drops and granules, smooth, hyaline about $14-16 \times 24-26 \mu$; paraphyses about $2 \mu$ in diameter gradually enlarged above to $4 \mu$.

On partially buried seeds of Livistona chinensis.

Distribution: Known only from the type locality.

IlLustratiovs: Mýcologia $31: 535, f$. 1 .

\section{Pseudombrophila deerrata.}

Range extended to New York (L. R. Hesler).

\section{Ryparobius sexdecimsporus.}

Range extended to California (O. A. Plunkett), Oregon (J. R. Kienholz), and Quebec (Myc. Foray).

\section{Ryparobius crustaceus.}

Range extended to Quebec (Myc. Foray).

\section{Ryparobius monascus.}

Range extended to Quebec (Myc. Foray).

\section{Thecotheus Pelletieri.}

Range extended to Oregon (J. R. Kienholz), and Quebec (Myc. Foray).

\section{Sepultaria.}

Add the note: The genera Sepultaria and Sarcosphaera have the same subterranean or semisubterranean habits. The sandloving Sarcosphaera ammophila grows at first entirely submerged as do some species of Sepultaria. The two genera differ in that Sepultaria has cups clothed on the outside with long brown hairs, while in Sarcosphaera they are naked so far as hairs are concerned.

149. Sepultaria arenicola (Plate 51 Fig. 2).

Add the note: Since writing the early chapters of this work the writer is able to supply a photograph made by Mr. S. C. Edwards from material collected at Colton, California; also. material was supplied by him.

When the Swedish material, supplied by Nannfeldt, and the Californian are placed side by side they could not be more alike if they had been parts of the same collection. The species is widely distributed. In Colorado, and doubtless other places, 


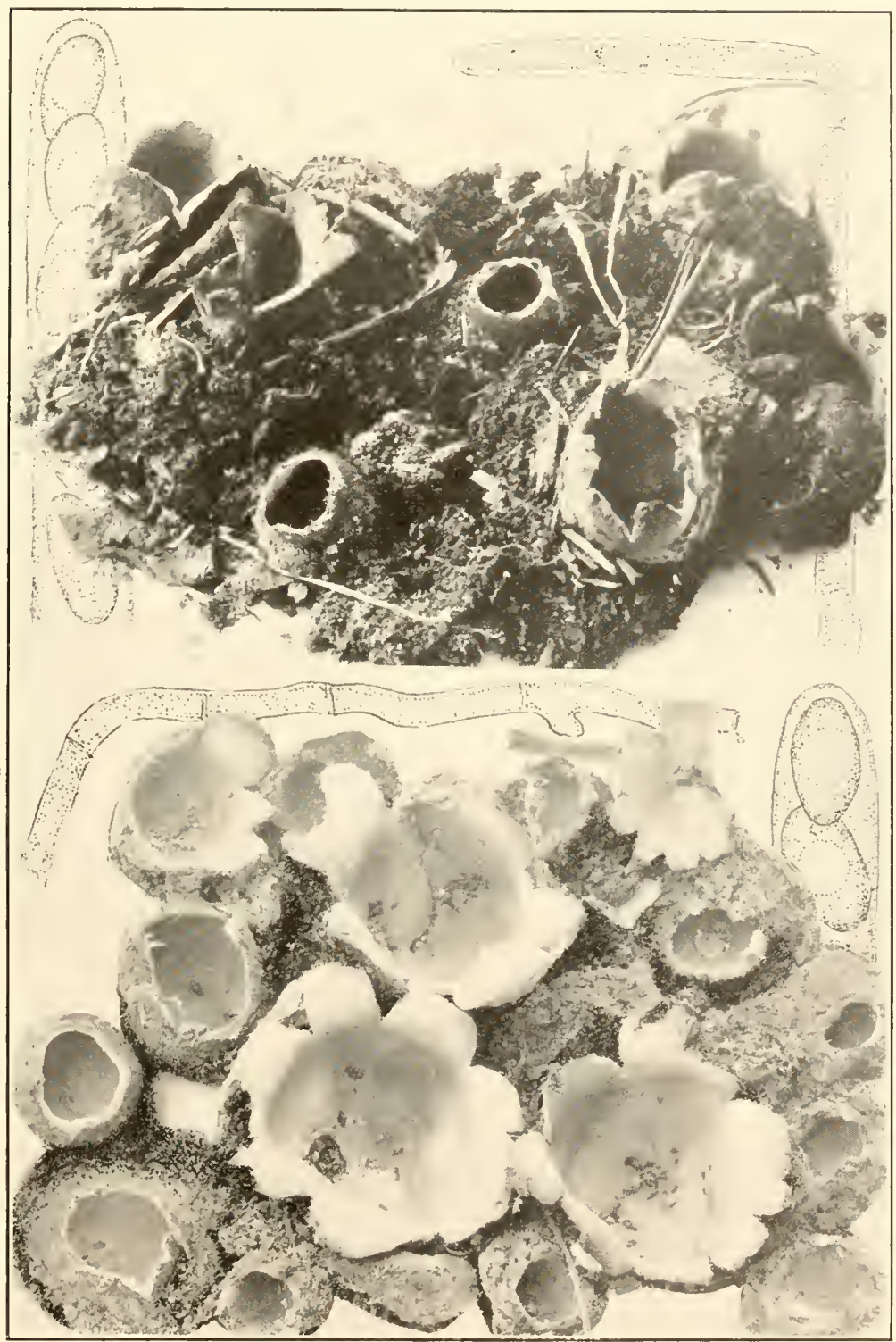

1. SEPULTARIA AURANTIA

2. SEPULTARIA ARENICOLA 

it is known as "The Hole in the Ground," a name which is just as fittingly also applied to Sarcosphaera ammophila and for similar reasons. See discussion under latter name.

\section{Sepultaria aurantia. (PLATE 51 FIG. 1).}

Add the synonym: ?Lachnea hybrida Sacc. Syll. Fung. 8: 168. 1889 .

Range extended to Colorado (F. J. Seaver \& P. F. Shope).

Add the note: This species was listed in the first part of the work, but at that time no material had been seen. During the summer of 1929, while collecting with Dr. Shope about the University of Colorado Summer Camp, an abundance of what appears to be this species was collected. The apothecia were more than half immersed in the ground or entirely so when young, and opened with the splitting characteristic of this species and exposing the egg-yellow or pale-orange hymenium, which is very different from the creamy-white hymenium of the previously named species. The color is suggestive of Pezisa hybrida, but the writer is not sure that they are the same.

\section{Pseudopithyella minuscula (Plate 52).}

Re-collected and apparently well established in Bermuda 1938 and 1940 (F. J. Seaver \& J. M. W' Taterston).

Recently reported from Yosemite National Park, California, on incense cedar Libocedrus decurrens. See Yosemite Nature Notes 20: 98-99. 1941.

\section{Perrotia flammea.}

Add the synonyms: Peziza atrofuscata Schw. 'Trans. Am. Phil. Soc. 1I. 4: 174. 1832. Lachnella atrofuscate Sacc. Sỳll. Fung. 8: 399. 1889. Dasyscypha rubrifulie Clenents, Bull. Torrey Club 30:89. 1903.

Range extended to Oregon (S. M. Zeller).

Add to exsiccati: Clements, Crypt. Form. Colo. $8+$ (as Dasyscypha rubrifulia Clements).

\section{Lasiobolus equinus.}

Add the synonym: Lasiobolus longisetosus Povah, Papers Nich. Acad. 9: 258. 1928.

Range extended to Venezuela (C. E. Chardon), Manitoba (G. R. Bisby), and Quebec (Myc. Foray). 


\section{Patella cubensis.}

Range extended to Costa Rica (C. II. Dodge \& V. F. (iocrger), Dominican Republic and Venezuela (C. E. Chardon), Hawaii (O. Degener), and Bermuda (F. J. Seaver \& J. M. Waterston).

\section{Patella umbrorum.}

Range extended to New Hampshire (F. J. Seaver), California (L. W. Nuttall), and Costa Rica (C. IV. Dodge \& II. S. Thomas).

\section{Patella Lusatiae.}

Range extended to Vermont (A. M. Hadley), and Ontario (H. Haining).

\section{Patella miniata.}

Range extended to North Carolina (L. R. Hesler).

\subsection{Patella ovilla.}

Range extended to Quebec (Myc. Foray).

166. Insert:

\section{2a. Patella contradicta Seaver, Mycologia $32: 567$. 1940. (Plate 53.)}

Apothecia sessile, thickly gregarious or usually densely crowded, early becoming subdiscoid with the margin scarcely elevated, brown, reaching a diameter of $1-2 \mathrm{~mm}$., rarely slightly larger, clothed about the margin with an inconspicuous fringe of hairs; hymenium plane or slightly concave, same color as the outside of the apothecium; hairs relatively short, bristly, tapering into a rather sharp tip, usually consisting of several cells, the basal one strongly swollen and subglobose, hyaline or subhyaline, usually not exceeding $50-80 \mu$ in length and often much shorter; asci cylindric or subcrlindric, reaching a length of $125-160 \mu$ and a diameter of 12-16 $\mu, 8$-spored; spores usually 1 -scriate, broad ellipsoid, usually containing 2 oil-drops, about $10 \times 12-16 \mu$; paraphyses enlarged above, the tips reaching a diancter of $5 \mu$.

On soil where wood has been burned.

Type Locality: The New lork Botanical Carden.

Distribution: Known only from the type locality.

\section{Patella setosa.}

Range extended to Panama (G. Wr. Martin), and Winnipeg (G. R. Bisby). 


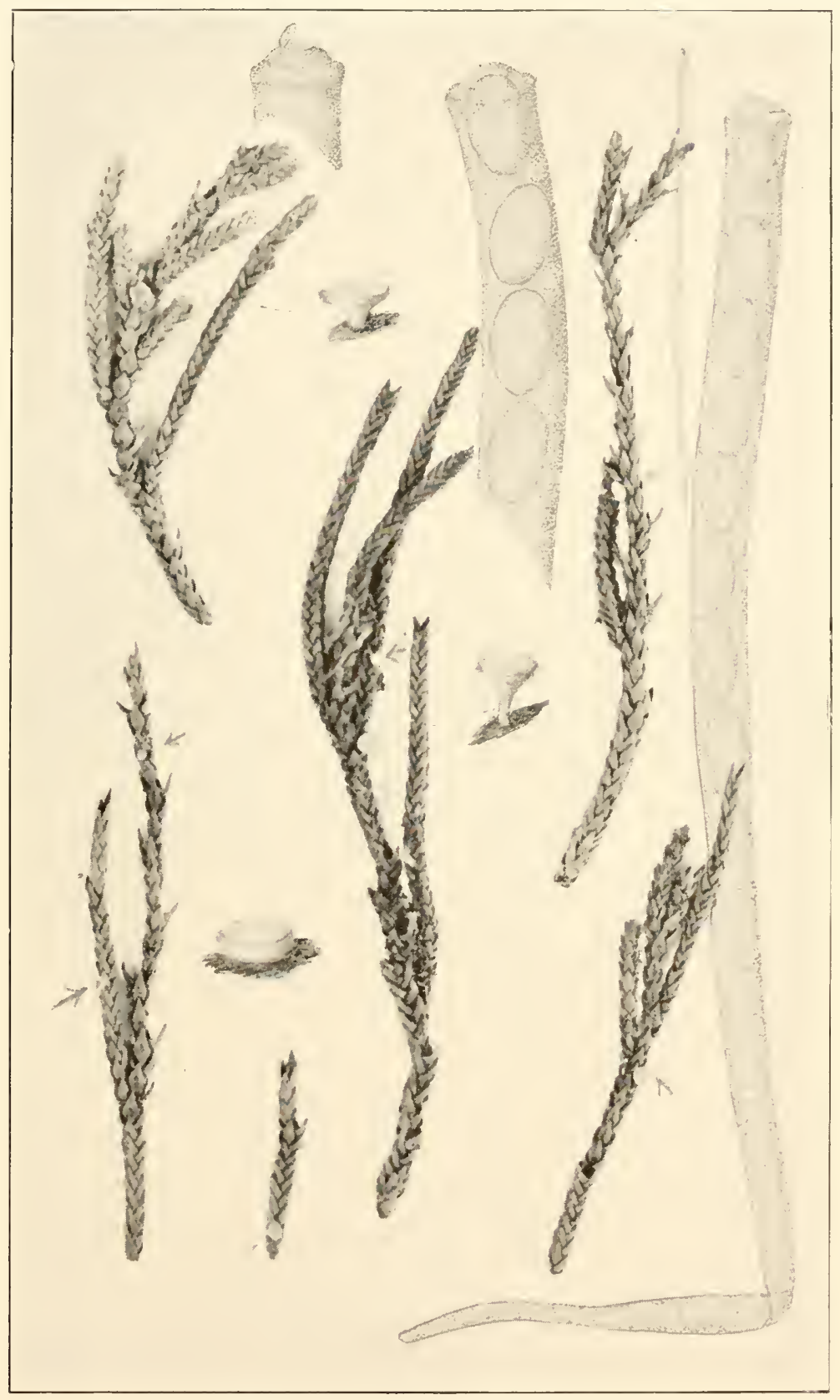





\section{Patella melaloma.}

Add the synonym: Inmarina macrocystis Snyder, Mycologia 28: 484. 1936 .

Range extended to Bermuda (F. J. Searer \& J. M. Waterston).

169. Patella stercorea.

Range extended to Winnipeg (G. R. Bisby).

\section{Patella theleboloides.}

Range extended to Costa Rica (C. IV. Dodge \& V. F. Coerger).

\section{Patella coprinaria.}

Range extended to Quebec (Ayc. Foray), Florida (IV. I. Murrill), and the Doninican Republic (C. E. Chardon).

\section{Patella pulcherrima.}

Range extended to Washington (J. R. Kienholz), Michigan (B. Kanouse), and Venezuela (C. E. Chardon).

174. Insert:

\section{4a. Patella michiganensis Povah, Mycologia 24:} 240. 1932 .

Scutellinia michiganensis Povah, Papers Nich. Acad. 20: 130. 1934.

"Apothecia gregarious, ochraceous-orange to cinnamon (R.), 0.3-0.7 mm. in diameter; clothed with simple, septate, brown hairs, $300-900 \times 30-50 \mu$, those hairs near the margin of the apothecium with an enlarged and often forked base, those hairs lower down on the apothecium with a tapering base; asci cylindrical $180-200 \times 9-10 \mu$, not staining blue with iodine, 8 spored; spores uniseriate, smooth, hyaline, elliptical, 13.5-15.5 $\times 8.5-9 \mu$; paraphyses slender, clavate at the tip where the diameter is $5.5 \mu$."

"Collected on July 16, 1930, by А. H. P'ovah on moose dung at Moose Lake, Tobin Harbor, Isle Royale, Michigan."

\section{Patella albida.}

Range extended to Quebec (Myc. Foray), Florida (H. E. Bratley \& E. West), Idaho (J. R. Weir), Manitoba (G. R. Bisby \& IV. L. Gordon), and Costa Rica (C. IV. Dodge \& W. S. Thomas).

\section{Patella Erinaceus.}

Range extended to Nebraska (Catharine Lieneman). 
178. Patella albospadicea.

Range extended to Oregon (J. R. Kienholz), and Tennessee (M. Shipe).

\section{Wynnea americana.}

Range extended to Pennsylyania (E. E. Honey). Also reported from Japan by S. Imai (Bot. Mag. Tokyo 52: 181. 1938 ).

Add to illustrations: Bot. Mag. Tokyo 52: pl. $2 f .5$.

\section{Phillipsia domingensis.}

Idd the synonyms: Peziza crispata Berk. \& Curt. Jour. Limn. Soc. 10: 367. 1869. Phillipsia polyporoides Berk. Jour. Linn. Soc. 18: 388. 1881. Geopyxis Ilarmoge Sacc. Syll. Fung. 8: 65. 1889. Phillipsia gigantea Seaver, N. Am. Cup-fungi 183. 1928.

Range extended to Costa Rica (C. WV. Dodge \& IV. S. Thomas), Panama (C. IV. Dodge), and Venezuela (C. E. (hardon).

\section{Phillipsia gigantea.}

Boedijn (see bibliography) has made this a synonym of Phillipsia domingensis claiming that the separation on size is unwarranted since the latter often reaches a diameter of $6 \mathrm{~cm}$.

\section{Phillipsia Chardoniana.}

Range extended to Florida (C. F. Weber), and the Dutch East Indies (K. B. Boedijn).

\section{Phillipsia dochmia.}

Range extended to Puerto Rico (N. L. \& E. G. Britton). 185. Scodellina leporina (Plate 54, FIG. 2).

Range extended to Winnipeg (G. R. Bisby), and New Hampshire (F. J. Seaver). Also reported from Japan by S. Imai (Bot. Mag. Tokyo 52: 185. 1938).

\section{Scodellina grandis.}

Range extended to W'ashington (J. B. Flett).

\section{Cookeina Tricholoma.}

Add the synonyms: Periza obliqua Zolling, Nat. Gen. Arch. Ned. Indië 1:383. 1844. Sarcoscypha obliqua Sacc. Syll. Fung. 8: 156. 1889. Pilocratera Tricholoma celebica Henn. Monsunia $1: 33.1900$. 


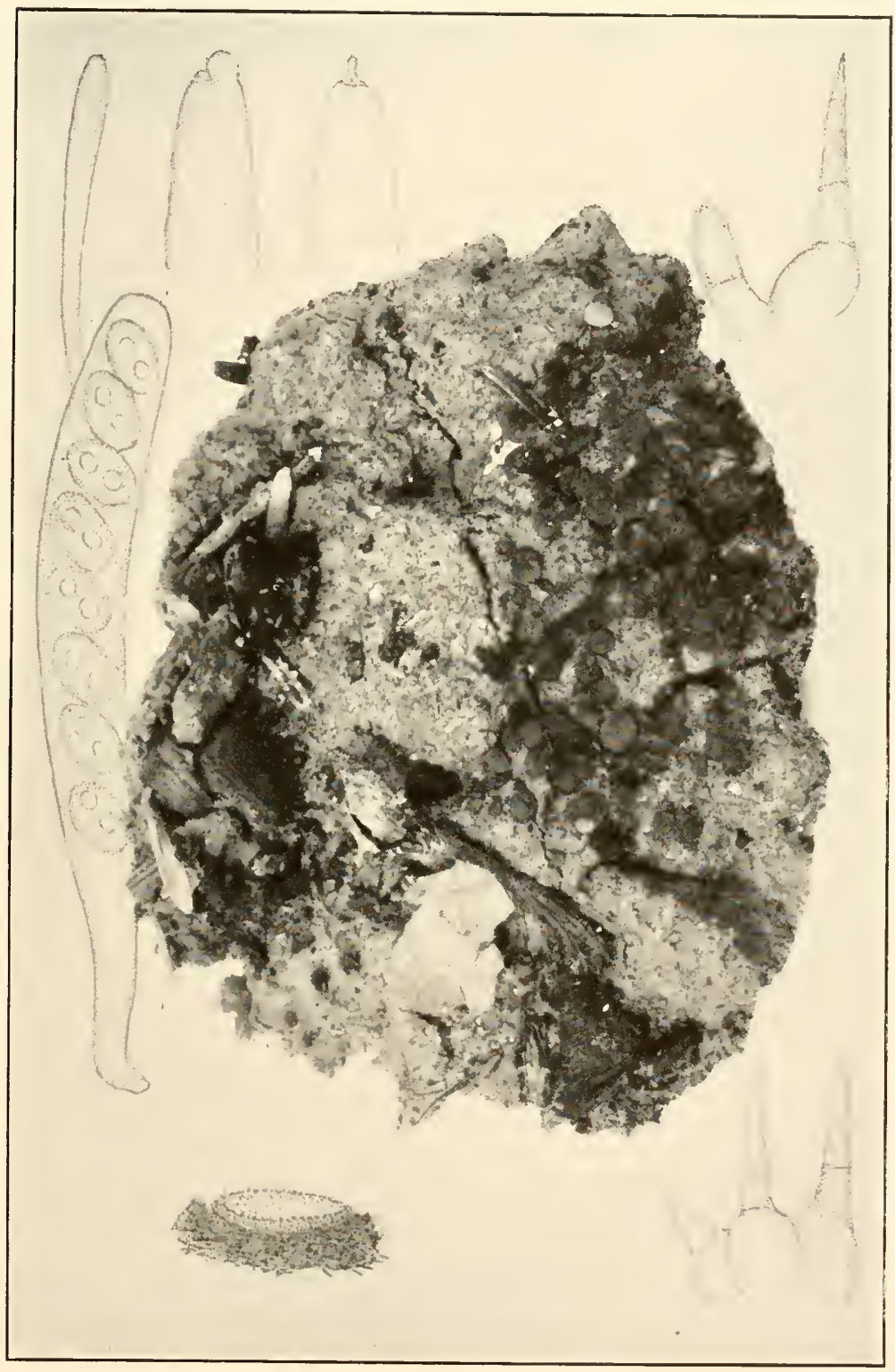

PATELLA CONTRADICTA 

188. Cookeina sulcipes.

Add the synonyms: Peziza aurantiaca stipitata Zoll. \& Mor.; Zoll. Nat. Gen. Arch. Ned. Indië 1:384. 1844. Peziza jazanica Nees; Lér. Ann. Sci. Nat. III. 3: 39. 1845. Peziza leptopus Pers. : Lév. Ann. Sci. Nat. III. 3: 39. 1845. Peziza amoena Lév. Ann. Sci. Nat. Ill. 3: 39. 1845. Geopyxis scabra Rehm, Hedwigia 28: 302. 1889. Trichoscypha amoena Sacc. Syll. Fung. 8: 64. 1889. Trichoscypha javanica Sacc. Syll. Fung. 8: 162. 1889. Cookeina amoena Kuntze, Rev. Gen. Pl. 2: 849. 1891. Cookeina javanica Kuntze, Rev. Gen. PI. 2: 849. 1891. Pilocratera cantareirensis Henn. Hedwigia 43: 208. 1904. Pilocratera maxima Sydow, Ann. Myc. 10: 82. 1904. Pilocratera nova-guineensis Ramsbottom, in Gibbs, Contr. Phytogr. Fl. Arfak Mts. 185. 1917. Cookeina sumatrana Boedijn, Trav. Bot. Neerland 26: 407. 1929.

\section{Cookeina tetraspora.}

Range extended to Costa Rica (C. W. Dodge \& W. S. Thomas), and Venezucla (C. E. Chardon \& R. Toro).

Boedijn (see bibliography) states that it is improbable that this species belongs with Cookeina. It might more properly be placed in IIumarina, but if this is done the name becomes untenable. It has much in common with IIumarina Waterstonii but is distinct in its 4 -spored asci.

\section{Cookeina Colensoi.}

Add to distribution: Venezucla and Brazil.

Range extended to Colombia (G. IV. Martin).

191. Plectania coccinea (Plate 55).

Range extended to California (J. IV. Cooke), Vermont (C. IV. Dodge \& D. H. Linder), Oregon (F. P. Sipe), and Florida (E. West).

\section{Plectania occidentalis.}

Range extended to Florida (E. West).

\section{Plectania hiemalis.}

Change the specific name in the first line of synonymy from "hiemale" to "hiemalis."

Change the specific name in the third line of synonymy from "prostrata" to "protracta," and the dates of this and the preceding citation to 1851 . 
This species has been reported from Japan by S. Imai (Bot. Mag. Tokyo 52: 362. 1938.). The combination Plectania protracte should be attributed to (ielin (1937) not Inai (1938).

Add the note: Olor E. V. Gelin (Kongl. Norske Vidensk. Selsk. 10: 194. 1937.) states: "In early spring 1851 Elias l'etrus Fries had the great pleasure of finding a beautiful spring fungus at Gottsunda in the neighbourhood of Uppsala. In the same year his father Elias Fries, the great mycologist, described the fungus in Novarum Symbolarum Mycologicarum Mantissa under the name of Pesiza protracta. Another interesting novelty is also described in the same work, viz. Peziza cruciata, collected by Th. M. Fries from the same locality, with the note "aestatis fine". The specimen, deposited in the Uppsala Botanical Museum, is typical $P$. protractu, and the date of collection must be a mistake. Seaver (1928) also considered $P$. cruciata as synonymous with $P$. protracta. Since the proposal, in 1869, of the genus Plectania by Fuckel, this fungus should be named Plectania protracta (Fries) Gelin, comb. nov., and not Plectania hiemalis (Nees et Bernst.) Seaver. This latter combination is due to a deplorable mistake by Seaver (1928) as to the year of publication of Fries' Nov. Symb. Myc. I nay here refer to the works of Heim (1925) and Seaver (1928) for the complete synonymy." The name Plectania protracta (Fries) Gelin should therefore be substituted for the name Plectania hiemalis.

\section{Doubtful Species.}

Add: Sarcoscypha imperialis (Peck) Sacc. Syll. Fung. 8: 157. 1889. Peziza imperialis Peck, Ann. Rep. N. I. State Mus. 29: 54. 1878. pl. 1,f.13-15. The description suggests Scodellina grandis except that the spores are too small. Nothing more is known of the species.

\section{Bulgaria.}

Add the note: The genus Bulgaria was established by Fries, as indicated in the early part of this work, several species now regarded as unrelated having been originally included since they all represented species with a more or less gelatinous apothecial structure. The first two of these were Bulgaria globosa with ellipsoid hyaline spores, and Bulgaria inquinans with unequalsided, colored spores. Also, the former has an operculate ascus and the latter an inoperculate, and under present day classifications belong to different sections of the Discomycetes. 


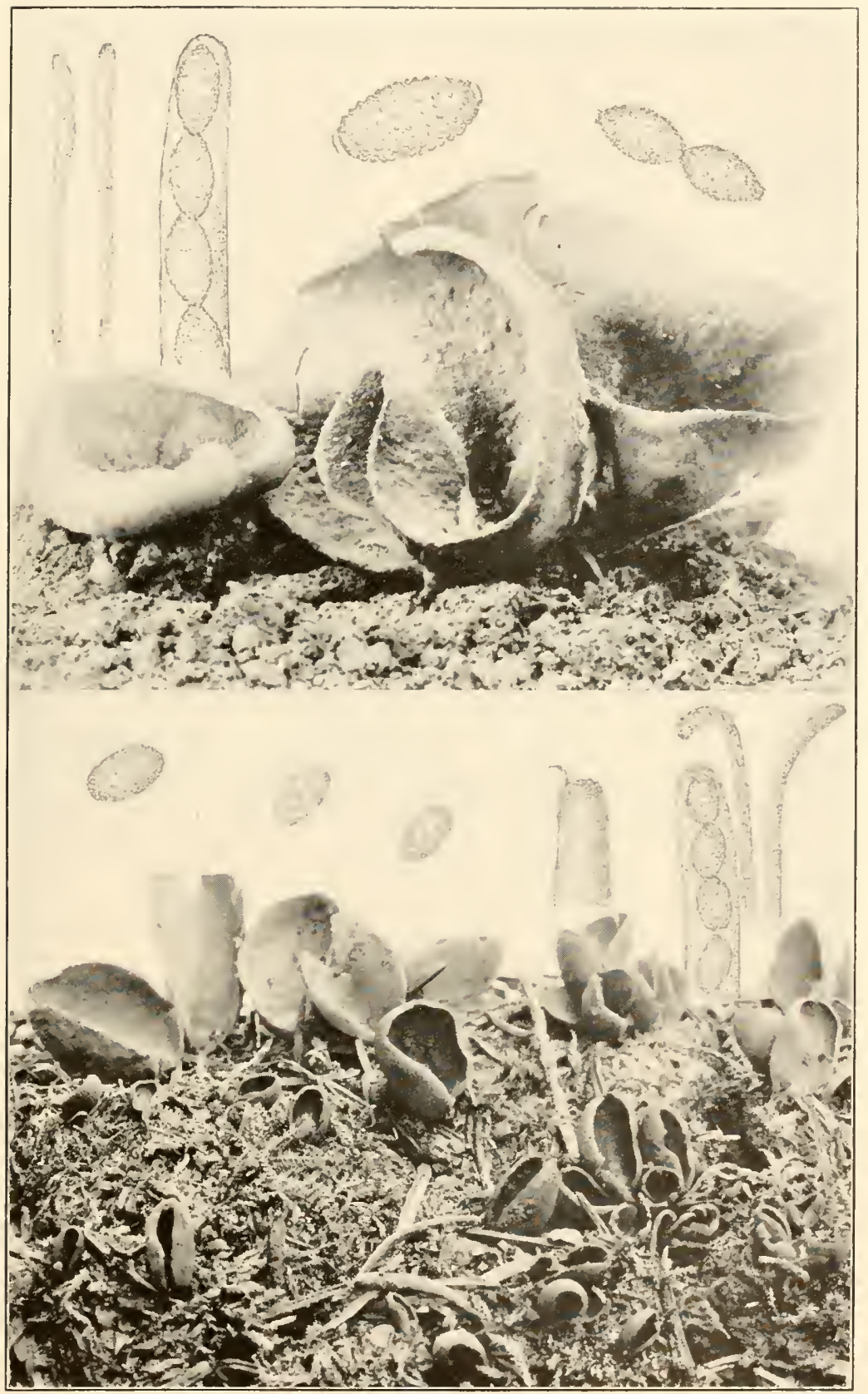

1. PEZIZA BADIA

2. SCODELLINA LEPORINA 

Since the first species mentioned by Fries under the genus was an operculate the name is retained for those forms, while those with inoperculate asci and colored spores are placed in the genus Phaeobulgaria proposed by the writer (Mycologia 24: 253) with Phaeobulgaria inquinans (Fries) Nannfeldt as the type species.

In 1937, Yosio Ĺobavasi (Jour. Japanese Bot. 13: 510-520) attempted to reverse the conclusions of the writer, using Bulgaria for the inoperculate forms, and reviving the old genus Sarcosoma for the operculate. Such a procedure would seem to be unjustified and to serve no useful purpose.

Perhaps the most common species of the genus Bulgaria as here recognized is Bulgaria rufa Schw. This species usually grows in dense cespitose clusters on decaying wood of various kinds and has thick, very gelatinous apothecia with a reddishbrown hymenium. Since no illustration was available for the species in the early part of this work a plate is here provided (PLATE 56). The upper figure on this plate represents a single apothecium about natural size, and was provided by Dr. IT. S. Thomas, author of "Field book of common gilled mushrooms," and is the best photograph yet seen of this species. The lower figure shows a large clump considerably reduced, and is an excellent habit photograph. This was provided by L. R. Hesler of the Iniversity of Tennessee.

A third species placed in this genus, somewhat reluctantly, by the writer is Bulgaria melastoma (Sow.) Seaver (p. 197); reluctantly, because while this species has been placed in various genera at different times so far as noted it had never been placed in Bulgaria. However, since writing the preliminary chapters of this work the writer has had the opportunity of examining a portion of the type of Sarcosoma cyttarioides Rehm, published by Durand (Jour. Myc, 9: 104. 1903) and finds it identical. Since Sarcosoma and Bulgaria, as treated here, are identical it would indicate that Rehm regarded this as a Bulgaria.

This species has a wide distribution throughout the temperate and tropical regions of the world. Since it was not illustrated in the early part of the work it is done here (PLATE 57). Tnfortunately it was necessary to use dried material. The wrinkling of the outside of the apothecia and the cracking of the hymenium are quite characteristic and since the apothecia do not shrink much in drying, the photographs will we trust serve the purpose intended. 


\section{Bulgaria globosa (Plate 74).}

In fourth line of synonymy change the specific name from "globosa" to "globosum."

Add the note: This species, formerly known in this country only from Toronto, has recently been reported as occurring in white pine woods in Oregon and Idaho by Sylvan Cohen. His technical description is as follows: "Apothecium single, sessile, entirely black; externally tomentose by virtue of the possession of flexuous brown hairs about $6 \mu$ in diameter; the substance mostly yellow-brown gelatinous internally, and enclosed by a thin tough black layer of hyphae which wrinkles strongly upon drying: specimens vary from $7.0-10.5 \mathrm{cms}$. in diameter and 6-7.5 cms. in height; hymenium slightly concave, more like a flat layer within the apothecium, sunken about $2 \mathrm{cms}$. into the cup-shaped structure, and tapering to the thin inrolled, irregular margins of the hypothecium; smooth and glistening, splitting into vein-like crevices as the outer black layer dries, exposing the internal gelatinous structure; apothecia connected to the humus by dense tufts of mycelium at bases; asci cylindric, varying greatly in length from $250-520 \mu$, and $12.6-15.1 \mu$ in diameter, tapering below into a long slender base; ascospores usually lic in the upper $120 \mu$ of the ascus, leaving the lower portions hyaline; ascospores cllipsoid, not narrowed at ends, hyaline to subhyaline, averaging $26.57 \times 10.54$ microns in our specimens, sometimes possessing numerous guttules; paraphyses filiform, hyaline to subhyaline, scarcely enlarged above, about 8-septate, as long as the asci and 2.6-3.8 $\mu$ wide."

196. Bulgaria rufa (Plate 56).

Range extended to Connecticut (F. J. Seaver), Tennessee (L. R. Hesler), and Florida (E. V'est).

\section{Bulgaria melastoma (Plate 57).}

Add the synonym: Sarcosoma cyttarioides Rehm; Durand, Jour. Myc. 9: 104. 1903.

Range extended to Bermuda (F. J. Seaver \& H. H. Whetzel), and Manitoba (G. R. Bisby).

198. Insert:

32a. Wolfina Seaver, Mycologia 29: 678. 1937. (Plate 58.)

Apothecia gregarious, sessile or tapering into a thick stemlike base made up of a compact mass of dark-brown or blackish 


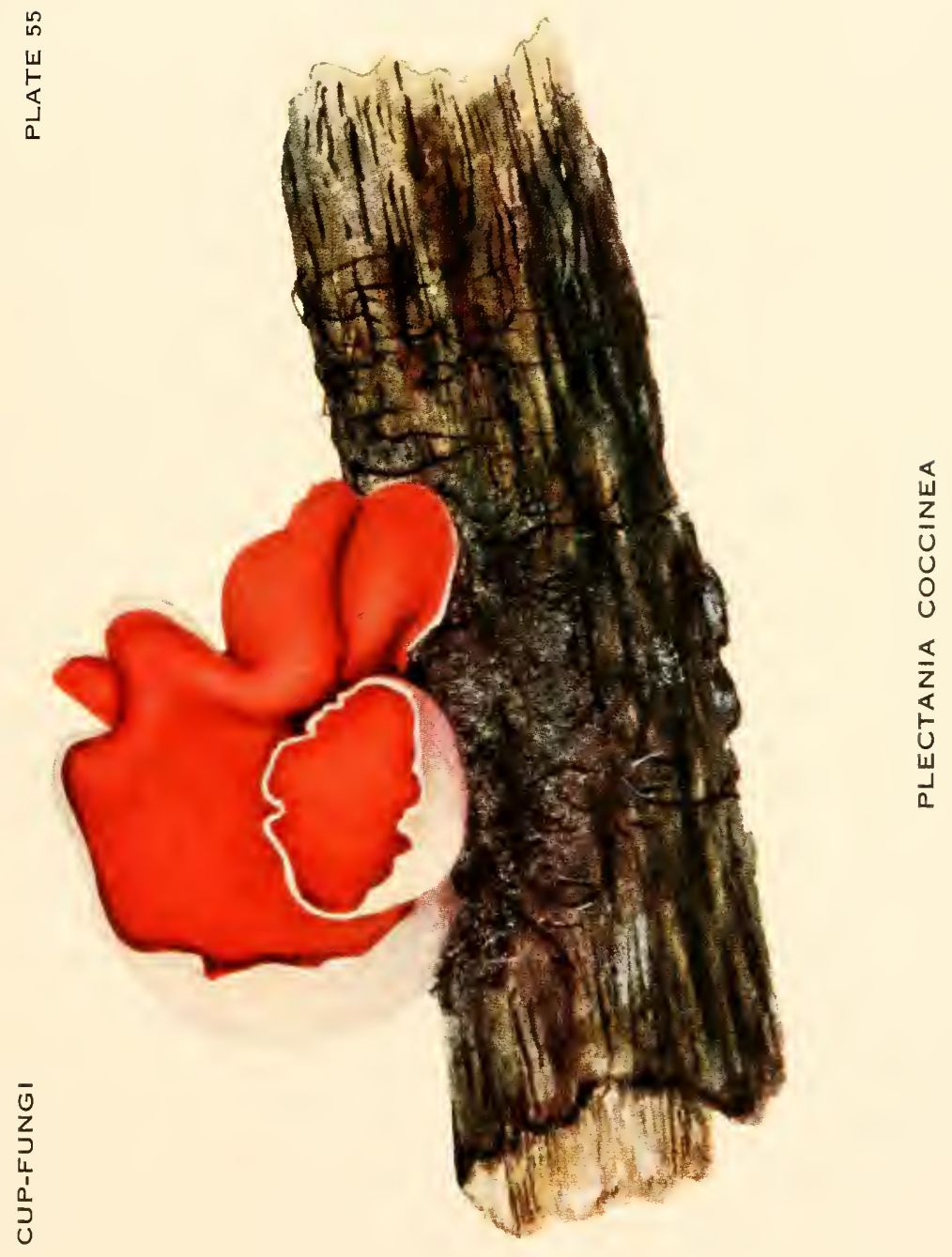



mycelium with which the outside of the apothecium is also covered, shallow cup-shaped, the substance of the hypothecium thick, white and decidedly corky in dried specimens; hymenium concave, of a reddish color; asci cylindrical, 8-spored; spores uniseriate, comparatively large; paraphyses filiform, only slightly enlarged above.

Wolfina aurantiopsis (Ellis) Seaver, Mycologia 29: 680. 1937. (PLATE 58.)

Peziza aurantiopsis Ellis, Bull. Torrey Clul, 9: 18. 1882.

Lachnea aurantiopsis Sacc. Sỳll. Fung. 8: 180. 1889.

Scutellinia aurantiopsis Kuntze, Rev, Gen. Pl. 2: 269. 1891.

Sarcosoma curolinianum Durand, Jour. Myc. 9: 103. 1903.

Apothecia gregarious, sessile, attached to the substratum by the entire under surface except the extreme margin which is free and slightly elevated and more or less incurved, externally brownish-black, the under side covered with numerous projecting folds, clothed with a dense growth of black mycelium, the substance within white, several mm. thick and in dried plants decidedly corky; hymenium pale-yellow or reddish, darker in dried plants; mycelium pale-brown, thin-walled, branched, septate, and externally often minutely rough; asci cylindric above, gradually tapering below into a stem-like base, reaching a length of $300 \mu$ and a diameter of $17-18 \mu$; spores 1-seriate or with the ends slightly overlapping, broad-ellipsoid, granular within, hyaline or slightly yellowish, $16-18 \times 27-33 \mu$; paraphyses slender, slightly enlarged above and hyaline or nearly so, reaching a diameter of 3-4 $\mu$.

On bare soil, decaying wood and leaves in low sandy oak and pine woods.

Type locality: Newfield, New Jersey.

Distribution: New Jersey, Pennsylvania, North Carolina and (Colorado?).

Illustrations: Seaver, Iowa Discom. pl. 11, f. 2; Mycologia 29: 679, f. 1 .

Since the publication of the above genus the writer has had the opportunity of examining a part of the type of Sarcosoma carolinianum described by the late E. J. Durand, and finds that it is identical with the above. Durand refers to the corky consistency of the dried apothecia which is one of the characteristics of the species.

\section{Urnula Craterium.}

Range extended to Oregon (J. R. Weir), Manitoba (G. R. Bisby), and Massachusetts (G. E. Morris).

Add to illustrations: Sv. Bot. Tidsk. 24:306, f. 1 . 


\section{Urnula Geaster (Plate 59, 60).}

Add the note: This interesting species so far as our American records show occurs only in the State of Texas. Recently a specimen of this species has been reported from Japan by $R$. Imazeki (Jour. Japanese Bot. 14: 680-684. f. 1-3. 1938.). However, only a single specimen was found and no further reports have been received. Since the publication of the early pages of this work abundant material, excellent photographs, and valuable observations have been received from Dr. G. IV. Goldsmith of the University of Texas. Perhaps the best way to present these observations is to quote them in the series of letters which were exchanged with the collector. Whether the name Devil's Cigar refers to the form of the young specimens which resemble a bloated cigar in form, as well as in color, or to the fact that the fungus appears to "smoke" at maturity, we cannot say. Perhaps both factors entered into the case. At any rate, the name is very appropriate. The correspondence is as follows:

November 29, 1932.

Dr. Fred J. SeAver

New York Botanical Garden

New York City.

Dear Sir:

Under separate package I am sending you a box of Crmula in the fresh condition. I hope that they reach you in good condition but of course a shipment of fresh material is always a risk. It this season this species is rather abundant here and we are trying to secure photographs of the spore discharge such as the one of this phenomenon shown in your book for Sclerotinia. Our Irnula discharges spores with a sound which can be heard for several feet. I am forwarding this package of material because Dr. Mc Nllister mentioned your being desirous of it.

Very truly,

Signed-G. II. Golwsith

December 5, 1932 .

Mr. G. W. Goldswith

University of Texas

Box 1611 Univ. Station

Austin, Texas.

Dear Mr. Goldsmith:

The splendid collection of Lrmula Geaster was received in fine shape. This is the first chance I have had to study this from fresh material. I am 


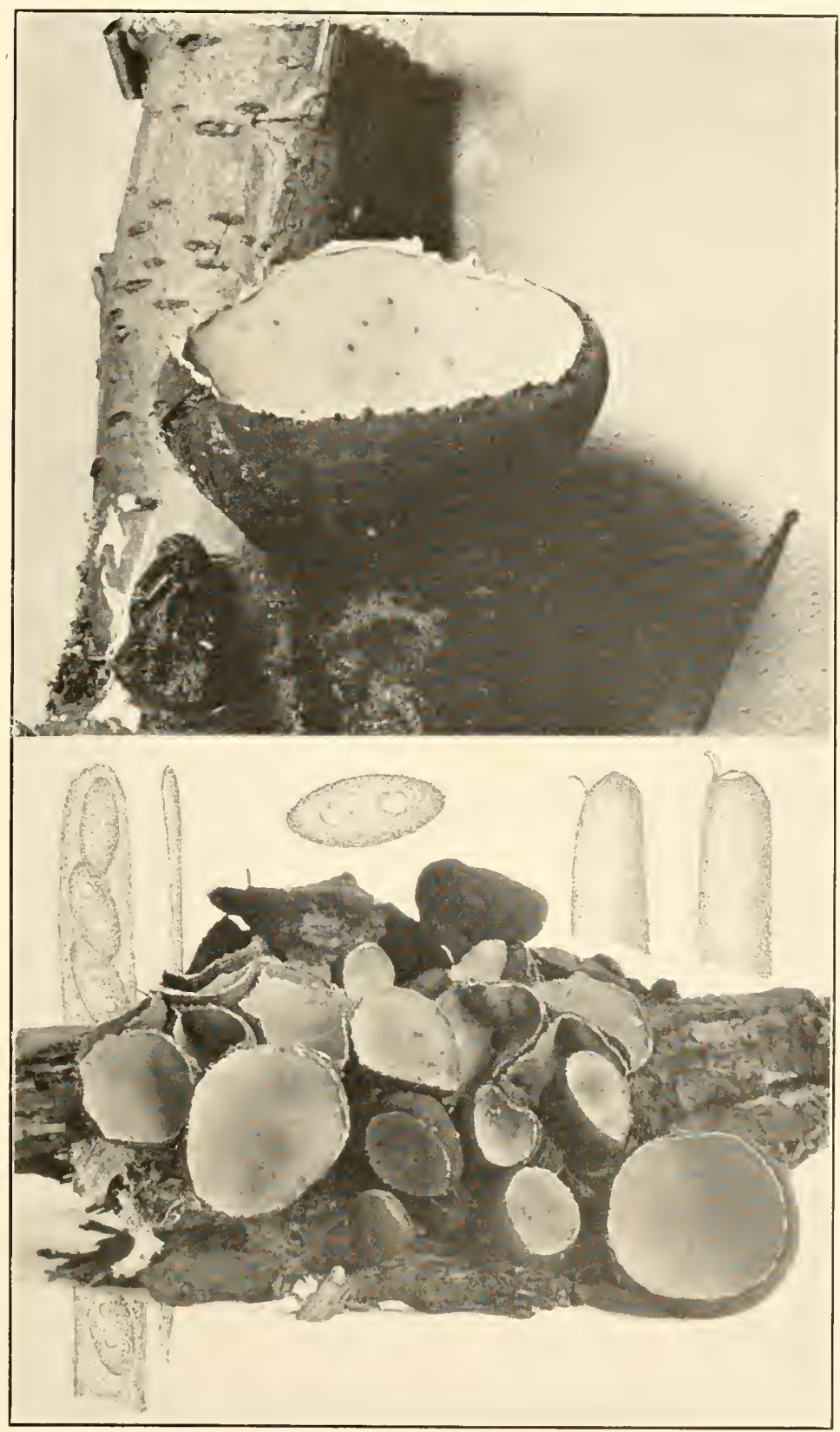

BULGARIA RUFA 

very much interented in your note on the audible spore discharge. There is another character in this plant which is very conspicuous and which I think no one hats mentioned. This is the peculiar swelling of the cells of the paraphyses below the tips. They lecome almost globose and closely resemble the cells of monilioid conidia. This swelling, of course, serves the purpose of turning the plant inside out in order that the hymenium may be more completely exposed. While the paraphyses are often swollen I have never seen anything approaching this condition. I suspect in the young plants the paraphyses are filiform but, unfortunately, I did not have any very young plants from which to study them. Wish you would check up on this.

I have succeeded in getting an excellent photograph and will add this drawing in order to make a supplementary plate for the operculate cup-fungi. If this material is abundant I would be glad to have dried specimens enough for distribution. I have never seen it except from Texas. P'lease give my. regards to Dr. McAllister. Again thanking you, I am

Very sincerely yours,

Signerl-FRED J. SEAVER

January 12, 19.32.

I) R. FRED J. SEAYER

New York Botanical Garden

New York City.

Dear Dr. Seaver:

It is gratifying that the package of fresh Lrmula Geaster reached you in good condition. A package of dry material went forward a few days ago. This species is abundant on favorable years around Austin. This year was not as good as many due to the fact that when we finally had moist weather it was also cold.

I have been unable to find so late in the season any specimens in which the paraphyses are not somewhat swollen. This is probally due to the fact that considerable pressure tending toward expansion develops early. I wonder if these cells do not branch as well as swell during the period just preceding maturity. I will make observations earlier next year.

The fungus is attached to the roots of oak and elm but not to cedar. I have found none on the roots of living trees. Often the course of a long root under ground can be followed by the Urnula.

There appears to be a thin spot at the end of each ascus and I assume that it is here that the first discharge break occurs. I have been surpriserl to see that spore discharge seems to be initiated by either a fall or an increase in humidity.

Several prints are inclosed. All were made here this fall and can probably le improved next year with the present experience. I am very curious to learn whether or not all the asci of a given limited area discharge simultaneously. The discharge occurs from a limited number of comparatively small areas and $I$ can see no relation of the position of these to age.

Very sincerely,

Signed-G. IV. Goldswitu 
January $16,193.3$.

Mr. G. II. Goldsmith

Iniversity of Texas

Iustin, Texas.

Dear Mr. Goldsmith:

Your letter received and I am interested in the further data regarding Lrmula Geaster, and am especially glad to have the photographs. I would like to get a larger photograph $+x 5$ inches of the habitat sketches and also the spore discharge. If we had the negatives we could have them made here, but probably you could get them made there to better advantage. The habitat sketch is exceptionally good, and 1 think you have done remarkalbly well with the spore discharge also.

In reading over a report on this species in the Botanical Gazette by Heald and Wolf, I notice that they have described the paraphyses as being very slender, and of uniform thickness throughout their entire length. They also figure them that way. Since they must have worked with fresh material I do not understand how they could have made such a record. Is it possible that there are two species with similar appearance? Jou are in excellent position to check up on these points and I think we should have more detailed information on this apparently endemic species in Texas. I will look forward to your results this year with a great deal of interest. With best regards, I am

Very sincerely yours,

$$
\text { Signed-FrED J. SEAVER }
$$

The peculiar moniliform or catenulate formation of the paraphyses in this species is absolutely unique in the cup-fungi, so far as the writer's observations have gone. The individual cells of the paraphyses, except the tip, are swollen until they are almost globose in form and look like a string of huge conidia. The structure and behavior of bodies is doubtless responsible for the literally turning inside out of apothecia of this species. In a previous paper it has been referred to as an "expansion apparatus." While the paraphyses in other species of ten swell at their tips the writer has never encountered anything like the condition observed here.

\section{Paxina Acetabulum.}

Range extended to California (E. E. Morse), Vermont (C. IV. Dodge), Kashmir, India (R. R. Stewart), and North Dakota (J. F. Brenckle).

Add to exsiccati: Brenckle, Fungi Dakotenses 502.

\section{Paxina platypodia.}

Add the synonym: Acetabula murina Zeller, Mycologia 19: 139. 1927.

Sixth line from bottom change " $100-135 \mu$ " to "300-350 $\mu$." 


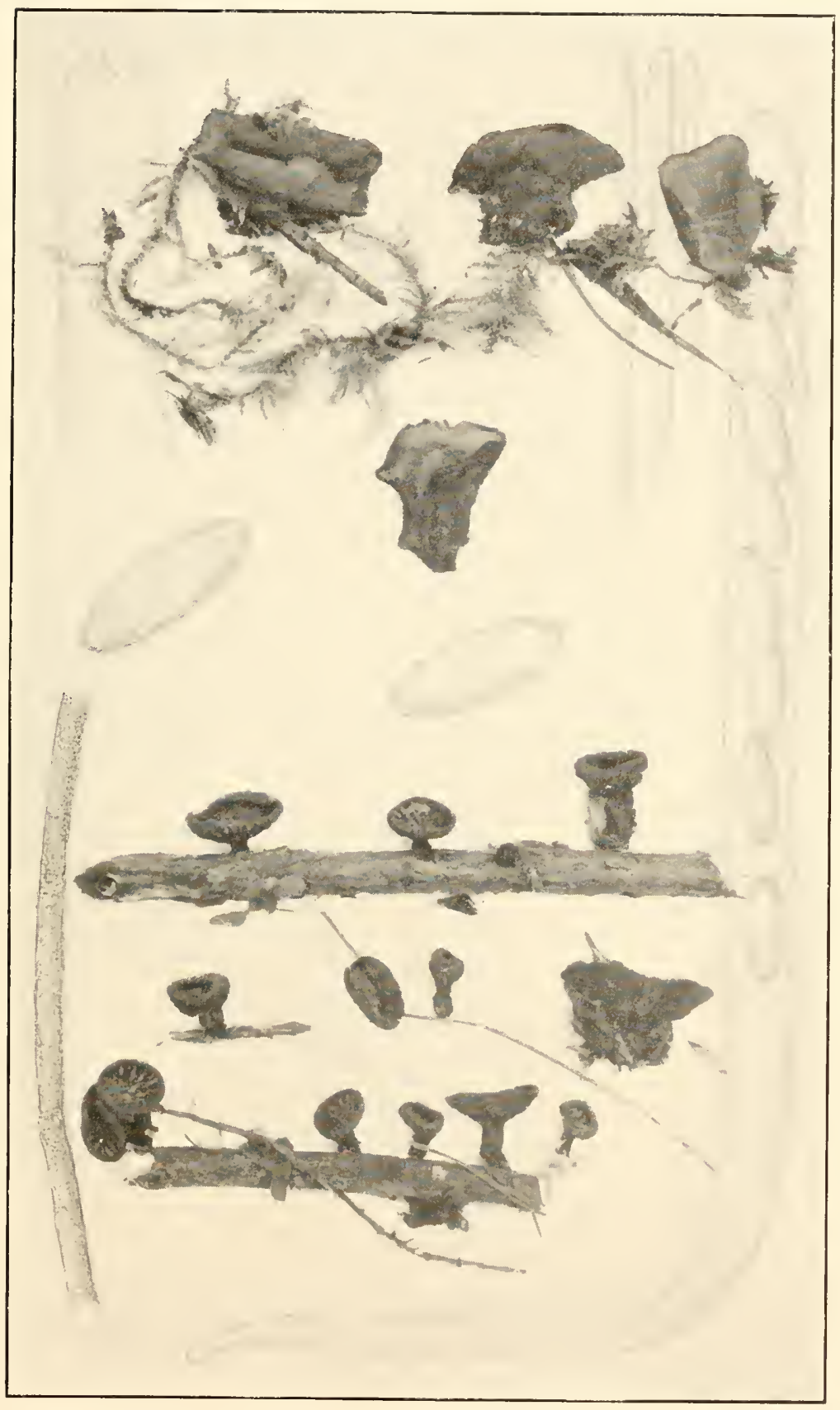

BULGARIA MELASTOMA 

Range extended to Nova Scotia (L. E. Wehmeyer), Nebraska (Bea Brenckle), Ohio (M. B. Walters), and Oregon (J. R. Kienholz).

\section{Paxina leucomelas.}

Range extended to Idaho (J. R. Weir).

\section{Paxina sulcata.}

Range extended to California (O. Ml. (Oleson), and Toronto (E. H. Moss).

\section{Paxina hispida.}

Range extended to Winnipeg (G. R. Bisby), Quebec (Myc. Foray), Vermont (G. Burlingham), and India (R. R. Stewart).

\section{Paxina subclavipes.}

Range extended to Florida (1:. W'est).

\section{Paxina Dupainii.}

Range extended to California (S. C. Edwards).

\section{Paxina Corium.}

Range extended to Michigan (A. H. II. Povah), and Maine (F. L. Harvey). (hange under Exsiccati no, 537 to 526.

\section{Paxina nigrella.}

Range extended to Mt. Shasta, California, near melting snow banks (II. B. Cooke), Colorado around snow drifts (F. J. Seaver \& P. F. Shope), with a doubtful specimen from North Carolina (F. A. Wolf).

\section{Paxina semitosta.}

Range extended to Missouri (D. H. Linder), North Carolina (H. R. Totten), and Pennsylvania (L. O. Overholts).

Add: Exsiccati: N. Am. Fungi $27+0$.

\section{Paxina fusicarpa.}

Range extended to Vermont (C. II. Dodge), New Hampshire (F. J. Seaver), Tennessee (L. R. Hesler), Michigan (A. H. IV. Povah), and Quebec (Myc. Foray).

211. Insert:

15. Paxina compressa Snyder, Mycologia 28: 486. 1936.

"Apothecia scattered, stipitate, laterally compressed, becoming irregularly lobed, reaching a diameter of 3-4 cm., ex- 
ternally grayish white, covered with fascicles of loosely interwoven hairs; hairs consisting of swollen cells, reaching a diameter of 20-30 microns; stalk white, $4-5 \mathrm{~cm}$. long, up to $1 \mathrm{~cm}$. wide at the base and 5-8 $\mathrm{mm}$. wide where the stalk joins the apothecium, very slightly lacunose; hymenium grayish brown, wavy, smooth; asci cylindrical, $350-400 \times 14-16$ microns; spores ellipsoid, containing one very large oil-drop and numerous small ones, 13-19 $\times$ 23-25 microns, smooth; paraphyses filiform, slightly enlarged above to $3-6$ microns."

Type locality: Easton, Washington.

Distribution: Known only from the type locality.

Illustrations: Mycologia 28: 485, $f .3 a$.

\section{Paxina recurva Snyder, Mycologia 28: 487. 1936.}

"Apothecia with short thick stalks, widespreading, reaching a diameter of 10 or more cm., with a strongly recurved margin on three or more sides giving the top an angular appearance, externally dull-white, finely tomentose; stalk short and thick, $2-3 \mathrm{~cm}$. long and up to $3 \mathrm{~cm}$. wide where it joins the apothecium, whitish, slightly lacunose, tomentose; excipulum prosenchymatous, consisting of interwoven, swollen-celled hyphae; hymenium convex, smooth to wavy, light brown; asci cylindrical, with a narrow twisted base, 325-350 × 13-15 microns, 8-spored; spores broad-ellipsoid, $14-16 \times 9-11$ microns, with two large oil-drops, very minutely roughened by small warts; paraphyses up to 8 microns at the apex, brown, sparingly septate."

Type Locality: Snoqualmie Pass, Washington.

Distribution: Known only from the type locality.

Illustrations: Mycologia 28: 485, $f .2 a$.

\section{Geopyxis cupularis.}

Range extended to Maine ( $R$. Thaster), and Tennessee (L. R. Hesler).

\section{Geopyxis bronca.}

Range extended to Manitoba (G. R. Bisby), and Colorado (P. F. Shope).

\section{Geopyxis vulcanalis.}

Add the note: When IIumarina ochroleuca Clenents was listed (p. 131) very little material was available for study. During the summer of 1929 the writer in company with Dr. Paul Shope of the University of Colorado spent a few days on Pikes Peak with Dr. and Mrs. Clements. Some time was spent 


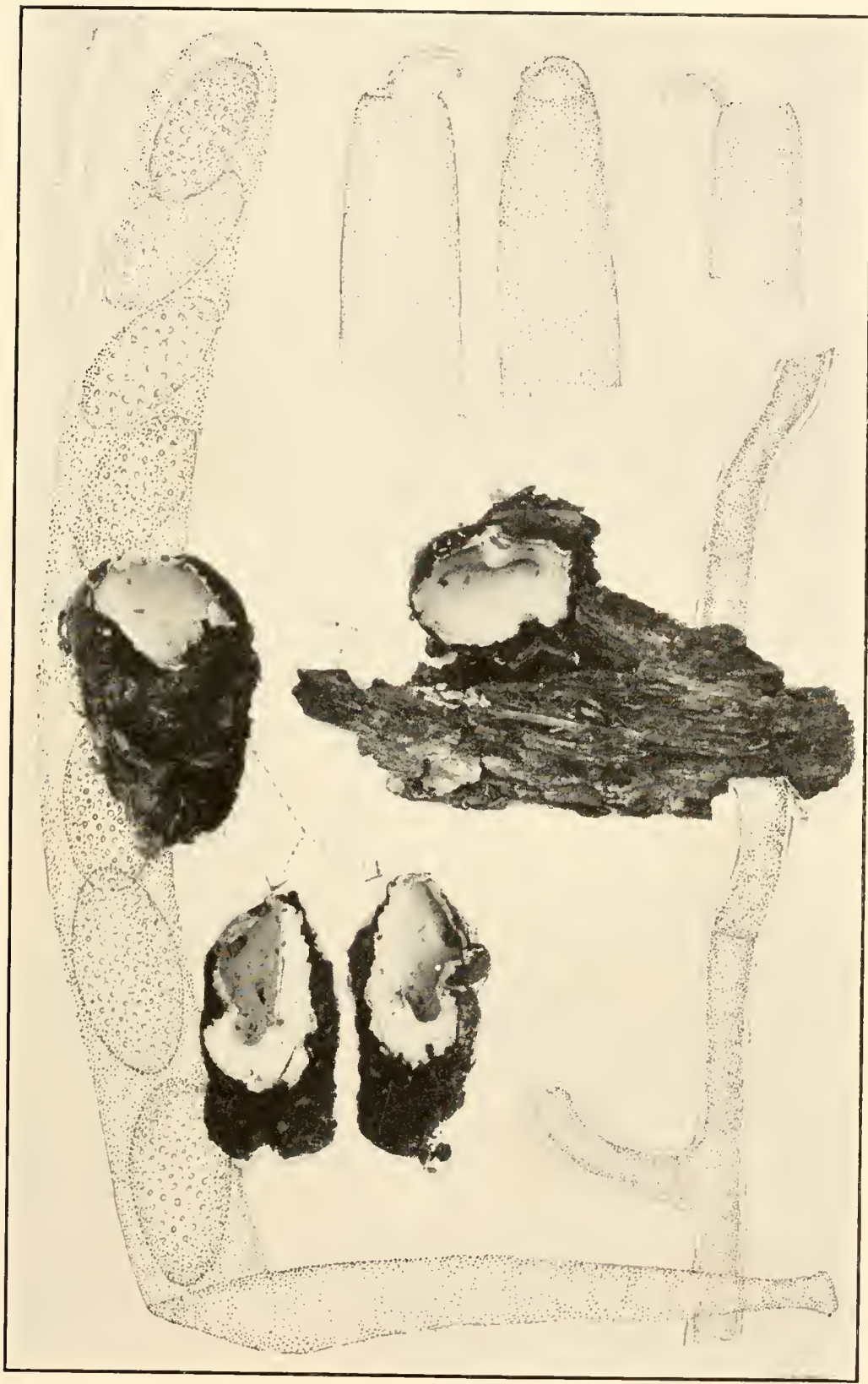

WOLFINA AURANTIOPSIS 

collecting fungi about the Alpine Laboratory. Specimens of Humaria ochroleuca Clements, collected and determined by Dr. Clenents, proved to be Geopyxis vulcanalis (Peck) Sacc. Later comparisons with Clements' exsiccati and photograph convinced the writer that the two are identical. Peziza vulcanalis Peck antidates IIumaria ochroleuca Clements, and is therefore the tenable name.

\section{Rhizina inflata.}

Range extended to Maine ( $R$. Thaxter), Massachusetts (A. B. Seymour), Oregon (S. M. Zeller) and British Columbia (J. R. Weir).

See introduction for note on parasitisn.

\section{Discina ancilis.}

Change citation date "1899" to "1889."

Add the synonym: ? Discina macrospora Bubak, Ann. Myc. 2: 395.1904 .

This species has been reported from Japan (S. Imai, Bot. Mag. Tokyo 52: 360. 1938).

\section{Discina leucoxantha.}

Range extended to Tennessee (L. R. Hesler), and Massachusetts (S. Davis).

\section{Peziza badia (Plate 54, FiG. 1).}

Range extended to Winnipeg (G. R. Bisby), Quebec (Myc. Foray), Trinidad (F. J. Seaver), with doubtful specimens from Costa Rica (C. IV. Dodge \& V. F. Goerger). Also reported from Japan (S. Imai, Bot. Mag. Tokyo 52:360. 1938).

Add the note: In the early part of this work it was suggested that $P$. badia and $P$. cochleata might be identical although it is difficult to definitely establish this. Since that writing a number of facts indicate that others have entertained the same idea. In looking over the Persoon Collection in Leiden, Holland in 1935, the writer was interested in noting that Persoon had a specimen labeled Pesiza cochleata var. badia or vice versa, indicating that he regarded them as close, if not identical.

Boudier's Icones ( $p l .983)$ is labeled Galactinia badia (Pers.) Boud. The original drawings from which this plate came to The New York Botanical Garden through the Massee Collection is labeled Pesiza cochleata, apparently by someone at Kew. 
This at least shows that the two names have been confused and adds some strength to the suggestion of their identity.

Many species become more or less cochleate at maturity but this is especially characteristic of Peziza badia as indicated by the accompanying illustration which was made from material collected by the writer in the suburbs of New York City. Occasionally the apothecia are partially split on one side. Apparently, because of this fact, Fuckel included Pesiza cochleata in the genus Otidea which is characterized by having cups split on one side and of ten elongated on the opposite side.

\section{Peziza brunneoatra.}

Range extended to Oregon (J. R. Kienholz). Also reported from Japan (S. Imai, Bot. Mag. Tokyo 52:361. 1938).

\section{Peziza succosa.}

Range extended to Vermont (C. IV. Dodge), Maine (S. Davis), with one doubtful specimen from Oregon.

\section{Peziza pustulata.}

Range extended to Manitoba (G. R. Bisby).

See description of conidial stage in introduction under Asexual Reproduction.

\section{Peziza melaleuca.}

Range extended to Washington (1). Bethel).

\section{Peziza violacea.}

Range extended to Oregon (S. M. Zeller), California (H. E. Parks) and Winnipeg, Manitoba (G. R. Bisby).

Add: Exsiccati: Rel. Farl. 138.

\section{Peziza griseorosea.}

Range extended to New Mexico (II. H. Long).

\section{Peziza proteana.}

Range extended to Ohio (C. G. Lloyd).

\section{Peziza concentrica.}

Range extended to Oregon (G. Burlingham).

\section{Peziza abietina.}

Add: Exsiccati: Crypt. Form. Colo. 125. 


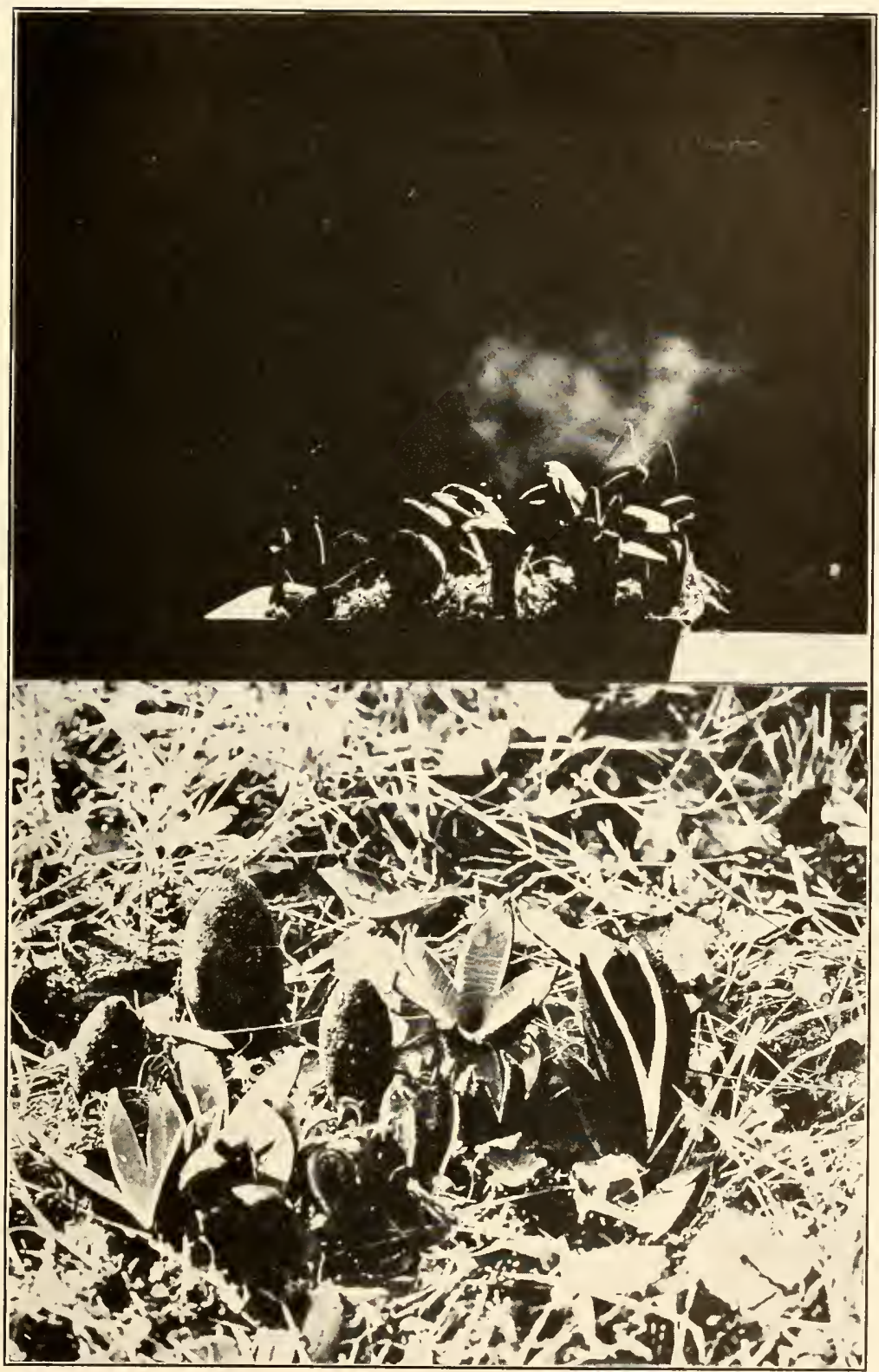

URNULA GEASTER 



\section{Peziza venosa.}

Range extended to Nebraska (L. B. Walker), Colorado (P. F. Shope), California (H. WT. Harkness), and doubtfully to Florida (E. West).

\section{Peziza domiciliana (Plate 61).}

Range extended to Winnipeg, Manitoba (J. J. Neilson \& C. R. Bisby), Quebec (Myc. Foray), Washington (J. B. Flett), Vermont (C. W. Dodge), Utah (A. O. Garrett) and Tennessee (L. R. Hesler).

Add under illustrations: Mycologia 8: pl. 188.

Add the note: It is difficult to identify with certainty many of the large fleshy cup-fungi, since in many cases the species are based on variations in form and color which are entirely obliterated in dried or preserved specimens. This has necessarily given rise to much confusion of names.

This was impressed on the writer in looking over the description of Peziza carnea by Bessie B. Kanouse (Papers Mich. Acad. Sci. 22: 121. 1936.), since the description and illustrations agree exactly with what the writer has described as Peziza domiciliana. Which determination is correct, or whether the two are identical, it is difficult to state. All we can do is to present the facts and let the reader decide for himself. Perhaps it would not be out of place to quote here a previous discussion of this species (Mycologia 8: 195. 1916), as follows.

"Peziza domiciliana was originally described by Cooke from specimens found growing on the walls, ceilings, and floors of a house which had been partly destroyed by fire. The specific name is a very appropriate one, since, from our own observations, the species usually occurs about the cellars of houses and in caves."

The species was first encountered by the writer in Iowa, where it was found growing in the basement of one of the college buildings at Iowa IVesleyan University. There it grew on piles of damp coal-dust which had been left over from the winter's supply. The plants were described and illustrated in lowa Discomycetes under the name of Peziza repanda Pers.

The species was next found in the basement of the Museum Building of The New York Botanical Garden where the ground was kept moist by the drip from an ice-box. The plants grew 
on sandy or gravelly soil, as indicated by the particles adhering to the base of the apothecia.

On March 10, 1914, the writer received still other specinens from Mr. Carl A. Schwarze, of the New Jersey Agricultural Experiment Station. These plants, which were found growing in the sand of a cutting bench in one of the greenhouses, were accompanied by the following description: "First of all the plants were gregarious, had a short but distinct stem, cups concave, nearly white and translucent when young, a yellowishbrown when old, later becoming repand and umbelicate, and more or less angular. The stem is obscured by the expanding disc. The largest disc became convex and measured at least $10 \mathrm{~cm} . "$

In April of the same year, similar specimens were collected by Mr. L. O. Overholts in a mushroom cellar in Missouri. These specimens, which were referred to the writer, were accompanied by the following description: "Cups 3-8 cm. broad, somewhat stipitate, margin involute, depressed in the center, hymenium smooth, ochraceous-buff (Ridgw.) or somewhat more brownish, exterior covered with white meal."

All of the American specimens referred to above agree well with specimens of Peziza domiciliana from the herbarium of Cooke, so far as we can judge from dried specimens. According to Cooke, the apothecia are sessile, although in our American specimens they are, at least when young, short-stipitate. Also we have not noted any of the violet tints referred to by Cooke, although in his original description he allows for a rather liberal range of color. The spore measurements of the American and European specimens are identical. The young plants are always pure-white and usually the flesh when broken turns goldenyellow. This fact was noted by Bresadola and was found to be true of specimens collected in New York. Whether this character is constant, we are unable to say, since no attention was given to this in some of the plants when fresh. From the studies which have been made, the writer feels safe in referring our American plants to Peziza domiciliana Cooke, and also in regarding this species as distinct from Peziza repanda Pers.".

Since the publication of the above notes, numerous specimens of fungi referable to this species have been received, a few of which are as follows: 1915, on the ground in greenhouse, Missoula, 


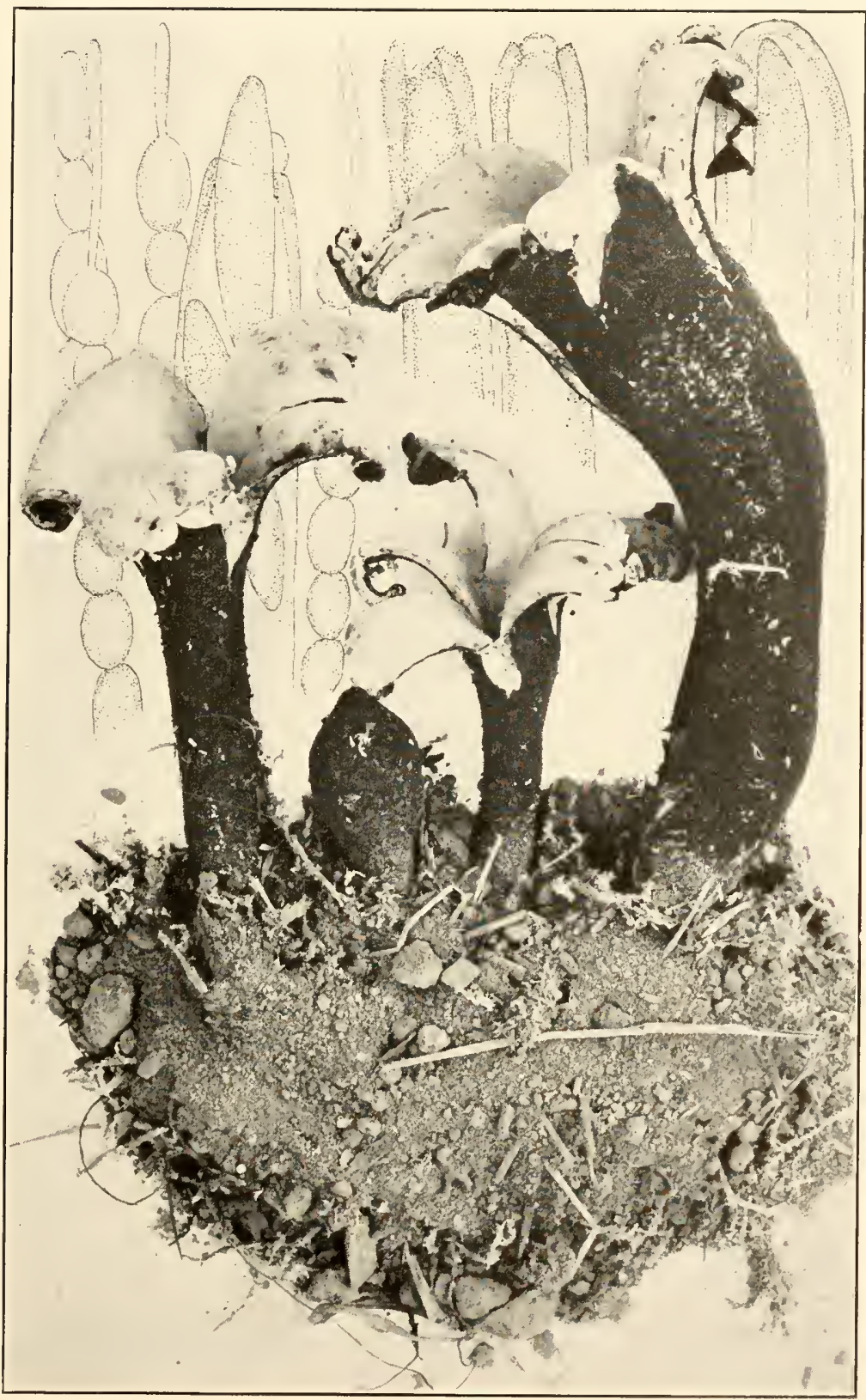

URNULA GEASTER 

Montana, J. R. Weir; 1918, on decaying timber in mill, Mass., R. J. Blair; 1920, on floor of abandoned dwelling, Charter Oak, Pa., F. J. Seaver; 1922, in a milk house, Pawlet, Vermont, C. IV. Dodge; 1922, in basement of college building, Wabash College, Crawfordsville, Indiana, A. R. Bechtel; 1927, in a cellar, Winnipeg, Canada, J. J. Nielson and G. R. Bisby; 1933, on cement wall in shower bath, Livingston, Tennessee, Mrs. Bob Adkisson; 1934, on soil of ash and humus mixture in cellar, Hood River, Oregon, J. R. Kienholz; 1936, in cellar of greenhouse, New York Botanical Garden, B. O. Dodge and F. J. Seaver.

From the above it will be seen that the name to which we have ascribed these specimens is at least appropriate since the fungus seems to be found ahmost exclusively around human habitations, especially in cellars, although presumably it must have been derived from some form which existed under more natural conditions.

\section{Peziza repanda.}

Range extended to Oregon (J. R. Kienholz).

Add under illustrations: Mycologia 8: pl. 189.

\section{Peziza vesiculosa.}

Range extended to Winnipeg, Manitoba (G. R. Bisby), Vermont (C. II. Dodge), and Bermuda (J. M. Waterston).

Add: Exsiccati: Rel. Farl. 137.

\section{Peziza fimeti.}

Range extended to Quebec (N. L. Fernald, C. IV. Dodge \& L. B. Smith), with a doubtful specimen from Massachusetts (1). H. Linder).

\section{Peziza sylvestris.}

Add the doubtful synonym: Pesiza bufonia Pers. ex Fries, Syst. Myc. 2: 54.1822.

Range extended to Oregon (S. M. Zeller), Washington ? (L. C. Snyder), California (E. E. Morse) and Manitoba (A. H. R. Buller \& G. R. Bisby).

\section{Peziza clypeata.}

Range extended to Indiana (A. R. Bechtel), Toronto (R. F. Cain), with doubtful specimens from Oregon (J. R. Kienholz). 
234. Insert:

21. Peziza pseudoclypeata sp. nov. (Plate 62).

Apothecia irregularly discoid, often umbilicate and with more or less radiating convolutions, reaching a dianeter of $3-4 \mathrm{~cm}$, the flesh brittle externally pallid; hymenium chestnut-brown; asci cylindric above, tapering below into a long stem-like base, reaching a length of $400-450 \mu$ and a diameter of $18-22 \mu$, 8 -spored; spores ellipsoid $12-14 \times 20-24 \mu$, containing two oildrops, sculptured, the sculpturing consisting of very long blunt spines or knobs, hyaline or pale vellowish; paraphyses clavate densely filled with granules $8-10 \mu$ in diameter.

Ipotheciis subdiscoirliis, umbilicatis, $3+\mathrm{cm}$. diam.; hymenio brunneo; ascis cylindraceis, stipitatis fragilibus, $18-22 \times 400+50 \mu, 8$-sporis; sporis ellipsoideis asperatis, subhyalinis; paraphysibus, clavato-incrassatis, $8-10 \mu$ dian.

On well decayed sugar maple log.

Trpe locality: Cleveland, Ohio.

Distributiox: Known only from the type locality.

\section{Peziza Waltersii sp. nov. (Plate 63).}

Apothecia gregarious, subturbinate, dull yellow throughout, reaching a diameter of $2.7 \mathrm{~cm}$. the hymenium slightly depressed, in the center a little paler than the outside of the apothecium; stem short, stout and attenuated below, the substance of the apothecia very soft, shrinking much in drying; asci cylindric, reaching a length of $340 \mu$ and a dianeter of $15 \mu$, 8-spored: spores ellipsoid, 1 -seriate, $10 \times 20 \mu$ becoming rather coarsely tuberculate: paraphyses enlarged above filled with granules, reaching a diameter of $5 \mu$.

Apotheciis gregariis, subturbinatis, flaviis; hymenio leniter concavo; ascis subcylindraceis, 8 -sporis, $15 \times 340 \mu$; sporis ellipsoideis, tuberculatis, $10 \times 20 \mu$; paraphysibus clavato-incrassatis, $8-10 \mu$ dian.

On much rotted wood of sugar maple and beech in beechmaple-hemlock forest in early June.

Type locality: Cleveland, Ohio.

Distributiox: Known only from the type locality.

This species is named in honor of Naurice B. Walters who has collected it several years in succession on the same decaying $\log$.

\section{Sarcosphaeria coronaria (Plate 46).}

Range extended to California (E. E. Morse \& H. E. Parks), and Oregon (J. R. Kienholz). 


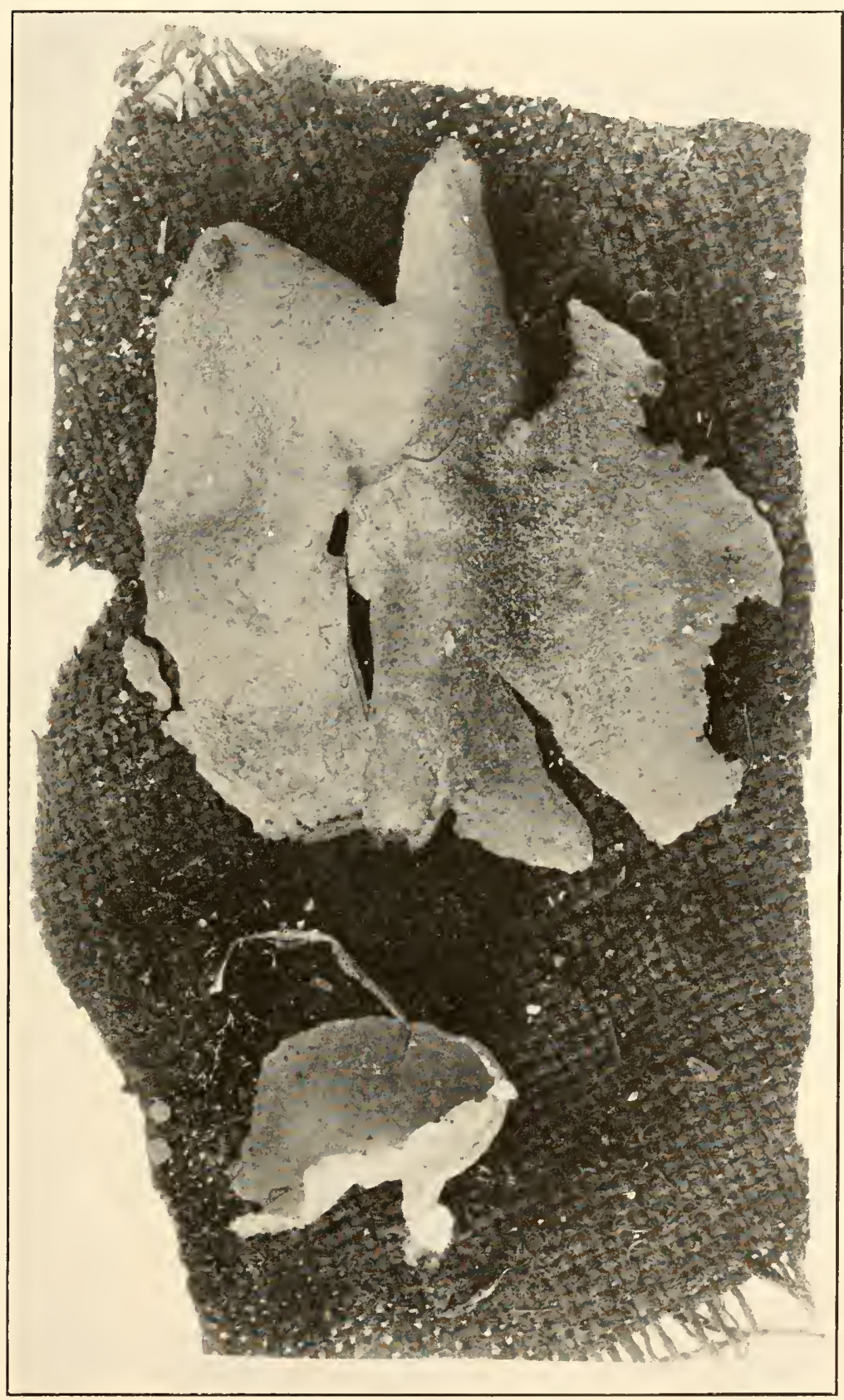

PEZIZA DOMICILIANA 

236. Insert:

2. Sarcosphaera ammophila (Dur. \& Lév.) comb. nov. (Plate 64.)

Peziza ammophila Dur. \& Lév.; Durieu, Expl. Sci. Alger. But. Altal 10. 1868. Pesiza funerata Cooke, Grevillea 6: 142. 1878.

Geopyxis ammophila Sacc. Syll. Fung. 8: 70. 1889.

Sarcosphaera funerata Seaver, Mycologia 22: 216. 1930.

Apothecia scattered, at first entirely immersed in the sand appearing as holes in the ground with the irregular or slightly star-shaped margin appearing above the surface of the sandy soil, nearly globose and reaching a diameter of $2-3 \mathrm{~cm}$. extended below into a stem-like base made up of a column of sand held together with fungus mycelium, the exterior of the cup pitted with particles of encrusted sand; hymenium exposed at maturity, dull umber brown; asci cylindric, reaching a length of $275 \mu$ and a diameter of $1214 \mu, 8$-spored; spores ellipsoid, smooth, 8-9 $\times 16-18 \mu$; paraphyses slender, slightly enlarged above, clinging together and not very distinct.

In sandy soil.

Type Locality: Algeria.

Distribution: Florida to California and Michigan; probably world wide in sand dunes.

Illustrations: Cooke, Mycographia pl. 107, f. 380; Mycologia 22: pl. 22, f. 1.; 24: pl. 14; FI. Alger. pl. 28, f. 2; Zeits. Pilzk. Darmst. 15: pl. 2.

In 1878, M. C. Cooke described Pesiza funerata from Gainesville, Florida, with the usual brief Latin diagnosis and the English note: "immersed in sandy soil." This was later illustrated by Cooke in Mycographia pl. 107, f. 380.

So far as the writer knows, nothing more was known or heard of this species in this country for nearly fifty years. In 1921, Dr. H. C. Beardslee sent me a collection of this Disconycete obtained at New Smyrna, Florida, with the following notes: "The plant grows in the bare sand in cultivated orange groves. It is immersed in the sand and only the irregularly star-shaped opening shows about like this (diagram). The shape is about as in my diagram roughly globose with the mouth constricted and somewhat star-shaped. Apparently it is at first closed and the mouth opens as it develops, as the interior is entirely free from sand unless it is brushed in by the rain. The color is dull umber throughout." 
"When they are appearing you will see here and there the irregular opening of the mouth in the white sand. I have found them in January and February in New Smyrna."

The writer did not recognize this species and wrote as follows:

PROFESSOR H. C. BEARDSLEY,

January 31, 1921 .

Box 1027, New Snyrna, Fla.

Dear Professor Beardsley:

I have just received the cup fungus, and looked it over with much interest. In habitat it is exactly like what is known in the Rocky Mountain regions as the "Hole in the Ground" because that is all that is visible when the plant first appears. That species, however, has the exterior of the cup clothed with a dense covering of brown hairs, also it has a very much larger spore. The only other species that I know of which is at first immersed is beatufully colored in purple or light lilac on the inside of the cup. Your species would probably fit better in the genus Sarcosphaera than in Sepultaria on account of the absence of hairs on the cup. I do not know the species, although I have been working the group for North America. While it may be described I am sure I have never seen it. If it would be possible for you to get any photographs from fresh material, I would be glad to write this up some time in the future. I will send you a reprint of a species of Sepultaria which will give you some iclea of the halit of this plant.

Thanking you for the specimens, I an

$$
\text { Very truly yours, }
$$

Signed-FRED J. SE.TVER

In 1929 the writer encountered a specimen of Peziza funerata from the collection of Geo. Massee in the herbarium and recognized it as being identical with the Florida material, and wrote the following:

Prof. H. C. BEARUSLEE

September 25, 1929.

Perry, Ohio.

Dear Professor Beardslee:

In 1921 you sent me a fine ])iscomycete which you collected buried in the sand in Florida. At the time I was uncertain of the species but as I have just determined its identity. I will report to you. It is Peziza funerata which should douhtless become Sarcosphaera funerata which was described by Cooke from material collected in Gainesville, Florida. The illustration and description fits exactly and there is no guestion about the identity. In preparing my book I overlooked this, probahly hecause it was undetermined, and would like to report this in the near future.

At the time of our correspondence 1 asked you for photographs which have never been received. Will it be possible for you to get photographs during the winter? I would be very glad to get this put up in shape so that it can be recognized in the future. Thanking you for anything you can do, I am 


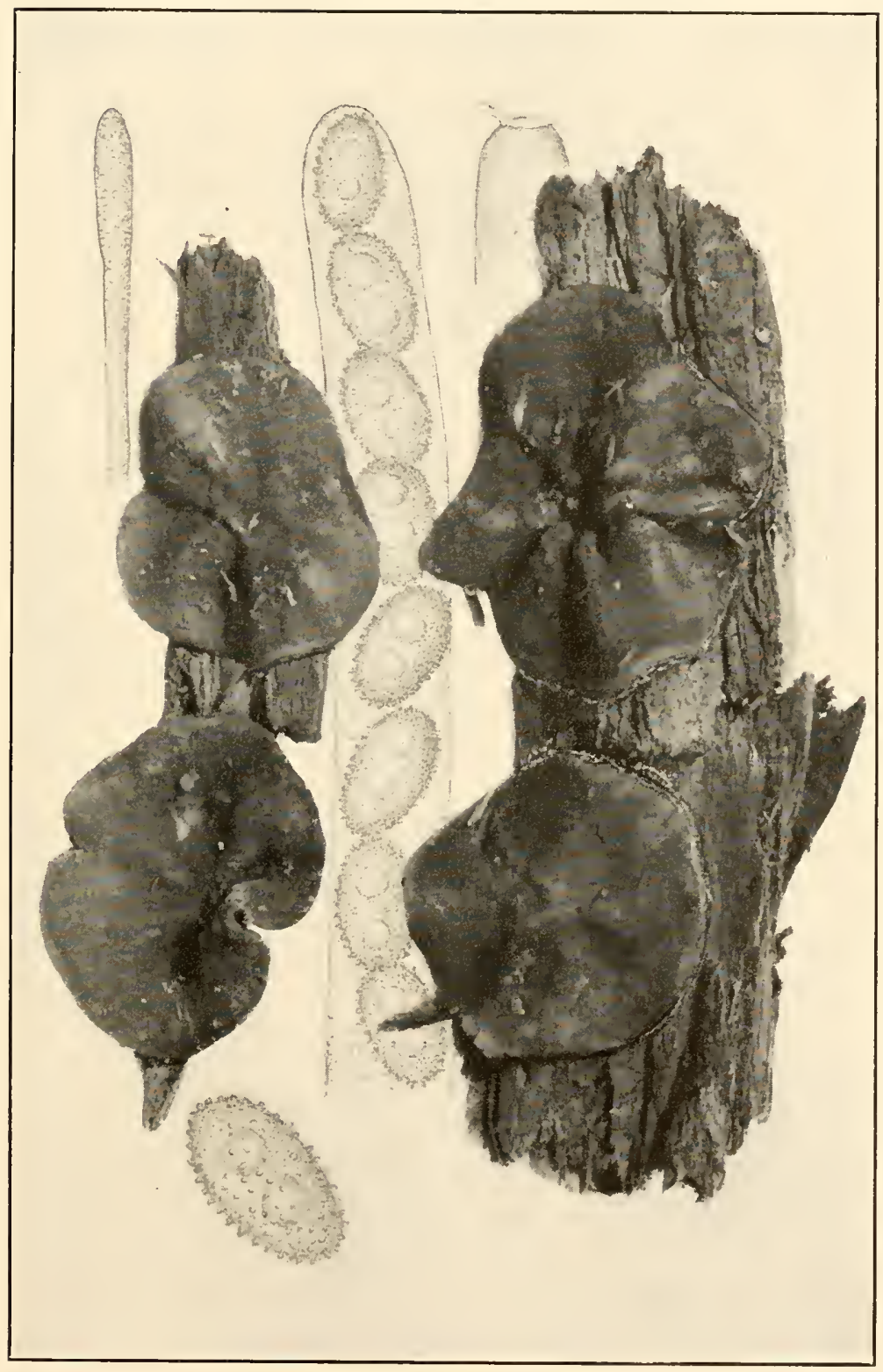

PEZIZA PSEUDOCLYPEATA 

In 1930, the writer published a note on this species in Mycologia and in 1932 Dr. Erdman IVest published additional notes on this interesting species in Mycologia (24: 464-466. pl. 1t) and sent the writer additional material from Florida, and about the same time material was also received from Dr. Lee Bonar of California. In response to these two papers Dr. F. Kallenbach from Europe wrote as follows:

Herra Prof. Dr. Seaver, Redaktion "Mycologie," New York City/U. S. A., Botanical Garden Bronx Park

$\mathrm{K} / \mathrm{Be}$

Darmstadt, den 20. Oktober 1932.

Sehr geehrter Herr Professor!

Mit grossem Interesse habe ich die Arbeit über "Sarcosphaera funerata" in Ihrer geschätzten Zeitschrift gelesen. Die Bilder sehen genau aus wie die von mir zum erstenmal im Binnensandgelsiet Europas festgestellte Geopyxis ammophila. Sie kennen ja meine Veröffentlichung darüber in der Zeitschrift für Pilzkunde, 1931, S.87/88 mit Tafel 11. Sehr dankbar wäre ich Ihnen, wenn Sie mir einmal frisches Material lhres Pilzes zum Vergleich zusenden wollten. Evtl. kann ich Ihnen auch dieses Jahr noch Vergleichsmaterial von den hiesigen Standorten in frischem Zustand übermitteln.- Auf Wunsch stehen Ihnen auch unser illustriertes Hausschwamm-Merkblatt under unsere 6-farbige Ifausschwammtafel zur Verfügung.

Nit bestem Dank für lhre liebenswürdige Bemühung und mit der vorzüglichsten Hochachtung legrüisst Sie

Ihr sehr ergebener,

Signed-F. KilleENBich

To this note the writer replied as follows:

Dr. F. Kallenbach

November 18, 1932.

Frankfurter Str. 57

Darmstadt, Germany:

Dear Dr. Kallenbach:

Your card calling attention to the identity of Peziza funerata Cooke and Peziza a mmophila Dur. \& Lév. has been received and it is exceedingly interesting. It had never occurred to me that these two were identical. I have never collected Peziza funerata myself but have written to Mr. West in Florida to send you some fresh material from the type locality. In the meantime I would le very much pleased to receive specimens from Europe for comparison. Thanking you for your cooperation, I am

Very sincerely yours,

Signed-Fred J. SEAVER

On September 12, 1935, the writer examined specimens of Peziza ammophila in the Persoon Collection at Leiden, Holland, and they are apparently identical with the above. In those specimens the mouths of the apothecia are strongly constricted, indicating young specimens. 


\section{Morchella crassipes (PLATE 66).}

Add the note: This species has been reported from Japan (S. Inai). It seems to differ from the succeeding species by the strongly thickened base and the thinnish ridges. Since the publication of this work an exceedingly fine specimen of this species was brought into the laboratory during the spring of 1929, collected by Herman Johnson at Pelham, New York. The specinen was ten inches high, the largest the writer has ever seen. Some of the asci had four large spores instead of eight.

\section{Morchella esculenta (Plate 65 and tExt Figure 18).}

Add the note: This species cccurs with us almost exclusively in the month of May. While the time might vary with latitude and altitude, its occurrence at that time is so constant that it might be called the "May mushroom." It often fruits in abundance over an extremely short period.

\section{Morchella deliciosa.}

Range extended to Idaho (J. R. Weir), California (E. E. Morse), and Quebec (H.S. Jackson). This species has also been reported from Japan (S. Imai).

\section{Morchella angusticeps.}

Range extended to Minnesota (S. M. Stocker), California (E. E. Morse) and Alberta (N. B. Sanson). This species has also been reported from Japan (S. Imai).

\section{Morchella hybrida.}

Range extended to Pennsylvania (L. O. Overholts). This species has also been reported from Japan (S. Inai).

\section{Durandiomyces (Plate 67, 68).}

Add the note: The genus Durandiomyces was established in North Anerican Cup-fungi (p. 242) in honor of Elias J. Durand, one of the early American students of the cup-fungi. The genus was founded on Gyromitra Phillipsii Massee.

Since that time several additional specimens have been brought to the attention of the writer which have added much to our knowledge of this interesting species. These specimens were collected by Mr. S. C. Edwards of Colton, California. Observations made by Mr. Edwards indicated that this fungus was subhypogeous at least in its early stages. 


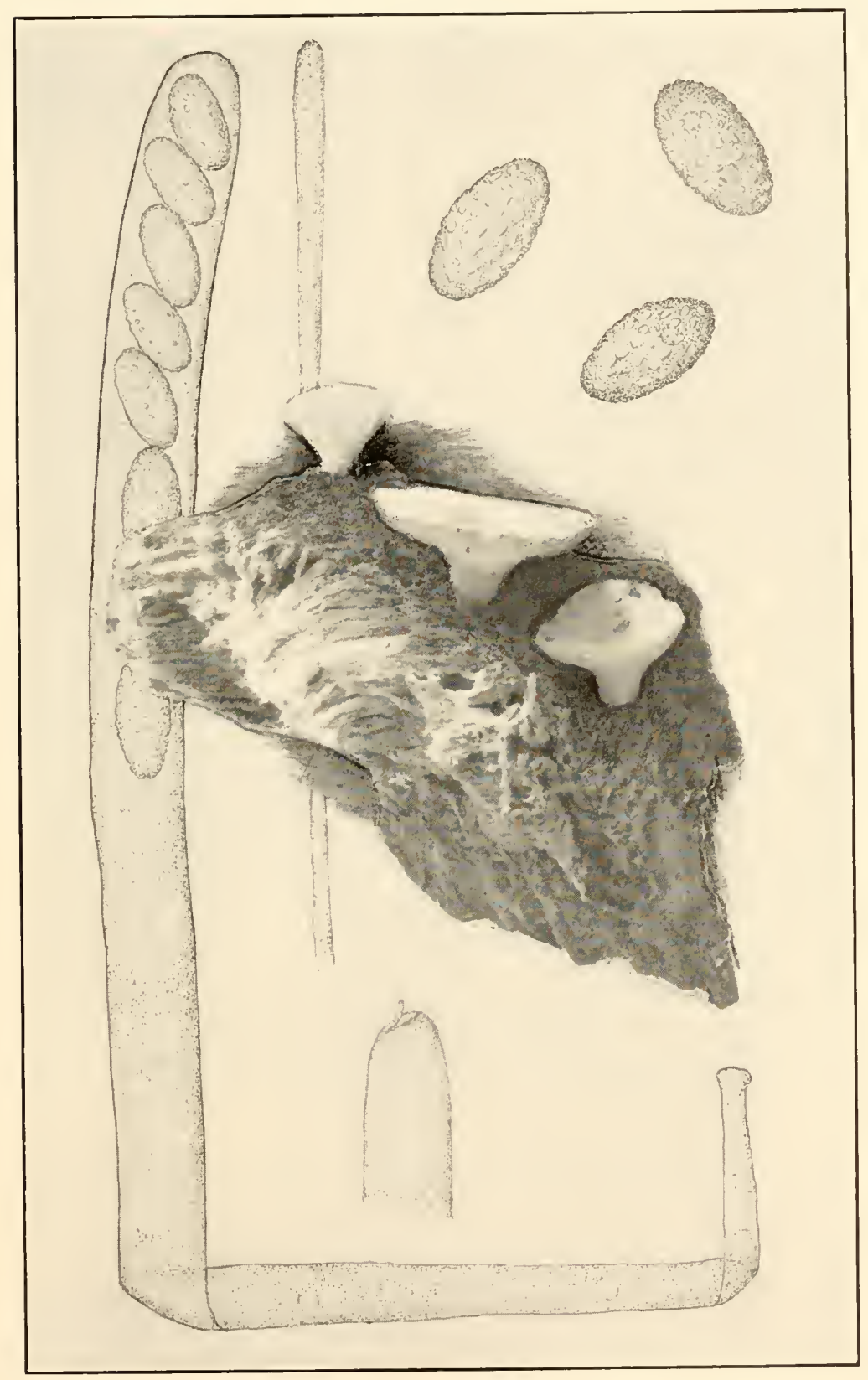

PEZIZA WALTERSII 

Miss Elizabeth Morse of the California Mycological Society first suggested that she believed Durandiomyces was identical with Daleomyces Setche!l. The genus Daleomyces was described in Mycologia (16:240) and referred to the Tuberales. Perhaps this is the reason Daleomyces was never considered in our treatment of the Disconycetes. Since examining fragments of Daleomyces the writer is fully convinced that the two genera are identical and Daleomyces must be considered the authentic generic name by reason of priority. The following then is the synonymy:

Daleomyces Setchell, Mycologia 16:240. 1924.

Durandiomyces Seaver, N. Am. Cup-fungi 242. 1928.

Type species, Gyromitra Phillipsii Massee.

Daleomyces Phillipsii (Massee) Seaver, comb. nov.

Daleomyces Gardneri Setchell, Mycologia 16: 241. 1924.

For description and complete synonymy see p. 242.

Some object to placing this interesting genus in the Helvellaceae. It is, however, equally out of place in any other family of the Operculatae. Boudier considered it a variety of Peziza proteana. So far as the writer can learn there is no evidence that the species ever produces a simple Pesiza cup. For the time its position is left as indicated.

On May 21, 1941 Dr. Helen M. Gilkey writes:

"I have not found the opportunity to complete the investigation of the Daleomyces-Durandionyces problem; Lut a year ago last fall I)r. Zeller and I were called out into the country to see a specimen which undoubtedly was your genus, and which was pushing out of a rotting log until it exentually reached a diameter of 40 inches. The flesh at first wats leautifully white and brittle, and delicious eating, uncooked. This should have been reported long ago, but there are not hours enough in the day."

\section{Verpa.}

Add the synonym: Ptychoverpa Boud. Hist. ('lass. Discon. Eu. 34. 1907.

\subsection{Verpa conica.}

Range extended to Oregon (S. M. Zeller), and Pennsylvania (L. O. Overholts). Also reported from Japan (S. Imai).

\section{Verpa bohemica.}

Add the synonym: Ptychoverpa bohemica Boud. Hist. Class. Discom. Eu. 34. 1907. 
Range extended to Oregon (J.R. Kienholz). Also reported from Japan (S. Imai).

\section{Elvela.}

Add the synonyms: Melvellella Imai, Bot. Mag. Tokyo 46: 174. 1932. Neogyromitra Imai, Bot. Mag. Tokyo 46: 174. 1932 .

\section{Elvela Mitra.}

Remove the synonym: Leptopodia elastica Boud.

Reported from Japan (S. Imai).

Add the note: Specimens collected in California by E. E. Norse extend the measurements to $15 \mathrm{~cm}$. high, $5 \mathrm{~cm}$. broad at the base and cap. These measurements are from dried specimens and in fresh condition must be considerably more. Under the International Rules the above specific name should be replaced by "lacunosa" Afz.

\section{Elvela crispa.}

Reported from Japan (S. Imai).

\section{Elvela atra.}

Range extended to Maine (S. Davis), North Carolina (Myc. Foray), with doubtful specimens from Costa Rica (C. IV. Dodge \& IV. S. Thomas).

\section{Elvela elastica.}

Add the synonym: Leptopolia elastica Boud. Hist. Class. Discom. 37. 1907.

Range extended to Florida (E. West), Washington (S. M. \& E. B. Zeller), Vermont (C. II. Dodge), Kashmir, India (R. R. \& I. D. Stewart). Also reported from Japan (S. Inai).

250-251. Elvela californica and Elvela umbraculiformis (PLATE $69,70)$.

Add the note: On page 251 the writer described Elvela umbraculiformis as a new species differing from Elvela califormica mainly in its much shorter stem. Since the publication of that species there have been received numerous specimens from Miss Maude E. Morris of Seattle, Washington, which have convinced us that the two species mentioned above are identical. This was suspected at the time the species was described but material 


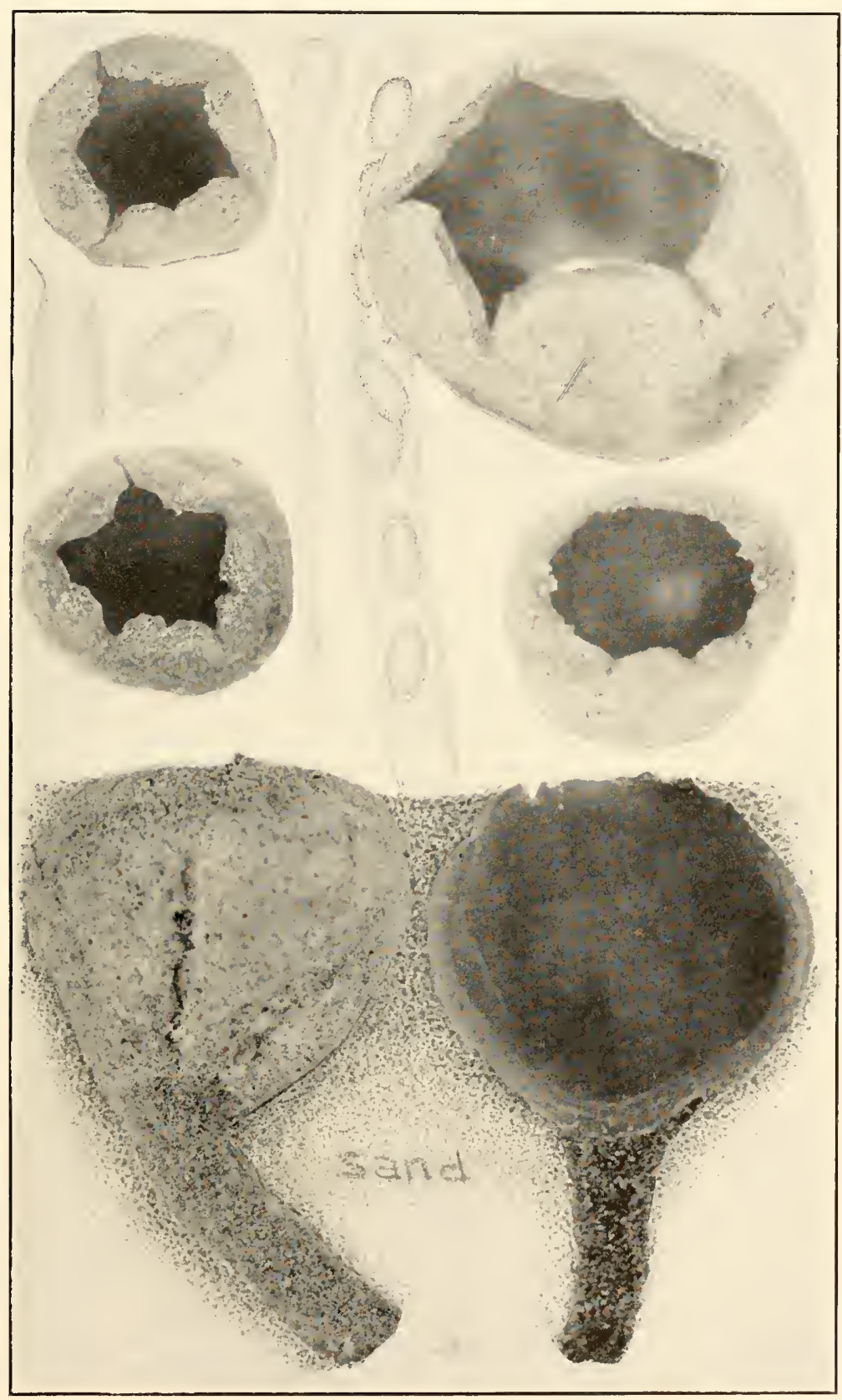



to prove it was lacking. Recent material shows all gradations in stem length.

The species is characterized by the spreading pileus and the convoluted stem, the convolutions of which extend up on the under side like the ribs of an umbrella. The photographs accompanying this article were supplied by Miss Morris and were taken by Mr. C. F. Todd. The following notes were supplied by Miss Morris:

"Date, June 14, 1929

Habitat: Cascades (Mountains) in western Washington along old skid roads, the ground thoroughly moistened by prolonged rains but not boggy, the soil being composed of sandy loam heavily covered by leaf mould. Pileus: Size, very large, up to eight inches, much lobed, deflexed, irregular from its caespitose characteristic manner of growth although occasional specimens occurred singly as shown in photograph 1. Color, tannish-brown which persists in all stages of growth, pure white underneath and somewhat veined. When fresh the whole plant has a translucent appearance, beconing somewhat pulveraceous upon drying. Stipe: Large, 2-31/2 inches long, 1-2 inches broad, deeply sulcate extending entire length of stem without interruption, compressed strongly at extreme base, white, stained with purple at base in all specimens and frequently at the apex. Not stuffed but divided into compartments. Odor none, taste none."

The following is the strnonymy of the species:

EIvela californica Phill. Trans. Linn. Soc. II. 1: 423. 1880.

Elvelu umbruculiformis Seaver, N. Am. Cup-fungi 251. 1928.

Distribution: California to Washington and Idaho.

\section{Elvela infula (Plate 71).}

Reported from Japan by S. Imai.

Add the note: In the early part of this work the writer claimed that, in his opinion, the so-called Gyromitra esculenta was only a gyrose form of Elvela infula. The reasons for these views were presented in an earlier paper (Mycologia 12: 1-5. 1920.).

Since that time much material has been received, and many comments, some attempting to disprove the above conclusions. While all of these have been given due consideration there seems to be no concrete evidence to disprove previous conclusions, 
although the writer is still open to conviction on the controversial point. A few illustrations might be sighted:

CoOlinge Corner, Mass. 26 July 1917.

Dear Doctor:

May not my specimens sent this morning and called Gyr. esculenta be named Gyr. Friesii Cooke, and if so aren't they merely a form of Gyr. infula, not so saddle shape, as type form. And doesn't this finally lead to our identifying them as Heliella infula?

Respectfully submitted,

Signed-SIMON DAvis

The specimens referred to by Mr. Davis were exceedingly gyrose and might be called Gyromitra esculenta if there is any such species. Yet even as a casual observer he suspected that it was only a form of Elvela infula.

Some correspondence took place in 1936 between the writer and Mr. G. S. Bell of Toronto, Canada. These letters are as follows:

Dear Dr. Seaver:

April 20/36

You nay remember meeting the writer in Dr. Jackson's office at the University of Toronto, when you were here sometime ago.

At that time we had some discussion as to whether Eliela infula Schaeff. and Gyromitra esculenta Fr. were only forms of the same species. From my observations E. infula occurs in the fall and grows on rotting woorl and $G$. esculenta occurs in the spring (April \& May) and grows on the ground. If my memory serves me correctly. I believe you stated that you were not familiar with the latter. Thinking you might be interested in some specimens I collected yesterday at the edge of a pine woods in a pasture. I am sending specimens under separate cover. The soil is a sandy loam. I have found this species nearly every year $(15$ to 20$)$ in the same location. They attain a much larger size as a general rule. I have eaten them a number of times without ill effects. I have some photos by W. S. Odell of Ottawa of Elvela infula which he reports as always growing on rotting wood and his collections were made in Sept., Oct. \& Nov.

I would be interested to learn if you still think $G$. esculenta simply a gyrose form of E. infula.

$$
\text { Yours very truly, }
$$

$$
\text { Signed-G. S. BELL }
$$

April 22, 1936

Dear Mr. Bell:

Your letter regarding Elzela infula and Gyromitra esculenta received. I am still open to conviction on the question of the identity of these two forms. If, as you say, the one occurs exclusively in the spring and the other in the fall, 


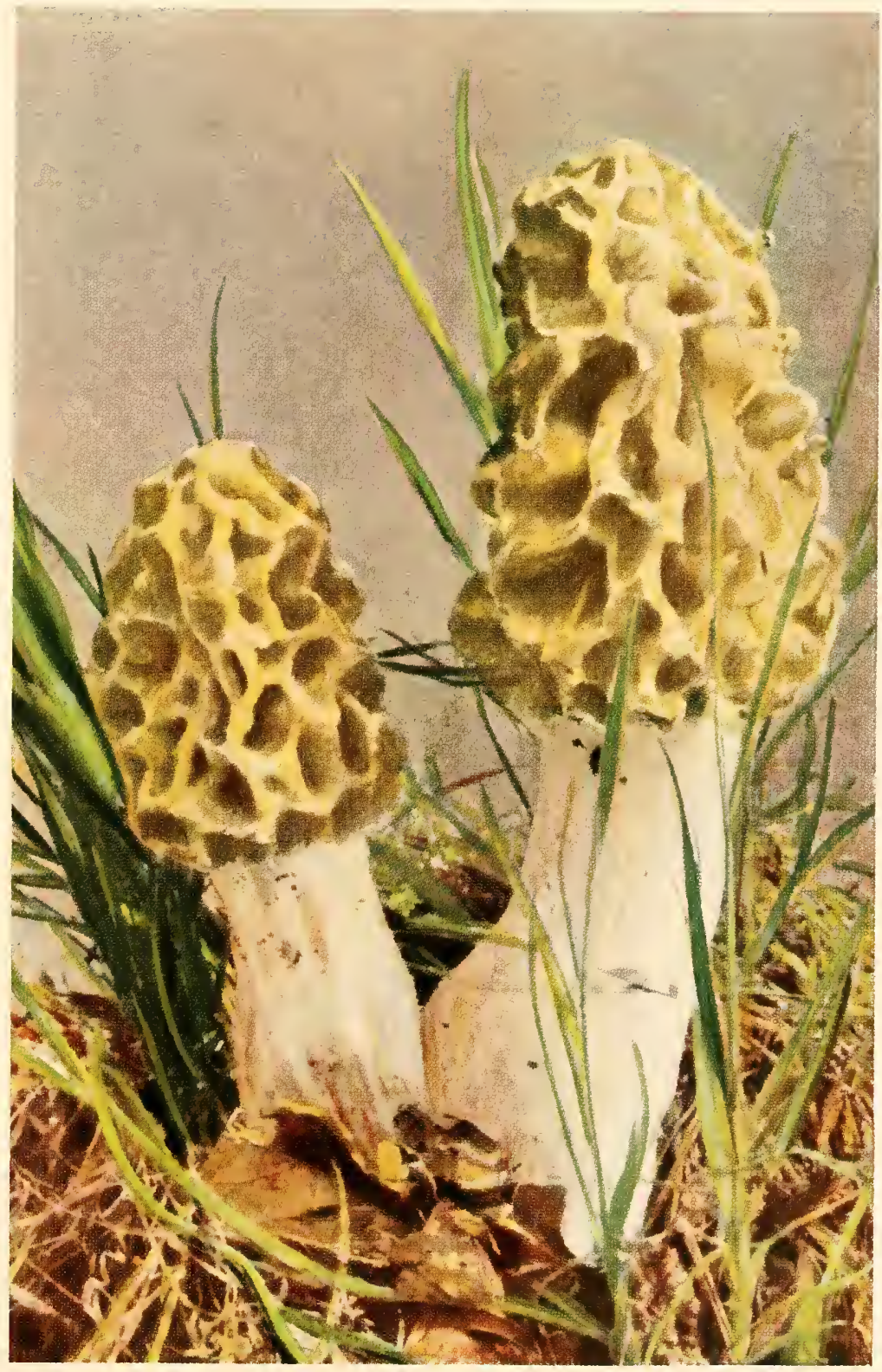



that is a very good point. I suspect that they may le specifically distinct but still maintain that they should not be placed in two genera. If you can get together some good photographs of the two forms it might be well to prepare a paper on the subject. I would be glad to cooperate in any way possible.

Very sincerely yours,

Signed-Fred J. SEAVER

Dear Mr. Bell:

April 29, 1936

I received, the other day, the specimens of Elrela which you sent. Iside from being slightly broken they came through in excellent condition and I am having a photograph of some of them made. The mounts 1 made of the spores seem to be immature. Externally this is exactly my idea of Elvela infula. I have not checked carefully on the time of the occurrence of this species. However, I am still open to conviction and wish to thank you for the material you sent. I would be glad to receive any other specimens should they reoccur.

Very sincerely yours,

$$
\text { Signed-Fred J. SEAVER }
$$

The accompanying photographs were made from the material sent by Mr. Bell and are typical of what we have been calling Elvela infula. So far as the time is concerned forms which might be referred to either name have been collected from early spring to late summer. Also the species may occur either on soil or rotted wood. The extremely gyrose form collected by Mr. Davis was obtained in July. The writer does not believe that the time element can be used as a distinguishing feature.

\section{Elvela caroliniana (Plate 72, 73).}

Add the synonyms: Neogyromitra caroliniana Imai, Bot. Mag. Tokyo 46: 174. 1932. Neogyromitra Gigas Imai, Bot. Mag. Tokỹo 52: 358. 1938.

Under illustrations remove Hard Mush. f. +19 , and add Bot. Mag. Tokyo 52: pl. 2, f. 1-2.

Range extended to California (D. L. Burdick); specimens sent by Miss E. E. Morse.

Add the note: Since the publication of the early part of this work considerable information has come to hand regarding this species, or at least the writer's conception of it.

In 1931 Dr. Leva B. Walker sent the writer a specimen collected by Dr. W. E. Bruner of Baldwin, Kansas, with the following notes: "The spores are conspicuously sculptured reticulately and contain when younger a large and two smaller 
oil globules. In size they are $25-30 \times 12-14 \mu$. The asci are about $350 \mu$ long with the spores usually uniseriate. The paraphyses are much branched and septate where the branches arise. The stem is gyrosely solid. The plant stood $8 \frac{1}{2}$ inches high and was about 6 inches wide. The stem below the pileus was about $2 \frac{1}{2}$ inches across, while it was 4 inches across at the base."

In 1933 Dr. A. R. Bechtel sent the writer a specimen which was very similar to the Kansas specimen except that the stem was shorter. The spores were $25-28 \times 12-14 \mu$ and for the most part smooth. However faint reticulations could be detected and the writer is inclined to believe that the spore sculpturing varies somewhat with age.

Later the same year a third specimen was sent ly Miss Elizabeth E. Morse of California which agreed very closely with the two just mentioned, in spore size. Again the spore sculpturing was very faint and sometimes not apparent. Occasionally the spores had a knob-like apiculus. The writer believes that these are all the same species as named above.

On May 5, 1941, an exceptionally fine specimen was received from Walter B. Welch, collected near Carbondale, Illinois, by Clifford Fore. When fresh the specimen weighed four and onehalf pounds. The entire fruiting body was about one foot high, and the head about ten inches in diameter.

Imai (Bot. Mag. Tokyo 52: 359. 1938.) states: "As far as can be judged from the illustrations of Hard and Seaver, the American species Morchella caroliniana Bosc. ex F. is undoubtedly a distinct species from the European and Japanese species IIelvella Gigas Krombh." The writer is not convinced that Imai's conclusions are correct. More field study is necessary.

\section{Elvela sphaerospora.}

Range extended to Ontario (J. Dearness). This species has been reported from Japan ( $\mathrm{S}$. Imai).

\section{Underwoodia columnaris.}

Range extended to Iowa (H. C. Gilbert \& G. W. Martin). Add under illustrations: Mycologia 28: 237, f. 1 . 


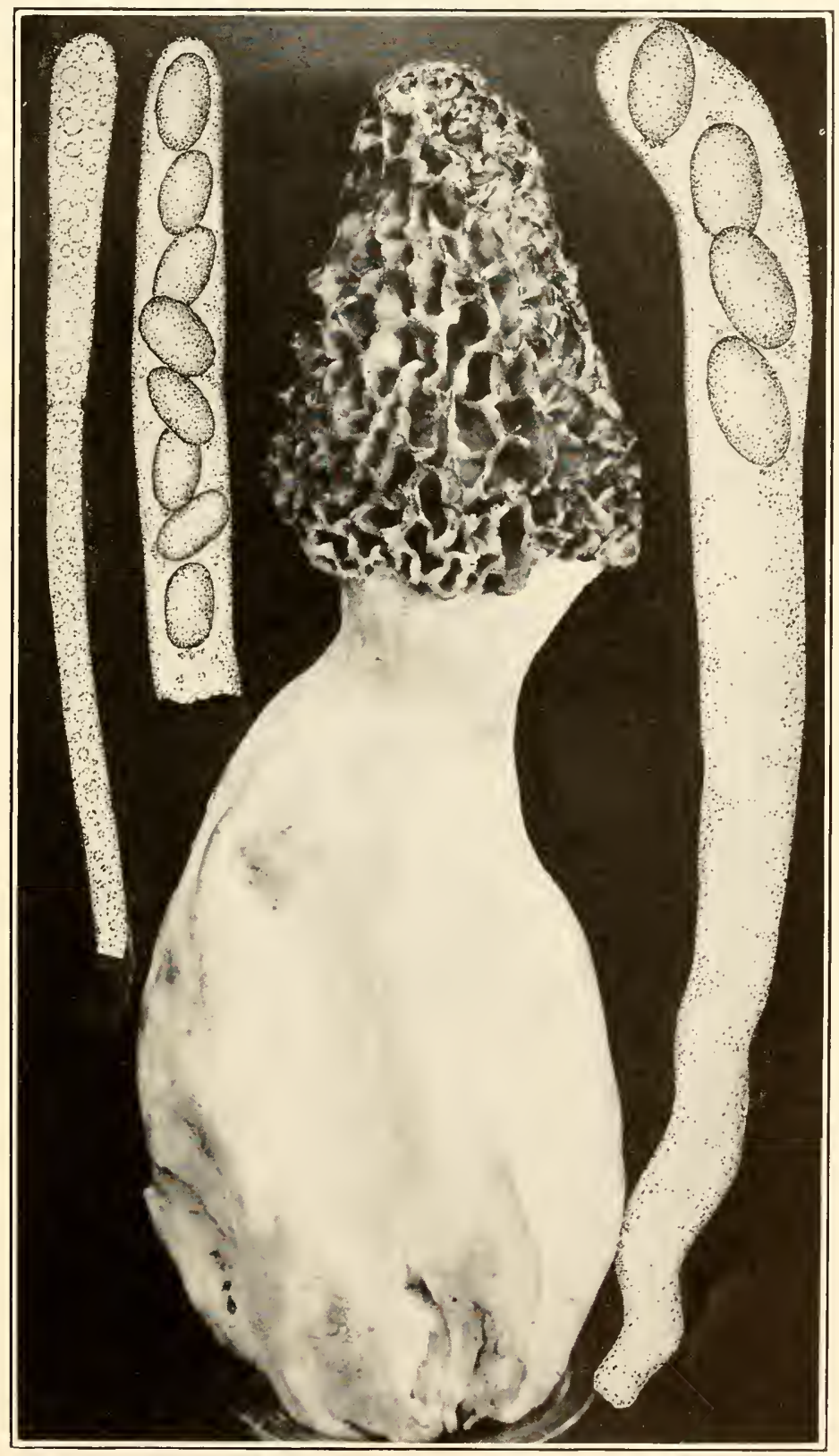

MORCHELLA CRASSIPES 



\title{
EXPLANATION OF PLATES
}

\author{
Plate 46
}

Surcosphaera coronaria. Several apothecia at different stages of development, somewhat reluced. Left, portion of an ascus with spores. This colored illustration was drawn by Miss Fleda Griffith from photographs submitted by Miss Elizabeth E. Morse from California, the coloring having been approved by her.

\section{Plate 47}

Boudiera Il alkerae. Center, photograph of several clumps of apothecia on soil, enlarged about four times. Below, one apothecium, much enlarged, showing the surface roughened by the ends of the protruding asci. Left, an ascus with mature spores and a portion of a paraphysis. Right, a paraphysis. Mbove, portion of an ascus showing the operculum. Below, two spores showing younger stages of development.

\section{Plate 48}

Lamprospora sphagnicola. Center, photograph of one mature apothecium and several young ones showing habitat. Below, drawing of one immature apothecium, enlarged. Right, drawing of an ascus when immature. Left, mature ascus with spores and paraphyses. Nbove, three stages in the development of the spore; also tip of ascus showing operculum.

\section{PLATE 49}

Aleuria aurantia. Colored illustration of a clump of apothecia, drawn by Miss Fleda Griffith from material collected in The New York Botanical Garden, about natural size.

\section{Plate 50}

IIumarina ll'aterstonii. Center, photo of several infected seeds of Licistona chinensis, slightly enlarged, from material collected in Bermucla. Left, an ascus with spores and paraphyses greatly enlarged. Ipper right, an ascus which had discharged all of the spores except two, one of which has its nose through the ascostome. Below center, sketch of two apothecia enlarged; also three views of empty asci showing the ascostome and operculum from different angles.

\section{Plate 51}

Upper figure. Sepultaria aurantia. Photograph of a cluster of apothecia at various stages of development, about natural size, furnished by Dr. Paul F. Shope from material collected by us in Colorado. Left, drawing of a portion of an ascus with spores and the tip of a paraphysis. Right, drawing of one of the hairs from the outside of an apothecium. 
Lower figure. Sepultaria arenicola. Photograph of a cluster of apothecia at variousstages of levelopment, furnished by Mr. S. C. Edwards from material collected in Colton, California. Left, drawing of a portion of a hair of an apothecium. Right, tip of an ascus with spores.

\section{PLATE 52}

Pseudopithyella minuscula. Photograph of several dead twigs of Juniperus bermudiana showing apothecia with drawings much enlarged, from material collected in Bermuda. Right, an ascus with spores. Upper center, portion of an ascus showing the ring-like collar, and tip of an ascus with the operculum attached.

\section{Plate 53}

Patella contradicta. Center, a large clump of apothecia on burned ground and charcoal, collected in The New York Botanical Garden. Below, at the left, one apothecium much enlarged. Right, three hairs with swollen bases. Left, an ascus with spores and one paraphysis. Above, tips of two asci showing opercula. Upper right, two hairs from the exterior of the apothecium.

\section{Plate 54}

Upper figure. Peziza badia. Photograph of three apothecia, about natural size, from material collected in Van Cortlandt Park, New York City. Left, drawing of a portion of an ascus and two paraphyses. Right, drawing of two spores, enlargerl. Center, one spore at higher magnification.

Lower figure. Scodellina leporina. Photograph of a clump of apothecia, furnished by Dr. Paul F. Shope from material collected by him in Colorado, with drawings of portions of asci and paraphyses, and three spores showing stages in development.

\section{Plate 55}

Plectania coccinea. Colored illustration made by Clara D. Eppling from material furnished by Dr. B. O. Dodge, the material having been collected at Algoma, Wisconsin.

\section{PLATE 56}

Bulgaria rufa. Hoove, photographs of an apothecium, fumished hy 1 r. IV. S. Thomas from material collected in New England. Below, clump of apothecia, furnished hy I)r. L. R. Hesler from material collected in Tennessee, with drawings of portions of asci, paraphyses and spores.

\section{PLATE 57}

Bulgaria melastoma. I'hotographs (from (Iried material) of a number of apothecia, made from material collected in Jamaica by $\mathrm{W}$. A. Murrill, with drawings of an ascus with spores and paraphyses, and a portion of an ascus with the operculum. 


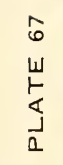

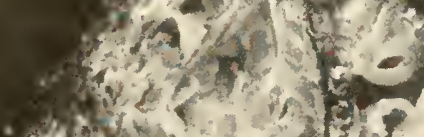

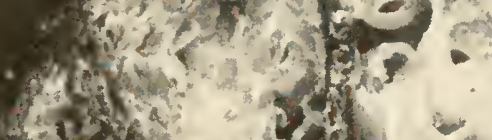

$4+1+2 t^{2}$ ?

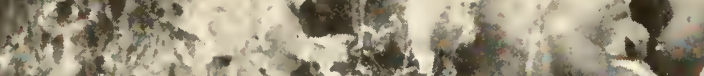

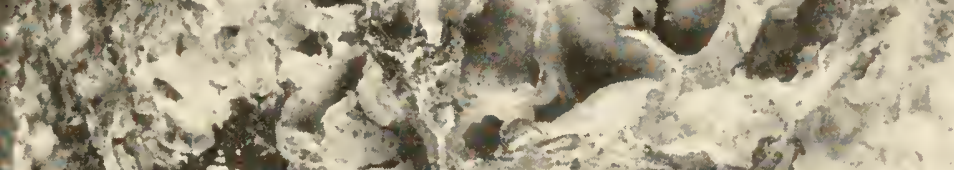

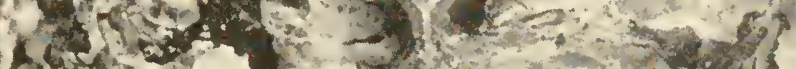

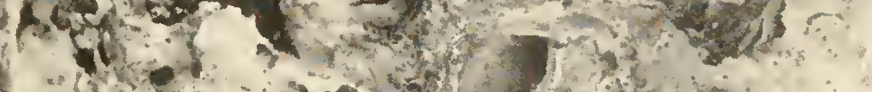

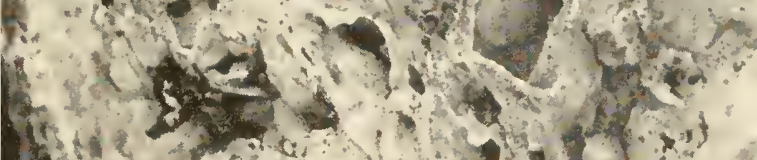

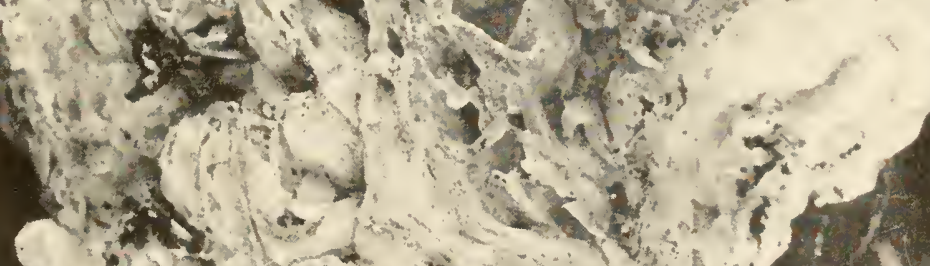

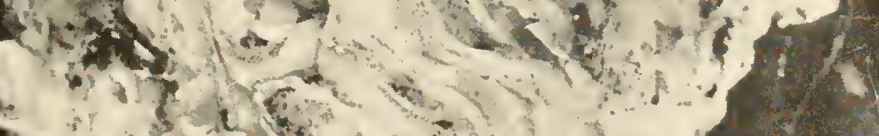

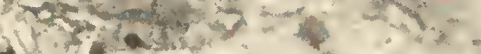

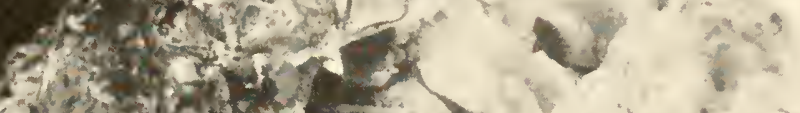

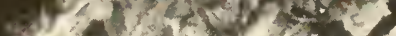

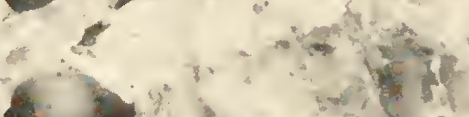





\section{Plate 58}

IIolfina aurantiopsis. Ihotographs of several apothecia, about natural size, with one split to show the thick consistency of the apothecial tissue. Left, drawing of an ascus with spores and two paraphyses. Right, portion of a hair from the outside of the apothecium. Howe, portions of the asci with the opercula attached.

\section{Plate 59}

Urmula Geaster. Habitat groups, furnished by G. IV. Goldsmith from material collected in Texas, the upper one showing spore discharge.

\section{PLATE 60}

Urnula Geaster. Photographs of several apothecia at different stages of development, somewhat reduced, with drawings of portions of asci and spores, and the much swollen paraphyses, from material collected in Texas by G. IV. Goldsmith.

\section{PLATE 61}

Peziza domiciliana. Photographs of two apothecia on burlap bag, collected by B. O. Dodge and F. J. Seaver in the cellar of the conservatory at The New York Botanical Garden. The lower apothecium show the stemlike structure in the younger plants, about natural size.

\section{PLATE 62}

Pesiza pseudoclypeata. Photographs of several alpothecia on rotten wood, collected by M. B. Walters at Cleveland, Ohio, about natural size, with portion of an ascus with spores, a typical paraphysis, and the tip of an ascus with the operculum attached. Below, one spore much enlarged.

\section{Plate 63}

Peziza llaltersii. Three apothecia, alout natural size, on rotten wood, collected in Cleveland, Ohio, by M. B. Walters. Left, lrawings of an ascus with spores and one paraphysis. Below, tip of an ascus showing operculum. I ${ }^{\top}$ pper right, three spores much enlarged.

\section{PLATL 64}

Sarcosphaera ammophila. Photographs of several apothecia, from material collected in Florida by Erdman West. Below, two apothecia with diagram showing the submerged character and the stem-like columns of sand which are held together by the mycelium of the fungus. Above, clrawing of a portion of an ascus and a paraphysis. Also, tip of an ascus with operculum, and one spore much enlarged.

\section{Plate 65}

Morchella esculenta. Reproduction of a photograph of two fruiting bodies. colored by Miss Fleda Griffith from material collected in Elmsford, New York, by the author. 
P'LATE 66

Morchella crassipes. Mbout two-thirds natural size, the specinen measuring ten inches in height; also drawings of asci with spores and a paraphysis. One four-spored ascus was observed.

\section{PLATE 67}

Daleomyces Phillipsii. Cabbage-heat fungus, reduced one-fourth, from material collected ly. S. C. Eclwards in Californit. The head was eight inches in diameter.

$$
\text { PLATE } 68
$$

Daleomyces Phillipsii. Section through an ascophore, reduced onefourth, from material collected by S. C. Edwards in California.

$$
\text { PLATE } 69
$$

Elvela californica. Hout two-thirds natural size, from material furnished by Mautle E. Morris from Seattle, Washington, photographs having been made by Mr. C. F. Todel. The specimen measured eight inches across. This is a short stemmed form.

I'LATE 70

Elvela californica. Ibout two-thirds natural size, from material furnished by Maude E. Morris from Seattle, Washington, photographs having been made by Mr. C. F. Todd, with drawings of an ascus with spores and a paraphysis; also diagram of section of stem.

\section{PLATE 71}

Elvela infula. Photographs of several fruiting bodies, from material collected in Canada by. G. S. Bell, with drawing of an ascus with spores and a paraphysis.

\section{Plate 72}

Eliela caroliniana. Photograph of a fruiting body, somewhat reduced, from material collected by WI. E. Bruner of Baldwin, Kansas, and sent to the writer by Dr. Leva B. Walker of Lincoln, Nebraska. Right, drawing of an ascus with spores and portion of a paraphysis. Left, spore much enlarged, showing the delicate reticulation.

\section{Plate 73}

Elvela caroliniana. Photograph of a fruiting body, from material collected by A. R. Bechtel in Crawfordsville, Indiana. Right, drawing of an ascus with spores and paraphyses. Left, drawings of two spores, much enlarged, showing delicate reticulations.

\section{Pl.ite 74}

Bulgaria globosa. Photographs of four apothecia, somewhat reduced. From material collected in Oregon and sent by Mr. Sylvan Cohen. 

1)

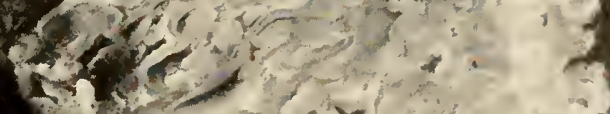
Def

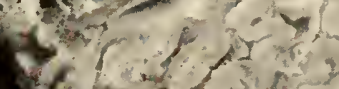





\section{BIBLIOGRAPHS}

This bibliography has been prepared by Gussie Mildred Viller, who has consulted freely the records of Dr. John Hendley Barnhart, to whom we are indebted for valuable assistance and consultation.

\section{Adanson, Michel, 1727 1806 (Adans.).}

Fam. I'l. 1:1-189. 2: 1-640. 1763.-Familles des plantes.

Afzelius, Adam, $1750-1837$ (Afzel.).

Sv. Vet.-Akad. Nya Handl. 4: 299-313. 1783.-Svamp-slägtet Helvella. Albertini, Johannes Baptista von, 1769 1831; Schweinitz, Lewis David von, 1780-1834 (Alb. \& Schw.).

Consp. Fung. 1-376. pl. 1-12. 1805.-Conspectus fungorum in Lusatiae superioris agro niskiensi crescentium.

Arthur, Joseph Charles, 1850-(Arth.).

Bull. Geol. Nat. Hist. Surv. Minn. 3: 1-56. 1 O 1887.- Report on botanical work in Mlinnesota for the year 1886.

Atkinson, George Francis, 1854-1918 (Atk.).

Ann. Miscouri Bot. Gard. 2: 315-376. 10 figs. 1915.-Phylogeny and relationships in the Ascomycetes.

Auerswald, Bernhard, 18181870 (Auersw.).

Hedwigia 7: 50 -52. 1868.-Die Ascobolus = Irten auf Iundekoth.

Hedwigia 8: 82, 83. 1869. - Sarcosphaera Awd., novum genus I liscomycetum.

Bainier, Georges, 1920 (Bainier).

Bull. Soc. Myc. Fr. 23: 132-140. pl. 18, 19. 1907.-Mycotheque de l'Ecole de Pharmacie-XX. Evolution du Papulaspora aspergilliformis et étude de deux $\mathrm{A}$-codesmis nouveaux.

Batsch, August Johann Georg Carl, 1761 -18C2 (Batsch).

Elench. Fung. 1783-89.-Elenchus fungorum.

Elench. Fung. 1-183. pl. 1-12. 1783.

Elench. Fung. Contin. 1: 1-279. pl. 13-30. 1786.

Elench. Fung. Contin. 2: 1-163. pl. 31-12. 1789.

Berkeley, Miles Joseph, 18031889 (Berk.).

Ann. Mag. Nat. Hist. 6: 355-365. 1841.-Notices of British fungi.

Ann. Mag. Nat. Hist. II. 9: 192-203. pl. S. Mr 1852.-Enumeration of some fungi from St. Domingo.

Grevillea 3: 145-160. 1875.-Notices of North American fungi.

Grevillea 4: 1-16. 1875.-Notices of North American fungi.

In Hooker's F1. New Zealand 2: 172-210. 1885.-Nat. Ord. CII. Fungi.

In Smith, Engl. Fl. 52: 1-386, $1^{*}-32^{*}$. 1836.-Fungi.

Jour. Bot. and Kew Misc. 3: 200-206. 1851.-Decarles of fungi.

Jour. Linn. Sor. 9: 423-425. pl. 12. 1867.-On some new fungi from Mexico. 
Jour. Linn. Soc, 10: 341-392. 16 Je 1868. - On a collection of fungi from Cuba. Part II., including those belonging to the families Gasterumycetes, Conionycetes, Hyphomycetes, Phyconycetes, and Ascomycetes.

Jour. Linn. Soc. 13: 155-177. 29 My 1872.- - Mustralian fungi, received principally from Baron F. von Mueller and Dr. R. Schomburgk.

Jour. Linn. Soc. 18: 38.3-389. 1881.-Australian fungi-II. Received principally from Baron F, von Mueller.

London Jour. Bot. 1: 138-142. pl. 6, f. 1-3. 1842.-Enumeration of fungi, collected by Dr. Hostmann, in Surinam.

London Jour. Bot. 1: 447-457. pl. 14, 15. 1842.-Description of fungi, collected by R. B. Hinds, Esq., principally in the Islands of the Pacific.

London Jour. Bot. 5: 1-6. 1846.-Decades of fungi.

London Jour. Bot. 6: 312-326. 1847.-Decades of fungi.

Outl. Brit. Fungol. 1-442. pl. 1-27. 1860.-Outlines of British fungology.

Trans. Linn. Soc. 25: 431,432 pl. 55 . 1866. On two new British fungi.

Berkeley, Miles Joseph, 1803-1889; Broome, Christopher Edmund, 1812-1886 (Berk. \& Br.).

Ann. Mag. Nat. Hist. 18: 73 82. 1846.-Notices of British hypogaeous fungi.

Ann. Mag. Nat. Hist. II. 7: 176-189. Mr 1851.-Notices of British fungi.

Ann. Nag. Nat. Hist. I1. 13: 458-469. pl. 15, 16. Je 1854--Notices of British fungi. (Continued.)

Inn. Mag. Nat. Hist. III. 15: 44t-452. 1865. -Notices of British fungi. Ann. Mag. Nat. Hist. I11. 18: 121-129. pl. 3-5. Au 1866.-Notices of British fungi.

Ann. Mag. Nat. Hist. IV. 7: 425-436. 1873.-Notices of British fungi.

Ann. Mag. Nat. Hist. IV. 11: 339-349. pl. 7-10. 1873.-Notices of British fungi.

Ann. Mag. Nat. Hist. IV. 15: 28-41. pl. 1, 2. Ja 1875.- Notices of British fungi. (Continued.)

Ann. Mag. Nat. Hist. IV. 17: 129-145. pl. 9-11. 1876.-Notices of British fungi.

Jour. Linn. Soc. 14: 29 64. 9 O 1873; 65-140. pl. 2-10. 3 D 1873.Enumeration of the fungi of Ceylon. Part 11 , containing the remainder of the Hymenomycetes, with the remaining established tribes of Fungi.

Trans. Linn. Soc. II. 2: 53-73. pl. 10-15. 1883.--List of fungi from Brisbane, Qucensland; with descriptions of new species.-Part Ii.

Berkeley, Miles Joseph, 1803 -1889; Curtis, Moses Ashley, 1808-1872 (Berk. \& Curt.).

Jour. Linn. Soc. 10: 280-341. 1868.-Fungi cubenses (Hymenomycetes).

Proc. Am. Acad. 4: 111-130. 1859.-Characters of new fungi, collected in the North Pacific Exploring Expedition of Charles ITright.

Bessey, Charles Edwin, 1845-1915 (Bessey).

-Bot. Surv. Nebr. 3: 5-20. 1894.-Additions to the reported flora of Nebraska made during 1893. 


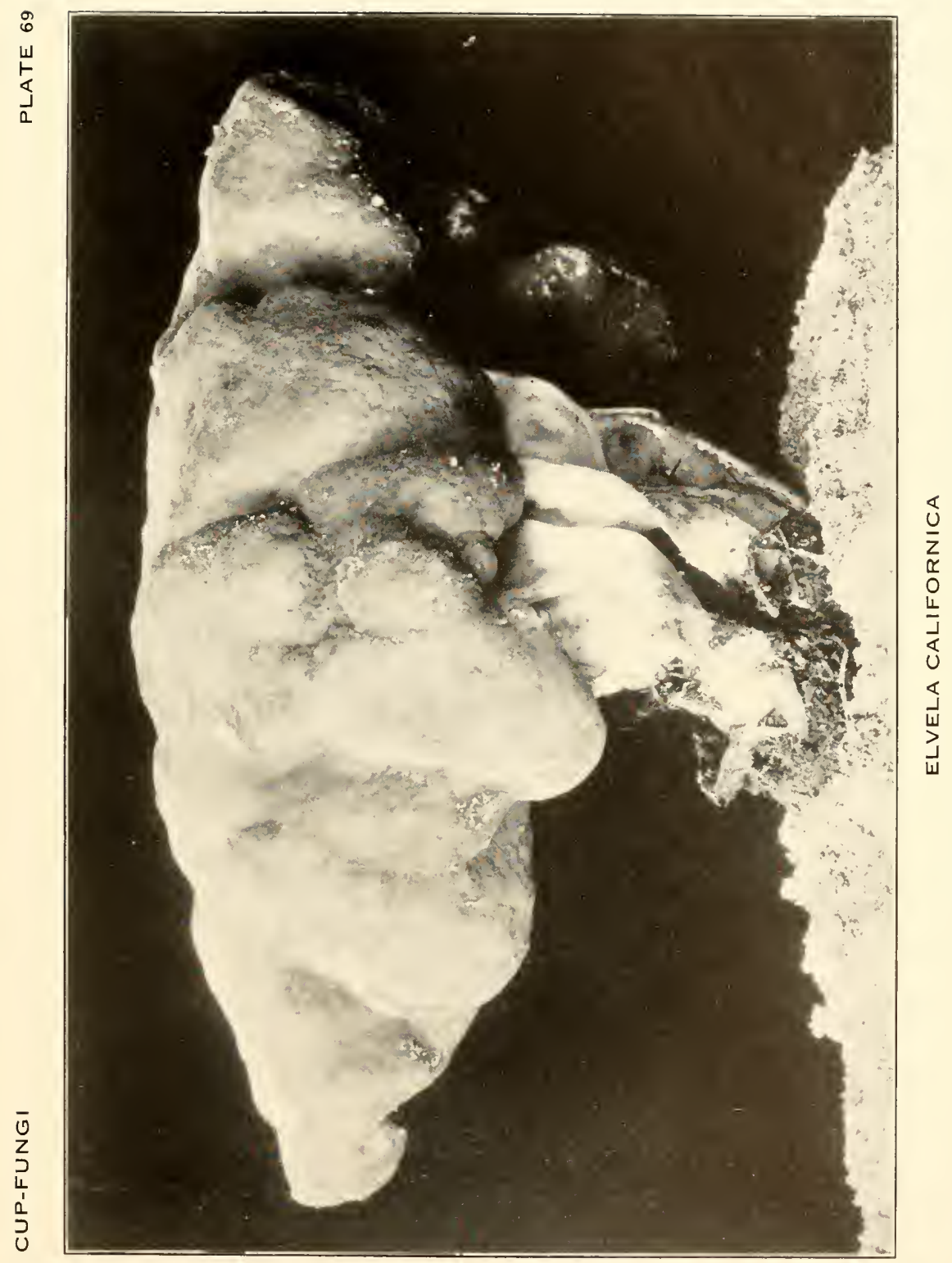





\section{Betts, Edwin Morris, 1892- (Betts).}

Am. Jour. Bot. 13: 427-432. 1926.-Heterothallism in . Iscobolus carbonarius.

Betts, Edwin Morris, 1892-; Meyer, Samuel Lewis, (Betts \& Meyer).

Am. Jour. Bot. 26: 617-619. 1939.-Heterothallism and segregation of sexes in Ascobolus geophilus.

Bolton, James, $17-1799$ (Bolt.).

Hist. Fung. 1-182. pl. 1 -182. 1788-91.-An history of fungusses, growing about Halifax.

$$
\begin{aligned}
& \text { 1-92. pl. 1-92. 1788. 93-138. pl.93-138. } 1789 . \\
& \text { 139-182. pl. 139-182. } 1791 .
\end{aligned}
$$

Bivona-Bernardi, Antonio, 1774-1837 (Biv.).

Stirp. Rar. Sic. 1813-16.- Stirpium rariorum minusque cognitarum in Sicilia sponte provenientium descriptiones.
1: [1-18.] pl. 1, 2. 1813.
3: 1-30. pl. 1-t. 1815.
2: [1-16.] pl. 1, 2. 181t.
4: 1-39. pl. 1-6. 1816.

Boedijn, Karel Bernard, 1893- (Boedijn).

Bull. Jardin Bot. Buitenzorg 1II. 13:57-76. 1933.-The genera Phillipsia and Cookeina in Netherlands India.

Rec. Trav. Bot. Néerl. 26:396-439.f. 1-17. 1929.-Beitrag zur Kenntnis der Pilzflora von Sumatra.

\section{Borszczow, Elia Grigorievicz, 1833-1878 (Borsz).}

Beit. Pflanzenkunde 10: 53-64. pl. 1-8. 1857.-Fungi Ingrici novi aut minus cogniti.

Bosc, Louis Augustin Guillaume, 1759-1828 (Bosc).

Ges. Nat. Freunde Berlin Mag. 5: 83-89. pl. t-6. 1811.-Mémoire sur quelques espèces de champignons des parties mericlionales de l'Amérique septentrionale.

Boudier, Jean Louis Émile, $1828-1920$ (Boud.).

Ann. Sci. Nat. Y'. 10: 191-268. pl. 5-12. 1869.-Memoire sur les Ascobolés.

Bull. Soc. Bot. Fr. 24: 307-312. pl. 4. 1877.--De quelques especes nouvelles de champignons.

Bull. Soc. Bot. Fr. 26: 228-236. 1879.-Diagnoses nouvelles de quelques espèces critiques de champignons.

Bull. Soc. Bot. Fr. 28: 91-98. pl. 2, 3. 1881.-Nouvelles especes de champignons de France.

Bull. Soc. Myc. Fr. 1:91-121. 1885.-Nouvelle classification naturelle des discomycetes charnus connus généralement sous le nom de Paris.

Bull. Soc. Myc. Fr. 3: 88-96. pl. 8. 1887.-Notice sur les Discomycetes figurés dans les dessins inedits de Dunal conservés a la Faculté de Montpellier.

Bull. Soc. Myc. Fr. 4: XLVIJI-L. pl. 2. 1888.-Description de trois nouvelles espèces d'Ascobolés de France.

Bull. Soc. Myc. Fr. 10: 59-67. pl. 1, 2. 1894.-Nourelles espèces de champignons de France.

Bull. Soc. Myc. Fr. 12: 11-17. pl. 3, t. 1896.-Description de quelques nouvelles espèces de Discomycetes de France.

Bull. Soc. My c. Fr. 13: 129-153. 1897.-Revision analytique des Morilles de France. 
Bull. Soc. Myc. Fr. 14: 16-23. pl. 3-5. 1898.-Descriptions et figures de quelques espèces de Discomycètes operculés nouvelles ou peu connues.

Bull. Soc. Myc. Fr. 14: 125-129. pl. 11. 1898.- Sur deux nouvelles espèces d'Ascobolés et observations sur l'Lrnula Craterium récemment découvert en France.

Bull. Soc. Myc. Fr. 15: 49-54. pl. 2, 3. 1899.-Note sur quelques champignons nouveaux des environs de Paris.

Bull. Soc. Myc. Fr. 17: 23-25. 1901.-Note sur le genre Perrotia, nouveau genre de Discomycetes opercules.

Bull. Soc. Myc. Fr. 18: 137-143. pl.6-8. 1902.-Champignons nouveaux de France.

Hist. Class. Discom. Eu. 1-221. 1907.-Histoire et Classification des Discomycetes d'Europe.

Ic. Myc. 1-362. pl. 1-600. "1905-10" [1904-11].- Icones mycologicae, ou iconographie des champignons de France.

The plates appeared 1904-10, but not in the sequence of their numbers.

The text cited above was issued in 1911. There was, however, preliminary text for each of the 6 series in which the plates were issued; the year-dates of publication of this preliminary text are:
1: 1 -12. 1904 .
2: 5 20. 1906.
4: 1-29. 1907.
1: $13-19.1905$.
3: $1-8 . \quad 1906$.
5: $1-28.1908$.
2: 1 - t. 1905 .
3: $9-26.1907$.
6: 1-24. 1909.

Boudier, Jean Louis Émile, 1828-1920; Torrend, Camillo, (Boud. \& Torrend).

Bull. Soc. Myc. Fr. 27: 127-136. pl. f-6. 1911.-Discomycetes nouveaux de Portugal.

Brenckle, Jacob Frederick, 1875- (Brenckle).

Fungi Dak. 1-675. 1908-29.-Fungi dakotenses.

\begin{tabular}{|c|c|c|c|}
\hline $1-25$ & $\perp 1908$. & $351-375$. & Ja 1916. \\
\hline $26-50$. & Mr 1909. & $376-100$. & O 1916. \\
\hline $51-75$ & O 1909. & $401-125$. & D 1916. \\
\hline $76-100$. & Ja 1910. & $+26-150$. & Au 1917. \\
\hline $101-125$. & Au 1910. & $451-775$. & Au 1918. \\
\hline $126-150$. & S 1911. & $476-500$. & Au 1921. \\
\hline $151-175$ & F 1912. & $501-525$. & JI 1922. \\
\hline $170-200$. & D 1912 . & $526-550$. & Jl 1923. \\
\hline $201-225$ & JI 1913. & $551-575$. & i) 1924 . \\
\hline $220-250$. & N 1913. & $576-000$. & Jl 1927 \\
\hline $251-275$. & O 1914. & $601-025$. & N 1927 \\
\hline $270-300$. & 1) 1914 . & $626-650$. & Iu 1928. \\
\hline $301-325$ & Jl 1915. & $651-675$. & O 1929. \\
\hline $326-350$ & & & \\
\hline
\end{tabular}

Mycologia 8: 318. 1916.-Lamprospora detonia sp. nov.

Bresadola, Giacomo, 1847-1929 (Bres.).

Fungi Trid. 1881-1900.-Fungi tridentini novi, vel nondum delineati.
1: $1-14$. pl. $1-15.1881$.
1: 71-114. pl. T6-105. 1887.
1: 15-26. pl. 16-30. 1882.
2: 1-46. pl. 106-150. 1892 .
1: $27-12 . p l .31-+5.1883$.
2: $47-81$. pl. 151-195. 1898.
1: $43-70$. pl. t6-75. 1884 .
2: 82-118. pl. 196-217. S 1900 .

Rev. Myc. 4: 211,212. 1882.-Discomycetes nonnulli Tridentini novi. 


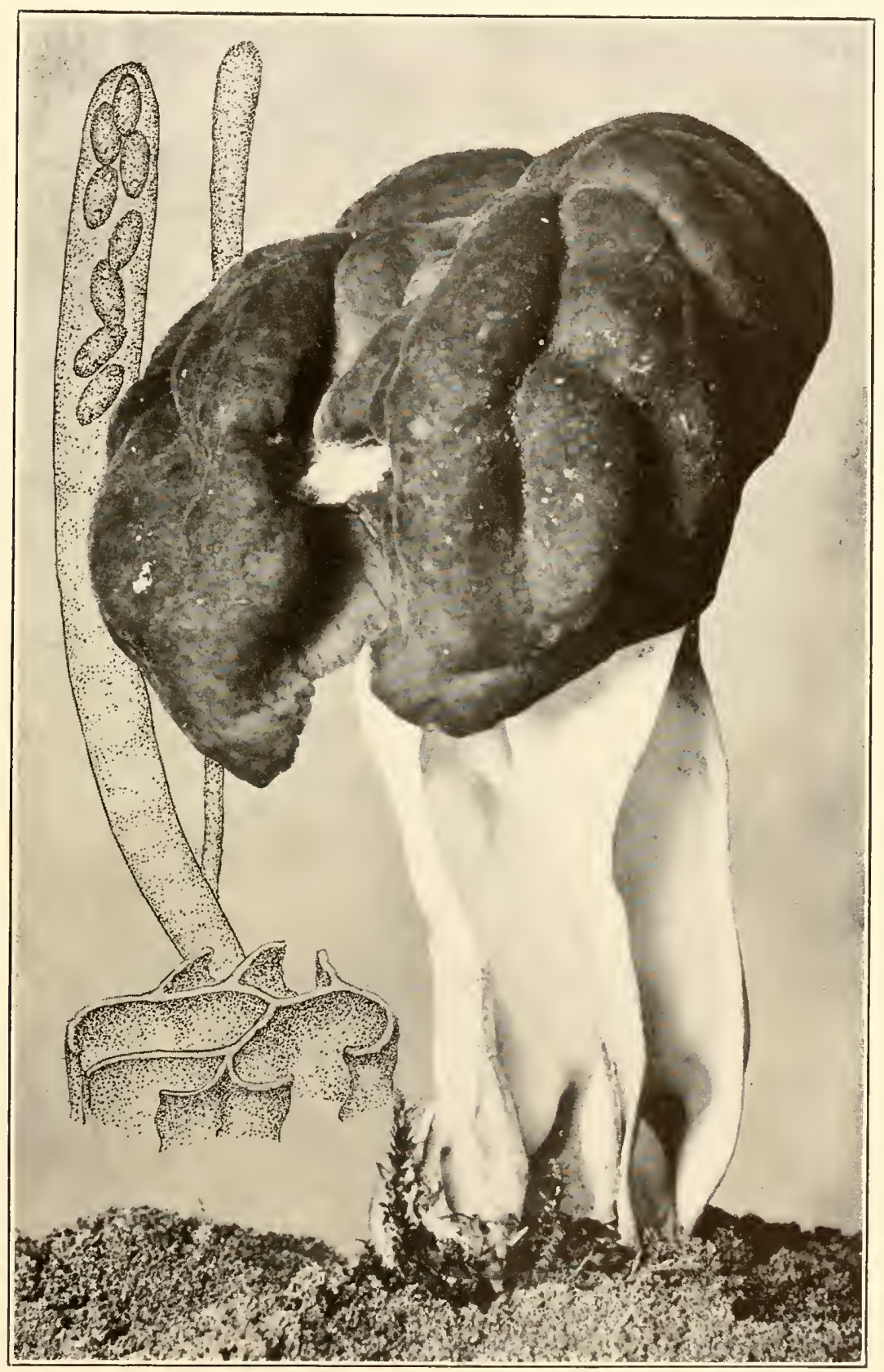

ELVELA CALIFORNICA 

Brown, William Henry, 1884-1939 (W. H. Brown).

An. Jour. Bot. 2: 289-298. 1915.- The development of Pyronema confluens var. inigneum.

Bubák, František, 18651925 (Bubák).

Ann. Myc. 2: 395-401. 21 figs. 1904. Neue oder kritische Pilze.

Bulliard, Jean Baptiste Francois, 1752-1793 (Bull.).

Herb. Fr. pl. 1-600. 1780-93.- - Herbier de la France.

$\begin{array}{cccc}\text { pl. } 1-48 . & 1780 . & \text { pl. } 337-38 t . & 1787 . \\ \text { pl. } 19-96 . & 1781 . & \text { pl. } 385-132 . & 1788 . \\ \text { pl. } 97-1+4 . & 1782 . & \text { pl. } 433-480 . & 1789 . \\ \text { pl. } 1+5-192 . & 1783 . & \text { pl. } 481-528 . & 1790 . \\ \text { pl. } 193-240 . & 1784 . & \text { pl. } 529-576 . & 1791 . \\ \text { pl. } 2+1-288 . & 1785 . & \text { pl. } 577-600 . & 1793 ? \\ \text { pl. } 289-336 . & 1786 . & {[p l .601,602 .]} & 1798 ?\end{array}$

Hist. Champ. Fr. 1-700. 1791-1812.- Histoire des champignons de lat France.

1-368. 1791. 369-5 $1809 . \quad 5+1-700.1812$.

Butler, Ellys Theodora, 1906- (E. T. Butler).

Mycologia 31: 612-623. f. 1, 2. 1939.-Ascus dehiscence in Lecanidion atratum and its significance.

Calkins, William Wirt, 1842-1914 (Calkins).

Jour. Myc. 2: 104-106. 1886.-Notes on Florida fungi-no. 8.

Carus, Carl Gustav, 1789-1869 (Carus).

Nova Acta Acad. Leop.-Carol. 17: 367-375. pl. 27. 1835.-Beobachtung einer sehr eigenthümlichen Schimmel-vegetation (I'yronema marianum mihi) auf Kohlenboden.

Caspary, Johann Xaver Robert, 1818-1887 (Casp.).

Clark, Ernest Dunbar, 1886- ; Seaver, Fred Jay, 1877- (Clark \& Seaver).

Mycologia 2: 109-124. pl.2t-26. 1910.-. Studies in pyrophilous fungi-1I. Changes brought about by the heating of soils and their relation to the growth of Pyronema and other fungi.

Clements, Frederic Edward, 1874- (Clements).

Bull. Torrey Club 30: 83-94. 1903.- Nova asconycetum genera speciesque.

Crypt. Form. Colo. 1-615. 1906-08.-Cryptogamae formationum coloradensium.

$$
\text { 1-200. 1906. 201-400. 1907. to1-015. } 1908 .
$$

Cooke, Mordecai Cubitt, 1825-1914 (Cooke).

Bull. Buffalo Soc. Nat. Sci. 2: 285-300. 1875. - Synopsis of the discomycetous fungi of the United States.

Fungi Brit. 1-700. 1865-74.-Fungi britannici exsiccati.

$$
\begin{array}{rrrr}
1-100 . & 1865 . & 301-400 . & 1870 . \\
101-200 . & 1866 . & 401-600 . & 1872 . \\
201-300 . & 1867 . & 601-700 . & 1874 .
\end{array}
$$

Gard. Chron. 41: 793, 794. 1877.-Crop of Peziza.

Grevillea 3: 30, 31. pl. 27-30. 1874.-Carpology of Peziza.

Grevillea 3: 73, 74. pl. 31-34. 1874.-Carpology of Peziza.

Grevillea 4: 109-114. pl. 67. 1876.-New British fungi.

Grevillea 5: 118-122. 1876.-New British fungi. 
Grevillea 6: 71 76. pl. 97. 1877.-New British fungi.

Grevillea 6: 110. 1878.-Fungi exsiccati.

Grevillea 6: 129-146. 1878.- Ravenel's American fungi.

Grevillea 8: 54-68. 1879.-New Zealand fungi.

Grevillea 21: 69-73. 1893.-New British fungi.

Grevillea 21: 73-75. 1893.-Exotic fungi.

Hedwigia 6: 154-157. 1867.-Foliicolous Sphacriate. (Blatthewohnende Spharien.)

Hedwigia 14: 81-85. 1875.-Pezizae americanae.

Jour. Bot. 2: 147-15t. 9 fig. 186t.-The genus Ascobolus, with descriptions of the British species.

Mycogr. 1-267. pl. 1-113. "1879" [1875-79].-Mycographia, seu icones fungorum. Vol. I. Discomycetes, part I. [No more published.]

1-44. pl. 1-20. 1875. 179-214. pl. 81-100. 1878.

45-136. pl. 21-60. 1876. 215-267. pl. 101-113. 1879.

137-178. pl. 61-80. 1877.

Trans. Bot. Soc. Edinb. 10: 439-443. 2 fig. 1870.-Kashmir morels.

Trans. Bot. Soc. Edinb. 13: 44-46. 1877.- T'ezizae at Inverleith House.

Cooke, Mordecai Cubitt, 1825-1914; Ellis, Job Bicknell, 1829-1905 (Cooke \& EIlis).

Grevillea 5: 49-55. pl. 80, 81. 1876.-New Jersey fungi.

Grevillea 6: 1-18. pl. 95, 96. 1877.-New Jersey fungi.

Cooke, Mordecai Cubitt, 1825 1914; Massee, George Edward, 1847-1917 (Cooke \& Massee).

Cooke, Mordecai Cubitt, 1825-1914; Peck, Charles Horton, 1833-1917 (Cooke \& Peck).

Grevillea 1: 5-7. 1872.-Peziza americanae.

Cooke, William Bridge, 1908 (W. B. Cooke).

Mycob. N. Am. 1-115. 1939-41.-Mycobiota of North America exsiccati.

Copeland, Edwin Bingham, 1873- (Copeland).

Ann. Myc. 2: 507-510. pl. 12. 1904.-New or interesting California fungi II.

Corda, August Carl Josef, 18091849 (Corda).

1c. Fung. 1837-54.--Icones fungorum hucusque cognitorum.

$$
\begin{array}{llll}
\text { 1: 1-32. pl. 1-7. } 1837 . & \text { 4:1-53. pl. 1-10. } 1840 . \\
\text { 2:1-43. pl. 8-15. } 1838 . & \text { 5:1-92. pl. 1-10. } & 1842 . \\
\text { 3: 1-55. pl. 1-9. } & 1839 . & \text { 6:1-91. pl. 1-20. } & 1854 .
\end{array}
$$

Coulter, John Merle, 1851-1928 (Coult.).

Rep. U. S. Geol. Surv. Terr. 6: 747-792. 1873.-Botany.

Crouan, Pierre Louis, 1798 1871; Crouan, Hippolyte Marie, 18021871 (Crouan).

Ann. Sci. Nat. IV. 7: 173-178. pl. t. 1857.--Note sur quelques Ascobolus nouveaux et sur une espèce nouvelle de $\mathrm{Y}$ ibrissea.

Ann. Sci. Nat. IV. 10: 193-199. pl. 13. 1858.-Note sur neuf Ascobolus nouveaux.

F1. Finist. 1-262. frontisp., pl. 1-31, pl. suppl. 1867.-Florule du Finistère. 


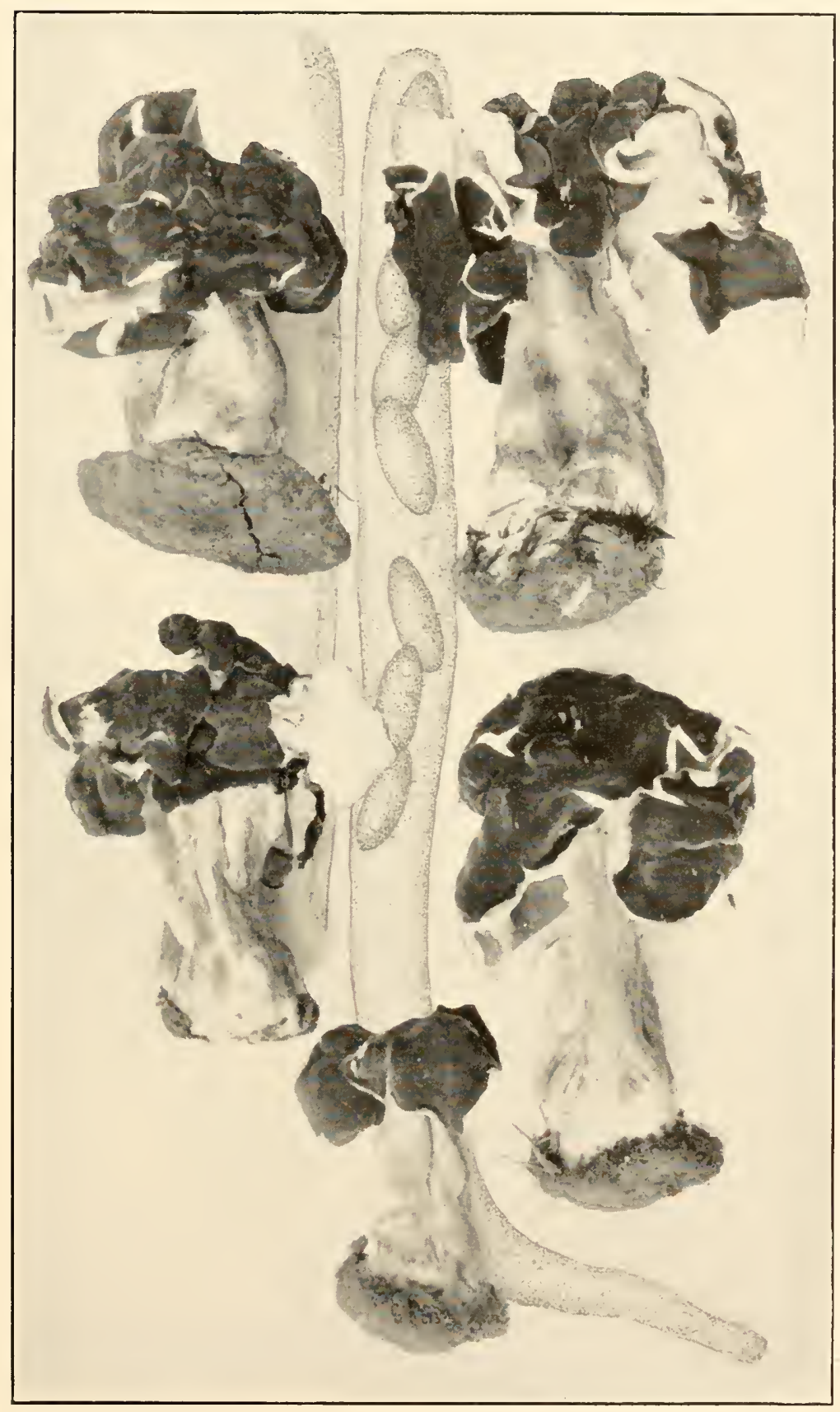

ELVELA INFULA 

Currey, Frederick, $1819-1881$ (Currey).

Trans. Linn. Soc. 24: 151-160. pl. 25. 1863.-Notes on British fungi.

Trans. Linn. Soc. 24: 191-496. pl. 51. 1864.-Notes on British fungi.

DeNotaris, Giuseppe, $1805-1877$ (De-Not.).

Comm. Soc. Critt. Ital. 1: 357-388. 1864.-Proposte di alcune rettificazione al profilo, (lei D)iscomiceti.

\section{Desmazieres, Jean Baptiste Henri Joseph, 17861862 (Desmaz.).}

Inn. Sci. Nat. 1I. 6: 242 247. 18.36. - Notice sur quelques cryptogames nouvelles qui ont été publiées, en nature, dans les Fascicules XI-XYII des plantes cryptogames de France.

Ann. Sci. Nat. II. 15: 129-146. pl. 1f, f. 1, 2. 1841.-Huitieme notice sur quelques plantes cryptogames, la plupart inédites, récemment decouvertes en France, et qui vont paraite en nature dans la collection publiée par l'auteur.

Dietrich, Albert, $1795-1856$ (A. Dietr.).

Fl. Boruss. pl. 1-\$6t. 1833-44.-Flora regni borussici. Floril des Königreichs Preussen. Each plate with accompanying text. Yeardiates:

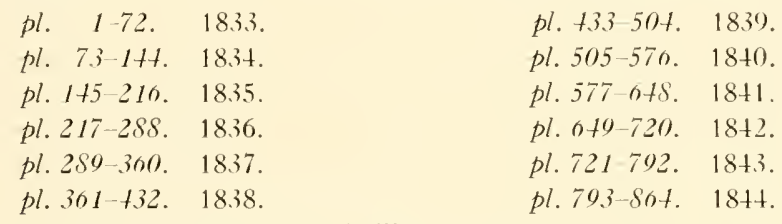

Dillenius, John Jacob, 16841747 (Dill.).

Cat. I'l. Grissa 1-240. pl. I-11. 1718; App. 1-174. pl. I-16. 1719.Catalogus plantarum sponte circa Grissam nascentium. Cum appendice.

Dodge, Bernard Ogilvie, 1872 - (B. O. Dodge).

Mycologia 4: 218-222. pl. 72, 73. 1912.-Artificial cultures of Ascololus and Neuria.

Mycologia 12: 115-134. pl. 78, f. 1-28. 1920. - The life history of Ascobolus magnificus.

Mycologia 29: 651-655. I fig. 1937. - The conidial stage of Peziza pustulata.

Science 1I. 41: 173. 1915.-The Papulaspora question as related to Ascobolus.

Trans. Wis. Acad. 17: 1027-1056. 1914.-Wisconsin Disconycetes.

Dodge, Carroll William, 1895- (C. W. Dodge).

Ann. Missouri Bot. Gard. 21: 709-712. 1934.- l'roposals for annenelment of article 20 of the International Rules of Nomenclature.

Dowding, Eleanor Silver, 1901- (Dowding).

Ann. Bot. 45: 621 637. pl. 19, f. 1-10. O 193!.- The sexuality of Iscobolus stercorarius and the transportation of the vidia by mites and fies.

Durand, Elias Judah, 1870- (E. J. Durand).

Bull. Torrey Club 29: 458-465. 1902. - Studies in North Imerican Discomycetes. II. Some new or noteworthy species from central and western New Jork. 
Jour. Nyc. 9: 102-104. 1903.-The genus Sarcosoma in North America.

Jour. Myc. 12: 28-32. 1906.-Peziza fusicarpa Ger. and Peziza semitosta B. \& C.

Mycologia 11: 1-3. pl. 1. 1919.-Peziza proteana var. sparassoirles in America.

Durieu de Maisonneuve, Michel Charles, 1796-1878 Durieu).

Expl. Sci. Mlgér. Bot. 1846-68.--Exploration scientifique de l'Mlgérie, publiée par ordre du gouvernement. Sciences naturelles: Botanique. Flore d'Algérie.

$$
\begin{aligned}
& \text { 1: } 1-160 \text { ? } 1846 . \quad 2: 1-120.1855 . \\
& 1: 161 \text { ? }-288 \text { ? } 18+7 . \quad 2: 121-240.1856 . \\
& 1: 289 \text { ? }-440 \text { ? } 1848 . \quad 2: 241-312.1867 . \\
& \text { 1: } 441 \text { ? }-600.1849 . \quad 2 \text { : introcl. } 1868 .
\end{aligned}
$$

Earle, Franklin Sumner, 1856-1929 (Earle).

In Greene, 1'l. Baker. 2: 1-30. 25 Mr 1901.-Fungi.

Ellis, Job Bicknell, 1829-1905 (Ellis).

Bull. Torrey Club 8: 6t-66. 1881.-New species of North Imerican fungi.

Bull. Torrey Club 9: 18-20. 1882.-New North Imerican fungi.

Ellis, Job Bicknell, 1829-1905; Dearness, John, 1852- (Ellis \& Dearness). Ellis, Job Bicknell, 1829-1905; Everhart, Benjamin Matlack, 1818-1904 (Ellis \& Ev.).

Am. Nat. 31: 426-430. Ny 1897.-New species of fungi from various localities. (Continued.)

Bull. Lab. Nat. Hist. Univ. Iowa 4:67-72. 1) 1896.-New species of tropical fungi.

Bull. Torrey Club 10: 97, 98. 1883.-New species of fungi.

Bull. Torrey Club 24: 277-292. 1897.-New species of North Mmerican fungi from various localities.

Erythea 1: 197-206. 2 O 1893.-New west American fungi.

Jour. Myc. 1: 148-15t. 1885.-New fungi.

Jour. Myc. 4: 97-107. 1888.-New species of fungi from varions localities.

N. Am. Fungi 1501-3600. 1886-98.- North American fungi. Second series.

Ellis, N. Am. Fungi $1-1500$ counted as "first series."

$\begin{array}{llll}1501-1700 . & 1886 . & 2701-2800 . & 1892 . \\ 1701-1900 . & 1887 . & 2801-3000 . & 1893 . \\ 1901-2100 . & 1888 . & 3001-3200 . & 1894 . \\ 2101-2300 . & 1889 . & 3201-3300 . & 1895 . \\ 2301-2500 . & 1890 . & 3301-3500 . & 1896 . \\ 2501-2700 . & 1891 . & 3501-3600 . & 1898 .\end{array}$

Proc. Acad. Phila. 1894: 322-384. 11 1) 1894.- New species of fungi from various localities.

I'roc. Acad. Phila. 1895: 413-434. 5 N 1895.-New species of fungi from various localities.

Ellis, Job Bicknell, 1829-1905; Holway, Edward Willet Dorland, 18531923

(Ellis \& Holway).

Jour. Myc. 1:4-6. 1885.- New fungi from lowa. 


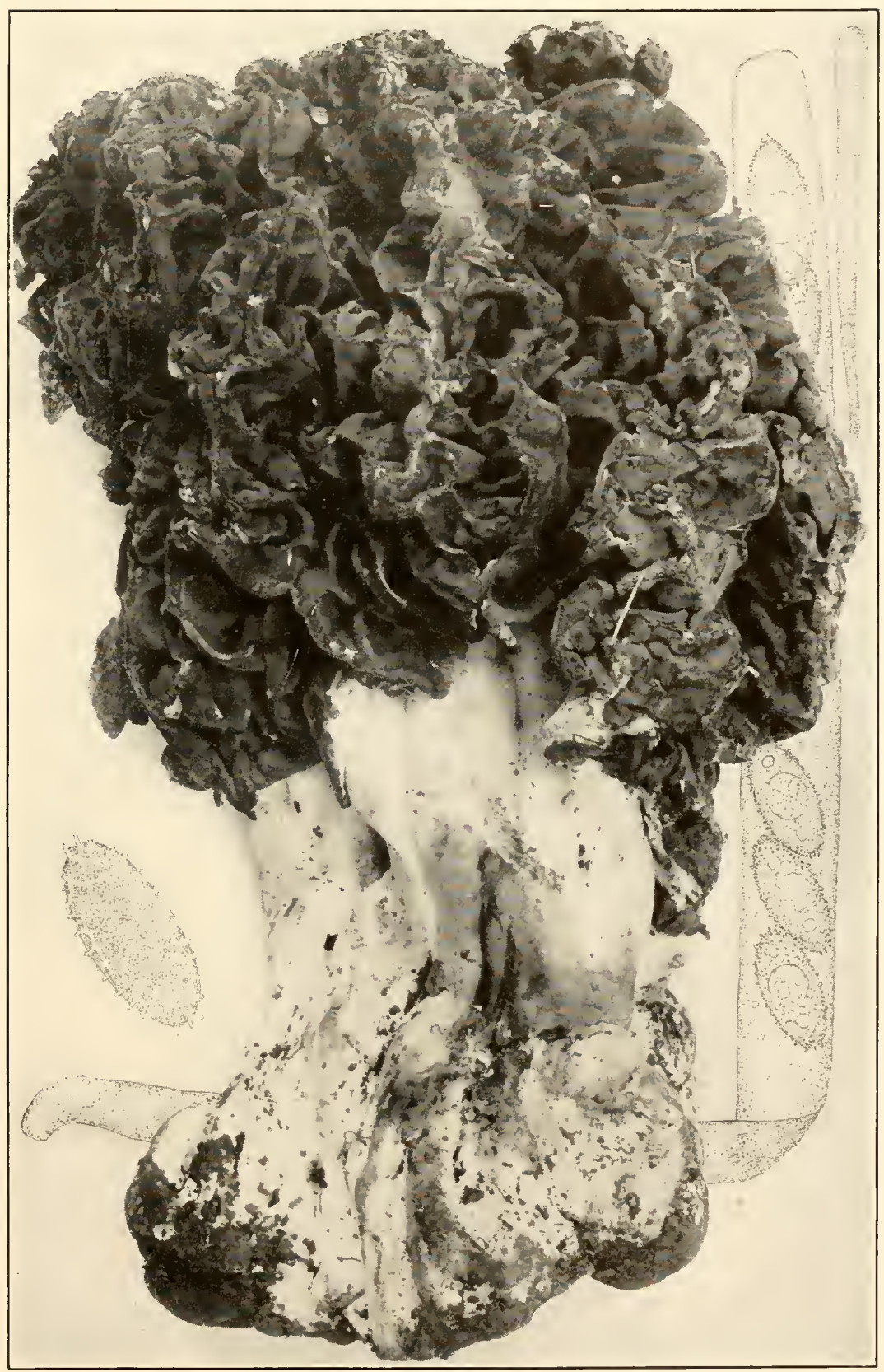



Endlicher, Stephan Ladislaus, 18041849 (Endl.).

Gen. 1836-50.-Genera plantarum secunchun ordines naturales disposita.

$\begin{array}{rr}1-160 . & 1836 . \\ 161-400 . & 1837 . \\ 401-640 . & 1838 . \\ 641-960 . & 1839 . \\ 961-1360 . & 1840 .\end{array}$

1.361-1+8.3. $18+1$

Suppl. 2: 1-114. $18+2$.

Suppl. 3: $1-110.18+3$.

Suppl. $4^{2}: 1-95.18+7$.

Suppl. 5: 1-104. 1850.

Engler, Heinrich Gustav Adolf, 1844 1930; Prantl, Karl Anton Eugen, 1849 1893 (E. \& P.).

Nat. Pfl. 1887-1911.-Die natürlichen Planzenfamilien.

The year-dates of the mycological parts of this work are:

$\begin{array}{cccccc}1^{1}: & 1-32 . & 1889 . & 1^{1 *}: & 97-14 t . & 1905 . \\ 1^{1}: & 33-80 . & 1892 . & 1^{1 *}: & 145-192 . & 1906 . \\ 1^{1}: & 81-128 . & 1893 . & 1^{1 *}: 193-249 . & 1907 . \\ 1^{1}: & 129-176 . & 1894 . & 1^{1 * *}: & 1-96 . & 1897 . \\ 1^{1}: & 177-272 . & 1896 . & 1^{1 * *}: 97-288 . & 1898 . \\ 1^{1}: & 273-513 . & 1897 . & 1^{1 * *}: 289-336 . & 1899 . \\ 1^{1 *}: 1-48 . & 1898 . & 1^{1 * *}: 337-570 . & 1900 . \\ 1^{1 *}: 19-96 . & 1903 . & & \end{array}$

Fries, Elias Magnus, 1794-1878 (Fries).

Elench. Fung. 1: 1-238. 2: 1-15t. 1828.-Elenchus fungorum.

Nov. Acta Soc. Sci. Upsal. III. 1: 17-136. 1851.-Novae symbolie mycologicae in peregrinis terris a botanicis danicis collectae.

Cited as "Nov. Syml." at various places in this volume, especially on the earlier pages.

Obs. Myc. 1815-18.-Observationes mycologicae.
1: 1-230. pl. 1-t. 1815.
2: 1-372. pl. 5-8. 1818.

Oefv. Sv. Vet.-Akad. Handl. 28: 171-174. pl. t. 1871.-Queletia, noxa

Lycuperdaceorum genus, accedit nova Gyromitrae species.

Summa Veg. Scand. 1-572. 18+5-49.-Summa vegetabilium Scandinaviae. $1-258.18+5$. 259-572. 1849.

Sv. Metl. Svamp. 1 53. pl. 1-93. "1861" [1860-66].-Sveriges ätliga och giftiga srampar.

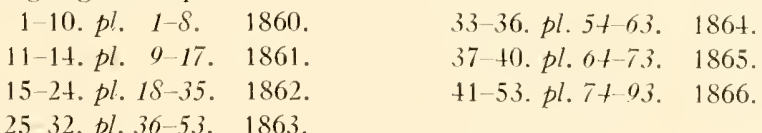

Syst. Myc. 1821-32.-Systema mycologicum.
1: $\quad 1-520.1821$.
3: $\quad 1-260.1829$.
2: 1-274. 1822.
3: 261-524. 1832.

2: 275-620. 1823 .

Fuckel, Karl Wilhelm Gottlieb Leopold, 18211876 (Fuckel).

Bot. Zeit. 19: 249-252. pl. 10. 30 Au 1861.-Mykologisches.

Fungi Rhen. 1-2700. 1863-74.-Fungi rhenani exsiccati.

$\begin{array}{rrll}1-800 . & 1863 . & 2201-2300 . & 1869 . \\ 801-900 . & 1864 . & 2301-2400 . & 1871 . \\ 001-1000 . & 1865 . & 2401-2500 . & 1872 . \\ 1001-1900 . & 1866 . & 2501-2600 . & 1873 . \\ 1901-2100 . & 1867 . & 2001-2700 . & 1874 . \\ 2101-2200 . & 1868 . & & \end{array}$


Hedwigia 5: 1-5. 1866.-Ueler rheinische Ascobolus-Urten.

Jahrb. Nass. Ver. Nat. 23-24: 1-459. pl. I 6. 1870.-Symbolae mycologicae. Beiträge zur Kenntniss der rheinischen Pilze.

This volume appeared separately, dated 1869, and in North American Flora it was assumed that this separate was issued in advance; it now seems that this assumption was an error.

Jahrb. Nass. Ver. Nat. 25 26: 287-346. 1871.- Symbolae mycologicae. Beiträge zur Kenntniss der rheinischen P’ilze. Erster Nachtrag.

Jahrb. Nass. Ver. Nat. 27-28: 1-99. pl. 1873.-Symbolae mycologicae. Beiträge zur Kenntniss der rheinischen Pilze. Zweiter Nachtrag.

Jahrb. Nass. Ver. Nat. 29 30: 1-39. 1875.-Symbolae mycologicae. Beiträge zur Kenntniss der rheinischen Pilze. Dritter Nachtrag.

Gelin, Olov E. V. (Gelin).

Kongl. Norske Vidensk. Selsk. 10: 194-197.f. 1. 1937.-The distribution in Scandinavia of Plectania protracta (Fries) Gelin, comb. nov. and Plectania coccinea (Scop.) Fuckel.

Gerard, William Ruggles, 1841 1914 (W. Gerard).

Bull. Torrey Club 4: 47,48 . O 1873.-New species of fungi. No. 1.

Bull. Torrey Clul, 6: 31, 32. Ip 1875.-New fungi. No. I.

Gibbs, Lilian Suzette, 1870-1925 (L. S. Gibbs).

Contr. Phytog. Arfak 1-226. pl. 1-t. Jl 1917.-Dutch N.II. New Guinea. A contribution to the phytogeography and flora of the Arfak Mountains, \&c.

Gillet, Claude Casimir, 1806-1896 (Gill.).

Champ. Fr. 1-828. pl. 1-133. 1874-78.-Champignons (Fungi, Hyménomycètes) qui croissent en France

Supplementary plates were issued at intervals, bringing the total number up to above 700 , and they were successively and repeatedly renumbered in lists distributed with them.

Approximate dates of text.

1-176. 1874. 177-560. $1876 . \quad 561-828 . \quad 1878$.

Gmelin, Johann Friedrich, 1748-1804 (J. F. Gmel.).

Syst. Nat. 1788-93.-Caroli a Linné Systema naturae. Editio decima tertia, aucta, reformata.

1: $1-4120.1788 . \quad 2: 1-1661.1791 . \quad 3: 1-476.1793$.

Botany in vol. 2 only.

Gonnermann, Wilhelm, 1806-1884; Rabenhorst, Gottlob Ludwig, 1806-1881 (Gonn. \& Rab.).

Myc. Eur. 1869 72.-Mycologia europaea.

Six sets of pagination and plate-numbers.

Agaricus pl. 20-25 exist, but scem never to have been published, unless with reissue of parts $7-9$ in 1882.

Agaricini 1-6. pl. 1, 2. 1869.-Agaricini.

Agaricus 1, 2. pl. 1-6. 1869.-Agaricus.

Agaricus 3-14. pl. 7-18. 1872.-Agaricus.

Panus 1. 1872.-Panus. (Agaricus pl. 12, pars.).

Pez. 1-10. pl. 1-6. 1869.-Pezizacei.

Polyp. 1-4. pl. 1-7. 1870.-1'olyporei. Boletus.

Pyren. 1-30. pl. 1-12. 1869.-Pyrenomycetes. 


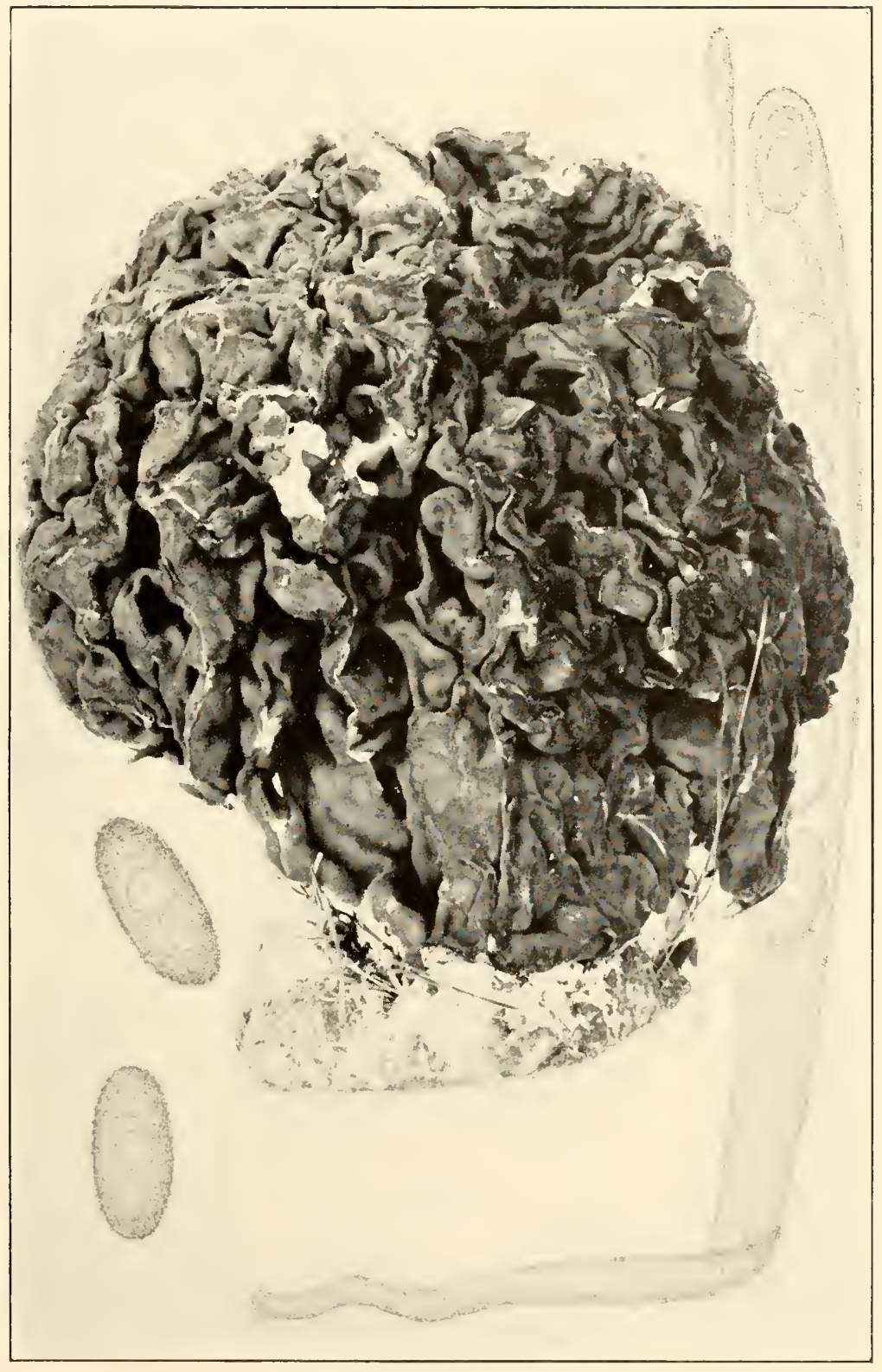

ELVELA CAROLINIANA 

Gray, Samuel Frederick, 17661836 (S. F. Gray).

Nat. Arr. Brit. Pl. 1: 1-82t; pl. 1 21. 2: 1-757. 1821.--1 natural arrangement of British plants.

Greville, Robert Kaye, $1794-1866$ (Grev.).

F1. Edin. 1-478. pl. 1-t. 1824.-Flora edinensis: or a rescription of plants growing near Edinburgh.

Scot. Crypt. Fl. pl. 1-360. 18[22]-28.-Scottish cryptogamic flora.

Issued in 72 monthly parts of 5 plates (the text not paged) each, J1 1822 Je 1828.

$\begin{array}{lccll}\text { Pl. } & 1-30 . & 1822 . & \text { Pl. 211-270. } & 1826 . \\ \text { Pl. } & 31-90 . & 1823 . & \text { Pl. 271-330. } & 1827 . \\ \text { Pl. } & 91-150 . & 1824 . & \text { Pl. } 331-360 . & 1828 .\end{array}$

Pl. $151-210.1825$.

Gwynne-Vaughan, Helen Charlotte Isabella, 1879- ; Williamson, Helen Stuart, 1884-1934 (Gwynne-Vaughan \& Williamson).

Ann. Bot. 46: 653-670. pl. 21-23, f. 1-13. 1932. - The cytology and development of Ascobolus magnificus.

Hansen, Emil Christian, 1842-1909 (E. C. Hansen).

Vidensk. Medd. 1876: 207-35t. pl. f 9. 1877.-1 )e danske Gjodningsivampe (Fungi fimicoli danici).

Harkness, Harvey Willson, 1821-1901; Moore, Justin Payson, 18411923 (Hark. \& Moore).

Cat. Pacific Coast Fungi 1-46. 1880.- Catalogue of the Pacific Coast fungi.

Harper, Robert Almer, 1862 (Harper).

Ann. Bot. 14: 321-400. pl. 19-21. 1900.-Sexual reproduction in Pyronema confluens and the morphology of the ascocarp.

Hazslinsky, Friedrich August, 1818-1896 (Hazsl.).

Oesterr. Bot. Zeits. 32: 7, 8. 1882.-Peltidium unt Geoglossum.

Verh. Zool.-Bot. Ges. Wien 37: 151-168. pl. 3. 1887.-Einige neue orler wenig bekannte Discomyceten.

Hedwig, Johann, 17301799 (Hedw.).

Descr. 178 -97.-Deseriptio et adumbratio microscopico-analytica muscorum frondosorum.

1: 1-110. pl. 1-t0. 1787.

2: 1-58. pl. 1-20. 1788 .

4: 1-26. pl. 1-10. 1793.

2: 59-112. pl. 21-40. 1789.

4: 27-52. pl. 11-20. 1794.

3: 1-72. pl. 1-30. 1791.

3: 73-100. pl. 31-70. 1792 .

$4: 53$-80. pl. 21-30. 179-.

4: 81-106. pl. 31-40. 1797.

Hedwig, Romanus Adolf, 1772-1806 (Hedw.f.).

Heimerl, Anton, 1857- (Heimerl).

Niederösterr. Ascob. 1-32. pl. 1. 1889.-1)ie niederösterreichiscen . Iscoboleen.

Hennings, Paul Christoph, 1841-1908 (P. Henn.).

Bot. Jahrb. 14: 337 373. pl. o. 1892.-Fungi africani.

Hedwigia 42: (22)-(24). 5 fig. 1903.-Ruhlandiella berolinensis P. Henn. $\mathrm{n}$. gen. et n. sp., eine neue deutsche Rhizinacee.

Hedwigia 43: 197-209. 1904.-Fungi S. Paulenses 1I1. al cl. Puttemans collecti. 
Hedwigia 43: 242-273. pl. f, 15 fig. 1904.-Fungi amazonici ll. a cl. Ernesto Ule collecti.

Monsunia 1: 1-38. pl. 1. 1900.-Fungi.

Hesler, Lexemuel Ray, 1888- (Hesler).

Jour. Tenn. Acad. 12: 239-254. 5 figs. 1937.-Notes on southern Appalachian fungi, 11.

Hoffmann, Georg Franz, $1761-1826$ (Hoffm.).

Veg. Crypt. 1787-90.-Vegetabilia cryptogamica.
1: 1-42. pl. 1-8. 1787.
2: 1-34. pl. 1-8. 1790.

Holmskjøld, Theodor, 1732-1794 (Holmsk.).

Otia 2: 1-70. pl. 1-41. 1799.-Beata ruris otia fungis danicis.

Volumen II.

Volume 1 was published in 1790 under the title "Topsvampene som indbefatte kïlle og Greensvampene."

Hone, Daisy S. (Hone).

Minn. Bot. Studies 4: 65-132. pl. 1.t-19. 1909.-The Pezizales, I'hacidiales, and Tuberales of Minnesota.

Hotson, John William, 1870 (Hotson).

Bot. Gaz. 64: 265-284. pl. 21-23, f. 1-6. 1917.- Notes on bulbiferous fungi with a key to described species.

Proc. Am. Acad. 48: 225-306. pl. 1-12. 1912.-Culture studies of fungi producing bulbils and similar propagative bodies.

House, Homer Doliver, 1878 - (House).

Bull. N. Y. State Mus. 205-206: 32-42. illust. 1919.-New or interesting species of fungi $\backslash$.

Hudson, William, $1730-1793$ (Huds.).

Fl. Angl. ed. 2. 1-690. 1778.-Flora anglica. Editio altera, emendata et aucta.

Imai, Sanshi, 1900 - (Imai).

Bot. Mag. Tokyo 46: 172-175. $20 \mathrm{Ap}$ 1932.-Contribution to the knowledge of the classification of Helvellaceae.

Bot. Mag. Tokyo 52: 357-363. pl. 2. 20 Jl 1938.-Symbolae ad floram mycologicam Asiae orientalis. 11 .

Imazeki, Rokuya (Imazeki).

Jour. Japanese Bot. 14: 680-684. f. 1-3. 1938.-A rare fungus, Urnula Geaster Peck grows in Kyusyu, Japan.

Inzenga, Giuseppe, 1816-1887 (Inzenga).

Fung. Sic. 1865-69.-Funghi siciliani studii.
1: 1-95. pl. 1-8. 1865.
2: 1-79. pl. 1-10. 1869.

Jacquin, Nikolaus Josef von, 1727-1817 (Jacq.).

Fl. Austr. 1773-78.-Florae austriacae, sive plantarum selectarum in Austriae archiducatu sponte crescentium, icones.
1: 1-61. pl. 1-100. 1773.
4: 1-53. pl. 301-400. 1776.
2: 1-60. pl. 101-200. 1774 .
5: 1-56. pl. $401-450$.
3: 1-55. pl. 201-300. 1775.
App. pl. $1-50 . \quad 1778$.

Misc. Austr. 1778-81.-Niscellanea austriaca ad botanicam, chemiam et historiam naturalem spectantia.
1: 1-212. pl. 1-21. 1778.
2: 1-423. pl. 1-23. 1781 .

Kalchbrenner, Károly, 1807-1886 (Kalchbr.).

Hedwigia 2: 58, 59. pl. 10: 111, 1. 1862.-Peltidium Kalchbr. nov. gen. 


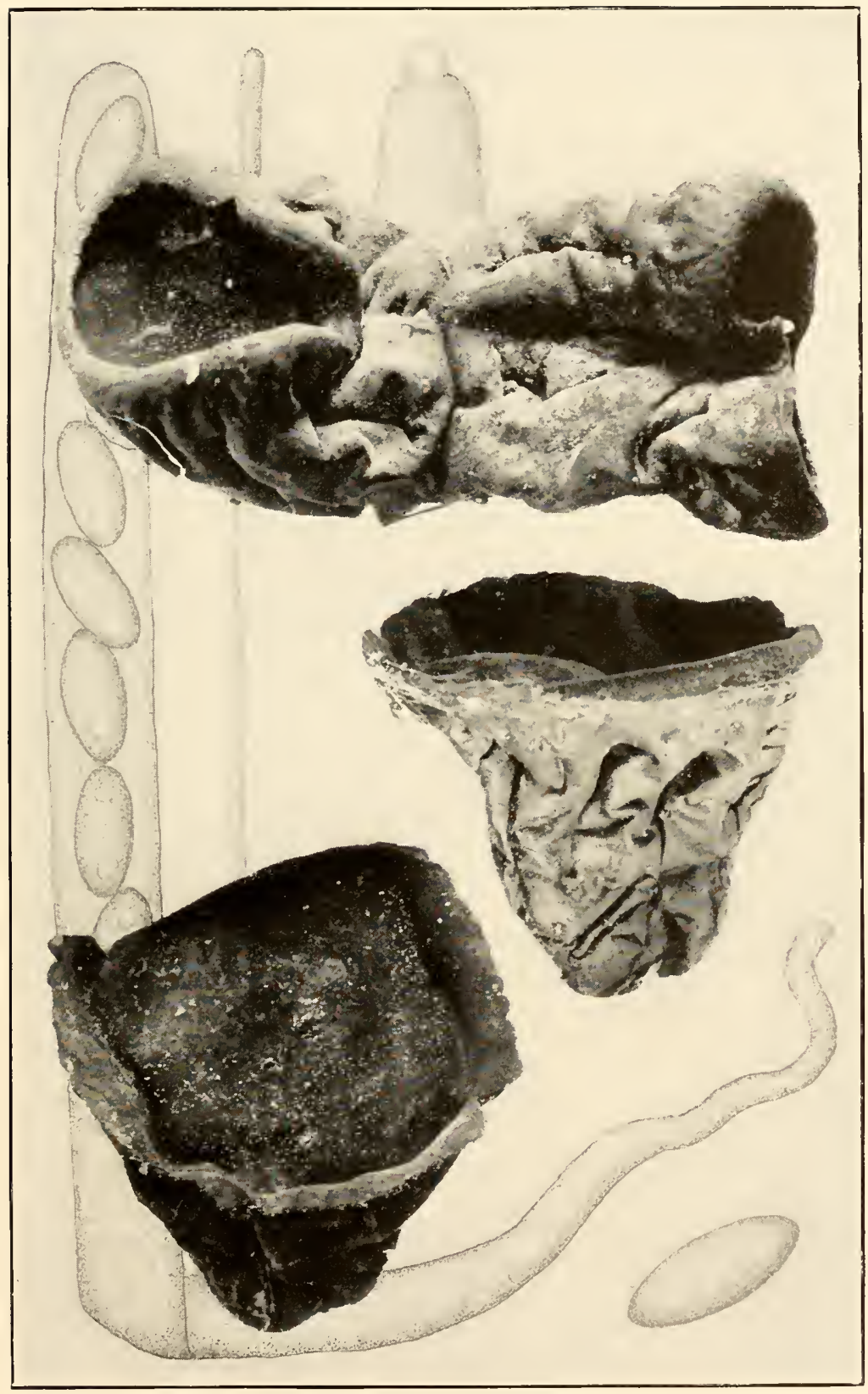

BULGARIA GLOBOSA 

Kalchbrenner, Károly, 1807-1886; Cooke, Mordecai Cubitt, 1825-1914 (Kalchbr. \& Coske).

Grevillea 9: 17-34. S 1880. - South African fungi.

Kallenbach, Franz Joseph, 1893- (Kallenb.).

Zeits. Pilzk. 10: 85-88. pl. 11. 30 Je 1931.- Sandpilze unserer deutschen

Binnendünen.

Kanouse, Bessie Bernice, 1889- (Kanouse).

Papers Mich. Acad. Sci. 22: 117-122. pl. 15, 16. 1936.-Notes on new or unusual Michigan Discomycetes. IT.

Karsten, Petter Adolf, 1834-1917 (P. Karst.).

Acta Soc. Faun. Fl. Fenn. 2f: 1-174. 1885.-Revisio monographica atque synopsis Ascomycetum in Fennia hucusque detectorum.

Biclr. Finl. Nat. Folk 19: 1-264. 1871.-Mycologia fennica, Pars prima: Discomycetes.

Fungi Fenn. 1-1000. 1865-70.-Fungi Fenniae exsiccati. Sammling of Finska svampar.

$\begin{array}{rrrr}1-300 . & 1865 . & 701-800 . & 1868 . \\ 301-600 . & 1866 . & 801-900 . & 1869 . \\ 601-700 . & 1867 . & 001-1000 . & 1870 .\end{array}$

Sometimes cited erroneously in this volume as "Finl. Fungi;" the wet used was one made up by Karsten from specimens collected (at least in part) long after the original exsiccati were distributed, and is therefore not wholly reliable.

Medd. Soc. Faun. Fl. Fenn. 16: 84-106. 1889.- Symbolae ad mycologiam fennicam. Pars XXIX.

Not. Fauna Fl. Fenn. 10: 99-206. 1869.-Monographia Pezizarum fennicarum.

Not. Fauna Fl. Fenn. 11: 197-210. 1870.-Nonographia Ascobolorun Fenniae.

Kellerman, William Ashbrook, 1850-1908 (Kellerm.).

Jour. Myc. 14: 3-7. 1908.-Dr. Rehm's first report on Guatemalan Ascomycetae.

Kobayasi, Yosio (Kobayasi).

Jour. Japanese Bot. 13: 510-520. 10 figs. 1937.-On the gelatinous cup fungi, Bulgaria-group.

Krombholz, Julius Vincenz von, 1782-1843 (Krombh.).

Mbbild. 1831-46.-Naturgetreue Abbildungen und Beschreibungen der essbaren, schädlichen und verdachtigen Schwämme.
1: 1 - 85. pl. 1 -6. 18.31 .
6: 1 -30. pl. 39-t6. 1841 .
2: 1 -30. pl. $7-1$ t. 1832 .
7: 1-24. pl. $47-5+.18+1$.
3: $1-36$. pl. $15-22$. 18.34 .
8: 1-31. pl. 55-02. 1843 .
4: 1-32. pl. 23-30. 1836 .
9: 1-28. pl. 63-7G. 1845.
5: 1 -17. pl. 31-38. 18.36.
10: 1-28. pl. 71 - 7 h. $18+6$.

Kuntze, Carl Ernst Otto, 18431907 (Kuntze).

Rev. Gen. 1891 98.-Revisio generum plantarum.

Vols. 1 and 2 consecutively pagel; a third volume issued later, as an afterthought.
1-1011.
$5 \mathrm{~N} 1891$.
$3^{2}: 1-202 . \quad 28 \mathrm{~S} 1898$.
3: i-ceccxi. 5 \a 1893.
$3^{3}: 1-576 . \quad 28 \mathrm{~S} 1898$. 
Kunze, Gustav, 1793-1851; Schmidt, Johann Carl, 1793-1850 (Kunze \& Schmidt).

Myk. Hefte 1817-23.-Mykologische Hefte.
1: 1-109. pl. 1,2. 1817.
2: 1 176. pl. 1, 2. 1823.

Kupfer, Elsie Mabel, 1877- (Kupfer).

Bull. Torrey Club 29: 137-144. pl. 8. 1902.- Studies on Lrnula and Geoprxis.

Lagarde, Joannês Joseph, 1866 - (Lagarde).

Inn. Myc. 4: 203-256. pl. 3, f,f. 26-58. 1906. - Contribution à l'étude des Disconycètes charnus.

Lamarck, Jean Baptiste Antoine Pierre Monnet de, 1744-1829 (Lam.).

Encyc. 1783-1808.-Encyclopédie methodique. Botanique.

$\begin{array}{rrrrrr}\text { 1: } 1-368 . & \text { D } 1783 . & 4: & 1-400 . & 1796 . \\ \text { 1: } 369-752 . & \text { Au } 1785 . & 4: 401-764 . & \text { F } 1797 . \\ \text { 2: } 1-368 . & \text { O } 1786 . & 5: & 1-748 . & 1804 . \\ \text { 2:369-774. } & \text { Ip } 1788 . & 6: & 1-786 . & 1804 . \\ \text { 3: } 1-360 . & 1789 . & 7: & 1-731 . & 1806 . \\ 3: 361-755 . & 1791 . & 8: & 1-879 . & 1808 .\end{array}$

Lambotte, J B Ernest, 1832-1905 (Lambotte).

Fl. Myc. Belg. 2: 5-599. 1880.-Flore mycologique belge.

Léveillé, Joseph Henri, 17961870 (Lév.).

Inn. Sci. Nat. I1. 16: 235-242. pl. 14, 15. O 1841.-Descriptions de quelques espèces nouvelles de champignons.

Inn. Sci. Nat. I11. 3: 38-64. Ja 1845; 65-71. F 1845.-Champignons exotiques. (Suite.)

Ann. Sci. Nit. 111. 5: 249-304. My 1846.-1)escription des champignons de l'herbier du Muséum de Paris. (Suite.)

Ann. Sci. Nat. I11. 9: 119-144. 1848. Fragments mycologiques.

Lindau, Gustav, 1866-1923 (Lindau).

In E. \& P. Nat. Pfl. 1 ${ }^{1}$ : 178-243. f. 1th-181. 1896.-[Pezizineas: II. Pezizaceae-Phymatosphaeriaceae.]

Linnaeus, Carl, 17071778 (L.).

Sp. Pl. 1-1200. 1753.-Species plantarum.

Lloyd, Curtis Gates, 1859 -1926 (C. G. Lloyd).

Myc. Notes 52: 737, 738.f. 1103-1105. 1917. Thelebolus lignicola from Stewart H. Burnham, New York.

McCallum, Alan Wilfred, 1893 - (McCallum).

Mycologia 11: 293-295. pl. 14. 1919.-The occurrence of Bulgaria platydiscus in Canada.

Maire, René Charles Joseph Ernest, 1878- (Maire).

Myc. Bor.-Afr. 1 175. 1912-1914.-Mycotheca boreali-africana.

$$
\text { 1-75. 1912. T6-100. 1913. 101-175. } 1914 .
$$

Massee, George Edward, 1850-1917 (Massee).

Brit. Fungus-F1. 4: 1-522. illust. 1895.-British fungus-flora.

Grevillea 22: 65 67. 1894.-Fungi. Elvela auricula, Schaeff.

Jour. Bot. 30: 161-164. pl. 321-323. 1892.- Some Mest Indian fungi.

Jour. Bot. 34: 145-154. pl. 357. 1896.-New or critical fungi.

Jour. Linn. Soc. 31: 462-525. pl. 16-18. 1896.-Redescriptions of Berkeley's types of fungi.

Kew Bull. Misc. Inf. 1898: 123. 1898.-Geopyxis elata sp. nov. 
McLennan, Ethel Irene, ; Cookson, Isabel Clifton, (McLennan \& Cookson).

Proc. Roy. Soc. Vict. II. 35: 153-158. pl. 9, 10. 31 My 1923.-. Idditions to the Australian Iscomrcetes. No. I.

Proc. Roy. Soc. Vict. II. 38: 70-76. pl. t-6. 31 Jl 1926.-Arlditions to Australian Ascomycetes. No. II.

Milde, Carl August Julius, 1824-1871 (Milde).

Bot. Zeits. 10: 208, 209. 1852.-Ueber ein neues Pilz-Genus. Microstoma hiemale Neess et Bernst.

Montagne, Jean Pierre Francois Camille, 17841806 (Mont.).

Ann. Sci. Nat. II. 2: 73-79. 1834.-Description de plusieurs nouvelles espèces de cryptogames decouvertes par M. Gaudichaud dans l'Amerique meridionale.

Morgan, Andrew Price, 18361907 (Morgan).

Jour. Cinc. Soc. Nat. Hist. 18: 36-45. pl. 1-3. 20 O 1895.-New North American fungi.

Jour. Myc. 8: 179 192. 1902. - The discomycetes of the Miami Valley, Ohio.

Mougeot, Jean Baptiste, 1776 1858; Nestler, Christian Gottfried, 17781832 (Moug. \& Nestl.).

Stirpes Crypt. 1-1600. 1810 90.-Stirpes cryptogamae vogesorhenanat.

$\begin{array}{rrrr}1-100 . & 1810 . & 801-900 . & 1826 . \\ 101-200 . & 1811 . & 901-1000 . & 1833 . \\ 201-300 . & 1812 . & 1001-1100 . & 18+0 . \\ 301-400 . & 1813 . & 1201-1200 . & 1843 . \\ 401-500 . & 1815 . & 1301-1400 . & 1850 . \\ 501-600 . & 1818 . & 1401-1500 . & 1866 . \\ 601-700 . & 1820 . & 1501-1600 . & 1890 . \\ 701-800 . & 1823 . & & \end{array}$

\section{Mouton, Victor (Mouton).}

Bull. Soc. Royale 13ot. Belg. 25: 137-162. pl. I1. 1886.-Ascomycetes observés aux environs te Liège.

Müller, Otto Fridrich, 17301784 (Müll.).

Fl. 1)an. 4: 3-8. pl. 601 o 70 . 1775.-Nomenclatura et loci natales plantarum, quas undecimus hic fasciculus exhibet.

Fl. 1)an. 5: 3-8. pl. 721-780. 1778.-Nomenclatura et loci natales plantarum, quas decimus tertius hic fasciculus exhibet.

Nees von Esenbeck, Christian Gottfried Daniel, 17761858 (Nees).

Syst. Pilze Selow. 1-334. pl. 1-ft. [Mr] 1816.-1)as System der V'ilze und Schwämme.

Some copies dated 1817, hut "nuperrime" publisherl in Ip 1816 (sec Mart. Fl. Crypt. Erlang. xxi, xxvii).

Niessl von Mayendorf, Gustav, 18391919 (Niessl).

Nylander, William, $1822-1899$ (Nyl.).

Not. Fauna Fi. Fenn. 10: 1-97. 1869.--Observationes circa l'ezizas Fenniae.

Oeder, Georg Christian von, 17281791 (Oeder).

Fl. Dan. 3: 2-8. pl. $\$ 81-5+0$. 1770.- Nomenclatura et hei natales plantarum, (quas nonus hic fasciculus exhibet. 
Oudemans, Corneille Antoine Jean Abram, 1825-1906 (Oud.).

Beih. Bot. Centr. 11: 523-541. 1902.- Beiträge zur Pilzflora der Niederlande.

\section{Patouillard, Narcisse Théophile, 1854-1906 (Pat.).}

Tab. Fung. 1883-89.- Tabulac analyticae fungorum.
1: $\quad 1-40$. f. 1 -100. 1883 .
1: $181-232 . f .401-500.1886$.
1: $41-85$. f. $101-200.1883$.
2: $\quad 1-30$. f. 501-575. 1886.
1: $89-134 . f .201-300.1884$.
2: $31-42 . \quad$ f. $576-605.1887$.
1: 137-180.f. 301-400. 1885.
2: 43-75. f. $606-700.1889$.

Peck, Charles Horton, 18331917 (Peck).

Inn. Rep. N. Y. State Mus. 24: 41-108. pl. 1-t. 1872.-Report of the Botanist [for 1870].

Ann. Rep. N. Y. State Mus. 26: 35-91. Ap 1874.-Report of the Botanist [for 1872].

Inn. Rep. N. Y. State NIus. 27: 73-113. pl. 1, 2. 1875.-Report of the Botanist [for 1873].

Inn. Rep. N. Y. State Mus. 28: 31-88. pl. 1, 2. “1875” [1876].-Report of the Botanist [for 1874].

Inn. Rep. N. Y. State Mus. 29: 29-82. pl. 1, 2. 1878.-Report of the Botanist [for 1875].

Inn. Rep. N. Y. State Mus. 30: 23-78. pl. 1, 2. 1878.-Report of the Botanist [for 1876].

Ann. Rep. N. Y. State Mus. 31: 19-60. 1879.- Report of the Botanist [for 1877 ].

Inn. Rep. N. Y. State Mus. 32: 17-72. 1879.-Report of the Botanist [for 1878].

Ann. Rep. N. Y. State Mus. 33: 11-49. pl. 1, 2. "1880" [1883].--Report of the Botanist [for 1879].

Inn. Rep. N. Y. State Mus. 34: 24-58. pl. 1 t. "1881" [1883].-Report of the Botanist [for 1880].

Inn. Rep. N. Y. State Mus. 43: 5-54. pl. 1-t. 1890.-Annual report of the State Botanist [for 1889].

Ann. Rep. N. Y. State Mus. 46: 83-149. 1893.-Annual report of the State Botanist [for 1892].

Ann. Rep. N. Y. State Mus. 47: 5-48. 1894.- Annual report of the State Botanist [for 1893].

Inn. Rep. N. Y. State Mus. 51: 267-321. pl. I, B, 51-56. 1898.-Report of the State Botanist, 1897.

Bot. Gaz. 5: 33-36. Mr 1880.-New species of fungi.

Bot. Gaz. 6: 239-241. Jl 1881.-New species of fungi.

Bull. N. Y. State Mus, $1^{2}$ : 5-24. 1887.-New species of New York fungi.

Bull. N. Y. State Mus. 54: 9.31-984. 1902.-Report of the State Botanist 1901.

Bull. N. Y. State Mus. 157: 1-139. pl. 124-130, I'II, I'III. 1 Mr 1912.Report of the State Botanist 1911.

Bull. Torrey Club 23: 411-420. 1896.-New species of fungi.

Bull. Torrey Club 26: 6.3-71. 1899.-New species of fungi.

[3ull. Torrey Club 29: 69-74. 1902.-New species of fungi. 
Bull. Torrey Club 30: 95-101. 1903.-New species of fungi.

Bull. Torrey Club 31: 177-182. 1904.-New species of fungi.

Bull. Torrey Club 32: 77 -81. 1905.-New species of fungi.

Bull. Torrey Club 3.3: 213-221. 1906.-New species of fungi.

Persoon, Christiaan Hendrik, 1761-1836 (Pers.).

Champ. Comest. 1-276. pl. 1-t. 1818.-Traité sur les champignons comestibles.

Comm. Fung. Bavar. 1-130. 1800.-Commentarius D, Jac. Christ. Schatferi... Fungorum Bavarice indigenorum icones pictas... illustrans.

Ic. Descr. Fung. 1-60. pl. 1-1t. 1798-1800.-Icones et descriptiones fungorum minus cognitorum.
1-26. pl. 1-7. 1798.
27-60. pl. 8 -1t. 1800 .

Ic. Pict. Fung. 1-64. pl. 1-24. 1803 06.-Icones pictae rariorum fungorum.
1-14. pl. 1-0. 1803.
29 44. pl. 13-18. 1805
15-28. pl. $7-12.1804$.
45-64. pl. 19-24. 1806.

Mye. Eur. 1822-28.- Mycologica europaea.

1: 1-356. pl. 1-12. 1822. 3: 1-282. pl. 23-30. 1828.

2: 1-21t. pl. 13-22. 1825.

Nenes Mag. Bot. 1: 63-128. pl. 1-t. 1794.-Newer Versuch einer systematischen Eintheilung der Schwämme.

Obs. Myc. 1796 99.--Observationes mycologicae.

1: $1-32=$ Ann. Bot. Usteri 15: 1-32. 1795.

1: 1-115. pl. 1-6. 1796. 2:1-106. pl. 1-6. 1799.

Syn. Fung. i-xxx. 1-706. pl. 1-5. 1801.-Synopsis methorlica fungorum.

Tent. Disp. Fung. 1-76. pl. 1-t. 1797.-Tentamen dispositionis methodicae fungorum.

Pages $1-48=$ Neues Mag. Bot. 1: 81-128.

Phillips, William, 1822-1905 (Phill.).

Brit. Discom. 1-462. pl. 1-12. 1887. $-A$ manual of the British Discomycetes.

Grevillea 5: 113 118. Mr 1887.-Fungi of California and the Sierra Nevada Mountains. (Collected l,y H. Wr. Harkness, M.D., and J. I'. Morr, Esq.)

Grevillea 7: 20-23. 1878.-Fungi of California. (Collected 1y 1)r. 11. W. llarkness and Mr. J. P'. Moor.)

Grevillea 18: 82-86. 1890.-British Discomycetes. Notes and additions no. 2 .

Jour. Bot. 31: 129-132, pl. 337. 1893.-Gyromitra gigas (Krombh.) Cooke.

Trans. Linn. Soc. II. 1: 423. pl. 48. 1880. - On a new species of Helvella.

Phillips, William, 1822 1905; Harkness, Harvey Willson, 18211901 (Phill. \& Hark.).

Bull. Calif, Acad. Sci. 1: 21-26. 1884.-Fungi of California.

Phillips, William, 1822-1905; Plowright, Charles Bagge, 18491910 (Phill. \& Plow.).

Grevillea 2: 186-189. 1873.- -New and rare British fungi.

Grevillea 8: 97-109. 1879.-New and rare British fungi. 
Pound, Roscoe, 1870- ; Clements, Frederic Edward, 1874 (Pound \& Clements).

Bot. Surv. Nebr. 4: 5-23. 1896.-New species of fungi.

Bot. Surv. Nebr. 5: 5-11. 1901.- New species of fungi.

Povah, Alfred Hubert William, 1889 (Povah).

Mycologia 24: 240-244. 2 figs. 1932.-New fungi from Isle Royale.

Papers Mich. Acad. Sci. 9: 253-272. 1928.- Some non-vascular cryptogams from Vermilion, Chippewa County, Michigan.

Papers Mich. Acad. Sci. 13: 173-189. f. 12-1t. 1930.-Fungi of Rock River, Michigan.

Papers Mich. Acad. Sci. 20: 113-156. pl. 21-24. 1934.-The fungi of Isle Royale, Lilke Superior.

Preuss, C. G. Traugott, -1855 (Preuss).

Linnaea 24: 99-153. 1851.-Ueber sicht untersuchter Pilze, besonders aus der Umgegend von Hoyerswerda.

Quélet, Lucien, 1832-1899 (Quél.).

Issoc. Fr. Av. Sci. Compte Rendu 9: 661-675. 1881.-Quelques espèces critiques ou nouvelles de la flore mycologique de France.

Assoc. Fr. Av. Sci. Compte Rendu 14²: H4t-453. 1886.--Quelques espèces critiques ou nouvelles de la flore mycologique de France.

Bull. Soc. Bot. Fr. 24: 317-332. pl. 5, 6. 1877.-Quelques espèces de champignons nouvellement observées dans le Jura dans les Vosges (1) et aux environs de Paris.

Bull. Soc. Bot. Fr. 25: 287-292. 1878.-Quelques espèces nouvelles de champignons.

Champ. Jura Vosg. 1872 75.-Les champignons du Jura et des V'osges. (1:) 1-320. pl. 1-27. 1872. 3:1-128. pl. 1-t. 1875.

(2:) $321-424$. pl. $1-5 . \quad 1873$.

Ench. Fung. 1-352. 1886.-Enchiridion fungorum.

Grevillea 8: 115-117. pl. 131. 1880.-Some new species of fungi from the Jura and the Vosges.

Rabenhorst, Gottlob Ludwig, 18061881 (Rab.).

Fungi Eur. 1-2600. 1859-80.-Fungi europaei exsiccati.

$\begin{array}{rrrrrr}1-100 . & 1859 . & 901-1100 . & 1866 . & 1701-1900 . & 1874 . \\ 101-300 . & 1860 . & 1101-1200 . & 1868 . & 1901-2000 . & 1875 . \\ 301-400 . & 1861 . & 1201-1300 . & 1869 . & 2001-2200 . & 1876 . \\ 101-500 . & 1862 . & 1301-1400 . & 1870 . & 2201-2300 . & 1877 . \\ 501-600 . & 1863 . & 1401-1500 . & 1871 . & 2301-2400 . & 1878 . \\ 601-700 . & 1864 . & 1501-1600 . & 1872 . & 2+101-2500 . & 1879 . \\ 701-900 . & 1865 . & 1601-1700 . & 1873 . & 2501-2600 . & 1880 .\end{array}$

Continued as Rab.-W'int. Fungi Eur.

Hedwigia 17: 113-116. 1878. - Einige neue P'ilze und Algen.

Krypt.-Fl. 1880-1939 $\rightarrow$.- Kryptogamen-Flora von Deutschland, Oesterreich und der Schweiz. "Zweite Aullage."

By various a uthors; Pilze ly Winter; by Rehm; by A. Fischer; by E.

Fischer; by Allescher; by Lindau.

Sitz.-ber. Nat. Ges. Isis 1867: 22, 23. pl. 1. "Ja-Mr" 1867.--[Ueber eine neue Peziza, Peziza Geaster.] 
Rabenhorst, Gottlob Ludwig, 1806-1881; Winter, Heinrich Georg, 1848-1887 (Rab.-Wint.).

Fungi Eur. 260t-3600. 1881-86.-Fungi europaei et extraeuropaci. Continuation of Rab. Fungi Eur.
2601-2700. 1881 .
$2701-2000.1882$.
2901-3000. 1883.
$3001-3200.1884$.
$3201-3400.1885$.
$3+101-3600.1886$.

Rafinesque, Constantine Samuel, 17831840 (Raf.).

Med. Repos. II. 5: 356-363. [JI] 1808.-Essential generic and specific characters of some new genusses and species of plants observed in the Inited States of America, in 180.3 and 1804.

Ramsbottom, John, 1885- (Ramsb.).

In L. S. Gibbs, Contr. Phỵtog. Arfak 185-190. Jl 1917.-Fungi.

Ravenel, Henry William, 1814-1887 (Rav.).

Fungi Am. 1-800. 1878-82.--Fungi americani exsiccati.

$\begin{array}{rrrr}1-200 . & 1878 . & 401-600 . & 1881 . \\ 201-400 . & 1879 & 601-800 . & 1882 .\end{array}$

Fungi Car. 1852-60.-Fungi caroliniani exsiccati.
$1: 1-100.1852$.
4: $1-100.1855$.
2: $1-100.1853$.
5: $1-100.1860$.
3: $1-100.1855$.

Rebentisch, Johann Friedrich, 1772-1810 (Rebent.).

Prodr. Fl. Neom. 1-406. pl. 1-t. 1804--Prodromus florae neomarchicale.

Rehm, Heinrich, 1828-1916 (Rehm).

Ann. Myc. 2: 32-37; 351-354. 1904.-Ascomycetes Americae borealis.

Ann. Myc. 3: 22t-231. 1905.-Ascomycetes exs. Fasc. 34.

Ann. Myc. 3: 516-520. 1905.-Ascomycetes Americae borealis.

Ann. Myc. 5: 516-546. 1907.-Ascomycetes novi.

Ann. Myc. $7: 531-542$. 1909.-Ascomycetes novi.

Ascom. 1-2175. 1868-1917.-Ascomyceten. (Fasc. 1-21, nos. 1-1050)-

Ascomycetes exsiccati. (Fasc. 21-57, nos. 1051-2175).

$\begin{array}{rrrrrr}1-50 . & 1868 . & 801-850 . & 1885 . & 1751-1525 . & 1903 . \\ 51-100 . & 1872 . & 851-900 . & 1887 . & 1526-1575 . & 1904 . \\ 101-200 . & 1873 . & 901-950 . & 1888 . & 1576-1625 . & 1905 . \\ 201-250 . & 1874 . & 951-1000 . & 1889 . & 1626-1675 . & 1906 . \\ 251-300 . & 1875 . & 1001-1050 . & 1891 . & 1670-1750 . & 1907 . \\ 301-350 . & 1876 . & 1051-1100 . & 1892 . & 1751-1800 . & 1908 . \\ 351-700 . & 1877 . & 1101-1150 . & 1895 . & 1801-1875 . & 1909 . \\ 401-500 . & 1878 . & 1151-1200 . & 1896 . & 1870-1925 . & 1910 . \\ 501-550 . & 1879 . & 1201-1250 . & 1898 . & 1926-1975 . & 1911 . \\ 551-600 . & 1881 . & 1251-1300 . & 1899 . & 1976-2025 . & 1912 . \\ 601-650 . & 1882 . & 1301-1350 . & 1900 . & 2026-2075 . & 1913 . \\ 651-700 . & 1883 . & 1351-1400 . & 1901 . & 2076-2125 . & 1914 . \\ 701-800 . & 1884 . & 1401-1450 . & 1902 . & 2126-2175 . & 1917 .\end{array}$

Ascom. Lojk. 1-70. 1882.-Ascomycetes Lojkani lecti in Hungaria, Transsydvania et Galicia.

Ber. Naturh. Ver. Augsburg 26: 3-132. 1881.-Ascomyceten.

Hedwigia 22:33-41. 1883. -Ascomyceten fasc. XIV.

Hedwigia 24: 225-246. 1885.-. Iscomyceten fasc. XYII. 
Hedwigia 27: 163-175. 1888.-. Iscomyceten fasc. XIX.

Hedwigia 28: 295-303. 1889.-Exotische Ascomyceten.

Hedwigia 31: 299-313. 1892.- - scomycetes exs. fasc. 22.

Herlwigia 38: (242)-(246). 1899.-Ascomycetes exs. fasc. 26.

In Rab. Krypt.-Fl. 13 ${ }^{3}$ 1-1275. 1887-96.-Die Pilze Deutschlands, Oesterreichs und der Schweiz. 1II. Mtheilung: Ascomyceten: Hysteriaceen und Discomiceten.

Renny, James, 17871867 (Renny).

Jour. Bot. 12: $353-357$. pl. 153 156. 1874.-New species of the genus Iscobolus.

Rick, Johann, 1869- (Rick).

Oesterr. Bot. Zeits. 48: 59-63. 1898.-Zur I'ilkkunde Vorarlbergs.

Ripart, Jean Baptiste Marie Joseph Solange Eugène, 1814 - 1878 (Ripart).

Bull. Soc. Bot. Fr. 23: 307-310. 1876.-Description d'une nouvelle Pezize.

Rodway, Leonard, 1853-1936 (Rodway).

Proc. Roy. Soc. Tasmania 1924: 90-122. 1925.-Tasmanian Discomycetes.

Rostrup, Frederik Georg Emil, 1831 - 1907 (Rostr.).

Medel. Grónland 18: 43-81. 1894.- Ost-Gronlands Svampe.

Saccardo, Pier' Andrea, 1845-1920 (Sacc.).

Bot. Centr. 18: 213-220. 1884.-Conspectus generum Discomycetum hucusque cognitorum.

Michelia 2: 241-301. 1881.-Fungi veneti novi vel criticiv. Mycologiae Venetae addendi.

Myc. Ven. 1-1000. 1875-81.-Mycotheca veneta sistens fungos venetos exsiccatos.

$$
\begin{array}{cccc}
1-300 . & 1875 & 1301-1+00 . & 1879 . \\
301-1300 . & 1876 . & 1+01-1600 . & 1881 .
\end{array}
$$

Syll. Fung. 1882-1931.- Silloge fungorum onnium hucusque cognitarum.

\begin{tabular}{|c|c|c|c|c|c|c|}
\hline $1-768$ & $13 \mathrm{Je}$ & 1882. & 14: & $1-1273$ & $20 \mathrm{Au}$ & 1899. \\
\hline 1-815, ii-1xix. & $13 \mathrm{Je}$ & 1883. & 16: & 1-123. & $1 \mathrm{~F}$ & 1902. \\
\hline $1-860$ & $15 \mathrm{D}$ & 1884. & 17: & 1-991. & $25 \mathrm{My}$ & 1905. \\
\hline $1-807$ & $10 . \backslash p$ & 1886. & 18: & $1-740$. & $30 \mathrm{Ja}$ & 1906. \\
\hline $111+6$. & $28 \mathrm{My}$ & 1887. & 19: & 11158. & $31 \mathrm{Mr}$ & 1910. \\
\hline 1928. & $1 \mathrm{Xu}$ & 1888. & $20:$ & $1-1310$. & $25 \mathrm{My}$ & 1911. \\
\hline $7^{1}: \quad 1-498$. & $15 \mathrm{Mr}$ & 1888. & 21: & 1-928. & $15 \mathrm{Mr}_{\mathrm{r}}$ & 1912. \\
\hline $7^{2}: 449-882$ & $28 \mathrm{O}$ & 1888. & 22: & $1-1612$. & $20 \mathrm{Au}$ & 1913. \\
\hline $8: \quad 1-11+3$. & $20 \mathrm{D}$ & 1889. & 23: & $1-1026$ & $15 \mathrm{Ap}$ & 1925. \\
\hline $1-11+1$. & $15 \mathrm{~S}$ & 1891. & 24: & $1-703$ & $15 \mathrm{Jl}$ & 1926. \\
\hline $1-964$ & $30 \mathrm{Je}$ & 1892. & $24:$ & $705-1438$. & $25 A_{p}$ & 1928. \\
\hline$[\mathrm{i}-\mathrm{vii}] 1-718$. & J1 & 1895. & 25: & $1-1093$ & $25 \mathrm{Je}$ & 19.31 \\
\hline
\end{tabular}

Vols. 12, 13, and 15 comprise indexes only.

Saccardo, Pier' Andrea, 1845-1920; Saccardo, Domenico, 1872- (Sacc. \&

D. Sacc.).

Saccardo, Pier' Andrea, 1845-1920; Sydow, Paul, 1851-1925 (Sacc. \& Syd.).

In Sacc. Syll. Fung. 14: 1-1273. 20 Aı 1899.-Supplementum universale, pars iv. 
In Sacc. Syil. Fung. 16: 1-1233. 1 F 1902.-Supplementum universale, pars $v$.

Saccardo, Pier' Andrea, 1845 1920; Traverso, Giovanni Battista, 1878 (Sacc. \& Trav.).

Saccardo, Pier' Andrea, 1845 1920; Trotter, Alessandro, 1874- (Sacc. \& Trott.).

Schaeffer, Jacob Christian, $1718-1790$ (Schaeff.).

Fung. Bavar. 1762 74.-Fungorum (qui in Bavaria et Palatinatu circit Ratisbonam nascuntur icones.

In 4 volumes, each plate accompanied by text without page-numbers.
(1:) pl. 1-100. 1762.
(4:) pl. 301-330. 1774.
(2:) pl. 101-200. 1763.
4: Ind. $1-136.1774$.

(3:) pl. 201-300. 1770.

Schmidel, Casimir Christoph, 1718-1792 (Schmidel).

Ic. Pl. 1-280. pl. 1-75. 1747-97.-Icones plantarum ateri incisale atrue vivis coloribus insignitae.

1-16. pl. 1-3. 1747 .

17-32. pl. t-6. 1750?

$33-52$. pl. $7-12.1762$.

119-146. pl. 32-37. 1773?

53-72. pl. 13-19. 1765?

147-166. pl. 38-42. 1774 ?

73-94. pl. 20-25. 1770 ?

167-198. pl. 43-50. 1776?

199-234. pl. 51-58, 1790 ?

95-118. pl. 26-31. 1772.

235-280. pl. 61-75. 1797.

Schrader, Heinrich Adolph, 1767-1836 (Schrad.).

Jour. But. 22: 55-70. 1799.- I'lantae cryptogamicale nouae, rariores aut minus cognitae.

Schroeter, Joseph, 1857-1894 (Schroet.).

Krypt.-Fl. Schles. 3': 1-814. 32: 1-597. 1885-1908.-Die I'ilze Schlesiens.

\begin{tabular}{|c|c|c|c|c|}
\hline $3^{1}: \quad 1-128$. & $10.1 \mathrm{p} 1885$. & $3^{2}: \quad 1-128$ & $\mathrm{O}$ & \\
\hline-256 & Iu 1886. & $3^{2}: 129-256$. & () & \\
\hline $3^{1}: 257-384$ & 27 \u 1887 . & $3^{2}: 257-384$ & $N$ & \\
\hline $3^{1}: 385 \quad 512$. & $2 \mathrm{~J} \cdot 1888$. & $3^{2}: 385-500$ & & \\
\hline & $\begin{array}{ll}10 \mathrm{~F} & 1889 . \\
15 \mathrm{~S} & 1889\end{array}$ & $3^{2}: 500 \mathrm{a}-597$. & & \\
\hline
\end{tabular}

Schulzer, von Müggenburg, Stephan, 1802-1892 (Schulzer).

Verh. Zool.-Bot. Ges. IVien 16: 30-65. 1866.-[1)ie lisher bekannten Pflanzen Slavoniens.] Fungi

Schumacher, Heinrich Christian Friederich, 1757-1830 (Schum.).

Enum. ['1. Saell. 1801-03.-Enumeratio plantarum in partibus Sactlandiae septentrionalis et orientalis.
1: 1-304. 1801
2: $1-489 . \quad 1803$

Schweinitz, Lewis David von, 1780-1834 (Schw.).

Schr. Nat. Ges. Leipzig 1: 20-131. pl. 1, 2. 1822.-Synopsis fungorum Carolinae superioris.

Trans. Ans. Phil. Soc. I1. 4: 141-316. 1832.-Synopsis fungorum in America boreali media degentium.

Scopoli, Johann Anton, $1723-1788$ (Scop.).

F1. Carn. ed. 2. 1: 1-448. pl. 1-32. 2: 1-496. pl. 33-65. 1772.-Flora carniolica. Editio secunda. 


\section{Seaver, Fred Jay, 1877- (Seaver).}

Bull. Lab. Nat. Hist. State Univ. lowa 5: 335-406. pl. 1-25. 1904.-The Discomycetes of eastern Iowa.

Bull. Lab. Nat. Ilist. State Univ. Iowa 6: 41-219. pl. 1-11. 1905.-Iowa Discomycetes.

Jour. Myc. 11: 2-5. pl. 75. 1905. - I new species of Sphaerosoma.

Mem. N. Y. Bot. Gard. 6: 501-511. 1916.-Bermuda fungi.

Mycologia 3: 57-66. 1911. - Studies in Colorado fungi-I. Discomycetes.

Mycologia 4: 45-48. pl. 57. 1912.-The genus Lamprospora with descriptions of two new species.

Mycologia 5: 185-193. pl. 88-90. 1913.- Some tropical cup-fungi.

Mycologia 5: 299-302. pl. 109, 110. 1913.-The genus Pseuloplectania.

Mycologia 6: 5-24. pl. 114. 1914. - I preliminary study of the genus Lamprospota.

Mycologia 6: 273-278. pl. 1+2-1+t. 1914.-North American species of Aleuria and Aleurina.

Mrcologia 7: 197-199. pl. 161. 1915.--Illustrations and descriptions of cup-fungi-II. Sepultaria.

Mycologia 8: 1-4. pl. 172. 1916.-North American species of Ascodesmis.

Mrcologia 8: 93-97. pl. 184. 1916.-The earth-inhabiting species of Ascobolus.

Mycologia 8: 195-198. pl. 188, 189. 1916.-Photographs and descriptions of cup-fungi-III. Peziza domiciliana and Peziza repanda.

Mycologia 9: 1-3. pl. 1. 1917.-Photographs and descriptions of cupfungi- $Y$. Peziza proteana and Peziza violacea.

Mycologia 12: 1-5. pl. 1. 1920.-Photographs and descriptions of cupfungi-VIII. Elvela infula and Gyromitra esculenta.

Mycologia 13: 67-71. pl. t. 1921.-Photographs and descriptions of cup-fungi-1X. North American species of Discina.

Mycologia 17: 45-50. pl. 4. 1925. - Studies in tropical Ascomycetes-I1I. Porto Rican cup-fungi.

Mycologia 19: 86-89. 1927.-A tentative scheme for the treatment of the genera of the Pezizaceae.

Mycologia 22: 215-218. pl. 22, 23. 1930.-Photographs and descriptions of cup-fungi-XIII. Subhypogeous forms.

Mycologia 24: 248-263. 1932.--The genera of fungi.

Mycologia 26: 102, 103. pl. 17. 1934.-Photographs and descriptions of cup-fungi-XX. A new Lamprospora.

Mycologia 29: 678-680. 1 fig. 1937.-Photographs and descriptions of cup-fungi-XXYill. A proposed genus.

Mrcologia 31: 499-501. 1 fig. 1939.-Photographs and descriptions of cup-fungi-XXXIll. A new Boudiera.

Mycologia 31: 533-536. 1 fig. 1939.-Photographs and descriptions of cup-fungi-XXXIV. A new Humarina.

Mycologia 32: 567-569. 1 fig. 1940.-Photographs and descriptions of cup-fungi-XXXV. A new species of Patella.

N. Am. Cup-fungi 1-28t. pl. 1-75. 1928.-The North American Cupfungi (operculates).

North Dakota Fungi 1-100. 1907-8.- North Daknta fungi exsiccati. 
Setchell, William Albert, 1864- (Setch.).

Mycologia 16: 240-244. pl. 18, 19. 1924.-Three new fungi.

Univ. Calif. Pub. 4: 107-120. pl. 15. My 26 1910.-The genus Sphaerosoma.

Shear, Cornelius Lott, 1865 (Shear).

N. Y. Fungi 1-400. 1893-96. -New York fungi.

$$
\text { 1-200. } 1893 .
$$

Smith, Worthington George, 1835-1917 (W. G. Smith).

Gard. Chron. 37: 9. fig. 1, 1872.--Peziza Charteri sp. nov.

Snyder, Leon Carlton, 1908- (Snyder).

Mycologia 28: 483-488. 3 figs. 1936.-New and unusual Discomycetes of western Washington.

Sorokin, Nikolai Vasilievicz, 1846-1909 (Sorok.).

Trudy Obshch. Estestv. Kazan 2(2) ${ }^{1}$ : 1-51. pl. 3-7. 1872.-Mikologisheskiya izslyedovaniya.

Sowerby, James, 1757-1822 (Sow.).

Engl. Fungi pl. 1-4 40. 1795-1815. - Coloured figures of English fungi or mushrooms.
pl. $1-10 . \quad 1795$.
pl. $3+1-378.1802$.
pl. $11-60 . \quad 1796$.
pl. $379-400.1803$.
pl. $61-120.1797$.
pl. $401-406.1809$.
pl. 121-180. 1798.
pl. $40 \mathrm{~T}-412.1810$.
pl. 181-240. 1799.
pl. 413-429. 1814.
pl. 2+1-300. 1800 .
pl. $430-40.1815$
pl. 301-370. 1801.
(Dates of 407-440 are prolabilities only.)

Spegazzini, Carlo Luigi, 1858-1926 (Speg.).

Anal. Soc. Ci. Argent. 10: 5-33. Jl 1880.-Fungi argentini. Pugillus secunclus. (Continuatio.)

Mlichelia 1: 222-238. 1879.-Fungi coprophili veneti.

Starbäck, Karl, 1863- (Starb.).

Bot. Not. 1898: 201-219. 1898.-Nogra märkligare skandinaviska ascomycetfynd.

Stevenson, John Albert, 1890- (Stev.).

Jour. Depart. Agr. Porto Rico 2: 125-26t. 1918. - A check list of Porto Rican fungi and a host index.

Sturm, Jacob, 1771-1848 (Sturm).

Deuts. F1. I'ilze 1813-62.--Deutschlands Flora. 11I. Abtheilung. Die Pilze Deutschlands.

Six volumes were finished, and four others (to which numbers had not been assigned) begun.

1: 1-34. pl. 1-16. 1813.

1: 35-66. pl. 17-32. 1814.

1: 67-98. pl. 3.3-48. 1816.

1: 99-130. pl. 49-6t. 1817.

Text of vol. 1 by Ditmar.

2: 1-35. pl. 1-16. 1828.

Text of vol. 2 by Corda.

2: 37-136. pl. 17-64. 1829.

3: 1-64. pl. 1-32. 1831.

3: 65-96. pl. 33-48. 1833.

3: 97-144. pl. 49 67. 1837.

Text of vol. 3 by Corda.

4: 1-36. pl. 1-16. 1828.

4: 69-100.pl. 33-48. 1837. 
4: 37-68. pl. 17-32. 1830

Text of vol. 4 by Rostkovius.

5: 1-36. pl. 1-16. 1839.

Text of vol. 5 by Rostkovius.

6: 1-48. pl. 1-2+. $18+8$.

6: 49-96. pl. 25-48. 1851.

Text of vol. 6 by Preuss.

19-20: 1-52. pl. 1-16. 1841. Text by Corda.

27-28: 1-48. pl. 1-27. 1848. lext by Rostkorius.

31-32: 1-48. pl. 1-2t. 1851. Text by Schnizlein.

33-34: 1-48. pl. 1-2t. 1853. Text by Strauss.

Swartz, Olof Peter, 1760-1818 (Sw.).

Sv. Vet.-Akad. Handl. 1815: 108-131. pl. +B. 1815.-Svampar saknade

i Fl. Sr. L., funne i Sverige, och anteknade.

Sydow, Hans, 1879 (H. Sydow).

Fungi Exot. 1-450. 1912-15.-Fungi exotici exsiccati.
$1-50.1912$.
201-300. 1914.
51-200. 1913 .
$301+50.1915$.

Sydow, Hans, 1879 - ; Sydow, Paul, 1851-1925 (Sydow).

Ann. Myc. 10: 77-85. 1904.-Novae fungorum species-V'll.

Sydow, Paul, 1851-1925 (P. Sydow).

Mrc. Mar. 101-4900. 1881-1899.-Mycotheca marchica.

$\begin{array}{cccccc}101-200 . & 1881 . & 1901-2500 . & 1888 . & +001-4200 . & 1894 . \\ 201-400 . & 1882 . & 2501-2900 . & 1889 . & +201-400 . & 1895 . \\ 401-600 . & 1883 . & 2901-3100 . & 1890 . & +401-4600 . & 1896 . \\ 601-800 . & 1884 . & 3101-3500 . & 1891 . & +601-4700 . & 1897 . \\ 801-1000 . & 1885 . & 3501-3800 . & 1892 . & +701-4800 . & 1898 . \\ 1001-1300 . & 1886 . & 3801-4000 . & 1893 . & +801-4900 . & 1899 .\end{array}$

1301-1900. 1887.

Thaxter, Roland, $1858-1932$ (Thaxter).

Bot. Gaz. 39: 241-247. pl. 4, 5. 1905.-Contributions from the Cryptogamic Laboratory of Harvard Iniversity. LX. A new American species of IVynnea.

Thümen, Felix Karl Albert Ernst Joachim von, 18391892 (Thüm.).

$\mathrm{N}_{\mathrm{yc}}$. Iniv. 1-2300. 1875-1884,-Mycotheca universalis.

$\begin{array}{rrrrrr}1-300 . & 1875 & 901-1200 . & 1878 . & 1801-2100 . & 1881 . \\ 301-600 . & 1876 . & 1201-1500 . & 1879 . & 2101-2200 . & 1883 . \\ 01-900 . & 1877 . & 1501-1800 . & 1880 . & 2201-2300 . & 1884 .\end{array}$

Tode, Heinrich Julius, 1733-1797 (Tode).

Fungi Meckl. 1790-91.-Fungi mecklenburgenses selecti.
1: 1-47. pl. 1-7. 1790.
2: 1-64. pl. $8-17.1791$.

Trattinnick, Leopold, 17641849 (Tratt.).

Fungi Austr. 1-202. pl. 1-18. 1805 06.-Fungi austriaci.

$$
\text { 1-15t. pl. 1-15. 1805. 155-202. pl. 16-18. } 1806 .
$$

Tulasne, Edmond Louis René, 1815-1885; Tulasne, Charles, 18161884 (Tul.).

Fung. Carp. 1861-65.- Selecta fungorum carpologia.
1: 1-242. pl. 1-5. 1861 .
3: 1-221. pl. 1-32. 1865.
2: 1-319. pl. 1-3t. 1863. 
Underwood, Lucien Marcus, 1853-1907 (Underw.).

Proc. Ind. Acad. 1893: 30-67. 1894. - List of cryptogams at present known to inhabit the State of Indiana.

Trans. Ind. Hort. Soc. 1893: 62 68. pl. 1894.-Edible fungi-a great waste of vegetable food in Indiana.

Underwood, Lucien Marcus, 1853-1907; Cook, Orator Fuller, 1867 (Underw. $\&$ Cook).

Illust. Fungi $1-100$. S 1889 . - A century of illustrative fungi.

Underwood, Lucien Marcus, 1853 1907; Earle, Franklin Sumner, 18561929 (Underw. \& Earle).

Bull. Nla. Exp. Sta. 80: 111-283. i-xwii. 1897.-1 preliminary list of Nlabama fungi.

Van Tieghem, Philippe Édouard Léon, 18391914 (Van Tieghem).

Bull. Soc. Bot. Fr. 23: 271-282. 1876.--Sur le developpement du fruit des Ascodesnis, genre nouveau de l'ordre des Ascomycetes.

Ventenat, Etienne Pierre, 1757-1808 (Vent.).

Mém. Inst. 1: 503-523. pl.7. 1798.-Dissertation sur le genre I'hallus.

Voss, Wilhelm, $1849-1895$ (Voss).

Verh. Zool.-Bot. Gres. IVien 37: 207-252. pl. 5. 1887.-Materialien zur Pilzkunde Krains. V.

Vuillemin, Jean Paul, 1861-1932 (Vuill.).

Jour. de Bot. 1: 33-37. 1 fig. 1887.-Sur un nouveau genre d' . Scoloblées.

Wallroth, Carl Friedrich Wilhelm, 1792-1857 (Wallr.).

Fl. Crypt. Germ. 1831-33,-Flora cryptogamica Germaniate.
1: 1-65t. 18.31.
2: 1923. 1833.

Weber, Georg Heinrich, 17521828 (Weber).

Weberbauer, Otto, -1881 (Weberb.).

Pilze Norddeuts. 1-10. pl. 1-6. 1873; 11-18. pl. 7-12. 1875.-I)ie Pilze Norddeutschlands mit besonderer Berücksichtigung Schlesiens.

Weir, James Robert, 1882 - (Weir).

Jour. Igr. Res. 4: 93 95. pl. 8 . 1915.-Observations on Rhizina inflata.

West, Erdman, 1894- (West).

Mycologia 24: 464-466. pl. 1t. 1932.- Notes on Sarcosphatal funcrata.

Wettstein, Richard von, 18631931 (Wettst.).

Verh. Zool.-Bot. Ges. Wien 35: 383-386. pl. 16. 1886.- Inthopezizal noxum genus Disconycetum.

Wiggers, Friedrich Heinrich, 175 - (Wiggers).

Prim. Fl. Holsat. 1-112. Mr 1780.-Primitiae Horde holsaticate.

Is explained in the preface, all names in this work not stherwise credited are those of [Georg Heinrich] Weber.

Willdenow, Carl Ludwig, 17651812 (Willd.).

Fl. Berol. 1-439. pl. 1-7. 1787.-Florate berolinensis prolsomus.

Winter, Heinrich Georg, $1848-1887$ (Wint.).

Flora 55: 508 511. 1872.-I)iagnosen und Totizen zu Rehun's Iseomyceten.

Woronin, Michael Stepanovič, 1838-1903 (Woronin).

Abh. Senck. Nat. Ges. 5: 333-34t. pl. 1-t. 1866.-Zur Entwicklungsgeschichte des Ascoloolus pulcherrimus Cr. und einiger Pezizen. 
Wulfen, Franz Xaver von, 1728-1805 (Wulfen).

Beob. Ges. Nat. Freunde Berlin 2 ${ }^{1}: 83-162$. 1787.-Winterbelustigungen. Zeller, Sanford Myron, 1885- (Zeller).

Mycologia 19: 130-143. figs. 1-4. 1927.-Contributions to our knowledge of Oregon fungi-II. Mycological notes for 1925.

Mycologia 27: 449-466. 3 figs. 1935.-Some miscellaneous fungi of the Pacific northwest.

Zollinger, Heinrich, $1818-1859$ (Zoll.).

Nat. Geneesk. Arch. Neêrl.-Ind, 1: 372-405. 1844.-OObservationes phytographicae praecipue genera et species nova nonnulla respicientes. 


\section{INDEX TO ILLLSTRATIONS}

The following species are illustrated in this work; black and white illustrations in plain type, and colorerl illustrations in bold face type.

Aleuria aurantia, pl. 8,49

rhenana, pl. 9

rutilans, pl. 9,45

Aleurina atrovinosa, pl. 8

Ascobolus carlonarius, Text-fig. 4 ;

pl. 7

geophilus, pl. 7

immersus, pl. 7

magnificus, Text-fig. 5,20 ; pl. 6

stercorarius, Text-fig. 21 ; pl. 45

subglobosus, pl. 7

viridis, pl. 7

Ascodesmis microscopica, pl. 5 porcina, pl. 5

Ascophanus argenteus, pl. 11

Aurora, pl. 11

bermudensis, pl. 11

cinereus, pl. 11

glumarum, pl. 11

granulatus, pl. 11

granuliformis, pl. 11

Holmskjoldii, pl. 11

isabellinus, pl. 11

lacteus, pl. 11

nicrosporus, pl. 11

minutissimus, pl. 11

sarcobius, pl. 11

Boudiera areolata, pl. 2

echinulata, pl. 2

Walkerae, pl. 47

Bulgaria glolosa, Text-fig. 2

melastoma, pl. 57

rufa, pl. 56

Cookeina Colensoi, Text-fig. 10; pl. 17

insititia, Text-fig. 17

sulcipes, Text-fig. $17 ; \mathrm{pl} .18$

1 baleomyces Phillipsii, pl. 67, os

I)iscina ancilis, pl. 28

convoluta, pl. 28

Durandiomyces Phillipsii, pl. 37

Elvela californica, pl. 69,70

caroliniana, pl. 72, 73 crispa, pl. 39

elastica, pl. 40

elastica gigantea, pl. 40

infula, Text-fig. 15; pl. 42, 71

Mitra, pl. 39

umbraculiformis, pl. 41

Inderwoodii, pl. 4.3

Geopyxis cupularis, pl. 26

Gyromitra esculenta, Text-fig. 15

I [umarina glumarum, pl. 11

IVaterstonii, pl. 50

L.amprospora annulata, pl. 3

areolata, pl. 3

ascoboloides, pl. 3

Constellatio, pl. 45

Crec'hqueraultii, pl. 3, 45

Crouani, pl. 3, 45

discoidea, pl. 45

haemastigma, pl. 45

lobata, pl. 3

sphagnicola, pl. 48

spinulosa, pl. 3, 45

tuberculata, pl. 3

tuberculatella, pl. 3, 45

Wrightii, pl. 3

Lecaniclion atratum, Text-fig. 23

Melastiza Charteri, pl. 45

Morchella crassipes, pl. 35, 66

esculenta, pl. 36, 65

hrbrida, pl. 36

Patella abundans, Text-fig. 12

albida, pl. 14

albocincta, pl. 45

contradicta, pl. 53

coprinaria, pl. 45

gregaria, pl. 15, 45

melaloma, pl. 15

pulcherrima, Text-fig. 19

ricciophila, pl. 45

scutellata, pl. 14, 45

Paxina Acetabulum, pl. 23

fusicarpa, pl. 25 
hispida, pl. 24

semitosta, pl. 25

sulcata, Text-fig. $1 ;$ pl. 24

Peziza batlia, pl. 54

clypeata, pl. 34

clomiciliana, pl. 26, 61

proteana, pl. 30

pseudoclypeata, pl. 62

pustulata, '1ext-fig. 22; pl. 29

repanda, pl. 32

sylvestris, pl. 33

venosa, pl. 31

vesiculosa, pl. 29

violacea, pl. 30,45

Waltersii, pl. 63

Phillipsia Chardoniana, frontispiece, Text-fig. 9

domingensis, pl. 17

gigantea, pl. 17

lithya Cupressi, pl. 4

lacunosa, pl. 4

pithỹa, pl. 4

l'lectania coccinea, pl. 19, 55

floccosa, pl. 19

hiemalis, pl. 19

occidentalis, pl. 19, 45

Pseudopithyella minuscula, pl. 52
Pseudoplectania nigrelli, pl. I

vogesiaca, pl. 1

Pyronema omphalodes, Text-fig. 3, 13, 14; pl. 10

Rhizina inflata, pl. 27

Ryparol,us monascus, pl. 12 polysporus, pl. 12 sexdecimsports, pl. 12

Sarcosphaera ammophila, pl. $6+$ coronaria, pl. 46

Sclerotinia, Text-fig. 7

Scorlellina leporina, pl. 54

Sepultaria arenicola, pl. 51 aurantia, pl. 51

Longii, pl. 13

Sphaerosoma fuscescens, pl. 2

Streptotheca obscura, pl. 12 woolhopensis, pl. 12

Thecotheus Pelletieri, pl. 12

Underwoodia columnaris, pl. 44

Urnula Craterium, pl. 21

Geaster, Text-fig. 16; pl. 21, 59, 60

Verpa bohemica, pl. 38 conica, pl. 38

Wolfina aurantiopsis, pl. 58

Wynnea americana, Text-fig. 11; pl. 16 


\section{INDEX TO GENERA AND SPECIES}

\section{(Synonyms in ilalics)}

Acetabula murina, 324

Aleuria aurantia, 308

bicucullata, 308

cestrica, 308

rhenana, 309

rutilans, 309

wisconsinensis, 308

Aleurina atrovinosa, 309

Ascobolus, 293, 307

carbonarius, 308

carneus, 311

geophilus, 285,308

magnificus, 293, $30 \tau$

pilosus, 302

pulcherrimus, 292

stercorarius, 285, 293, 294

striisporus, 308

strobilinus, 285

viridulus, 307

Ascophanus argenteus, 310

Aurora, 310

bermudensis, 310

carneus, 310

cerinus, 310

cinereus, 310

granulatus, 310

granuliformis, 310

Holmskjoldii, 310

isabellinus, 310

lacteus, 310

ochraceus, 310

sarcobius, 310

Boudiera Wilkerae, 304

Bulgaria, 318, 319

globosa, 318, 320

inquinans, 318

melastoma, 319,320

rufa, 319,320

Cookeina, 289, 290, 299, 317

amoena, 317

Colensoi, 317

insititia, 288

jav'enica, 317 sulcipes, 288, 290, 317

sumatrana, 317

tetraspora, 317

Tricholoma, 316

Cubonia lublbifera, 307

Daleomyces, 337

Gardneri, 337

Phillipsii, 337

Dasyobolus, 307

Dasyscypha rubrifula'a, 31.3

1)iscina ancilis, 327

leucoxantha, 327

macrospora, 327

Durandiomyces, $336,3.37$

Elvela, 338

atra, 338

californica, 338, 339

caroliniana, 341

crispa, 338

elastica, 338

equina, 302

inflata, 301

infula, 339-341

lacunosa, 338

Mitra, 338

sphaerospora, 342

umbraculiformis, 338, 339

Galactinia badia, 327

Geaster, 286

Geopyxis ammophila, 3.3.3, 3.35

lronca, 326

(upularis, 326

II armoge, 316

scabra, 317

vulcanalis, $311,326,327$

Gyromitra esculenta, 339, 340

Friesii, 340

infula, 340

Phillipsii, 336, 337

Ilelvella Gigas, 342

infula, 340

ITelvellella, 338

Humaria ochroleuca, 327 
Humarina, 317

aggregata, 311

araneosa, 311

coccinea, 311

convexula, 311

hepatica, 311

leucoloma, 311

marrocystis, 315

ochroleuca, $311,326,327$

semiimmersa, 311

testacea, 311

trachyderma, 311

Waterstonii, 311, 317

Lachnea aurantiopsis, 321

hybrida, 313

Lachnella atrofuscata, 313

Lamprospora carbonaria, 306

Constellatio, 305

Crec'hqueraultii, 305

Detonia, 305

fulgens, 304

haemastigma, 305

leiocarpa, 305

Planchonis, 306

pyrophila, 306

sphagnicola, 306

spinulosa, 305

trachycarpa, 305

tuberculatella, 305

IVrightii, 305

L.asiobolus equinus, 302, 313

longisetosus, 313

Lecanidion, 297

atratum, 298

Leptopodia elastica, 3.38

Melastiza asperrima, 309

Charteri, 309

pennsylvanica, 309

Microstoma hiemalis, 317

Morchella angusticeps, 336

caroliniana, 342

crassipes, 336

deliciosa, 336

esculenta, 290, 336

hybrida, 336

Neogyromitra, 338

caroliniana, 341

Gigas, 341

Oedocephalum, 295, 296

Otidea, 301,328
Papulaspora, 292, 293 magnifica, 293, 307

Patella albida, 315

albospadicea, 316

contradicta, 314

coprinaria, 315

cubensis, 314

Erinaceus, 315

Lusatiae, 314

melaloma, 315

michiganensis, 315

miniata, 314

ovilla, 314

pulcherrima, 292, 315

setosa, 314

stercorea, 315

theleboloides, 315

umbrorum, 314

Patellaria, 289, 297, 299

atrata, 297, 298

Paxina Acetabulum, 324

compressa, 325

Corium, 325

Dupainii, 325

fusicarpa, 325

hispida, 325

leucomelas, 325

nigrella, 325

platypodia, 324

recurva, 326

semitosta, 325

subclavipes, 325

sulcata, 325

Perrotia flammea, 313

Peziza, 301, 337

abietina, 328

ammophila, 333, 335

amoena, 317

ancilis, 302

atrofuscata, 313

aurantiaca stipitata, 317

aurantiopsis, 321

badia, 327,328

brunneoatra, 328

bufonia, 331

carnea, 329

clypeata, 331

cochleata, 327, 328

cochleata badia, 327

concentrica, 328 
crispata, 316

cruciata, 318

doniciliana, 329, 330

fimeti, 331

funerata, 333-335

griseorosea, 328

hybricla, 313

imperialis, 318

jazenica, 317

leptopus, 317

melialeuca, 328

obliqua, 316

perlata, 302

proteana, 328, 337

protracta, 317,318

pseudoclypeata, 332

pustulata, 295, 296, 328

repanda, 329-331

succosa, 328

sylvestris, 331

venosa, 329

vesiculosa, 331

violacea, 328

vulcanalis, 327

Waltersii, 332

Phaeobulgaria, 319

inquinans, 319

Phaeopezia Detonia, 305

Phillipsia, 289, 290, 299

Chardoniana, 316

(lochmia, 316

domingensis, 316

gigantea, 316

polyporoides, 316

Pilocratera cantareirensis, 317

maxima, 317

nora-guineensis, 317

Tricholoma celebica, 316

Pithya Cupressi, 307

pithya, 306, 307

vulgaris, 306,307

Plectania, 318

coccinea, 317

hiemalis, $289,317,318$

occidentalis, 317

protracta, 318

Pseudombrophila deerrata, 312

Pseudopithyella minuscula, 313

Pseudoplectania fulgens, 304 nigrella, 304

rogesiaca, 304

Psilopezia aquatica, 309

hyclrophila, 309

nummularia, 309

Ptychoverpa, 337

bohemica, 337

Pyronema omphalodes, 309

Rhizina, 301

inflata, 301-303, 327

undulata, 301, 302

Ryparobius crustaceus, 312

monascus, 312

sexilecimsporus, 312

Saccobolus depauperatus, 308

Kerverni, 308

Sarcoscypha imperialis, 318

obliqua, 316

Sarcosoma, 319

carolinianum, 321

cyttarioides, 319,320

globosum, 320

Sircosphaera, 312, 334

ammophila, 312, 313, 333

coronaria, 332

funerata, 333-335

Selerotinia, 285, 322

Scodellina, 301, 318

grandis, 316

leporina, 301, 316

Scutellinia aurantiopsis, 321 michiganensis, 315

Sepultaria, 312,334

arenicola, 312

aurantia, 313

Sphaerospora brunnea, 304

Therotheus Pelletieri, 312

Trichoscypha amoena, 317 javanica, 317

Inderwoodia columnaris, 342

Irnula, 322, 323

Craterium, 321

Geaster, 285, 286, 322-324

Virpa, 337

hohemica, 337

conica, 337

IVolfina, 320

aurantiopsis, 321

IIrnnea, 299

americana, 316 



$$
\text { • }
$$



